\title{
Medezeggenschap op ondernemingsniveau inzake veiligheids- en gezondheidsaangelegenheden in de Europese Gemeenschap
}

Citation for published version (APA):

Steyger, E. (1990). Medezeggenschap op ondernemingsniveau inzake veiligheids- en gezondheidsaangelegenheden in de Europese Gemeenschap. [Doctoral Thesis, Maastricht University]. Rijksuniversiteit Limburg. https://doi.org/10.26481/dis.19901101es

Document status and date:

Published: 01/01/1990

DOI:

10.26481/dis.19901101es

Document Version:

Publisher's PDF, also known as Version of record

Please check the document version of this publication:

- A submitted manuscript is the version of the article upon submission and before peer-review. There can be important differences between the submitted version and the official published version of record.

People interested in the research are advised to contact the author for the final version of the publication, or visit the DOI to the publisher's website.

- The final author version and the galley proof are versions of the publication after peer review.

- The final published version features the final layout of the paper including the volume, issue and page numbers.

Link to publication

\footnotetext{
General rights rights.

- You may freely distribute the URL identifying the publication in the public portal. please follow below link for the End User Agreement:

www.umlib.nl/taverne-license

Take down policy

If you believe that this document breaches copyright please contact us at:

repository@maastrichtuniversity.nl

providing details and we will investigate your claim.
}

Copyright and moral rights for the publications made accessible in the public portal are retained by the authors and/or other copyright owners and it is a condition of accessing publications that users recognise and abide by the legal requirements associated with these

- Users may download and print one copy of any publication from the public portal for the purpose of private study or research.

- You may not further distribute the material or use it for any profit-making activity or commercial gain

If the publication is distributed under the terms of Article $25 \mathrm{fa}$ of the Dutch Copyright Act, indicated by the "Taverne" license above, 
MEDEZEGGENSCHAP OP ONDERNEMINGSNIVEAU INZAKE VEILIGHEIDS- EN GEZONDHEIDSAANGELEGENHEDEN IN DE EUROPESE GEMEENSCHAP 


\section{Voor Tamar}




\section{MEDEZEGGENSCHAP OP ONDERNEMINGSNIVEAU INZAKE VEILIGHEIDS- EN GEZONDHEIDSAANGELEGENHEDEN IN DE EUROPESE GEMEENSCHAP}

\section{PROEFSCHRIFT}

ter verkrijging van de graad van doctor aan de Rijksuniversiteit Limburg te Maastricht, op gezag van de Rector Magnificus, Prof.Dr. F.I.M. Bonke, volgens het besluit van het College van Dekanen, in het openbaar te verdedigen op donderdag, 1 november 1990 om 16.00 uur

door

\section{Elisabeth Steyger}

geboren te 's-Gravenhage in 1956 


\section{Promotores:}

Prof. dr. A.T.J.M. Jacobs

Prof. mr. A.J.C.M. Geers

Beoordelingscommissie:

Prof. mr. C. Flinterman (voorzitter)

Prof. mr. J.K.M. Gevers

Dr. B. de Witte

Van deze uitgave is tevens een handelseditie verschenen in de serie Europese Monografieën onder ISBN 9026820771. 
Rita Mae Brown heeft eens gezegd dat het leukste moment bij het schrijven van een boek, het moment is dat je degenen die een bijdrage hebben geleverd aan de totstandkoming ervan, mag bedanken. Ik onderschrijf dit. Omdat het noemen van alle personen die met mij de inhoud bediscussieerd hebben en op deze wijze aan het boek hebben bijgedragen zoveel tekst zou vergen dat het bedanken aanzienlijk minder leuk zou worden, wil ik hen in het algemeen bedanken. Niettemin wil ik enkelen in het bijzonder noemen. Allereerst wil ik mijn promotores danken. Prof. mr. Ad Geers gaf mij de ruimte om het onderzoek uit te voeren waarvoor ik belangstelling had. Prof. dr. Antoine Jacobs wil ik danken voor zijn voortdurende inhoudelijke steun.

Voorts wil ik Caroline Forder bedanken voor het reviseren van de Engelse samenvatting, Joof Schöpping en Réjean Pinckaers voor hun bijdrage aan de opmaak van dit boek. Mijn vader nam de lastige taak van het opstellen van het zakenregister op zich, daarvoor ben ik hem zeer dankbaar.

Bovendien wil ik mijn ouders in meer algemene zin bedanken: zonder hun voortdurende steun, tijdens mijn rechtenstudie en daarna, had ik geen mr. laat staan dr. kunnen worden.

Mijn dank gaat ook uit naar Nico Verheij voor zijn steun en zijn vertrouwen in mijn vermogen dit boek tot een goed einde te brengen.

Tenslotte, maar niet het onbelangrijkst, wil ik mijn dochter Tamar bedanken. Om te beginnen hielp zij mee met de berekening van één van de tabellen. Bovenal ben ik haar echter dankbaar dat zij mij met enige regelmaat liet beseffen dat er belangrijker zaken in het leven zijn dan het schrijven van een proefschift.

Maastricht, juni 1990.

Elies Steyger.

Dit tekst van dit boek is afgesloten op 1 juli 1990. 

Lijst van afkortingen $\quad$ XI

Hoofdstuk I INLEIDING

1. Inleiding 1

2. Medezeggenschapswetgeving in de lid-staten 2

2.1. Medezeggenschap als uitnodiging aan de werknemer 5

3. Medezeggenschap inzake veiligheids- en gezondheidsaangelegenheden in internationale regelingen 7

4. Probleemstelling, afbakening van het onderzoeksgebied en verantwoording van de onderzoeksmethode

4.1. Het instrumentarium van vertegenwoordigers op ondernemingsniveau 15

5. Enkele begripsbepalingen 17

5.1. Medezeggenschap en medezeggenschapsinstrumentarium 17

5.2. Veiligheid, gezondheid, arbeidsomstandigheden, arbeidsmilieu 18

5.3. Werknemer en randgroepwerknemer 19

5.4. Onderneming, ondernemer en werkgever 20

$\begin{array}{ll}\text { 6. Opbouw van het boek } & 20\end{array}$

Hoofdstuk II

SOCIAAL BELEID EN MEDEZEGGENSCHAP IN

DE EUROPESE GEMEENSCHAP;

PLAATSBEPALING EN INVENTARISATIE

1. Inleiding 23

2. De plaats van de sociale politiek in de Gemeenschap 26

2.1. De plaats van de sociale politiek in het EEG-verdrag 26

2.2. De relatie tusser de socialle politiek en het

vrij verkeer van personen: dispariteiten en distorsies

2.3. De relatie tussen de gemeenschappelijke markt en werknemersrechten als medezeggenschap

2.4. Een veranderende attitude ten opzichte van de sociale politiek?

3. Harmonisatie van sociale wetgeving in de gemeenschap 39 
3.1. Harmonisatie van medezeggenschapswetgeving in de gemeenschap

4. De richtlijnen en de voorstellen 45

4.1. De institutionele invalshoek 46

A. Het Groenboek als basis voor gedachtenvorming 49

B. De fase van de alternatieven 50

C. De haalbaarheid van de institutionele voorstellen 53

4.2. De instrumentele invalshoek 54

A. De Vredeling-voorstellen $\quad 55$

B. Terug naar de sociale dialoog 61

C. Medezeggenschapsbepalingen in bestaande richtlijnen $\quad 62$

D. Betekenis van de richtlijnen 65

4.3. Tussenconclusie 69

5. Implementatie van richtlijnen door collectieve overeenkomsten 71

5.1. De vrijheid van collectief onderhandelen 74

5.2. Het toezicht van de Commissie op de naleving van richtlijnbepalingen

5.3. Medezeggenschap op multinationaal niveau door middel van collectieve overeenkomsten.

6. Slotopmerkingen

Hoofdstuk III

WERKNEMERSVERTEGENWOORDIGING

OP ONDERNEMINGSNIVEAU

1. Inleiding

2. Ondernemingsraden, shop stewards en andere werknemersvertegenwoordigers

2.1. Ondernemingsraden en samenwerkingsorganen

2.2. Shop stewards en vakbondsafvaardigingen in de onderneming

2.3. Werknemersvertegenwoordigers met taken inzake veilligheids- en gezondheidsaangelegenheden

3. Slotopmerkingen

Hoofdstuk IV

HET INSTRUMENTERIUM VOOR SAMENWERKING

EN ONDERHANDELING OP ONDERNEMINGSNIVEAU

IN DE LID-STATEN

1. Inleiding

2. Het recht op informatie 133

3. Consultatie, instemmingsrechten en onderhandelingsrechten 148

$\begin{array}{ll}\text { 3.1. Consultatie } & 149\end{array}$

$\begin{array}{ll}3.2 . & 1453\end{array}$

3.3. Onderhandelingsrechten 158 
3.4. Uitbreiding en beperking van de bevoegdheden van vertegenwoordigers op ondernemingsniveau

3.5. Consultatie, instemming en onderhandelingen inzake veiligheids- en gezondheidsaangelegenheden

3.6. Tussenconclusie

4.1. Geschillen over naleving

5. Directe sancties

6. Slotopmerkingen

\section{Hoofdstuk V}

VEILIGHEIDS- EN GEZONDHEIDSAANGELEGENHEDEN; INSTRUMENTARIUM VAN SPECIFIEK BELANG VOOR DIT TERREIN.

1. Inleiding

1.1. De rol van de wet in veiligheids- en gezondheidsaangelegenheden

2. Werknemerstoezicht en deskundigeninformatie

2.1. Het recht toezicht te houden

2.2. Het inschakelen van externe deskundigen als steun

3. Het recht van werknemersvertegenwoordigers

(een deel van) de onderneming stil te leggen

4. Interne en externe ondersteunende instanties bij

het voeren van een veiligheids- en gezondheidsbeleid

5. De mogelijkheid een beroep te doen op de arbeidsinspectie

6. De individuele werknemer in medezeggenschapssystemen

m.b.t. veiligheids- en gezondheidsaangelegenheden

6.1. Het recht het werk neer te leggen bij dreigend gevaar

6.2. Klachtenprocedures binnen de onderneming

6.3. De randgroepwerknemers: het democratieprobleem

6.4. Vertegenwoordiging in homogene groepen als steun voor de individuele werknemer

7. Conclusies met betrekking tot het totaal aan instrumentarium van de vertegenwoordigers in de lid-staten

Hoofdstuk VI

NAAR EEN EUROPESE REGELING VOOR

MEDEZEGGENSCHAP INZAKE VEILIGHEIDS-

EN GEZONDHEIDSAANGELEGENHEDEN

1. Inleiding

2. Een op de wetgeving en praktijk van de lid-staten te baseren concept voor een medezeggenschapsregeling 
inzake veiligheids- en gezondheidsaangelegenheden

2.1. Artikel 118A: een rechtsgrondslag voor minimum-voorschriften

A. De reikwijdte van artikel $118 \mathrm{~A}$

2.2. Een concept voor een communautaire regeling geïnspireerd door de nationale praktijken

3. Beleid, richtlijnen en richtlijnvoorstellen

3.1. Richtlijnen en richtlijnvoorstellen daterend van vó́r de invoering van artikel 118A

A. Opmerkingen over de medezeggenschaps-bepalingen in het licht van het bovengenoemde concept

B. De richtlijnvoorstellen

3.2. Richtlijnen en richtlijnvoorstellen op basis van artikel 118A 315

A. De nieuwe raamrichtlijn

B. De richtlijn bekeken in het licht van het op de nationale regelingen en praktijken gebaseerde concept

C. Op artikel 118A gebaseerde richtlijnen en richtlijnvoorstellen voor maatregelen op specifieke gebieden

$\begin{array}{ll}\text { 4. Nieuwe beleidsgebieden voor een te maken richtlijn } & 338 \\ \text { 4.1. De individuele werknemer in een te maken regeling } & 338\end{array}$

4.2. Medezeggenschap op multinationaal niveau 342

5. Slotopmerkingen

1. Inleiding

2. De effectiviteit van richtlijnen

3. Conclusies ten aanzien van de probleemstelling 358

4. Een voorstel voor een richtlijn 361

4.1. Toelichting 369

5. Slotbeschouwing 371

Summary

Lijst van geraadpleegde literatuur $\quad 383$

$\begin{array}{ll}\text { Jurisprudentieregister } & 395\end{array}$

Trefwoordenregister 


$\begin{array}{ll}\text { AA } & \text { Ars Aequi } \\ \text { ACAS } & \text { Advisory Conciliation and Arbitration Service } \\ \text { ASiG } & \text { Arbeitssicherheitsgesetz } \\ \text { BAG } & \text { Bundesarbeitsgericht } \\ \text { BetrVG } & \text { Betriebsverfassungsgesetz } \\ \text { BGB } & \text { Bundesgesetzbuch } \\ \text { BGBl } & \text { Bundesgesetzblatt } \\ \text { BST } & \text { Betriftsundhedstjeneste } \\ \text { BW } & \text { Burgerlijk Wetboek } \\ \text { CAC } & \text { Central Arbitration Committee } \\ \text { CC } & \text { Code Civile } \\ \text { CdT } & \text { Code du travail } \\ \text { CHSCT } & \text { Comité d'hygiéne, de sécurité et des conditions de travail } \\ \text { CMLRev.Common Market Law Review } \\ \text { ECRM } & \text { Europese Conventie voor de Rechten van de Mens } \\ \text { EIRR } & \text { European Industrial Relations Review } \\ \text { EP } & \text { Europees parlement } \\ \text { EPA } & \text { Employment Protection Act 1975 } \\ \text { ESH } & \text { Europees Sociaal Handvest } \\ \text { ETUC } & \text { European Trade Union Confederation } \\ \text { FIDE } & \text { Federation international pour le droit Europeén } \\ \text { HSC } & \text { Health and Safety Commission } \\ \text { HSE } & \text { Health and Safety Executive } \\ \text { HSWA } & \text { Health and Safety at Work Act 1974 } \\ \text { IIJ } & \text { Industrial Law Journal } \\ \text { ILO } & \text { International Labour Organization } \\ \text { IRLR } & \text { Industrial Relations Law Reports } \\ \text { JORF } & \text { Journal Officièl de la Republique Francaise } \\ \text { Jur. } & \text { Jurisprudentie van het Hof der Europese Gemeenschappen } \\ \text { LAG } & \text { Landesarbeitsgericht } \\ \text { NJ } & \text { Nederlandse Jurisprudentie } \\ \text { NJB } & \text { Nederlands Juristenblad } \\ \text { OK } & \text { Ondernemingskamer } \\ \text { Pb. } & \text { Publicatieblad. } \\ \text { Rl. } & \text { EEG-richtlijn } \\ \text { ro. } & \text { rechtsoverweging } \\ \end{array}$


SER Sociaal Economische Raad

SEW Sociaal Economische Wetgeving

SMA Sociaal Maandblad Arbeid

Stb. Staatsblad

Trb Traktatenblad

UNICE Union of Industries of the European Communities

Vo. EEG-verordening

WOR Wet op de Ondernemingsraden 


\section{Inleiding}

\section{Inleiding}

Dit boek gaat over de mogelijkheden voor harmonisatie van medezeggenschapsbepalingen inzake veiligheid en gezondheid op het niveau van de Europese Gemeenschap. Daarbij wordt er van uitgegaan dat er op alle niveaus van een onderneming medezeggenschap moet zijn.

De Europese Gemeenschap is, wanneer men naar het EEG-oprichtingsverdrag kjjkt, vooral een economische gemeenschap. De doelstellingen van de Gemeenschap zijn gericht op het bevorderen van de economische activiteit binnen de Gemeenschap, een gestadige evenwichtige expansie, een grotere stabiliteit, nauwere betrekkingen tussen de lid-staten en niet te vergeten een toenemende verbetering van de levensstandaard. Deze doelstellingen moeten worden bereikt door onder meer de instelling van een gemeenschappelijke markt, een gemeenschappelijk handels-, landbouw en vervoerbeleid en harmonisatie van wetgeving in de mate waarin dit voor de gemeenschappelijke markt noodzakelijk is.

Daarnaast dient de Gemeenschap een sociale politiek te voeren. Deze sociale politiek is enigszins onderbedeeld in het EEG-verdrag en heeft ook lange tijd een min of meer slapend bestaan geleid. Dit had mede te maken met het, bij de opstellers van het EEG-verdrag levende idee, dat de socialle politiek vanzelf wel de economische vooruitgang zou volgen, als men het marktmechanisme maar zijn gang zou laten gaan (1). Sedert de inwerkingtreding van de Europese Akte (2), die de voltooiling van de interne markt moet vergemakkelijken is de sociale politiek weer meer in de bellangstelling komen te staan (3).

1. B.A. Hepple. The Crisis in EEC Labour Law, 16 Industrial law Journal, 1987, p. 77.

2. Verdrag tot wijzing van het EEG-werdrag, Luxemburg 17 februari $1986, \mathrm{~Pb}$. $1987 \mathrm{~L} 169$, Trb. 1986, no. 63, in werking getreden op 1 jull 1987.

3. Zie o.m. A.TJ.M. Jacobs, De arbeidsrechtelijke aspecten van de voltooing van de Europese binnenmarkt, NJB 1988, p. 836; E. Steyger, Sociaal beleid en harmonisatic van sociale wetgeving: stiefkind en zorgenkind, AA 38 (1989)5, p. 168 ev.; J. vam Rens, Wordi de Europese gemeenschap een sociale unie, AA 38(1989)5, p. 176 ew. 
Een Europese sociale politiek acht ik noodzakelijk om de nadelen die de voltooiing van de gemeenschappelijke markt oplevert compenseren. Die nadelen kunnen voortvloeien uit het wegnemen van de belemmeringen tussen de lid-staten, waardoor ondernemingen zich gemakkelijker elders kunnen vestigen, of van grensoverschrijdende constructies gebruik kunnen maken. Door de faciliteiten die de interne markt biedt kunnen zij hun zetel vestigen in de lid-staat met de voor die onderneming gunstigste regelingen. Hierdoor kan een verschuiving ontstaan binnen de Gemeenschap van het vestigingspatroon van ondernemingen ten gunste van de landen met een laag niveau van arbeidsbescherming.

Deze verschuiving kan een verlaging van het niveau veroorzaken in de lidstaten waar de arbeidsbescherming nu nog een hoog niveau heeft. Een dergelijke consequentie kan een verlies aan rechten van werknemers in bepaalde lid-staten opleveren. Lid-staten zouden op den duur uit concurrentie-overwegingen geen andere mogelijkheid overhouden dan het verlagen van het niveau van bescherming. Een sociaal beleid geïnitieerd vanuit de Gemeenschap kan een dergelijke consequentie tegengaan.

Een van de onderdelen van het sociale beleid in de Gemeenschap is de medezeggenschap op ondernemingsniveau. Vanaf het begin van de jaren zeventig is gepoogd medezeggenschapsrechten op ondernemingsniveau met name op concernniveau te creëren (4). Hoewel in het Europees parlement door leden van praktisch alle politieke stromingen en uit alle lid-staten (5) verklaard werd dat medezeggenschap op ondernemingsniveau van groot belang was, is het nooit tot communautaire regulering gekomen. Op deelgebieden van de sociale politiek kwamen wel medezeggenschapsparagrafen in de gemeenschapsregelgeving terecht. Maar men kan niet zeggen dat met deze deelregelingen alle vraagstukken van medezeggenschap in het algemeen en in multinationale ondernemingen in het bijzonder zijn opgelost. Een van die deelgebieden is veiligheids- en gezondheidsaangelegenheden (6).

\section{Medezeggenschap inzake veiligheid en gezondheid in de lidstaten}

Rond de jaren zeventig werd in een aantal Europese landen de wetgeving ter bescherming van de veiligheid en gezondheid van werknemers vernieuwd

4. Zie o.m. de voorstellen voor de vijfde richtlijn met betrekking tot het vemnootschapsrecht ( $\mathrm{Pb}, 1972$, C 131, laatste gewijzigd voorstel, Bulletin van de Europese gemeenschappen, Luxemburg, 1983, Suppl. 6/83) en het voorstel voor een richtlin betreffende procedures voor het informeren en consulteren van werknemers van ondernemingen met complexe structuren, i.h.b. transinationale ondernemingen (Pb 1980, C 297).

5. Zie. o.m. de handelingen van het Europees Parlement bij de behandeling van het mooit tot richtlijn geworden Vredeling-Richardwoorstel, 14-2-1982, Doc. 1-288, met name p. 22, 44, $45,48,50,51,52,53,54,57,59,63,65,66$, waar parlementariers van praktisch alle politieke stromingen en wit praktisch alle lid-staten van dit standpunt blijk gaven.

6. $\quad$ RI. $89 / 391$, Pb. 1989 L 183. 
of gewijzigd (7). De vernieuwingen kwamen onder meer voort uit de snelle ontwikkelingen in de techniek en een daarmee gepaard gaande schaalwergroting in de procesindustrie (8). In veel landen was de onvrede met de traditionele wetgeving die veelal bestond uit een onoverzichtelijk stamenstel van regelingen, reden om tot een herziening van de wetgeving overgaan. Daarbij was een gewijzigde visie op de rol van de wetgever inzake het vaststellen van normen op ondernemingsniveau, een reden om ook de werknemers meer bij de vitvoering binnen de onderneming te betrekken (9).

Om ordening te brengen in de versnippering van normen werden in een aantal lid-staten raamwetten op veiligheids- en gezondheidsgebied tot stand gebracht, waarin de algemene verplichtingen van werkgevers en werknemers werden vastgelegd. Soms bleven naast deze wetten specifieke regels en besluiten bestaan voor de verschillende sectoren. Het was echter in de meeste lid-staten de bedoeling dat de verplichtingen uit de raamwetten de bijzondere regelingen zouden overkoepelen. Dit streven is overigens niet overal helemaal gelukt (10).

Een ander nieuw aspect dat in een aantal van de wetten was tenug te vinden, was de uitbreiding van de klassieke beschermingsgebieden als veiligheid en gezondheid met de bescherming van het welzijn van werknemers in één of andere vorm. Zo schrijft de Britse Health and Safety at Work Act 1974 de werkgever voor "(....) to ensure (...) the health, safety and welfare (onderstreping ES) at work of all his employees"; de Nederlandse Arbeidsomstandighedenwet, en ook de Wet op de Ondernemingsraden spreken van de veiligheid, gezondheid en het welzijn bij (of in verband met) de arbeid (11). Ook in de Duitse wetgeving wordt een medezeggenschapsrecht aan de Betriebsrat toegekend wanneer het gaat om een extra belasting voor de werknemers bij veranderingen op de werkplek, de werkomgeving of de organisatie van het werk (12), een terrein dat niet tot de directe bescherming van de veiligheid en gezondheid van de werknemers gerekend kan worden.

7. Voor een overzicht van de rechtsontwikkeling $m \cdot b$. de wetgeving op het gebied van veiligheid en gezondheid in (megen van) de lid-staten van de Europese Gemeenschappen zie o.m.: J.K.M. Gevers, Zeggenschap van werknemers inzake gezondheid en veiligheid in bedrijven, Deventer 1982.

8. Zie o.m. A. Geers, Veilig en wel, De Arbeidsomstandighedemwet, een nieuwe laak voor de OR, Alphen a/d Rijn, 1985, p.14.

9. Zie J.K.M. Gevers, a.w.(noot 7), p. 13.

10. Zie o.m. A. Broadhurst, The Health and Safety at Work Act in Practice, London 1978, p. 10; A. Geers, a.w.(noot 9), p. 19-20.

11. Zie over de ontwikkeling van het Nederlandse arbeids-omstandighedenrecht in het algemeen en de tot standkoming van de Arbowet in het bijzonder: A.J.C.M. Geers, Recht en humanisering van de arbeid, Deventer 1988, p.17-81 en p. 82-110.

12. Paragraaf 91 Betriebsverfassungsgesetz (BetrVG) (1972, laatstelijk gewijzigd op 24 juli 1986). 
De derde en belangrijkste wijziging in de nieuwe wetgeving is de wijze waarop werknemers bij de bescherming van arbeidsveiligheid en gezondheid worden betrokken. De traditionele wetgeving bestond in veel gevallen uit arbeidersbeschermende matregelen; maatregelen waarin de werknemer als object van bescherming werd gezien, maar zelf weinig of geen invloed uit kon oefenen of zelfs geraadpleegd werd over het in de onderneming te voeren beleid. Algemeen werd ingezien dat juist arbeidsomstandigheden zich bijzonder lenen voor medezeggenschap van werknemers. Daarmee zou de betrokkenheid van de werknemers en dus de kans op effectieve bescherming, doordat men zelf, in elk geval ten dele meegewerkt had aan het opstellen van een arbeidsomstandighedenbeleid, of erover geraadpleegd was, worden vergroot. Deze medezeggenschap kreeg in een aantal landen de vorm van bijzondere medezeggenschapsregelingen naast, meer algemene, bestaande regelingen of praktijken.

Op zichzelf was medezeggenschap in de zin van beilinvloeding van het ondernemingsbeleid door werknemers of hun vertegenwoordigers geen nieuw fenomeen. In een aantal lid-staten van de Europese Gemeenschap is in de loop der jaren een praktijk gegroeid waarin vakbonden middels vertegenwoordigers op verschillende manieren en in verschillende relaties, invloed uitoefenen (13), een praktijk ten opzichte warvan de overheid zich in meer of mindere mate terughoudend opstelde (14). In andere EG lid-staten was de medezeggenschap in het algemeen al eerder in de wet geregeld. De tweedeling tussen stelsels van medezeggenschap op wettelijke basis en die van medezeggenschap op basis van collectieve overeenkomst is dan ook de meest algemene die er in de Europese Gemeenschap te maken valt (15).

Deze ruwe tweedeling heeft ook een meer ideologische achtergrond. De in de wet (en dus met overheidsbemoeienis tot standgekomen) voorziene medezeggenschapsorganen waren (en zijn) in het algemeen gericht op het belang van de onderneming, hetgeen een taak tot samenwerking met de werkgever oplevert. Het instrumentarium waarvan de wet hen voorzag rechten tot overleg, het recht om geconsulteerd te worden en eventueel het recht om in te stemmen met besluiten- weerspiegelt een dergelijke samenwerkingsidee. Vakbonden en vakbondsvertegenwoordigers daarentegen zijn ontstaan om de belangen van de werknemers te behartigen. Belangenbehartiging kan door met de werkgever samen te werken gerealiseerd worden, maar ook door, indien nodig, het conflict met de werkgever te zoeken. Het instrumentarium waar zij gebruik van maken -het afsluiten van overeenkomsten, en ultiem, het stakingswapen als werkgevers weigeren te

13. Zie on. K. Nagels, F. Sorge, Industrielle Demokratie in Europa, Frankfurt 1977, p. 91, B. Perryns, Trade Union Law, London 1985 p. 16, S. Sciarra, The Rise of the Italian Shop Steward, Industrial liaw Journal, 1977, P. 35-44.

14. K. Nagels, F. Sorge, a.w. (noot 13), p. 79.

15. Zie hierower o.m. J.H.T.H. Andriessen, Medezeggenschap gesteumd door wet- en regelgeving, TVVS 1984, p. 244-252. 
contracteren- wijst niet echt op een primaire attitude tot samenwerking mét diezelfde werkgever.

Deze tweedeling is echter niet zo extreem ais zij op het eerste gezicht lijkt. In een aantal landen werd weliswaar medezeggenschap gereguleerd op vrijwillige basis, maar werden op nationaal niveau, door de federaties van werkgevers- en werknemersverenigingen de hoofdlijnen en grenzen vastgelegd van de medezeggenschap zoals die meestal door de vakbonden wordt uitgeoefend. En zelfs in Italië en Groot Brittannië waar de mate van vrijwilligheid bij het systeem van medezeggenschap het grootst is werden vakbondsvertegenwoordigers voorzien van enige wettelijke bescherming. Anderzijds in de systemen waar samenwerking voorop stond, kregen de medezeggenschapsorganen toegang tot de rechter om hun rechten af te dwingen. De scherpe kantjes zijn er, hoe groot de verschillen ook zijn, op deze wijze enigzins afgesleten.

Het is, gezien deze verschillen in de achtergrond van de medezeggenschapssystemen opvallend, dat bij de herziening van de verschillende veiligheidsen gezondheidswetten in de lid-staten, de wetgever kennelijk een wettelijk basis voor medezeggenschap noodzakelijk vond. Hoezeer ook vrijwilligheid voorop stond, blijkbaar werd inzake veiligheid en gezondheid een minimum van medezeggenschap, in de zin van informatie en consultatierechten voor werknemersvertegenwoordigers (of zij nu vakbondswertegenwoordigers zijn of niet) noodzakelijk geacht.

\subsection{Medezeggenschap als uitnodiging aan de werknemer}

Veiligheid en gezondheidsbeleid in de onderneming is van belang voor iedere werknemer die in de onderneming werkt. Zolang werknemers geen enkele invloed op deze zaken kunnen uitoefenen, en slechts object zijn van wettelijke, of eenzijdig door de werkgever opgelegde (beschermende) regels, heeft de individuele werknemer op dit punt geen mogelijkheid (althans niet waar het niet gaat om privaatrechtelijke aansprakelijkheid) dit belang tot gelding te brengen. Bij klachten kan hij zich wenden tot de werkgever of tot de vakbond; heeft hij geluk dan wordt zijn klacht erkend en wordt er iets aan gedaan en heeft hij pech dan gebeurt er niets. De keerzijde is dat de individuele werknemer ook geen (of slechts een zeer beperkte) verantwoordelijkheid kan dragen, ten aanzien van de gang van zaken in dezen.

Als de mogelijkheid tot medezeggenschap ontstaat, ontstaat daarmee niet alleen voor de werknemerswertegenwoordigers, maar ook voor alle andere werknemers een eigen nieuwe verantwoordelijkheid. Op dat moment is het immers aan de werknemer zelf om via zijn vertegenwoordigers iets aan zijn situatie te doen, om de vertegenwoordigers de ernst van de klacht te doen inzien, hen te bewegen dit in het overleg met de werkgever in te brengen en hen eventueel er toe te brengen over de klacht te gaan onderhandelen. Als de werknemer dit alles nalaat, of zijn pogingen om de vertegenwoordi- 
gers voor zijn geval te interesseren falen, dan is de keerzijde hiervan dat de werkgever tot op zekere hoogte gelegitimeerd is om problemen op dit gebied in de onderneming te negeren.

Dit betekent dat een medezeggenschapsregeling een aantal nieuwe eisen oplevert waaraan werknemers moeten proberen te voldoen, zoals de eis van mondigheid. Zo zal het soms noodzakelijk blijken te zijn, klachten te uiten met voorbijgaan aan de directe chef, hetgeen werknemers niet direkt populair bij die bewuste chef zal maken.

Daarnaast kunnen de toepassing van een medezeggenschapsregeling en de eisen van participatie er toe leiden, dat de belangen van delen van het personeel ondergesneeuwd raken in het overleg; hetzij omdat de belangen van deze personeelsleden marginaal zijn vergeleken met die van hun collega's, hetzij omdat zij van oudsher toch al slecht of helemaal niet participeren of kunnen participeren in geïnstitutionaliseerde overlegsituaties. Slecht of niet participeren, omdat ook aan het functioneren in een medezeggenschapsstructuur eisen gesteld worden, meer eisen nog dan de hierboven al genoemde mondigheid. Die mondigheid is belangrijk; het is een eerste voorwaarde om te kunnen meedoen. Maar ook andere factoren als opleiding, acceptatie door andere werknemers, deskundigheid en de hoeveelheid tijd die een werknemer buiten werktijd in het overleg kan en wil steken, komen hierbij kijken (16).

Naast deze eisen zijn de formele eisen om te kunnen participeren in de overlegsituaties van belang. Hieraan voldoen lang niet altijd alle werknemers, bijvoorbeeld in veel landen niet de parttimers, thuiswerkenden, en werknemers op rechtspositioneel niet heldere afroepcontracten (17). Nu de flexibilisering van de arbeid toeneemt behoren steeds minder werknemers tot de "reguliere" werknemers, die in het algemeen de beste participatiemogelijkheden hebben.

Voor de niet-participerende werknemers kunnen de problemen nog toenemen wanneer de werknemersvertegenwoordigers, om welke reden dan ook, niet in staat zijn om in het overleg enige invloed uit te oefenen. Waar het, bij een goed functionerende vertegenwoordiging in elk geval nog mogelijk is via dit orgaan iets aan de eigen situatie te doen, is dit juist voor niet-participerende werknemers bij een slecht functionerende vertegenwoordiging praktisch uitgesloten. Kortom: niet-participerende werknemers

16. A. Koopnnan-Iwema, Macht, motivatie, medezeggenschap, een studie naar participatief gedrag van leden van overlegorganen in industriële bedrijven, Nijmegen 1980.

17. Om"een voorbeeld te noemen: art. 6 lid 3 WOR legt aan het passieve kiesrecht beperkingen op woor hen die nog niet lang in een onderneming werkzaam zijn. Mensen met flexibele arbeids-contracten alls afroepcontracten, waarvan de status nog niet geheel duidelijk is, zouden dit artikel tegengeworpen kunnen krijgen indien zij zich verkiesbaar stellen. Ook in andere landen kent men regelingen waarin voorwaarden gesteld worden het passieve kiesrecht in de onderneming, zie bijwoorbeeld Ruth Nielsen, Laerebog i arbejdsret, Kopenhagen 1987 , p. 98. 
hebben, ondanks het feit dat zij aan medezeggenschapsregelingen mogelijk minder zullen hebben dan werknemers, die wel op enigerlei wijze bij de medezeggenschap betrokken worden, onder alle omstandigheden belang bij vertegenwoordigers die op goede en effectieve wijze werken (18).

Dit alles betekent dat de medezeggenschapsregeling in elk geval de voorwaarden moet scheppen voor werknemersvertegenwoordigers om de belangen van de werknemers binnen de overlegsituatie op goede en effectieve wijze te behartigen. Die voorwaarden zijn gelegen in het instrumentarium dat de regeling de werknemersvertegenwoordigers biedt. Echter, hoe goed dat instrumentarium ook is, de garantie voor goede belangenbehartiging is daarmee niet gegeven. Teulings heeft in zijn onderzoek naar het functioneren van Nederlandse ondernemingsraden aangetoond dat daar meer voor nodig is (19).

Dit betekent dat naast medezeggenschapsregelingen specifieke beschermende regelingen noodzakelijk blijven. Bovendien valt te verdedigen dat mogelijkheden moeten bestaan voor individuele werknemers om, indien van het medezeggenschapsinstrumentarium niet of op onvoldoende wijze gebruik wordt gemaakt, het systeem 'binnen te dringen', om hun eigen belangen naar voren te kunnen brengen. De uitnodiging, die van medezeggenschapregelingen uitgaat om te participeren en invloed uit te oefenen op het ondernemingsbeleid, moet naar behoren geformuleerd zijn en mag niet volledig degenen die haar niet kunnen aanvaarden uitsluiten van de mogelijkheid tot behartiging van hun eigen belang.

3 Medezeggenschap inxake veiligheids- en gezondheidsaangelegenheden in internationale regelingen

Niet alleen nationale wetgevers, maar ook internationale gouvernementele en niet-gouvernementele (20) organisaties pleitten voor opname van participatierechten in wetgeving, of deden aanbevelingen waaraan wetgeving zou moeten voldoen. Met name vanuit de International Labour Organization (ILO) zijn verdragen, aanbevelingen en 'model codes' (21) voortgekomen, die de bescherming van de veiligheid en gezondheid van werknemers

18. Vgl. A.W.M. Teulings, Prominenten en volgers, Tijdschrift voor arbeidsvraagstukken, 1(1985)1, p. 51 ev.

19. A.W.M. Teulings, Ondernemingsraadspolitiek in Nederland, een onderzoek naar de omgang met macht en conflict door de ondernemingsraad, Amsterdam, 1981.

20. O.m. World Conference on Safety and Health and the Workin-environment, georganiscerd door de internationale federatie van chemie, energie en fabrieksarbeidersbonden, Geneva, 1974.

21. ILO-verdragen zijn bindend voor de Lid-Staten die ze hebben geratificeerd, aanbevelingen hebben geen bindende werking. Leden van de ILO zijn echter ook voor wat betreft de aanbevelingen onderworpen aan de toezichtsprocedure van het ILO-verdrag. De 'model codes' hebben louter advieswaarde. 
als object hadden. In een aantal hiervan worden participatie-instrumenten voorgesteld (22).

Het Europees Sociaal Handvest bevat pas sedert kort bepalingen met betrekking tot medezeggenschap op ondernemingsniveau. Aanvankelijk was er slechts artikel 3 ESH aangaande het recht op veillige en hygiënische arbeidsomstandigheden, dat voorschrijft dat de overeenkomstsluitende partijen zich verbinden tot het uitvaardigen van wettelijke voorschriften inzake veiligheid en hygiène, en voor de naleving daarvan door controlemaatregelen zorg te dragen. Daarnaast moest zonodig overleg gepleegd worden met organisaties van werkgevers en werknemers omtrent maatregelen die bedoeld zijn om bedrijfsveiligheid en -hygiëne te verhogen. Uit dit laatste kan men hooguit een verplichting tot consultatie voorafgaand aan wetgeving destilleren.

Recentelijk zijn medezeggenschapsrechten door middel van een Protocol aan het ESH toegevoegd (23). Deze rechten zijn o.m. het recht van werknemers op informatie en consultatie (artikel 2), en het recht om deel te nemen in de beslissing over en de verbetering van de arbeidsomstandigheden en de werkomgeving (artikel 3) (24).

Ook de Europese Gemeenschap, voor veel Europese landen een organisatie van directer belang, heeft gepoogd tot de regulering van en harmonisatie van medezeggenschap op (bovennationaal) ondernemingsniveau te komen. $\mathrm{Zij}$ heeft daartoe twee invalshoeken gekozen. De eerste pogingen, de ontwerp verordening voor een Europese vennootschap (Statuut SE) (25) en het ontwerp vijfde richtlijn (26) gingen uit van een institutionele invalshoek. De bedoeling van beide voorstellen was medezeggenschapsorganen te institutionaliseren in de vennootschapsrechtelijke structuur. In het eerste voorstel moest dat door de creatie van een Europese vennootschap, het tweede betrof een voorstel binnen het kader van de harmonisatie van de vennootschapsregelgeving. Het latere Vredelingvoorstel (27) verliet de institutionele invalshoek en stelde het instrumentarium en de onderwerpen warover medezeggenschap moest plaatsvinden voorop. Geen van de drie woorstellen haalde overigens de eindstreep.

22. Van het uitgebreide scala wan verdragen en aanbevelingen op gebied zijn met name Verdrag no. 155 en Aanbeveling no. 164 concerning occupational safery and health and the working environment, van belang die op de $67 \mathrm{ste}$ International Labour Conference werden aangenomen. Voor een overzicht tot 1981 zie: Conventions and Recommandations, 1919 1981, 1LO, Geneva 1981.

23. European Treaty Series, no. 128.

24. Zie L. Betten, Het Europees Sociaal handvest, Europa's stiefkind, NJCM-bulletin 1988 (135), p. 446, ook L. Betten, The Protocol to the European Social Charter: more Rights a better impact? Netherlands Quarterly of Human Rights, vol. 6 (1988) p. 9 ev. Zie ook: Verslag Comite van Ministers aan de raadgevende vergadering, Doc. 5538,1985 , p. 30 ev.

25. Pb. 1970 C 124, laatste gewijzigd voorstel COM (89) 268 def.

26. $\mathrm{Pb} .1972, \mathrm{C} 131$, laatste gewijzigd voorstel $\mathrm{Pb} .1983$, C $240 / 2$.

27. Pb. 1980 C 279, laatste gewijzigd woorstel Pb 1973 C 217. 
Met betrekking tot veiligheids- en gezondheidsaangelegenheden kwam er van Gemeenschapswege meer van de grond. Sedert de invoering van de Europese Akte (28), in juli 1987, is an het EEG-verdrag een artikel (118A) toegevoegd dat een rechtsgrondslag biedt voor het nemen van minimummaatregelen op het gebied van de bescherming van veiligheid en gezondheid van werknemers. Dit artikel biedt ruimere mogelijkheden tot regelgeving voor een gebied waarop de gemeenschap zich al eens bewoog: sedert 1977 waren al enkele richtlijnen (29) op het gebied van veiligheid en gezondheid tot standgekomen, waarvan er éen een medezeggenschapsparagraaf bevatte (30).

De regelgeving van de Europese Gemeenschap bindt de aangesloten staten in beginsel niet méér, dan de verdragspartijen door eerdergenoemde verdragen gebonden worden. Maar doordat op de handhaving veel beter kan worden toegezien, is het effect van de verplichtingen op basis van gemeenschapsregels groter. Dit komt mede doordat burgers zelf, meer dan bij verdragsverplichtingen, in bepaalde gevallen die naleving kunnen afdwingen.

Overigens is harmonisatie van medezeggenschap door de Europese Gemeenschap nog steeds niet onomstreden. De voormalige minister van sociale zaken De Koning stelde nog in 1988 dat harmonisatie van medezeggenschap, ook in het licht van de voortschrijdende integratie en de voltooiing van de interne markt, nodig noch wenselijk is (31). Hij meent dat er economisch geen dringende reden voor aanwezig is; een negatieve invloed van de huidige medezeggenschapsregeling op de concurrentiepositie van in Nederland gevestigde bedrijven ten opzichte van het buitenland is nooit aangetoond en niet waarschijnlijk (32). Bovendien stelde De Koning dat het sociaal gezien van belang kan worden geacht dat historisch gegroeide medezeggenschapsstructuren in stand blijven en hun eigen ontwikkeling volgen. Hij sluit daarbij overigens niet uit dat de behoefte kan ontstaan aan aanvullende Europese regelgeving met betrekking tot grensoverschrijdende activiteiten van multinationale ondernemingen.

28. De Europese Akte (Luxemburg 1986/"s-Gravenhage 1986, Trb 1986 63, Pb. 1987 L 169 is een verdrag tussen de lid-staten van de EEG dat mede wijziging vam het $\mathbb{E E G}$-verdrag ( 25 maart 1957, Trb 1957, 74 en 91) ten doel had. Het verdrag is in werking getreden op 1 juli 1987, Trb 1987, 118, Pb. 1987 L 169.

29. Zo xijn te noemen: RI $77 / 187$ EEG, Pb. 1977 L 2, veiligheids-maatregelen op de werkplaats, Rl. 78/610, Pb. 1978 L 197, bescherming van werknemers die alan vinylchloridemonomeer zijn blootgesteld, en de tot dusver belangrijkste RI 80/1107, Pb. $1980 \mathrm{~L} 225$, raamrichtlijn betreffende bescherming wan werknemers tegen de risico's van blootstelling aan chemische, fysische em biologische agentia op het werk. Op basis van deze richtlijn zijn bijzondere richtlijnen tot stand gekomen voor een beperkt aantal agentia.

30. Artikel $6 \mathrm{Rl} .80 / 1107$.

31. Rede gehouden door de minister van sociale zaken op een conferentie in Doorm, Staatscourant, 26 augustus 1988 , no. 165.

32. Anders: J van Wulfften Pallthe, Industriële medezeggen-schapsrechten in rechtsvergelijkend werband, Eindhoven 1986, pp. 2, 457, 508 . 
Schrijvers als Shanks (33) en Smuraglia (34), daarentegen hebben al sedert het midden van de jaren zeventig gepleit voor een regeling op Gemeenschapsniveau, waarbij er een mogelijkheid is voor werknemersmedezeggenschap inzake veiligheids- en gezondheidsaangelegenheden. $\mathrm{Zij}$ menen dat moderne inzichten en een groeiend verband tussen industriële demokratie en veiligheids- en gezondheidsaangelegenheden, ook de Gemeenschap zullen nopen zich met het vraagstuk van medezeggenschap bezig te houden.

Ook Gevers (35) vindt een communautaire regeling voor medezeggenschap in elk geval voor zover het veiligheid en gezondheidsaspecten betreft wenselijk. Hij baseert dit op drie argumenten: de sociale doelstellingen van de Gemeenschap, de werking van de gemeenschappelijke markt en een argument ontleend aan aan het beleid wan de gemeenschap terzake van de veiligheid en gezondheid bij de arbeid.

Ongelijkheid tussen zeggenschapsrechten staat volgens Gevers niet alleen op gespannen woet met de artikelen 2 en 117 EEG-verdrag, waarin de Gemeenschap zich verplicht te streven naar een verbetering van het levenspeil en het verkleinen van de verschillen hierin tussen de lid-staten, maar zou ook de concurrentieverhoudingen ongunstig kunnen beïnvloeden. Hoewel hij hierbij aantekent dat het moeilijk te zeggen is hoe groot het effect van verschillen in zeggenschapsregelingen is op de gemeenschappelijke markt, en dat er geen sprake is van een zodanige (potentiële) verstoring van de werking van die markt, dat daaraan voldoende argumentatie kan worden ontleend voor communautaire regelgeving, meent hij wel dat ook overwegingen met betrekking tot de gemeenschappelijke markt ondersteuning kunnen bieden voor de visie dat communautaire voorschriften wenselijk zijn.

Aan de argumentatie van de voorstanders van communautaire regulering valt nog wel het een en ander toe te voegen. De internationalisering van het bedrijfsleven schrijdt voort. Zij wordt met name door EEG-regelingen ter harmonisatie van het vennootschapsrecht (36) vergemakkelijkt. Door deze harmonisatie wordt de vestiging van ondernemingen in die lid-staten waar het klimaat in alle opzichten, en dus ook voor wat betreft de

33. M. Shanks, European Social Policy, today and tomorrow, Oxford 1977, p. 65.

34. Zie C. Smuraglia, La sicurrezza e l'ygiene del lavoro nella politica sociale della C.E.E., Rivista giuridica del lavoro e providenza sociale 1973, nr. 1, p. 76 .

35. J.K.M. Gevers, a.w. (noot 7), p. 271.

36. Inmiddels hebben zeven richtlijnen ter harmonisatie van het vennootschapsrecht het licht gezien (woor een overzicht: zie D. Lasok, The professions and Services in the European Economic Community, Deventer 1986 , p. 188-206) en is de discussie over een Europese vennootschapsworm na tien jaar in de koelkast te hebben gestaan, weer nieuw leven ingeblazen (zie P. VerLoren van Themaat, Europa 1992, en P. Roos, Europees Vennootschapsrecht, vestigingsvrijheid, zetelverplaatsing en IPR, en C.T. Dekker, Internationale fusie als titoefening van het recht op vrije vestiging in AA 38(1989)5, p. 323334; p. 382-390; p. 375-381). 
financiële zijde van de sociale aspecten het gunstigst is, steeds eenvoudiger. Ondernemingen krijgen de keuze om zich te vestigen, daar waar de lonen het laagst zijn, de vakbonden het zwakst en de medezeggenschap afwezig.

Het risico dat daarmee medezeggenschapsrechten in die lid-staten, die een goede wetgeving of praktijk worden uitgehold, is niet denkbeeldig. Ook het verzinnen van constructies door multinationals om de lid-staten met "lastige" medezeggenschapsregelingen of vakbonden te ontwijken zal gemakkelijker kunnen toenemen (37). Deze ontwikkeling leidde tot Jacobs "advies" aan werkgevers (38): "Ga mondiaal en gij zijt vrij. Ge overstijgt de kwellingen van vakbonden en medezeggenschap. Ge kunt $U$ losmaken van beknellende loonstructuren ontslagperikelen enz.".

Nationale vakbonden, maar ook nationale wetgevers staan tegen deze ontwikkeling machteloos. Vakbonden, omdat zij zich nog niet op bovennationaal niveau zodanig georganiseerd hebben dat zij een tegenmacht kunnen vormen; wetgevers omdat hun regelingen hoe mooi goed en goedbedoeld ook nu eenmaal nooit de nationale grenzen kunnen overschrijden. In Europa zou de Europese Gemeenschap hier, door middel van wetgeving, iets aan kunnen doen.

Anderzijds kan het argument dat medezeggenschap op nationaal niveau een nationale zaak is, en dat het een sociaal belang kan zijn deze historisch gegroeide en daardoor uitgebalanceerde medezeggenschapspraktijken niet te verstoren, met nieuwe uit "Brussel" opgedrongen elementen, niet zonder meer terzijde worden gesteld. Een opgedrongen regeling met meer rechten zou wel eens slechter kunnen uitpakken dan een gematigde regeling waar werknemersvertegenwoordigers en werkgever mee vertrouwd zijn, en waarin zowel de samenwerkingskant als de onderhandelingskant in thet grotere geheel van arbeidsverhoudingen passen. Een communautaire regeling zou als ongewenst vreemdeling in een nationaal systeem kunnen terechtkomen (39), en dientengevolge de status van dode letter kunnen krijgen.

Of een Gemeenschapsregeling wenselijk is en effect kan sorteren hangt daarom vooral af van de inhoud van die regeling. De mogelijkheden tot

37. Dat multinationals die neiging hebben blijkt wel uit het aantal Nederlandse vennootschappen die de structuur wan internationale holding met beperkte medezeggenschap hebben aangenomen. Een dergelijke holding kan vrijstelling van het structuurvennootschapsregime aanvragen, waardoor de mede-zeggenschap met betrekking tot de concerntop aanmerkelijk verzwakt. Inmiddel hebben onder meer Philips, Akzo en Elsevier een dergelijke structuur. Met betrekking tot de aanvraag van Douwe Egberts is een artikel 26 beroep van de Ondernemingsraad door de Ondernemingskamer afgewezen, omdlat de belangen van de COR in casu niet groot genoeg zouden zijn (OK 16 februari 1989, TVVS 1989, p. 104-106).

38. A.T.J.M. Jacobs, De ondermijning van het sociaal recht, Sociaal Recht 1989-2, p. 39.

39. Zoals gebeurde met de Richtlijn ter bescherming van werknemers bij collectief ontslag (RI. $75 / 129, \mathrm{~Pb} .1975 \mathrm{~L} 48$ ) in Groot Brittanië, waarin informatierechten werden toegekend aan de werknemersvertegenwoordigers, die echter door de werkgever eenzijdig kunnen worden aangewezen. Zie B. Hepple, a.w. (noot 1), p. 86. 
uitvoering en inpassing van de regeling in het bestaande systeem, en de keuze van instrumenten is van het grootst mogelijke belang voor de kans orn tot acceptatie door én in de lid-staten te leiden. Een regeling zou zonder meer acceptabel zijn als het een absolute minimumregeling zou zijn, waartegen geen enkele lid-staat iets kan hebben omdat hij niets nieuws, niets schokkends en niets modificerends bevat, ook niet waar dat wel nodig zou zijn. Harmonisatie is echter meer dan een technische operatie, het is een proces van wetgeving (40) waarbij wel degelijk beleidsafwegingen moeten worden gemaakt. Acceptatie door de lid-staten is één van die afwegingen, naast andere, zoals de afwegingen in het kader van de gemeenschappelijke markt, en sociaal-politieke afwegingen. Bij die laatste soort zal ook de Gemeenschap zich moeten buigen over de vraag hoe zij de verhouding tussen werkgever en werknemers ziet en wil zien.

4 Probleemstelling, afbakening van het onderzoeksgebied en verantwoording van de onderzoeksmethode

De probleemstelling van dit onderzoek luidt als volgt: Is het wenselijk en mogelijk om, gezien het in de lid-staten bestaande instrumentarium voor beleidsbeïnvloeding in de onderneming inzake veiligheids- en gezondheidsaangelegenheden op communautair niveau een regeling te maken, die voorziet in mogelijkheden voor deelneming aan de besluitvorming op alle ondernemingsniveaus, waarbij de kans dat deze bruikbaar is voor alle werknemers groot is.

Om tot een antwoord op deze vraag te komen moeten de volgende deelvragen worden beantwoord:

- Wat is de politiek van de Gemeenschap tot dusver op het gebied van medezeggenschap (zowel ten aanzien van regelingen die binnen de nationale grenzen werken, als voor multinationale ondernemingen) geweest?

- Wat voor soort vertegenwoordigingssystemen kennen de lid-staten, en welke positie neemt individuele werknemer daarin in?

- Over welk instrumentarium beschikken vertegenwoordigers in het algemeen en meer in het bijzonder op veiligheids- en gezondheidsgebied?

- Welk beleid volgt de Gemeenschap op veiligheids- en gezondheidsgebied?

- Zou een gemeenschappelijke regeling inzake veiligheids- en gezondheidsaangelegenheden ook ook in medezeggenschap in multinationale ondernemingen kunnen voorzien?

De belangrijkste vraag in dit geheel is de vraag naar het instrumentarium van de werknemersvertegenwoordigers. Een regeling voor medezeggenschap

40. Zie: C.W.A. Timmermans, Harmonisatie van wetgeving en Nederlands recht: beeld van bewogen beweging, R.M. Themis 4/5 1980, p. 411. 
op Europees niveau, zal mijns inziens eerder uit moeten gaan van instrumentele dan van institutionele elementen. Om tot een medezeggenschapsregeling op communautair niveau te komen kan men niet om de in de lid-staten bestaande praktijken heen; inspiratie zal juist geput moeten worden uit die praktijken (41). Hiermee wil ik niet zeggen dat gemeen schapsregulering opgebouwd moet zijn uit die elementen die de lid-staten gemeenschappelijk hebben, of zoals Gevers verdedigt (42) dat de Gemeenschap zich in de door haar vast te stellen richtlijn moet beperken tot gemeenschappelijke principes, waarmee de lid-staten rekening hebben te houden. Juist door bestudering en vergelijking van de bestaande praktijken en het daarbij gehanteerde instrumentarium in de lid-staten, kan men tot een communautaire regeling komen die veel meer inhoudt dan een formulering van gemeenschappelijke principes. Daarvoor is een zekere abstrahering nodig van het instrumentarium zoals dat in de verschillende wettelijke regelingen voorgeschreven is, of in de praktijk gegroeid is. Deze abstrahering betekent dat een instrument uit zijn ideologische achtergrond zal moeten worden gelicht en op zijn merites bekeken zal moeten worden. Op deze wijze kan het worden vergeleken met instrumenten in andere lidstaten. In een volgende paragraaf zal ik hier nog op ingaan.

Het onderzoek beperkt zich, tot op zekere hoogte tot medezeggenschapsinstrumenten voor het gebied van veiligheids- en gezondheidsbescherming van werknemers. Niettemin zal veel van wat daarover te zeggen valt, gelijkelijk toepasbaar zijn voor medezeggenschap met betrekking tot het ondernemingsbeleid in het algemeen. Omgekeerd hebben instrumenten die werknemers worden geboden ten aanzien van het algemene ondernemingsbeleid hun weerslag op de regels die specifiek voor veiligheid en gezondheid gelden. Het is dan ook de bedoeling om medezeggenschap bij het algemene ondernemingsbeleid te behandelen als algemeen kader voor het instrumentarium bij veiligheids- en gezondheidsbeleid, en meer in het bijzonder voor zover het van belang is voor dit laatste gebied.

Een andere beperking ligt in het soort medezeggenschap waaraan ik het onderzoek zal wijden. Men kan een onderscheid maken tussen werknemersparticipatie in het bestuur of in toezichthoudende organen als een raad van toezicht of een raad van commissarissen en medezeggenschap door middel van werknemersvertegenwoordigers die, eventueel verenigd in een $\mathrm{min}$ of meer zelfstandig orgaan, samenwerken of onderhandelen met de werkgever. Het instrumentarium dat aan de laatste soort van medezeggenschap verbonden moet worden is voorwerp var dit onderzoek. De eerste soort van zeggenschap zal slechts besproken worden in verband met voorstellen tot gemeenschapsregulering, aangezien daar de invloed van eerder gedane voorstellen in verband met werknemersparticipatie in raden van toezicht op

41. Zie ook O. Kahn-Freund, Common law and and civil law, imaginary and real obstacles to assimilation, in New Perspectives for a Common Law in Europe, Loydan 1987 p. 164-168

42. J.K.M. Gevers, a.w. (noot 7), p. 290. 
de discussie omtrent medeggenschap in het algemeen onmiskenbaar aanwezig is geweest.

De methode van het onderzoek is in hoofzaak de rechtsvergelijking. Deze rechtsvergelijking concentreert zich op het instrumentarium van de werknemersvertegenwoordigers in de verschillende lid-staten, en de positie van de individuele werknemer ten opzichte van het medezeggenschapssysteem. Om deze vergelijking enigszins relief te geven is een eerste vergelijkend hoofdstuk gewijd aan de soorten van vertegenwoordigers en de wijze waatop zij in de onderneming verkozen worden. De bedoeling van het onderzoek was oorspronkelijk een vergelijking tussen de systemen van de twaalf EG lid-staten. Helaas bleek dit onmogelijk. Hoewel van Portugal nog te achterhalen was wat er voor soort vertegenwoordigers op ondernemingsniveau zijn, heb ik dit land bij de vergelijking van het instrumentarium dat de vertegenwoordigers ter beschikking staat moeten uitzonderen. Er was niet voldoende materiaal in een voor mij beheersbare taal voorhanden om een verantwoorde beschouwing te geven.

Niet iedere lid-staat wordt in de vergelijking even uitgebreid behandeld. Dit heeft om te beginnen te maken met het taalprobleem. Voor een aantal landen heb ik mij moeten behelpen met vertaalde bronnen. Daarnaast heb ik gepoogd de beschrijving van de praktijken in de verschillende lid-staten zoveel mogelijk te beperken tot de saillante eigenschappen van die praktijken. Tenslotte zijn enkele landen meer uitgesproken behandeld omdat ik ze uiteindelijk voor het resultaat belangrijker achtte dan andere. Zo is de behandeling van Luxemburg vrij beperkt gebleven.

Naast de vergelijking van het instrumentarium is hier en daar aangegeven hoe dit instrumentarium werkt in de praktijk. Hier ben ik op het probleem gestuit dat ik gebruik heb moeten maken van bestaand onderzoek. De meeste sociologische onderzoeken naar de praktijk van medezeggenschap inzake veiligheid en gezondheid in de lid-staten van de Gemeenschap dateren echter uit eind jaren zeventig, begin jaren tachtig. De situatie in een aantal landen is, in elk geval voor zover het de wetgeving betreft, sedertdien vrij sterk gewijzigd, zodat de resultaten van deze onderzoeken niet per definitie meer geldend zijn. Deze oudere onderzoeken heb ik dan ook gebruikt, woor zover ik deze in later, zij het vaak partiëel, onderzoek bevestigd zag. Dit betekent concreet dat van een aantal lid-staten over de werking in de praktijk zonder nader onderzoek praktisch niets te zeggen valt.

De laatste wraag, die betrekking heeft op de multinationale medezeggenschap wordt, zoals al uit de inleiding bleek, steeds belangrijker. Dit geldt evenzeer voor medezeggenschap inzake veiligheids- en gezondheidsaangelegenheden als voor andere (economische of sociale) aangelegenheden. Het is hierom dat dit onderzoek zich niet alleen zal bezighouden met de pure harmonisatie van medezeggenschapsinstrumenten binnen de grenzen van de lid-staten, mar ook zal ingaan op de mogelijkheid tot communautaire 
regelegeving waardoor dit instrumentarium ook grensoverschrijdende medezeggenschap kan opleveren.

\subsection{Het instrumentarium van vertegenwoordigers op ondememingsniveau}

Rechten, waarmee invloed uitgeoefend kan worden op het beleid van een onderneming, kunnen zowel bij wet aan werknemers of hun vertegenwoordigers zijn toegekend als in de praktijk door werknemers of vakbonden zijn verworven, en eventueel later door wettelijke bepalingen ondersteund zijn. Al deze rechten, waarvan sommigen aan elkaar verwant zijn, zullen hier tot het instrumentarium van medezeggenschap van werknemers worden gerekend. Deze instrumenten zijn te onderscheiden naar sterkte. Het criterium daarvoor is gelegen in de mate waarin de werkgever belemmerd wordt zelfstandig en eenzijdig een besluit te nemen, of een beleid vast te stellen. Kan de werkgever dit niet dan is er sprake van een gezamenlijke beslissingsbevoegdheid van de werkgever en de werknemersvertegenwoordigers en is er dus sprake van een zeer sterk instrument.

Het recht op informatie kan als zelfstandig recht worden gezien, maar ook als voorwaarde voor de andere medezeggenschapsrechten gelden (43). Zonder informatie kunnen immers instrumenten als het geven van advies of instemming niet worden benut. Echter op zichzelf zal een verplichting tot het verstrekken van informatie, zeker als de mogelijkheid tot het uitlokken daarvan door werknemers bestaat, het ondernemingsbeleid eveneens beïnvloeden. Dat is de reden waarom het als een zelfstandig instrument hier behandeld zal worden.

Het recht om geconsulteerd te worden houdt in dat de werkgever verplicht is alvorens een besluit te nemen de werknemersvertegenwoordigers om advies te vragen, zonder dat dit advies hem bindt tot het nemen van een bepaald besluit. Het adviesrecht kan een meer of minder zware vorm aannemen, bijvoorbeeld doordat het afwijken van het advies onderworpen is aan voorschriften met betrekking tot motivering, arbitrage of beroep.

Het recht met de ondernemer een overeenkomst af te sluiten gaat een stap verder. Enerzijds biedt het de werknemers, doordat niet over een concreet besluit hoeft te worden beslist, meer mogelijkheden om al onderhandelend tot een resultaat te komen, anderzijds zullen werknemers in die onderhandelingen compromissen moeten sluiten over hun standpunt. $\mathrm{Zij}$ zullen echter ook met het resultaat moeten instemmen, anders komt er geen overeenkomst. Er is dus evenals bij het toegekende instemmingsrecht, een recht om mee te beslissen. Dit geldt echter alleen als er een verplichting is tot een overeenkomst te komen. Is deze er niet en kan de werkgever na het mislukken van de onderhandelíngen, alsnog eenzijdig een besluit nemen dan kan niet gesproken worden van een gezamenlijke beslissingsbevoegdheid. In

43. A.J.C.M. Geers, a.w. (noot 11), p. 12. 
dat geval is het recht een overeenkomst af te sluiten weliswaar meer dan een recht op consultatie (afhankelijk van de sanctiemogelijkheden van de werknemerswertegenwoordigers) maar minder dan een recht op instemming.

Het instemmingsrecht met bepaalde besluiten of bij de vaststelling van een beleid, gaat nog een stap verder: hier is de werkgever wel gebonden aan de opinie van de werknemersvertegenwoordigers. De waarde van dit recht hangt eveneens samen met een geschillenregeling: is er een orgaan dat vervangende toestemming kan geven, is er een gewone arbitrageregeling of een beroepsrecht aan verbonden?

Over de vraag of het (wettelijk) recht op instemming en het recht op collectief onderhandelen vergelijkbaar zijn kan men twisten (44) . Ik kan mij voorstellen dat ze in het algemeen onvergelijkbaar blijken te zijn. Wanneer men de vergelijking beperkt tot de onderhandelingsrechten van vertegenwoordigers op ondernemingsniveau wordt dit echter al anders. Dan lijken de beide rechten meer op elkaar dan men in eerste instantie zou denken. Het onderhandelingsrecht kan tot het sluiten van compromissen leiden. Werknemersvertegenwoordigers kunnen tijdens die onderhandelingen de keus krijgen tussen een, in hun ogen matig, besluit of geen besluit waarbij ze in hun besluitvorming uit moeten gaan van het: iets is beter dan niets. Het instemmingsrecht, dat in zuivere vorm, weinig ruimte voor voor onderhandelingen biedt, kan zelf als onderhandelingsinstrument gebruikt worden (45), waarbij de werkgever mogelijk besluiten krijgt opgedrongen die hij liever niet of anders zou hebben gezien. De verschillen tussen het instemmingsrecht en het recht om overeenkomsten af te sluiten op ondernemingsniveau zijn gradueel en hangen af van de sanctiemogelijkheden, de machtsverschillen in de onderneming en de wijze waarop de actoren er gebruik van maken. De verschillen zijn niet inherent aan de rechten op zichzelf.

Het recht op inspectie behelst het recht van werknemers of hun vertegenwoordigers toezicht te houden op de uitvoering van wettelijke regels en beleidsvoornemens. Het recht wordt versterkt indien er mogelijkheden zijn om (onafhankelijke) deskundigen te raadplegen, die de door de werkgever verstrekte informatie kunnen toetsen, waardoor het toezicht door de werknemers meer inhoud krijgt. Ook hier zijn geschillenregelingen medebepalend voor de inhoud van het recht: indien bij inspectie blijkt dat de bewuste regels niet nageleefd worden zijn de bevoegdheden en de verplichtingen van de autoriteiten van belang.

44. Zie: J.K.M. Gevers, a.w. (noot 7), p. 266-267; J. van der Wulfften Palthe maakt in Industriele medezeggenschapsrechten in rechtsvergelijkend verband, Eindhoven 1986 een zeer strikt onderscheid tussen de wettelijke medezeggenschapsrechten en de rechten in verband met collectieve onderhandelingen, hetgeen er op wijst dat hij ze kennelijk als onvergelijkbaar beschouwt.

45. Zie hierover A.W.M. Teulings, a.w.(noot 18), p. 51-64; ook A.W.M. Teulings, a.w. (noot 19). 
Ter ondersteuning van deze instrumenten zijn mogelijkheden nodig de rechten af te dwingen. Enkele van dergelijke mogelijkheden zijn al genoemd, waaronder de mogelijkheid van geschillenbeslechting door een arbiter of rechter. Voordat het zover komt, behoort met name in het arbeidsomstandighedenrecht veelal bemiddeling door min of meer onafhankelijke organen tot de mogelijkheden. Met deze organen worden bedoeld organen als deskundige diensten en uiteindelijk de arbeidsinspectie. De wijze waarop deze organen hun functie als conflictoplosser kunnen uitoefenen hangt zowel af van de hen toegekende bevoegdheden als van de rechten die werknemers ten opzichte van deze organen hebben.

Het laatste en ultieme instrument om beïnvloeding van het beleid af te dwingen is de mogelijkheid van directe sancties van werknemers. Hierbij wordt gedacht aan de mogelijkheid van stillegging van het werk door de werknemers als collectief, ofwel als recht geformuleerd in de veiligheids- en gezondheidswetgeving, ofwel als vrijheid tot staken.

Daarnaast is het instrumentarium van de individuele werknemers van belang. Hierbij moet gedacht worden aan een recht van werkweigering van de individuele werknemer in het geval de onstandigheden waarin hij werkt zodanig bedreigend zijn voor zijn veiligheid en gezondheid dat van hem in redelijkheid niet gevergd kan worden dat hij doorgaat met werken, maar ook aan een individueel klachtrecht.

Al deze instrumenten zijn op één of andere manier in de meeste lid-staten aanwezig, in hun eigen juridische en traditionele context. Wil men op gemeenschapsniveau keuzes maken tussen deze instrumenten dan zal daarmee rekening moeten worden gehouden. Dit betekent dat een communautaire regeling flexibel genoeg moet zijn om in meer dan één traditie te passen.

\section{Enkele begripsbepalingen}

\subsection{Medezeggenschap en medezeggenschapsinstrumentarium}

Medezeggenschap, het woord zegt het al, gaat het om het recht in de onderneming mee te mogen spreken om op deze wijze het belleid of de besluitvorming in een onderneming te beïnvloeden. Die beïnvloeding kan geschieden door bovengenoemde instrumenten, maar bijvoorbeeld ook door overleg. Wachter (46) meent overigens dat wanneer alleen van informatie en overlegrechten sprake is, het onjuist is over medezeggenschap te spreken.

46. B. Wachter, Ontwikkelingen op het gebied van de medezeggenschap, mede in Europees verband, Geschriften voor de vereniging voor arbeidsrecht, no. 3, Alphen a/d Rijn 1980, p. 11. 
Geers (47) definieert zeggenschap als "alle mogelijkheden die werknemers kunnen aamwenden om op een of andere wijze de gang van zaken te beïnvloeden", en perkt dit begrip in door een aantal zeggenschapsrechten concreet te noemen. In dit boek zou ik de beperking willen leggen bij het boven beschreven instrumentarium voor werknemersvertegenwoordigers. Medezeggenschap kan in dit boek beschouwd worden als het beïnvloeden wan het ondernemingsbeleid met behulp van bovengenoemde instrumenten. Dat betekent niet alleen dat wettelijke instrumenten tot de medezeggenschapsinstrumenten behoren, maar ook het collectief onderhandelen door werknemersvertegenwoordigers op ondernemingsniveau.

\subsection{Veiligheid, gezondheid, arbeidsomstandigheden, arbeidsmillieu}

Het begrip arbeidsomstandigheden in de Nederlandse Arbowet kan ontrafeld worden in drie componenten: de klassieke begrippen bescherming van de veiligheid en gezondheid en bescherming van het welzijn (48). In wetgeving elders in Europa vindt men een vergelijkbare terminologie terug. De begrippen veiligheid en gezondheid komen praktisch overal voor. Voorts worden in de verschillende wetten specifieke begrippen gehanteerd zoals "welfare", arbeidshygiëne, en arbeidsmilieu. Deze laatste term is ook te vinden in artikel 118A EEG-verdrag. Voor wat betreft deze specifieke terminologie wilde $\mathrm{ik}$ aansluiten bij de in het bewuste land gebruikelijke definities. De definiëring daarvan komt, waar nodig, aan de orde bij de bespreking ervan in de tekst.

De begrippen veiligheid en gezondheid zijn in de Europese wetgeving veruit de meest voorkomende en de meest belangrijke. Deze begrippen zijn aan elkaar gerelateerd, hoewel ze elkaar niet geheel overlappen. Veiligheid heeft betrekking op fysieke veiligheid, het beschermd zijn tegen aantasting van de gezondheid tegen fysiek gevaar. Men denkt hier al gauw aan fysieke schade en arbeidsongevallen door onveilige installaties, gezondheidsschade door het op onvoldoende veilige wijzen werken met en verwerken van gevaarlijke stoffen.

Bij de bescherming van de gezondheid gaat het in ieder geval om bescherming van de fysieke gezondheid, die door de omstandigheden waaronder gewerkt wordt schade kan leiden. Naast schade veroorzaakt door onveilige situaties moet men denken aan omstandigheden die op zich zelf geen direct gevaar opleveren maar die op den duur wel schade kunnen berokkenen. Over de vraag in hoeverre ook psychische gezondheid deel uitmaakt van het begrip, kan men twisten. Uit het Europees Sociaal Handvest valt niet af te leiden dat het daarin voorziene recht op bescherming van de gezondheid ook psychische gezondheid omvat, evenmin als uit

47. A.J.C.M. Geers, a.w. (noot 11), p. 12.

48. De considerans van de Nederlandse Arbowet spreekt daarnaast nog van "arbeidsomstandigheden in het algemeen" als vierde, maar aangezien de wetgever met dit begrip niets doet, en het elders ook niet gebruikt wordt zal ik het dus maar laten liggen. 
het recht op veilige en hygiënische arbeidsomstandigheden. In de klassieke definitie van de World Health Organization, echter, wordt het begrip omschreven als een staat van sociaal, geestelijk en lichamelijk welzijn. Discussies bij de totstandkoming van verschillende nationale wetten, zoals de Nederlandse Arbowet maken duidelijk dat gezondheid ruim moest worden gezien (49). De Deense Arbejdsmiljo/lovet (wet op de arbeidsomsgeving) gebruikt de definitie van de World Health Organization, terwijl de Griekse wet van 1985 het begrip weliswaar niet definieert, maar bedrijfsartsen wel opdraagt te adviseren op het gebied van de psychologische aspecten van het werk in relatie tot de gezondheid (50). Er lijkt dus genoeg aanleiding om in dit boek een ruime definitie te hanteren.

\subsection{Werknemer en randgroepwerknemer}

Het begrip werknemer heeft vooral belang voor de bescherming die men aan de status van werknemer kan ontlenen. Die bescherming is afhankelijk van de wettelijke regeling die in die bescherming voorziet. In dit boek wil ik aansluiten bij de definitie van werknemer zoals die in de verschillende nationale wettelijke regelingen gehanteerd wordt. Tussen de verschillende definities zijn overigens grote overeenkomsten. In het algemeen wordt in de EG lid-staten een arbeidsovereenkomst of arbeidsverhouding gekoppeld aan de elementen van gezag, vergoeding en prestatie. Werknemers zijn in elk geval diegenen die op arbeidsovereenkomst of in een dergelijke arbeidsverhouding werkzaam zijn, en voorts diegenen die zonder arbeidsovereenkomst onder het gezag werkzaam zijn maar die onder het toepassingsbereik van de voor dit proefschrift van belang zijde wetten vallen. Degenen die met het bestuur of de leiding van een onderneming belast zijn, ook al werken zij op arbeidsovereenkomst zijn van deze definitie uitgezonderd.

Naast werknemers introduceer ik een aparte categorie namelijk de randgroepwerknemers. Het woord randgroep (51) wordt veelal gebruikt in de combinatie randgroepjongere waarmee bedoeld wordt: de jongere die aan de zelfkant van de maatschappij leeft. Het begrip randgroepwerknemer zou ik het willen definiëren: de werkende die geheel of gedeeltelijk buiten de bescherming van het arbeidsrecht (en medezeggenschapsrecht) valt (ook weer niet zijnde leidinggevende of bestuurder). Deze categorie valt niet volstrekt duidelijk af te bakenen en verschilt per land. Eronder kunnen vallen, diegenen die hoewel zij voor een onderneming werken een onduidelijke status hebben binnen de voor dit boek van belang zijnde arbeidsrechtelijke wetgeving. Men kan hierbij denken aan personen met

49. Advies Raad van bestuur in Arbeidszaken, 19 september 1977, p. 4. Zie TK. 1977-78, 14 497 mo. 4 pp. $5,9,10$.

50. Engelse tekst van Wet 1568, EIRR 144, January 1986.

51. Alg. betekenis: bevolkingsgroep die op het bestaansminimum leeft. 
flexibele contracten, maar ook aan aan thuiswerkers, telewerkers en in sommige landen partimers, tijdelijke en ingeleende arbeidskrachten (52).

\subsection{Onderneming, andernemer en werkgever}

De begrippen onderneming, ondernemer en werkgever worden in het medezeggenschapsrecht en het arbeidsomstandighedenrecht door elkaar gebruikt, en kunnen aanleiding geven tot verwarring.

OHet begrip onderneming wordt in deze studie gebruikt als: "elk in de maatschappij als zelfstandige eenheid optredend organisatorisch verband, waarin krachtens arbeidsovereenkomst arbeid wordt verricht". Deze definitie ontleend aan de Nederlandse Wet op de Ondernemingsraden heeft het voordeel dat hij zo ruim is dat filialen, bijkantoren, afhankelijke dochterondernemingen er ook onder vallen. Voor ondernemingen in de vorm van complexe organisaties met verschillende vertakkingen zal, voor dat hogere niveau, de term concern of holding gebezigd worden. De termen ondernemer en werkgever zal ik in dit boek door elkaar gebruiken. Bedoeld wordt: de persoon die, of het orgaan (bestuur) dat de beslissingen neemt terzake waarvan werknemers de bovengenoemde medezeggenschapsinstrumenten kunnen gebruiken.

Opbouw van het boek

$\mathrm{Na}$ dit inleidende hoofdstuk zal de focus eerst op de het beleid en de regelgeving van de Europese Gemeenschap ten aanzien van medezeggenschap gericht worden. De plaats van de sociale politiek en medezeggenschap in het gemeenschapsrecht, de harmonisatie van sociale wetgeving en de mogelijkheden van verruiming van vormen en middelen op nationaal niveau komen hierbij aan de orde. De ontwikkeling van het sociaal beleid van de gemeenschap met name waar het werknemersbescherming betreft zal worden beschreven en in die context worden geplaatst.

Het derde hoofdstuk geeft een beschrijving van de verschillende vertegenwoordigingssystemen in de lid-staten. Het geeft enig idee

welke vertegenwoordigers er in de ondernemingen van de lid-staten zijn, op welke wijze deze vertegenwoordiging is gereguleerd en wat de rechtsgrondslagen zijn. Speciale aandacht wordt ook geschonken aan de vraag wat de criteria zijn om als vertegenwoordiger te kunnen worden gekozen.

Het vierde hoofdstuk is rechtsvergelijkend van karakter en zal het informatie-, het consultatie- en het instemmingsrecht in de verschillende lid-

52. Zie i.h.a. Y. Kravaritou-Manitakis, New Forms of Work: Labour Law and Social Security Aspects in the European Community, Luxemburg 1988; Voor een overzicht van van vage contracten EIRR 1989, no. 182, en EIRR 1988, no. 179, voor Nederland: Y Konijn, Afroepcontractanten en het recht op loon, SMA 1985, p. 805 ev; O. Albers, Y. Konijn, Losse en flexibele arbeidsrelaties, Alphen a.d. Rijn 1987; C.J. Smiltskam, Flexibele arbeidsrelaties, Deventer 1989. 
staten in het algemeen behandelen, en de context waarin zij zich bevinden. De nadruk bij de behandeling ligt op de wijze waarop deze instrumenten kunnen worden gebruikt inzake veiligheids- en gezondheidsaangelegenheden. Daarnaast wordt bekeken in hoeverre hogere regelingen het gebruik van het instrumentarium van de vertegenwoordigers kunnen beperken of uitbreiden. Voorts wordt aandacht besteed aan de mogelijkheden tot geschillenbeslechting en directe sancties.

Het vijfde hoofdstuk is toegespitst op die medezeggenschapsinstrumenten die inzake veiligheids- en gezondheidsaangelegenheden van bijzonder belang zijn. Hier komen ook de specifieke instrumenten die gericht zijn op bescherming van de veiligheid en gezondheid aan de orde als de rol van deskundige diensten en arbeidsinspecteurs aan de orde. Aan de hand van de in dit en in het vorige hoofdstuk gemaakte vergelijkingen zullen in het zesde hoofdstuk criteria worden opgesteld waaraan een Europese medezeggenschapsregeling moet voldoen.

In het zesde hoofdstuk zal voorts het beleid van de Europese Gemeenschap met betrekking tot arbeidsomstandigheden aan de orde komen. De consequenties van het nieuwe artikel $118 \mathrm{~A}$, zowel materieel als institutioneel zijn daarbij van belang. Bestaande richtlijnen en bij de Raad van Ministers ingediende richtlijn-voorstellen zullen aan de opgestelde criteria worden getoetst.

Het laatste hoofdstuk zal concluderende beschouwingen bevatten, omtrent de mogelijkheden van gemeenschapsregulering op een zowel voor de lidstaten acceptabel als voor werknemers bruikbaar niveau. Voorts wordt een concept voor een richtlijnvoorstel gegeven op basis van de uit de wetgeving gedestilleerde critera. 



\section{Sociaal beleïd en medezeggenschap in de Europese Gemeenschap; plaatsbepaling en inventarisatie.}

\section{Inleiding.}

In het oprichtingsverdrag wan de Europese Economische Gemeenschap (1), werd onder meer als doelstelling een toenemende verbetering van de levensstandaard opgenomen. Een van de middelen om die verbetering te bereiken was het instellen van een gemeenschappelijke markt, die naast de instelling van een douane-unie en enkele geheel gemeenschappelijke beleidsterreinen, de verwijdering van hinderpalen voor het vrije verkeer van personen diensten en kapitaal omvatte (2).

De artikelen die het vrij personenverkeer handen en voeten geven, voorzien in een uitwerking van het algemene discriminatieverbod van artikel $7 \mathrm{EEG}$ verdrag dat voor de gehele werkingssfeer van het verdrag geldt en die bestaan uit een vrij verkeer van werknemers en een recht van vrije vestiging. Het vrij verkeer van werknemers (artikel 48 ev.) omvat een discriminatieverbod tussen werknemers van de verschillende lid-staten, voor wat betreft werkgelegenheid, de beloning en de overige arbeidsvoorwaarden, behoudens uitzonderingen in verband met de openbare orde, veiligheid en volksgezondheid (3). Het discriminatieverbod van artikel 48 is rechtstreeks van toepassing. Niet alleen wettelijke en bestuursrechtelijke maatregelen mogen niet discrimineren maar ook bepalingen opgenomen in collectieve

1. Verdrag van 25 maart 1957, Trb. 1957, 74 en 91, gewijzigd en aangevuld door (voor zover van belang) het Verdrag van 8 april 1965 , Pb. $1967 \mathrm{~L}, 152 / 2, \mathrm{Trb} 1965,130$ en 1967,97 (Fusieverdrag); het besluit van de Raad (70/243 /EGKS, EEG, Euratom) van 21 maart 1970, Pb. 1970 L 94/19, Trb 1970, 109 (Eigen middelen Besluit); het Verdrag van 22 april 1972, Pb. 1971 L 2/1, Trb 1970, 110 en 1971, 14 (Eerste verdrag budgettaire bepalingen); het Verdrag van 22 juli 1975, Pb. 1977 L. 359/1, Trb. 1975, 124 en 1977, 88 (Tweede verdrag budgettaïre bepalingen); de Europese Akte 17 en 18 februari 1986, Trb 1986, 63.

2. Hierower in het algemeen: Dertig jaar Germeenschapsrecht, (m.m.v Rudolf Bernardt e.a.), Bureau voor Officiële Publikaties der Europese gemeenschappen, Luxemburg 1983.

3. Zie in het algemeen hierover $\mathrm{F}$. Burrows, Free Movement in Community Law, Oxford 1987, p. 117-179; G. Druesme, Liberté de Circulation des personnes. Les Prolongements de la libre Circulation des salariés: Droit de Sejour et de progres Social, 3 Revue Trimestrielle de Droit Europeenne 1982, $\mathrm{p}_{4} 556, \mathrm{H}$. ter Heide, The Free Movement of Workers in the Final Phase, Common Market Law Review (1968-9)6, p. 466. 
regelingen (4) vallen onder werkingssfeer van artikel 48 EEG-verdrag. Ten aanzien van ander privaatrechtelijk handelen en nallaten is de rechtstreekse toepassing van artikel 48 nooit uitdrukkelijk uitgesproken (5). De meeste lid-staten hebben bepalingen met betrekking tot discriminatie naar nationaliteit bij de toegang tot de arbeid in hun wetgeving opgenomen (6).

Naast rechten voor werknemers voorziet artikel 48 ook in het recht op verblijf nadat het werk beëindigd is. De bepalingen van artikel 48 zijn uitgewerkt in verschillende verordeningen en richtlijnen, die voorzover zij voor dit boek van belang zijn besproken zullen worden. Betrekkingen in overheildsdienst zijn van het vrij verkeer uitgezonderd; het Hof van Justitie der Europese gemeenschappen heeft deze uitzondering echter restrictief uitgelegd (7).

Bij de laatste verdragswijziging, door invoering van de Europese Akte (8), is bepaald dat na 1992 een interne markt tot stand moet zijn gekomen: een interne markt zonder binnengrenzen. De bepaling (artikel 8A) die de basis biedt voor de versnelde harmonisatie van wetgeving in verband met die interne markt, zal vermoedelijk door haar uitwerking, vooralsnog weinig invloed hebben op het vrij personenverkeer (9). Dit wordt in een latere paragraaf toegelicht (10).

Naast en ter ondersteuning van zowel het vrij werknemersverkeer als de in artikel 2 genoemde doelstelling kent het EEG-verdrag een hoofdstuk sociale politiek. In dit hoofdstuk staan bepalingen die onder meer voorzien in gelijke beloning voor mannen en vrouwen (artikel 119), handhaving van de gelijkwaardigheid van de bestaande bepalingen met betrekking tot betaalde vakantie (artikel 120), en een mogelijkheid tot delegatie voor de uitvoering van gemeenschappelijke maatregelen (m.n. inzake sociale zekerheid van migrerende werknemers) aan de Commissie (artikel 121).

Belangrijk zijn de bepalingen $117,118,118 \mathrm{~A}$ en $118 \mathrm{~B}$. In artikel 117 wordt de noodzaak erkend de verbetering van de levensstandaard en van de arbeidswoorwaarden van de werknemers te bevorderen en onderling tussen de lid-staten aan te passen "op de weg van de vooruitgang". Dit laatste is

4. Zaak 36/74, Jur. 1974, p. 1405 (Walrave-Koch).

5. Zie F. Burrows, a.w. (noot 5), p. 131.

6. Zie FIDE-report, The effect of Community Law on National Employment Law, Vol. 2, Thessaloniki 1988. Nederland heeft op dit gebied overigens geen expliciete bepaling (FIDE-reports, p. 263).

7. Zaak 152/73, Jur 1974, p. 153 (Sotgiu); zie ook zaak 225/85, Jur. 1987, p. 2625-2641, (Commissie vs Italië) waarin het als een verdragsschending beschouwd wordt dat Italië buitenlandse wetenschappelijk medewerkers uit EG-lid staten aan universiteiten in tegenstelling tot Italiaanse medewerkers cen vaste aantstelling weigert.

8. Zie noot 1 .

9. Zie hierover o.m. J. Stuyk, 1993, De Europese interne markt, de Lid-Staten, de marktdeelnemers en de burgers ${ }_{n}$ Oratie, Brussel 1988.

10. Zie paragraaf II.2.1. 
een niet onbelangrijke toevoeging, aangezien hiermee impliciet wordt aangegegeven dat aanpassing op een laag niveau niet de bedoeling is. Artikel 118 geeft de Commissie tot taak het bevorderen van de samenwerking van de lid-staten op sociaal gebied met name op de terreinen van werkgelegenheid, arbeidsrecht en arbeidsvoorwaarden, beroepsopleidingen en voortgezette vorming, sociale zekerheid, bescherming tegen arbeidsongevallen en beroepsziekten, de arbeidshygiëne en van het recht zich te organiseren in vakbonden en het collectief onderhandelen tussen werkgevers en werknemers.

De Commissie dient zich in nauw contact met de lid-staten met deze vraagstukken bezig te houden. $\mathrm{Zij}$ doet dit door middel van het verrichten van studies (11), het uitbrengen van adviezen en het organiseren van overleg. Artikel 117 is een typische instruktienorm (evenals trouwens artikel 118). Het Hof van Justtie stelde in het arrest Gimenez Zaera (12) ten aanzien van artikel 117, dat, hoewel het programmatische karakter van de in dit artikel genoende doelstellingen niet met zich meebrengt dat deze ieder rechtsgevolg missen, noch de uitgangspunten voor het nationale beleid noch bijzondere maatregelen door de rechter op hun verenigbaarheid met de in artikel 117 genoemde doelstellingen kunnen worden getoetst. Wat het eventuele rechtsgevolg zou kunnen zijn waar het Hof op wijst is niet duidelijk; wel lijkt de uitspraak een aanvulling op, en versterking te zijn van reeds eerder gedane uitspraken (13). Artikel 118 houdt een opdracht in aan de Commissie waarbij deze moet samenwerken met de lid-staten. Deze bepalingen laten de bevoegdheden wan de lid-staten op sociaal gebied onverlet voor zover zij geen deel uitmaken van andere in het verdrag geregelde bevoegdheden.

Artikel 118A, toegevoegd in 1987 door artikel 21 van de Europese Akte, werkt het laatste deel van artikel 118 uit. Hierbij worden de lid-staten geïnstrueerd zich te beijveren voor de verbetering van met name het arbeidsmilieu teneinde de veiligheid en de gezondheid van de werknemers te beschermen en zich de harmonisatie bij de verbetering van de op dit gebied bestaande omstandigheden ten doel te stellen. De bepaling voorziet in een procedurele verplichting tot het ontwerpen van harmonisatierichtlijnen (zonder overigens termijnen te stellen). De implicaties van dit artikel kunnen ook voor de medezeggenschap van werknemers groot zijn, in het zesde hoofdstuk zal dan ook uitgebreid aandacht worden geschonken aan artikel 118A.

11. In dit verband kan onder meer worden gewezen op de door de Commissie verrichte studies Apprenticeships in the Member-Stales, Brussel/Luxemburg 1987, The Dignily of Women at Work, Brussel/Luxemburg 1987, en zeer recent de Comparative Study on Rules Governing Working Conditions in the Member States, Brussel 1989.

12. In zaak 126/86, Jur. 1987, p. $3697-3718$ (Giminez Zaera vs Instituto Nacional de la Seguridad Social en Tesoria General de la Seguridad Social).

13. Met name zaak $43 / 75$, Jur 1976 , p. 455 ro. 9, $10,11,12$ (Defrenne 1I). 
Artikel $118 \mathrm{~B}$ ten slotte instrueert de Commissie zich te beijweren de dialoog tussen de sociale partners op Europees niveau verder te ontwikkelen, en stipt aan dat dit mogelijkerwijs tot contractuele betrekkingen kan leiden.

In dit hoofdstuk zal de plaats van de sociale politiek in de Europese Gemeenschap besproken worden. In verband hiermee zal ook aandacht geschonken worden aan het zeer recent aanvaarde communautaire Sociaal Handvest, dat garanties voor de werknemers zou moeten bieden in verband met eventuele aantasting van rechten door de voltooiing van de interne markt. Voorts zal meer in het bijzonder het beleid van de gemeenschap aangaande medezeggenschap op ondernemingsniveau worden bekeken.

\section{De plaats van de sociale politiek in de Europese Gemeenschap.}

\subsection{De plaats van de sociale politiek in de systematiek van het verdrag.}

De sociale politiek is sedert het begin van de jaren zeventig (14) in het gemeenschappelijk beleid een rol wan betekenis gaan spelen. Na $1975 \mathrm{kwam}$ een aantal richtlijnen tot stand die de verdragsbepalingen witwerkten en handen en voeten gaven. Met het in werking treden van de bepalingen die door de Europese Akte aan het verdrag zijn toegevoegd is een impuls aan de discussie omtrent de tot dusver gebrekkige (15) sociale politiek gegeven, mede in relatie tot de economische politiek.

Naast de artikelen $118 \mathrm{~A}$ en $118 \mathrm{~B}$ zijn voor de sociale politiek van belang de artikelen $130 \mathrm{At} / \mathrm{m} \mathrm{E}$ die de economische en sociale samenhang binnen de gemeenschap moeten waarborgen. In deze artikelen staan de economische en sociale samenhang in het algemeen en de verschillen tussen de regio's in het bijzonder centraal. In het werdrag is geen definitie van economische en sociale samenhang gegeven. Volgens het Europees parlement moet de economische samenhang zijn de verschillen in ontwikkeling tussen de regio's op te heffen. De sociale samenhang heeft ten doel de oorzaken van discriminatie en de sociale spanning weg te nemen door de verschillen in levensstandaard en inkomen zowel op het regionale als op het persoonlijke vlak te verkleinen (16).

De taak van de lid-staten is, volgens deze titel, het voeren en coördineren van het sociaal beleid en de samentiang op economisch en sociaal gebied te verwezenlijken. Daarnaast moet bij de tenuitvoerlegging van het

14. Uit de Topconferenties van Den Haag (1969), Parijs (1972) en Kopenhagen (1973) kwamen verklaringen aangaande de sociale politiek voort die als basis konden dienen voor een verdere beleidsontwikkeling op dit gebied. Zie voor de ontwikkeling van het standpun in de Europese raad: G. Debunne, Vakbonden en Europa, Leuven 1987, p. 96-115. In 1974

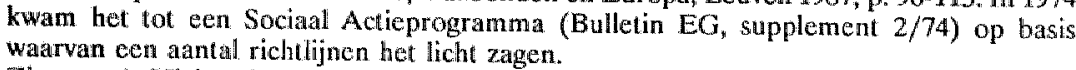
15. Zie o.m. A. Hick, Whatever happened to the European Social Policy, The European 1987
(Vol 1, no. 3)p. 48-49.

16. $\mathrm{Pb} .1989 \mathrm{C} 47 / 55$. 
gemeenschappelijk beleid en de gemeenschappelijke markt de doelstelling van artikel $130 \mathrm{~A}$ en die van artikel $130 \mathrm{C}$ in acht worden genomen. Het accent in artikel $130 \mathrm{~A}$ ligt met name op de regionale ontwikkeling. De door de Commissie in haar ontwerptekst van de Akte opgenomen bredere formulering waarin naast de regionale ontwikkeling ook de verbetering van de arbeidsomstandigheden, arbeidsvoorwaarden en werkgelegenheid ten doel werd gesteld, is niet in het uiteindelijke artikel terechtgekomen (17). Het gevolg van deze verenging is dat sociale component in de titel nauwelijks aan bod komt (18).

De Gemeenschap ondersteunt deze taken door acties middels Fondsen met een structurele strekking en andere bestaande financierings-instrumenten. Artikel $130 \mathrm{C}$ kent aan het Europees Fonds voor regionale ontwikkeling het doel toe een bijdrage te leveren aan regionale onevenwichtigheden in de Gemeenschap. Deze bijdrage levert zij door deel te nemen aan de ontwikkeling van achtergebleven regio's en aan de omschakeling van industriegebieden met een afnemende economische activiteit.

De behandeling van de sociale politiek in het EEG-verdrag, die door Kapteyn en VerLoren van Themaat als stiefmoederlijk is gekarakteriseerd (19) heeft met de toevoeging van deze artikelen een iets meer nadrukkelijke plaats als component in het gehele economische beleid gekregen. De sociale politiek is nadat dat dit al eerder impliciet was gebeurd (20), nu expliciet als een zelfstandige factor in het gemeenschapsbeleid erkend.

Het is echter een zelfstandige factor met een bijzondere status. De reden daarvoor is vermoedelijk dat, naast in de culturele context van de lid-staten gelegen redenen, sociaal beleid binnen het gemeenschapsbeleid in eerste instantie een kosten- en geen opbrengstenpost is. Leveren over het geheel genomen het instellen van een interne markt en het coördineren en op elkaar laten aansluiten van de nationale economieën baten op, het harmoniseren van sociale wetgeving, zeker wanneer dit met een verhoging van de kwaliteit gepaard gaat, kost geld aan de lid-staten die voorzieningen tot het niveau van die kwaliteit dienen te treffen, terwijl de baten die de harmonisatie op den duur kan opleveren niet vaststaan of te overzien zijn.

Het gevolg van deze speciale positie van de sociale politiek is dat bij te nemen maatregelen op dit terrein de Commissie (en ook de Raad) niet

17. J. de Ruyt, L'acte unique europeén, Brussel 1987, p. 198.

18. K.J.M. Mortelmans, De juridische aspecten van de "Economische en Sociale Samenhang", voordrachi gehouden op het Asser Colloquium Europees recht, $19 \mathrm{e}$ zitting 1989, p. 5-6, vermoedelijk in 1991 te verschijnen in de colloquiumbundel "Economische en Sociale samenhang" T.M.C. Asser instituut, Den Haag.

19. P.J.G. Kapteyn en P. VerLoren van Themaat, Inleiding tot het recht van de Europese gemeenschappen, Deventer 1987, p. 413.

20. Zie o.m. J Pipkorn, J Forman, W. Stabenow in Von der Groeben, Boeck, Thiesing en Ehlermann, Kommentar zum EWG-vertrag, Baden-Baden 1983, pp. 1985-2089. 
alleen aanloopt tegen de gewone nationale aversie tegen maatregelen die in de lid-staten een verandering bewerkstelligen, maar mede tegen de aversie die ontstaat als gevolg van de kosten die die verandering met zich meebrengt. Dit komt niet alleen tot uiting bij het nemen van nieuwe besluiten ten aanzien van de sociale politiek, maar ook waar het gaat om uitwoering wan reeds genomen besluiten (21). Zelfs indien een lid-staat geen wijzigingen in zijn sociaal beleid hoeft aan te brengen, aangezien zijn wetgeving al in overeenstemming is met een voorgestelde regeling, dan nog betekent dit alleen maar het niet hoeven te maken van kosten, niet een directe mogelijkheid opbrengsten te verhogen. Kortom, ook dan hebben de lid-staten weinig direct belang bij regelingen op dit terrein.

Dit kan overigens veranderen op het moment dat de vestigingsstromen zich verplaatsen naar de lid-staten met een lagere standaard in de sociale wetgeving. Dan wordt het verschil in kosten tussen de lid-staten met een hoge standaard en die met een lage standaard acuut een factor in de concurrentiestrijd tussen de lid-staten. Het belang bij harmonisatie van wetgeving van de lid-staten met een hoge standaard neemt in dat geval dienovereenkomstig toe. Het risico dat dan ontstaat is enerzijds druk van de "goedkope" lid-staten, tegen harmonisatie op hoog niveau en anderzijds acceptatie van de "dure" lid-staten hun standaard te verlagen. Het resultaat zou dan harmonisatie op betrekkelijk laag niveau zijn.

De grondslag voor harmonisatie van wetgeving door middel van richtlijnen wordt gevormd door bijzondere verdragsartikelen, het algemene artikel 100 EEG-verdrag en het "rest"artikel 235 EEG-verdrag, of een combinatie hiervan (in het geval een bijzonder verdragsartikel geen duidelijke harmonisatieverplichting oplegt, dan wel geen procedureregels geeft). Wanneer een bijzonder verdragsartikel een harmonisatieverplichting oplegt, is het mogelijk dat het verdrag om een richtlijn aan te nemen een eenvoudige of gekwalificeerde meerderheid van stemmen in de Raad eist ofwel eenparigheid van stemmen. Op basis van art. 100 en art. 235 EEGverdrag vast te stellen richtlijnen (of in het geval van dit laatste verdragsartikel andere maatregelen) kunnen alleen worden aangenomen met eenparigheid van stemmen.

Met de verdragswijziging ingevoerd door de Europese Akte zijn de mogelijkheden voor het aannemen van maatregelen ter harmonisatie van wetgeving uitgebreid, voor zover het maatregelen betreft die noodzakelijk zijn voor de aanpassing van wettelijke en bestuursrechtelijke bepalingen die

21. De handelwijze van de Nederlandse staatsecretaris wan Sociale Zaken, die, nadlat de termijn van RL. $79 / 7$ (gellijke behandeling van mannen en vrouwen in de socilale zekerheid) was verstreken, de gemeenten dwong de met de strijdige richtlijn bestaande WWVbepaling te blijwen toepassen middels zijn circulaire van 21 december 1984, omdat niettoepassing te veel geld zou gaan kosten, is hiervan wel een heel duidelijk voorbeeld. Zie hierover: Roel de Lange en Louise Mulder, noot bij FNV tegen de Staat Recht en Kritiek 11(1985)3, p. 296. 
de werking van de interne markt betreffen. Artikel 100A waarom het hier gaat spreekt van "maatregelen" hetgeen meer kan omvatten dan de "richtlijnen" van artikel 100. Echter in artikel $100 \mathrm{~A}$ worden bepalingen inzake het vrij verkeer van personen en bepalingen die zien op rechten en belangen van werknemers uitdrukkelijk uitgezonderd. Het verschil tussen artikel 100 en artikel $100 \mathrm{~A}$, is dat richtlijnen op grond van dit laatste artikel kunnen worden aangenomen met gekwalificeerde meerderheid van stemmen, terwijl zoals gezegd dit bij harmonisatie op grond van artikel 100 niet het geval is.

Dus hoewel de interne markt volgens de definitie van artikel $8 \mathrm{~A}$ waarnaar artikel $100 \mathrm{~A}$ verwijst een ruimte omvat zonder binnengrenzen, waarin het vrije verkeer van goederen, personen, diensten en kapitaal is gewaarborgd, wordt niet alleen harmonisatie van sociaal politieke maatregelen (die het vrije verkeer van personen kunnen beïnvloeden) maar het gehele vrij personenverkeer buiten de harmonisatieprocedure van artikel $100 \mathrm{~A}$ gelaten.

Voor het vrij verkeer van personen is dat overigens niet zo verwonderlijk, aangezien voor dit terrein speciale harmonisatie-artikelen in het verdrag zijn opgenomen (22) op basis waarvan zowel richtlijnen als verordeningen met gekwalificeerde meerderheid kunnen worden vastgesteld. Voor het sociaal beleid ligt dit anders: alleen artikel 118A EEG-verdrag geeft een procedure, voor andere sociaal politieke maatregelen geldt in beginsel de zwaardere procedure van artikel 100 nog steeds. Dit zou alleen niet het geval zijn wanneer een verdragsartikel dat een bijzondere rechtsgrondslag biedt (en dat gekwalificeerde meerderheid van stemmen eist) kan worden gebruikt voor harmonisatie. Hier kom ik in een latere paragraaf op terug (23).

Een denkbare reden voor het overwegend vasthouden aan eenstemmigheid is, dat ook hier het al eerder genoemde kostenaspect van sociaal politieke maatregelen een rol heeft gespeeld. Als harmonisatie kostenverhogend werkt of kan werken, is besluitvorming met eenparigheid van stemmen voor de lid-staten van groot belang. Dit maakt de sociale politiek welliswaar niet tot sluitpost van een mogelijk harmonisatiestreven, maar wel tot een gebied waarbij de lid-staten de grootst mogelijke invloed wensen te hebben bij het aannemen van voorgestelde maatregelen. Dat verlangen naar invloed, tot uiting komend in een relatief "moeilijke" procedure, heeft overigens wel tot gevolg dat harmonisatie van sociale wetgeving maar moeilijk tot stand komt.

22. Voor het vrij werknemersverkeer is dit artikel 49 EEG-verdrag, voor het recht van vestiging artikel 54 (m.n. lid 2) EEG-verdrag.

23. Zie paragraaf II.4.2.A. 
2.2 De relatie tussen de sociale politiek en het vrij verkeer van personen: dispariteiten en distorsies.

Hoewel de sociale politiek oorspronkelijk een economische drijfveer had (24) -bij oprichting van het verdrag werd sterk gedacht aan concurrentievervalsing middels dispariteiten op het gebied van sociale wetgeving- kan gesteld worden dat deze sector van het gemeenschapsbeleid door haar uitwerking in richtlijnen een eigen leven is gaan leiden. Niettemin is concurrentie-vervalsing nog steeds een factor die meespeelt in en bijdraagt tot het ontwikkelen en uitbouwen van sociaal politieke maatregellen.

Het beleid van de Gemeenschap met betrekking tot concurrentie is én van de kernsectoren in de gemeenschappelijke markt. Een doel van de gemeenschappelijke markt is tenslotte de produktie daar te laten plaatsvinden waar dit op de meest effectieve wijze kan gebeuren. Door het bevoordelen van de lid-staten van de eigen markteconomie, kan de werking van de gemeenschappelijke markt verstoord worden. Het resultat is dat de gemeenschappelijk markt minder slagvaardig wordt dan nodig is. Het steunen van lid-staten van ondernemingen of sectoren door middel van subsidies, in welke vorm dan ook, wordt slechts onder een gelimiteerd aantal omstandigheden toegelaten (25). Ook ondernemingen dienen zich in het algemeen te onthouden van concurrentievervalsende overeenkomsten of handelingen. Naast deze vorm van concurrentievervalsing kunnen ook verschillen in wetgeving ten koste gaan van de werking van de gemeenschappelijke markt. Mede hierom worden wettelijke en bestuursrechtelijke maatregelen geharmoniseerd.

Verschillen in sociale wetgeving kunnen ook leiden tot de keuze van ondernemingen voor de plaats van hun produktie. De kosten, in ruime zin, van de produktiefactor arbeid spelen uiteindelijk ook een rol in dit proces. Wanneer men meent dat de groei van de economie en de vergroting van de slagvaardigheid van de gemeenschappelijke markt niet ten koste mag gaan van de Europese burgers (en van hen met name de werknemers), hetgeen impliciet in artikel 2 EEG-verdrag is te lezen, moet men wel tot de conclusie komen, dat verschillen in de prijs van de factor arbeid, ontstaan door te grote en voor de burgers van de Europese landen nadelige uitpakkende dispariteiten in de sociale wetgeving, in feite concurrentievervalsend zijn.

Zolang de verschillen in sociale politiek en in concreto op werknemers betrekking hebbende regelingen binnen Europa groot zijn zal de gemeenschappelijke arbeidsmarkt enerzijds, en de effectuering van de produktie op die plaats die daarvoor het meest aangewezen is anderzijds, niet gestimu-

24. Zie 0.m. N. Verhaaren, Gelijke beloning in West-Europa, Nemesis $3(1987) 5$, p. $248 ;$; ook zaak 28/66, Jur. XIV p. 1 (Nederland vs Commissic).

25. Artikel 92 EEG-verdrag; zie o.m. R. Barents, Recente ontwikkelingen in de rechtspraak ower steunmaatregelen, SEW 1988, p. 352-364. 
leerd worden. Dit heeft tot gevolg dat een gemeenschappelijke Europese economie minder slagvaardig en daarmee minder concurrerend is dan zij zou moeten zijn om een vooraanstaande plaats op de wereldmarkt te behouden.

Op zichzelf is het binnen de Europese Gemeenschap noch verboden noch wordt het zelfs maar onwenselijk geacht, dat wetgeving van het ene land verschilt met die van het andere land (tenzij het wetgeving betreft op een gebied dat als gemeenschappelijk beleid door de gemeenschap gereguleerd wordt). Een andere attitude ten opzichte van de nationale wetgeving zou zowel gezien de juridische als culturele historie van de Europese nationale staten niet houdbaar zijn, nog daargelaten dat de Gemeenschap in eerste instantie een economische gemeenschap is. Nu de integratie van de Europese rechtsorde en die van de lid-staten voortschrijdt, blijkt dat dispariteiten op velerlei gebied steeds meer weerstand beginnen te ontmoeten, een weerstand die niet alleen maar nationale regelingen betreft, maar waar ook het gemeenschapsrecht mee te maken krijgt.

Deze dispariteiten mogen op de inwoners van het land waar moeilijker aan de normen te voldoen is, dan in het andere land als onrechtvaardig en discriminerend overkomen (26); feit is dat dergelijke verschillen niet discriminerend zijn, zolang eigen onderdanen en onderdanen van andere EG lid-staten gelijk behandeld worden door één lid-staat.

Dispariteiten in wetgeving kunnen wel tot gevolg hebben dat distorsies ontstaan. Ook distorsies zijn niet verboden (27), zij worden echter wel onwenselijk geacht en moeten middels harmonisatie van wetgeving worden opgeheven. Distorsies worden veroorzaakt door dispariteiten tussen de wettelijke en bestuursrechtelijke maatregelen die de mededingingswoorwaarden op de gemeenschappelijke markt vervalsen. Hoewel het verdrag geen definitie van distorsies geeft distilleren Kapteyn en VerLoren van Themaat (28) uit het rapport Spaak (29) en uit een systematische interpretatie van het verdrag, drie criteria waaraan de dispariteit moet voldoen om als

26. Een goed voorbeeld hiervan is te vinden in de wereld wan beroepswielrennerij: Nederlandse wielrenners moeten om een beroepslicentie te verkrijgen voldoen aan een aantal voorwaarden die in andere EG lid-staten in het geheel niet bestaan. Dit wordt door Nederlandse wielrenmers als onrechtvaardig ervaren, aangexien het daardoor bij hen aanzienlijk moeilijker is dan voor andere EG-onderdanen hun sport te gelde te maken. Echter van discriminatie is hier in helt geheel geen sprake. Bron: Eddy M.J. Beugels, De arbeidsrechtelijke positie van de Nederlandse beroepswielrenner, doktoraalscriptie geschreven alan de Universiteit wan Amsterdam (10 februari 1987), begeleider: D. Christe.

27. Zie de arresten 14/68, Jur. XV p.1. (Wilhelm vs Bundeskartellamt), 155/80, Jur 1981, p. 1993 (Oebel), 126/82, Jur 1983 p. 93 (Smit).

28. P.J.G. Kapteyn en P. VerLoren van Themaat, a.w. (noot 19), p. 318.

29. Rapport van het Intergouvernementeel Comite onder voorzitterschap van $\mathbf{H}$. Spatak, ingestejd bij resolutie op de Conferentie van Messina, $1-2$ juni $1955_{;}$afgerond in april 1956 resulterend in de basis voor de onderhandelingen over het oprichtingsverdrag tijdens de Intergouvernementele Conferentie van 29 juni 1956. 
een distorsie te worden aangemerkt. Zo moet het volgens hen gaan om een maatregel waardoor een groep van ondernemingen in een lid-staat meer belast wordt dan in een andere; in andere lid-staten moet geen gelijke afwijking voor dezelfde groep van ondernemingen ten opzichte van andere ondernemingen bestaan en daarnaast moet de vastgestelde afwijking niet door andere lasten of voordelen worden gecompenseerd. Deze drie criteria worden door Kapteyn en VerLoren van Themaat sterk gelieerd aan artikel 101 EEG-verdrag. Het is niet geheel duidelijk of de artikelen 101 en 102 op globale distorsies van toepassing zijn (30). Lauwaars en Maarleveld achten artikel 101 alleen van toepassing op specifieke distorsies (31). Volgens de Commissie kan overigens een specifieke distorsie wel voortvloeien uit algemene maatregelen (32).

Artikel 101 EEG-verdrag voorziet in een procedure van consultatie van de Lid-Staten die ertoe moet leiden dat dergelijke distorsies worden opgeheven. Indien deze consultatie tot niets leidt kan de Raad met gekwalificeerde meerderheid van stemmen en op voorstel van de Commissie de voor het doel noodzakelijke richtlijnen vaststellen, dan wel alle andere noodzakelijke dienstige maatregelen nemen waarin het verdrag voorziet. Ook voorgenomen maatregelen of een wijziging van een bestaande maatregel die een distorsie kan veroorzaken kunnen voorwerp worden van een consultatieprocedure, volgens artikel 102 EEG-verdrag. Door de beperkte toepasselijkheid van de artikelen zullen deze mijns inziens niet gebruikt kunnen worden om distorsies veroorzaakt door sociale maatregelen op te heffen. Daarbij zall er namelijk vooral sprake zijn van globale distorsies, zelden van specifieke. De artikelen zijn überhaupt zeer weinig gebruikt. Tot dusver zijn er wel enkele consultatieprocedures in gang gezet, maar deze hebben nog weinig consequenties gehad. Deze artikelen zijn dan ook enigszins in het vergeetboek geraakt (33). Dit zou echter kunnen veranderen nu met het verder opengaan van de grenzen, de belangen bij het opheffen van distorsies groter worden.

In het rapport Spaak worden als distorsies opleverende verschillen onder meer genoemd: vrouwenlonen, arbeidsduur de reglementering van betaalde overuren en kredietpolitiek, althans voor zover zij naar bedrijfstakken of andere groepen van ondernemingen gedifferentieerd zijn. Hieruit blijkt dat al vroeg werd ingezien dat verschillen in sociaal beleid mogelijk düstorsies kunnen opleveren, die de gemeenschappelijke markt kunnen frustreren. De sociale politiek van de Gemeenschap dient dus naast de algemene doelstelling van het verbeteren van de levensstandaard, het belang van de gemeenschappelijke markt als geheel, hetgeen betekent dat zij ook voor de

30. Zie zaak $173 / 73$ Jur. 1974 , p. 720 (Italië vs Commissie).

31. R.H. Lauwaars, J.M. Maarleveld, Harmonisatie wan wetgeving in Europese organisaties, Amsterdarn 1987 , p. 53.

32. Antwoord wan de Commissie op schriftelijke vraag no. 2226/80, Pb. 1983 C 257/1.

33. J. Mégret (ed), La droit de la Communauté Economique Européenne, Bruxelles 1973, vol. $5, \mathrm{p} .195$. 
middelen om de doelstelling te bereiken tenminste een ondersteunende functie heeft.

2.3 De relatie tussen de gemeenschappelijke markt en werknemersrechten als medezeggenschap.

De relatie tussen medezeggenschap op ondernemingsniveau en de gemeenschappelijke markt heeft vooral te maken met de vrijheid van personenverkeer en de vrijheid van vestiging. Het recht van vrije vestiging in de gemeenschap wil er mede voor zorgen dat de produktie dalar plaatsvindt waar deze het effectiefst kan plaatsvinden, en de mobiliteit van de economische factoren zo effectief mogelijk gebruikt wordt (34). Dit moet bereikt worden door de lid-staten te verbieden EG-onderdanen te discrimineren bij het zich vestigen als zelfstandig ondernemer, dan wel als beoefenaar van een vrij beroep in een andere lid-staat. Het discriminatieverbod geldt voor directe en indirecte discriminatie. Deze laatste vorm van discriminatie kan zowel geschieden door regels te stellen waaraan buitenlanders materieel moeilijker kunnen voldoen dan eigen onderdanen, als door het stellen van specifieke additionele eisen aan de EG-onderdaan, waaraan in de eigen Lid-Staat al is voldaan (35).

Een ondernemer kan daardoor de lid-staat uitzoeken die voor zijn type produktie het gunstigst is, waarbij naast een aantal andere kewzecriteria, ook de rechten van werknemers in de onderneming een rol kunnen spelen. Weinig individuele en collectieve rechten van werknemers, (of individuele en collectieve rechten waarvan het gebruik is afgebakend in een duidelijke wettelijke regeling zódat ondernemers weten waarmee zij rekening hebben te houden en dus niet voor verrassingen komen te staan) kunnen de slagvaardigheid van de ondernemer vergroten. Daarmee zijn werknemersrechten een factor in de beslissing over de vestigingsplaats geworden. Dubois (36) beschrijft hoe de Ford-fabrieken in 1972 besloten een nieuwe onderneming in Spanje neer te zetten, in plaats van Groot Brittannië aan de daar bestaande stakingspraktijken te ontkomen. Investeringsplannen voor Groot Brittannië werden ingetrokken.

Hoewel het hier eerder draaide om de wijze van uitoefening van werknemersrechten en niet zozeer om de anwezigheid van de rechten zelf, blijkt uit dit geval dat ondernemers rekening houden met de altitude van werknemers tegenover ondernemers. En ook al wordt deze attitude niet altijd bepaald door wettelijk toegekende rechten aan werknemers; werknemers

34. Lasok, The Professions and Services in the European Economic Community, Deventer 1986 , p. 4; J.P. de Crayenour, De Europase gemeenschap en thet wrije verkeer van wrije beroepsbeofenaren, Brussel-Luxemburg 1983, p. 12.

35. Zaken 33/74 Jur. 1978 , p. 1980 (van Binsbergen), 110 en 111/79, Jur 1979, p. 35 (v. Wesemael), 279/80, Jur 1981, p. 3305 en p. 3320 (Webb).

36. P. Dubois, Multinational Enterprises and Collective Bargaining at international lovel, Common Market Law Review 1974, p. 146. 
hebben wel meer mogelijkheden gebruik te maken van rechten als staking, collectief onderhandelen en medezeggenschap, als deze rechten hen bij wet zijn toegekend of door de wet in elk geval niet te veel zijn beperkt. Aangezien zowel stakingen als concessies, te doen bij collectieve onderhandelingen, en vetorechten door medezeggenschapsorganen, voor een ondernemer kastenverhogend kunnen werken, zullen, kunnen deze rechten dus een rol spelen in de keuze van de vestigingsplaats. Deze rol kan groter worden naarmate andere factoren minder gewicht in de schaal leggen bij de keuze van de vestigingsplaats.

Dit spreekt te meer wanneer het gaat om multinationale ondernemingen met vestigingen in meer lid-staten. Deze kunnen zonder veel moeite hun produktie verplaatsen naar een vestiging in een andere lid-staat. Voor instandhouders van dergelijke ondernemingen is het, door de enorme consequenties die aan een dergelijke verplaatsing voor de werknemers kleeft, zelfs mogelijk om bestaande medezeggenschapsrechten met name waar het gaat om onderhandelingsrechten en veto-mogelijkheden te manipuleren en in het extreme geval te frustreren.

De uiterste consequentie van een dergelijk ondernemersgedrag zou kunnen zijn dat de produktie juist niet plaatsvindt dàar waar deze het effectiefst is voor zover het om de produktiefactor arbeid gaat, maar op de plaats waar het voor de ondernemer gezien deze produktiefactor arbeid in relatie tot de aan werknemers toegekende rechten het best uitkomt (37). Het is dan mogelijk om werknemers met de voor produktie benodigde kwalificaties (bijvoorbeeld werknemers met een bepaald soort scholing) naar de produktieplaats toe te halen in plaats van de onderneming te vestigen waar deze gekwalificeerde werknemers aanwezig zijn. Een dergelijk (misschien nu theoretisch, maar toch niet geheel denkbeeldig) ondernemersgedrag zou in strijd zijn met ideëen over de wijze waarop de Gemeenschap de economische en sociale samenhang wil realiseren (38).

Hoewel een soortgelijke relatie tussen sociaal beleid en het vrij verkeer van werknemers te construeren is, moet worden toegegeven dat deze aanzienlijk diffuser en minder duidelijk is. Ook werknemers die overwegen gebruik te maken van hun recht op vrij verkeer krijgen te maken met de dispariteiten in sociale wetgeving. Een werknemer in een land met uitgebreide individuele en collectieve werknemersrechten zal bij de overstap naar een onderneming in een lid-staat waar dit alles aanzienlijk slechter geregeld is te maken krijgen met een achteruitgang in rechten (39).

37. Zie C. Pissuisse, Grenzeloos optimisme over 1992, Intermediair, 9 september 1988, p. 69; L. Timmerman, 1992 en de medezeggenschap van de werknemers, Kluwer seminar, Europa $1992,23 / 24$ nov. 1988 , p. 2 .

38. L. Timmerman, a.w. (noot 37), p.4.

39. Door de coördinatieverordening sociale zekerheid (Vo. 1408/71 Pb. 1971, L 149) is voor een, voor in een andere lid-staat werkzame werknemers, brandende vraag: "wat gebeurt er met mijn inkomen als ik werkloos c.q. arbeidsongeschikt wordt", een voorziening 
Het is echter niet onmiddellijk waarschijnlijk dat de keuze om de overstap te maken daardoor bepaald wordt. Dat het verlies wan rechten die de werknemer direct raken, als loonshoogte en aantal vakantiedagen, en mogelijkerwijs andere (slechtere) veiligheidsnormen (die in feite een direct risico vormen), bij die overwegingen worden betrokken kan men zich nog wel voorstellen. De mogelijkheid tot medezeggenschap of collectief onderhandelen in een onderneming, zal naast de vele andere zaken die moeten worden overwogen om tot een dergelijke beslissing te komen vermoedelijk een minimale, of zelfs geen enkele, rol spelen. Wanneer het gaat om een werkloze werknemer zal een (in dat geval betrekkelijk theoretisch) verlies van rechten vermoedelijk nauwelijks bij de overwegingen om te vertrekken worden betrokken.

Dit betekent dat dispariteiten met betrekking tot sociale wetgeving, althans voor zover die dispariteiten betrekking hebben op collectieve werknemersrechten (in welke vorm dan ook) op de gemeenschappelijke arbeidsmarkt, zo lang alleen individuele werknemers van onderneming en lid-staat veranderen, weinig invloed hebben. Dit kan echter veranderen wanneer verplaatsing van productiecentra naar andere regio's binnen de gemeenschap, groepen van werknemers noodzaakt hun vestigingsplaats elders te zoeken. Indien dit staat te gebeuren kunnen verschillen in de wetgeving aangaande collectieve werknemersrechten wel degelijk van groter belang worden.

\subsection{Een veranderende attitude ten opzichte van de sociale politiek?}

Het hierbovenbeschrevene koppelt de plaats van de sociale politiek in de systematiek van de Gemeenschap sterk aan de negatieve integratie, aan het opheffen van dispariteiten en als eventuele correctie van de nadelen door de gemeenschappelijke (of interne) markt veroorzaakt. Zo zijn sociaal politieke maatregelen lange tijd gezien, en gerechtvaardigd. Nog steeds wordt, onder meer in parlementaire kringen, de sociale politiek veelal in die context gezien (40). Naarmate de integratie in de vorm van de interne markt, voortschrijdt dringt ook het besef door dat de sociale zijde van interne markt meer moet zijn het enkele opheffen van de door die interne markt ontstane nadelen (41). De Europese Raad te Madrid, was in aansluiting op eerdere Raden te Hannover en Rhodos van mening dat evenveel belang moet worden gehecht aan de sociale aspecten als aan de economische aspecten bij de totstandbrenging van de Europese markt (42). De sociale en economische samenhang moet een beleid opleveren, waarbij

getroffen.

40. Zie 0.m. opmerkingen van thet parlementslid Fitzgerald, Hand. EP, 13-9-1989; zie ook TK. 1988/89, 21240 no. 2 p. 6-8 (Sociale dimensie Europa 1992).

41. Zie ook Commissie van de Europese gemeenschappen, Social Europa, de socialle dirmensie van de interne markt, Luxemburg 1988, p. 8-9.

42. Verklaring Europese Raad te Madrid, 1989, zie ook preambule gemeenschapshandvest, COM. (89) 471 def. (tekst na aanvaarding nog niet gepubliceerd). 
de te nemen maatregelen niet geheel afhankelijk zijn van de stand van de interne markt (43), maar waarin de sociale zijde een zelfstandig karakter draagt.

Een van de middelen die aangewend moet worden is de sociale dialoog tussen de sociale partners. Doel van deze dialoog is het het organiseren van een Europese ruimte voor arbeidsverhoudingen. Deze dialoog kan uitmonden in contractuele betrekkingen tussen de sociale partners, eventueel in de vorm van bovennationale collectieve arbeidsovereenkomsten (44).

Een andere weg om dit te bereiken is gezocht in het erkennen van communautaire sociale en economische fundamentele rechten. Deze erkenning zou hebben kunnen plaatsvinden door toetreding van de gemeenschap tot het Europees Sociaal Handvest (45) waarbij het Handvest kan dienen als rïchtsnoer voor gemeenschapsregelingen.

Er is echter gekozen voor een aparte communautaire regeling waarin fundamentele sociale en economische rechten zijn vastgelegd (46). Het voordeel van een eigen communautaire regeling (die in het verwarrende spraakgebruik waar men op Europees niveau wel vaker last van heeft, al het Europese sociale handvest wordt genoemd) is dat de Gemeenschap zelf kan bepalen op welke wijze binnen het gemeenschapsrecht de toepassing van deze rechten kan worden gewaarborgd (47). Dit was één van de argumenten waarmee wel eerder op de wenselijkheid van een dergelijke communautaire waarborg is gewezen (48). Een nadeel is dat een communautair handvest ongetwijfeld ten dele een doublure wordt van het Europees Sociaal Handvest, en de status van dit laatste verdrag lager en/of onduidelijk wordt (49).

43. Zie o.m. de rede van J. Delors gehouden in het Europees parlement, Hand. EP, 13-9$1989, \mathrm{p}, 207-210$.

44. Door de Commissie wordt deze optie overigens nog niet realistisch geacht, Sociaal Europal, de sociale dimensic van de interne markt, Luxemburg 1988, p. 73. Anderen denken daar anders over: De bijdragen van Jacobs, Daübler en Le Friant in Arbeitsrecht im Betrieb, februari 1989 (speciaal nummer aver multinationale ondernemingen) en J. van Wulfften Palthe, De internationale CAO, Namens 1989 afl. 4, p. 27-34.

45. P. van Dijk, Is het Europees Sociaal Handvest dan niet Europees?, NJB 1989, p. 14121413.

46. Het Gemeenschapshandvest van Sociale grondrechten is aanvaard door elf van de twaalf lid-staten tijdens de zitting van de Europese Raad op 9 december 1989 te Straatsburg.

47. Zie o.m. de verklaring van de Raad van Ministers van Arbeid en Sociale Zaken Doc. $6736 / 87$ en Pb. 1988 C 208.

48. O.m. L. Betten, The Right to Strike in Community Law, North Holland 1985 .

49. L. Betten, Prospects for a Social Policy of the European Community and its impact on the functioning of the European Social Charter, in The future of European Social Policy, Deventer 1989, p. 126-127. 
Volgens het advies van het Economisch en Sociaal Comité (50) had de communautaire regeling in hoge mate moeten aansluiten op de instrumenten die al in andere verdragen (waaronder het ESH maar ook de ILO) zijn vastgelegd. Wel wijst het Comité erop dat enkele specifieke rechten in de communautaire regeling moeten zijn gewaarborgd. Zij noemt daarvan onder meer het recht van alle werknemers, ongeacht de aard van hun arbeidsverhouding collectief te onderhandelen, op alle niveaus, met name op het niveau van bedrijven, concerns, beroepsgroepen, regio's en lid-staten. Een dergelijke bepaling is echter niet terug te vinden in het Gemeenschapshandvest van Sociale Grondrechten dat in december door de Europese Raad in Straatsburg is aanvaard (51). Het Handvest schrijft slechts voor dat voorlichting, raadpleging en deelneming van de werknemers op gepaste wijze moeten worden ontwikkeld, rekening houdend met de wettelijke en contractuele bepalingen alsmede de in de lid-staten geldende gebruiken. Dat zou met name moeten gelden voor ondernemingen met vestigingen of bedrijven in verscheidene lid-staten van de Gemeenschap.

Ook voor het overige lijkt het Handvest een wel zeer flauwe afspiegeling van het advies van het Economisch en Sociaal Comité te zijn. De rechten die erin worden gegarandeerd, zijn merendeels rechten die allang op gemeenschapsniveau verwezenlijkt zijn. In het Europees parlement is bij de bespreking van het ontwerp-handvest, dit document al te mager genoemd (52). Het Parlement vond dat het handvest gepaard moest gaan met een concreet actie-programma voor sociale gemeenschapswetgeving, een programma dat er ook gekomen is (53).

De European Trade Union Confederation (ETUC) ging nog veel verder in haar voorstel voor een "Community Charter of Social Rights" (54). Niet alleen aansluiting bij bestaande ILO-verdragen maar een netwerk van aanwullende wetgeving op gemeenschapsniveau wordt noodzakelijk geacht. Ook Bercusson (55) stelde in zijn rapport aan de Gemeenschap een aantal rechten voor, waarover noch het Economisch en Sociaal Comité noch het Handvest rept. Zo is hij onder meer van mening dat een aantal medezeggenschapsrechten van werknemersvertegenwoordigers inzake veiligheids- en gezondheidsaangelegenheden ook tot de fundamentele communautaire rechten moeten behoren. In het Handvest is omtrent veiligheids- en gezondheidsaangelegenheden slechts voorgeschreven dat "alle werkenden (......) recht (hebben) op een toereikende bescherming van hun gezondheid

50. Pb. 1989 C 126.

51. Gemeenschapshandvest van Sociale Grondrechten, COM. (89) 471 def. (tekst na aanvaarding nog niet gepubliceerd $).$

52. Hand. EP. 13-9-1989, p. 138 .

53. Hand EP, 13-9-1989, p. 135, 150.

54. ETUC-document Community Charter of Social Rights van 12 december 1988.

55. B. Bercusson, Fundamental Social and Economic Rights, Report to the European Community, Florence 1989. 
en veiligheid, in het bijzonder op de arbeidsplaats". Voorts zou er harmonisatie van wetgeving in opwaartse zin moeten plaatsvinden.

De belangrijkste vraag met betrekking tot het Handvest is op welke wijze de daarin voorziene rechten voor de burgers wat zullen opleveren. Dit is afhankelijk zowel van de inhoud als van de status van het Handvest. De inhoud wordt niet als eindstadium gezien. De in het Handvest voorziene rechten moeten uitgewerkt worden door middel van de sociale dialoog. Individuen kunnen dan onder de bereikte overeenkomsten de rechten inroepen. Bercusson stelt dat de fundamentele rechten ook inroepbaar moeten zijn (m.a.w. direct werkend) voor die personen die niet gedekt worden door een collectieve overeenkomst. Hij wil in feite directe horizontale werking van de in het Handvest voorgestelde rechten (56). Ook in het Parlement zijn stemmen opgegaan om de rechten directe werking toe te kennen (57).

De status van het nu aangenomen Handvest is binnen het gemeenschapsrecht enigszins dubieus. Het Handvest wijzigt het EEG-verdrag niet; overigens is dat ook nooit de bedoeling geweest (58). Het is geen communautair, maar in feite een intergouvernementeel Handvest. Het is geen verdrag naast het EEG-verdrag, zoals bijvoorbeeld wel titel III van de Europese Akte. Men kan het als een kaderbesluit zien (59), en in dat geval de status verkrijgen van internationale overeenkomst. Op zichzelf betekent dit niet dat het Handvest daarmee niet bindend zou zijn, maar of het daarmee directe werking binnen het gemeenschapsrecht zou kunnen verkrijgen lijkt mij zeer twijfelachtig. Bovendien worden kaderbesluiten in het algemeen met eenparigheid van stemmen genomen, en dat is in dit geval niet gebeurd. De Britse regering is niet akkoord gegaan met het Handvest (60). Mijns inziens is het Handvest dan ook niet mér dan een (mogelijk vrij harde) intentieverklaring voor een in de toekomst te voeren beleid. Of dat een teleurstelling moet worden genoemd, is nog maar de vraag: het Handvest biedt niet veel nieuws.

56. B. Bercusson, a.w. (noof 55), p. 2.

57. Hand. EP, 13-9-1989, p. 135 .

58. Rede van J. Delors in het Europees Parlement, Hand. EP 13-9-1989.

59. Kaderbesluiten zijn besluiten wan de vertegenwoordigers van de lid-staten in het kader van de Raad bijeen. Het zijn ih.a. geen officiële gemeenschapsbeshiten; zie PJ.G. Kapteijn, P. VerLoren van Themaat, a.w. (noot 19), p. 146-149.

60. Tijdens de behandeling wan het handwest, toen de weerstand van Groot Brittamnië al duidelijk was stelde het Britse (Labour) lid van het Europees parlement, Glyn Ford, al voor om het handvest met elf van de twaalf landen aan te nemen, en het niet omwille van de twaalde handtekening af te zwakken (Hand EF, 13-9-1989, p. 149). 
3 Harmonisatie van sociale wetgeving in de gemeenschap.

Ter harmonisatie van een aantal dispariteiten in de sociale wetgeving heeft de Gemeenschap sedert 1975 een aantal richtijnen aanvaard op dit terrein. Deze zijn overigens niet allemaal op eén van de artikelen betreffende de sociale politiek in samenhang met artikel 100 gebaseerd; enkele hebben, hoewel zij wel tot de sociale politiek gerekend worden, het "rest"artikel 235 EEG-verdrag tot grondslag (61).

Richtlijnen zijn bedoeld om omgezet te worden in nationale wetgeving en op deze wijze een aantal door de Gemeenschap gewenste maatregelen te incorporeren in de nationale wetgeving. Zij zijn dan ook slechts naar resultaat verbindend; in de keuze van de middelen om dit resultaat te bereiken zijn de Lid-Staten vrij. Hoe vrij hangt af van de wijze de richtlijn zelf is uitgewerkt: als gekozen wordt voor een resultaat dat vervat wordt in algemene beginselen geeft dit de lid-staten meer vrijheid dan wanneer gedetailleerde regels worden gesteld (62).

Harmonisatie van wetgeving kan op verschillende wijzen gezien worden. Men kan van de optiek uitgaan dat de harmonisatie-regeling er slechts naar moet streven opheffen van verschillen in wetgeving voor zover deze het economische verkeer belemmeren op te heffen. In dat geval is er sprake van een technisch proces dat zich tot de noodzakelijke aanpassingen beperkt. Anderzijds kan men harmonisatie zien als het aanpassen van de nationale wetgeving aan nieuwe door de Gemeenschap opgestelde normen in verband met het tot standkomen van de gemeenschappelijke markt en in het licht van de doelstellingen van het EEG-verdrag. In deze optiek beperkt de harmonisatierichtlijn zich niet tot het wegnemen van dispariteiten (63), maar is onderdeel van de wetgevende taak van de gemeenschap, waarin tot de juridische uitwerking van beleidskeuzes moet worden gekomen (64). Voor de lid-staten heeft de harmonisatie van wetgeving een overdracht van bevoegdheden naar de Gemeenschap tot gevolg. Nadat het recht eenmaal geharmoniseerd is verliezen de lid-staten de bevoegdheid de nationale regeling aan te passen aan nieuwe ontwikkelingen, in ieder geval

61. Dit geldt met name voor RI 76/207/EEG Pb. $1975 \mathrm{C} 111$ (gelijke behandeling van mannen en vrouwen), $\mathrm{Rl}$. 79/7, $\mathrm{Pb} 1979 \mathrm{~L} 6$ (gelijke behandeling van mannen en vrouwen in de sociale zekerheid) en $86 / 378$, Pb. $1986 \mathrm{~L}$. 225 (gelijke behandeling van manmen en vrouwen in ondernemings- en sectoriële regelingen inzalke sociale zekerheid). Hoewel het Hof wan Justitie een aantal malen heeft witgesproken dat discriminatie in pensioenregelingen in strijd kan zijn met art. 119, en het dus mogelijk was de richtlijn op dit artikel te baseren, heeft de gemeenschaps-wetgever dit niet gedaan, ondat "gelijke behandeling" (richtlijn) ruimer is dan "gelijke beloning"(artikel 119).

62. Men kan twisten over hoever de detaillering mag gaan, zie hierover R.H. Lauwaars, J.M. Maarleveld, a.w. (noot 31), p. 62-64.

63. C.W.A. Timmermans, EEG-harmonisatie en Nederlands recht, beeld van bewogen beweging R.M.Themis 1980, p. 411.

64. Zie ook Th. W Vogelaar, Het nader tot elkaar brengen wan de nationale wetgevingen bij toepassing van het Verdrag van Rome, SEW 1974, pp. 299-327. 
voor zover de wijziging niet met het gemeenschapsrecht in overeenstemming dreigt te zijn.

Deze wetgevende zijde van harmonisatie zou bij de harmonisatie van sociale wetgeving mijns inziens moeten worden benadrukt. Wanneer sociale regelingen op een zeer laag niveau geharmoniseerd worden, betekent dit om te beginnen dat vrij grote dispariteiten blijven bestaan, dispariteiten die lid-staten kunnen uitnodigen het beschermingsniveau van hun sociale regelgeving te verlagen. Maar belangrijker nog is dat bij harmonisatie op een zeer laag niveau dit niveau impliciet geaccepteerd wordt als beleidskeuze van de gemeenschapswetgever voor haar burgers. En dat kan in het licht van de doelstellingen zoals geformuleerd in artikel 2 (verbetering van de levenstandaard) en artikel 117 (harmonisatie van sociale wetgeving "op weg naar de vooruitgang") niet de bedoeling zijn. De Gemeenschap moet het opstellen van harmonisatierichtlijnen, mogelijk nog meer dan bij de andere beleidsterreinen, belangen afwegen en keuzes maken tussen verschillende alternatieven. De werking van de gemeenschappelijke markt, hoewel basis voor harmonisatie, mag bij die afweging niet het enige beoordelingscriterium zijn, omdat anders de gemeenschappelijke markt ten koste van het bereikte niveau van sociale wetgeving zou kunnen gaan (65).

Men kan zich overigens afvragen of de Gemeenschap voldoende democratische legitimatie heeft om tot dergelijke beleidskeuzen in de wetgeving te kunnen komen. De bevoegdheden op sociaal gebied zijn niet op de hier verdedigde schaal aan de Gemeenschap overgedragen bij het sluiten van het EEG-verdrag of haar wijzigingsverdragen. Anderzijds leidt ook de harmonisatie in verband met de interne markt tot een mate van bevoegdheidsoverdracht, die niet altijd voorzien is geweest (66). Voor het sociale beleid is dat niet anders. Nu het gebrek aan democratische legitimatie voor regelingen ten aanzien van de interne markt geaccepteerd wordt, kan men niet volhouden dat dat gebrek onacceptabel is als het erom gaat de gevolgen van die interne markt te verzachten.

Als richtlijnen eenmaal omgezet zijn, betekent dit niet dat iedere dispariteit op dat specifieke gebied altijd volledig is opgeheven (67). Naast verschillen

65. Een door mij angedragen oplossing voor de juridische zijde van de problematiek van dit dilemma is de idee van een uit artikel 117 afgeleide anvullende bevoegdheidsoverdracht naar de gemeenschap, die er toe leidt dat lid-staten, na harmonisatie van wetgeving het
beschermingsnivesu van hun verlagen, zelfs aiet als deze verlaging zich noget meer zonder objectieve grond mogen toegestane beleidsruimte bevindt. Zie: $\mathbb{E}$. Steyger, boci kader wan de door de richlijin sociale wetgeving; stiefkind en zorgenkind p. 168 (478) -175 (485).

66. Zie ook: E. Steyger, Vertrowwen is goed, controle is beter; bevoegdheidsoverdracht en democratische controle in pre-federaal Europa, in Bestuursrechtelijke bewegingen (A.W.

67. D. I 85. 
die aanwezig blijven door de beleidsvrijheid die richtlijnen kunnen bieden, zullen nuance-verschillen in de vertalingen, maar ook de interpretatie van begrippen uit richtlijnen op nationaal niveau in plaats van een eenvormige gemeenschapsinterpretatie, ervoor zorgen dat weliswaar kleine, maar niet altijd onbelangrijke verschillen kunnen blijven bestaan (68). Niettemin wordt met name voor het sociaal beleid, vanwege de grote culturele en traditionele verschillen in de lid-staten de richtlijn het meest effectieve harmonisatieinstrument geacht (69).

De burgers krijgen in het algemeen indirekt met geharmoniseerd recht te maken: na omzetting maakt het geharmoniseerde recht deel uit van hun nationale recht. In beginsel kunnen zij zich als de lid-staten de verplichtingen die door richtlijnen worden opgelegd niet nakomen, niet op richtlijnbepalingen beroepen, De jurisprudentie heeft deze regel echter gemitigeerd: indien lid-staten de richtlijn niet binnen de (in die richtlijn) voorgeschreven termijn om zetten in nationaal recht dan is een beroep op richtlijn bepalingen onder omstandigheden wel mogelijk (70). Als zo'n beroep wordt gehonoreerd, hetgeen afhangt van de nauwkeurigheid, duidelijkheid en de onvoorwaardelijkheid van de bepaling, en de vraag of er uitvoeringsmaatregelen nodig zijn, moeten bestaande wetsbepalingen die met de richtlijn strijdig zijn, buiten toepassing worden gelaten.

Wanneer een richtlijn wél is omgezet in nationale wetgeving, bestaat de kans dat dit niet goed is gebeurd, zodat de wetgeving onverenigbaar met de richtlijn is, bijwoorbeeld doordat de uitvoeringsmaatregel zich buiten het door de richtlijn toegestane kader begeeft. In eerste instantie heeft de rechter de plicht om met de richtlijn strijdige wetgeving conform de richtlijn uit te leggen (71). Indien de nationale maatregel echter zodanig verschilt van de richtlijn dat dit verschil niet meer weggeïnterpreteerd kan worden, komt men in de problemen. Is dit het geval, dan sluit het Hof van Justitie niet uit dat de (nationale) rechter de uitvoeringsmaatregel buiten toepassing laat, voor zover daarbij de beoordelingsurijheid, die het kader van de richtlijn biedt, is overschreden (72). De richtlijnbepaling moet dan wel aan

68. G. Schnorr, European Communities, in Comparative Labour Law and Industrial Relations (gen ed. R. Blanpain), Deventer 1985, p. 118; E. Steyger, De Gemecnschappelijke arbeidsmarkt en het socialle beleid van de gemeenschap; over discriminatie distorsies $\mathrm{em}$ ingebakken dispariteiten, NJB 1988, p. 249-253.

69. Jacobs verdedigt overigens dat voor specifieke regelingen als standaarden de verordening ook heel bruikbatar zou zijn als harmonisatieregeling. A.T.J.M. Jacobs, De arbeidsrechtelijke aspecten wan de Europese binnenmarkt, NJB 1989, p. 837.

70. Zaak 41/74, Y'vonne van Duyn ws Home Office, Jur. 1974, p.1331, ook zaak 152/84, 262-1986, Jur. 1986, p. 723-751 (Marshall vs Southampton and South West Area Health Authority), Meer in het algemeem over harmonisatie van wetgeving: C.W.A. Timmermans: a.w. (noot 63), p. 421; R.H. Lauwaars, J.M. Maarleveld, a.w. (noot 31).

71. Zaak 14/83, Jur 1984, p. 1909, (van Colson en Kamann), vooral ook zaak 80/86, Jur. 1987, p. 3969-3988, (Kolpinghuis).

72. Zaak 51/76, Jur. 1977 , p. 113 (VNO), zaak $38 / 77$ Jur. 1977, Jur. 1977, p. 2203 (ENKA), AA 1978 , p. 354-361 m.n. Timmermans. 
de voorwaarden van "inroepbaarheid" voldoen (73), dat wil zeggen voldoende nauwkeurig zijn om zich voor het inroepen door een burger te lenen. Deze voldoende nauwkeurigheid kan gevonden worden in de bepaling zelf, maar ook in de grenzen die de bepaling aangeeft waarbinnen de uitvoeringsmaatregel zich moet bevinden (74). Deze vorm van (marginale) toetsing van een nationale norm aan de interpretatie van het gemeenschapsrecht, die overigens niet leidt tot een algemene verplichting van de nationale rechter om de verenigbaarheid van iedere uitvoeringsmatregel met een richtlijn te onderzoeken (75), wordt door Timmermans aangeduid met "algemene rechtmatigheidstoetsing" (76).

Richtlijnen hebben geen horizontale werking, zodat het inroepen door de burger van een richtlijnbepaling alleen tegenover de lid-staat, niet tegenover particulieren mogelijk is (77). Anderzijds legt een richtlijn uit zichzelf geen verplichtingen aan particulieren. Dit alles betekent onder meer dat werknemers zich niet ten opzichte van hun werkgever kunnen beroepen op een richtlijnbepaling, indien de lid-staat zijn verplichtingen niet nagekomen is, tenzij die lid-staat zelf de werkgever is (78). Hoewel te verdedigen valt dat dit een arbitrair verschil tussen de rechten van werknemers in dienst van de overheid en werknemers in dienst van particulieren oplevert, meende het Hof dat "such a distiction may be easily avoided if the Member State concerned has correctly implemented the directive in national law" (79). Lid-staten kunnen ook als werkgever, de burgers hun eigen nalatigheid niet tegenwerpen (80).

Een van de eerste richtlijnen op sociaal gebied was een uitwerking van en een aanvulling op artikel 119 (81), het artikel dat gelijke beloning van mannen en vrouwen waarborgt. De richtlijn verandert volgens thet Hof niets aan de reikwijdte van artikel $119(82)$; echter doordat hij bedoeld is de toepassing van het verdragsartikel te vergemakkelijken is het effect wel

73. M. Maresceau, Het verbindend karakter wan richtlijnen volgens de rechtspraak van het Hof van Justitie, SEW 1980 , p. 665

74. Zaak 222/84, 15-5-1986, Margherite Johnston ws Royal Ulster Constabulary, m.n. ro. 5254; Zaak 152/84, Jur. 1986, p. 723-751 (Marshall); zie ook P.J.G. Kapteyn, P. Verloren van Themaat, a.w. (noot 19), p. 237.

75. R.H. Lauwatars, Het voorbehoud van openbare orde als beperking van het vrije verkeer wan personen in de EEG, SEW, 1978, p. 838 .

76. C.W.A. Timmermans, a.w, (noot 63); ook C.W.A. Timmermans, Directives, Their effect within the National Leggal Systems, 16 C.M.L.Review, 1979, p. 545.

77. Zaak 152/84, Jur. 1986, p. 723-751 (Marshall) .

78. Zic in dit verband ook Zaak 76/81 Jur. 1982, p. 417 (Trans-poroute et Travaux SA ws. Ministerie van Openbare Werken) waar (zij het meer impliciet) een vergelijkbare uitspraak werd gedaan voor de overheid als opdrachtgever.

79. Zaak $152 / 84$, ro. 51 .

80. Zaak 80/86, Jur. 1987, p. 3969-3988 (Kolpinghuis).

81. RI $75 / 117$ van 10 februari 1975 , Pb L 45 .

82. Zaak 43/75, Jur. 1976, p. 455-483 r.o, 60. Zie ook zaak 96/80, Jur. 1981, p. 911 (Jenkins ws Kingsgate) en zaak 192/85, Jur. 1987, p. 4753-4787, (George Joel Newstead vs Department of Transport and Her Majesty's Treasury). 
degelijk geweest dat het beginsel van gelijke beloning op ruimere schaal kon worden toegepast, namelijk voor zover het indirecte discriminatie betreft. In het Defrenne II-arrest (83) was namelijk nog door het Hof uitgemaakt dat artikel 119 wel rechtstreeks toepasselijk was op directe discriminatie voor zover deze met behulp van de in artikel 119 gegeven criteria waren vast te stellen, maar niet op zijdelingse, verkapte (84) en indirekte discriminatie. Deze laatste vorm van discriminatie dient ofwel in nationale wetgeving, ofwel door harmonisatierichtlijnen te worden opgeheven. In deze zin vult de richtlijn artikel 119 aan, omdat hier althans in de visie van enkelen wel indirecte discriminatie (m.n. voor wat betreft onderscheid naar burgerlijke staat of gezinsomstandigheden) onder wordt begrepen (85). Ook anderszins kan men zeggen dat de verduidelijking van de richtlijn een aanvulling oplevert op artikel 119, doordat deze onder gelijke arbeid ook arbeid van gelijke waarde verstaat. In de Worringhamzaak stelde het Hof echter uitdrukkelijk dat het om een verduidelijking gaat (86).

Het probleem van beïnvloeding van de reikwijdte van een verdragsartikel heeft bij de andere richtiijnen die betrekking hebben op het sociaal beleid geen rol gespeeld. Dit heeft ongetwijfeld te maken met het karakter van de bewuste verdragsbepalingen, die veel minder dan artikel 119 een concrete en duidelijke verplichting inhouden, en zelf meer instructiebepalingen zijn en een opdracht tot het formuleren van een beleid inhouden. Het is echter niet uitgesloten dat een dergelijk probleem zich op den duur kan voordoen, zodat naast artikel 100 en $100 \mathrm{~A}$ de harmonisatiegrondslag voor richtlijnen die in verband met de gemeenschappelijke markt uit het verdrag voortvloeien, artikel 235 van belang blijft voor het formuleren van een sociale politiek.

Na 1975 nam het aantal richtlijnen op het gebied van het sociaal beleid gestaag toe. Een aantal hiervan hebben gelijke behandeling van mannen en vrouwen op andere terreinen dan gelijke beloning tot onderwerp, andere zijn specifiek gericht op werknemersbescherming in een veranderende economische constellatie en een derde groep is gericht op werknemersbescherming voor wat betreft veiligheid en gezondheid.

83. Zaak $43 / 75$, Jur. 1976 , p. $455-483$ (Gabriëlle Defrenne vs Belgïsche Luchtvaart Maatschappij Sabena).

84. In zaak 96/80 Jur, 1981, pp. 77-96 (Jenkins vs Kingsgate) verklaarde thet Hof artikel 119 ook toepasselijk op zijdelingse en verkapte discriminiaties. Op indirecte discriminalies, en daarbij gaat het met name on die soorten van discriminatie waarbij sexe-neutrale criteria worden gebruikt, maar waarbij de stelsels zo ingewikkeld zijn dat niet met behulp van een eenduidig criterium is vast te stellen of de gewraakte criteria tot benadeling (en dus ongeoorloofde discriminatie) leiden, is artikel 119 nog steeds niet direct toepasbaar.

85. Zie S. Prechal, Gelijke behandeling in de rechtspraak van hell Europese Hof van Justitie, Nemesis 1(1984/5)4, p. 171.

86. Zie ook zaak 69/80, Jur. 1981, p. 767 (Worringhan vs Lloyds bank Ldd). 


\subsection{Harmonisatie van medezeggenschapswetgeving in de gemeenschap.}

Wanneer in communautair verband gesproken wordt over harmonisatie van medezeggenschapswetgeving is deze term in feite onjuist. Er is geen sprake van harmonisatie van wetgeving, aangezien in een deel van de lid-staten geen algemene medezeggenschapswetgeving bestaat, en zelfs medezeggenschapsorganen in de enge zin van het woord, namelijk in geïnstitutionaliseerde vorm ontbreken. Daarnaast is de term onjuist omdat de eerste pogingen tot regulering niet gericht waren op harmonisatie van het bestaande. $\mathrm{Zij}$ hadden veeleer constituering van medezeggenschap ten doel, mede op een niveau, waarop medezeggenschap tot dan toe niet (en nog steeds niet, maar dit terzijde) bestond.

In feite is medezeggenschap het gemeenschapsrecht niet als zelfstandige factor binnengeslopen maar via de harmonisatie van het vennootschapsrecht. Doordat het gebruik van het recht van vrije vestiging voor ondernemingen vereenvoudigd moest worden, wilde men de ondernemingen onderwerpen aan een bepaalde organisatiestructuur. Binnen die structuur diende ruimte te zijn voor medezeggenschapsverhoudingen, op éen of andere wijze. Dat met een dergelijke opgedrongen structuur inclusief medezeggenschap de basis zou worden weggeslagen onder systemen van industriële verhoudingen, waar de structuur juist door onderhandelingen tussen de sociale partners worden vastgesteld, werd in de eerste voorstellen niet genoeg onderkend.

Hier schuilt uiteraard een probleem. Wanneer een systeem van beleidsbeinvloeding is gebaseerd op onderhandelingen tussen werkgevers en werknemers (vakbondsvertegenwoordigers) en daarmee op betrekkelijk subtiele (en soms wat minder subtiele) verschuivingen in de machtsverhoudingen binnen de onderneming maar ook binnen de vakbonden, dan levert iedere wettelijke regeling een kunstmatige druk op die machtsverhoudingen op. Een dergelijke druk kan ten voordele van werknemers uitpakken: een bij wet (of gemeenschapsrechtelijke regeling) toegekend recht wordt een ononderhandelbaar gegeven en dus niet meer inwisselbaar. Anderzijds kan een bij wet toegekend recht aan werknemers (en niet specifiek aan vakbonden) de noodzaak om vakbonden bij de onderhandelingen in te schakelen verkleinen, en het evenwicht in de verhouding tussen werknemers en werkgever vernietigen. Dit geldt des te sterker, wanneer de toegekende rechten betrekking hebben op instituties binnen de onderneming. Instituties zoals deze in het eerste voorstel voor herziening van de structuur van de vennootschap werden voorgesteld, waren voor in elk geval een aantal van de in de lid-staten opererende vakbonden vakbondsvreemd. Vakbonden hadden, als deze voorstellen werkelijkheid geworden waren, met deze instituties moeten leren omgaan (87), hetgeen een zekere mate van training

87. Hierbij ga ik uit van de idee van Peters dat recht door de actoren veroverd dient te worden: A.A.G. Peters, Recht als Project, AA 28(1979)11, P. 245 (881)- 256(893). 
vergt die in eerste instantie ten koste van het evenwicht in de onderneming had kunnen gaan.

Dit verhaal gaat overigens voor medezeggenschap op multinationaal niet op. Op het niveau van multinationale ondernemingen is er op dit moment geen sprake van een machtsevenwicht, aangezien de vakbonden om verschillende redenen niet in staat zijn geweest op dit niveau eisen te stellen. Eén van de redenen is de gebondenheid aan de nationale grenzen van de verschillende vakbonden (of vakbondsfederaties). De vakbonden zullen een deel van hun souvereiniteit moeten opgeven om tot afspraken op hoger niveau te komen, opgeven aan de ETUC (88). Dit betekent dat zij gebonden kunnen worden tegen hun wil aan door het ETUC af te sluiten raamovereenkomsten. Tot dusver zijn de nationale vakbonden echter even (zo niet meer) terughoudend geweest voor wat betreft overdracht van bevoegdheden als. de lid-staten binnen wier grenzen zij zich bevinden.

Zelfs als de vakbonden in staat zouden zijn eisen te stellen, is het nog maar de vraag of werkgevers gedwongen zouden kunnen worden te contracteren. Het klassieke antwoord aan onwillige werkgevers is de staking. De vraag of een Europese vakbond, al heeft zij de bevoegdheden ook de feitelijke macht zou hebben stakingen te bewerkstelligen lijkt mij niet gemakkelijk te beantwoorden.

Dit alles leidt tot de conclusie dat het machtsevenwicht zoals dat op nationaal niveau gegroeid is, op multinationaal niveau vooralsnog niet aanwezig is. Om op dit evenwicht te gaan zitten wachten lijkt onverstandig. Gemeenschapsregelgeving is daarom, ook voor die landen die op zichzelf bij voorkeur een op vrijwilligheid gebaseerd systeem zouden handhaven, een noodzakelijke voorwaarde om het evenwicht tussen werkgevers en werknemers op ondernemingsniveau niet al te ver zoek te laten worden.

De Commissie heeft tot dusver een aantal voorstellen gedaan op het gebied van medezeggenschap zowel op multinationaal niveau als voor een zekere mate van harmonisatie van de wetgeving van de lid-staten zelf. Tot dusver zijn echter geen nieuwe rechten gecreëerd. Dit geldt ook voor die richtlijnen waarin bepalingen met betrekking tot consultatie van werknemers of werknemers- vertegenwoordigers zijn opgenomen, die in de volgende paragrafen onder de loep zullen worden genomen.

\section{De richtlijnen en de voorstellen.}

Harmonisatie van consultatie- en informatierechten voor werknemers(vertegenwoordigers) in het algemeen, hebben het tot dusver niet verder gebracht dan de status van richtlijnvoorstel. Sedert de dialoog tussen de sociale partners in de jaren zestig werd opgestart, zijn een aantal voorstel-

88. Zie ook. G, Debunne, a.w. (noot 14), p. 166-167. 
len tot stand gekomen. Uit de jaren zeventig dateren verschillende voorstellen die verschillende uitgangspunten hadden. Zo was er het voorstel voor een vijfde richtlijn in verband met het vennootschapsrecht, dat vooral harmonisatie van medezeggenschap op nationaal niveau beoogde. Daarnaast kwamen het Vredeling-Richard-voorstel (89) aangaande informatie en consultatie van werknemers in multinationale ondernemingen en het ontwerp Statuut voor een Europese Vennootschap (Societas Europea; verder te noemen Statuut SE) tot stand dat ook gericht was op bovennationale medezeggenschap. Geen van deze voorstellen zijn tot op heden als richtlijn aanvaard. Wel aanvaard zijn regelingen op deelgebieden als collectief ontslag, overgang van ondernemingen, en veiligheid en gezondheid van werknemers. Bovendien lijkt aanvaarding van de nieuwste versie van het voorstel met betrekking tot de Europese vennootschap tot de mogelijkheden te behoren.

In de volgende paragrafen zullen de verschillende harmonisatie-pogingen aan een nadere beschouwing onderworpen worden. Bij deze bespreking zal geen strikt chronologische volgorde van de verschillende voorstellen worden aangehouden, maar een gescheiden benadering van beide soorten voorstellen worden gehanteerd. Hierbij zal van algemene naar specifieke regelingen gewerkt worden. Eerst worden de voorstellen die de structuur van de vennootschap moesten harmoniseren, besproken. Daartoe behoren het vijfde richtlijn voorstel en het Statuut SE. Daarnaast wordt gekeken naar de "issue"-gerichte invalshoek. In deze paragraaf worden die voorstellen en richtlijnen besproken die de verschillende soorten van vertegenwoordiging in de lid-staten ongemoeid lieten, maar zich beperkten tot minimumharmonisatie van het instrumentarium en van de onderwerpen waarover geïnformeerd en geconsulteerd moet worden. Tot deze categorie behoren de Vredelingvoorstellen, de bepalingen aangaande medezeggenschap in de voorstellen en de bestaande richtlijnen en hun implicaties, en de voorzichtig in de sociale dialoog tot ontwikkeling komende ideëen over invoering van nieuwe technologie.

\subsection{De institutionele invalshoek.}

De eerste pogingen tot wetgeving met betrekking tot werknemers-medezeggenschap dateren uit het begin van de jaren zeventig. In 1970 deed de Commissie een voorstel voor een verordening om tot een Europese vennootschap te komen (90), dat in 1975 in geamerideerde vorm tot het voorstel voor een statuut voor Europese ondernemingen (91). In dezelfde periode werd een voorstel voor een vijfde richtlijn in het kader van de harmonisatie van het vennootschapsrecht gedaan (92), een voorstel dat, hoewel het de structuur van vennootschappen als onderwerp had, door de

89. Voorstel voor een richillijn van oktober $1980, \mathrm{~Pb} .1980 \mathrm{C} 297$.

90. Pb. $1970, \mathrm{C} 124$.

91. Bull. EG, Supp. 4/75.

92. $\mathrm{Pb}$. 1972, C 131, laatste gewijzigd woorstel $\mathrm{Pb} .1983$, C $240 / 2$. 
wijze waarop werknemersmedezeggenschap in die structuur vervlochten was de nodige reacties van de lid-staten en werkgevers- en werknemersorganisaties te verwerken $\mathrm{kreeg}$.

Het (eerste) voorstel voor de vijfde richtlijn ging uit van een structuur van de vennootschap waarin een bestuursorgaan het dagelijks bestuur van de onderneming voert, deze vertegenwoordigt en in beginsel de beslissingsbevoegdheid heeft over de dagelijkse gang van zaken. Daarnaast bestaat een toezichthoudend orgaan, dat de bevoegdheid heeft bestuursleden te benoemen en te ontslaan. Bovendien zou het toezichthoudend orgaan een recht van instemming hebben bij de volgende besluiten: de sluiting of overdracht van de onderneming of belangrijke onderdelen daarvan, belangrijke uitbreiding of inkrimping van de activiteiten van de onderneming, belangrijke reorganisaties en het aangaan of beeindigen van duurzame samenwerking met andere ondernemingen. Een derde orgaan was een algemene vergadering van aandeelhouders, die voor dit onderwerp verder niet van belang is.

De leden van het orgaan van toezicht zouden moeten worden benoemd, ofwel door de algemene vergadering van aandeelhouders, ofwel door middel van coöptatie van het orgaan zelf; in het eerste geval zouden werknemers of hun vertegenwoordigers het recht hebben een derde van het aantal leden te benoemen of een voor de benoeming bindende voordracht te doen, in het tweede geval zou aan de werknemers of hun vertegenwoordigers een geclausuleerd vetorecht toekomen ten aanzien van de te benoemen personen, op grond van ongeschiktheid voor de taakvervulling, dan wel samenstelling van het orgaan van toezicht.

Het door de Commissie voorgestelde model was overigens niet origineel: er was zowel van het Duitse als het Nederlandse model

uitgegaan, waarbij de modellen als alternatieven voor elkaar konden dienen (93). Dat daarbij de harmonisatie niet tot unificatie zou leiden werd acceptabel geacht omdat beide modellen als gelijkwaardig werden ervaren (94).

In dezelfde periode dat het eerste voorstel voor de vijfde richtlijn werd ontwikkeld kwam, zoals gezegd, ook een ontwerpverordening voor de Europese vennootschap tot stand. De bedoeling van dit voorstel was dat twee of meer ondernemingen die samen een holding zouden vormen dit zouden kunnen doen onder Europese regels, waarmee ingeval de holding een multinationaal zou worden, de problemen die de verschillende wettelijke systemen boden omzeild konden worden. Het Europese karakter van de SE werd nog onderstreept door de wijze van registratie in een bij het Hof neer te leggen Europees handelsregister, en de publikatie van

93. Zie ook C.W.A. Timmermans, De structuur van de naamloze vennootschap en het voorstel voor een vijfde EEG-richtlijn, TVVS 1973, p. 168 .

94. Toelichting op het ontwerp wiffde richt $1 \mathrm{ij} \mathrm{j}, 17 \mathrm{NBV}$ december 1972 , p. 24. 
vitale infomatie van de SE door het Publikatieblad van de gemeenschap. Het statuut SE is een lijvig document, dat een aantal medezeggenschapsbepalingen omvat.

De structuur van de SE heeft veel weg van hetgeen in het voorstel voor de vijfde richtlijn al naar voren kwam. Ook hier is geopteerd voor een tweestromenland van bestuur en toezichtsorgaan. Dit laatste orgaan zou de leden van het eerste benoemen. Het toezichtsorgaan zou bestaan uit een oneven aantal leden dat deelbaar is door drie (indien de SE vestigingen in meer dan eên lid-staat heeft is er een minimum van negen leden). Een derde van de leden zou worden benoemd door de werknemersvertegenwoordigers van elke lid-staat, of als de SE zich in eén lid-staat bevindt door middel van rechtstreekse verkiezingen.

Naast deze vorm van werknemersparticipatie zou ook een Europese ondernemingsraad (EOR) bestaan. Deze zou moeten worden geinstalleerd wanneer de SE vestigingen in meer Europese landen heeft, ongeacht of de nationale wetgeving al in medezeggenschap voorziet. De EOR zou geen vakbondsinstituut zijn, maar de werknemers van de SE als geheel representeren (95). Desalniettemin zou de EOR zelf bij meerderheid van stemmen kunnen besluiten een vertegenwoordiger van een bepaalde vakbond tot de vergaderingen toe te laten waar deze een adviserende stem zou hebben. De Europese ondernemingsraad zou blijven bestaan naast de nationale vorm van werknemersmedezeggenschap. Het aantal leden van de EOR zou evenredig zijn aan het aantal werknemers in elke vestiging. De verordening zou voor de leden van de EOR een aantal faciliteiten in het leveren roepen om hen het functioneren mogelijk te maken, zoals tijd om te vergaderen en ontslagbescherming.

De EOR zou recht hebben op dezelfde informatie als de aandeelhouders van de holding, en overleggen met de Raad van Bestuur die rapportage verplichtingen aan de EOR zou hebben. Daarnaast zou de EOR adviesrecht omtrent werkclassificatiesystemen het niveau van het werk en in zaken als de inkrimping, uitbreiding en verandering van de activiteiten hebben. Indien adviezen niet gevolgd zouden worden, zou een gemotiveerde afwijzing voorgeschreven zijn.

Instemmingsrechten zouden de EOR toekomen inzake veiligheids- en gezondheidsbescherming, promoties en ontslag, opleiding, sociale faciliteiten, werktijden en vakanties. Indien geen overeenstemming tussen de EOR en de Raad van Bestuur zou worden bereikt zou een beroep op een arbitrage college gedaan kunnen worden waarvan de helft door de EOR is gekozen, de andere helft door de Raad van Bestuur; de leden van het arbitragecollege zouden een onafhankelijke voorzitter kunnen benoemen.

95. Over de mogelijkheid dat EOR-leden inderdaad als representatief gezien zouden kunnen worden bestond overigens wel enige twiffel, zie Y. Scholten, Medezeggenschap van werknemers en structuur van de wennootschap in Europees verband, SEW 1987, p. 714. 
Als deze ontwerpverordening, die ook op andere gebieden praktisch de vorm heeft van een Europees wetboek voor ondernemingsrecht, uit het stadium van voorstel was gekomen, had dit boek er heel anders uitgezien. Het Statuut SE noch het vijfde-richtlijn voorstel bleek echter haalbaar. Met name uit Groot Brittannië kwam de kritiek dat op deze wijze te zeer ingegrepen zou worden in het systeem van industrial relations (96), dat in Groot Brittannië zelf veeleer gebaseerd is op confrontatie dan op samenwerking tussen werkgever en werknemers. Kahn-Freund kwalificeerde de representatie in het toezichtsorgaan als onrealistisch (97), ook al werd dit door anderen gezien als een niet onwelkome nieuwe constructie van "conflictual partnership" (98). Noch de Britse regering noch de vakbonden voelden ervoor dit Britse systeem door middel van de door de Commissie voorgestelde structuur uit balans te halen (99).

$\mathrm{Na} 1975$ werd er in eerste instantie weinig meer van het Statuut SE vernomen. In de zomer van 1989 werd echter een nieuw voorstel ingediend dat voor wat de medezeggenschap betreft op een andere leest geschoeid is. Op dit voorstel zal in een latere paragraaf worden teruggekomen (100).

\section{A Het Groenboek als basis voor gedachtenvorming}

Het Groenboek (101) "Medezeggenschap van werknemers en de structuur van de vennootschap" (102) werd door de Commissie in 1975 uitgebracht, toen bleek dat bij de harmonisatie van het vennootschapsrecht de medezeggenschap een struikelblok zou worden. De doelstelling van het Groenboek was dan ook de discussie omtrent medezeggenschap te verbreden in dier voege dat meer varianten in overweging zouden worden genomen. Harmonisatie van vennootschapswetgeving diende volgens de commissie een medezeggenschapscomponent te bevatten, omdat bij de hervorming van instituties als vennootschappen in het licht van de gemeenschappelijke markt rekening moet worden gehouden met maatschappelijke evoluties als democratisering en verandering.

De Commissie geeft in het Groenboek een beschrijving van de verschillende wijzen van medezeggenschap in de lid-staten waarbij zij een onderscheiding maakt tussen medezeggenschap in vertegenwoordigende organen met informatie, consultatie en instemmingsbevoegdheden, medezeggenschap in besluitvormende organen, via collectieve overeenkomsten en via werkne-

96. Dit standpunt is o.m. terug te vinden in het Bullock rapport (Report of the Committee of Inquiry on Industrial Democracy) en het White Paper "Industrial Democracy" (HSMO 1978) van de Labour regering.

97. O Kahn Freund, Industrial Democracy, I.L.J. 1977, p. 65

98. P. Davies, Wedderburn, This Land of Industrial Democracy, I.L.J. 1977, p. 211.

99. Zie D. Lasok, a.w. (noot 34), p. 210.

100. Zie paragraaf II.4.1.B.

101. De term groenboek is afkomstig uit de Engelse parlementaire praktijk, waar 'green papers" staan voor discussiestukken voor zowel politici als maatschappelijke groeperingen en "white papers" voor discussiestukken in het parlement.

102. Bulletin EG, Supp. 8/75. 
mersaandelen. Deze laatste twee medezeggenschapsvormen worden niet rijp geacht voor een regeling op communautair niveau.

De Commissie pleit in het Groenboek voor een communautair vast te stellen minimumniveau voor informatie, voor de vertegenwoordigende organen en de verplichting op een aantal terreinen deze organen te consulteren. $\mathrm{Zij}$ acht deze organen echter niet geschikt om instemmingsrechten te hebben bij economische aangelegenheden. Een dergelijk instemmingsrecht zou het risico in zich zou bergen dat de handelingsurijheid van de onderneming zou worden verlamd. De harmonisatie van medezeggenschap in besluitvormende organen moet volgens de Commissie geregeld worden volgens het in de vijfde richtlijn voorgestelde stelsel. $\mathrm{Zij}$ brengt voor wat de structuur van de vennootschap betreft wel wijzigingen aan. Die landen die in eerste instantie een structuur met een bestuur en een toezichtsorgaan afwijzen, moeten kunnen kiezen voor een mogelijkheid van werknemersparticipatie in een toezichthoudende rol binnen het bestuur. Veel van wat daarover wordt gesteld is in het geamendeerde voorstel voor een vijfde richtlijn terug te vinden.

Naast medezeggenschap op ondernemingsniveau behandelt het Groenboek ook medezeggenschap op concernniveau. De Commissie gaat er van uit dat er op beide niveaus mogelijkheden tot inspraak moeten zijn. Voor zover dit problemen op kan leveren voor de verhouding moeder-dochtervennootschap, meent de Commissie dat dit op te lossen valt door de medezeggenschap te koppelen aan de concerntop. Wanneer de vereiste inspraakprocedure (bijvoorbeeld goedkeuring) over eventuele instructies aan de dochter heeft plaatsgevonden, kan de moeder deze bindend aan de dochter opleggen. Voorwaarde is dan wel dat de medezeggenschap bij de top gelijkwaardig is aan die op nationaal niveau in de dochter zodat verdergaande procedures op nationaal niveau niet "overruled" kunnen worden door middel van de holdingconstructie. Dit stelt uiteraard wel de nodige eisen aan de communautaire regeling.

De keuzes die in het Groenboek gemaakt worden gaan echter nog steeds uit van de omstreden institutionele invalshoek. Uit de discussies die in de jaren na het verschijnen ervan volgden, kwam een nieuw initiatief dat veel meer de issues waarover werknemers inspraak zouden kunnen krijgen tot onderwerp had, dan de vorm waarin die inspraak gegoten moest worden.

\section{$B$ De fase van de alternatieven}

In $1983 \mathrm{kwam}$ de Commissie met een herzien voorstel voor de vijfde richtlijn (103). Het idee van een dualistische structuur van de vennootschap (bestuursorgaan en toezichtsorgaan) is in thet nieuwe voorstel facultatief gemaakt. De nationale wetgeving moet deze mogelijkheid bieden, maar ondernemingen kunnen opteren voor een monistisch systeem, waarin 
overigens wel in een scheiding van toezicht en bestuur door middel van beherende en niet-beherende bestuursleden is voorzien. Het monistische model lijkt in die zin op het dualistische dat de beherende leden de toezichthoudende taak vervullen die in het dualistische model aan het toezichthoudende orgaan toekomen.

In het voorstel zitten vier verschillende modellen voor werknemersmedezeggenschap. Als eerste is dat het oorspronkelijke model van een toezichthoudend orgaan waarvan tenminste een derde van de leden door de werknemers wordt benoemd. Het tweede komt ook uit het oude richtlijnvoorstel, waarbij het toezichtsorgaan door middel van coöptatie in nieuwe benoemingen voorziet, maar waarbij de vertegenwoordigers een geclausuleerd vetorecht hebben.

Naast deze twee is voorzien in medezeggenschap door middel van een orgaan dat de werknemers vertegenwoordigt, vergelijkbaar met de Nederlandse ondernemingsraad, dat soortgelijke informatierechten zou moeten hebben als het toezichthoudende orgaan. Het vertegenwoordigend orgaan moet geconsulteerd worden over al die besluiten waar goedkeuring van het toezichthoudende orgaan voor nodig is. Indien het toezichthoudend orgaan het advies van de 'ondernemingsraad' niet volgt moet het dit gemotiveerd ter kennis brengen. De verplichting tot consultatie kan op nationaal niveau worden uitgebreid.

Het vierde model behelst een bij collectieve overeenkomst geregelde medezeggenschap. Het lijkt revolutionairder dan het is, omdat de contractspartners nauwelijks enige onderhandelingsvrijheid hebben. De keuze die de contractspartners wordt gelaten is in feite een keuze tussen eén van de drie bovenstaande modellen. Komt er geen overeenkomst tot stand, of loopt deze af zonder dat een nieuwe tot stand is gekomen, dan moet de nationale wet in een medezeggenschapsregeling voorzien, eveneens volgens één van de drie eerder genoemde modellen.

De twee laatstgenoemde vormen van medezeggenschap kunnen toegepast worden bij zowel het dualistische als het monistische model met een bestuursorgaan waarin beherende leden zijn opgenomen.

Voor concernverhoudingen zijn vergaande uitzonderingen opgenomen die met name de verhouding moeder-dochter betreffen. Als bij de moeder medezeggenschap op voldoende wijze wordt geraliseerd en daarbij rekening wordt gehouden met de belangen van de werknemers bij de dochter, dan is deze laatste voor wat de medezeggenschap betreft vrijgesteld. Is de moeder een internationaal concern, en heeft zij als enige doelstelling de financiering en het leidinggeven aan haar dochters, dan kunnen de lid-staten eveneens van de medezeggenschapsbepalingen afwijken. Met deze bepaling 
is in feite de medezeggenschap op bet multinationale niveau teruggelegd bij de nationale wetgever (104).

Daarnaast heeft de Commissie ${ }_{y}$ in verband met de voltooiing van de interne markt, in het Witboek (105) en het Actieprogramma Sociale Dimensie van de Interne Markt (106) onder meer gepland de discussie rond de Europese vennootschap te heropenen. Voor de Europese Vennootschap werd in augustus 1989 een nieuwe ontwerp-verordening ingediend bij de Raad (107). De bepalingen met betrekking tot de plaats van de werknemers in de SE zijn echter uit dit ontwerp gelicht, en vastgelegd in een voorstel voor een richtlijn ter aanvulling van de verordening (108). Deze ongebruikelijke formule wordt in de preambule gemotiveerd met een beroep op de grote verschillen in reglementering en in gebruik in de lid-staten die niet zouden toelaten de plaats van de werknemers in de SE, op eenvormige wijze te regelen.

Het richtlijnvoorstel voorziet in werknemersvertegenwoordiging in het toezichthoudend of het bestuursorgaan (artikel 4). Deze keuze hangt af van de structuur die voor de SE gekozen is (een dualistische of een monistische). Benoeming van ten minste een derde en ten hoogste de helft van de leden kan geschieden door de werknemers of hun vertegenwoordiging of door coöptatie. In dat laatste geval moet verzet van (o.m.) de werknemersvertegenwoordigers om bepaalde, in de regeling omschreven, redenen mogelijk zijn. Alleen een onafhankelijk publiekrechtelijk orgaan kan dit verzet ongegrond verklaren.

Daarnaast voorziet het voorstel in medezeggenschap door een afzonderlijk orgaan (artikel 5). De samenstelling van dit laatste wordt geregeld in overleg met degenen die overeenkomstig de wet of het gebruik van de lidstaten de werknemers in de oprichtende vennootschappen vertegenwoordigen. Artikel 4 en 5 zijn semi-dwingend recht. Bij collectieve overeenkomst tussen de leidinggevende organen van de oprichtende vennootschappen en de werknemers(vertegenwoordigers) kunnen andere modellen dan die in artikel 4 of 5 worden vastgesteld (artikel 6).

Indien het afzonderlijk orgaan van artikel 5 wordt ingesteld heeft dit informatie- en consultatiebevoegdheden. Informatie wordt verstrekt over de zaken van en de ontwikkeling van de vennootschap met inbegrip van de door haar gecontroleerde ondernemingen. Bovendien heeft het afzonderlijk orgaan het recht specifieke informatie te eisen, voor zover dat voor de uitoefening van haar functie noodzakelijk is. Het recht geconsulteerd te

104. Zie ook J. Pipkorn., The Draft Directive on Procedures for Informing, and Consulting Employees, C.M.L.Rev. 1983, p. 732, m.n. noot 29.

105. Witboek van de Commissic voor de Europese Raad, Com. 185, 310 def.

106. Sociale dimensie van de interne markt, 14 september 1988, SEC (88) 1148 def.

107. COM(89) 268 def.

108. Com(89) 286 def. 
worden ziet op maatregelen van groot belang voor de vennootschap als bedoeld in artikel 72 van de verordening (109).

Wanneer voor het alternatief van artikel 6 wordt gekozen hebben de vertegenwoordigers in de vertegenwoordigende organen over het geheel genomen dezelfde rechten als het afzonderlijk orgaan. Vergeleken met de combinatie van artikel 4 en 5 is dit uiteraard minder: de vertegenwoordiging van artikel 6 hoeft niet per se vertegenwoordiging in een toezichtsorgaan c.q. bestuursorgaan te betekenen. Bovendien kan bij collectieve overeenkomst worden bepaald (indien de wetgeving van de lid-staat waar de SE haar zetel heeft dit toestaat) dat gevoelige informatie aan de werknemersvertegenwoordigers mag worden onthouden indien dit de belangen van de vennootschappen ernstig zou kunnen schaden of haar projecten zou kunnen doen mislukken. Deze bepaling, die vermoedelijk omwille van de Britten (110) in het voorstel is beland, maakt dat het hele voorstel wel erg zwak wordt. Met artikel 6 hebben de werkgevers een ijzersterk onderhandelingspunt in handen. Wanneer vakbonden voor een dergelijke bepaling in een collectieve overeenkomst niet voelen, hoeven vennootschappen de keuze voor de SE helemaal niet te maken. Of er voor wat de multinationale medezeggenschap betreft van de SE veel verwacht moet worden lijkt mij dan ook te betwijfelen.

Het is de bedoeling om richtlijn en ontwerpverordening gezamenlijk te behandelen. Volgens het in de bijlage gegeven tijdpad zou de behandeling afgerond moeten zijn in oktober 1990. De verordening zou op 1 januari 1992 in werking moeten treden; deze datum correspondeert met de datum waarop de richtlijn in het nationale recht verwerkt zou moeten zijn. Het probleem van de scheiding tussen de twee regelingen is, dat nu het risico is ontstaan dat bij de behandeling van de verordening de bepalingen betrekkelijk snel kunnen worden geaccepteerd, terwijl de richtlijnbepalingen gemakkelijk kunnen worden afgezwakt. Bovendien zal nog moeten blijken hoe sterk de koppeling tussen verordening en richtlijn wordt gehandhaafd.

\section{De haalbaarheid van de institutionele voorstellen}

Uit het bovenstaande blijkt dat het scala van voorstellen waarin gepoogd wordt tot een zekere harmonisatie van medezeggenschap binnen de structuur van de vennootschap te komen inmiddels tamelijk groot is. Of alle voorstellen aan elkaar gelijkwaardige modellen bieden wordt overigens betwijfeld (111). Bovendien is niet van alle voorstellen zeker of deze ook medezeggenschap op het bovennationale niveau mogelijk maken.

109. Artikel 72 ziet op besluiten waarvoor toestemming nodig is van het toezichtsorgaan of unanimiteit van het bestuursorgaan (maatregelen van groot belang voor de vennootschap).

110. Zie ook paragraaf II.4.2.A.. en paragraaf IV.2.

111. C.W.A. Timmermans, Gewijzigd voorstel Vijfde EEG-richtlijn vennootschapsrecht, TVVS 1984, p. 14-15, ook L. Timmerman, a.w. (noot 37), p. 9. 
De vijfde richtlijn maakt een kans om aangenomen te worden mits men de medezeggenschapskant inderdaad beschouwt als een vorm van harmonisatie van het vennootschapsrecht. In dat geval is het op basis van de artikel 54 EEG-verdrag mogelijk de richtlijn met gekwalificeerde meerderheid van stemmen aan te nemen. Ook materiêel is deze mogelijkheid aanwezig, doordat het woorstel inmiddels zozeer is aangepast en zoveel modellen bevat dat het voor de meeste lid-staten mogelijk acceptabel is. Met name de mogelijkheid tot uitvoering bij collectieve overeenkomst zou de bezwaren bij een aantal lid-staten kunnen wegnemen, hoe beperkt die mogelijkheid ook is. De vijfde richtlijn levert echter geen bovennationale medezeggenschap op.

Het nieuwe ontwerp Statuut SE voorziet wel in bovennationale medezeggenschap. Ook dit voorstel gaat al van verschillende modellen uit, waarvan de gelijkwaardigheid niet vaststaat. Voorts is het probleem dat de Europese vennootschap optioneel is. Concerns kunnen voor deze vorm kiezen maar hoeven dit niet. Bovennationale medezeggenschap kan dan ook slechts bereikt worden in die concerns, die daar zelf voor kiezen.

De Commissie heeft als grondslag voor zowel de verordening als voor de richtlijn voor artikel 54 EEG-verdrag gekozen. Voor de verordening zal dit geen problemen opleveren voor de richtlijn kan dit mijns inziens wel het geval zijn. Het gaat in deze richtlijn met name om de expliciet bij artikel $100 \mathrm{~A}$ uitgezonderde rechten en belangen van werknemers. In de preambule van het voorstel wordt naar artikel $8 \mathrm{~A}$ verwezen, waarvan artikel $100 \mathrm{~A}$ tenslotte het "uitvoerings"artikel is (112). Juist de splitsing tussen verordening en richtlijnvoorstel kan een argument zijn voor het standpunt dat het richtlijnvoorstel niet strikt betrekking heeft op de vennootschap. Mocht de Raad besluiten het voorstel aan te nemen met gekwalificeerde meerderheid dan valt niet uit te sluiten dat de richtlijn aangevochten wordt op grond van het gebruik van een verkeerde grondslag. Het Hof heeft al een keer uitgesproken dat de kwestie van de grondslag voor regelgeving niet slechts een formele kwestie is, in verband met de stemvereisten in de Raad (113).

\subsection{De instrumentele invalshoek.}

Nadat in de jaren zeventig de institutionele benadering van medezeggenschap binnen de Gemeenschap niet tot overeenstemming bleek te kunnen leiden, werd door de Commissie naar andere mogelijkheden voor harmonisatie van medezeggenschapsbepalingen gezocht. Op enkele deelgebieden kwam, zoals gezegd, een zekere mate van harmonisatie tot stand. Hier werden medezeggenschapsbepalingen gekoppeld aan specifieke issues. Deze

112. Ditzelfde zou overigens kunnen opgaan voor de vijfde richtlijn. Men kan verdedigen dat de rechten en belangen van werknemers in het voorstel zozeer de overhand krijgen dat de vijfde richtlijn niet meer als pure harmonisatie van het vennootschapsrecht beschouwd kan worden.

113. Zaak $131 / 86,23-2-1988$, nog niet gepubliceerd. 
richtlijnen, die verderop (114) besproken worden, losten echter niet het probleem van medezeggenschap op hogere niveaus op. Bovendien dekten de deelgebieden -in eerste instantie alleen collectief ontslag, overgang van ondernemingen en enkele maatregelen op veiligheids- en gezondheidsgebiedmaar een zeer beperkt gedeelte van de besluiten. Er werd door de Commissie een poging gedaan, om een meer algemene richtlijn die zowel voor medezeggenschap inzake economische als sociale aangelegenheden kon gelden, te formuleren.

\section{A De Vredelingvoorstellen}

Het voorstel voor een richtlijn, in 1980 , waarin verstrekking van informatie en consultatie van werknemers in ondernemingen met een complexe structuur en multinationale ondernemingen (115) (hierna te noemen: het Vredeling-voorstel) centraal stond, was na de mislukkingen van de instrumentele voorstellen, een volgende stap in de pogingen tot harmonisatie van wetgeving (116).

In tegenstelling tot het vijfde richtlijn voorstel en het Statuut SE ging het Vredeling-voorstel niet uit van de wijze waarop medezeggenschap binnen een concern geïnstitutionaliseerd moest worden, maar van het instrumentarium dat werknemers geboden moet worden om medezeggenschap te verkrijgen. Het voorstel was er op gericht om, met name in transnationale ondernemingen, werknemers van informatie te voorzien over aangelegenheden ten aanzien van de gehele onderneming. Dit is van belang, aangezien informatie die op grond van het nationale arbeids- of medezeggenschapsrecht dient te worden verstrekt op grond van die regelgeving zich niet hoeft uit te strekken, en in sommige gevallen zich zelfs niet mag uitstrekken tot het territorium van andere (lid)staten. Ook de bestaande richtlijnen, die voorzien die in een zekere verplichting tot informatieverstrekking en consultatie, zijn gericht op omzetting in wetgeving met deze zelfde restricties (117).

Daarnaast beoogde het voorstel de vertegenwoordigers van de werknemers een mogelijkheid tot overleg met het lokale management te creëren, ook over die zaken waar op een niveau beslist wordt dat hoger is dan het lokale.

De Vredelingrichtlijn zou van toepassing hebben moeten zijn op die ondernemingen die vestigingen in de lid-staten hebben waarin meer dan 100 werknemers werkzaam zijn. Waar de dominante onderneming zich zou

114. Zie paragrafen II.4.2.C. en II.4.2.D.

115. Officiële benaming: Voorstel woor een richtlijn betreffende procedures voor het informeren en consulteren wan werknemers van ondernemingen met compleze structuren in het bijzonder transnationale ondernemingen, $\mathrm{Pb} 1980$ C 297.

116. Richard D. Fera, The EEC and the Vredeling Proposal, The Debate to Temper Ideology with Realism, California Western Law Journal 1986, Vol. 16, p. 250-281.

117. $\mathbb{R}$. Blanpain, F Blanquet, F. Herman, A. Mouty, The Vredeling Proposal, Deventer, 1983, p. 36 . 
bevinden maakte niet uit: dat kon zowel binnnen als buiten de gemeenschap zijn. Deze extra-territoriale werking ontmoette met name in de Verenigde Staten veel kritiek (118).

De hoofdlijnen van het voorstel hadden betrekking op informatie en consultatierechten voor de werknemers. In medebeslissingsrechten werd niet voorzien. De informatierechten hadden deels betrekking op algemene informatie en deels op informatie omtrent specifieke issues (119). Algemene informatie zou door het bestuur van de dominerende onderneming (120) aan de vertegenwoordigers van de werknemers periodiek worden verstrekt. Daarnaast zou incidenteel (121) informatie worden verstrekt in verband met op handen zijnde belangrijke besluiten. In beide gevallen rustte de verplichting tot informatieverstrekking op het bestuur van die vestiging. Wanneer het lokale bestuur geen informatie zou verstrekken zou de verplichting overgaan op het het bestuur van de dominerende onderneming.

In het geval een belangrijke beslissing op handen was zou het bestuur verplicht zijn tenminste dertig dagen voor de beslissingsdatum de opinie van de werknemers te vragen. Als de werknemersvertegenwoordigers zouden menen dat de beslissing rechtstreeks de belangen van werknemers ten aanzien van de werkgelegenheid zou raken, zou een consultatieronde gehouden moeten worden. Hierin zou gepoogd moeten worden overeenstemming over de ten behoeve van de werknemers te nemen maatregelen te bereiken. Indien geen overeenstemming bereikt zou worden zou het voorstel inhoudelijk ter toetsing aan een beroeps- of arbitrageinstantie kunnen worden voorgelegd. Ook hier zou het lokale bestuur in eerste instantie verplicht zijn de consultatieronde te houden; pas als deze er niet in zou slagen deze te organiseren, zou de verplichting op het bestuur van de dominante onderneming overgaan.

118. Zie o.m. R. Fera, a.w. (noot 116), p. 257-261.

119. Het Vredieling voorstel bestaat uit twee onderdelen die, naast de algemene bepalingen, voorzien in bepalingen betreffende informatie en consultatie van werknemers. Het eerste onderdeel (artikelen $4 \mathrm{t} / \mathrm{m}$ 9) is gericht op informatie en consultatie van werknemers bij transmationale ondernemingen, het tweede (artikelen $10 \mathrm{t} / \mathrm{m} \mathrm{14}$ ) ziet op informatie en consultatie bij ondernemingen met een complexe structuur waarvan het besluitwormend centrum gelegen in in de lid-staat waar ook de werknemers werkzaam zijn. Onder een onderneming met een complexe structuur wordt een onderneming met verschillende vestigingen verstaan.

120. Wat precies een dominerende of moeder-onderneming is, is omschreven in artikel 1: het gaat om een onderneming die de controle heeft over haar dochters, ofwel middels meerderheid van stemmen gerelateerd aan de aandelen, ofwel middels de mogelijkheid ten minste de helft van het bestuur of andere organen met supervisie te benoemen.

121. Incidentele informatie zou moeten worden verstrekt over beslissingen die de onderneming betreffen en effecten zou hebben op belangen van werknemers. Veertig dagen van te voren zou het bestuur de gronden voor de beslissing moeten aangeven, de juridische, economische en sociale consequenties voor de betrokken werknemers, en de voorgenomen maatregelen met betrekking tot deze werknemers. 
Daarnaast was een aantal regels opgenomen voor het oplossen van competentieproblemen tussen verschillende vertegenwoordigende organen en voor geheimhoudingsplichten.

De kritiek op dit voorstel was aanzienlijk. De Union des Industries de la Communauté Européenne (UNICE) kwam met een reeks (122) van kritiekpunten, die varieerden van de stellingname dat er geen noodzaak was voor een communautaire regeling op dit punt, tot de opvatting dat een regeling alls voorgesteld de bestaande verhoudingen tussen ondernemingen en werknemers zoals deze zich in de verschillende lid-staten hebben ontwikkeld zou afbreken, terwijl in de praktijk geen betere bescherming van de belangen van werknemers zou worden bereikt.

Werknemersorganisaties, bij monde van de ETUC (123) waren begrijpellijkerwijs veel positiever ten aanzien van het voorstel. Hun voornaamste bezwaren richtten zich tegen een aantal oningevulde bepalingen met name waar het ging om passende maatregelen en strafmaatregelen. De ETUC vreesde dat de ruimte die aan de Lid-Staten wordt geboden om deze in te vullen nog zodanig was, dat te "zachtaardige" bepalingen zouden kunnen worden opgenomen.

Het voorstel bleek geen haalbare kaart. Na consultatie van het Europees Parlement (124) en het Economisch en Sociaal Comité (125) werd er een geamendeerd (126) voorstel ingediend (hierna te noemen: het VredelingRichardvoorstel (127)). Dit voorstel werd onderwerp van tussen ondernemers en vakbondsleiders in de gemeenschap. Het Vredeling-Richardvoorstel werd voor wat de toepassing betreft, veel sterker gekoppeld aan het ontwerp voor de zevende vennootschapsrichtlijn (128). De informatie- en consultatieprocedure werd volgens het geamendeerde voorstel alleen van

122. Advies van de Union des Industries de la Communauté Europeênne, van 1.9 februari 1981 , tekst o.m. opgenomen in R. Blanpain (ed), a.w. (noot 117), p. 75-86.

123. Besluit van het Uitvoerend comite van the European Trade Umion Confederation (ETUC) van 4 december 1980, voor de tekst, zie R. Blanpain (ed), a.w. (noot 117), p. 100-109.

124. Rapport van de Parlementaire Commissie van sociale zaken en werkgelegenheid (rapporteur, T. Spencer), uitgebracht in april 1982; rapport wan de Parlementaüre Commissie van Juridische Zaken, (rapporteur H. Vetter, uitgebracht in januari 1981, rapport van de Commissie van Economische en Monetaire Zaken (rapporteur, Mr. von Bismarck) waarin een aantal wijzigingen werden voorgesteld. $\mathrm{Na}$ het plenaire debat van 12 oktober 1982 werd een geamendeerde tekst voorgesteld.

125. Rapport van thet Economisch en Sociaal Comite (rapporteur mr. Muhr, co-rapporteur Mr. Zinkin) witgebracht op 10 december 1981, geaccepteerd door het comité op zijn 194ste zitting op 27 en 28 januari 1982.

126. $\mathrm{Pb}$. 1983, C 217, Geamendeerd Vredeling voorstel van 8 juli 1983.

127. Het eerste voorstel kreeg in het spraakgebruik (ongebruikelijk voor een richtlijnvoorstel) de naam vam de toenmalige Commissaris wan Sociale Zaken, Henk Vredeling, het geamendeerde voorstel dat met name op de naam van zijn opvolger Sir Ivor Richard is te schrijven heeft dan ook de naam Richard er aan toegevoegd gekregen.

128. Ontwerp 7 e richtlijn, 4 mei 1976, Pb. C 121, gewijzigd bij voorstel van 17 januari 1979, $\mathrm{Pb}$. 1983, Pb. C 14, zie ook Pb L 193 (geconsolideerde jaarrekening), Zie TVVS 1983, p. 77. 
toepassing op vestigingen van een onderneming, die tenminste 1000 werknemers in dienst had, dan wel op een onderneming die in zijn in de Gemeenschap gevestigde dochters tenminste 1000 werknemers in dienst had (129). In het Vredeling-Richard-voorstel werd geen onderscheid meer gemaakt tussen transnationale en nationale complexe ondernemingen, hetgeen de tekst aanzieniijk bekortte en vereenvoudigde.

Een andere wijziging was dat periodieke informatie minder vaak hoefde te worden verstrekt en minder gebieden hoefde te beslaan. Voor de verstrekking van incidentele informatie werd het aantal gebieden juist uitgebreid, onder meer met veiligheids- en gezondheidsaangelegenheden en de invoering van nieuwe produktiemethoden.

De meest radicale wijziging (130) van het oorspronkelijke voorstel was het nieuwe hoofdstuk over gevoelige informatie. In tegenstelling tot het oude voorstel dat alleen een geheimhoudingsbepaling kende geeft het VredelingRichatd-voorstel de lid-staten de mogelijkheid te regelen dat informatie mag worden achtergehouden als het "geheim" is. Informatie kan als geheim worden bestempeld wanneer het belangrijke schade aan de onderneming kan toebrengen of tot het mislukken van plannen van de onderneming kan leiden.

Tenslotte werd de mogelijkheid voorstellen waarover tijdens de consultatieronde geen overeenstemming werd bereikt inhoudelijk te laten toetsen geschrapt. Slechts rechterlijke of arbitrale controle op de naleving van de bepalingen zou nog mogelijk zijn.

Nadat ook dit gewijzigde voorstel niet haalbaar bleek omdat teveel lidstaten bezwaren hadden, werd op initiatief van de toenmalige lerse voorzitter van de Raad, een ad-hoc werkgroep geformeerd, die tot taak had het geamendeerde voorstel nog eens te bekijken. De bedoeling was om het voorstel iets bij te stellen, en met name de onduidelijkheden die er ten aanzien van de technische kanten en de implementatie van het voorstel bij de verschillende lid-staten bestonden op te helderen (131). De bedoeling van de werkgroep was om de kritiek die ten aanzien van de informatie en consultatieprocedures in relatie tot de bestaande industriële verhoudingen wat af te doen nemen.

De voorstellen van de ad-hoc werkgroep, die zij kwalificeerden als een 'nieuwe benadering' vereenvoudigden het voorstel nog verder (132). Zo

129. Hiermee verdween de extraterritoriale werking niet, maar werd wel sterk beperkt. Toch was dit ook nog voorwerp van kritiek: zie 0.m. WJ. Slagter, SER adwies over de Vredeling. richtlijn, TVVS 1984, p. 122.

130. C. Docksey, Information and Consultation of Employees: the United Kingdon and the Vredeling-Directive, Modern Law Review 1986, Vol. 49 p. 290.

131. R. Fera, a.w. (nioot 116), p. 273.

132. New Approach on "Vredeling", EIRR 10, 10(1985). 
werd bijwoorbeeld het hele idee dat alleen ondernemingen met een complexe structuur eronder zouden vallen verlaten. De ad-hoc werkgroep ging uit van ondernemingen van een bepaalde grootte, ook als deze slechts één vestiging hadden (133).

Daarnaast breidde de ad-hoc werkgroep ook de typen van informatie die aan werknemersvertegenwoordigers gegeven diende te worden, evenals het aantal malen dat dezen geconsulteerd moeten worden flink uit. Voorts werd de consultatieverplichting afgezwakt De zinsnede dat deze "moesten worden gehouden met het oogmerk tot overeenstemming te komen," uit de eerdere voorstellen, werd "kunnen worden gehouden met het oogmerk (...etc) $)^{n}$. De angel werd er uitgegehaald, en de verplichting werd een wenselijkheidsnorm.

Ook de sancties zowel op de informatieverstrekking werden aanzienlijk afgezwakt. De verplichtingen aan de Lid-Staten arbitrage- of rechterlijke instanties in te stellen die over de consultatie en informatieverplichtingen kunnen oordelen werd vervangen door een verplichting aan de lid-staten passende maatregelen tot afdwinging te implementeren.

In de "nieuwe benadering" werd voorgesteld dat de richtlijn in beginsel ook bij collectieve overeenkomst moet kunnen worden geïmplementeerd. Dit voorstel was bedoeld als tegemoetkoming aan Groot Brittannië. Daarmee zou een belangrijk obstakel voor de onderhandelingen in de Raad zijn weggenomen. Bovendien, nu een soortgelijke benadering in het ontwerp vijfde richtlijn al was geaccepteerd zouden beide richtlijnen op dit punt met elkaar sporen.

$\mathrm{Na}$ nieuwe onderhandelingen begin 1985 in de Raad van Ministers bleek dat Denemarken en Groot Brittannië nog steeds niet bereid waren het voorstel te steunen. Totdat de Commissie zou besluiten de "nieuwe benadering" als voorstel in te dienen leken de onderhandelingen dan ook vastgelopen. In 1986 leidde deze situatie opnieuw tot iets bijzonders: de Raad maakte, in de vorm van Conclusies, zijn onvermogen om tot een besluit te komen bekend in het Publikatieblad (134). In de Conclusies wordt (enigszins gratuit) gewezen op de noodzaak van een dialoog tussen werknemers en werkgevers op alle niveaus en wordt de Commissie verzocht de ontwikkelingen in de lid-staten zowel wat wetgevingspraktijk als de praktijk van het collectieve onderhandelen nauwlettend te volgen en daarover jaarlijks te rapporteren. Voorts werd aangekondigd in 1989 de discussie over de zaak te hervatten, ofwel op basis van het het geamendeerde Vredeling-voorstel, ofwel op basis van een nieuw Commissie voorstel, dat dan mogelijk op de "nieuwe benadering" gebaseerd kan zijn. Ook zou

133. De term onderneming in deze zinsnede moet de plaats innemen van moeder-onderneming en haar vestigingen als geheel. Deze laatste terminologie was door de gewijzigde toepasselijkheid van de richtlijn owerbodig geworden.

134. Pb 1986 C 203, Conclusies van 21 juni 1986. 
omstreeks die tijd mogelijk de discussie omtrent het ontwerp vijfde richtlijn weer worden opgenomen.

Inmiddels staat het Vredeling-Richard-voorstel in de bijlage van het Actieprogramma "Sociale dimensie van de interne markt" opgenomen als voorstel in voorbereiding (135). De Commissie spreekt nu niet meer van een richtlijnvoorstel maar van een maatregel voor informatie, consultatie en participatie van de werknemers. Wat dit voor instrument zou moeten zijn, als het geén richtlijn moet worden is niet duidelijk. Het wordt door de Commissie nadrukkelijk niet gepreciseerd (136). Dit laatste voorstel zal vermoedelijk wel met eenparigheid van stemmen door de Raad aangenomen moeten worden, in tegenstelling tot de op artikel 118A gebaseerde richtlijnen.

Dit is alleen niet het geval wanneer de Commissie besluit het voorstel op artikel 54 lid 3 sub g jo. 54 lid 2 te baseren en erin zou slagen een gekwalificeerde meerderheid van de Raad ertoe te bewegen deze grondslag te accepteren. Deze optie is onorthodox (strict genomen behoort het Vredeling-voorstel niet tot het vennootschapsrecht (137)) maar juridisch niet onmogelijk. Artikel 54 lid 3 sub g biedt een coördinatieverplichting voor de Raad en Commissie ter waarborging van de bescherming van belangen van, onder meer, derden. Werknemers zouden in deze redenering tot de derden gerekend worden wier belangen beschermd moeten worden. Op zichzelf zou dit een ingang kunnen bieden om het Vredeling-voorstel (in welke vorm het dan ook gegoten mag gaan worden) alsnog erdoor te krijgen.

Of een dergelijke grondslag geaccepteerd wordt door de Raad, of houdbaar is wanneer hij door het Hof getoetst wordt is nog maar de vraag. Die lidstaten die niet instemmen met het voorstel zullen de grondslag ongetwijfeld bestrijden. Daarbij staat dan zowel de kwestie of werknemers derden in de zin van artikel 54 lid 3 sub g zijn ter discussie, als de vraag of medezeggenschap tot de waarborgen in de zin van dit artikel kunnen worden gerekend. Op beide vragen kan het antwoord mijns inziens wel bevestigend zijn. Voor werknemers is op zichzelf niets geregeld binnen het vestigingsrecht, en niemand zal kunnen ontkennen dat zij bij de harmonisatie daarvan, voor zover deze tot liberalisering leidt, belanghebbenden zijn. Ook de term waarborgen lijkt mij op medezeggenschapsrechten van toepassing indien een liberalisering van het vestigingsrecht tot het verlies van deze rechten leidt. Tenslotte: het feit dat rechten en belangen van werknemers van de werkingssfeer van artikel $100 \mathrm{~A}$ zijn uitgezonderd hoeft niet per se tot de conclusie te leiden dat zij per definitie onder artikel 100 vallen. Een ander

135. Sociale Dimensie van de interne markt, SEC (88) 1148 def.

136. Europe, Agence Internationale d'Information pour la presse, 13 januari 1990, no. 5171, p. 8.

137. K. van Hulle, De harmonisatie van het vennoatschapsrecht in de Europese gemeenschap, in Harmonisatic van vennootschaps- en effectenrecht, (B. Wachter e.a.) Deventer 1988, p. 45 . 
artikel waarbij met gekwalificeerde meerderheid van stemmen moet worden besloten kan evengoed als grondslag dienen, wanneer dit artikel van toepassing is. Maar ik durf geen garantie te bieden dat de Raad of in voorkomende gevallen het Hof er eenzelfde visie op na houdt.

Of de hernieuwde discussie iets zal opleveren, is gezien het bovenstaande dus nog maar de vraag. Het is nog steeds niet uit te sluiten dat, zoals Timmermans stelt, het Vredeling-voorstel een "staats- pardon communautaire begrafenis" heeft gekregen (138).

\section{$B$ Terug naar de sociale dialoog}

De communautaire sociale dialoog waarnaar de Raad in zijn Conclusies verwees, dateert al uit de jaren zestig. In die periode werd vanuit verschillende invalshoeken gedacht over sociale regulering op gemeenschapsniveau, ofwel door middel van communautaire wetgeving, of wel door middel van Europese collectieve contracten. Door de sociale partners werden in die tijd organisaties op Europees niveau opgericht als de ETUC en de UNICE. De dialoog tussen deze organisaties, de Raad van Ministers en de Commissie vond plaats in het in 1969 opgerichte Standing Committee on Employment, maar leidde tot betrekkelijk teleurstellende resultaten (139).

Door middel van de Europese Akte kreeg de sociale dialoog een iets formelere status. Artikel 118B EEG-verdrag schrijft voor dat de Commissie de sociale dialoog moet stimuleren, en dat deze indien de partners dat wensen tot contractuele betrekkingen kan leiden. Sedert 1985 lijkt er ook weer enige beweging in het overleg te zijn ontstaan. Deze beweging kan, ten aanzien van de instrumentele zijde van medezeggenschap, aanzetten voor nieuwe regelingen opleveren. Hepple wijst er op dat mogelijk gedragscodes op het punt van medezeggenschap in het verschiet zouden kunnen liggen (140).

Bovendien lijkt van de sociale dialoog op beperkt terrein wel enige resultaten te leiden. Het gaat hierbij om de problematiek van de invoering van nieuwe technologieën. In 1985 leidde het overleg te Val Duchesse (141), tot een gezamenlijke verklaring van de sociale partners om onderzoek te verrichten naar de mogelijkheden voor (onder meer) medezeggenschap op dit terrein (142). In 1987 bleken de deelnemers aan het overleg bereid te zijn over twee onderdelen hiervan verder te praten,

138. C.W.A. Timmermans, Vredelingrichtlijn ten grave gedragen?, TVVS, 1986 no. $86 / 10, p_{n}$ 247.

139. R. Tavitian, Trade Union Trends in Western Europe: A European Perspective, in Industrial Relations in Europe, London 1985, p. 235-239.

140. B. Hepple, The Crisis in EEC Labour law, ILJ 1987, p. 85-87.

141. Over het verloop van het Val Duchesse-overleg in eerste instantie: zie G. Debunne, a.w. (noot 14), p. 138-150.

142. Gemeenschappelijke intentie verklaring van 12 november 1985 . 
namelijk training en informatie en consultatie (143). De informatie en consultatierechten die in deze verklaring werden voorgesteld gaan overigens niet verder dan die, die al in bestaande richtlijnen zijn opgenomen. Informatie zou verstrekt moeten worden bij veranderingen of de introduktie van nieuwe technologie. Wanneer de introductie van nieuwe technologie of wijzigingen in het gebruik belangrijke consequenties voor werknemers zouden hebben, zouden deze geconsulteerd moeten worden. Hoewel deze medezeggenschapsvormen niet aan de mogelijkheid tot onderhandelingen in de weg zouden moeten staan, stelt het document expliciet dat de uiteindelijke beslissingsbevoegdheid on handen van de ondernemingsleiding blijft. Uit een tweede gezamenlijke verklaring uit het Val Duchesse overleg blijkt bovendien dat de sociale partners overeenstemming hebben bereikt over onderwerpen, als de bescherming van veiligheid en gezondheid en andere aspecten van de arbeidsverhoudingen, die wijzigingen kunen ondergaan door de invoering van nieuwe technologie (144). Tot dusver heeft het overleg echter niet geleid tot concrete overeenkomsten.

Mochten de gezamenlijke verklaringen op den duur tot (werkbare) Collectieve overeenkomsten op multinationaal niveau gaan leiden, dan is het echter niet uitgesloten dat deze zich als een olievlek gaan verspreiden naar andere gebieden. Eén daarvan is al genoemd: het gebied van de veiligheid en gezondheid van werknemers, dat nauw verbonden is met de introduktie van nieuwe technologie. Met het sluiten van Collectieve contracten zijn overigens niet alle problemen opgelost. Vragen omtrent de toepasselijkeheid van het nationale recht op een dergelijke bovennationale overeenkomst en in hoeverre deze de onderhandelingsvrijheid op nationaal niveau kan beïnvloeden blijven bestaan (145). Hierop wordt in paragraaf 4 teruggekomen.

\section{$C$ Medezeggenschapsbepalingen in de reeds werkende richtlijnen}

Terwijl over medezeggenschap op multinationaal niveau geen overeenstemming te bereiken viel, werden in een aantal richtlijnen op sociaal gebied in die periode wel bepalingen opgenomen die de nationale wetgever verplichten tot de opname van informatierechten, of een zekere mate van overleg tussen werkgevers en werknemers, of beide, in de wetgeving of bestuursrechtelijke bepalingen. Het gaat hierbij om de richtlijnen die voorzien in bescherming van werknemers bij collectief ontslag (146), overgang van ondernemingen (147) en tegen de risico's van chemische, fysische en biologische agentia op het werk (148). De'in 1989 tot stand

143. Gezamenlijke verklaring van 6 maart 1987.

144. Hierbij moet gedacht worden aan werktijden, maar ook aan de wijzigingen die werkzaamheden kunnen ondergaan, zie verklaring van 9 december 1988, doc. 652 PO2, p. $4,8,10$.

145. Hierover uitgebreid: A.T.J.M. Jacobs, Het recht op collectief onderhandelen, Alphen a/d/ Rijn/Brussel 1986, p. 388-295 en p. 415-432.

146. Rl. $75 / 129 / \mathrm{EEG}, \mathrm{Pb}$. $1975, \mathrm{~L} 48$.

147. RI 77/187/EEG, Pb $1977 \mathrm{~L} 61$.

148. RI. $80 / 1107 / \mathrm{EEG}, \mathrm{Pb} .1980, \mathrm{~L} 327$. 
gekomen richtlijn betreffende uitvoering van maatregelen ter bevordering van de verbetering van de veiligheid en gezondheid van werknemers op het werk (149) (verder te noemen: de nieuwe raamrichtlijn) bevat eveneens een medezeggenschapsbepaling. Omdat deze haar weerslag zal gaan hebben op alle communautaire regelingen met betrekking tot veiligheid en gezondheid zal de bespreking van deze richtlijn in hoofdstuk VI, waarin het gemeenschapsbeleid aangaande veiligheid en gezondheid wordt besproken) plaatsvinden. Slechts wanneer de nieuwe richtlijn een wijziging betekent met betrekking tot de bepalingen van de richtlijn met betrekking tot chemische; fysische en biologische agentia zal daarop gewezen worden.

De richtlijn betreffende de aanpassing van de wetgeving inzake collectief ontslag voorziet in een verplichting tot raadpleging van de vertegenwoordigers van de werknemers wanneer de werkgever overweegt collectief ontslag te verlenen. De bedoeling van de verplichting is tot een akkoord te komen, hetgeen er op duidt dat de raadpleging meer is dan vrijblijvende adviesverstrekking maar het karakter van onderhandelingen kan verkrijgen indien een akkoord niet zonder meer bereikbaar is. Dit blijkt ook uit de toelichting van rapporteur Della Briotta bij de verdediging van het voorstel in het Europees Parlement (150). De raadpleging moet niet alleen betrekking hebben op de gevolgen van het collectief ontslag en de mogelijkheden deze te verzachten, maar moet volgens de richtlijn tenminste betrekking hebben op de mogelijkheid deze te voorkomen. Dit impliceert dat het tijdstip van de raadpleging zodanig moet zijn, dat werknemersvertegenwoordigers nog invloed kunnen uit kunnen oefenen op het besluit tot collectief ontslag.

Ter vergemakkelijking van de mogelijkheid inwloed uit te oefenen kent de richtlijn een verplichting tot het verstrekken van informatie (van "alle nuttige gegevens") en van in elk geval het verstrekken van een schriftelijke mededeling omtrent de redenen van het ontslag, het atantal voor ontslag in aanmerking komende werknemers, het aantal werknemers dat hij gewoonlijk in dienst heeft en de periode die wordt overwogen voor het doen plaatsvinden van de ontslagen.

De richtlijn spreekt uitdrukkelijk over "vertegenwoordigers van de werknemers", daarbij in het midden latend of het hier moet gaan om vakbondsvertegenwoordigers, dan wel om vertegenwoordigers in niet van de vakbonden afhankelijke medezeggenschapsorganen.

Dit is ook het geval in de richtlijn met betrekking tot het behoud van rechten van werknemers bij overgang van ondernemingen. Ook hier wordt in het midden gelaten welke vertegenwoordigers voor deze consultatie de bevoegde zijn.

149. Rl. 89/391 Pb. 1989 L 183.

150. Handelingen van het Europese Parlement, Vergadering van 12 maart 1973, p. 14. 
In deze laatste richtlijn is een informatieverplichting opgenomen waarin uitdrukkelijk is vastgesteld dat informatie tijdig vóor de overgang verstrekt moet worden. De informatie moet betrekking hebben op de reden van overgang, de juridische, economische en sociale gevolgen voor werknemers, en de ten aanzien van werknemers overwogen maatregelen. Niet alleen de vervreemder moet tijdig informatie verstrekken, maar ook de verkrijger van de onderneming is hiertoe verplicht, namelijk voordat deze werknemers in hun dienstverband en arbeidsomstandigheden rechtstreeks worden getroffen. Indien maatregelen in één van de bij de overgang betrokken ondernemingen worden overwogen, moet over deze maatregelen tijdig overleg gepleegd worden met de betrokken werknemersvertegenwoordigers. De verplichting tot overleg lijkt hier meer een 'echte' consultatieverplichting, waarbij het komen tot een akkoord niet direct tot de vereisten behoort. De nadruk in de richtlijn ligt dan ook bij het tijdstip van informatieverschaffing, en de onderwerpen die daarbij aan bod moeten komen.

Voor die lid-staten waar de nationale wetgeving in de mogelijkheid voorziet voor werknemersvertegenwoordigers om over ten aanzien van de werknemers te treffen maatregelen een beroep te doen op een arbitrageinstantie, biedt de richtlijn de mogelijkheid de werking van de verplichtingen te beperken. Volgens de richtlijn mag in dat geval de lid-staat informatie en consultatieverplichtingen beperken tot de vestiging van de onderneming waar de overgang kan leiden tot wijzigingen die een aanmerkelijk nadeel kan betekenen voor een belangrijk gedeelte van de werknemers.

De ratio van deze beperking is hierin gelegen, dat een bindende beslissing van een arbitrage-instantie over een geschil met betrekking tot voor werknemers te treffen maatregelen, terwijl de werknemers om wie het gaat niet werkzaam zijn in de vestiging waar het beroep wordt ingesteld, een rare consequentie kan hebben. Zouden deze laatste werknemers wel beroep kunneninstellen dan zouden zij namelijk de overname van een onderneming kunnen verhinderen, waar zij zelf geen nadeel van ondervinden, en bovendien invloed kunnen uitoefenen op voor werknemers te treffen maatregelen, waar zij zelf geen last van zouden hebben.

In de richtlijn betreffende bescherming van werknemers tegen chemische, fysische en biologische agentia op het werk is in artikel 5 als aanvullende verplichting op een aantal in artikel 3 en 4 gegeven normen, die betrekking hebben op het reduceren van gevaar door blootstelling aan agentia, een aantal maatregelen met betrekking tot de werknemers gegeven. Deze aanvullende maatregelen bestaan naast de verplichting tot medisch toezicht uit de verplichting tot voorlichting van de werknemers of hun vertegenwoordigers bij overschrijding van de grenswaarden zoals voorzien bij artikel 4 van de richtlijn en uit rechten op informatie van werknemers of hun vertegenwoordigers.

Deze informatierechten bestaan uit toegang tot de resultaten van metingen van werknemers of hun vertegenwoordigers, toegang van de betrokken 
werknemers tot de resultaten van de tests op henzelf genomen, die de mate van blootstelling aangeven en een algemeen recht op informatie van werknemers of hun vertegenwoordigers ter vermeerdering van de kennis over de gevaren waaraan zij zijn blootgesteld.

Artikel 6 voorziet daarnaast in een consultatierecht. Dit recht is tweeledig. Om te beginnen is er een verplichting voor de lid-staten om werkgeversen werknemersorganisaties te consulteren voordat de noodzakelijke maatregelen die ter uitvoering van de in artikel 3 voorgeschreven verplichtingen worden aangenomen. Het gaat hier dus om consultatie voorafgaand aan de implementatie van de concrete normen. Medezeggenschap ten aanzien hiervan is uitdrukkelijk voorbehouden aan vakorganisaties. Daarnaast moeten de lid-staten zorgen dat over de toepassing van de bepalingen uit artikel 3 in de onderneming de vertegenwoordigers van de werknemers geraadpleegd worden. Hier wordt geen gewag gemaakt zoals in artikel 4 van een of/of mogelijkheid (werknemers of hun vertegenwoordigers) maar uitsluitend van vertegenwoordigers van de werknemers, in die ondernemingen of bedrijven waar dergelijke vertegenwoordigers bestaan. De consultatieverplichtingen gelden voor de in artikel 3 gestelde normen. Aangezien echter in artikel 3 verwezen wordt naar de maatregelen uit artikel 4 van de aanvullende maatregelen uit artikel 5 , mag worden aangenomen dat werkgevers- en werknemersorganisaties ook geconsulteerd moeten worden over de wijze waarop de informatie in ruime zin aan werknemers gegeven wordt.

Kort gezegd: infọrmatie in het algemeen en in het bijzonder dient verstrekt te worden aan alle werknemers, consultatie op ondernemingsniveau is beperkt tot de toepassing van maatregelen en is voorbehouden aan werknemersvertegenwoordigers, consultatie over de maatregelen zelf is voorbehouden aan de organisaties van werkgevers en werknemers.

De drie richtlijnen lijken te verschillen op het punt van de inhoud van de medezeggenschapsverplichting. Deze houdt in de ene richtlijn het recht op informatie en pure consultatie in (overgang van ondernemingen en chemische, fysische en biologische agentia) terwijl de richtlijn met betrekking tot collectief ontslag lijkt uit te gaan van een veel verdergaande consultatieverplichting die, eventueel middels onderhandelingen tot een overeenkomst tusen werknemers en werkgevers zou moeten leiden.

\section{$D$ Betekenis van de bepalingen}

De vraag is nu welke nieuwe medezeggenschapsrechten de richtlijnen in de nationale rechtsorde hebben gecreëerd of hebben beoogd te creëren. Op institutioneel gebied zijn dat er geen. De richtlijnen gaan geheel uit van bestaande medezeggenschaps-structuren. Waar van werknemersvertegenwoordigers gesproken wordt wordt geen nadere aanduiding gegeven wie dat zijn: er kunnen ondernemingsraden of soortgelijke organen, vakbondsvertegenwoordigers, shop stewards of veiligheidsvertegenwoordigers mee bedoeld worden. 
Voor de situatie waarin geen werknemersvertegenwoordiging bestaat wordt in een aantal gevallen geen oplossing gegeven: dit is het duidelijkst in de richtlijn ter bescherming van werknemers tegen chemische fysische en biologische agentia op het werk (151). Hierin wordt medezeggenschap ten aanzien van de toepassing van de bepalingen in de onderneming uitdrukkelijk voorbehouden aan vertegenwoordigers van werknemers door de formulering "in ondernemingen en bedrijven waar dergelijke vertegenwoordigers bestaan" en niet toebedeeld aan werknemers in het algemeen. Dit is een punt waarop de nieuwe raamrichtlijn een wijziging zal brengen voor de oude. Deze richtlijn spreekt uitdrukkelijk over werknemers en/of hun vertegenwoordigers. De harde formulering van de oude raamrichtlijn is door de nieuwe verzacht.

In de rïchtlijn met betrekking tot collectief ontslag wordt eveneens alleen gesproken van vertegenwoordigers van de werknemers, waarmee volgens artikell 1 de vertegenwoordigers volgens het recht of het gebruik van de lidstaten worden bedoeld. Voor beide richtlijnen geldt dat, indien consultatie van alle werknemers in plaats van consultatie van de vertegenwoordigers wordt overwogen, dat niet buiten het kader van de richtlijn zou vallen. Voor de werknemers gunstiger regelingen zijn immers altijd mogelijk. Anderzijds, in het geval dat niet geconsulteerd wordt, omdat geen vertegenwoordigers in de onderneming aanwezig zijn, kunnen werknemers volgens mij geen recht op consultatie aan de richtlijn ontlenen.

Een zelfde formulering wordt aangetroffen in de richtlijn met betrekking tot overgang van ondernemingen. Ook hier is alleen voorzien in een overlegverplichting voor de vertegenwoordigers van werknemers. Ook informatieverstrekking is voor wat deze richtlijnen betreft, in tegensteling tot de richtlijn ter bescherming tegen chemische, fysische en biologische agentia voorbehouden aan vertegenwoordigers van de werknemers. Dit vindt ten dele zijn oorzaak in het feit dat informatie met betrekking tot veiligheid en gezondheid van werknemers, belangrijk is voor alle werknemers, terwijl dat van meer economische informatie niet per definitie gezegd kan worden. Bovendien kan men veronderstellen dat informatie gegeven aan alle werknemers gemakkelijker naar buiten kan komen dan wanneer zij alleen gegeven wordt aan, een gelimiteerd aantal, vertegenwoordigers, bij wie een zwijgplicht gemakkelijker te handhaven en te controleren valt. Met name bij overgang van een onderneming kan dit voor de ondernemer van groot belang zijn.

Hoewel de formuleringen in de richtlijnen verplichten tot het verstrekken van informatie en het consulteren van de vertegenwoordigers van de werknemers kan men hieruit mijns inziens geen verplichting tot het opnemen van een werknemersvertegenwoordiging in de nationale wetgeving

151. Na 31 december 1990 zal dit probleem overïgens zijn opgeheven omdat dan de bepalingen van $\mathrm{xl}$. $89 / 391$ volledig in werking treden en van toepassing zullen zijn op de uitvoeringsregelingen van rl. $80 / 1107$. 
gericht tot de lid-staten lezen. Het valt natuurlijk te verdedigen dat lidstaten in de geest van de richtlijnen zouden handelen wanneer zij, in het geval vertegenwoordiging op ondernemingsniveau ontbreekt, deze in de uitvoeringswetgeving opnemen. Een juridische verplichting valt, mijns inziens, niet uit de bepalingen af te leiden, zodat in het theoretische geval dat een lid-staat geen wettelijke werknemers-vertegenwoordiging op ondernemingsniveau kent, en vakbonden zich niet met vertegenwoordiging op ondernemingsniveau bezighouden de richtlijnen op zichzelf geen soelaas bieden. Op het moment echter, dat in een onderneming vertegenwoordigers aanwezig zijn of verkozen worden, onverschillig op welke basis, kunnen zij aan de in nationale wetgeving omgezette richtlijn informatie- en consultatierechten ontlenen.

De kwaliteit van de te verstrekken informatie wordt door middel van de richtlijnen wel gereguleerd in die zin, dat deze moet voldoen aan bepaalde minimumeisen. Dit geldt voor alle drie de richtlijnen, waarin voorwaarden zijn genoemd welke informatie verstrekt moet worden en wie deze moet verstrekken. De informatieverstrekking, waarover naast tijdstip en aard van het onderwerp niets geregeld is, is onderworpen aan het nationale recht, bijvoorbeeld voor wat betreft regelingen omtrent vertrouwelijkheid. Als in een concreet geval bepaalde informatie in het nationale recht als zodanig vertrouwelijk wordt gezien, dat men meent dat voor dat soort informatie uitzonderingen gemaakt kunnen worden, dan zal deze op basis daarvan niet aan de werknemersvertegenwoordigers verstrekt worden.

Door het ontbreken van bepalingen hieromtrent in de richtlijn is dit deel van het recht niet onderworpen aan gemeenschapscontrole. Het gevolg kan dan zijn dat het nationale recht zal worden toegepast in het concrete geval, en dat werknemers dus met de richtlijn bepaling, door zijn open redaktie niet al te veel zullen opschieten. Slechts aan het tijdstip van de informatie worden kwalitatieve eisen gesteld.

Op het gebied van de informatieverstrekking geldt dat de richtlijn nieuwe rechten creëert, voorzover het de aard van de informatie betreft, maar dat het van zowel de implementatie in de nationale wetgeving als van de interpretatie van de nationale wetgeving in het algemeen over informatieverstrekking af zal hangen of deze nieuwe rechten in concreto kunnen worden toegepast.

Voor de overlegverplichting geldt in wezen hetzelfde: het gebied waarover overleg moet worden gepleegd wordt toegevoegd aan de in de lid-staten reeds bestaande gebieden; aan de kwaliteit en de mate van medezeggenschap in het overleg worden in beginsel geen eisen gesteld, omdat het overleg moet verlopen middels de in de nationale regelgeving of naar nationaal gebruik bestaande procedures. Een uitzondering hierop is de bepaling in de richtlijn met betrekking tot collectief ontslag om omtrent het aantal ontslagen en de gevolgen van de ontslagen tot een akkoord te komen, en om daarnaast de vertegenwoordigers van de werknemers de 
mogelijkheid te bieden met constructieve voorstellen te komen. Deze uitzondering zou theoretisch gesproken nieuwe rechten kunnen creëren in lid-staten waarin medezeggenschapsorganen geen onderhandelingsrol, maar veeleer een samenwerkingsrol met al dan niet geclausuleerde advies- of instemmingsrechten hebben, maar aan welke in beginsel geen overeenkomstsluitende bevoegdheid is toebedeeld.

Toch geldt dit niet voor alle lid-staten. In het oorspronkelijke Commissievoorstel (152), evenals overigens in het voorstel voor een richtlijn voor behoud van rechten bij overgang van ondernemingen (153) was een sanctie ingebouwd. De bedoeling was dat, indien werkgever en werknemersvertegenwoordigers er in het overleg niet uitkwamen, er volgens de richtlijn collectief ontslag een bemiddelingsprocedure door de bevoegde instanties zou komen. Volgens het oorspronkelijk voorstel voor de richtlijn bij overgang van ondernemingen had een arbitrage-instantie een oordeel moeten geven. Dit bleek echter in het proces van regelgeving een te ver gaande bepaling, en in de uiteindelijke richtlijn is zij dan ook niet terug te vinden.

Betekent dit nu dat aan de verplichting tot onderhandeling geen sanctie is gekoppeld? Dit is niet noodzakelijkerwijs het geval. Het hangt alleen van de nationale wetgeving af welke deze sanctie is (154). Dit betekent dat de verplichting tot overeenstemming uit de richtlijn in de ene lid-staat harder is dan in de andere, waar geen sanctie op het ontbreken van overeenstemming is gesteld. In dat laatste geval zal men eerder moeten spreken van een geclausuleerde consultatieverplichting, waarbij een werkgever die overeenstemming volstrekt onmogelijk maakt bijvoorbeeld door de wijze waarop geconsulteerd wordt, eventueel wegens schending van de (nationale) wet is aan te pakken (155).

De medezeggenschapsbepalingen in de bestaande richtlijnen spelen in hoge mate in op de in de lid-staten geldende regelingen en gebruiken. De bepalingen zijn zo geredigeerd, dat zij geen harmonisatie brengen. Wel brengen zij minumumeisen, die aan aard en kwaliteit van informatie en

152. COM (72) 1400 def.

153. Pb. $1974 \mathrm{C} 104$.

154. In een aantal lid-staten bestaan sancties, maar deze verschillèn onderling sterk: bijyoorbeeld: artikel 26 WOR (Nederland), in Griekenland hebben indien geen overeenstemming wordt bereikt de voorzitter van het lokale bestuur of de minister van Arbeid op grond van het materiaal aangereikt door de onderneming en werknemersvertegenwoordigers en met inachtneming van andere belangen, als de nationale economie, te beslissen (Zie A. Kardaras, Der Einfluss des Europarechts auf das Griechische Arbeitsrecht, in FIDE Reports vol. 2, a.w. (noot 6), p. 122.

155. Voor Italie geldt dat indien een werkgever op dit punt zijn verplichtingen niet op juiste wijze nakomt hij voor de rechter gedaagd kan worden wegens het belemmeren van vakbonden in hun rechten (art. 28 Werknemersstatuut. Zie A. Saggio en R. Foglia, Influenza del diritto communitario sul diritto del lavoro degli Stati membri, FIDE Reports. Vol. 2, a.w. (noot 6), p. 211). 
consultatie gesteld worden, waardoor nu de werknemers een, door het gemeenschapsrecht gelegde vloer van rechten hebben.

\subsection{Tussenconclusie.}

Twintig jaar nadat de Commissie haar eerste voorstel voor een Europese Vennootschap lanceerde is het nog altijd niet mogelijk gebleken een algemene regeling voor medezeggenschap op bovennationaal niveau in een gemeenschappelijke regeling op te nemen. Noch de institutionele noch de instrumentele weg hebben op dit punt resultaat opgeleverd. Het is dan ook tekenend dat de enige verordening die een zekere mate van samenhang tussen vennootschappen in verschillende lid-staten mogelijk maakt, de verordening tot instelling van een Europees Economisch Samenwerkingsverband (156), geen medezeggenschapsregeling kent. Het is niet uitgesloten dat dit één van de oorzaken was dat dit voorstel, in tegenstelling tot het Statuut SE en ook pas na twaalf jaar, wel een haalbare kaart bleek (157).

Bovendien bleek een regeling waarbij medezeggenschap op het niveau van de nationale ondernemingen gerealiseerd werd, tot dusver onhaalbaar. Deels had dit te maken met de aversie tegen herstructurering van de vennootschapsmodellen in het algemeen, deels met de in die modellen ingebouwde medezeggenschapsstructuur. De enige harmonisatie van medezeggenschapsbepalingen die tot nu toe heeft plaatsgehad is harmonisatie van medezeggenschapsbepalingen op deelgebieden.

Ook bij deze laatste vorm van harmonisatie is gekozen voor de instrumentele weg. Institutioneel werd zo weinig geharmoniseerd, dat de lid-staten al zelf moesten voorzien in een zekere mate van vertegenwoordiging om de werknemers de vruchten van de richtlijnen te laten plukken. Doordat de meeste lid-staten wel een vorm van vertegenwoordiging hebben is dit op zich geen probleem geweest.

De in de richtlijnen toegekende rechten boden tot dusver rechten op informatie aan en consultatie van de werknemers(vertegenwoordigers). Met deze rechten legden zilj een vloer in met name die lid-staten waar het medezeggenschapssysteem volledig op vrijwilligheid is gebaseerd. Inspraak bij de besluitvorming hebben ook deze voorstellen niet weten te bewerkstelligen.

Uit het bovenstaande blijkt harmonisatie van medezeggenschaps-regelingen vooral acceptabel te zijn als de materie waarover medezeggenschapsrechten verleend worden vastgellegd is. Harmonisatie van, en daarmee het in een

156. Vo. 21/37/85, $\mathrm{Pb} .1985 \mathrm{~L} 199$ in werking getreden op 1 juli 1989 . Samenwerkingsverbanden tussen ondernemingen als bedoeld in de verordening hebben tot doel de economische werkzaamheden te vergemakkelijken, maar niet om als onderneming zelf winst te behalen.

157. P. Sanders, Het Europees Economisch Samenwerkingsverband, in Ter wermaak van Slagter, 1988, p. 251-252. 
aantal lid-staten in het leven roepen van algemene medezeggenschapsrechten lijkt, voor zowel geỉnstitutionaliseerde als instrumentele medezeggenschap, niet haalbaar. Dit geldt met name voor die lid-staten waar vrijwilligheid in de arbeidsverhoudingen de voornaamste wijze van regulering op dit punt is. Uit de recente ontwikkelingen in de sociale dialoog komt eenzelfde beeld naar voren. De meest concrete resultaten tot nu toe zijn geboekt op een specifiek gebied, namelijk de introduktie van nieuwe technologie. Alle tot dusver verleende rechten gaan echter het niveau van de eigen lid-staat niet te boven. Bovendien laten alle in de gemeenschapsregulering opgenomen rechten de uiteindelijke beslissingsbevoegdheid van de werkgever onverlet.

Ook in het in december 1989 door elf lid-staten aanvaarde Gemeenschapshandvest van sociale grondrechten blijken de voorschriften met betrekking tot specifieke gebieden het sterkst aangescherpt te zijn. Ten aanzien van medezeggenschap in het algemeen wordt bepaald (158) dat de voorlichting, de raadpleging en de deelneming van de werknemers op gepaste wijze moeten worden ontwikkeld. De nadruk wordt in het Handvest gelegd op de ontwikkeling van medezeggenschap in ondernemingen met vestigingen of bedrijven in verscheidene lid-staten van de gemeenschap. Het Handvest schrijft meer expliciet de gevallen voor waarin voorlichting, raadpleging en deelneming moeten plaatsvinden (159). Dit is het geval bij collectief ontslag of faillissement, fusies of herstructurering van de ondernemingen met consequenties voor de werkgelegenheid, in het geval dat grensarbeiders worden getroffen door het werkgelegenheidsbeleid van de onderneming waarvoor zij werken en bij de invoering van nieuwe technologie wanneer deze belangrijk is voor de arbeidsvoorwaarden van de werknemers. Wat deze voorschriften zullen gaan betekenen is zoals al eerdergesteld nog onduidelijk, in verband met de status van het Handvest. Een bepaling die voorschrijft 1 medezeggenschap ontwikkeld moet gaan worden, heeft echter sterk het karakter van een instructienorm, die op zichzelf niet meer rechten zou kunnen toekennen dan artikel 118B EEG-verdrag.

Uit deze constatering kan de conclusie worden getrokken dat harmonisatie beter op specifieke gebieden kan plaatsvinden, waarna men op een "olievlekwerking" mag hopen, dan door middel van grootse algemene regelingen. Hetzelfde kan gezegd worden voor de versterking van werknemersrechten en het uitbreiden van niveaus waarop medezeggenschap kan plaatsvinden. De meest uitgewerkte materie op een specifiek gebied is sedert de invoering van (in de dit boek later te bespreken) nieuwe raamrichtlijn inzake veiligheids- en gezondheidsaangelegenheden. Mogelijk zou op dit gebied als eerste een dergelijke versterking en uitbreiding kunnen plaatsvinden. 
Een dergelijke versterking kan mijns inziens echter alleen plaatsvinden als lid-staten in staat zijn richtlijnen te implementeren op een wijze die (in elk geval) ten dele aansluit bij de traditionele arbeidsverhoudingen. Daarvoor is het, het is hierboven al gesteld, noodzakelijk dat ook andere implementatie-instrumenten dan alleen wettelijke of bestuursrechtelijke maatregelen kunnen worden gebruikt. In enkele van de voorstellen, zoals het vijfde richtlijnvoorstel en het Statuut SE, die nu aan de orde zijn, wordt in deze mogelijkheid voorzien.

\section{Implementatie van richtlijnen door collectieve overeenkomsten.}

Een dringende vraag met betrekking tot harmonisatie van medezeggenschapswetgeving op communautair niveau is die van de implementatie van de communuautaire richtlijnen. Moeten die richtlijnen per se bij wettelijke of bestuursrechtelijke maatregelen uitgevoerd worden, of kan dit ook door middel van collectieve overeenkomsten gebeuren? Deze vraag die als belangrijk in de discussies omtrent de Vredeling voorstellen naar voren kwam, zal opgelost moeten worden wil de Gemeenschap überhaupt in staat zijn medezeggenschapsregelingen op minimumniveau te harmoniseren.

Het is een vraag die overigens een ruimer belang heeft; voor veel meer bepalingen betreffende sociaal recht kan men stellen dat in tenminste een aantal lid-staten de regeling aan de sociale partners wordt overgelaten. Een te stringent vasthouden aan de wet of bestuursrechtelijke maatregel als enig instrument richtlijnen uit te voeren kan het evenwicht dat in die lid-staten wordt bereikt door collectieve onderhandelingen doorkruisen, hetgeen niet te voorziene gevolgen kan hebben voor het hele sociaalrechtelijke systeem in die lid-staten. De aanvaarding door de Gemeenschap van collectieve overeenkomsten als implementatie-instrument van sociaal-politieke richtlijnen zou een oplossing kunnen bieden. Die aanvaarding brengt overigens wel haar eigen problemen met zich mee, met name met betrekking tot de werking en de status van collectieve overeenkomsten in het nationale recht, en van het toezicht op de naleving op gemeenschapsniveau. Deze problemen zullen hieronder worden besproken.

Tijdens de controverses rond het Vredeling-voorstel kwam de mogelijkheid van de collectieve overeenkomst als uitvoeringsregeling van richtlijnen ter sprake (160). Deze mogelijkheid werd gezien als een eventuele tegemoetkoming (161) aan Groot Brittannië gezien het bezwaar van dit land, dat een

160. Zie 0.m. Adelina Adinolfi, The implementation of Social Policy Directives through Collective Agreements, Common market Law Review 25, 1988, p. 294. Als mogelijkheid wan implementatie van verdragsbepalingen van o.m. het ESH en ILO-verdragen was dit al eerder ter sprake geweest, zie A.T.J.M. Jacobs, a.w. (noot 145), p. 289-309.

161. De Raad verzocht de Commissie op dit punt een studie te verrichten die zal worden meegenomen in een hernieuwde discussie, die in het begin van 1989 moest gaan plaatsvinden (conclusies van de Raad wan 16 juni 1986, doc 7536/86, SOC 198). 
richtllijn als het Vredeling-voorstel te zeer zou ingrijpen in de arbeidsverboudingen.

Op zich zelf is de oplossing niet zo gek. Als lid-staten niet door middel van wetgeving in het proces van collectieve onderhandelingen in hoeven te grijpen, maar de sociale partners kunnen laten onderhandelen, waarbij het minimum waaraan het resultaat van de onderhandelingen moet voldoen weliswaar vastligt, maar de vorm en middelen in plaats van door de wetgever, door de sociale partners kunnen worden gekozen, is de uitvoering van de bepalingen van de richtlijnen (in theorie) gewaarborgd.

In 1982 sprak het Hof van Justitie zich uit over de vraag in hoeverre collectieve overeenkomsten voor het implementeren van richtlijnen konden worden gebruikt. In de zaak Commissie vs Italië (162) stelde de Italiaanse regering dat hoewel geen wettelijke voorziening was getroffen de richtlijn ter bescherming van werknemers bij collectief ontslag uit te voeren, Italië zijn gemeenschapsverplichtingen toch was nagekomen nu collectieve overeenkomsten voorzagen in de noodzakelijke procedures, die niet verschilden van die, die door de richtlijn als verplicht werden gezien. Het Hof accepteerde deze redenering tot op zekere hoogte, door te stellen dat Italië zijn verplichtingen niet was nagekomen voor die gevallen die niet door collectieve overeenkomsten gedekt werden. Het Hof nam daarmee impliciet aan, dat collectieve contracten een middel kunnen zijn om richtlijnen te implementeren.

In 1985 bevestigde en verduidelijkte het Hof in de zaak Commissie vs Denemarken (163) deze visie. Het ging hier om de interpretatie van de richtlijn 75/117 (gelijke beloning van mannelijke en vrouwelijke werknemers). De Deense wet (164) bepaalde dat voor gelijke arbeid, gelijk loon moest worden betaald. Deze bepaling werd door de Commissie te eng bevonden, aangezien de richtlijn spreekt over gelijk loon bij gelijkwaardige arbeid. De Deense regering verdedigde de bepaling door op te merken dat in collectieve overeenkomsten die het merendeel van de arbeidsverhoudingen in Denemarken beheersen uitdrukkelijk de regel zou zijn aanvaard dat het beginsel van gelijke beloning ook voor gelijkwaardige arbeid geldt. Zij meende dat deze interpretatie met name berust, op de centrale overeenkomst uit 1970 waarin deze uitleg expliciet was opgenomen. Voorts was deze interpretatie nog bevestigd in een arbitrage uitspraak van 8 december 1977 (165).

Het Hof overwoog: "Het staat de lid-staten ontegenzeglijk vrij om de verwezenlijking van het beginsel van gelijke beloning in eerste instantie aan

162. Zaak $91 / 81$, Jur. 1982 p. 2133.

163. Zaak $143 / 83$, Jur. 1985 , p. 427 (Commissie vs Denemarken).

164. Wet van 4 februari 1976, no. 32, (Lovtidende A, blz. 64)

165. Arbitrage-uitsprakak wan 8 december 1977 , president van de Statens forligsinstitution $\mathrm{i}$ arbejdstridligheder. 
de sociale partners over te laten. Dit ontslaat hen evenwel niet van de verplichting om door passende wettelijke maatregelen te waarborgen dat alle werknemers in de Gemeenschap ten volle de door de richtlijn voorziene bescherming kunnen genieten. De overheid (cursivering ES) moet deze waarborg bieden in alle gevallen waarin om welke reden dan ook een doeltreffende bescherming niet anderszins is gewaarborgd, met name wanneer de betrokken werknemers niet bij een vakbond zijn aangesloten, de sector in kwestie niet onder een collectieve overeenkomst valt, of een dergelijke overeenkomst het beginsel van gelijke beloning niet ten volle waarborgt".

Ook in een zaak die betrekking had op de richtlijn 'overgang van ondernemingen' stelde het Hof dat collectieve overeenkomsten, ook al zijn zij wijdverbreid en belangrijk, deze geen adequat middel op volledige implementatie opleveren, indien zij slechts een deel van de sectoren dekken en alleen verplichtingen creëren tussen leden van de vakbonden en de door de overeenkomst gebonden werkgevers (166).

Met andere woorden: richtlijnen kunnen bij collectieve overeenkomsten geïmplementeerd worden, onder voorwaarde dat volledige implementatie in alle sectoren en voor alle werknemers is gewaarborgd (167). Indien dit niet het geval is, dan moet de overheid wettelijke of bestuursrechtelijke maatregelen nemen die als vangnet kunnen dienen voor die gevallen waarin de collectieve overeenkomsten niet (kunnen) voorzien.

In het geval waarin de werking van collectieve overeenkomsten door wettelijke tussenkomst uitgebreid kan worden tot alle werknemers en op deze wijze een erga omnes werking verkrijgt, werd het collectieve contract inderdaad wel geaccepteerd als middel voor implementatie dat in overeenstemming met het gemeenschapsrecht kon worden beschouwd (168). Ook hier is sprake van een wettelijk vangnet, maar dan in zijn, voor wat de inhoud van de implementatie betreft, meest terughoudende vorm. Een dergelijke algemeen verbindendverklaring is echter een praktijk die niet geaccepteerd is in alle lid-staten (169).

Naast het bovenstaande kan nog een ander probleem worden gesignaleerd. Wanneer een richtlijn wordt omgezet in nationaal recht is het nodig dat zowel in geval van niet juiste omzetting als schending van de nationale

166. Zaak $235 / 84$, Jur. 1986, p. 2291 (Commissie vs Italie).

167. Zie ook het standpunt van de juridische dienst van de Raad van Ministers, doc. 10559/84, IUR 148, SOC 323.

168. Zaak $215 / 83$, Jur. 1985 , p. 1039 (Commissie ws België).

169. In Italië werd een dergelijke algemeen verbindend verklaring van de centrale collectieve - overeenkomst op het gebied van procedures voor collectieve ontslagen ongrondwettig verklaard voor het deel dat betrekking had op het verplichten van colsultatieprocedures (Uitspraak wan \& feburari 1966, no. 8, 89 Foro Italiano (1966) p. 201). Zie ook A.T.J.M. Jacobs, Het Nederlandse cao-recht bezien door een Europese bril, SMA 1988, p. 251-252 en Jacobs, a.w. (noot 145), p.137 en p.226-231. 
regelgeving door een particulier (bijvoorbeeld een werkgever) de rechter hierover een oordeel kan vellen. Normaal gesproken worden in Groot Brittannië collectieve contracten echter niet als juridisch afdwingbaar beschouwd. Slechts indien in deze contracten expliciet en schriftelijk verklaard wordt dat zij dit well zijn is juridische afdwingbaarheid mogelijk, doch dit wordt als uitzondering beschouwd (170).

Het is niet zeker dat de huidige status van de Britse collectieve contracten binnen het recht, kan worden gezien als in overeenstemming met het gemeenschapsrecht op dit punt (171). Dit impliceert mijns inziens dat ook hier een wettelijk vangnet nodig is, in het geval waar het gaat om beroep van particulieren, wanneer contracten niet in overeenstemming zijn met het gemeenschapsrecht. Daarmee treedt het gemeenschapsrecht echter in hoge mate in de Britse arbeidsverhoudingen op een wijze die mogelijk voor de Britse sociale partners niet acceptabel zou zijn.

\subsection{De vrijheid wan collectief onderhandelen.}

Op basis van bovenstaande jurisprudentie kan de collectieve overeenkomst dus onder voorwaarden een adequaat middel zijn om richtlijnen te implementeren, voorzover het bereikte resultaat zich binnen de in de richtlijn gegeven kaders bevindt. Dit betekent dat het gemeenschapsrecht gaat voorzien in een (minimum)resultaat dat door de sociale partners bereikt moet worden, hetgeen op gespannen voet zou kunnen komen te staan met de vrijheid van collectief onderhandelen zoals voorzien in de regelgeving (of afwezigheid van regelgeving) in de lid-staten.

Met het aanvaarden van de collectieve overeenkomst als implementatieinstrument wordt een beperking van de vrijheid van onderhandeling wel meteen geaccepteerd. Bij beschouwing van de medezeggenschapsregulering levert dat het volgende beeld op. Indien er geen wettelijke regeling is die een zekere mate van medezeggenschap voorschrijft hebben de sociale partners de mogelijkheid op vrijwillige basis tot medezeggenschapsvormen te komen (172). De term vrijwilligheid geeft aan dat binnen het proces van collectief onderhandelen ten aanzien van informatieverstrekking en consultatieprocedures een variatie van nul (geen informatie/consultatie) tot oneindig (volledige informatie en consultatie maar eventueel ook medebeslissingsrecht) kan zitten, afhankelijk van macht en mogelijkheden van de onderhandelingspartners. Met andere woorden, de graad van medezeggenschap is hier geheel afhankelijk van buiten het recht gelegen factoren als

170. Zie o.m. B. Hepple en D. Freedman, Great Britain, in R. Blampain International Encyclopedia of Labour Law and Industrial Relations, Deventer 1986, para. 465, 466, 467, $468,469$.

171. De juridische dienst van de Raad van Ministers meent van niet, (23 november 1984, doc. 10550/84, IUR 148 SOC 323)

172. Zie ook het advies van de UNICE, t.a.v. de Vredelingrichtijn. 
conjunctuur en sociaal-psychologische verhoudingen tussen ondernemers en werknemers.

Door een minimum-voorziening via het recht op te leggen is de ruimte om regelingen te treffen door middel van collectieve onderhandelingen zodanig beperkt dat het recht verbiedt onder deze minimum-voorziening te gaan zitten, zelfs als dat op basis van overeenkomst mogelijk zou zijn. In die zin zouden werkgevers een deel van hun vrijheid verliezen en zou, als richtlijnvoorstellen door middel van collectieve overeenkomsten geïmplementeerd zou worden, er althans theoretisch, ingegrepen worden in de arbeidsverhoudingen in die lid-staten waar medezeggenschap gebaseerd is op een systeem van collectieve onderhandelingen. Theoretisch, omdat meestal in die landen de nationale regelgeving ook al minimumvoorzieningen biedt, zodat het voorstel veeleer aansluit op hetgeen al manwezig is, dan dat het werkelijk een nog niet eerder gepleegde ingreep doet.

Deze ingreep door de Gemeenschap als wetgever is des te meer aanwezig in het geval transnationale ondernemingen aan de minimumwoorziening uit een richtlijn zou worden onderworpen, omdat hier voor werknemersvertegenwoordigers een (aan de nationale wetgeving, of mogelijkerwijs direct aan de richtlijn te ontlenen) recht creëert in een gebied waar op dit moment geen enkele wettelijke voorziening aanwezig is.

$\mathrm{Nu}$ is die inperking door wettelijke maatregelen op zichzelf niets nieuws. Iedere nationale wettelijke regelling op het gebied van arbeidsverhoudingen, of het nu een standaard- of minimumregeling is, perkt de vrijheid van collectief onderhandelen in. Er zou in beginsel geen probleem hoeven te zijn om op gemeenschapsniveau op dezelfde wijze deze vrijheid in te perken, daar het gaat om een aantal aan de Gemeenschap overgedragen bevoegdheden.

Deze bevoegdheidsoverdracht kan echter de vrijheid die op nationaal niveau op het gebied van collectief onderhandelen bestaat doorkruisen. Hiermee bedoel ik dat hoewel het lid-staten vrij staat op een bepaald terrein de regelgevende bevoegdheid aan de gemeenschap over te dragen, deze overdracht de vrijheid van collectief onderhandelen op zichzelf niet beïnvloedt. Indien in een lid-staat de nationale wet niet aan bepaalde rechten kan tornen, omdat deze tot het onderhandelingsterrein van de sociale partners behoren (173), dan bestaat het risico van op zijn minst een botsing, indien de regelgevende bevoegdheid op dit specifieke terrein aan de gemeenschap wordt overgedragen, en de Gemeenschap door regulering bij wege van richtlijn gebruik maakt. De botsing kan dan hieruit bestaan dat de lid-staat een bevoegdheid overdraagt aan de Gemeenschap, en de lid-staat na deze overdracht de opdracht krijgt tot regulering en daarmee tot ingrijpen in bepaalde uit collectieve onderhandeling ontstane rechten,

173. Zie hierover i.h.a. A.T.J.M. Jacobs, a.w. (noot 145), p. 334-350. 
waaraan de nationale wetgever op grond wan het feit dat de collectieve onderhandelingsvrijheid in die lid-staat als grondrecht wordt gezien, geen recht heeft te tornen. De lid-staat draagt in dat geval een bevoegdheid over die hij niet heeft. Weliswaar wordt de ingreep gepleegd door de gemeenschapswetgever, de vraag is dan wel in hoeverre de gemeenschapswetgever de bevoegdheid heeft een regeling te treffen die de lid-staat dwingt een in zijn constitutie erkend grondrecht te schenden.

Ten aanzien van de klassieke grondrechten heeft het Hof hierover een aantal uitspraken gedaan, die erop neerkomen dat fundamentele rechten een bestanddeel vormen van de algemene rechtsbeginselen waaraan het gemeenschapsrecht gebonden is (174). Bij de eerbiediging van deze rechten put de gemeenschap uit de gemeenschappelijke constitutionele tradities (175), waarbij het Hof in de Nold-zaak (176) stelde geen maatregelen te kunnen aanvaarden, waarvan bleek dat deze met de gemeenschappelijke tradities in strijd zijn, en uit internationale verdragen die de bescherming van de rechten van de mens ten doel hebben (177). Over sociale grondrechten is geen specifieke jurisprudentie, maar er is geen reden om aan te nemen dat deze geen bestanddeel van de beginselen van het gemeenschapsrecht zouden vormen. Bij het beperken van de collectieve onderhandelingsvrijheid kan de gemeenschapswetgever tegen deze jurisprudentie oplopen.

Een probleem omtrent de onderhandelingsvrijheid kwam in 1988 in Frankrijk aan het licht. Het ging in deze zaak (178) om, in collectieve overeenkomsten opgenomen, speciaal aan vrouwen toegekende, bijzondere rechten die niet onder de uitzondering van zwangerschap en moederschap vielen, en volgens het Hof in strijd waren met het beginsel van gelijke behandeling zoals geformuleerd in richtlijn 76/207 (gelijke behandeling van mannen en vrouwen).

Om aan de richtlijn te voldoen was er in 1983 een wet aangenomen (179), die enerzijds op straffe van nietigheid alle met de richtlijn strijdige clausules betreffende gelijke behandeling verbood, maar anderzijds geen beletsel vormde voor de bepalingen die bijzondere rechten voor vrouwen creëerden, in die collectieve contracten die op het moment van inwerkingtreden van de wet nog van kracht waren. De discriminatie in de bepalingen kon alleen worden afgeschaft door heronderhandeling tussen de sociale partners. In de wet was geen termijn opgenomen waarbinnen die hernieuwde onderhande-

174. Zaak 29/69, Jur. 1969, p. 419 (Stauder).

175. Zaak 11/70, Jur. 1970, p. 1125 (Internationale Handelsgesellschaft).

176. Zaak 4/73, Jur. 1974, p. 491, (J. Nold, Kohlen und Baustoffenhandlung ws Commissie).

177. Zaak 4/73, Jur. 1974, p. 491 (Nold); zaak 36/75, Jur. 1975, p. 1219 (R. Rutili vs De Miaister van Binnenlandse Zaken); zaak 44/79, Jur. 1979, p. 3727, (L. Hauer vs Land Rheinland Pfalz). Voor de ontwikkeling in de jurisprudentie van het Hof zie: L. Betten, a.w. (noot 48), p. 25-45 en P. van Dijk, G.J. van Hoof, De Europese Conventie in theorie en praktijk, Dewenter 1982, p. $553-561$.

178. Zaak 312/86, arrest van 25 oktober 1988, nog niet gepubliceerd (Commissie vs Frankrijk).

179. Loi no. 83-635, du 23 juillet 1983 (JORF du 14 juillet 1983, p. 2176). 
lingen plaats moesten vinden; dit is des te saillanter, daar de collectieve contracten in Frankrijk meestal lang lopen in verband met goedkeuringsprocedures.

De Franse regering verdedigde de uitzondering in de wet voor bestaande rechten door te stellen dat heronderhandeling de enig aangewezen weg voor het afschaffen van de discriminatie was. Dit, omdat in de eerste plaats rechten verkregen door collectieve contracten niet door een latere wet opzij gezet kunnen worden, en daarnaast omdat alleen dan de sociale partners invloed konden uitoefenen op de wijze van afschaffing.

Het Hof ging op deze verdediging niet in maar overwoog: "(.....) il suffit de constater de, mème si cette thèse devait être considérée comme exacte, elle ne saurait justifier une legislation nationale qui, plusieurs années après l'expiration du delai prévu pour la mise en oeuvre de la directive, renvoie l'abolition de certaines inegalités au partenaires sociaux sans leur fixer de délai pour se conformer à cette obligation." Kortom: hoewel de Franse wetgever niet in mag grijpen in eerder door middel van collectief onderhandelen bereikte resultaten, draagt het Hof de Franse regering op dit nu wel te doen. Daarbij moet aangetekend worden dat volgens de Franse regering verkregen rechten niet opzij gezet kunnen worden door latere wetgeving. Daarmee is niet gezegd dat de afschaffing van de discriminatie 'naar boven' dus door het bij wet verlenen aan mannen van de in de collectieve overeenkomsten verkregen rechten in strijd is met de vrijheid van collectief onderhandelen. Hoe dan ook, de bevoegdheden van de Gemeenschap kunnen volgens het Hof niet beperkt worden door de wijze waarop in de lid-staat het recht op collectief onderhandelen "is ingevuld. De oplossing moet op nationaal niveau gezocht worden met inachtneming van het gemeenschapsrecht.

Wanneer echter de communautaire regelgeving op sociaal gebied talrijker wordt, komt men vroeger of later toch voor de vraag te staan op welke wijze het recht op collectief onderhandelen dat ook naar internationaal recht (men denke aan het Europees Sociaal Handvest) als sociaal grondrecht moet worden gezien en het gemeenschapsrecht zich met elkatar verhouden. Een oplossing voor het probleem zou gevonden kunnen worden in opname van een recht op collectief onderhandelen in het Communautaire sociale handvest, of in een richtlijn omtrent Europese arbeidsverhoudingen waarin de verhouding tussen de gemeenschapsbevoegdheden en het recht op collectief onderhandelen geregeld zouden kunnen zijn (180).

Een botsing met collectieve onderhandelingsvrijheid kan zich vooral voordoen in geval van een richtlijn met standaardnormen. Het vijfde richtlijnoorstel, dat weliswaar medezeggenschap door middel van collectieve

180. De bepaling die in het ontwerp-handvest is opgenomen, regelt niets hieromtrent, zie Gemeenschapshandvest wan Sociale Grondrechten, COM. (89) 471 def. (tekst na aanvaarding nog niet gepubliceerd). 
onderhandelingen mogelijk wil maken, maar de keuze wel tot op grote hoogte beperkt kan in dit opzicht als problematisch worden gezien. Wanneer een richtlijn minimumnormen voorschrijft, en de lid-staten gerechtigd zijn om verder te gaan in hun bescherming van werknemers, dan kan die verdergaande bescherming net zo zeer in collectieve overeenkomsten geregeld worden als bij wet, als die collectieve overeenkomsten maar in overeenstemming zijn met andere delen van het gemeenschapsrecht.

\subsection{Het toezicht wan de Commissie op de naleving van de richtijimbepalingen.}

Een ander probleem dat zich bij het accepteren van collectieve contracten als middel voor de implementatie van richtlijnen voordoet, is het toezicht op de naleving van het gemeenschapsrecht. Dit toezicht is door het verdrag opgedragen aan de Commissie. Het toezicht op alleen al de de wettelijke en bestuursrechtelijke maatregelen van twaalf lid-staten is een niet eenvoudige taak; om die reden worden dan ook door het Hof eisen van helderheid en doorzichtigheid gesteld aan die maatregelen (181).

Het toevoegen van collectieve contracten als zelfstandige methode voor de implementatie van richtlijnen aan deze maatregelen maakt m.i. de taak van de Commissie een onmogelijke. Niet alleen collectieve contracten op nationaal of brancheniveau zouden moeten worden bekeken, maar ook contracten op ondernemingsniveau. Zeker daar waar het gaat om de toepassing van veiligheids en gezondheidsregelingen, en om informatie en consultatieprocedures worden veel regelingen afgesloten op nationaal niveau. Indien er geen nationale bepaling is, die de richtlijnbepalingen 'doorsluist' (en op die wijze in de eigen wetgeving een vloer legt), wordt het toezicht op de naleving van richtlijnen voor de Commissie nagenoeg onmogelijk. Zelfs indien men genoegen neemt met een steekproefsgewijze contrôle kan de Commissie nauwelijks in staat geacht worden naleving en toepassing van deze bepalingen binnen het nationale systeem van collectief onderhandelen te controleren.

Adinolfi (182) draagt als mogelijke verzachting van dit probleem een rapportageplicht van de lid-staten naar analogie van de rapportageplicht zoals deze voor de implementatie van ILO-Conventies geldt, maar stelt tevens dat dit probleem in een meer algemene context van de verbetering van de contrôle-instrumenten geplaatst zou moeten worden. Een rapportage verplichting zou m.i. een doekje voor het bloeden zijn en de Commissie zou, zelfs als een dergelijke verplichting ingesteld zou worden, het overzicht en daarmee haar toezichtsmogelijkheden totaal kwijt zijn. Zelfs met meer

181. Zie bijwoorbeeld zaak 316/86, arrest van 30 juni 1988 (Commissie vs Frankrijk) nog niet gepubliceerd, waarin het Hof oordeelde dat een wervingsregeling voor ambtenaren in strijd kon komen met het gemeenschapsrecht (richtlijn 76/207) onder meer omdat door het ontbreken van objectieve criteria in de regeling zelf, de doorzichtigheid onvoldoende was. Daardoor kon de controle van de Commissie op die regeling in verband met de sociale ontwikkelingen niet op afdoende wijze worden uitgeoefend.

182. A. Adinolfi, a.w. (noot 160), p. 314. 
personele middelen is het m.i. onmogelijk alle collectieve contracten gesloten in de lid-staten, anders dan in de vorm van een nationaal of centraal akkoord, te toetsen.

Dit impliceert dat m.i. nationale en branche overeenkomsten, die een hele branche dekken, als middel tot implementatie zouden kunnen worden gebruikt. Deze zouden de onderhandelaars op ondernemingsniveau de gelegenheid kunnen geven om bepalingen uit de nationale overeenkomst en binnen de grenzen daarvan uit te werken op de wijze die voor de onderneming in kwestie passend is. Op deze wijze zou een deel van het door de Commissie uit te oefenen toezicht doorgesluisd worden naar de contractspartijen. Het probleem daarbij is echter dat niet alle lid-staten overleg op nationaal niveau kennen, en zeker geen nationale akkoorden. Zou een dergelijk model voor Denemarken onder omstandigheden kunnen werken, voor Groot Brittannië moet het voorlopig als enig middel, waarbij geen wettelijk of bestuursrechtelijk vangnet is ingebouwd, zowel voor wat betreft de materiële als wat betreft de contrôle aspecten uitgesloten worden geacht (183).

\subsection{Medezeggenschap op multinationaal niveau door middel van collectieve contracten.}

Op zichzelf zou men voor medezeggenschap op multinationaal niveau helemaal geen richtlijn nodig hebben; men kan argumenteren dat men dit op uitsluitend contractuele basis kan regelen voor die sectoren waar, en op de wijze waarop daar behoefte aan is (184). Dit zou echter wel op enige problemen stuiten.

Hoewel men mag aannemen dat de mogelijkheid van opname van medezeggenschapsrechten in collectieve overeenkomsten, die op multinationaal niveau, en bij voorkeur op Europees niveau gesloten worden uitdrukkelijk in artikel 118B geboden is (sterker nog, de Commissie moet een dergelijke sociale dialoog, die tot contractuele betrekkingen kan leiden, zelfs bevorderen) is het de vraag hoe de uitwerking van deze mogelijkheid kan geschieden. Afgezien van een aantal praktische problemen waarvan de oplossing nog lang niet in het verschiet ligt (185) ligt er ook nog een meer theoretisch probleem. De uitwerking van het recht een collectieve overeenkomst af te sluiten, is op nationaal niveau geregeld. Een collectieve overeenkomst op gemeenschapsniveau met betrekking tot medezeggenschap zou wanneer zij aan de beperkingen van het nationale recht met betrekking tot collectieve overeenkomsten wordt onderworpen, aan kracht in kunnen boeten en er zelfs praktisch ineffectief door kunnen worden.

183. Lord Wedderburn, The Worker and the Law, Harmondsworth 1986, p. 303.

184. A.T.J.M. Jacobs, a.w. (noot 145), p. 417.

185. Zie hierover o.m. Y. Scholten, a.w. (noot 95), p. 712-714. 
Een richtlijn vanuit de gemeenschappen die enkele minimum-voorwaarden en procedurele regels schept, zou dit probleem kunnen oplossen (186). Het probleem dat collectieve contracten geen erga omnes werking hebben, blijft nog wel bestaan, hetgeen betekent dat hoe dan ook wettelijke vangnetten noodzakelijk zijn voor die gevallen waarin de collectieve contracten niet voorzien. Uitwerking van een dergelijke richtlijn op Europees collectief niveau ligt overigens well voor de hand, omdat dan op de juiste niveau's onderhandeld kan worden tussen werkgevers en vakbonden.

\section{Slotopmerkingen.}

De gemeenschapsbemoeienis met het sociaal beleid is zeker wanneer men haar vergelijkt met andere gebieden waarop de gemeenschap regelend optreedt, een onderontwikkeld gebied. Niettemin is er inmiddels op enkele deelgebieden wel wat bereikt, en dat zijn dan met name die deelgebieden waar sociale regelingen onderdeel zijn van een groter gemeenschapsbelang. Dit zijn echter enerzijds regelingen die de arbeidsverhoudingen in de lidstaten op zichzelf niet raken, zoals de richtlijnen gelijke beloning en gelijke behandeling en anderzijds regelingen die nodig waren in het kader van een groter gemeenschapsbelang als harmonisatie van het vennootschapsrecht. Ook van die laatste regelingen kan gezegd worden dat de precaire punten ten aanzien van arbeidsverhoudingen ongemoeid worden gelaten.

Regelingen omtrent medezeggenschap van werknemers zijn tot stand gekomen voor slechts enkele deelgebieden. In deze regelingen blijft medezeggenschap geheel binnen de nationale grenzen, en sluit in grote lijnen aan bij de nationale wettelijke regelingen of praktijk. Toch hebben de tot dusver in de richtlijnen opgenomen bepalingen op medezeggenschapsgebied wel degelijk hier en daar veranderingen gebracht: zowel waar het de gebieden van informatieverstrekking en consultatie betreft als ten aanzien van wélke soort informatie moet worden verstrekt en over welke gebieden de werknemers geconsulteerd moeten worden. Met name voor landen die geen wettelijke regeling met betrekking tot medezeggenschap hadden, hebben door middel van de richtlijn en de daarop gebaseerde wettelijke of bestuursrechtelijke maatregelen een stelsel van minimumregelingen opgelegd gekregen. De Gemeenschap zou zich mijns inziens op versterking en uitbreiding van deze rechten moeten concentreren.

Geheel of tenminste gedeeltelijk nieuwe medezeggenschapsverplichtingen, zoals voorzien in het ontwerp-vijfde richtlijn en de Vredeling-voorstellen in hun verschillende fasen stuiten op een grote aversie van de lid-staten om aan hun interne arbeidsverhoudingen te sleutelen. In bepaalde opzichten is deze weerzin mijns inziens terecht. In een land als Groot Brittannië waar het medezeggenschapssysteem gebaseerd is op nogal precaire verhoudingen tussen vakbonden en ondernemers, en eerder berust op machtsverhoudingen

186. Zie ook A.TJ.M. Jacobs, a.w. (noot 145), p. 400, en 419-425. 
dan op juridische constructies, is het niet verwonderlijk dat men aarzelt dit evenwicht (of soms totaal gebrek aan evenwicht) te doorbreken via het recht. Voor Denemarken geldt dit misschien nog sterker: het systeem van medezeggenschap lijkt veel op het Britse maar de attitude van de partijen ten opzichte van elkaar is veel gematigder, hetgeen verstoring van het evenwicht nog meer tot een bedreiging kan maken.

Ondernemingen worden grootschaliger en de voltooiing van de interne markt stimuleert ze daartoe. Juist daarom is het bijzonder belangrijk dat medezeggenschap op een hoger niveau dan dat van de eigen vestiging van de onderneming, en in elk geval voor economische aangelegenheden bij de concerntop tot stand komt. Mijns inziens is dit noodzakelijk om werknemers niet een te grote achterstand te laten oplopen in informatie en invloed op de eigen situatie zowel op het gebied van economische aangelegenheden als dat van de sociale.

De noodzaak hiervan vloeit voort uit de voortschrijdende integratie binnen de gemeenschap. Mede door harmonisatie van het vennootschapsrecht worden de mogelijkheden tot vestiging in de verschillende lid-staten vergroot. Indien de wetgevingen van de lid-staten te veel verschillen en medezeggenschap zich binnen die nationale grenzen zal blijven bevinden, zullen de werknemers de verliezers worden ten opzichte van ondernemingen. Ondernemers kunnen zich, met het oog op sociale verhoudingen, gaan vestigen in die lid-staten waarvan men van werknemerswertegenwoordigers en vakbonden de minste "last" zullen ondervinden. Als dit op grote schaal gebeurt zal dat zijn weerslag hebben op de arbeidsverhoudingen, zowel in de lid-staten waar massaal gevestigd wordt, als in die lid-staten waar juist geen investeringen worden gedaan. Dit zal mogelijk het sterkst zijn invloed hebben in die landen waar het systeem van medezeggenschap afhankelijk is van machtsverhoudingen zonder al te veel juridische regulering.

Harmonisatie van mëdezeggenschapsinstrumenten die door werknemersvertegenwoordigers slechts gebruikt kunnen worden binnen de nationale grenzen is in dit licht bezien minder dringend. Ook hier kunnen, door integratie gewijzigde structuren echter op de lange termijn invloed hebben, zodat harmonisatie in elk geval wenselijk genoemd kan worden. 



\section{Werknemersvertegenwoordiging op ondernemingsniveau}

\section{Inleiding.}

In dit hoofdstuk zal een overzicht worden gegeven van de verschillende soorten werknemersvertegenwoordiging die op ondernemingsniveau in de lid-staten van de Europese gemeenschap bestaan. Om deze soorten vertegenwoordiging in hun context te plaatsen zal een korte schets van de meest opvallende ontwikkelingen ten aanzien van medezeggenschap worden gegeven.

Medezeggenschap op ondernemingsniveau in de lid-staten van de Europese gemeenschappen is een fenomeen dat, met name waar het gaat om de juridische aspecten ervan, tot bloei is gekomen in de decennia na de tweede wereldoorlog. Dat wil niet zeggen dat voor die tijd geen ideëen over inspraak door werknemers in de onderneming leefden (1).

Vanaf het eind van de vorige en het begin van deze eeuw, kwamen in een aantal landen min of meer gereguleerde medezeggenschapssystemen tot stand. In een aantal landen was deze regelgeving tot op zekere hoogte de codificatie van een feitelijke situatie. Personeelsvertegenwoordiging was met de door de industriële revolutie, gepaard gaande schaalvergroting, aarzelend op gang gekomen (2).

In Duitsland dateert de eerste regulering ten aanzien van medezeggenschap op ondernemingsniveau uit 1891 , hoewel deze wettelijke regeling later niet erg bevredigend bleek (3). In de Weimarrepubliek kwam een meer publiekrechtelijk getinte regeling tot stand, met medezeggenschaporganen op drie niveaus, te weten ondernemingsraden (Betriebsräte), districtsondernemingsraden (Bezirksarbeiterräte), en aan de top een rijkseconomische raad (Reichswirtschaftsrat). Het concept werd echter maar gedeeltelijk gerealiseerd: de

1. Zie voor de ontwikkelingen tot 1945 in negen landen: Th. Ramm, Workers' Participation, Labour representation, and Special Labour Courts in The Making of Labour Law in

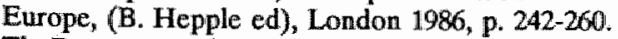

2. Th. Ramm, a.w. (noot 1), p. 246 ,

3. F. Gamillscheg, Sixty years of Labour Law and Social Security in Germany in Fifty Years of Labour law and Social Security, Deventer 1986 p. 77. 
Reichswirtschaftsrat werd weliswaar opgericht in 1920, maar werd nauwelijks effectief en de districtsondernemingsraden kwamen al helemaal niet tot stand. De ondernemingsraden werden wel geïntroduceerd. Vanaf 1933, tijdens het naziregime, werd het hele stelsel geleidelijk aan afgebroken (4).

In Luxemburg werd in 1915 een wet aangenomen die de regering de bevoegdheid gaf (en nog steeds geeft) de economische belangen tijdens oorlog te beschermen. Op basis van deze wet werden in 1919 en 1920 decreten vastgesteld die ondernemingsraden introduceerden. Nadat deze in 1921. waren ingetrokken werden zij in 1925 in ere hersteld. Het ging hier vooral om vertegenwoordigers van de handwerkslieden, in 1938 werd daarnaast ook een vertegenwoordiging van witte boordenwerkers mogelijk gemaakt. De algemene commités van de handwerkslieden hadden onder meer de bevoegdheid veiligheidsafgevaardigden te verkiezen (5).

In Nederland varieerden de vooroorlogse ideeën over zeggenschap voor werknemers van op initiatief van de werkgever opgerichte fabriekskernen (6) tot alomvattende corporatieve concepten waarin bedrijfsraden bedrijfstakgewijs medezeggenschapsrechten zouden krijgen zowel ten aanzien van het ondernemingsbeleid als het arbeidsvoorwaardenbeleid (7). De Bedrijfsradenwet van 1933 (8), gebaseerd op een publiekrechtelijke invalshoek, maakte de instelling van paritair samengestelde bedrijfsraden mogelijk.

Wettelijke regeling van medezeggenschap in België begon in 1926. Toen werd voorzien de oprichting van paritair samengestelde comité's voor de Spoorwegen. Deze comité's hadden tot taak een werknemersstatuut te ontwerpen (9). Daarnaast kwam in die periode vertegenwoordiging door middel van vakbond(svertegenwoordigers) tot stand. In Belgie dwongen, nadat in 1921 de vrijheid van vakvereniging was erkend, de vakbonden, door een algemene staking in 1936 garanties voor het respecteren van hun rechten in de onderneming af. De paritaire comité's op bedrijfstakniveau die sedert 1921 een zekere mate van belangrijkheid hadden verkregen werkten de bij deze staking verkregen rechten verder uit (10).

4. J. van der Wulffen Palthe, Industriële medezeggenschapsrechten in rechtswergelijkend verband, Eindhoven 1986, p. 284.

5. Th. Ramm, a.w. (noot 1), p. 254.

6. F. Koning, Omtrent de ondernemingsraad, SMA 1975, p. 85.

7. J.P. Windmïller, C. de Galan, A.F. van Zweeden, Arbeidswerhoudingen in Nederland, Utrecht/Antwerpen (4e druk) 1983 , p. 354 ev.

8. Wet van 7 april 1933, ingetrokken bij de totstandkoming van de Wet op de Bedrijfsorganisatie, 27 januari 1950, Stb. K 22.

9. Th. Ramm, a.w. (noot 1), p. 254.

10. R. Blanpain, Fifity years of Labour Law in Belgium in Fifty Years of Labour Law and Social Security, Deventer 1986, p. 54. 
De Franse ontwikkeling naar wettelijk geregelde vertegenwoordiging op ondernemingsniveau kwam op gang door druk van de vakbonden. Het Matignon Akkoord van 1936 (11) maakte personeelsvertegenwoordigers op ondernemingsniveau mogelijk. Voor dergelijke vertegenwoordigers was overigens al tijdens de eerste wereldoorlog gepleit, maar zij waren maar op zeer beperkte schaal in de (oorlogs)industrie werkzaam (12). De wet van 24 juni 1936 gaf het instituut van de personeelsvertegenwoordigers (délégués de persomnel) een zekere status door voor te schrijwen dat regulering door middel van collectieve overeenkomsten alleen mogelijk was in ondernemingen met personeelsvertegenwoordigers. In 1938 kregen de vertegenwoordigers een wettelijke status.

In landen waar men zo min mogelijk bemoeienis van de overheid met de arbeidsverhoudingen voorstond, zoals Groot Brittannië en Denemarken groeide een rol voor "shop stewards" (vakbondsvertegenwoordigers op ondernemingsniveau). Hoewel met name in Groot Brittanie hun oorspronkelijke rol er vooral één van ledenwerver en contactpersoon van de vakbonden was, groeide deze uit tot de vertegenwoordiger tegenover en onderhandellaar' met de werkgever in de onderneming (13). Ook Italië kende zowel voor, als na het fascistische regime dat in 1922 aan de macht kwam een ontwikkeling naar vertegenwoordiging op basis van vrijwilligheid. Tussen 1908 en 1940 kwamen "commissioni interni" tot stand op basis van collectieve contracten. Ramm noemt met name het contract van de autofabriek ATALA in Turijn met de Italiaanse metaalbewerkers. Na 1922 had het land een corporatief systeem van arbeidsverhoudingen (14).

De ontwikkelingen in Spanje en Portugal (15) zijn van zeer jonge datum. Dit is mede te wijten is an de politieke situatie waarin deze landen tot ver na de oorlog verkeerden. In Spanje heeft het Franco-regime een breuk met een in gang gezette ontwikkeling op het gebied van de rechten van werknemers betekend. Meteen in 1938 werd Werknemershandvest (Fuero de Trabajo 1938) in Nationalistisch Spanje aangenomen, dat tijdens de Franco-periode praktische ongewijzigd bleef bestaan. Dit handvest werd na de burgeroorlog het belangrijkste stuk Spaanse arbeidswetgeving. Het

11. Akkoord van 7 juni 1936 , volgend op wijdverspreide stakingen.

12. Th. Ramm, a.w. (noot 1), p. 250.

13. Zie 0.m. B. Perryns, Trade Union Law, London 1985, p. 16.

14. Zie Th. Ramm, a.w. (noot 1), p. 249 en p. 295-260.

15. Bij deze twee landen moet evenals overigens bij Griekenland de aantekening worden gemaakt dat deze landen pas lid van de Gemeenschap geworden zijn nadlat de discussies over medezeggenschap op gemeenschapsniveau al hadden plaatsgevonden (Grickenland is toegetreden op 1 januari 1981, met overgangsrecht tot 1 januari 11986, Spanje en Portugal zijn toegetreden op 1 januari 1986, met owergangsrecht tot 31 december 1995). Dit kan zowell betekenen dat deze landen bij het tot stand brengen van medezeggenschapsregelingen reeds rekening hebben gehouden met hun komende EG-lidmaatschap (waardoor bestaande praktijk en mieuw recht discrepanties kunnen vertonen) als wel dat veranderingen in dit recht op voorhand meer acceptabel zijn geacht dan in de 'oude" lidstaten die ten volle aan de medezeggenschapsdiscussie hebben deelgenomen. 
voorzag in een corporatief systeem van arbeidsverhoudingen, waar vanuit staatszijde geïntervenieerd werd in praktisch alle aspecten van de arbeidsverhoudingen. De rol van de enige toegestane vakbond (de nationale vakbondsorganisatie) was sterk aan banden gelegd (16); vrije vakbonden waren eenvoudig verboden (17).

Portugal had zijn dictaturur al tien jaar eerder. Het land wordt door Hörster (18) in de periode 1926-1974 gekarakteriseerd als "ein autoritärer Ständestaat". Pas na de omwenteling van 25 April 1974 zou zich een structuur op arbeidsrechtelijk gebied ontwikkelen.

$\mathrm{Na}$ de oorlog kwam de doorbraak voor medezeggenschap op ondernemingsniveau. Dit vond mede zijn oorzaak in de noodzaak tot samenwerking tussen werknemers en werkgevers bij de opbouw van de economie, die door de oorlog in vergaande staat van desolatie was geraakt. Voor een deel kwamen regelingen tot stand die de uitwerking van medezeggenschap tot op zekere hoogte overlieten aan het initiatief van werkgever en werknemers binnen de onderneming.

In sommige landen als Duitsland en Nederland werden bij wet ondernemingsraden in het leven geroepen met meer of minder vergaande bevoegdheden, of werd de positie van vakbondsvertegenwoordigers in de onderming wettelijk beschermd. In andere lid-staten zoals Denemarken namen de sociale partners zelf het voortouw, hetgeen kon leiden tot Centrale Akkoorden die de positie van vertegenwoordigers op ondernemingsniveau tot in detail regelden. Weer andere lid-staten beperkten de bemoeienis van bovenaf tot een enkel expliciet gemaakt wettelijk recht voor de vakbonden, en een verbod voor de werkgever vakbondsactiviteiten in de onderneming onmogelijk te maken.

Wettelijke regelingen van ondernemingsraden kwamen in Frankrijk en België betrekkelijk snel na de oorlog tot stand. In Frankrijk werd bij Ordonnance al in 1945 de oprichting van "Comité's d'Entreprise" voorgeschreven, in 1946 werden zij bij wet geregeld (19). Zij kregen informatie en adviesbevoegdheden, maar geen onderhandelingsbevoegdheden. Deze bleven berusten bij vakbondsvertegenwoordigers, die op basis van collectieve overeenkomst in de ondernemingen konden werken.

De Belgische ontwikkeling liep hier vrijwel synchroon aan. In 1947 kwam een algemeen akkoord tussen vakbonden en werkgevers tot stand in verband met werknemersvertegenwoordigers van de vakbonden in de

16. Zie hierover a.m. ILO, The Labour and Trade Union Situation in Spain, Geneva 1969, p. $431 \mathrm{ev}$.

17. T. Lawhor, M. Rigby, Contemporary Spanish Trade Unions, Industrial Relations Journal, p. $250-251$.

18. H. E Horster; Die Koalitionsfreiheit der Arbeitnehmer in Portugall, in the Freedom of the Worker to Organize, Berlijn 1980, p. 704 .

19. M. Cohen; Le droit des comité's d'entreprise, Paris 1977, p. 15-35. 
ondernemingen. In 1946 werd de oprichting veiligheids- en gezondheidscommité's bij decreet geregeld. In $1948 \mathrm{kwam}$ een wet die voorzag in ondernemingsraden met informatie en adviesbevoegdheden tot stand (20).

In 1950 kwam de eerste Nederlandse Wet op de ondernemingsraden tot stand. Ondernemingsraden kregen bij deze wet informatie- en adviesbevoegdheden. De Duitse Betriebsverfassungsgesetz (BetrVG) dateert uit 1952. Deze was geënt op de wet van 1920. De wet voorzag in de oprichting van ondernemingsraden. De bevoegdheden van de ondernemingsraden betroffen vooral het verkrijgen van informatie, een zekere mate van contrôle op de uitvoering van wettelijke voorschriften (m.n. Duitsland) en het geven van advies.

In de vier bovengenoemde regelingen werd ondernemingsraad vooral gezien als orgaan van samenwerking tussen werkgever en werknemer (21). Dit kwam tot uiting in de samenstelling van de raden (de ondernemer was er voorzitter van) en de regeling van de beslissingbevoegdheid, die eveneens geheel bij de werkgever bleef. De collectieve onderhandelingen, waarbij het risico aanwezig zou zijn dat de werknemersvertegenwoordigers in een meer conflictueuze situatie met de werkgever zouden belanden, werden gevoerd door de vakbonden (22), al dan niet door middel van vertegenwoordigers in de onderneming. Daarnaast was het instrumentarium er met name éen van samenwerking: de ondernemingsraden werden geen onderhandelingsrechten of medebeslissende bevoegdheden toegekend.

Latere regelgeving ging veelal uit van verdergaande rechten voor de werknemersvertegenwoordiging. Zowel de Duits Betriebsverfassungsgesetz (BetrVG) van 1972 (23) als de Nederlandse Wet op de Ondernemingsraden (WOR) van 1971 met name na de wijziging van 1979 (24) voorzien de ondernemingsraden, van medezeggenschapsrechten als het instemmingsrecht en, in Duitsiand, het recht om overeenkomsten af te sluiten. De samenwerking tussen werkgevers en ondernemingsraden stond in de nieuwe wetgeving iets minder centraal. In de Franse wetgeving bleven onderhandelingsbevoegdheden voorbehouden aan de vakbonden, ook na de wijzigingen die in het begin van de tachtiger jaren in de Franse wetgeving werden aange-

20. R. Blanpain, a.w. (noot 10) p. 55 .

21. Zie voor Frankrijk: M. Cohen, a.w. (noot 19) p. 15-35; Nederland o.m. H.L. Bakels, Schets van het Nederlands arbeidsrecht, Deventer 1987, p. 229-230; voor Duitsland: $F$. Gamillscheg, a.w. (noot 3) p. 78.

22. O.m. J. Pelissier, La fonction syndicale dans l'entreprise après les lois Auroux, Droit Social 1984, p. 41-42.

23. Wet van 15 januari 1972 (BGBl. I p. 13), gewijzigd bij Wet van 24 juli 1986 (BGBI. I. p. 1110), zie ook Beck Texte Arbeitsgesetze, München 1986, laatstelijk gewijzigd bij wet van 16 december 1988. Deze laatste wijzigingen voerde o.m. een versterking van de representatierechten van vakbonden met een minderheid aan leden in de onderneming in, en specifiele informatic- en consultatierechten in verband met invoering van nieuwe technologieền (EIRR 189, January 1989, p.5).

24. Wet van 21 januari 1971, Stb. 54 laatstelijk gewijzigd bij Wet van 7 december 1983, Stb. 663. 
bracht (25). Het gevolg was dat vakbonden binnen de onderneming een meer uitgesproken rol konden blijven spelen, dan in Duitsland en Nederland het geval was..

De Luxemburgse wettelijke regeling die in 1974 tot stand kwam introduceerde de comité's mixtes als orgaan van samenwerking met de werkgever. Het comite, dat bestaat uit werkgevers en vertegenwoordigers vanuit de vakbonden (26), heeft informatie, advies en instemmingsbevoegdheden, onder meer ten aanzien van veiligheids- en gezondheidsaangelegenheden. Daamaast biedt de wet van 18 mei 1979 voor kleinere ondernemingen mogelijkheden tot medezeggenschap voor werknemers door middel van delégations du personnel.

Naast de medezeggenschap in ondernemingsraden zijn er ook nogal wat wettelijke regelingen die welliswaar medezeggenschap voorschrijven maar dit deels overlaten aan de vakbonden, of deze in elk geval de kans bieden hier een grote rol in te spelen. In Frankrijk bestaat deze regeling naast de bowenbeschrevene. en legt deze gedetailleerd de verhouding tussen de verschillende soorten medezeggenschap vast. In andere lid-staten als Spanje, Portugal, en Griekenland' wordt op andere wijze de relatie tussen wettelijke en vrijwillige medezeggenschap gelegd. In het laatste land is de verplichting tot instelling van ondernemingsraden afhankelijk gemaakt van de activiteiten van de vakbonden: instelling is slechts verplicht indien er geen vakbond in de onderneming aanwezig is.

De Portugese regelingen bieden een structuur die in eerste instantie betrekkelijk radicaal scheen en waarvan het vooral opvalt dat zelfs een aantal structurele aspecten in de grondwet werden geregeld. Zo kent de Portugese Grondwet, die als doel heeft het inrichten van een klasseloze gemeenschap (artikelen 1 en 2) een aantal bepalingen met betrekking tot werknemersparticipatie, die in andere EG lid-staten (27) in elk geval niet z6 gedetailleerd in de grondwet geregeld zijn. Artikel 55 Grondwet (28)

25. M.n. Wet no. 82-915, van 28 okober 1982 (relative au développement des institutions representatives du personnel), Journal Officiel de la Republique Francaise, 1982 p. 3255 ev.; Wet no. 82-957 van 13 november 1982 (relative à la négociation collective et au reglement des conflits collectifs du travail) JORF 1982, p. $3414 \mathrm{ev}$; Decreten 83469 en 83-470 van 8 juni 1983 , met betrekking tot de toepassing van Wet no. 82-915, JORF 1983 p. $1762 \mathrm{ev} . ;$ Wet 84-103 van 16 februari 1984, (relative à la democratision du secteur public), JORF 1984 p. 599 ev. Voor een overzicht: Ph. Seguin, Rôle et realité de la négociation d'entreprise dans les relations sociales d'aujourdhui, Droit Social 1988, p. 2 7, zie ook G.H. Camerlynck, G. Lyon-Caen, J. Pélissier, Droit du Travail, Paris 1984, p. 778.

26. R. Schintgen, La liberte syndicale des salariés au Grand Duche de Luxembourg, in The Freedom of the Worker to Organize, Berlin 1980, p. 494.

27. Ook andere constituties (bijw. artikel 39 en 46 van de Italiaanse Grondwet, artikel 19 van de Nederlandse Grondwet) voorzien in een recht tot van medezeggenschap in de onderneming dit is echter een recht dat verder uitgewerkt dient te worden.

28. Constitutie van 2 april 1976, Diario da República, 10 avril 1976, no. 86. p. 738, Franse tekst (Estraits), Bureau International du Travail, Série legislative 1976, Por. 2, 4/1977. 
biedt werknemers het recht om werknemerscommissies ter bescherming (verdediging van hun belangen op te richten) die informatie, controle en in bepaalde gevallen het recht van interventie en participatie hebben. Naast deze commissies hebben ook de vakbonden rechten op een vertegenwoordiging in de onderneming op grond van een Decreet uit 1976 (29).

In Spanje werd na 1958 (nog tijdens de Franco-periode) de rol van de staat iets minder manifest, dan in de eerste periode na de burgeroorlog. Er kwamen mogelijkheden voor collectieve onderhandelingen, zij het dat het Ministerie voor Arbeid wel de bevoegdheid hield te interveniëren. Die liberalisering van de arbeidsverhoudingen zette in de jaren zestig door, maar pas na de terugkeer naar de democratie kwam een groot aantal nieuwe ontwikkelingen op gang. Deze bouwden deels voort op de oude wetgeving, en hadden deels de aansluiting bij andere Europese landen tot doel (30). Het Werknemersstatuut (Estatuto de los Trabajadores) dat in 1980 in werking trad (31) is tot dusver het sluitstuk van die ontwikkeling. Op basis daarvan kon een verdere uitbouw plaatsvinden, waarbij de Spaanse wetgeving aangepast wordt aan de vereisten van de Europese Gemeenschap (32). Het voorziet in medezeggenschapsrechten voor Comites de Empresa (ondernemingsraden) in grote, en deleguados de personel in kleinere ondernemingen. Naast deze vorm van medezeggenschap hebben de vakbonden een vertegenwoordiging in de onderneming. Deze heeft een onderhandelingsrol, hoewel ook de ondernemingsraad bevoegd is te onderhandelen. Vakbonden en ondernemingsraden hebben in Spanje nauwe banden, mede doordat de vakbond adviserende leden in de ondernemingsraad kan hebben.

De jongste wettelijke regeling in de gemeenschap die medezeggenschap tot onderwerp heeft; stamt uit Griekenland waar in 1988 een wet op de ondernemingsraden werd aangenomen (33). Ook in Griekenland waren al langer vakbondsvertegenwoordigers in de onderneming aktief, aan wie wettelijke bescherming was toegekend (34). De ontwikkeling na 1976 is wat

29. Decreet van 1976, Diario da República 7 decembre 1976, no. 285, supplement p. 2684-2, Franse Tekst, Bureau International de Travail, Série legislative, 1976, Por. 4, 4/1977.

30. De Decreten no 17 van 4 maart 1977 betreffende het stakingsrecht, no. 1522 van 17 juni 1977 betreffende het coalitierecht voor ambtenaren (fonctionaires publics) kunnen als eerste uitdrukking van dit doel gezien worden.

31. Wet no 8, 10 maart 1980 Boleti'n Oficial del Estado, 14 maart 1980 no. 64 p. 5799 , Franse tekst Bureau International de Travail, Série législative 1980 Esp. 1, 1/1981.

32. Sedert het toetreden van Spanje tot de EG zijn een aantal decreten met name betreffende arbeidsveiligheid, -gezondheid en hygiêne aangenomen, zie hierover o.m. A.M. Valverde, La Incidencia del Derecho Comunitario Del Trabajo en ell Ordenamiento Espanol in The effect of Community law on National Employment law Thessaloniki 1988, p. 143-145.

33. Wet no. 1767, van 6 april 1988, samenvatting in het Engels te vinden in Social and Labour bulletin $3 / 88$ p. $304-305$.

34. Bijvoorbeeld ontslagbescherming voor vakbondsfunctionarissen in de onderneming bestaat al sedert 1952 (Wet 1803/1952, wervangen door Wet no. 330 van 29 mei 1976 (Fra. Tekst, Bureau International du Travail, Série législative 1976, Gre. 1 1/1977.). Zie D. Th. Tsatsos, Die Koalitionsfreiheit des Arbeitnehmers in Griechenland, in The Freedom of the Worker 
werknemersvertegenwoordiging op ondernemingsniveau betreft, nogal onoverzichtelijk. De Wet ter regulering en democratisering van de vakbonden van 1982 (35) onderscheidt drie niveaus waarop vakbonden kunnen bestaan. Het eerste niveau bestaat uit beroepsbonden, bonden in én onderneming of bonden met een lokaal karakter. Het tweede is dat van federaties van twee of meer bonden, het derde niveau is dat van de confederaties waarin de Algemene Werknemers Confederatie van Griekenland de belangrijkste is (36). De wet kent in artikel 16 aan vakbonden in de onderneming een aantal rechten toe, waaronder rechten op controle, zonder dat er expliciet sprake is van "shop stewards" met specifieke onderhandelingsrechten of een taak ter belangenbehartiging, zoals die in andere lid-staten bekend zijn. De wet van 1988 voegt daar nu dus de ondernemingsraden aan toe. Deze hebben informatie-, consultatie- en instemmingsrechten. Ondernemingsraden krijgen deze bevoegdheden alleen toebedeeld, wanneer de vakbonden in de onderneming niet vertegenwoordigd zijn. Wanneer dit wel het geval is hebben de ondernemingsraden alleen een adviesfunctie.

In een aantal Europese landen reguleerden of voorzagen de sociale partners zelf in medezeggenschap al dan niet door middel van Centrale overeenkomsten.

Het Deense systeem van arbeidsverhoudingen in de onderneming is gegroeid vanuit de vrijwillige deelname van de sociale partners. Denemarken kende het instituut van de "shop steward" (tillidsmand), al voor de oorlog. In 1960 is de positie van de shop steward geharmoniseerd door middel van een Centraal Akkoord (Hoved-aftalen) (37). Daarnaast waren in 1947 samenwerkingscommissies ontstaan, op basis van de eerste Samenwerkingsovereenkomst (38). Deze laatste hadden een taak als forum voor overleg met de werkgever en informatie- en consultatiebevoegdheden, terwijl de shop stewards een onderhandelingstaak hadden. In het Centraal Akkoord van 1970 (39), dat volgde op een Akkoord in 1964, werden de taken van de samenwerkingscommissie in han in hoofdzaak nog steeds bestaande vorm vastgelegd. De samenwerkingscommissie verkreeg informatie consultatie en participatiebevoegdheden in de onderneming. Het laatste Centraal Akkoord dateert uit 1986 (40), en bevat met name een hoofdstuk ten aanzien van de inwoering van nieuwe technologieeën (41).

to Organize, Berlijn 1980, p. 336.

35. Greek Trade Union Democracy Act, 1 juli 1982, EIRR 1983, p. 24-32.

36. A.G. Karakatsanis, Labor Law, in Introduction to Greek law, Athens 1988, (K.D.Kerameus, P.J. Kozyris eds), p. 224-225.

37. K. Nagels F. Sorge, Industrielle Demokratie in Europa, Frankfurt 1977, p. 91.

38. R. Nielsen, Learebog i Arbejdsret, Kopenhagen 1987, p. 112.

39. Samenwerkingsowereenkomst van 2 oktober 1970.

40. Samarbejdsaftalen mellem LO og DA, Engelse tekst in EIRR 151 August 1986.

41. De eerste Technologie-overeenkomst tussen LO en DA is van 1 maart 1981 en is als annex aan het Centraal Akkoord toegevoegd. 
In Italie werd in 1947 een bepaling in de grondwet opgenomen waarin het recht van werknemers om binnen door bij wet te stellen grenzen aan de leiding van de onderneming deel te nemen, werd vastgelegd (42). Uitvoeringswetgeving is echter nooit tot stand gekomen. Ook in het in 1970 tot stand gekomen Werknemersstatuut staan slechts enkele bepalingen met betrekking tot samenwerking en onderhandeling op ondernemingsniveau (43). Wel kwamen "commissioni interne" (bedrijfscommissies) tot stand, waarvan instelling en functioneren geregeld waren in Centrale Akkoorden (accordi interconfederale) in 1947 en 1966. Deze "commissioni interne" verloren overigens na 1966 snel aan betekenis (44), daar zij er in veel gevallen niet slaagden de belangen van de werknemers in de verschilende bedrijfsonderdelen te verwoorden (45). De door de werknemers verkozen afdelingsgedelegeerden de "delegati di reparti", namen de opengevallen plaats in (46). De "delegati" verenigden zich in een organisatiestructuur waaruit de "consigli dei fabricca", een soort ondernemingsraden waarbinnen de onderhandelingsbevoegdheden van de shop stewards gecoordineerd worden, (op vrijwillige basis) ontstonden. Het in 1970 inwerkinggetreden Werknemersstatuut (47) gaf de vakbonden een recht op vertegenwoordiging in de onderneming (artikel 19). De afdelingsgedelegeerden werden al snel met deze vakbondsvertegenwoordiging geïdentificeerd.

$\mathrm{Na} 1970$ ontstond een probleem tussen de bevoegdheden van de vakbondsvertegenwoordigers (shop stewards) enerzijds en de in de nationaal bedrijfstaksgewijs (contratto di categoria) afgesloten akkoorden. Het gebrek aan procedurele regels, waar met name de delegati (shop stewards) zich aan te houden hadden en de verhoudingen tussen de ondernemingsakkoorden en de nationale akkoorden waren daarbij van belang. Dit leidde in 1983 tot een nieuw Centraal Akkoord waarbij de Italiaanse regering de derde partij was (48). Dit Akkoord kan gezien worden als een eerste poging onderhandelingsprocedures op ondernemingsniveau vast te leggen, waardoor

42. Artikel 46, deze bepaling luidt: "Ai fini della elevazione economica e sociale del lavoro e in armonia con le esigenze della produzione, la Republicea riconosce il diritto dei lavoratori a collaborare, nei modi e nei limiti stabiliti dalle leggi, alla gestione delle aziende".

43. Het Statuto dei Laworatori vam 20-5-1970, no. 300 (werknemersstatuut) kent slechts enkele artikelen met betrekking tot medezeggenschap: dit zijn artikel 19 dat voorziet in de mogelijkheid van vakbondswertegenwoordiging in de onderneming en artikel 9 dat controlebevoegdheden schept voor de werknemersvertegenwoordigers ten aanzien van veiligheid en gezondheidsaangelegenheden. Deze zeer algemene bepalingen worden weliswaar ondersteund door andere, maar geven praktisch geen beperkende regels.

44. S. Sciarra, The rise of the Italian Shop Steward, I.L.J. 1977, p. 37.

45. W. Daübler, Das Grundrecht auf Mitbestimmung, Frankfurt am Main 1973 (derde druk 1975), p. 489.

46. Voor een overzicht, D. Weiss, La démocratie industrielle; cogestion ou controle ouvrir, Paris 1978, pp. 137-188.

47. Statuto dei Laworatori, 20-3-1970, no. 300, Engelse tekst, International Labour Office, Legislative Series, 1970-It.2.

48. S. Sciarra, Plant Bargaining, The Impact of Juridification on Current Deregulative trends in Italy, Comparative Labor Law Journal, Vol. 8, No. 2, Winter 1987, p. 132-133. 
de vergaand vrije wijze waarmee de shop stewards het instrumentarium konden gebruiken, werd ingedamd.

Tenslotte moet nog één ontwikkeling in Italië in het bijzonder worden genoemd. In 1984 kwam tussen de grootste werkgeversgroep binnen de publieke sector (het Instituut voor Reconstructie van de Industrie (IRI) en drie Italiaanse vakbonden (CGIL, CISL en de UIL (49)) een contract tot stand, waarin op experimentele basis paritair samengestelde samenwerkingsorganen zowel op ondernemings- als op centraal niveau zijn opgericht. Deze raden hebben in grote lijnen consultatieve bevoegdheden die vergelijkbaar zijn met die van een aantal ondernemingsraden, die een wettelijke basis hebben. Naast deze bevoegdheden zijn in de overeenkomst zowel conciliatie- als arbitrageprocedures ter oplossing van geschillen opgenomen. Of dit experiment tot een trend zal leiden is niet zeker. Andere werkgevers zoeken juist naar andere wegen om tot medezeggenschap te komen (50).

In Denemarken lijken Centrale Akkoorden een rustiger bezit dan in Italië. Hoewel de ontwikkeling van systemen van medezeggenschap op ondernemingsniveau uiterlijk op elkaar lijken, is die in Italië schoksgewijs verlopen, terwijl deze in Denemarken een geleidelijke groei doormaakte. Het tot stand komen van een wettelijke regeling als het werknemersstatuut bijvoorbeeld is mede een gevolg van de golf van stakingen die in Italië heerste in de jaren '68-'69 (51). In Denemarken bleven dergelijke conflicten in die jaren (in elk geval op een zo fell niveau) uit, zodat er voor de staat geen directe noodzaak was om te interveniëren in de arbeidsverhoudingen. Dit wil overigens niet zeggen dat in Denemarken in het geheel geen wettelijke regelingen zijn, waarin tot op zekere hoogte werknemers invloed op ondernemingsniveau wordt geregeld; de Wet op de arbeidsomgeving (Arbejdsmiljølovet) van 1975 (52) is er een voorbeeld van.

Vertegenwoordiging op ondernemingsniveau in Groot Brittannië werd eveneens door de socialle partners geïnitieerd, hoewel de ontwikkeling van het systeem een andere geschiedenis kent (53). De Britse arbeidsverhoudingen worden gekenmerkt door wantrouwen tegen bemoeienis van het recht met het collectieve optreden van vakbonden. Het voert te ver om hier in

49. De afkortingen staan woor Confederazione Generale Italiana del Lavoro (CGIL) met name gedomineerd door communisten, de Confederazione Italiana Sindicati Lavoratori (CISL), meer Christen-democratisch van inslag, en de Unione Italiana del Lavoro (UIL), sociaaldemocratisch.

50. T. Treu, S. Negrelli, Workers" Participation and Personel Management Policies in Italy, International Labour Review, Vol. 126, 1987 no. 1 p. 81-94.

51. Zie o.m T. Treu, Fifty years of Italian Labor Law, in Fifty Years of Labor Law and Social Security, Deventer 1986 , p. 129.

52. Wet van 23 december 1975 , no. 681 inwerking getreden op 1 juli 1977.

53. Zie over de geschiedenis van het Britse arbeidsrecht: Lord Wedderburn, The Worker and the Law, Harmondsworth, 1986, p. 16-68, P. Davies, M. Freedland, Kahn-Freunds Labour and the Law, London 1983 , p. $88-96$. 
te gaan op de ontwikkeling van het in Groot Brittannië (en Ierland (54)) bestaande systeem van arbeidsverhoudingen, ik volsta er mee te verwijzen naar de literatuur hierover (55).

Het bestaande wantrouwen leidde uiteindelijk tot een systeem van immuniteiten, waarbinnen de vakbonden in betrekkelijke vrijheid konden onderhandelen met werkgevers, zowel op sectorniveau als op ondernemingsniveau, door middel van vakbondsafgevaardigden (shop stewards). Centrale akkoorden of bedrijfstaksovereenkomsten, waarin de onderhandelingsvrijheid van shop stewards gereguleerd of aan banden werden gelegd kwamen in Groot Brittannië niet tot stand. Mede hierdoor (56) ontstond een zeer vrij systeem waarin shop stewards als onderhandelaars, zonder al te veel beperkingen konden optreden (57).

$\mathrm{Er}$ werden wel pogingen ondernomen om deze toestand meer te structureren. Het Donovan-committee in 1968 (58) en het Bullock-committee in 1977 (59) kwamen in hun respectieve rapporten met voorstellen voor herstructurering van de onderhandelingsstructuur in de onderneming. De voorstellen van het eerste committee bevatten onder meer aanbevelingen met betrekking tot de verhouding vakbonden-shop stewards; de aanbevelingen van het tweede betroffen de medezeggenschapsstructuur in de onderneming als institutioneel gegeven (60). De uitwerking van deze voorstellen heeft tot dusver echter niet tot concrete resultaten geleid. De Britse Labour regering kwam in 1969 met een "White Paper" (In place of Strife) waarin voorstellen werden gedaan tot regulering van de collectieve arbeidsverhoudingen door middel van wetgeving. Hierbij week men af van de aanbevelingen van het Donovan Committee, dat uitging van zelfregulering. De voorstellen werden ingetrokken na hevige protesten van de vakbeweging. In 1971 werd door door de Conservatieve regering echter de Industrial Relations Act 1971 geïntroduceerd, die weliswaar uitging van de conclusies van het Donovan Report, maar die een veel legalistischer benadering

54. Het lerse Arbeidsrecht liep parallel met het Britse tot 1922, het jaar waarin Ierland "a Nation once again" werd.

55. A.T.J.M. Jacobs, Collective Self-Regulation, p. 196-215, in The Making of Labour law in Europe, (B. Hepple ed.) London/New York 1986; B. Hepple, The Freedom of the Worker to Organize in the United Kingdom, in The Freedom of the Worker to Organize, Berlijn 1980; Lord Wedderburn, a.w. (noot 53), p. 16-96.

56. Donovan, Lord, Report Royal commission on trade-unions and employers association, 1965/1968 (Donovan-report), p. 262 (par. 1019): (....) (T)he central defect in British industrial relations is the disorder in factory and workshops relations and pay structures between the formal and informall system (.....), en in par. 1020: (F)actory wide agreements can however provide the remedy (.....).

57. Zie ook E.P. de Jong, Een inleiding tot het denken over arbeidsconflictenrecht, Deventer 1975 , p. 62.

58. The Royal Commission on Trade Unions and Employee Associations, 1965-1968, onder voorzitterschap van Lord Donovan, (Donovan Committee).

59. Committee of Inquiry on Industrial Democracy, onder voorzitterschap van Lord Bullock (Bullock-committee).

60. Zie o.m. B Hepple, a.w. (noot 55), p. 1004. 
hanteerde dan in het rapport was aanbevolen (61). Inmiddels zijn wel verschuivingen te constateren zijn in de wijze waarop vakbonden de positie van hun shop stewards definiëren en de houding van de shop stewards in de onderneming (62).

De beïnvloeding van het lerse systeem door het Britse, mede doordat Ierland tot 1922 deel van Groot Brittannië uitmaakte, maakt dat de neiging bestaat de systemen als praktisch gelijk te behandelen. Er zijn ook grote overeenkomsten. $Z o$ is het systeem eveneens gebaseerd op vrijwilligheid van de sociale partners om tot samenwerking en onderhandeling op ondernemingsniveau te komen. Hoewel een aantal wetten, veelal geworteld in de Industrial Relations Act 1946 (63), bijzondere voorzieningen geeft voor vestiging van gezamenlijke bedrijfscommissies (joint labour committees) en industriële raden (industrial councils), om te onderhandelen over minimumlonen en een aantal wetten tot stand is gekomen met betrekking tot veiligheid en gezondheid waarin werknemersvertegenwoordigers konden worden verkozen (64), is de relatie tussen werkgevers en werknemers op ondernemingsniveau niet wettelijk geregeld (65). De vakbonden in Ierland kennen wel shop stewards, zij spelen echter een aanzienlijk minder dominante rol dan in Groot Brittannië.

Daarnaast kent Ierland het instituut van ondernemingsraden, echter volledig op vrijwillige basis (66). De oprichting van deze raden is gestimuleerd door de ontwikkelingen in de EEG en een in 1980 uitgebracht Working Paper on Worker Participation (67). De enige wettelijke basis voor vertegenwoordiging in de private sector is de, in de volgende paragraaf, te bespreken Safety in Industries Act 1980. Voor de publieke sector is daar de reeds genoemde Worker Participations (State Enterprise) Act 1977, waarin op bestuursniveau voor medezeggenschap is gezorgd.

61. Over de Industrial relations Act 1971: A.W.J. Thomson an S.R. Engleman, The Industrial Relations Act, A Review and Analysis, London 1975. In 1974 werd deze wet vervangen door de vakbondsvriendelijker Trade Union and Labour Relations Act. Na 1979 kwamen de Conservatieven opnieuw met een met name de immunities beperkende serie wetten al. de Employment Acts van 1980, 1982 en 1988 en de Trade Union Act 1984, die stap voor stap beperkingen aanbrachten op rechten en vrijheden van de vakbonden.

62. B. Perryns; a.w. (noot 13), p. 17.

63. I. M. Kelly, The Freedom of the Worker to Organize in the Republic of Ireland, in The freedom of the Worker to Organize, Berlijn 1980, p. 368.

64. In de Factories Act 1955, werd voor het eerst een dergelijke bepaling opgenomen, deze is in het begin jaren tachtig vervangen door de Safety and Industries. Act 1980, waarin opnieuw de mogelijkheid geboden wordt commissies voor veiligheids- en gezondheidsaangelegenheden te kiezen.

65. Zie J.M. Kelly, a.w. (noot 63), p. 368. Voor de State Sponsored (semi-staats)ondernemingen bestaan op basis van de Worker participation (State Enterprises) Act 1976 overigens wel participatierechten voor de vakbonden (Kelly p. 381).

66. M. Redmond, Ireland, in International Encyclopedia for Labour Law and Industrial Relations (supplement 71) Deventer 1986, para. 409, 410.

67. M. Redmond, a.w. (noot 66), para. 402. 
De vertegenwoordiging inzake veiligheids- en gezondheids-aangelegenheden is ook in de lid-staten waar medezeggenschap op vrijwillige basis wordt georganiseerd wettelijk geregeld. Zowell Groot Brittannië en Ierland als Denemarken hebben in hun (veiligheids- en gezondheids)wetgeving grondslagen opgenomen voor vertegenwoordiging op ondernemingsniveau. In alle drie de landen is, hoewel shop stewards en veiligheidsvertegenwoordigers niet per se in de zelfde persoon verenigd hoeven te zijn, wel gezorgd voor sterke banden tussen de beide vertegenwoordigingssystemen. Dit is ook het geval in die lid-staten waar veiligheidsvertegenwoordigers een rol hebben naast de algemene medezeggenschapsorganen. Ook in Italië voorziet het Werknemersstatuut wel in mogelijkheden voor vertegenwoordiging, maar het regelt op dit punt niets.

Frankrijk, België en Griekenland kennen naast de algemene vertegenwoordigende organen specifieke veiligheids- en gezondheidscommissies. In de eerste twee landen hebben de commissies te maken met de algemene medezeggenschapsorganen, en hebben zij vooral bevoegdheden voor specifieke situaties. Over het algemeen neemt het algemene medezeggenschapsorgaan de bevoegdheden van de veiligheids- en gezondheidscommissies waar, als het laatste orgaan niet in de onderneming aanwezig is.

Het Griekse Centraal Akkoord van 1981 omtrent Veiligheidscomité's in de onderneming (68) bood de mogelijkheid voor ondernemingen veiligheidsen gezondheidscommissie te installeren met voornamelijk informatie- en inspectiebevoegdheden. In de Veiligheids en Gezondheidswet van 1985 (69), is eveneens sprake van veiligheids- en gezondheidscommissies, deze hebben eveneens informatie en consultatie bevoegdheden.

In Nederland voorziet de Arbeidsomstandighedenwet in de mogelijkheid dat een Arbocommissie kan worden ingesteld, als er geen ondernemingsraad in de onderneming is. Is dit wel het geval dan gaat dit laatste orgaan over veiligheids- en gezondheidsaangelegenheden. Op samenstelling, taken en bevoegdheden wordt in een later stadium nog teruggekomen.

In Duitsland kent men naast de ondernemingsraad, speciale op bijzondere wetten, gebaseerde veiligheids- en gezondheidscommissies en Beauftragten. Deze (deskundige) werknemers en commissies zijn echter geen vertegenwoordigers in die zin dat zij door de werknemers verkozen worden. De commissies en Beauftragten hebben ten opzichte van de ondernemingsraad een adviserende functie.

Uit het bovenstaande blijkt dat er in de meeste lid-staten een aantal verschillende vertegenwoordigers op ondernemingsniveau naast elkaar bestaan. Voordat ik ze meer gedetailleerd bespreek, volgt hier eerst een overzicht:

68. Centraal Akkoord tussen de SEV werkgeversconfederatie en de GSEE vakbondsconfederatie van 12 mei 1981, Engelse tekst, EIRR 1982, p. 24.

69. Wet 1568, Engelse tekst: Workers Health and Safety, EIRR 144, januari 1986 p. 27. 
Tabel I: Werknemersvertegenwoordigers op ondernemingsniveau. (70)

\begin{tabular}{|c|c|c|c|c|}
\hline land & $\begin{array}{l}\text { onderne- } \\
\text { mingsraden. }\end{array}$ & $\begin{array}{l}\text { Veil./gez.h. } \\
\text { vertegenw. }\end{array}$ & $\begin{array}{l}\text { Personeels- } \\
\text { vertegenw. }\end{array}$ & $\begin{array}{l}\text { Vakbonds- } \\
\text { vertegenw. }\end{array}$ \\
\hline Du. & Betriebsrat & $\begin{array}{l}\text { Sicherheits- } \\
\text { beauftragten } \\
\text { Arbeitsschutz- } \\
\text { ausschuss }\end{array}$ & & $\begin{array}{l}\text { Vertrauens- } \\
\text { leute }\end{array}$ \\
\hline Ned. & OR & Arbocie & & Bedrijvenwerk \\
\hline Fra. & $\begin{array}{l}\text { Comité d'en- } \\
\text { terprise }\end{array}$ & CHSCT & $\begin{array}{l}\text { délegués de } \\
\text { personnel }\end{array}$ & $\begin{array}{l}\text { délegués } \\
\text { syndicaux }\end{array}$ \\
\hline Bel. & OR & CVGVW & & $\begin{array}{l}\text { Syndicale } \\
\text { vertegenw. }\end{array}$ \\
\hline Lux. & Com. Mixte & & $\begin{array}{l}\text { Personeels } \\
\text { vertegenw. }\end{array}$ & \\
\hline Sp. & $\begin{array}{l}\text { Comité d'em- } \\
\text { presa }\end{array}$ & & delegados & $\begin{array}{l}\text { vakbonds- } \\
\text { vertegenw. }\end{array}$ \\
\hline Gr. & OR & Comité & & $\begin{array}{l}\text { vakbonds- } \\
\text { vertegenw. }\end{array}$ \\
\hline Port. & $\begin{array}{l}\text { Werknemers. } \\
\text { vertegenw. }\end{array}$ & & & $\begin{array}{l}\text { vakbonds- } \\
\text { vertegenw. }\end{array}$ \\
\hline It. & $\begin{array}{l}\text { Consigli } \\
\text { di fabricca }\end{array}$ & $\begin{array}{l}\text { Vakbonds- } \\
\text { vertegenw. }\end{array}$ & & $\begin{array}{l}\text { delegati di } \\
\text { reparti }\end{array}$ \\
\hline Den. & $\begin{array}{l}\text { samenw. } \\
\text { commissie }\end{array}$ & $\begin{array}{l}\text { Veiligh. } \\
\text { vertegenw. }\end{array}$ & & $\begin{array}{l}\text { tillids- } \\
\text { mand }\end{array}$ \\
\hline $\begin{array}{l}\text { Gr. } \\
\text { Br. }\end{array}$ & & $\begin{array}{l}\text { Veiligh. } \\
\text { vertegenw. }\end{array}$ & & $\begin{array}{l}\text { shop } \\
\text { stewards }\end{array}$ \\
\hline Ierl. & & $\begin{array}{l}\text { Veiligh. } \\
\text { vertegenw. }\end{array}$ & & $\begin{array}{l}\text { shop } \\
\text { stewards. }\end{array}$ \\
\hline
\end{tabular}

70. Voor een overzicht van de rechtsgrondslagen wan de verschillende soorten vertegenwoordiging zie de bijlage bij tabel $\mathbb{I}$ aan het eind wan Hoofdstuk III. 
2 Medezeggenschapsorganen, shop stewards, en andere werknemersvertegenwoordigers.

In de verschillende Europese landen kan een onderscheid worden wargenomen tussen op algemene en individuele belangenbehartiging gerichte werknemersvertegenwoordigers als shop stewards (71), en organen die meer op samenwerking (maar ook en dan veeleer op algemene belangenbehartiging) met de werkgever gericht zijn. De status van medezeggenschapsorganen als ondernemingsraden of samenwerkingsverbanden van shop stewards kan ontleend worden aan de wet, collectieve overeenkomst, een combinatie van deze twee elementen of aan de praktijk.

Een duidelijk onderscheid tussen de personele invulling van het medezeggenschapsorgaan en de algemene vertegenwoordigers is niet altijd te maken. Voor die organen die een wettelijke grondslag hebben is de situatie een duidelijke, de samenstelling en collectieve taak van deze organen staat meestal duidelijk omschreven. Voor organen waaraan een collectieve overeenkomst ten grondslag ligt is dit in het algemeen minder het geval: veelal gaat het hier om organen waarin nu juist de op individuele basis gekozen shop stewards verenigd zijn.

Voor de overzichtelijkheid is voor de volgende wijze van bespreking gekozen. In paragraaf III.2.1. worden de ondernemingsraden, behandeld, in paragraaf III.2.2. komen de vakbondsvertegenwoordigers aan de orde. De categorie van werknemersvertegenwoordigers met een specifieke taak kent in een aantal lid-staten ook weer het probleem van de overlapping van personele invulling met de ondernemingsraadsleden of shop stewards. In paragraaf III.2.3. wordt op de specifieke veiligheids- en gezondheidsvertegenwoordigers (voor zover dit een aparte categorie is), hun taken en de aan hun positie te ontlenen bijzondere rechten en bescherming, ingegaan.

\subsection{Ondernemingsraden en andere samenwerkingsonganen.}

Praktisch alle ondernemingsraden in de lid-staten hebben een wettelijke regeling als basis. Slechts de Deense samenwerkings-commissie ontleent haar bestaansrecht aan een Centraal Akkoord. In deze wettelijke of collectieve regelingen staat in het algemeen voorgeschreven wanneer een ondernemingsraad moet worden ingesteld, hoe de samenstelling ervan moet zijn, wie er verkiesbaar zijn, wie het actieve kiesrecht hebben en op welke wijze de leden beschermd zijn tegen een nadelige behandeling. In enkele van deze staten zijn ook centrale, groeps- of concernondernemingsraden

71. De taak van individuele belangenbehartiging door shop stewards blijkt in bepaalde landen uit de naam: in Duitsland wordt gesproken van Vertrauensleute, in Denemarken van Tillidsmand (vertrouwensman), hetgeen een zekere waarde aan de shop steward toekent. Vergelijk ook de in Nederlandse CAOs in zwang gekomen term Vertrouwenswrouw, voor werknemers die zich specifiek met individuele problemen omtrent ongewenste intimiteiten bezighouden. 
mogelijk. De mogelijkheden tot de vorming van deze raden, en hun plaats binnen het concern komt aan het eind van deze paragraaf aan de orde.

Duitsland en Nederland kennen van de lid-staten de meest gedetailleerde regeling ten aanzien van hun ondernemingsraden. Met name in Duitsland (72) zijn zaken als verkiezingen tot in de puntjes geregeld; in andere lid-staten (73) gaan de wettelijke voorschriften zelden zo ver.

In Duitsland moeten ondernemingsraden worden gekozen in ondernemingen met tenminste vijf kiesgerechtigde werknemers waarvan er drie het passieve kiesrecht hebben. In andere lid-staten wordt het aantal werknemers (kiesgerechtigd of niet) aangehouden, en dit aantal is meestal hoger (74): voor Nederland geldt een minimum van 35 werknemers, in Spanje, Griekenland en Frankrijk 50, in België 100 en in Luxemburg 150. In Luxemburg kent men in ondernemingen met meer dan 15 werknemers het instituut van de personeelsdelegatie. Deze kan in grote ondernemingen bestaan naast de ondernemingsraad. In Spanje worden personeelsgedelegeerden gekozen in ondernemingen met minder dan 50 werknemers. Ondernemingsraad en personeelsgedelegeerden sluiten elkaar hier uit. Hoewel de Portugese werknemerscommissie hun bevoegdheden aan de grondwet ontlenen is geen minimumaantal werknemers voorgeschreven voor de oprichting van een dergelijke commissie . Of een dergelijke commissie in de onderneming opgericht moet worden, wordt bepaald door een algemene vergadering van werknemers.

De Deense samenwerkingsovereenkomst van 1986 schijft de oprichting van een samenwerkingscommissie (samarbejdsudvalg) voor indien een onderneming meer dan 35 werknemers heeft.

De zittingstijden van de raden variëren van twee tot vier jaar.

In het algemeen staat het aantal leden van de raden in verhouding tot het aantal werknemers in onderneming. De mate van zelfstandigheid van de organen is verschillend: in Duitsland, Nederland, Spanje en Griekenland kiezen de ondernemingsraadsleden zelf een voorzitter uit hun midden, en is de werkgever geen lid van de raad. In het geval dat personeelsgedelegeerden in Spanje worden gekozen hebben deze slechts tot op zekere hoogte zelfstandigheid ten opzichte van elkaar, hoewel zij op persoonlijke titel gekozen worden. $\mathrm{Zij}$ worden geacht collectief op te treden hetgeen betekent dat zij zonder instemming van hun medevertegenwoordigers hun

72. Nemen de bepalingen omtrent verkiezingen in de BetrVG zelf al de nodige ruimte in beslag (artikelen $7 \mathrm{t} / \mathrm{m} 20$ voot de gewone ondernemingsraad, $60 \mathrm{t} / \mathrm{m} / 63$ voor de jeugdvertegenwoordiging en 115 en 116 voor de vertegenwoordiging op schepen), de Wahlordnung 1972 (BGbl I p. 49) preciseert het verkiezingsgebeuren op buitengewoon vergaande wijze. Slechts het Spaanse Werknemersstatuut kent in artikel 75 een gedetailleerde regeling omtrent de werkiezingen die enigszins vergelijkbaar is.

73. Te weten: Griekenland, Frankrijk, België en Luxemburg.

74. Theoretisch kan het natuurlijk zo zijn dat een aantal van vijf "kiesgerechtigde" werknemers een veel hoger reëel werknemertal met zich mee brengt; gezien het feit dat iedere werknemer boven dle achttien jaar kiesgerechtigd is zal dit niet snel het geval zijn. 
achterban niet kunnen binden. Ook de Portugese commissie kent zelfstandigheid. In België, Luxemburg, Frankrijk (75) en Denemarken is de raad of de commissie paritair samengesteld, waarbij de ondernemer als voorzitter functioneert, De Luxemburgse personeelsdelegatie bestaat alleen uit werknemersvertegenwoordigers.

Aan zowel het passieve als het actieve kiesrecht zijn beperkingen verbonden. Zo hebben in de Bondsrepubliek en Spanje diegenen die zes maanden in dienst van de onderneming zijn het passieve kiesrecht. In Nederland moet men een jaar in dienst zijn. Daarnaast is het in deze landen voor het passieve kiesrecht noodzakelijk, dat de werknemer de arbeid daadwerkelijk in de onderneming verricht, al hoeft dat in Duitsland niet voltijds te zijn (76). Voor geen van deze landen geldt dat de kandidaten lid van een vakbond moeten zijn, ook al hebben de vakbonden wel een expliciet recht kandidaten stellen.

Voor het passieve kiesrecht in Frankrijk moet men tenminste een jaar onafgebroken in de onderneming gewerkt hebben, en minimaal achttien jaar zijn. De werknemers worden naar categorie verkozen, een deel door de arbeiders, het andere door de ingenieurs, chefs technici en vergelijkbare categorieën (77). De representatieve vakbonden hebben het exclusieve recht om in de eerste ronde van de verkiezingen kandidaten te stellen, in de tweede ronde is de kandidaatsstelling vrij (78). Naast de verkozen werknemersvertegenwoordigers hebben vakbondsafgevaardigden met een adviserende stem, zitting in de ondernemingsraden.

In België heeft de vakbond het alleenrecht om de lijsten voor kandidaten voor de ondernemingsraad vast te stellen. Dit betekent overigens niet dat de afgevaardigden per se vakbondslid moeten zijn (79), hoewel dat in de praktijk vaak het geval zal zijn. De verkiezingen zijn, evenals in Spanje (80), naar categorie gescheiden. Onderscheid wordt gemaakt tussen werklieden, bedienden en jonge arbeiders, indien van deze categorieën bepaalde aantallen werknemers in de onderneming aanwezig zijn. De "jonge arbeiders" hebben een raadgevende stem in de ondernemingsraad (81). Werkmemers moeten zes maanden in de onderneming werkzaam zijn,

75. Lyon-Caen en Pélissier spreken overigens van tripartite wertegenwoordiging: de werkgever, de gekozenen door het personeel en vakbondsafgevaardigden. G. Lyon-Caen, J. Pellissier, Droit du Travail, Paris 1988 , p. 819 .

76. G. Etzel, Betriebsverfassungsrecht, Neuwied/Darmstadt, 1987, p. 28.

77. L. 433-2, Code du Travail.

78. L. 433-13 Code du Travail, zie ook G. Lyon-Caen, J. Pélissier, a.w. (noot 75), p. 741.

79. R. Blanpain, Belgium, in International Encyclopedia for Labour Law and Industrial Relations (supplement 93) Deventer 1988, para. 245.

80. De Spaanse regeling kent een dergelijke scheiding tussen technisch en administratief personeel en overig (geschoold of ongeschoold) personeel bij de verkiezingen (Wet no 32 van 2 augustus 1984, ter wijziging van het Werknemersstatuut 1980, Franse tekst: Bureau International du Travail, Séries législative, 1984, Esp. 1, 2/1985.

81. H. Slomp, Tj vam Mierlo, Arbeidswerhoudingen in België, Antwerpen 1984, p. 111. 
voordat zij het passieve kiesrecht verwerven. In het Luxemburgse systeem zijn de verkiezingen voor de ondernemingsraad getrapt. De leden van ondernemingsraad worden door de (eventueel in categorieën opgesplitste (82)) personeelsdelegaties gekozen. De personeelsdelegatie wordt indien een onderneming uit tenminste drie afdelingen bestaat per afdeling gekozen. Vakbonden kunnen, zowel voor de ondernemingsraad als voor de vergadering van de personeelsdelegatie adviseurs aanwijzen als de werknemersleden daarom verzoeken. In Griekenland moeten werknemers twee maanden in dienst van de onderneming zijn, om het passieve kiesrecht te verkrijgen; slechts werknemers met een leerovereenkomst zijn uitgesloten.

De leden van de Deense samenwerkingscommissie zijn over het algemeen de in de onderneming gekozen shop stewards, naast de leden aangewezen door de leiding. Indien er meer plaatsen in de commissie zijn dan shop stewards in de onderneming, worden deze bezet door uit de rest van het personeel gekozen leden.

Ook het actieve kiesrecht is in het algemeen aan beperkingen gebonden. In Griekenland geldt hetzelfde als voor het passieve kiesrecht, maar werknemers met een leerovereenkomst worden van het actieve kiesrecht niet uitgesloten. Het Duitse kiesrecht is voorbehouden aan hen die in de onderneming hun arbeidsplaats hebben en de leeftijd van achttien jaar bereikt hebben. In Nederland moet men zes maanden in de onderneming werkzaam zijn, in Spanje één maand; daar moet men tenminste 16 jaar zijn. In Frankrijk wordt het actieve kiesrecht voor de ondernemingsraden toegekend aan die werknemers die tenminste zestien jaar oud zijn en tenminste drie maanden in de onderneming werkzaam zijn. De Belgische leeftijdgrens is 14 jaar, daarboven hebben alle werknemers stemrecht, vakbondslidmaatschap is niet vereist (hetgeen voor het Belgische systeem uiteraard van meer belang is dan voor de systemen die niet zo sterk aan vakbonden gekoppeld zijn). Voor de Deense samenwerkingscommissie geldt het kiessysteem van de shop stewards.

Uit het bovenstaande blijkt dat het passieve en actieve kiesrecht voor randgroepwerknemers per land verschilt. In een aantal landen wordt de eis gesteld dat de werknemer in de onderneming werkzaam moet zijn, hetgeen thuiswerkers uitzondert. Dit geldt onder meer voor België en Frankrijk. Voorts wordt in praktisch alle lid-staten het kiesrecht beperkt tot hen die een zekere tijd in de onderneming werkzaam zijn, hetgeen ten nadele kan werken voor werknemers in tijdelijke dienst. In Spanje heeft men dit opgelost door een bepaling in het werknemersstatuut op te nemen dat ondernemingen waar tijdelijke en losse arbeids arbeidskrachten $20 \%$ van het totale werknemersbestand uitmaken, deze groepen eigen vertegenwoordigers

82. Zie J.K.M. Gevers, Zeggenschap van werknemers inzake gezondheid en veiligheid in bedrijven, Deventer 1982, p. 212 . 
kunnen kiezen. Per 25 werknemers kan een vertegenwoordiger worden verkozen (83).

Daarnaast kennen de lid-staten beperkingen die in het begrip werknemer zelf liggen. Zo geeft de Nederlandse WOR geen definitie van het begrip werknemers, maar bedoeld worden zij die op arbeidsovereenkomst werkzaam zijn. De bedrijfscommissie kan bepalen dat ook anderen tot de in de onderneming werkzame personen worden gerekend. Deze algemene regel is dus nadelig voor arbeidskrachten met flexibele contracten of thuiswerkers waarvan de status als werknemer niet zeker is. $\mathrm{Zij}$ zullen in de regel geen kiesrecht voor de ondernemingsraad hebben. De Duitse BetrVG is voor wat het actieve kiesrecht ruimer. Daar behoren ook thuiswerkers die hun werkzaamheden in hoofdzaak voor één onderneming verrichten tot kring van kiesgerechtigden voor de ondernemingsraad (84). Doordat thuiswerkers echter voor het passieve kiesrecht niet in aanmerking komen, hebben zij toch weinig mogelijkheden zich binnen de medezeggenschapsorganen te laten gelden.

De ondernemingsraadsleden genieten in de meeste lid-staten bescherming tegen benadeling. De verschillen in beschermingsregelingen op basis van wetgeving zijn gradueel, en hebben vooral betrekking op ontslagprocedures wegens dringende redenen.

In Nederland neemt deze de vorm aan van een ontslagverbod tijdens het lidmaatschap, en een geclausuleerd ontslagverbod na lidmaatschap en voor de kandidaten voor de ondernemingsraad (85). Ook Spanje kent een dergelijke regeling; daar strekt zich het ontslagverbod tot een jaar na afloop van het lidmaatschap uit (86). In Nederland wordt dit verbod doorbroken door ontslag wegens dringende redenen of wegens een ontbinding door de kantonrechter wegens gewichtige redenen (87); in Spanje moet ook bij ontslag wegens dringende redenen een aparte procedure worden gevoerd, waarbij de belanghebbende en de ondernemingsraad moeten worden gehoord. Daarnaast bestaan in Nederland en Spanje expliciete verboden de raadsleden te benadelen in hun carrie're wegens hun optreden in de raad. De Spaanse personeelsgedelegeerden genieten dezelfde bescherming als ondernemingsraadsleden.

In Duitsland kan het ontslagverbod door ontslag wegens dringende redenen worden doorkruist; in dat geval is toestemming van de ondernemingsraad

83. Artikel 72 Werknemersstatuut.

84. Paragraaf 6 BetrVG.

85. Artikel 21 WOR.

86. Artikel 68 Werknemersstatuut.

87. Artikel 21 WOR lid 5 , zie ook TK. $1988 / 89,20583$, no. 11 p. 7. 
(of de daarvoor in de plaats tredende rechterlijke toestemming) vereist (88). In Griekenland is er een ontslagverbod en een verbod van discriminatie bij het werk. De Belgische wet kent eveneens een ontslag verbod van ondernemingsraadsleden, maar laat ontslag toe wegens technische of economische redenen. Hiervoor is echter vooraf toestemming van het paritair comité vereist en het ontslag moet bovendien worden goedgekeurd door de arbeidsrechter. Deze redenen zijn door de arbeidsrechters zo strikt geinterpreteerd, dat in beginsel alleen ontslagen bij de sluiting van de gehele of een deel van de onderneming, en het ontslag van een specifieke groep van werknemers worden geaccepteerd (89).

Voor Franse kandidaatleden, leden en oud-leden van de ondernemingsraad is het ontslag onderworpen aan een verzwaarde procedure, waarbij de arbeidsinspecteur moet bekijken of er geen sprake is van een discriminatoire maatregel. Het maakt daarbij niet uit wat de reden voor ontslag is; zowel ontslag om persoonlijke redenen als om economische is niet zonder meer mogelijk (90). De Portugese leden van de werknemerscommissie hebben dezelfde bescherming als vakbondsvertegenwoordigers: ontslag van vertegenwoordigers of oud-vertegenwoordigers die minder dan vijf jaar voorafgaand aan het ontslag hun functie hebben uitgeoefend wordt geacht onrechtmatig te zijn gegeven. Zij hebben de keuze tussen opnieuw tewerkgesteld te worden of een schadevergoeding (91). In Denemarken wordt een deel van de ontslagbescherming die shop stewards hebben ook geboden aan de leden van de samenwerkingscommissie die geen shop steward zijn. Het komt neer op een verlenging van de opzegtermijn van ten hoogste zes weken. Hiermee biedt de Deense samenwerkingsovereenkomst wel een saillant magere bescherming, wanneer dat vergeleken wordt met de rechten die ondernemingsraadsleden hebben in lid-staten waar een wettelijke regeling aan de raad ten grondslag ligt.

De taken van de ondernemingsraden beslaan veelal zowel economische als sociale aangelegenheden. Ter uitoefening van die taken heeft de ondernemingsraad in een aantal lid-staten zoals Nederland de mogelijkheid zelf commissies al dan niet samengesteld uit zijn leden in te stellen. In andere landen bestaan krachtens andere wetgeving vaste commissies zoals in Duitsland waar naast de ondernemingsraad voor veiligheids- en gezondheidsaangelegenheden een Sicherheitsausschuss of een Arbeitsschutz-

88. Paragraaf 15,16 Kündigungsschutzgesetz, in samenhang met paragraal 103 BetrVG. Paragraaf 78 BetrVG biedt daarnaast bescherming tegen benadeling in de loopbaan, paragraaf 78 a bescherming voor leden van medezeggeschapsorganen met een opleidings-
aanstelling.

89. R. Blanpain, a.w. (noot 79), para. 290.

90. Artikelen 436-1 en 436-2, van wet 82-915, 28 oktober 1982 , JORF 29 oktober 1982 , p. 3266 .

91. Artikel 35 jo. 24 Decreet-wet no. 215-B/75, van 30 april 1975 gewijzigd op 7 december 1976, Franse tekst, Bureau International de Travail, Série législative, 1976 Por. 4 4/1977. 
ausschuss bestaat. Deze permanente commissies hebben ten opzichte wan de ondernemingsraad een adviserende bevoegdheid (92).

De Duitse BetrVG kent zelf een permanente Wirtschaftsausschuss. Dit is een informatie- en overleggremium, dat moet worden ingesteld bij een werknemersaantal van meer dan honderd werknemers, over het totaal van de diverse onderdelen van een onderneming. Zijn taak is de ondernemingsrad in zijn werk te ondersteunen. Zelf is de Wirtschaftsauschuss geen vertegenwoordigend orgaan met medezeggenschapsbevoegdheden (93). De speciale commissies voor veiligheids- en gezondheidsaangelegenheden worden verderop besproken.

In andere lid-staten hebben de ondernemingsraden eveneens mogelijkheden commissies in te stellen. Systemen zoals het Duitse waarin dergelijke op de wet gebaseerde, permanente adviesorganen van de ondernemingsraad optreden, zijn minder gebruikelijk.

In Nederland kan de ondernemingsraad zowel commissies ter behandeling van specifieke onderwerpen, als commissies ter voorbereiding van zijn taken instellen. Aan de eerste soort commissies (94) kunnen de bevoegdheden geheel of gedeeltelijk gedelegeerd worden. De meerderheid van de leden moet lid van de ondernemingsraad zijn, andere leden moeten in elk geval in de onderneming werkzaam zijn. De voorbereidingscommissies (95) kunnen in hoofdzaak uit leden bestaan die geen zitting in de ondernemingsraad hebben, als er maar één ondernemingsraadslid deel van uitmaakt. Naast deze twee commissies kan de ondernemingsraad bij reglement voor verspreide onderdelen van de onderneming commissies in het leven roepen (96). In deze commissies kunnen personen uit de onderdelen en ondernemingsraadsleden zitting hebben. Bevoegdheden van de ondernemingsraad voor dat onderdeel kunnen op basis van het reglement worden overgedragen aan de commissie.

De Belgische ondernemingsraad kan zichzelf opsplitsen in afdelingen die zich met specifieke taken bezighouden.

De Deense samenwerkingsovereenkomst biedt de samenwerkingscommissies eveneens de mogelijkheid subcommissies te benoemen, die zowel een permanent als een ad-hoc karakter kunnen hebben. In de overeenkomst wordt er van uitgalan dat de subcommissies ofwel een bepaald deel van de onderneming tot hun terrein hebben, ofwel een bepaald onderwerp. De bevoegdheden van de subcommissies worden in de samenwerkingscommissie vastgesteld.

92. De aansluiting op de werknemersmedezeggenschapsorganen is geregeld in paragraaf 89 BetrVG.

93. De Wirtschaftausschuss is geregld in de BetrVG, paragraaf $106 \mathrm{ev}$.

94. O.g.v. artikel 15 lid 1 . WOR.

95. Artikel 15 lid 3 WOR.

96. Artikel 15 lid 2 WOR. 
De Franse wetgeving maakt het mogelijk dat de ondernemingsraad in een onderneming met tenminste 1000 werknemers uit zijn midden een comité économique kiest. Het comitê moet uit hooguit vijf werknemersvertegenwoordigers bestaan waarvan tenminste één lid van het leidinggevend personeel. De voorzitter is lid van de ondernemingsraad. Het comité heeft de bevoegdheid leden van de leiding te horen indien de ondernemer daarmee instemt. Daarnaast kan de ondernemingsraad een aantal in de wet omschreven bevoegdheden delegeren aan het comité (97).

De wetgeving in andere lid-staten refereert niet aan het instellen van commissies. Daarmee is overigens niet gezegd dat het opdragen van taken aan subcommissies onmogelijk is, alleen kan men aannemen dat het delegeren van bevoegdheden die volgens de wettelijke regeling aan de gehele ondernemingsraad toekomen, is uitgesloten.

De taken van de ondernemingsraden liggen in het algemeen op zowel het economische als het sociale vlak. Van deze taken wordt hier slechts een schets gegeven; in de volgende hoofdstukken kom ik daar uitgebreider op terug.

In Frankrijk en België gaat het op zowel het sociale als het economische gebied vooral om bevoegheden tot het houden van toezicht en het geven van advies. In Nederland heeft de ondernemingsraad advies- en instemmingsbevoegheden op deze gebieden, taken in het kader van de Arbeidsomstandighedenwet (hier wordt in paragraaf III.2.3. op teruggekomen) en enkele bijzondere taken en bevoegdheden zoals het waken over de naleving van de voor de werknemers geldende voorschriften in het algemeen en tegen discriminatie tussen mannen en vrouwen in het bijzonder (98). Ook de Duitse ondernemingsraad heeft een aantal bijzondere taken naast de algemene toezichthoudende, meebeslissende en initiërende, namelijk op het gebied van de individuele werknemers, sociale aangelegenheden, arbeidsbescherming, beroepsopleiding en veranderingen in de onderneming (99).

De taken van de Spaanse ondernemingsraden bevinden zich met name op sociaal gebied: zij houden toezicht op regels betreffende de werknemers in ruime zin, op veiligheids- en gezondheidsmaatregelen voor zover deze niet aan gespecialiseerde organen zijn opgedragen en zij overleggen met de werkgever in welzijnsbevorderende activiteiten voor de werknemers en hun familie. Ook werken zij mee aan het uitvoeren van produktiebevorderende maatregelen en kunnen zij onderhandelen met de werkgever over collectieve overeenkomsten voor de onderneming en over zaken die betrekking hebben op individuele werknemers.

97. Artikel 434-5, Wet no. 82-915, van 28 oktober 1982, JORF 29 oktober 1982 , p. $3264-3265$.

98. Artikelen 25,27 , en 28 WOR.

99. Met name de paragrafen $80 \mathrm{t} / \mathrm{m} 85$, en $92 \mathrm{t} / \mathrm{m} 94,95$ en 99 BetrVG. 
De Deense samenwerkingscommissie heeft eveneens een takenpakket dat vooral op het sociale gebied ligt: het bevorderen van de arbeidsomstandigheden binnen de onderneming, scholing, het uitwisselen van ideëen over de inrichting van de onderneming in ruime zin, en het meedenken over de consequenties van nieuwe technologieën zowel op economisch als op millieugebied in ruime zin (100).

De Griekse raad heeft een adviserende functie naast de vakbondsvertegenwoordigers, en als taak in samenwerking met de aanwezige vakbonden de arbeidsvoorwaarden- en omstandigheden te verbeteren. De rol van de raad verschuift overigens indien in de onderneming geen vakbondsvertegenwoordiging aanwezig is. In dat geval neemt hij deel aan het overleg en beslist mee in een aantal sociale zaken in de onderneming, als werkregulering, veiligheids- en gezondheidsaangelegenheden en opleidingsprogramma's.

In een aantal lid-staten die wettelijke medezeggenschap hebben, kent men de mogelijkheid van medezeggenschap op groeps- of concernniveau. Dit is in Nederland (101), Duitsland (102), Frankrijk (103) en Spanje (104) het geval. De Deense samenwerkingsovereenkomst makt eveneens een groepscommissie voor samenwerking mogelijk (105). Deze centrale of groepsondernemingsraden kunnen niet in alle opzichten als echte "concern"ondernemingsraden worden gezien. Om te beginnen zijn zij dat alleen als het concern geheel nationaal is, en dat is steeds minder het geval. Binnen internationale concerns kan een centrale ondernemingsraad op dit moment niet meer zijn dan een koepelorgaan voor de nationale vestigingen (106).

100. Denmark, New Coöperation Agreement, EIRR 151 August 1986, p. 27; R. Nilsen, a.w. (noot 38), p. 112-113.

101. Artikelen 33-35 WOR, voorzien in groeps- en centrale ondernemingsraden die door de onderneming moeten worden ingesteld indien meer ondernemingsraden in een groep van ondernemingen aanwezig zijn, dan wel in de onderneming als geheel aanwezig zijn. Het initiatief is aan de werkgever, de ondernemingsraden kunnen bezwaar maken.

102. Artikelen 47-59 BetrVG voorzien in Gesamtbetriebsra"te wanneer in eén onderneming meer ondernemingsraden aanwezig zijn en Konzernbetriebsra"te. Deze laatste kunnen worden opgericht op initiatief van een Gesamtbetriebsrat en moeten de instemming vatm de andere Gesamtbetriebsra"te hebben.

103. Artikel $\mathbb{L}$ 439-1 van de wet no. 82-915, schrijft woor dat een comite de groupe wordt gecreëerd binnen een groep van ondernemingen waarvan de domimante onderneming is gesitueerd binnen het Franse grondgebied.

104. Artikel 63 Werknemersstatuut biedt de mogelijkheid voor een gezamenlijke ondernemingsraad op te richten bij collectieve overeenkomst. De bevoegdheden van dit orgaan worden in de collectieve overeenkomst vastgelegd.

105. Zie EIRR, no. 151, August 1986, p. 29.

106. In elkele landen gelden in geval er sprake is van een concern met de hoofdzetel buiten de eigen landsgrenzen extra beperkingen ten aanzien van de medezeggenschap. In Frankrijk biedt artikel $\mathbb{L}$. 439-1 van de Code du Travail alleen mogelijkheid tot oprichting van een comite de groupe wanneer de dominante onderneming de meerderheid van zijn kapitaal zich tot Frankrijk uitstrekt en de sociale zetel binmen de landsgrenzen is geistueerd. In Nederland verzwakt het structuurregime (artikel 2:155 en 2:265 ew. BW) de medezeggenschap eveneens, zij het op op zeer marginale wijze. Het gaat om verzwakking van de invloed van de Raad van Commissarissen op o.m. benoeming van directeuren. De 
Daarnaast komt dan nog de vraag in hoeverre de centrale ondernemingsraad bevoegdheden heeft ten aanzien van typische (nationale) concernaangelegenheden.

In Nederland is dit laatste omstreden. Honeé (107) meent dat de Centrale ondernemingsraad niet bevoegd is ten opzichte van concernaangelegenheden, aangezien de bevoegdheden van de Centrale ondernemingsraad slechts van de lokale ondernemingsraden afgeleid zijn. Indien de bedoeling was geweest de Centrale ondernemingsraden meer bevoegdheden te geven had de wetgever, volgens hem, een veel duidelijker en dwingender regeling omtrent de Centrale ondernemingsraden moeten geven. Van Solinge meent dat vit het begrip "gemeenschappelijke belang voor de meerderheid van de groepsondernemingen" een andere interpretatie valt af te leiden (108), die erop neerkomt dat de Centrale ondernemingsraad zich wel met het concernbeleid mag bemoeien. Ook de de minister van Sociale Zaken lijkt geneigd de bepaling in deze zin te interpreteren (109).

In geval een centrale of groepsondernemingsraad in een onderneming aanwezig is gaan overleg-, instemmings- en adviesbevoegdheden van rechtswege op deze organen over. Hieraan is de beperking verbonden dat deze ondernemingsraden alleen bevoegd zijn waar het gaat om aangelegenheden die van gemeenschappelijk bellang zijn, of van belang zijn voor de meerderheid van de ondernemingen waarvoor zij zijn ingesteld. Een nevengeschukte bewoegdheid van de lokale ondernemingsraad is uitgesloten (110).

De formulering in de Duitse BetrVG verschilt in zoverre van de Nederlandse dat de Concernondernemingsraad in paragraaf $58 \mathrm{BetrVG}$ bewoegd verklaard wordt ten aanzien van aangelegenheden "die den Konzern oder mehrere Konzernunternehmen betreffen". De afgrenzing met de bevoegdheden van ondernemingsraden en groepsondernemingsraden is gelegen in de formule dat deze niet in staat moet zijn deze aangelegenheden zelf af te handelen. Uit deze formulering blijkt dat de Duitse Concernondernemingsraad nu juist wel bevoegd is ten aanzien van aangelegenheden die het concern betreffen, sterker nog, indien het concern opdrachten heeft gegeven aan een van zijn ondernemingen betreffende een zaak die de werknemers van de overige ondernemingen aangaat, dan kan de Concernondernemingsraad met het bestuur van deze onderneming onderhandelen (111).

ondernemingsraad kan vita de artikelen $2: 158$ en $2: 268 \mathrm{BW}$ (indirecte) invloed hierop uitoetenen.

107. H.R. J.M. Honee, De territoriale werking van de Wet ondernemingsiaden, in Ondernemingsraad an vennootschap, Deventer 1982, p. 44-45.

108. A. $\mathrm{i}_{\mathrm{n}}$ van Solinge, Concernrecht en medezeggenschap, N.V. 60 (1982) p. 58-59.

109. Zie adviesaanvraag an de SER over de Wet op de Ondernemingsraden, 21 augustus 1989, Bijlage, pagina 15 .

110. Hof. A'dam (Ondernemingskamer) 25 juni 1981, NJ 1982, no. 248; zie ook de noot van Ma, bij Hof A'dam (Ondernemingskamer) 21 januari 1982, NJ 1983, no. 31.

111. Fiting ces. noemen als voorbeeld dienstwoningen die door een bij het concern behorende ondermeming in stand worden gehouden, K. Fitting, F. Auffarth, H. Kaiser, F. Heither, Betriebswerfassungsgesetz, Handkommentar, München 1987, p. 702 . 
Het Franse Comité de groupe heeft aanzienlijk minder rechten dan de ondernemingsraden, en is niet zozeer een medezeggenschapsorgaan op centraal niveau, als wel een informatieontvanger (112). Het comité kan geen aanspraak maken op de adviesrechten die de ondernemingsraad wel. heeft, hetgeen overigens ook in Frankrijk niet onomstreden is (113).

In Spanje is de creatie van Centrale ondernemingsraden, en de toekenning van bevoegdheden aan deze instituten overgelaten aan de sociale partners. De wet beperkt zich tot het voorschrijven van de samenstelling, die gerelateerd moet zijn aan de aanwezigheid van de vakbonden in de ondernemingen, en de begrenzing van de bevoegdheden (114). Deze bevoegdheden kunnen datgene wat de centrale ondernemingsraden bij de collectieve overeenkomst waarbij zij zijn opgericht is toegekend, niet overschrijden. Het aardige van deze formulering is dat, wanneer de vakbonden met de ondernemers een verdergaande medezeggenschap op concernniveau overeenkomen, deze niet op de wettelijke beperkingen stuit die de bovengenoemde regelingen in andere lid-staten wel hebben. Het nadeel van deze formulering is dat een Centrale ondernemingsraad alleen dan tot stand komt, als de werkgever(s) daar mee akkoord gaat, wat de werkgever(s) een sterke positie geeft in onderhandelingen over de bevoegdheden van een dergelijk orgaan.

De formulering van de Deense samenwerkingsovereenkomst ten aanzien van centrale samenwerkingscommissies is bijna gelijk aan die van de Nederlandse Wet op de Ondernemingsraden: groepscommissies zijn competent terzake van datgene, wat in het gemeenschappelijke belang van de ondernemingen is. Hierbij is de bevoegdheid van de samenwerkingscommissies met betrekking tot het vaststellen van de beginselen van het veiligheids- en gezondheidsbeleid niet zonder belang. Voor groepscommissies kan op die grond een competentie voor het vaststellen van een algemeen raamwerk voor het veiligheids- en gezondheidsbeleid op centraal niveau worden aangenomen, temeer daar in een dergelijke constructie de ondernemer altijd een grote stem blijft behouden (115).

In de andere lid-staten zijn geen bepalingen die medezeggenschap op concernniveau mogelijk maken dan wel bevorderen. Daarmee is overigens niet gezegd dat op een dergelijk niveau medezeggenschap uitgesloten is, al zal zij via collectieve onderhandelingen moeten worden afgedwongen. Met name in een lid-staat als Griekenland waar de strakke wettelijk gereguleerde

112. Zie voor een overzicht van de bevoegdheden van het comité de groupe, J. van der Wulfften Palthe, a.w. (noot 4), p. 152 ev.

113. P. Rodière, L'adaption du comite d"entreprise aux structures d'entreprise, Droit Social 1983, p. 361 .

114. Artikel 63 lid 3 Werknemersstatuut 1980 , zoals gewijzigd door de wet van 2 augustus 1982 (Boletin Oficial de Estado 48-1984, no. 1986, p. 22731, Franse tekst, Bureau international du travail, Séries législative, 1984, p. 195).

115. P. Jacobson, Denmark, International Encyclopedia for Labour Law and Industrial Relations, (supplement 33) Deventer 1983, para. 589, 595. 
indeling in vakbondsorganisaties op verschillende niveaus mogelijkheden hiervoor biedt, zou dit een te bereiken doel zijn. Of dit ook gebeurt (de Trade Union Democracy Act is nog betrekkelijk jong) is mij niet bekend.

\subsection{Shop stewards en vakbondsafvaardigingen in de onderneming.}

Vakbondsafvaardigingen in de onderneming bestaan in de meeste lid-staten. In enkele landen nemen zij naast de ondernemingsraden een een betrekkelijk marginale plaats in. In andere lid-staten zoals België en Frankrijk is vakbondsafvaardiging, ook al zijn er ondernemingsraden aanwezig, nog steeds van groot belang. In Groot Brittannie, Jerland, Denemarken en Italië is de vakbondsafvaardiging het belangrijkste medezeggenschapsorgaan op ondernemingsniveau.

De wijze waarop de medezeggenschap door middel van vakbondsvertegenwoordiging op ondernemingsniveau is geregeld verschilt van land tot land. Hier vallt eenzelfde indeling te hanteren als bij ondernemingsraden. Een enkele lid-staat reguleert de positie van de vakbondsvertegenwoordiger bij wet (Frankrijk), in de meeste echter speelt de wet hooguit een rol als vangnet (Spanje). De shop stewards ontlenen aan de wet hun rechten in de onderneming; hun bevoegcheden worden echter gereguleerd bij Centraal Akkoord (België, Spanje) of op geheel vrijwillige basis (Italie). In een enkele lid-staat, als Denemarken (en ook Groot Brittannië) komt er zelfs nauwelijks enige wettelijke regeling aan te pas.

In Frankrijk liggen de rechten en plichten van de vakbondsvertegenwoording evenals die van de ondernemingsraad vast in de Code du Travail. De Franse vakbondsvertegenwoordiging neemt een belangrijke positie in de onderneming in. Dit is deels op het conto te schrijven van de wijzigingen in de Franse wetgeving eind jaren zestig (116). Een wet van het begin van de jaren tachtig, versterkte de positie van de vakbonden op ondernemingsniveau, nadat de jurisprudentie van deze rechten langzaamaan steeds een stukje had afknabbeld (117). In beginsel kan iedere onderneming een vakbondsvertegenwoordiging hebben: sedert de wet van 4 augustus 1982 is de mogelijkheid geopend dat ondernemingen met minder dan 50 werknemers, die geen vakbondsafdeling hebben, toch een vakbondsvertegenwoordiger kunnen aanwijzen (118). De vakbondsvertegenwoordigers hebben in tegenstelling tot de ondernemingsraden, het recht op onderhandeling. Daarnaast maken enkele vertegenwoordigers (als adviseụr) deel uit van de ondernemingsraad.

Ook in Griekenland hebben de vakbondsvertegenwoordigers een positie in de onderneming die stoelt op een wettelijke basis. Verkiezingsprocedures van de vertegenwoordigers zijn geregeld in de Greek Trade Union

116. G. Lyon-Caen, J. Pelissier, a.w. (noot 75), p. 16.

117. J. Pelissier, a.w. (noot 22), p. 41.

118. Ph. Seguin, a.w. (noot 25 ), p. 3 . 
Democracy Act (119). De vertegenwoordigers zijn de verbindingsschakel tussen de werknemers in de onderneming en de federatie van bonden waarbij de vakbond hoort. Hun rol is vergeleken met die van de ondernemingsraad groot: zij hebben de onderhandelingsrechten in de onderneming.

In Portugal heeft de vakbondsvertegenwoordiging een wettelijke basis (120). De vakbond heeft het recht personeelsvertegenwoordigers aan te wijzen die eventueel een commissie kunnen vormen. Hoeveel vakbondsvertegenwoordigers in de onderneming aanwezig kunnen zijn is afhankelijk van de grootte van de onderneming. Regels voor verkiezingen noch voor het kiesrecht worden gegeven.

In de lid-staten die de regulering van de positie van de vakbondsvertegenwoordiging in de onderneming overlaten aan de sociale partners zelf is een scala van soorten regulering die varieert van een gedetailleerd Centraal Akkoord zoals in Denemarken, België en Spanje tot een praktisch geheel vrije situatie.

De positie van de Deense shop steward is gereguleerd bij Centraal Akkoord. Het kiezen van shop stewards gebeurt bij een minimum aantal werknemers, meestal is dit minimum vijf a zes. Aan het actieve kiesrecht worden weinig eisen gesteld: in beginsel heeft iedere werknemer, dus ook het nietvakbondslid, kiesrecht. Het kiezen van shop stewards is een recht, geen plicht. Dit kan veranderen wanneer duidelijk is dat een CAO binnen de onderneming niet uitgevoerd kan worden zonder de medewerking van shop stewards. In dat geval kan er een verplichting tot verkiezingen zijn (121). Het passieve kiesrecht is minder ruim. In de meeste CAO's zijn er enkele eisen aan verbonden. De meest voorkomende zijn: de kandidaat moet georganiseerd zijn, hij moet een zekere tijd binnen de onderneming werken (meestal een jaar), en hij moet een erkend geschikt (anerkendt dygtig) werknemer zijn. Deze laatste eis ziet met name op de houding van de werknemer in de onderneming; de bereidheid tot het bevorderen en instandhouden van de samenwerking met de werkgever moet aanwezig zijn (122). De werkgever kan protesteren indien een shop steward niet aan de eisen die in de overeenkomst zijn gesteld voldoet. Met name het geschiktheidscriterium kan daarvoor een grond zijn. Dit betekent een zekere mate van invloed van de werkgever op de persoon van de shop stewards in de onderneming.

De Deense shop stewards zijn, in een aantal ondernemingen, verenigd in de hierboven besproken samenwerkingscommissie. Op grond van het Centraal

119. Greek Trade Union Democracy Act, 1 juli 1982, Engelse tekst EIRR, August 1982, no. 103, p. 24.

120. Decreet-wet no. 215-B/75 van 30 april 1975 gewijzigd op 7 december 1976, Franse tekst, Bureau International de Travail, Séries législative, 1976, Por. 4, 4/1977.

121. P. Jacobsen, Kollektiv Arbejdsret, Kopenhagen 1981 (3e dr.), p. $697 \mathrm{ev.}$

122. R. Nilsen, a.w. (noot 38), p. 99. 
Akkoord omtrent deze commissies, hebben zij een aantal collectief uit te oefenen extra bevoegdheden verkregen.

In België heeft de vakbond niet alleen een belangrijke invloed op de samenstelling van de ondernemingsraad; naast deze bestaat ook nog een belangrijke vakbondsafvaardiging in de onderneming. De positie van de afvaardiging, die in ondernemingen met meer dan 20 werknemers moet worden ingesteld, is gebaseerd op een nationale CAO (123). De leden van de afvaardiging worden of gekozen of door de vakbonden aangewezen na overleg met de georganiseerden. Wanneer meer bonden in een onderneming aanwezig zijn, wordt overlegd over de hoeveelheid kandidaten die de verschillende bonden leveren. De vakbondsvertegenwoordiging onderhandelt op ondernemingsniveau en heeft een coördinerende taak met betrekking tot de ondernemingsraad. Indien geen ondernemingsraad aanwezig is, neemt de afvaardiging zijn taak geheel over (124). In dat geval krijgt de afvaardiging de rechten van de ondernemingsraad, uitgezonderd die met betrekking tot het ondernemingsbeleid. Ten opzichte van het in de navolgende paragraaf te bespreken Comité voor veiligheid, gezondheid en ter verfraaiing van de werkplaatsen geldt hetzelfde.

Naast de ondernemingsraad en de personeelsdelegatie kent het Spaanse recht een vakbondsvertegenwoordiging in de onderneming. Deze is gebaseerd op het werknemersstatuut van 1980 en gereguleerd op basis van de Centraal Akkoorden van 1983 (125) en 19851986 (126). De vakbondsvertegenwoordiging kan in de ondernemingsraad verkozen worden, maar dit hoeft niet. Is dit niet het geval dan hebben de vertegenwoordigers het recht om de vergaderingen van de ondernemingsraad en ook van veiligheids- en gezondheidscommissies (indien die in de onderneming aanwezig zijn) bij te wonen en te adviseren. Bovendien hebben zij het recht door de werkgever gehoord te worden over die maatregelen die de door hen vertegenwoordigde werknemers direct aangaan.

In een aantal landen berust de vakbondsvertegenwoordiging op een praktisch geheel vrijwillige basis in de onderneming. Zo is in Italië vakbondsvertegenwoordiging een aan het Werknemersstatuut te ontlenen recht. Er is echter geen plicht tot vertegenwoordiging en regulering van de positie van de shop steward is in deze wettelijke regeling niet te vinden. Het passieve kiesrecht voor vakbondsvertegenwoordiger is gebonden aan vakbondslidmaatschap; het makt niet uit of deze vakbond is aangesloten

123. Overeenkomst nummer 5, gesloten in de Nationale Raad voor de Arbeid op 24 meil 1971. Voor de publieke sector werd op 29 september 1984 een regeling getroffen bij Koninklijk besluit om trent dezelfde materie (Belgisch Staatsblad, 1984, p. 14000).

124. Dit is een opmerkelijk verschil met bijvoorbeeld Griekenland, waar de ondernemingsraad na de vakbond komt. In Belgie ligt de formele verhouding precies andersom.

125. Akkoord van 15 maart 1983, Engelse tekst: EIRR April 1983, no. 111, p. 25.

126. Akkoorden van 9 oktober 1984 , Engelse tekst EIRR Decemiber 1984 no. 131 p. 25 en 1985/86, Engelse tekst: EIRR 132, January 1985, p. 24. 
bij ến van de grote confederaties. Indien de in de onderneming werkzame vakbond partij is bij de nationale of provinciale overeenkomst, die in de onderneming toegepast wordt, kan ook deze vakbond vertegenwoordigers leveren (127).

De vakbondsvertegenwoordigers worden verkozen binnen beroepsgroepen die in de onderneming in ongeveer gelijke (arbeids)-omstandigheden verkeren, de z.g. "gruppo omogeneo". Alle werknemers (ook niet vakbondsleden) hebben het actief kiesrecht. Voor het passieve kiesrecht is vakbondslidmaatschap praktisch een vereiste. De Italiaanse shop stewards werken samen in de "consigli dei fabbrica". Deze "consigli" vertonen wat meer samenhang dan de Britse "combine"committees, maar zijn minder georganiseerd dan hun Deense pendanten. Voorschriften over hun functioneren, zowel procedureel als inhoudelijk bestaan niet op centraal niveau. Bovendien bestaat er in veel ondernemingen onduidelijkheid over de functie die de "consiglio" inneemt ten opzichte van de onderhandelingen op ondernemingsniveau. De leden binnen de "consigli" zijn het eerste niveau van de vakbondsorganisatie en tegelijkertijd de directe vertegenwoordigers van en onderhandelaars voor de werknemers. De "consigli" als geheel kunnen de inhoud van de ondernemingsakkoorden slechts beinvloeden. Via de "consigli" wordt wel vakbondsinvloed (en controle) op de individuele leden uitgeoefend. Om deze redenen levert, volgens Cella en Treu de rol van de consigli in het geheel van arbeidsverhoudingen een vrij grote ambivalentie op (128).

Het Britse systeem is het meest vrije van allemaal. De shop steward is hier een betrekkelijk onafhankelijke onderhandelaar, wiens positie slechts sedert enkele jaren en dan nog sporadisch lijkt te worden ingeperkt. Hij is vakbondsvertegenwoordiger ten opzichte van de ondernemer, en de eerst aanspreekbare persoon voor de andere werknemers op de werkvloer. Shop stewards worden verkozen volgens de regels van de vakbond of volgens de gewoonte in de betreffende onderneming. Hun mandaat bedraagt in het algemeen twee jaar, zij kunnen daarna herkozen worden. Zij zijn uiteraard vakbondsleden en worden gekozen door vakbondsleden. In Groot Brittannië is een groot deel van de werknemers vakbondslid (mede door de nog altijd bestaande closed shops), de vertegenwoordiging is op deze wijze verzekerd (129). Hier moet echter bij aangetekend worden dat in Groot Brittannië niet elke vakbond per se door de werkgever erkend hoeft te worden, hetgeen de leden van deze vakbonden, maar ook ongeorganiseer-

127. Artikel 19 Werknemersstatuut, (Gazetta Ufficiale della Republica Italiana, 27 mei 1970, no. 131, p. 3404, Engelse tekst, Internationall Labour Office, legislatiwe series, 1970, 1t. 2, May- June 1970).

128. G.P. Cella en T. Treu, Relazioni Industriali. Manuale per l'analisi della esperienza Italiana, Bologna 1982, p.113-118.

129. De closed shop is in Groot Brittanië is door middel van de Employment Acts van 1980 en 1982 aam beperkingen gebonden (pogingen daartoe waren all in de Industrial Relations Act 1971 ondernomen). Zie in dit verband P. Davies, M. Freedland, a.w. (noot 53), p. 258 . 270; A.TJ.M. Jacobs, Het recht op collectief onderhandelen, Deventer 1986, p. $107-111$. 
den buiten spel zal zetten. In de praktijk lijkt dit echter niet een groot probleem te vormen (130).

Sedert enkele jaren hebben een aantal vakbonden hun shop stewards een meer formele status gegeven, om enige greep te krijgen op hun handelen. $\mathrm{Zij}$ werden verenigd in disctrict-committees met meer shop stewards in dezelfde regio. De bedoeling van deze committees was mede om de shop stewards wat meer oog te laten krijgen voor de belangen van de leden van de bonden in andere ondernemingen om in geval van conflicterende belangen enige coördinatie te krijgen (131).

Daarnaast ontstonden spontane "combine"committees in de onderneming van shop stewards van verschillende bonden. Deze zijn geheel gebaseerd op vrijwilligheid. Zij hebben geen formele status en zijn vooral bedoeld om de felle, en soms contra-productief werkende concurrentie tussen de verschillende bonden in één onderneming te beteugelen (132).

Ook lerland kent een traditie van shop stewards, werkzaam op de werkvloer met onderhandelingsrechten ten opzichte van de werkgever. Het actieve en passieve kiesrecht is voorbehouden aan vakbondsleden. $\mathrm{Er}$ is geen wettelijke regulering van hun positie.

Voor Denemarken, Italië, Ierland en Groot Brittannië geldt dat de shop stewards al dan niet verenigd in comiteé's kunnen worden gezien als de enige algemene samenwerkings en onderhandelingsorganen op ondernemingsniveau. In de andere EG-lidstaten is dit niet zo, daar nemen de vakbondsafvaardigingen een plaats in naast de ondernemingsraad. Van belang wordt dan uiteraard hoe de rolverdeling is tussen de twee verschillende soorten vertegenwoordiging. Hoe verder de participatierechten van de ondernemingsraad gaan, hoe kleiner de rol van de vakbondsvertegenwoordiging zal worden. Er kan wel een rolvermenging optreden indien de vakbonden door middel van kandidaatsstelling (bijvoorbeeld exclusief zoals in België of bevoorrecht als in Frankrijk) of door middel van een vakbondsafvaardiging in de ondernemingsraden (Frankrijk) een grote rol krijgen toebedeeld.

In Duitse en Nederlandse ondernemingen verrichten de vakbonden naast de wettelijke medezeggenschapsorganen bondswerk in de onderneming. Het gaat om vakbonden die als zodanig in het onderneming werkzaam moeten zijn. In Duitsland bevat de BetrVG een richtlijn voor de wijze waarop vakbondsvertegenwoordigers met de medezeggenschapsoganen moeten samenwerken (133), hun rechten daaromtrent kunnen worden afgeleid uit paragraaf 9 Grundgesetz en worden geformuleerd in collectieve overeenkomsten.

130. Lord Wedderburn, a.w. (noot 53), p. 283-286.

131. B. Perryns, a.w. (noot 13), p. 17.

132. E. Batstone, Working Order, Londem 1984, p. $219-221$ en 310-311.

133. Paragraaf 2 BetrVG. Herin wordt bepaald dat ook met de vakbond samengewerkt moet worden. 
De Gewerkschaftsbeauftragte heeft op grond van de BetrVG een beperkt en aan voorwaarden gebonden toegangsrecht tot het bedrijf en tot vergaderingen van de ondernemingsraad. Deze toegang kan alleen geweigerd worden door de werkgever op grond van de persoon van de Beauftragte, het doel van het bezoek en ondernemingsbelangen. Bij deze laatste weigeringsgrond moet door de werkgever de maatregel gekozen worden die de Gewerkschaftsbeauftragte het minst in de uitoefening van zijn rechten belemmert (134). Voorts hebben de in de onderneming werkzame vakbonden het recht om aan ledenwerving te doen, zij het onder voorwaarden.

In verschillende Nederlandse ondernemingen zijn in de jaren zeventig bedrijfsledengroepen opgericht, met name om de contacten met de leden te bevorderen en invloed te kunnen uitoefenen op het beleid van de ondernemer. Deze vakbondsleden hebben geen speciale wettelijke rechten, wel zijn er in collectieve overeenkomsten steeds meer faciliteiten voor hen gecreëerd (135). Ook is de ontslagbescherming verbeterd (136), veelal wordt aansluiting gezocht bij de regelingen uit de WOR (137). Het bondswerk in de onderneming is mede gericht op het ondersteunen van de vakbondsleden in de ondernemingsraad (138).

Ook in andere landen hebben de vakbondsafvaardigingen in veel gevallen bescherming tegen benadeling door de werkgever in verband met hun taak. In een aantal landen, zoals van enkele hierboven al is beschreven is deze bescherming dezelfde als van ondernemingsraadsleden. Dit geldt in het algemeen voor de ontslagbescherming van de Duitse, de Deense, de Spaanse de Portugese, de Franse en de Griekse vakbondsvertegenwoordigers. De ontslagbescherming van de Deense shop steward is iets ruimer dan die van de overige leden van de samenwerkingscommissie omdat naast de al eerder genoemde verlenging van de opzegtermijn, in veel overeenkomsten ook de ontslaggronden limitatief zijn geformuleerd. Het gaat dan om ontslag wegens dringende redenen; deze redenen kunnen gelegen zijn zijn functioneren als werknemers en in zijn taakopvatting als shop steward. Voor het overige verschilt de ontslagbescherming niet veel met die van andere werknemers hoewel de bewijslast voor de werkgever bij het ontslag van shop stewards soms wat verzwaard kan zijn (139).

134. G. Etzel, a.w. (noot 76), p. 423-425.

135. DCA-rapport, vakbondswerk in de onderneming, Den Haag juni 1984.

136. Het wetsontwerp Vakbondswerk in de onderneming TK 1980/81, 16.703, no. 3 p. 6, waarin regeleingen zou worden getroffen met betrekking tot faciliteiten en ontslag is nog steeds niet tot wet verheven. Zie ook A.J.C.M. Geers, Recht en humanisering van de arbeid, Deventer 1988, p. 252-253.

137. H.L. Bakels, a.w. (noot 21), p. 161.

138. G.E. van Vliet, Bedrijwenwerk als vorm van belangenbehartiging, Alphen a/d Rijn, 1979, p. $542 \mathrm{ev}$.

139. Bijvoorbeeld: bij het teruglopen van de hoeveelheid werk in de onderneming mag een shop steward wel ontslagen worden, het is echter aan de werkgever te bewrizzen dat dit gebrek aan werk noodzaakt tot het ontslag wan nu juist de shop steward. 
De Belgische regeling ter bescherming van vakbondsvertegenwoordigers gaat minder ver dan die voor ondernemingsraadsleden: zij mogen niet ontslagen worden om redenen die gelegen zijn in hun mandaat. Voor vertegenwoordigers en kandidaatvertegenwoordigers geldt een bijzondere ontslagprocedure (140).

De Britse shop steward heeft in beginsel geen bijzondere ontslagbescherming. Zijn taak is gebonden aan en eindigt met zijn arbeidsovereenkomst, dus ook bij ontslag (141). Wel zijn er in de Employment Protection (Consolidation) Act 1978 beschermingsmaatregelen tegen discriminatoir ontslag in het algemeen (142). Ontslag wordt automatisch als "unfair" gezien als de hoofdreden van ontslag de (voorgenomen) activiteiten van een werknemer in een onafhankelijke vakbond betreffen. Voor toepasselijkheid van die regel hoeft de werknemer geen lid van een (al) erkende bond te zijn. Bijzondere regels voor shop stewards zijn niet opgenomen, ook al kan men zich voorstellen dat de bestaande (algemeen beschermende) regels in geval van ontslag van een shop steward, gemakkelijker toepasbaar zijn. De beschermende wetgeving was deels bedoeld om het aantal stakingen dat ontslagen veroorzaakten te reduceren. Dit lijkt niet het geval geweest te zijn (143). De dreiging van werknemers te staken bij ontslag van een shop steward levert een niet-juridische, maar mogelijk effectievere, bescherming op dan de bestaande wettelijke regeling.

De Italiaanse shop steward ontleent zijn wettelijke ontslagbescherming aan artikel 14 Werknemersstatuut, dat het ontslag van werknemers om redenen van vakbondslidmaatschap, vakbondsactiviteiten of deelname aan stakingen verbiedt. In het geval de werkgever de rechtmatigheid van het ontslag niet kan bewijzen kan de rechter herstel van dienstbetrekking bevelen in elke fase van het proces. Indien de werknemer de uitvoering van dit bevel niet wil afdwingen is de werkgever verplicht een bedrag ter hoogte van het salaris in een apart (zekerheids)fonds te storten (144). Daarnaast ontlenen de vakbond en zijn vertegenwoordigers bescherming aan artikel 28 Werknemersstatuut, een artikel dat anti-syndicaal gedrag van de werkgever verbiedt. Tegen werkgevers die de activiteiten van de vakbonden proberen te belemmeren (bijwoorbeeld door benadeling van haar vertegenwoordigers) kunnen de vakbonden opkomen in een betrekkelijk simpele procedure.

De taken van shop stewards en van de syndicale afvaardiging in een aantal landen zijn in hoofdzaak die van belangenbehartiging van de werknemers

140. Voor deze procedure zie R. Blanpain, a.w. (noot 79), para. 235.

141. City and Hackney Health Authority ws NUPE [1985], Industrial Relations Law Reports, 252 (Court of Appeal).

142. Zie Lord Wedderburn, a.w. (noot 53), p. 312-313.

143. B. Hepple in Industrial Relations in Britain, (G.S.Bain ed.) Oxford 1983, p. 409-412.

144. Zie over de tregulering en de problemen in de rechtspraak daarmee: S. Sciarra, Italy, Restructuring labour at the Enterprise, in Bulletin of Comparative labour relations,
Deventer 1987 , p. $56-58$. 
in het algemeen en de leden van de vakbond in het bijzonder. Deze belangenbehartiging neemt in de meeste landen de vorm aan van onderhandelingsbevoegdheden op punten als loon en arbeidsvoorwaarden en zaken aangaande bedrijfsopleidingen en arbeidsomstandigheden (m.n. Griekenland en Italie). Daarnaast wordt aan individuele belangenbehartiging gedaan (o.m. Nederland) De Deense shop steward heeft een additionele samenwerkingstaak met de werkgever. Deze taak sluit overigens belangenbehartiging niet uit (145).

In de landen waar ondernemingsraden zelfstandiger zijn, en vakbonden gecentraliseerder en op hogere niveaus werken (Nederland, Duitsland) is contact onderhouden tussen vakbond en leden een belangrijke taak van de vakbondsvertegenwoordiging. Deze taak wint aan belang naarmate vakbonden groter worden, en de directe invloed van de leden op besluiten en belleid vermindert. Een derde takenpakket van shop stewards en vakbondsafvaardiging is in een aantal landen de vertegenwoordiging in het kader van veiligheids-en gezondheidsregelingen. Deze taak berust in de meeste landen (alleen in Italië niet) op een specifieke wettelijke of collectief arbeidsrechtelijke regeling. Om die reden worden deze taken in een aparte paragraaf besproken.

De verhouding tussen ondernemingsraad en vakbondsafvaardiging voor wat betreft de plaats die deze binnen de onderneming inneemt, is in Duitsland en Nederland, zeker wanneer men ze vergelijkt met de andere lid-staten, sterk verschoven ten gumste van die van de ondernemingsraad. Dat dit niet altijd tot onaanspreekbaarheid van de vertegenwoordigers hoeft te leiden blijkt uit een onderzoek naar de uitoefening van de bevoegdheden van de Nederlandse ondernemingsraad (146). Hierin werd gesteld dat er in ruime mate contacten zijn, ook al hebben deze een vrij ongestructureerd karakter. Voor vakbondsafvaardigingen die niet gekozen worden op de werkvloer maar door de vakbond aangewezen worden kan het probleem van onaanspreekbaarheid overigens op eenzelfde wijze naar voren komen als voor ondernemingsraden (147).

145. In de arbitrage uitspraak in de zaak Plastindustriens Arbejdgiververforening vs Si van 12 september 1985 werd uitgemaakt dat het meewerken aan acties die niet in overeenstemming met de $\mathrm{CAO}$ zijn, in zijn algemeenheid gerechtvaardigd kunnen zijn, wanneer de belangen van werknemers ter behartiging waarvan de shop steward geworven, tot deze acties noodzaken.

146. J.C. Looise, J.Z. Heijink, De OR en zijn bevoegdheden, Nijmegen 1986, p. 112-113. Dit onderzoek heeft overigens kritiek gekregen ten aanzien van de representativiteit ervan: zie P. Lakeman, Hoe representatief is het evaluatie onderzoek 'De OR en zijn bevoegdheden, OR-informatie 1986, p.22.

147. M. Rodrigues-Piñero en S. Del Rey Gaunter, Workers Representative Bodies and Collective Bargaining At the Workplace: Notes On the Recent Evolution in Western Europe, The International Journal of Comparative Labour Law and Industrial Relations, 1985 , no 2 , p. 75 . 
2.3 Werknemersvertegenwoordigers met specifieke taken inzake veiligheids- en gezondheidsaangelegenheden.

Praktisch alle lid-staten hebben regelgeving op het gebied van veiligheidsen gezondheidsaangelegenheden waarin werknemers-vertegenwoordiging is opgenomen Deels is dit het gevolg van regulering op dit gebied door de Europese Gemeenschap, hoewel de bestaande richtlijnen strikt genomen niet verplichten tot invoering van medezeggenschapsorganen (148). Anderzijds is het ook een gevolg van gegroeide praktijken van medezeggenschap in het algemeen in de lid-staten. Bij herstructurering van het arbeidsomstandighedenrecht gingen medezeggenschapsbepalingen vrij automatisch deel uitmaken van wettelijke regelingen, ook als de medezeggenschap voor het overige op vrijwillige basis geregeld was.

In de meeste lid-staten waar medezeggenschap op zichzelf op vrijwillige basis is geregeld, ligt aan de rechten omtrent veiligheid en gezondheid nu juist wel een meer uitgebreide, wettelijke regeling ten grondslag. Zowel Groot Brittannie, Denemarken als Ierland kennen wettelijke maatregelen die voorzien in een zekere mate van medezeggenschap, voornamelijk bestaand uit informatie- en consultatiebevoegdheden.

In Groot Brittannië speelde de wet al lang een centrale rol in veiligheidsen gezondheidsaangelegenheden (149). Pas rond het eind van de jaren zestig werden medezeggenschapsrechten een punt van discussie (150), toen het Robens-report (151) aparte veiligheidsvertegenwoordigers los van de vakbonden tot de mogelijkheden achtte te behoren. In dit rapport werd een scherp onderscheid gemaakt tussen "participation", waarbij een benadering van samenwerking met de werkgever werd beoogd en "collective bargaining". Samenwerking met de werkgever werd noodzakelijk geacht omdat anders werkelijke vooruitgang in veiligheids- en gezondheidsaangelegenheden onmogelijk zou worden. De Health and Safety at Work Act 1974 draagt de sporen van deze visie (152). "Bargaining" werd gezien als niet gewenst indien het om veiligheids- en gezondheidsaangelegenheden ging; de natuurlijke belangenverstrengeling van werkgever en werknemers maakte dit

148. Zie de argumentatie in paragraaf II.4.2.D.

149. Zie Lord Wedderburn, a.w. (noot 53), p. 413 ev.

150. Wettelijke maatregelen voor werknemersparticipatie waren er wel voor de mijn-industrie: de Mining Industry Acts 1926 voorzagen in de mogelijkheid gezamenlijke safety committees op te zetten. Zie hierover R.W.L. Howells, Worker Participation in Safety, I. The development of Legal Rights, Industrial Law Review 1974, p. 91-92. 151. Safety and Hieralth at Work, Report of the Robens Committee 1970-1972, HMSO Londem
1972 .

152. Section 2 lid 6 HSWA 1974: It shall be the duty of every employer to consult any such representatives with a wiew to the making and maintainance of arrangements which will enable him and his employees to coöperate effectively in promoting and developing measures to ensure the health and safety at work of the employees (...). 
volgens het rapport overbodig (153). Om die reden achtte het Robenscommittee het noodzakelijk om de consultatie gescheiden te houden van de collectieve onderhandelingsmachinerie, hetgeen met andere woorden betekent dat de shop stewards en vertegenwoordigers in veiligheidscommissies niet in één persoon verenigd zouden moeten zijn.

Opvallend is wel dat het Robens-committee van mening was dat de veiligheidscommissies organen op vrijwillige en niet op wettelijke basis dienden te zijn. Een wettelijke verplichting veiligheidscommissies in te stellen zou volgens het Committee "too rigid" en "too narrow in concept" blijken te zijn. Toch werd er in the Employed Persons (Safety and Health) Bill een poging ondernomen de leiding van ondernemingen met meer dan 100 werknemers te verplichten veiligheidscommissies in te stellen, indien de vakbondsvertegenwoordigers daarom vroegen. In ondernemingen met meer dan tien werknemers zouden vakbonden het recht krijgen veiligheidsvertegenwoordigers te benoemen. Het wetsvoorstel werd na de val van de Labourregering in 1970 ingetrokken.

Door middel van de Health and Safety at Work Act (HSWA 1974) wordt een aantal bevoegdheden toegekend aan vertegenwoordigers van de werknemers. Op basis van deze wet (154) moet de werkgever de werknemers een geschreven veiligheidsbeleidsplan aanbieden, en hebben erkende (155) vakbonden het recht veiligheidsvertegenwoordigers te benoemen. Dit wil niet zeggen dat veiligheidsvertegenwoordiger en shop steward in één persoon verenigd moeten zijn, maar het gebeurt wel (156). Voor de shop stewards is de benoeming als veiligheidsvertegenwoordiger overigens aantrekkelijk, aangezien er faciliteiten als vrijstellingen aan de taak verbonden zijn (157).

De algemene taak van de veiligheidsvertegenwoordigers is te overleggen met de werkgever over het ontwikkelen en bevorderen van veiligheidsmaatregelen en hun effectiviteit. Zij hebben tot taak risico's, oorzaken van ongevallen en klachten van werknemers te onderzoeken. Zij houden toezicht op de werkvloer en op documentatie van de werkgever over veiligheidsaangelegenheden. Wanneer de vertegenwoordigers verzoeken een veiligheidscommissie in te stellen is de werkgever daartoe verplicht. De taakstelling van de veiligheidscommissie is overigens niet gereguleerd. Slechts in de "guidance notes" (158) van de Health and Safety Commission (159) wordt

153. Zie cok D. Lewis, Worker Participation in Safety, II. An Industrial Relations Approach, Industrial Law Review 1974, p. 98.

154. Safety Representatives Regulations, no. 500, 1977, Reg 3 (4).

155. Vgl. Lord Wedderburn, a.w. (noot 53), p. 312, L. Betten The Right to Strike in Community law, North Holland 1985, p. 141-142.

156. J.K.M. Gevers, a.w. (noot 82), p. 105.

157. A. Broadhurst, The health and Safety at Work Act in Practice, London 1978, p. 49.

158. "Guidance notes" zijn een vorm van "quasi-legislation", waarvan de status kan worden versterkt door de wijze waarop de rechter ze bij zijn uitspraken betrekt. (Zie hierover o.m. G. Ganz, Quasi-legislation: Recent Developments in Secondary legislation, London 1987, hoofdstuk 1 ). De "Guidance notes on Safety Committees" hebben slechts een adviesfunctie.

159. Het toporgaan van de Britse veiligheids- en gezondheidsorganisatie. Zie hienover 0.m. G.K. Wilson, The politics of Safety and Health, Oxford 1985. 
een taakomschrijving gesuggereerd (160). De veiligheidsvertegenwoordigers zijn verplicht de vergaderingen van de veiligheidscommissie bij te wonen.

Denemarken kent naast de shop stewards ook een speciale veiligheidsvertegenwoordiging. De vertegenwoordigers worden gekozen voor een periode van twee jaar. De veiligheidsvertegenwoordigers hoeven in tegenstelling tot de shop stewards niet georganiseerd te zijn. Dit omdat het kiezen van veiligheidsvertegenwoordigers een verplichting is uit de Wet op de Arbeidsomgeving (Arbejdsmiljølovet 1975). De veiligheidsvertegenwoordigers nemen zitting in een veiligheidsgroep indien de onderneming meer dan tien werknemers heeft. De algemene taken van de groep liggen op het gebied van het oplossen van veiligheidsproblemen, toezicht op werkmethoden, materiaal en de kwaliteit van de informatievoorziening. Daarnaast neemt de groep deel aan onderzoeken op het gebied van veiligheid en gezondheid. De principes waarmee gewerkt wordt in de onderneming worden niet vastgelegd door de veiligheidsvertegenwoordigers of de groep maar door de samenwerkingscommissie. De aldus vastgelegde relatie tussen de werknemersvertegenwoordiging op vrijwillige basis en die op wettelijke basis waarborgt dat de wettelijke vertegenwoordiging de vrijwillige niet kan overvleugelen.

De ontslagbescherming van veiligheidsvertegenwoordigers is gelijk aan die van shop stewards. Overplaatsing naar een andere afdeling kan alleen geschieden wanneer daar "dwingende redenen" voor zijn, wat wil zeggen dat de voorwaarden voor een ontslag op hun eigen afdeling vervuld moeten zijn.

Ierland heeft een sterk op de Deense wet gelijkende regeling. Naast het shop steward systeem bestaat een wettelijke vorm van medezeggenschap op veiligheids- en gezondheidsgebied. Op basis van de Safety in Industry Act 1980 kent ook het Ierse systeem veiligheidsvertegenwoordigers en veiligheidscommissies. De veiligheidsvertegenwoordigers zijn werknemersvertegenwoordigers; de veiligheidscommissies worden benoemd door werkgevers en werknemers gezamenlijk, zodat ook werkgeversvertegenwoordigers in de commissie zitting hebben. Het is, in tegenstelling tot het Deense systeem, niet zo dat de veiligheidsvertegenwoordiger automatisch in de commissie zitting heeft. De veiligheidsvertegenwoordiger bestaat in ondernemingen met minder dan 20 personeelsleden. Ook in die kleine ondernemingen mag men een commissie instellen. In ondernemingen met meer personeelsleden wordt een commissie gekozen. De belangrijkste taak van beide gremia is het overleg over de toepassing van wettelijke en bestuursrechtelijke maatregelen. Deze laatste worden door de minister vastgesteld in overleg met de sociale partners (161).

160. A. Broadhurst a.w. (noot 157), p. 54.

161. M. Redmond, a.w. (noot 66), para. 183. 
De wettelijke basis voor de Griekse vertegenwoordiging voor veiligheids- en gezondheidsaangelegenheden is ouder dan de Wet op de Ondernemingsraden, maar niet veel. De wet dateert uit 1985 (162). Daarvoor konden overigens commissies op dit terrein op basis van het Centraal Akkoord van 1981 in het leven geroepen worden (163), en in de wet is rekening gehouden met de wijze waarop het systeem al functioneerde. Desondanks verloopt de instelling van veiligheids-comité's moeizaam. In 1987 bleek dat van 552 ondernemingen, met meer dan 150 werknemers, die volgens de wet uit 1985 een veiligheidscommissie zouden moeten hebben slechts 150 tot de instelling daarvan waren overgegaan (164). In ondernemingen met meer dan 20 werknemers moeten veiligheidsvertegenwoordigers worden gekozen, zijn er meer dan 50 werknemers dan moeten veiligheids-commissies worden ingesteld. Het instellen is een recht van de werknemers, het initiatief hiertoe ligt bij hen, niet bij de werkgever. De commissies staan los van de vakbondsvertegenwoordigers, of indien deze ontbreken van de ondernemingsraden. De rol van de commissies is vooral adviserend, daarnaast heeft de commissie de taak de noodzaak te bestuderen voor te nemen maatregelen en op te treden in geval van ernstig gevaar. De leden worden verkozen door alle werknemers, zowel voor het actieve als het passieve kiesrecht is vakbondslidmaatschap geen vereiste.

De Franse en Belgische wetgeving voorzien in veiligheids- en gezondheidscommissies naast de ondernemingsraad. In België bestaat op arbeidsomstandighedengebied in ondernemingen met meer dan 50 werknemers het comité voor veiligheid, gezondheid en ter verfraaiing der werkplaatsen. In enkele bedrijfstakken is zo'n comité bij minder werknemers verplicht. Ook hiervan is de ondernemer voorzitter, de leden worden gelijktijdig gekozen met de leden van de ondernemingsraad. Kandidaten voor dit comité hoeven niet per definitie door de vakbonden worden voorgesteld, al zal dit wel vaak het geval zijn. Bovendien is er vaak een overlapping van lidmaatschappen van de beide organen (165).

De taken van het comité zijn uitgebreider dan die van de ondernemingsraad op veiligheids- en gezondheidsgebied. Het houdt toezicht op de vakkrachten (bedrijfsartsen, veiligheidsdeskundigen) voor veiligheid en gezondheid in de onderneming, doet onderzoek naar risicofactoren en behandelt individuele klachten. De leden van het comité hebben een ontslagbescherming die gelijk is aan die van de leden van de ondernemingsraad.

Ook in Frankrijk bestaat in ondernemingen met meer dan 50 werknemers, naast de ondernemingsraad een speciale commissie voor veiligheids- en gezondheidsaangelegenheden. De verkiezing van de leden van de commissie

162. Wet no. 1568, van 18 oktober 1985, Engelse tekst EIRR 144, January 1986, p. 27-30.

163. Centraal Akkoord van 12 mei 1981, Engelse tekst, EIRR 1981, no. 90, p. 24.

164. Commissie van de Europese Gemeenschappen, Verslag over de sociale ontwikkeling 1987 , Brussel/Luxemburg. 1988, p. IX-6.

165. H. Slomp, Tj. van Mierlo, a.w. (noot 81), p.114. 
geschiedt getrapt: door de ondernemingsraad en de personeelsgedelegeerden (166). De ontslagbescherming van de leden en oud-leden van dit "comitê d'hygiëne, de sécurité et des conditions de travail (CHSCT)" is gelijk aan die van de ondernemingsraad.

Het comite is in de Code du Travail ingevoerd bij de wijzigingen van 1982, als vervanging van de twee commissies, die op het veiligheids- en arbeidsomstandighedenterrein bezig waren (167). De bevoegdheden van het comité zijn echter maar gedeeltelijk exclusief. Op veiligheids- en gezondheidsgebied spelen zowel de ondernemingsraad, als de personeelsgedelegeerden als de vakbondsafgevaardigden nog steeds een rol. Door de getrapte verkiezingen is echter de rol van de eerste twee organen materieel wel ingedamd (168).

In Luxemburg bemoeien eveneens meer organen op ondernemingsniveau zich met veiligheids- en gezondheidsaangelegenheden. Zowel de ondernemingsraad als van de personeelsdelegaties hebben een taak op dit gebied. Het eerstgenoemde orgaan heeft consultatie- en beslissingsbevoegdheden, het tweede kan voorstellen doen en initiatieven ontplooien. Een aparte veiligheidsvertegenwoordiging bestaat in sommige sectoren wel, maar heeft geen algemene wettelijke basis.

In Nederland en Spanje worden de taken met betrekking tot arbeidsomstandigheden in beginsel waargenomen door de ondernemingsraad. In Spanje kunnen de taken op dit terrein overgedragen worden aan gespecialiseerde commissies. In Nederland is dit eveneens het geval. Wanneer geen ondernemingsraad in de onderneming aanwezig is, ligt de situatie anders: in dat geval moet op basis van de Arbeidsomstandighedenwet een Arbocommissie worden opgericht, als die onderneming tenminste behoort tot een categorie die daartoe verplicht wordt bij AMVB. Ook de Arbo-commissie is een vertegenwoordigend orgaan, waarvan de leden door de werknemers worden gekozen. De Arbocommissie heeft specifieke bevoegdheden die zich richten op de bevordering van de veiligheid de gezondheid en het welzijn van de werknemers. Op dit terrein zijn deze bevoegdheden gelijk aan die van de ondernemingsraad. Ook ontslagbescherming en faciliteiten komen hier mee overeen.

Ontbreken in de onderneming zowel ondernemingsraad als Arbocommissie, dan neemt de in de onderneming werkzame vakbond een aantal rechten over. Het gaat hier met name om de mogelijkheid een verzoek tot wetstoepassing te doen (169).

166. Over de problemen van de verkiezing van de CHSCT in ondernemingen verenigd in een groep: J. Savatier, Le désignation des répresentants du personel au CHSCT, Droit Social $1989,645-646$.

167. Vgl. P. Chaumette, Le CHSCT et le droit de retrait du salarie, Droit Social 1983, p. 425.

168. G. Lyon-Caen, J Pélissier, a.w. (noot 75), p. 516-517.

169. Artikel 40 Arbeidsomstandighedenwet. Zie ook A.J.C.M. Geers, a.w. (noot 136), p. 254255. 
Doordat in Duitsland ondernemingsraden al moeten worden opgericht indien een onderneming meer dan vijf werknemers heeft, is het probleem van afwezigheid van zo'n raad niet dringend te noemen: bij afwezigheid zijn de werknemers zo weinig in getal dat vertegenwoordiging niet noodzakelijk kan worden genoemd.

De ondernemingsraad verricht zijn taken in samenwerking met de Sicherheitsausschuss en/of de Arbeitsschutzausschuss. De raad is dus niet het enig bevoegde orgaan op dit terrein.

De Sicherheitsausschuss is samengesteld uit Sicherheitsbeauftragten. Dit zijn ook geen werknemersvertegenwoordigers in de enge zin van het woord (gekozen vertegenwoordigers, maar gespecialiseerde werknemers op het gebied van veiligheid en gezondheid. Een Beauftragte moet worden aangewezen, door de werkgever, in ondernemingen met meer dan 20 werknemers. Zijn er meer dan drie Beauftragten dan vormen zij een Sicherheitsausschuss (170). Wanneer er op grond van de Arbeitssicherheitsgesetz een Arbeitsschutzauschuss (een commissie waarin ook de deskundigen binnen het bedrijf participeren, zoals de bedrijfsarts en de veiligheidskundige) verplicht is gesteld, vervalt de verplichting tot instelling van een Sicherheitsausschuss (171). Beide commissies zijn verplicht overleg te voeren met de Betriebsrat over alle onderzoeken en vraagstukken die samenhangen met arbeidsbescherming of ongevallenpreventie. Bovendien hebben de leden van de ondernemingsraad niet alleen het recht, maar zelfs de plicht deel te nemen aan de maandelijkse besprekingen van de werkgever met de Sicherheitsbeauftragten en de Sicherheitsausschuss of de Arbeitsschutzausschuss. Zij hebben recht op alle informatie die uit onderzoeken van de Beauftragten, ofwell de commissies naar voren is gekomen.

Sicherheitsbeauftragten en de commissies hebben binnen de medezeggenschapsregelingen de taak de ondernemingsraad op het gebied van veiligheid en gezondheid een steuntje in de rug te geven en van de nodige informatie te voorzien, zodat deze zijn beslissingen kan nemen met inachtneming van die informatie (172). Zelf hebben deze organen geen beslissingsbevoegdheid (173).

Naast deze permanente commissies kan de ondernemingsraad taken aan door hem zelf ingestelde commissies delegeren, althans voorzover hij daartoe bevoegd is. De delegatiebevoegdheid kent zijn beperkingen; de ondernemingsraad behoudt namelijk altijd zelf de bevoegdheid bedrijfsovereenkomsten (Betriebsvereinbarungen) te sluiten met de ondernemer. Deze beperking wordt gemotiveerd met de vergaande normatieve werking van die overeenkomsten (174).

170. De regeling is te vinden in paragraaff 719,720 Reichsversicherungsordnung.

171. Paragraaf 11 Arbeitssicherheitsgesetz.

172. G. Etzel, a.w. (noot 76), p. 198.

173. Men moet deze commissies niet verwarren met de deskundigen die zich met de bewuste onderwerpen bezighouden. Naast de Sicherheilsaussschuss kent de Duitse wetgeving (i.c. de Arbeitssicherheitsgesetz) vakikrachten die als deskundigen optreden.

174. K. Fitting, c.s., a.w. (noot 111), p. 390. 
De Duitse wetgeving heeft een zeer uitgewerkte structuur, die historisch gegroeid is. Daarin is zij niet uniek. Elders bestaan dergelijke specifieke werknemerscommissies of -controleurs inzake veiligheids- en gezondheidsaangelegenheden eveneens. De Engelse mijnbouw kende bijvoorbeeld al vroeg werknemersinspecteurs (175), en ook in Frankrijk bestond al een wettelijk voorschrift dat voorzag in een onafhankelijke gekozen veiligheidsgedelegeerde in de mijnen (176). Andere landen, als Nederland hebben dergelijke van oudsher ontstane organen niet of nauwelijks. Het bijzondere van Duitsland is echter dat de van oudsher bestaande organen vrijwel naadloos in de nieuwe structuren zijn ingepast.

De enige lid-staat waar de wettelijke basis voor medezeggenschap op arbeidsomstandighedengebied zo marginaal is, dat men praktisch kan spreken van afwezigheid van een regeling is Italië. De medezeggenschap in Italië inzake veiligheids- en gezondheidsaangelegenheden werd omstreeks het eind van de jaren zestig tot stand gebracht door acties van de werknemers zelf. Een tijd lang werd het Italiaanse systeem als hết grote voorbeeld van vrijwillige arbeidsverhoudingen voor andere West Europese landen gezien (177). De actieve opstelling van de werknemers vond mede haar oorzaak in de gebrekkige Italiaanse veiligheidswetgeving (178) en de zeer slechte situatie in veel bedrijven.

Een zeer minieme wettelijke basis voor medezeggenschap werd in 1970 gelegd. Artikel 9 van het werknemersstatuut schrijft voor de de werknemers gerechtigd zijn door middel van hun vertegenwoordigers toezicht te houden op uitvoering van wettelijke bepalingen die zien op de voorkoming van bedrijfsongevallen en beroepsziekten. Artikel 9 kent de vertegenwoordigers daarnaast het recht toe, de toepassing en de organisatie van alle maatregelen die erop gericht zijn de bescherming van de gezondheid te bevorderen te onderzoeken. Dit wetsartikel schrijft niet voor dat shop stewards en de vertegenwoordigers van artikel 9 per se in één persoon verenigd moeten zijn (179), echter in een deel van de arbeidsrechtelijke literatuur wordt wel aangenomen dat de vertegenwoordiging een recht is van de vakbonden (180).

In collectieve overeenkomsten is op verschillende wijze met de uitvoering van artikel 9 omgesprongen, waarbij shop stewards vaak de rol van vertegenwoordiger inzake veiligheids- en gezondheidsaangelegenheden op zich namen (181).

175. Zie R.W. Howells, a.w. (noot 150), p. 91.

176. Zie Th. Ramm, a.w. (noot 1), p. 246.

177. W Daübler, a.w. (noot 45), p. 490.

178. Voor een aantal gevaarlijke sectoren zijn op basis van een raamwet van 1955 decreten met betrekking tot het werken in gevaarlijke sectoren vastgesteld, waarvan de decreten om trent voorkoming van arbeidsongevallen ( 22 april 1956, no. 547) en dat met betrekking tot arbeidshygiëne (19 maart 1956, no 30) de belangrijkste waren. Slechts in enkele van de andere decreten waren (minimale) medezeggenschapswoorzieningen opgenomen.

179. G.M. Ambroso, Ambiente e sicurrezza del lavoro, Milano 1978, p. 54.

180. G.M.Ambroso, a.w. (noot 179), p. 57; S. Sciarra, a.w. (noot 44), p. 42.

181. S. Sciarra, a.w. (noot 44), p. 42 . 
De lid-staten van de Europese gemeenschap hebben allemaal op verschillende wijze een overleg- of onderhandelingsstructuur op ondernemingsniveau in hun wetgeving of in de praktijk opgenomen. De wijze waarop die vertegenwoordiging in de onderneming tot stand is gekomen en gereguleerd is verschilt sterk: de gedetailleerde wettelijke voorschriften van Duitsland en Nederland zijn nauwelijks vergelijkbaar met het praktisch geheel op vrijwilligheid gebaseerde Britse systeem. Wanneer men deze systemen op Europees niveau zou willen harmoniseren zouden deze uitersten tot elkaar gebracht moeten worden.

De vraag is dan wel of de verschillen materieel even groot zijn als zij op het eerste gezicht lijken. Kahn-Freund (182) meent van niet. Hij stelt dat "In (British, ES) trade union circles it is emphasized, not without reason if at times a little exaggeratedly, that the function of the German works councils is fully carried out by the shop stewards, without -from the British point of view- the oppressively gigantic legal apparatus of the works council system. Seen from Britain, the choice between the shop steward and the works council is the dilemma of choice between democracy and bureaucra$c y^{\prime \prime}$. Dit is een visie die volgens hem een overschatting is van de feitelijke verhoudingen mede wanneer men in aanmerking neemt dat de Britten negeren "the extent to which the works councils are the 'extended arm' of the trade unions".

Ten aanzien van de Duitse visie op het Britse shop steward systeem zegt hij: "Likewise, though there is a tendency in Germany to overrate the 'anarchic' element in shop steward organization", waarvan hij meent dat het deels op vooroordelen berust: "In general it (the shop steward system, ES) functions on the basis of routine, not laid down by the law, but nevertheless now supported by certain obligations on the employer which help to facilitate the activities of shop stewards and to protect them against discrimination particularly against discriminatory dismissal" (183).

Voor andere lid-staten geldt die vergelijkbaarheid m.i. sterker. De Deense samenwerkingscommissie die op vrijwillige basis geschoeid is en de Nederlandse ondernemingsraad die een wettelijke grondslag heeft, hebben qua bevoegdheden en werkwijze vrij veel van elkaar weg. De systemen hebben de mogelijkheid nog verder naar elkaar toe te groeien nu de wetgever steeds meer, zowel op eigen initiatief als gedwongen door Gemeenschapswetgeving verplicht is specifieke bevoegdheden in de wetgeving te implementeren en veelal ook gedwongen wordt de positie van de vertegenwoordigers door middel van wettelijke maatregelen te beschermen.

182. O. Kahn-Freund, Labour Law and Industrial Relations in Great Britain and West Germany, in Labour law and Industrial Relations: Building on Kahn-Freund (K.S. Wedderburn, R. Lewis, J. Clark, eds.), Oxford 1983, p.5-6.

183. O. Kahn-Freund, a.w. (noot 182), p. 6 . 
De mogelijkheid deel te nemen aan de medezeggenschap tussen vrijwillige systemen en systemen op wettelijke basis werschilt nogal. In beginsel hebben de systemen op vrijwillige basis als voorwaarde voor de deelneming aan de medezeggenschap in ondernemingen het vakbondslidmaatschap gesteld, voor het verkiezen van de deelnemers is dit niet altijd het geval. In lid-staten met een wettelijk systeem hebben meer werknemers de mogelijkheid om actief aan de medezeggenschap deel te nemen; echter ook hier zijn bepaalde categorieën werknemers uitgesloten. In veel gevallen zijn de uitgesloten werknemers degenen met een zwakke positie, die veel te winnen zouden hebben bij vertegenwoordiging in de onderneming.

In de jongere lid-staten is een deel van de ontwikkelingen, veelal na een periode van dictatuur en een daarmee gepaard gaande inperking van de vakbondswrijheid, op gang gekomen mede door invloed van de Europese Gemeenschap. In deze lid-staten heeft men in de regelingen de aansluiting gezocht bij de ontwikkelingen in de oudere lid-staten en de regelingen zoals voorgesteld in de verschillende ontwerprichtlijnen voor medezeggenschap op multinationaal niveau. Met name de Griekse Wet op de Ondernemingsraden is hier een voorbeeld van.

Twee niet te onderschatten tendenzen, met name in verband met mogelijke Europese regulering zijn de verschuiving van onderhandelingen van vakbonden op centraal niveau naar die van het niveau van de onderneming (184), en de tegelijkertijd bestaande neiging tot controle op de bevoegdheden van die onderhandelaars op ondernemingsniveau in sectoriële overeenkomsten of Centrale Akkoorden. In een aantal lid-staten waar de shop stewards tot dusver een relatief grote vrijheid genoten zijn meer bindende regelingen ten aanzien van die shop stewards op hoger niveau overeengekomen. Slechts Groot Brittannië is hier de uitzondering.

Wanneer de nationale regelingen worden aangelegd tegen de in hoofdstuk II besproken, ontwerprichtlijnen, met name het ontwerp vijfde richtlijn en het Vredeling-Richard voorstel, vallen een paar zaken op. Om te beginnen gaat het Vredeling-Richard voorstel voor wat betreft het toedelen van bevoegdheden aan werknemersvertegenwoordigers aanzienlijk minder ver dan de wetgeving of de praktijk van de lid-staten. Zelfs wanneer men constateert dat de meeste lid-staten geen medezeggenschap op concernniveau kennen, dan moet toch gesteld worden dat de informatie- en consultatiebevoegdheden van het Vredeling Richard voorstel ietwat mager aandoen, in het licht van het feit dat die lid-staten die wel medezeggenschap op concernniveau hebben, een uitgebreider scala van medezeggenschapsmogelijkheden kennen. Daarnaast geldt dat in andere lid-staten een uitbreiding van bewoegdheden met betrekking tot medezeggenschap bij concerns valt af te dwingen, door middel van collectieve overeenkomsten op hoger niveau.

184. M. Rodrigues-Piñero en S. Dell Rey Guanter, a.w. (noot 147), p. 83. 
Het ontwerp vijfde richtlijn, dat juist, door middel van al zijn alternatieven wel mogelijkheden lijkt te bieden tot participatiemogelijkheden, perkt echter de mogelijkheid om eenmaal verworven participatiebevoegdheden te gebruiken op concernniveau weer in, door zijn alternatieven zeer strak te koppelen aan de structuur van de vennootschap. Met name het gebruik van de collectieve overeenkomst die slechts kan worden gebruikt om én van de andere in het voorstel gegeven structuren te implementeren, laat weinig ruimte voor structuren, zoals deze in lid-staten als Italië en Groot Brittannië gegroeid zijn (185).

Het grote verschil tussen het Britse systeem en dat van het vasteland was dan ook lange tijd reden voor de Britse vakbonden om vierkant afwijzend te staan tegenover initiatieven voor medezeggenschapsregulering vanuit de gemeenschap. De beperkingen die de conservatieve regering sedert 1979 aan de vakbonden is gaan opleggen (186), heeft het Trade Union Congress in 1988 tot een herziening van het standpunt bewogen. Dit heeft geleid tot een meer positieve benadering van de Gemeenschapsvoorstellen (187).

185. Zie paragraaf II.4.1.B.

186. Jacobs spreekt van een abuse by abuse benadering, zie A.T.J.M. Jacobs, a.w. (noot 1.29), p. 89.

187. B. Napier, Gesellschaftliche und rechtliche Rahmenbedingungen für die Gewerkschaftsarbeit in Konzernen in Grossbritannien, Arbeitsrecht im Betrieb, 1989, p. 37. 
Bijlage bij tabel $\mathbf{I}$ : basis voor vertegenwoordiging in de verschillende lidstaten.

\section{Duitsland}

Betriebsrat - Betriebswerfassungsgesetz (BetrVG).

Sicherheitsbeauftragten zijn voorgeschreven in paragraaf 719 Reichsversicherungsordnung (RVO), de Arbeitsschutzausschuss is voorgeschreven in de Arbeitssicherheitsgesetz (ASiG).

Nederland

Ondernemingsraad - Wet op de Ondernemingsraden.

Arbocommissie - Arbeidsomstandighedenwet.

Frankrijk

CHSCT - L. 236-1 Code du Travail.

Comité d'entreprise - L. 431-1 Code du Travail.

Délegués de personnel - L. 421-1 Code du Travail.

Délegués syndicaux - L. 412-11 Code du Travail.

België

Ondernemingsraad - Bedrijfsorganisatiewet.

CVGVW - Wet van 10 juni 1952, betreffende de Veiligheid en Gezondheid van de arbeiders.

Syndicale vertegenwoordiging - CAO no. 5 van 24 mei 1971.

Luxemburg

Comité Mixte - Wet op de Comitê's Mixte van 6 mei 1974.

Personeelsgedelegeerden - Wet op de hervorming van de délegations du personnel van 18 meli 1979.

Spanje

Comité d'empresa - Artikel 62 Werknemerstatuut van 10 mei 1980.

Vakbondsvertegenwoordiging - Centrale Akkoorden van 15 maart 1983, 9 oktober 1984, en van 1985/86.

Delegados - Artikel 63 Werknemersstatuut van 10 mei 1980.

\section{Griekenland}

Veiligheidscomité - Wet no. 1568, van 18 oktober 1985.

Ondernemingsraad - Wet no. 1767,6 april 1988.

Vakbondsvertegenwoordiging - Greek Trade Union Democracy Act van 1 juli 1982.

\section{Portugal.}

Voorzien in Grondwet, invulling moet bij gewone wet. Ik heb niet kunnen achterhalen of uitvoeringswetgeving is aangenomen.

Vakbondsvertegenwoordiging - Decreetwetten nrs. 841-B van 7 december 1976 en $164-\mathrm{A}$ van 28 februari 1976.

Italië

Veiligheidsvertegenwoordigers - Werknemersstatuut, wet no. 300 van 20-51970 (artikel 9).

Shop stewards - Werknemersstatuut, wet. no. 300, 20-5-1970, (artikel 19) 
Denemarken

Samenwerkingscommissie - Samenwerkingsovereenkomst van 1986 tussen de federaties $L O$ en DA.

Veiligheidsvertegenwoordigers - Arbejdsmiljølovet van 1975 (wet no. 681.) Shop stewards - Centraal Akkoord van 1960.

Groot Brittanniè

Veiligheidsvertegenwoordigers - Health and Safety at Work Act 1974.

Ierland

Veiligheidsvertegenwoordigers - Safety in Industries Act 1980. 



\section{Het instrumentarium voor samenwerking en onderhandeling op} ondernemingsniveau in de lid-staten. (1)

\section{Inleiding}

De vertegenwoordigingssystemen in de EG lid-staten verschillen voor wat betreft het ontstaan en de mate van wettelijke regulering. Wanneer men ze bekijkt in het licht van een eventuele harmonisatie van wetgeving op communautair niveau is het de vraag hoe deze verschillen gekwalificeerd kunnen worden. Zijn ze zo essentieel, zoals Van Wulften Palthe onder aanhaling van Jacobs en Timmerman stelt, dat harmonisatie niet tot de mogelijkheden behoort (2)? Of zijn deze verschillen klein genoeg om wel voor harmonisatie in aanmerking te komen.

Het hangt er vanaf waar men naar kijkt. Van Wulfften Palthe baseert zijn stelling op een definitie die medezeggenschap in (en lidmaatschap van) bestuursorganen omvat. In dat geval kan men mogelijk de verschillen tussen de lid-staten als essentiëel kwalificeren. Dit kan echter veranderen wanneer alleen gekeken wordt naar die organen die in samenwerking met, of door onderhandelingen met de werkgever hun medezeggenschapsrechten witoefenen. Of de verschillen dan zo groot zijn dat zij als zo essentiëel moeten worden beschouwd dat harmonisatie onmogelijk is is mijns inziens nog maar de vraag. Een vraag die alleen beantwoord kan worden door naar het instrumentarium te kijken dat aan de vertegenwoordigers toekomt.

Medezeggenschapsinstrumenten zijn die instrumenten die werknemers en met name hun vertegenwoordigers kunnen gebruiken om besluiten van ondernemers te beïnvloeden. Ze zijn te rangschikken naar de mate waarin zij de werkgever kunnen belemmeren in zijn vrijheid besluiten te nemen of het beleid te bepalen.

1. Portugal zal in de volgende hoofdstukken buiten beschouwing blijven. Hoewel op basis van de wet blijkt dat met name onderhandelingsbevoegdheden bestaan was te weinig materiaal in andere talen dan het Portugees beschikbaar om an dit land een verantwoorde beschouwing te wijden.

2. J. van Wulffen Palthe, Nieuw raamwerk woor EG-Harmonisatie, De internationale CAO, Namens 1989 jrg. 4, afl. 4 p. 28, onder aanhaling wan L. Timmerman, 1992 en de medezeggenschap van werknemers, Kluwer seminars, 23/24 now. 1988 en A.T.J.M. Jacobs, Het Nederlandse CAO-recht bezien door een Europese bril, SMA 1988 p.244-253. 
Als minst vergaand kan het recht op informatie worden beschouwd. Op zichzelf is het recht niets meer dan een toegang tot informatie op basis waarvan de besluitvorming plaatsvindt. Daarmee is het een voorwaarde voor de uitoefening van de andere medezeggenschapsrechten. Het recht op informatie impliceert zelf echter ook een beïnvloedingsmogelijkheid, hoe indirect deze ook mag zijn. De werkgever die werknemers(vertegenwoordigers) moet informeren over de gang van zaken in een onderneming, geeft daarbij in veel gevallen impliciet een zekere motivering van de beslissing die hij wil nemen. Dit is met name het geval wanneer werknemers de ontsluiting van informatie tegen de zin van de werkgever kunnen afdwingen.

Vervolgens zijn er dan adviesrechten die een al wat sterkere beïnvloedingsmogelijkheid bieden. De werkgever die de werknemers over een bepaald onderwerp moet horen zal wellicht bij zijn besluitvorming rekening met die mening houden. Het kenmerk van consultatie is echter dat het geen wijziging brengt in de beslissingsbevoegdheid in de onderneming. Het recht op zich zelf houdt niets meer in dan de plicht voor de werkgever te horen hoe de werknemers of hun vertegenwoordigers over een voorgenomen besluit denken. Op het uiteindelijke besluit kunnen zij invloed uitoefenen, maar zij kunnen het niet tegenhouden. Consultatie als medezeggenschapsrecht impliceert verhoudingen tussen werkgevers en werknemers waarin werkgevers bereid zijn te luisteren naar werknemers en rekening te houden met en hun belangen, waarna zij na afweging van die belangen het juiste, sociaal én economisch, verantwoorde besluit kunnen nemen. Het weerspiegelt een zeker paternalisme.

Het adviesrecht wordt weer een stuk sterker wanneer de werknemers een zekere mate van druk kunnen uitoefenen. Indien de werkgever weet of vermoedt dat de werknemers, wanneer hun advies genegeerd wordt onrust zullen veroorzaken in de onderneming, ofwel door middel van het starten van een juridische procedure, ofwel door mobilisatie van andere werknemers om tot actie over te gaan, zal hij meer geneigd zijn rekening te houden met de wensen van werknemers, dan wanneer hij weet dat de werknemers niets zullen of kunnen ondernemen. De beïnvloedingsmogelijkheid van het recht op consultatie hangt dus in hoge mate samen met de andere mogelijkheden die de werknemers hebben hun wensen kracht bij te zetten.

De meest vergaande instrumenten zijn die waar de werkgever zonder de medewerking van de werknemers(vertegenwoordigers) geen besluit kan nemen of een beleid kan vaststellen. Hiertoe kan het recht op instemming worden gerekend. Voor dit instrument geldt dat besluiten worden genomen door medewerking van de werknemers-vertegenwoordigers. De kracht van het instemmingsrecht is overigens afhankelijk van de mogelijkheden die de werkgever heeft de instemming, indien de werknemers(vertegenwoordigers) deze niet wensen te geven, door een ander orgaan te laten vervangen. 
Het recht op onderhandelen kan eenzelfde resultaat bieden als het instemmingsrecht. De werknemers(vertegenwoordigers) kunnen over de te bespreken materie met de werkgever contracteren. De kracht van het recht hangt echter af van de beslissingsvrijheid van de werkgever indien het niet tot een overeenkomst komt. Is hij dan geheel vrij zelf te besluiten, dan is het onderhandelingsrecht weinig meer dan een consultatierecht. Wanneer er echter een plicht bestaat om over de te regelen materie tot een overeenkomst moet worden gekomen, ligt het onderhandelingsrecht al zeer dicht tegen een instemmingsrecht aan.

Kan men nu het recht om binnen de onderneming collectieve overeenkomsten af te sluiten, kortom het erkende recht van "collective bargaining" op ondernemingsniveau, vergelijken met een recht als het instemmingsrecht? In de Britse visie worden ze als twee verschillende, veelal tegenover elkaar staande grootheden beschouwd. Instemming door ondernemingsraden hoort thuis in een geïnstitutialiseerd model, waaraan wetgeving ten grondslag ligt, "bargaining" ontstaat in een situatie van vrijwilligheild (3). Wanneer men echter naar de Deense situatie kijkt blijkt dat die tegenstelling helemaal niet zo natuurlijk is. Daar bestaat in een vrijwillig systeem de samenwerkingscommissie die instemmingsrechten heeft. Een deel van de leden hebben echter als shop steward ook onderhandelingsbevoegdheden.

Erkend moet natuurlijk worden dat het recht op onderhandelen een andere achtergrond heeft, dan een instemmingsrecht bij te nemen besluiten. $\mathrm{Er}$ is een ideologisch verschil tussen het meebeslissen met de ondernemer waarbij belangenafweging binnen de onderneming, centraal staat en onderhandelen met de ondernemer waarbij belangenbehartiging het belangrijkst is. Echter, ook in het overleg met een ondernemer over een voorgenomen besluit zullen belangen van werknemers door ondernemingsraadsleden wel eens behartigd moeten worden, als de werkgever ze op een onjuiste wijze afweegt, en anderzijds zullen ook onderhandelaars er niet altijd omheen kunnen afwegingen te maken tussen werknemers- en werkgeversbelangen, om een zo gunstig mogelijk resultaat te bereiken.

Naast dit ideologische verschil, hebben beide rechten verschillende kenmerken. Om te beginnen is daar de wijze waarop de uitkomst in de besluitvormingsfase beînvloed kan worden. Onderhandelen impliceert op zich zelf al een proces van geven en nemen, van hier een punt verliezen om het ergens anders te winnen. In een situatie waarin de werknemers

3. Kahn-Freund onderscheidt "the land of company law" van the land of collective bargaining" als twee wolstrekt verschillende bases voor industriële democratie, hoewel ook hij de beperkingen van collective bargaining heel goed ziet, met name waar het gaat om de transnationalle dimensie: "at the International level we have management, but neither government nor effective union power. The entire basis of our thinking of collective labvour relations and collective labour law, is destroyed by this devellopment" ${ }^{\text {" }} \mathrm{O}$. KahnFreund, A Lawyers Reflections on Multinational Corporations, Journal of the Industrial Relations Society, 1972, p. 351 ev.. 
zwak staan zullen zij meer concessies moeten doen, dan zij in feite zouden willen, om toch maar een regeling met cen zekere aanvaardbaarheid te verkrijgen. Bij een zuivere toepassing van het instemmingsrecht hoort daarentegen geen onderhandelingsproces en heeft dit recht meer het karakter van de mogelijkheid tot slikken van of stikken in een kant en klaar voorstel. Het instemmingsrecht binnen een wettelijke constellatie kan echter in de praktijk tot onderhandelingen leiden: de mogelijkheid tot weigering van de instemming kan gebruikt worden om veranderingen in het voorgenomen besluit te bewerkstelligen (4). Anderzijds hangt de mate van wijzigingsmogelijkheden af van de vorm waarin een instemmingsrecht gegoten is. De kans dat meer dan marginale wijzigingen in de praktijk niet mogelijk zijn is niet denkbeeldig.

Daarnaast impliceert onderhandeling een initiatiefrecht van werknemerszijde, hetgeen natuurlijk binnen een wettelijke regeling ook aan een ondernemingsraad kan toekomen, ook al is dat niet direct gebonden aan het instemmingsrecht. Een ander en zeer belangrijk punt is dat het instemmingsrecht gebonden is aan datgene dat de wet toestaat terwijl onderhandelen in beginsel over alles mogelijk is. Dat geldt echter alleen zolang onderhandelingen op ondernemingsniveau niet aan beperkingen (ofwel wettelijk, ofwel door "hogere" collectieve contracten) gebonden zijn.

Anderzijds levert het zuivere onderhandelingsrecht minder op dan een instemmingsrecht kan doen: wanneer de werkgever niet wil onderhandelen, of vertegenwoordiging en werkgever niet tot overeenstemming kunnen komen, kan de ondernemer rechtsgeldig een besluit nemen, ook al is de werknemersvertegenwoordiging daartegen. Dit kan in beginsel alleen doorbroken worden wanneer een werkgever de (wettelijke) plicht heeft met de vertegenwoordigers te onderhandelen, zoals dit in Frankrijk in 1982 in de wet is opgenomen (5), met daar bovenop een verbod om eenzijdig een besluit te nemen wanneer de onderhandelingen niet slagen.

Bij het wegen van de laatste drie beïnvloedingsmogelijkheden kan het volgende worden vastgesteld. Het gaat bij alledrie om de mogelijkheid van beïnvloeding van besluiten. Vertegenwoordigers die alleen geconsulteerd moeten worden hebben in beginsel geen mogelijkheid een besluit tegen te houden. Dit is alleen anders wanneer een mogelijkheid tot beroep tegen een van het advies afwijkend besluit openstaat (6). Vertegenwoordigers met een instemmingsrecht kunnen een besluit tegenhouden, onderhandelingen

4. Het op deze wijze gebruiken van een aan de ondernemingsraad toekomend recht (het is trouwens niet alleen beperkt tot instemmingsrechten, ook en met name gesanctioneerde adviesrechten kunnen op deze wijze als pressiemiddel gebruikt worden) is niet slechts een theoretische mogelijkheid: zie A. Teulings, Prominenten en volgers, Tijdschrift voor Arbeidsvraagstukken, 1985, p. $51 \mathrm{ev}$.

5. M. Despax, La place de la convention d"enterprise dans le syste'me conventionel, Droit Social $1988^{\text {, p. }} 9$.

6. Artikel 26 WOR (Nederland) biedt 20 'n mogelijkheid. Een besluit dat van het advies afwijkt kan bij de Ondernemingskamer een willekeurtoetsing ondergaan. 
kunnen leiden tot een gewijzigde regeling. Het instemmingsrecht is op zichzelf sterker dan het onderhandelingsrecht, aangezien in beginsel de werkgever niet eenzijdig een besluit kan nemen tegen de zin van de werknemersvertegenwoordigers. Dit gaat alleen niet op, wanneer het onderhandelingsrecht eveneens voorzien is van een dergelijke blokkade, of wanneer de werkgever de niet-instemming gemakkelijk kan doorbreken (bijwoorbeeld door middel van een gemakkelijk te verkrijgen vervangende instemming van een ander orgaan). Dit leidt tot de conclusie dat instemmingsrecht enerzijds, en onderhandelingsrecht anderzijds weliswaar verschillende instrumenten zijn, maar dat de wijze waarop de rechten uitgewerkt worden, zoveel overeenkomsten (kunnen) vertonen dat het gezamenlijk behandelen en het vergelijken ervan, kan leiden tot een weging van de verschillende rechten in de lid-staten.

In dit hoofdstuk zullen de bovengenoemde instrumenten behandeld worden, zowel meer in het algemeen, als voor wat hun rol inzake veiligheids- en gezondheidsaangellegenheden betreft. De behandeling zal geschieden in samenhang met de mogelijkheden voor de werknemers hun rechten af te dwingen. Ik begin met het informatierecht. De behandeling van de rechten op consultatie, instemming en onderhandeling zal als volgt geschieden: eerst bespreek ik het consultatierecht, voorts het instemmingsrecht in de verschillende lid-staten, dat op de wet of een Centraal Akkoord gebaseerd kan zijn, daarna komt het onderhandelingsrecht aan de orde. Dit kan zowel op de wet of Centraal Akkoord als een in de praktijk gegroeide vrijwillige basis hebben.

Aan de mogelijkheden de verschillende rechten af te dwingen zal een aparte paragraaf gewijd worden. Behalve de aanwezigheid van de mogelijkheid maatregelen af te dwingen is het ook van belang hoe deze mogelijkheid in de praktijk geregeld is. Een eenvoudige en vooral snelle procedure bij een arbiter kan meer bergen verzetten, dan met alle rechtswaarborgen omgeven maar niettemin dure en ingewikkelde procedures. Ook andere wijzen om de medezeggenschapsrechten kracht bij te zetten zullen aan de orde komen.

Naast deze instrumenten die algemeen bruikbaar zijn, zal aantal instrumenten die meer specifiek in het bellang zijn waar het om veiligheids- en gezondheidsaangelegenheden gaat, zoals het recht op toezicht, het recht deskundigen te raadplegen, of de arbeidsinspectie in te schakelen in het volgende hoofdstuk behandeld worden.

\section{Het recht op informatie}

Het recht op informatie kan ten opzichte van de andere instrumenten beschouwd worden als een van de meest fundamentele rechten. Zonder informatie is immers adequate uitoefening van het recht geconsulteerd te worden, het recht op instemming, het recht te onderhandelen en toezicht 
nauwelijks mogelijk (7). Daarnaast heeft het recht op informatie wel degelijk een meer directe invloed op het beleid in de onderneming. Wanneer een werkgever verplicht is regelmatig en incidenteel, al dan niet op verzoek, informatie over te nemen beslissingen en te voeren beleid aan de werknemers te verschaffen, zal die werkgever een zekere zorgvuldigheid willen en moeten betrachten ten aanzien van de te geven informatie. Anders loopt hij het risico last te krijgen met die werknemers. Zorgvuldigheid bij het verschaffen van informatie kan en zal soms leiden tot een grotere zorgvuldigheid bij het afwegen in de besluitvorming (8).

Het recht op informatie valt uiteen in drie componenten. De eerste is de verschaffing van informatie door de werkgever aan de werknemersvertegenwoordigers, de informatie waar het om gaat, de wijze waarop en de gebieden die het betreft. Het verschaffen van informatie door de werkgever kan zowel regulier geschieden, door middel van het opstellen van (jaarlijkse) plannen en periodieke rapportages aan de werknemersvertegenwoordigers, als incidenteel ten aanzien van bijzondere gebeurtenissen of besluiten. De tweede component is de mogelijkheid voor de werknemersvertegenwoordigers tot het afdwingen van informatie bij de werkgever, indien nodig, via arbiter of rechter. De derde is de zwijgplicht van vertegenwoordigers met betrekking tot verkregen informatie ten opzichte van derden. Hiermee hangt de mogelijkheid voor andere werknemers om toegang te verkrijgen tot de informatie samen. De zwijgplicht van de vertegenwoordigers zal in het algemeen ook ten aanzien van hen zal gelden.

In de lid-staten waar de medezeggenschap een wettelijke basis heeft, voorziet die regeling in het algemeen ook in de bijbehorende informatierechten. In lid-staten waar medezeggenschap een zaak is van de sociale partners kan een wettelijke regeling de grondslag bieden, maar kan het recht ook geregeld zijn in Centrale Akkoorden of sectoriële overeenkomsten. Aan het recht op informatie inzake veiligheids- en gezondheidsaangelegenheden ligt praktisch overal een wettelijke regeling ten grondslag.

De ondernemingsraden van Nederland, Duitsland, Spanje en Frankrijk hebben een recht op die informatie van de werkgever die de raden nodig hebben voor de uitoefening van hun taak. In Nederland kunnen ondernemingsraden die informatie vragen bij de werkgever, deze is in beginsel verplicht te antwoorden (9). Dat antwoord mag echter geweigerd worden indien de vraag te algemeen is gesteld (10). De algemene verplichting is in de WOR aangevuld met een gedetailleerde regeling welke informatie op

7. Zie o.m. T.K. 1977/78, wo. 14 497, Voorlopig verslag, p. 2; A.J.C.M. Geers, Recht en humanisering van de arbeid, Deventer 1988 , p. 12.

8. Zie ook G.J.W. Arendsen de Wolff, De informatieplicht van de onderneming, Deventer 1976, p. 41.

9. A.F.M. Dorrestein, M. Verhorst, Het algemene informatierecht van artikel 31 lid 1 WOR, TVVS 1982, p. 191.

10. Afd. Rp. R.v.S., 7 februari 1983, Rechtspraak medezeggenschapsrecht 1984, no. 55. 
welk tijdstip in ieder geval moeten worden verstrekt. Het gaat hier met name om informatie over de werkzaamheden en resultaten, begroting, investeringen en personeelsbezetting en het sociaal beleid. Zowel op grond van WOR (11) als op grond van de Arbeidsomstandighedenwet (12) heeft de ondernemingsraad, dan wel de Arbocommissie, recht op informatie ten aanzien van veiligheid, gezondheid en welzijn. Deze informatie wordt verstrekt in het overleg tussen Raad of commissie en werkgever. Daarnaast moet de werkgever (ingeval hij daartoe aangewezen is) een jaarverslag maken, met daarin informatie op de bovengenoemde gebieden. Dit jaarverslag kan bij de informatie die over de personeelsbezetting aan de ondernemingsraad gevoegd worden.

De Franse Code du Travail geeft eveneens een algemene informatieplicht door voor te schrijven dat de werkgever de ondernemingsraad voorziet van al het materiaal dat nodig is zijn functie uit te oefenen (13). Dit recht omvat met name economische informatie waaronder de organisatie van de arbeid en produktietechnieken begrepen moeten worden (14). Er wordt hierbij onderscheid gemaakt tussen informatie die periodiek verstrekt moet worden, bijvoorbeeld in jaarlijkse rapporten en informatie die incidenteel verstrekt moet worden, wanneer het "belang van de organisatie" erbij betrokken is (15). Op sociaal gebied heeft het comite recht op zeer uitgebreide informatie over alle activiteiten van de werkgever, als over de financiering van die activiteiten. Ook resultaten van verrichte onderzoeken vallen hieronder. Daarbij heeft de ondernemingsraad een bevoegdheid toezicht te houden op de gespecialiseerde diensten als de medische en sociale dienst van de arbeid. Uit dit controlerecht vloeit een recht op informatie voort (16).

Op veiligheids- en gezondheidsgebied heeft de CHSCT, naast de ondernemingsraad (17), recht op alle informatie over maatregelen waarover hij geconsulteerd moet worden. Bovendien heeft de CHSCT een bevoegdheid toezicht te houden op de toepassing van de maatregelen, waaruit een verdergaand recht op informatie voortvloeit ten aanzien van onderzoeksresultaten op het gebied van beroepsziekten en ongevallen. Daar deze contrôlebevoegdheden de CHSCT de mogelijkheid bieden zelf onderzoeken

11. Artikel $31 \mathrm{~b}$ WOR.

12. Artikel 14 Arbowet.

13. Uitgebreid hierover B. Teyssié, Les restructurations, le rôle du comité d'entreprise, Droit Sacial 1989 p. 23-31.

14. Voorts valt daar informatie over de economische en financiële toestand wan en ontwikkelingen in de onderneming onder (CdT art. L.432-4).

15. Hierbij wordt met name gedacht aan informatie over zaken die wijzingingen in de interne organisatie van de onderneming, dan wel wijziging in de eigendom van de onderneming brengen.

16. G.H. Camerlynck, G. Lyon-Caen, J. Pélissier, Droit du Travail Paris 1984, p.768.

17. Over de problemen van de verschillende wertegenwoordigingssystemen nasst elkaar: $J$, Savatier, Le désignation des représentants du personnel au CHSCT, Droit Social 1989, p. 646. 
te verrichten en enquetes te houden, is de commissie niet alleen afhankelijk van de werkgever om aan informatie te komen.

De Duitse BetrVG kent de ondernemingstaad zowel een algemeen informatierecht toe ter uitoefening van zijn taak, als bijzondere informatierechten op basis van een aantal toegespitste bepalingen. Het verstrekken van informatie wordt in Duitsland beschouwd als onderdeel van de samenwerking tussen ondernemingsraad en werkgever (18). De informatieplicht omvat zowel algemene als bijzondere rechten op informatie en onderricht zowel op economisch, technisch alls sociaal gebied (19). Ook hebben ondernemingsraadsleden het recht op de informatie van Sicherheitsbeauftragte en de, binnen de onderneming werkzame, deskundigen op het gebied van veiligheid en gezondheid.

Andere werknemers met informatierechten zijn de leden van de Wirtschaftsausschuss, de Sicherheitsbeauftragten of de leden van de Sicherheitsausschuss dan wel Arbeitsschutzausschuss voor zover zij informatie voor hun taakuitoefening nodig hebben. Deze informatie wordt, indien nodig, doorgegeven aan de ondernemingsraad. Deze kan ten aanzien van de Ausschusse rechten op informatie doen gelden. Het niet of niet naar waarheid verstrekken van informatie door de werkgever kan in een aantal gevallen een strafbaar feit opleveren, dat beboet kan worden met een bedrag van ten hoogste 20.000 mark.

Het Spaanse Werknemersstatuut kent in tegenstelling tot de bovenstaande regelingen geen algemene verplichting tot het verschaffen van informatie. Wel is een recht op specifieke informatie in het Statuut opgenomen. De Spaanse ondernemingsraad heeft een recht op periodiek te verstrekken informatie van de werkgever, dat onder meer omvat: de algemene gang van zaken in de bedrijfstak waartoe de onderneming behoort, financiêle resultaten, en de beleidslijjnen voor de toekomst (20). Daarnaast moet de ondernemingsraad ingelicht worden over het soort arbeidscontracten die in de onderneming gebruikt worden en heeft hij toegang tot de documenten die betrekking hebben op ontslagen, disciplinaire maatregelen tegen werknemers, statistieken over ziekteverzuim, ongevallen, en beroepsziekten (21) en veranderingen van eigendom van de onderneming.

In België heeft de ondernemingsraad recht op informatie op zowel economisch als sociaal gebied. De economische informatie betreft de jaarrekening, overheidssteun, onderdelen van het tewerkstellingsbeleid (bv. brugpensioen), collectieve ontslagen en wachtgelden, arbeidswoorwaarden en

18. Zie. K. Fitting, F. Auffarth, H. Kaiser, F. Heither, Betriebsverfassungsgesetz, München 1987, p. 885.

19. Het gaat hier om de planning op deze gebieden, de personeelsplanning en maatregelen op het gebied van beroepsopleiding, maatregelen die individuele werknemers betreffen, het onderricht van de Wirtschaftsausschuss en het jaarverslag van deze commissie.

20. Artikel 64 Werknemersstatuut (Spanje).

21. Artikel 64 lid 7 Werknemersstatuut. 
de arbeidsorganisatie, en personeelsbeleid. De informatie die betrekking heeft op het sociaal beleid omvat de gebieden van het arbeidsreglement, maatstaven voor ontslag en wederindienstneming, en het beheer van sociale werken (22). Daarnaast heeft de ondernemingsraad recht op informatie betreffende de invoering van nieuwe technologieën. De bevoegdheid tot toezicht houden op de uitvoering van industriële en sociale wetgeving impliceert een informatierecht dat het terrein van deze bevoegdheid bestrijkt.

Het comité voor veiligheid, gezondheid en verfraaiing van de werkplaatsen heeft het recht op het inwinnen van informatie op veiligheidsgebied en over het werk van de gespecialiseerde diensten. De werkgever heeft de verplichting het comité van al de nodige informatie te voorzien. Dit impliceert inzage in alle noodzakelijke documenten en rapporten.

In Luxemburg heeft de ondernemingsraad recht op een halfjaarlijkse rapportage omtrent de algemene economische gang van zaken in de onderneming, de personeelsdelegatie heeft recht op een jaarlijkse rapportage. Aan de ondernemingsraad moet bovendien specifieke informatie voorafgaand aan te nemen beslissingen worden verstrekt. Hierbij gaat het ook om veiligheids- en gezondheidsaangelegenheden (23).

De Griekse wet verplicht de ondernemer zowel tot de jaarlijkse verstekking van informatie omtrent dié economische onderwerpen, die de werknemers aangaan (24), de introduktie van nieuwe technologieën, veiligheids- en gezondheidsaangelegenheden en overwerk, als incidentele verstrekking in verband met een te nemen besluit. Ook kan de ondernemingsraad om informatie verzoeken. In dat geval heeft de werkgever 20 dagen de tijd om hierin te voorzien. De Veiligheidscommissie heeft recht op aanvullende specifieke informatie met betrekking tot veiligheids-en gezondheidsaangelegenheden. Informatie die betrekking heeft op in het overleg aan de orde komende zaken moet drie dagen voor het overleg ter beschikking gesteld worden.

In Groot Brittannië, heeft de informatieverstrekking een wettelijke basis. Deze geeft slechts een beperkt recht op algemene informatie (25), en alleen voor erkende bonden (26). Britse ondernemers zijn verplicht informatie te verstrekken op grond van de Employment Protection Act 1975 op verzoek van de shop stewards, maar alleen wanneer het van belang is voor de

22. Uitgebreid hicrover R. Blanpain, Belgium in International Encyclopedia for Labour Law and Industrial Relations, (supplement 93) Deventer 1988, para. 261, 281.

23. C. Docksey, Employee Information and Consultation Rights in the Member States of the European Communities, Comparative Labor Law, Fall 1985, p. 62-63.

24. Hieronder worden de veranderingen in juridische status van de onderneming of veranderingen in de produktie, financiële zaken, economische vooruitzichten.

25. Hierover uitgebreid: O. Kahn-Freund, Labour and the Law, (second edition), London 1977 , p. $85-91$.

26. J.R. Bellace, H.F. Gospel, Disclosure of Information to Trade Unions, A Comparative Perspective, International Labour Review, Vol. 122 no.1. 1983, p. 65. 
collectieve onderhandelingen of wanneer het in overeenstemming met de praktijk van goede industriële verhoudingen zou zijn om de informatie te verstrekken woor het doel van de onderhandelingen (27). Bovendien zondert de EPA 1975 informatie waarvan de verstrekking een substantieel nadeel aan de onderneming van de werkgever zou toebrengen, van haar werking uit (28).

De bewoordingen van de wet hebben tot gevolg dat de vakbonden of hun vertegenwoordigers moeten aantonen de door hen verlangde informatie in verband met (komende) collectieve onderhandelingen nodig te hebben. De interpretatie die het Central Arbitration Committee (CAC) hieraan geeft, is niet ruim (29). Daarnaast geeft de EPA nog andere beperkingen waardoor informatie niet aan de shop stewards verstrekt mag worden (30). Deze wettelijke beperkingen worden zo ruim uitgelegd dat daarmee wel een erg zware last op het recht op informatie is komen te liggen (31). Bellace en Gospel stellen dan ook dat door de bewoordingen en de wijze waarop deze geïnterpreteerd zijn, de directe invloed die de wet heeft uitgeoefend, klein is geweest, ook al kan dat voor de indirecte invloed anders liggen (32).

Op het gebied van veilligheid en gezondheid is het informatierecht uitgebreider. Veiligheidsvertegenwoordigers hebben recht op uitgebreide informatie van de zijde van de werkgever, op basis van de Safety Representatives and Safety Committees Regulations 1977 en de HSWA 1974, inclusief het recht zelf inspecties en controles te verrichten. De wettelijke beperkingen zijn echter gelijk aan die, die voor informatieverstrekking aan de vakbonden gelden (33). Het verschil tussen deze twee regelingen op het gebied van informatieverstrekking is vermoedelijk gelegen in de visie dat de vakbonden overwegend onderhandelen met de werkgever en veiligheids-

27. De wet is in 1977 gevolgd door een code of practice (ACAS Disclosure of Information to Trade Unions for Collective Bargaining Purposes, London HSMO, 1977) van de Advisory Conciliation and Arbitration Service (ACAS) die een imterpretatie en aanbevellingen ten aanzien wan de wet biedt.

28. Section 18 (1)(c) EPA 1975.

29. In de zaak betreffende dreigende ontslagen waarin de vakbond informatie wille hebben over een vervroegde pensioenregeling van Kodak, omdat deze relevant kon zijn voor de ontslagen (ontslagen die door Kodak ontkend werden) verkreeg de vakbond deze informatie niet, omdat geen materiaal kan worden opgeeist, waarvan het verband met de onderhandelingem alleen maar bestond uit hypotheses van de vakbond (Kodak ws ASTMS, 82/16, Industrial Relations Review and Reports, January 1983, p. 288).

30. Informatie is vertrouwelijk wanneer het de nationale veiligheid of een individuele werknemer betreft, of wanneer door de werkgever wordt gesteld dat met het verstrekken het vertrouwen van een derde wordt geschaad. Bovendien hoeft een werkgever de informatie niet te verstrekken indien het de onderneming in moeilijkheden zou kunnen brengem, dan wel de plamen voor de toekomst zou kunnen bemoeilijken.

31. Bij de privatisering van schoonmaakwerkzaambeden op het Ministerie van Defensie bleken offertes van schoonmakbedrijven tot de vertrouwelijke informatie te behoren. Vgl. Civil Service Union ws CAC [1980], Industrial Relations Law Reports, p. 274).

32. J.R. Bellace en H.F. Gospel, a.w. (noot 26), p. 66.

33. B. Perryns, Trade union law, London 1985, p. 245. 
vertegenwoordigers veel meer een taak tot samenwerking met die werkgever hebben.

In Denemarken, Italië en Ierland ontlenen werknemersvertegenwoordigers hun informatierechten aan collectieve contracten en niet in de eerste plaats aan een wettelijke bepaling.

In Denemarken is deze materie geregeld in een Centraal Akkoord. In een algemeen recht op informatie is alleen voorzien voor de leden van en in het kader van de samenwerkingscommissie (34). Dit betekent dat de shop steward, die lid is van de commissie deze informatie uiteraard wel krijgt; echter in het kader van zijn taak als shop steward op zichzelf heeft hij geen algemeen informatierecht. Uit de taakstelling van de shop steward, en de in het Centraal Akkoord gebezigde terminologie, waaruit blijkt dat de shop steward overwegend als bemiddelaar wordt gezien, kan men wel afleiden dat deze een partieel informatierecht heeft dat ziet op een goede uitoefening van zijn vertegenwoordigende taken. Dit laatste valt ook af te leiden uit de bepaling dat de partijen bij de overeenkomst verplicht zijn tot actieve medewerking aan de uitvoering hiervan. Het weigeren van de benodigde informatie door de werkgever is een schending van die bepaling (35).

De samenwerkingscommissie heeft recht op informatie op het gebied van arbeidsomstandigheden, het economisch beleid en het gebied van nieuwe technologie. Op dit laatste gebied is het recht op informatie sedert de gewijzigde samenwerkingsafspraak van 1986 aanzienlijk uitgebreid. Er is een gedetailleerde regeling opgenomen die erin voorziet dat de informatie over nieuwe technologie (zowel voor het gebruik bij de produktie van de onderneming als in de administratie) volledig is, en zo tijdig wordt verstrekt dat deze in alle fasen van het besluitvormingsproces betrokken kan worden. De veiligheidsvertegenwoordiger heeft een beperkt recht op informatie, $\mathrm{nl}$. alleen voor zover deze betrekking heeft op zijn taakuitoefening als zodanig.

De Italiaanse shop stewards en de "consigli di fabricca" ontlenen hun recht op informatie veeleer aan de verschillende collectieve overeenkomsten dan aan de wet. De bepalingen omtrent de vakbondsactiviteiten van het Werknemersstatuut voorzien weliswaar in enkele faciliteiten om deze uit te oefenen, maar daar behoort geen wettelijk recht op informatie toe. Het Centraal Akkoord van 1976, een raamovereenkomst, gaf een recht op informatie aan de vakbonden om meer rationele, verantwoordelijke en coöperatieve onderhandelingen te bewerkstellingen, maar deze bepaling is slechts in enkele grote ondernemingen ten volle gebruikt. De in het tripartite Centraal Akkoord van 1983 overeengekomen bepaling, dat een recht op informatie bij de wet geregeld zou worden, heeft tot dusverre niet

34. New Coöperation Agreement EIRR, 151 August 1986, p. 26.

35. R. Nilsen, Laerebog i Arbejdsret, Kopenhagen 1987, p. 102. 
tot wetgeving geleid (36). Dit betekent overigens niet dat in het geheel geen informatie aan de vakbonden wordt verstrekt. Zowel periodieke als incidentele informatie wordt, voordat onderhandelingen over te nemen besluiten beginnen, verstrekt met betrekking tot een groot aantal onderwerpen (37). De wettelijke basis daarvoor is echter slechts het raamwerk wan artikel 19 van het Werknemersstatuut, ondersteund met name door het verbod van anti-syndicaal gedrag uit artikel 28 Werknemersstatuut.

Voor wat betreft het recht op informatie inzake veiligheid en gezondheid, biedt artikel 9 Werknemersstatuut een iets steviger wettelijke basis waarin een recht op contrôle is opgenomen, waarvan wel betoogd wordt dat het een een impliciet recht op informatie in zich bergt (38). In een aantal collectieve overeenkomsten zijn bepalingen opgenomen over de omvang van de informatie die verstrekt moet worden aangaande veiligheid en gezondheid, met name voor gevaarlijke stoffen die gebruikt worden of gaan worden, en voorgenomen investeringen ter verbetering van de werkomgeving. Voorts bestaan in collectieve overeenkomsten regelingen over risicodocumentatie, bestaande uit register inhoudende onderzoeksresultaten over risicofactoren in de arbeidsomsgeving, en statistische gegevens over ziekteverzuim. Resultaten van medische onderzoeken, beroepsziekten en ongevallen, en de persoonlijke gegevens van werknemers ten aanzien van de beroepsrisicos die zij lopen liggen ter inzage voor de werknemersvertegenwoordigers. Een kopie van de persoonlijke gegevens moet aan de betreffende werknemer zelf worden verstrekt (39).

Ook Ierland heeft geen expliciete wettelijke basis voor verstrekking van algemene informatie. Aanzetten voor een Code of Practice en een Centraal Akkoord omtrent verstrekking van informatie zijn omstreeks 1980 op niets uitgelopen (40). Informatie wordt in het algemeen verstrekt op basis van wat in collectieve overeenkomsten is geregeld. De Safety in Industries Act 1980 biedt wel een basis voor de verstrekking van informatie, hoewel deze niet erg uitgebreid is. De individuele werknemer heeft slechts een recht op informatie bij tewerkstelling aan machines. De veiligheidscommissies (of vertegenwoordigers) hebben recht op een (schriftelijke) verklaring over het veiligheidsbeleid (safety statement). Deze verklaring moet worden opgesteld in alle ondernemingen met meer dan tien werknemers. Indien geen commissie of vertegenwoordiger aanwezig is, hebben alle werknemers recht op deze verklaring. In het "safety statement" moet in elk geval informatie zijn opgenomen omtrent de bescherming van en de taken van werknemers die zij in samenwerking met de werkgever moeten uitvoeren. Voorts bevat

36. T. Treu, Fifty Years of Italian Labor Law in Fifty Years of Labour Law and Social Security, Deventer 1986, p. 137.

37. C. Docksey, a.w. (noot 23), p. 37, 60,61. 38. G. Zangari, Rappresentanze dei lavoratori e tutela delle salute, Il diritto del laworo 1973,
no. 1 p. 224 .

39. Vgl. J.K.M. Gevers, Zeggenschap van werknemers inzake gezondheid en veiligheid in bedrijwen, Deventer 1982 , p.151 ev. 40. M. Redmond, Ireland, in Encyclopedia for Labour Law and Industrial Relations,
(supplement 71 ), Deventer 1986, para. 416. 
het "statement" informatie over bijzondere problemen die op het werk kunnen ontstaan en de maatregelen die daartegen worden genomen en de verplichtingen van veiligheidsdeskundigen (indien aanwezig).

Het recht op informatie wordt aanzienlijk sterker wanneer het kan worden afgedwongen bij een arbitrage- of rechterlijke instantie. De regelingen die een wettelijke grondslag voor informatieverstrekking bieden, geven in het algemeen ook voorzieningen deze af te dwingen via arbiter of rechter indien de werkgever de informatie niet verstrekt. Griekenland voorziet hiervoor in een arbitrage procedure, Duitsland (41), België (42), Spanje (43) en Frankrijk (44) kennen een vrij eenvoudige procedure bij het arbeidsgerecht. In Nederland moet de ondernemingsraad (of Arbocommissie) zich tot de kantorechter wenden (45). In Luxemburg kan de arbeidsinspectie interveniëren na een klacht, en is een civiele procedure mogelijk.

Ook in landen waar het recht op informatie in hoofdzaak in een Centraal Akkoord of in (lagere) collectieve overeenkomsten geregeld is is in een dwangmogelijkheid voorzien. In Denemarken, Italië en Groot Brittannië, zijn mogelijkheden om via een arbiter of rechter de gevraagde informatie toch te verkrijgen.

In Denemarken is het informatierecht sterk gekoppeld aan de samenwerkingsoptie. De commissie mag, tijdens het streven naar overeenstemming met de werkgever over bepaalde punten, om voorlichting vragen bij de bedrijfscommissie (samarbejdsnaevnet). Dit is zelfs verplicht als de in de commissie vertegenwoordigde groepen daarom vragen. In feite is deze laatste regeling een eerste stap in de geschillenregeling over het recht op

41. Op basis van de Paragraaf 23 BetrVG biedt Paragraaf 85 Abs. 1 jo. paragraaf $2 a$ Arbeidsgerichtsgesetz een procedure, waarbij de informatie, op grond van het door de werkgever weigeren te voldoen aan een wettelijke plicht, de informatie indien deze noodzakelijk is, met spoed aan de werknemers ter beschikking kan worden gesteld.

42. Wanneer in Belgie ondernemingsraad of comitee het niet eens zijn, met de aard en de hoeveelheid informatie die wordt werstrekt kunnen zij een klacht indienen bij de arbeidsrechtbank. Dit is op zichzelf geen speciale procedure, maar behoort tot de algemene procedures over geschillen die toepassing van de wet betreffen. Deze procedure staat ook open voor de vakbondsvertegenwoordiging. De ondernemingsraad en het comite moeten aantonen, dat de verlangde informatie behoort tot de informatie waar zij wettelijk gezien recht op hebben. Daarnaast is de verplichting van de werkgever om informatie aan het comitê verstrekken, strafrechtelijk gesanctioneerd.

43. De ondernemingsraad kan zijn recht op informatie afdwingen bij de arbeidsrechter, een gespecialiseerd college dat bevoegd is in alle arbeidsgeschillen. Vakbondsvertegenwoordigers kunnen bij dezelfde rechter terecht.

44. Bij geschillen over het recht op informatie kan de Franse ondernemingsraad zelfstandig een actie ondernemen tegen de werkgever. Sedert 1983 is dit in de Code du Travail vastgelegd, waarmee een praktijk bevestigd werd die in de jurisprudentie was gegroeid.

45. Door het op 1 april 1990 in werkinggetreden Wet ter Wijziging van de Wet op de Ondernemingsraden en de Arbeidsomstandighedenwet strekkende tot opheffing van de samenloop van beide wetten en tot vereenvoudiging van de geschillenregelingen in de wet op de ondernemingsraden, TK. $1988 / 89$, no, 20583 , no. 11 , is de procedure aanzienlijk vereenvoudigd. 
informatie. De bedrijfscommissie zal proberen vast te stellen welke informatie er aan de commissie verstrekt moet worden, en deze zo nodig zelf verstrekken. Wanneer het de bedrijfscommissie niet lukt door bemiddeling tussen de werkgever en de commissie tot een oplossing te komen kan zij een scheidsgerecht instellen. Daarnaast kent de samenwerkingsovereenkomst een boeteregeling voor het schenden van die overeenkomst, dus ook voor het niet verstrekken van informatie (46). Deze wordt echter niet vaak gebruikt. Het recht op informatie voor veiligheidsvertegenwoordigers is afdwingbaar via de arbeidsinspectie.

De Italiaanse shop stewards kunnen hun recht op informatie recht afdwingen via bovengenoemd artikel 28 Werknemersstatuut; dit gaat echter alleen op als de werknemersvertegenwoordigers tevens vakbondsvertegenwoordigers zijn. Als dit niet het geval is, wat zich (en dan nog slechts theoretisch) alleen kan voordoen bij vertegenwoordiging op grond van artikel 9 Werknemersstatuut (47), zou eventueel een beroep gedaan kunen worden op het gewone burgerlijk recht (art. 700 Wetboek van burgerlijk procesrecht). Het niet nakomen van de CAO op dit punt levert de vakbonden c.q. de betreffende werknemer een vordering op op basis van het contractenrecht.

Vakbonden en hun shop stewards in Groot Brittannië kunnen wanneer een werkgever informatie weigert te verstrekken, waarop zij menen recht te hebben een klacht indienen bij het Central Arbitration Committee (CAC). Het probleem is dat, zelfs als het CAC meent dat de werkgever inderdaad verplicht is de bonden van de informatie te voorzien, hij dit niet dwingend kan opleggen. Het CAC heeft dat tot op zekere hoogte opgelost door 'voor recht te verklaren' dat het recht op (deze) informatie onderdeel is van de "consultative and negotiating machinery". In dat geval kunnen partijen de zaak opnieuw bezien, en wanneer men dan weer niet tot overeenstemming komt is een hernieuwd beroep op het CAC mogelijk, die bij haar uitspraak de eerder gegeven verklaring in de overwegingen kan betrekken. Volgens Wedderburn is dit een beschaafde oplossing (48), met name waar het gaat om multinationale ondernemingen. De veiligheidsvertegenwoordigers kunnen hun recht op informatie afdwingen via de normale juridische procedure (bij
industrial tribunals).

Het recht op informatie gaat samen met een plicht tot geheimhouding ten opzichte van derden, waaronder ook andere werknemers dan de geïnformeerde vertegenwoordigers. Deze plicht, hoewel hij binnen het medezeggenschapsrecht onvermijdelijk moet worden geacht (49) kan het verschil tusen vertegenwoordigers en andere werknemers versterken, omdat de eersten in

46. R. Nilsen, A.w. (noot 35), p. 113114.

47. P.G. Cella, T. Treu, Rellazioni Industriali. Manuale per l'analisi della esperienza Italiana,
Bologna 1982, p. 114.

48. Lord Wedderburn, The Worker and the Law, Harmondsworth 1987, p. 290.

49. G.J.W. Arendsen de Wolff, a.w. (noot 8), p. 75 . 
veel gevallen wel, en de tweeden van ingrijpende beslissingen omtrent de onderneming niet op de hoogte zijn. Daübler meent dat een geheimhoudingsplicht de communicatie tussen vertegenwoordigers en werknemers verzwaart, en de vervreemding versterkt (50).

Een zwijgplicht van werknemersvertegenwoordigers voor wat betreft beslissingen die de positie van de onderneming tot gevolg hebben, kan acceptabel zijn. Dit ligt mijns inziens moeilijker als veiligheidsvertegenwoordigers een zwijgplicht opgelegd krijgen, over zaken die direct de veiligheid en gezondheid van hun collegawerknemers raken. In Denemarken is er in de Wet op de Arbeidsomgeving geen officiële zwijgplicht voor de veiligheidsvertegenwoordiger opgenomen; hij heeft om die reden geen ruime toegang tot vertrouwelijke informatie uit het produktieregister (51). Het is niet uitgesloten dat dit is gebeurd om de veiligheidsvertegenwoordiger dit dilemma te ontnemen. De plicht tot geheimhouding voor leden van de samenwerkingscommissie bestaat wel en met name voor die informatie die betrekking heeft op nieuwe technologieën.

De leden van de Duitse ondernemingsraad hebben een geheimhoudingsplicht ten aanzien van bedrijfsgeheimen die hen in de uitoefening van hun functie ter ore komen. Het begrip bedrijfsgeheim wordt geacht een objectief bepaalbaar begrip te zijn (52); de geheimhoudingsplicht treedt pas in, nadat de werkgever er nadrukkelijk op gewezen heeft, dat deze op een bepaald feit van toepassing is (53). De werkgever kan deze redenering niet omkeren: onderwerpen die niet tot de bedrijfsgeheimen behoren, worden geen bedrijfsgeheim, doordat de werkgever geheimhouding oplegt. Naast deze algemene zwijgplicht die ook voor de leden van de Wirtschaftsausschuss geldt, gelden voor de leden van de ondernemingsraad ook de bijzondere geheimhoudingsplichten, ten aanzien van gegevens die betrekking hebben op individuele werknemers en die voortvloeien uit bepalingen in de arbeidsovereenkomst. Schending van de zwijgplicht is een strafbaar feit.

Ook Nederlandse ondernemingsraadsleden hebben een geheimhoudingsplicht voor bedrijfsgeheimen, daarnaast zijn zij verplicht tot zwijgen over die aangelegenheden waarover de ondernemer, de ondernemingsraad of de betrokken commissie hen geheimhouding heeft opgelegd, dan wel waarvan zij het vertrouwelijke karakter hadden moeten begrijpen (54). Deze zwijgplicht is ruimer geformuleerd dan de Duitse en met name de laatste clausule maakt de zwijgplicht tot een niet objectief afgebakende bepaling.

50. W. Daübler, Das Grundrecht auf Mitbestimmung, Frankfurt am Main, 1973 (2e dr. 1975), p. 62.

51. R. Nielsen, a.w. (noot 35), p. 110.

52. K. Fitting c.s., a.w. (noot 18), p. 869.

53. BAG. 16 maart 1982, Arbeilsrechtliche Praxis, no. 1 zu paragraaf 611 BGB Bietriebsgeheimnis.

54. Artikel 20 WOR. 
Het staat de werkgever overigens niet vrij de verplichting te verzwaren (55). Het overtreden van de geheimhoudingsplicht is een strafbaar feit.

In Frankrijk zijn de leden van de ondernemingsraad onderworpen aan een plicht tot geheimhouding voor wat betreft bedrijfsgeheimen, en verder alles wat te maken heeft met de fabrieksprocédé's. Hetzelfde geldt voor de vakbondsvertegenwoordiging in de ondernemingsraad. Bovendien is er een zwijgplicht ten aanzien van alle zaken die door de leiding van de onderneming als geheim zijn gekwalificeerd. Deze laatste verplichting is in de jurisprudentie restrictief uitgelegd (56); zij heeft vooral betrekking op informatie die de concurrentiepositie van de onderneming zou kunnen schaden. De geheimhoudingsplicht is strafrechtelijk gesanctioneerd. Dit is ook het geval met het verbreken van de wettelijk opgelegde zwijgplicht voor wat betreft de leden van de Luxemburgse ondernemingsraad of de personeelsdelegaties.

De Belgische wetgeving kent een algemene zwijgplicht met betrekking tot die zaken waarvan openbaarmaking de belangen van de onderneming kan schaden. Daarnaast heeft de werkgever de mogelijkheid expliciete zwijgplicht op te leggen voor die aspecten die, indien zij openbaargemaakt worden problemen voor de onderneming kunnen veroorzaken. Over meningsverschillen tussen de ondernemingsraad en de werkgever over de aard van de informatie kan worden beslist in een administratieve procedure (57).

Voor de leden van Spaanse ondernemingsraden bestaat zwijgplicht over informatie waarvan het management heeft gesteld dat deze geheim moet blijven. Bovendien is er een algemeen verbod voor de ondernemingsraad informatie te gebruiken buiten het gebied van de onderneming, en voor andere doelen dan waarvoor die informatie aan ondernemingsraadsleden werd verstrekt (58).

Een expliciete geheimhoudingsplicht voor Britse shop stewards en veiligheidsvertegenwoordigers is er niet. Wel geldt voor alle werknemers dat in hun contract een impliciete verplichting is opgenomen tot "fidelity", "trust" en "confidence", een verplichting waarin ook het zwijgen over vertrouwelijke informatie is begrepen. Deze verplichting is extensief uitgelegd in de jurisprudentie (59). Hoe hoger de functie van een werknemer in een onderneming, hoe sterker de verplichting tot "fidelity, trust and confiden$\mathrm{ce}^{\prime \prime}(60)$. Hieruit kan m.i. afgeleid worden dat voor werknemers die door

55. Beschikking van de Minister wan Sociale Zaken, 16 november 1976, no. 124888,

Rechtspraak medezeggenschapsrecht, 1971-1981, no. 40.

56. G. Lyon-Caen, J. Pélissier, Droit du Travail, Paris 1988, p. 861.

57. R. Blanpain, a.w. (noot 22), para. 286.

58. Artikel 65 Werknemersstatuut (Spanje).

59. Vgl. o.m. General Nutrition vs Yates, (1981)2 The Company Lawyer, p. 227.

60. Lord Wedderburn, The Worker and the Law, Harmondsworth 1986, p. 182-183. 
bun speciale positie in een onderneming aan vertrouwelijke informatie kunnen komen, de plicht over deze informatie te zwijgen in verhoogde mate zal gelden.

In de Ierse en Italiaanse regelingen zijn geen expliciete geheimhoudingsplichten voor werknemersvertegenwoordigers opgenomen. Voor Italiaanse werknemers geldt wel een algemene zwijgplicht over bedrijfsgeheimen, die net als de Britse op een fidelity-concept is gebaseerd (61). Het algemene contractenrecht van deze landen zal een oplossing moeten bieden in geval van doorspelen van vertrouwelijke informatie.

De toegang tot de aan de vertegenwoordigers verstrekte informatie die een vertrouwelijk karakter heeft, is voor de andere werknemers, voor zover dit derden zijn in de zin van de betreffende regelingen afgesloten. Maar niet alle informatie is vertrouwelijk. De vraag blijft dan hoe het zit met de toegang tot niet-vertrouwelijke informatie. In een aantal lid-staten zijn de vertegenwoordigers expliciet verplicht, informatie die zij verkrijgen door te sluizen naar de andere werknemers. Dit is in Denemarken (62) en Spanje het geval. In beide landen is de beperking aan deze verplichting, overigens gelegen in het feit dat doorgegeven informatie relevant moet zijn ten aanzien van de individuele werknemer. Voor Spaanse vakbondsvertegenwoordigers geldt dat zij op een beperkt deel van de informatie van de ondernemingsraad recht hebben. Gezien het feit dat zij gehoord moeten worden over collectieve maatregelen die betrekking hebben op werknemers in het algemeen en met name waar het om ontslag van of sancties tegen vakbondsleden gaat, mag men aannemen dat dit recht ook een recht op informatie over die maatregelen impliceert (63).

In Duitsland hebben werknemers die niet in éen van de medezeggenschapsorganen vertegenwoordigd zijn, niet zonder meer recht op de aan die organen verstrekte informatie. Wel hebben zij recht om informatie te ontvangen die hun persoon betreft en geïnformeerd te worden over de aard van hun werk en de manier waarop zij in het produktieproces passen. Daarnaast moeten zij voor het begin van hun werkzaamheden in de onderneming worden ingelicht over de gevaren voor ongevallen en gezondheid en de maatregelen die zij kunnen of moeten nemen deze te vermijdem. De BetrVG kent bovendien het instituut van de Betriebsversammlung (64). Dit is een vergadering van alle werknemers in de onderneming. Op deze vergaderingen wordt in elk geval dat deel van de informatie van de ondernemingsraad doorgesluisd, dat onmiddellijk betrekking heeft

61. T. Treu, Italy in International Encyclopedia of Labour Law and Industrial Relations, (supplement 58), Deventer 1985, para. 113, 114.

62. In Dememarken moet de samenwerkingscommissie communicatiemethoden in de onderneming ontwikkelen. Informatie die vam directe belang is in verband met de arbeidsplaats wordt verstrekt door de directe chef. Zie EIRR 151 August 1986 p. 26.

63. J.A. Sagardoy, in Spanish Business Law, (B.M. Cremades, ed.) Deventer 1985, p. 254.

64. Paragraaf 43 ev. BetrVG. 
op de onderneming (65). Daarnaast schrijft paragraaf 110 BetrVG voor dat in ondernemingen met meer dan 1000 werknemers de Wirtschaftsausschuss aan de werknemers informatie geeft over de financiële situatie in de onderneming.

Nederlandse werknemers die geen lid zijn van de ondernemingsraad hebben op grond van de WOR praktisch geen recht op informatie over de gang van zaken binnen de onderneming. In de Arbeids-omstandighedenwet is ten aanzien van de individuele werknemers geen algemeen recht op informatie opgenomen (66). De werknemers hebben een recht op voorlichting en onderricht in verband met, en voorzover dat noodzakelijk is voor, de bescherming van de veiligheid, de gezondheid en ter bevordering van het welzijn in de onderneming.

Voor vakbondsleden die in de onderneming bedrijvenwerk verrichten zijn geen bepalingen bij wet opgenomen, uitgezonderd een bepaling in de Arbeidsomstandighedenwet, die in de onderneming werkzame vakbonden het recht geeft, bij ontstentenis van ondernemingsraad of Arbocommissie, een verzoek tot wetstoepassing aan de arbeidsinspectie te vragen. Zo'n verzoek kan ook zien op het verstrekken van die informatie aan de werknemers waar zij volgens de wet recht op hebben (67). Wel wordt er in CAO's aandacht besteed aan het sociaal beleid in de onderneming, dat soms resulteert in een sociaal jaarverslag. Hierin worden dan met name gegevens verstrekt over personeelsopbouw, beloningssystemen, en soms ook informatie over veiligheid, gezondheid en welzijn of financiële gegevens. Het gaat hier om gegevens die in het algemeen niet vertrouwelijk zijn. Een sociaal jaarverslag doet, naast zijn functie als informatieverschaffer binnen de onderneming nog wel eens dienst als reclamemateriaal naar buiten toe.

Individuele werknemers in België hebben een uitvoerig maar niet nader gespecificeerd recht op informatie. Het is zowel an de werkgever als de ondernemingsraad als het comité voor veiligheid, gezondheid en ter verfraaiing van de werkplaatsen hierin te voorzien. Het gaat hier met name om het tewerkstellingsbeleid in de onderneming en zaken die betrekking hebben op veiligheid en gezondheid. De vakbondsvertegenwoordiging heeft een recht op informatie op sociaal gebied, met name daar waar zij de taken van de ondernemingsraad en comité op zich neemt, wanneer de laatste ontbreken. De vakbondsafvaardiging heeft, wanneer er wel een ondernemingsraad is geen recht op economische informatie van de werkgever; wel kan zij informatie verzamelen op basis van individuele klachten. Doordat de vakbonden ook in de ondernemingsraad vertegenwoordigd zijn, komt het er vaak op neer dat de ondernemingsraad door de vakbondsafvaardiging gebruikt wordt om aan economische informatie te komen (68).

65. Paragraaf 45 BetrVG, K. Fitting c.s., Betriebswerfassungs-gesetz, München 1987, p. 45.

66. Zie A.J.C.M. Geers, a.w. (noot 7), p. 269-271.

67. Artikell 40 jo artikel 35 lid 6 sub $d$ Arbowet .

68. H. Slomp, Tj. van Mierlo, Arbeidsverhoudingen in België, Antwerpen 1984, p. 110. 
De Luxemburgse werknemers hebben op zichzelf geen mogelijkheid informatie af te dwingen.

In Frankrijk moeten de individuele werknemers door de verschillende vertegenwoordigers in de onderneming van informatie voorzien worden. Ten opzichte van de werkgever hebben zij geen zelfstandig informatierecht. De vakbondsvertegenwoordiging in de Franse onderneming heeft eveneens geen op zich zelf staand recht op informatie van de werkgever. Niettemin kan uit de wettelijk geregelde vrijheden en de taakomschrijving van de syndicale vertegenwoordigers afgeleid worden dat zij een zeker recht op informatie hebben, samenhangend met hun taak binnen de onderneming. Het gaat hier met name om informatie die verstrekt moet worden in geval van belangenbehartiging van werknemers vooral in individuele gevallen (69).

Werknemers in Griekse ondernemingen hebben slechts via hun vakbondsvertegenwoordigers de mogelijkheid informatie te bemachtigen. Doordat de vakbond consultatie- en onderhandelingsrechten behoudt, ook indien een ondernemingsraad aanwezig is, mag worden aangenomen dat die informatie die niet vertrouwelijk is op deze wijze de werknemers bereikt. Op veiligheids- en gezondheidsgebied heeft de veiligheids- en gezondheidscommissie de plicht informatie over machines, werktuigen en nieuwe produktieprocessen te onderzoeken en door te geven, voorzover deze de de arbeidsomstandigheden beïnvloeden (70).

In Groot Brittannië en Italië ligt de zaak in zoverre anders dan in die landen met een wettelijke grondslag voor ondernemingsraden, dat men niet kan spreken van een mogelijkheid voor werknemers zelf informatie af te dwingen. Shop stewards kunnen informatie doorspelen naar vakbondsleden, voor zover die informatie doorgespeeld mag worden. Daarnaast hebben niet- vertegenwoordigers enige rechten op inzage van persoonlijke gegevens die henzelf aangaan. Een mogelijkheid tot afdwingen van algemene informatie is niet aanwezig. Hetzelfde geldt voor Ierland.

Wanneer men deze regelingen beoordeelt in het licht van wat er op Europees niveau aan voorstellen en richtlijnen ligt kan in elk geval eén conclusie getrokken worden. De vergaande geheimhoudingsbepalingen zoals deze in het Vredeling-Richard voorstel waren opgenomen, en in de richtlijn bij het Statuut SE mogelijk zijn gemaakt, zijn alleen noodzakelijk in verband met de Britse regeling (71). Het Vredeling-Richard voorstel kende een vrij absolute mogelijkheid om werknemers die informatie te weigeren die belangrijke schade aan de onderneming kan toebrengen of tot het

69. Zie hierover: J. Pélissier, La fonction syndicale dans l'entreprise après les lois Auroux, Droit Social 1984, p. 42-43.

70. Qf deze formulering een specifieke informatieplicht aan de werknemers in bet algemeen inhoudt is niet zeker.

71. C. Docksey, Information and Consultation of Employees: the United Kingdom and the Vredeling Directiwe, Moderm Law Review 1986, p. 290-291. 
mislukken van plannen van de onderneming kan leiden. De richtlijn bij het Statuut SE maakt het expliciet mogelijk een dergelijke bepaling bij collectieve overeenkomst vast te leggen (72). De Britse Employment Protection Act 1975 is de enige regeling die ook zover gaat. Voor het verkrijgen van informatie op het gebied van veiligheid en gezondheid is de mogelijkheid zelfs in Groot Brittannië ruimer. Een op transnationaal niveau te vestigen regeling zou op dat punt in beginsel geen problemen hoeven op te leveren.

Een ander aspect dat op gemeenschapsniveau overwogen zou moeten worden is de mogelijkheid tot het opleggen van een geheimhoudingsplicht aan de vertegenwoordigers. In de lid-staten ziet men de praktijk variëren tussen de Britse: geen expliciete, maar een impliciete die tot redelijk zware sancties (als ontslag) kan leiden, en die niet nauwkeurig omschreven is, en de Duitse die buitengewoon strikt is. De eerste regeling biedt de werknemers vrij veel armslag, maar maakt de risico's daarvan vrij groot. De tweede heeft het voordeel van de eenvoud. Voor een Europese regeling zou mijns inziens de Duitse de voorkeur verdienen, al zou daarbij een heldere clausule moeten worden ingevoegd wat dan wel onder bedriffsgeheimen te verstaan zou zijn. Voor de interpretatie van dit begrip kan mijns inziens enerzijds uit de nationale jurisprudentie in de verschillende lid-staten worden geput, anderzijds zouden paritair samengestelde bedrijfscommissies hierbij een rol kunnen spelen.

\section{Consultatie, instemmingsrechten en onderhandelingsrechten}

De belangrijkste instrumenten tot beleidsbeïnvloeding in de onderneming zijn de rechten van werknemers geconsulteerd te worden over voorgenomen besluiten en deel te nemen aan de besluitvorming. Deze beïnvloeding kan geschieden door het kenbaar maken in het overleg met de werkgever van het door de werknemers ingenomen standpunt, of door de mogelijkheid te onderhandelen over, of niet in te stemmen met eventuele voorstellen van de werkgever. Het recht geconsulteerd te worden wordt veruit het meest aangetroffen, bij medezeggenschap inzake (financiëel-) economische aangelegenheden. Omdat deze voor deze studie niet van overwegend belang zijn zal aan consultatierechten die daarop betrekking hebben, slechts beperkte aandacht worden geschonken. Consultatie-, instemmings- en onderhandelingsrechten inzake veiligheid- en gezondheidsaangelegenheden worden in een aparte paragraaf besproken (73).

72. Zie paragrafen II.4.1.B. en II.4.2.A.

73. Zie paragraaf IV.3.5. 


\subsection{Consultatie}

Consultatierechten komen in de lid-staten zelden als enige instrument voor. Bestaande Europeesrechtelijke regelingen leggen meestal wel alleen consultatieverplichtingen op (uitgezonderd de richtlijn met betrekking tot collectief ontslag, hoewel, zoals gezegd, deze niet echt veel verder gaat (74)) en laten het aan de nationale wetgeving of praktijk over om in een verdergaand instrumentarium te voorzien. Op basis van Europese regelgeving zijn in een aantal lid-staten specifieke consultatieverplichtingen opgenomen in de wetgeving. Deze regelingen zijn elders uitvoerig beschreven, zodat ik er hier niet op in zal gaan (75). In de lid-staten bestaan zowel regelingen die de consultatie zelf begeleiden, als naast consultatieregelingen de mogelijkheid tot onderhandelen of het gebruik van instemmingsrechten.

Een vorm van de begeleiding van het consultatierecht, die in een aantall lidstaten te vinden is, is het binden van het recht aan sancties. Een in Europa uniek voorbeeld hiervan is de Nederlandse regeling. In Nederland is het consultatierecht van de ondernemingsraad vrij strikt gescheiden van het instemmingsrecht. De ondernemingsraad heeft een recht om geconsulteerd te worden over economische aangelegenheden. Het gaat hier om een gekwalificeerd adviesrecht, waarbij het advies van de ondernemingsraad zo tijdig moet worden ingewonnen dat het ook daadwerkelijk van invloed kan zijn op het te nemen besluit (76). Het adviesrecht wordt gezien binnen het kader van overleg: voor het advies gegeven wordt moet er tenminste over de betreffende zaak met de werkgever overleg zijn gevoerd. Het negeren van het adviesrecht door de ondernemer kan door de ondernemingsraad worden aangevochten zowel bij de kantonrechter, als bij de Ondernemingskamer van het Hof Amsterdam. Deze laatste mogelijkheid is niet uit de wet af te leiden, maar in de jurisprudentie ontwikkeld, en geeft de mogelijkheid dat dit negeren vernietigbaarheid van het besluit oplevert (77). Daarnaast heeft de ondernemingsraad de mogelijkheid een besluit waartegen een

74. Zie paragraaf II.4.2.D.

75. Zie The Effect of Commmunity Law, on National Employment Law, FIDE-reports Vol 2, Thessaloniki 1988.

76. Zie hierover F. Koning, Rechtspraak medezeggenschap, SMA 1980, p. 545 .

77. Hof A'dam (OK) 1 mei 1981, NJ 1981, 271 (Linge-ziekenhuis) De ondernemingskamer nam aan dat, indien het adviesrecht van de ondernemingsraad genegeerd was, de ondernemer niet alle af te wegen belangen in zijn besluitworming had gekend, en zodoende de ondernemer bij afweging van de betrokken belangen niet in redelijkheid tot zijn besluit had kunnen komen. De zienswijze van de ondernemingsraad, ter kennis te brengen via het uitbrengen van het advies werd als voorwaarde gezien voor bet kunnen afwegen van de betrokken belangen. Deze uitspraak is overigens bekritiseerd door o.m. P. van Schilfgaarde, Lingeziekenhuiis, Ars Aequi, 29 (1980) 11, p. 785-787, en in latere uitspraken genuanceerd: Hof A'dam (OK), 25 februari 1982, NJ, 1983, 27. Hof A'dam (OK), 14 januari 1982, NJ 1983, 28. 
negatief advies is uitgebracht te laten vernietigen op grond van kennelijke onredelijkheid door beroep in te stellen bij de Ondernemingskamer (78).

In andere lid-staten worden er additionele eisen aan de consultatie gesteld (men moet pogen tot overeenstemming te komen). Dit is het voorschrift dat in het Spaanse Werknemersstatuut is opgenomen. De Spaanse ondernemingsraad heeft het recht geconsulteerd te worden over een gelimiteerd aantal aangelegenheden, voordat de ondernemer zijn beslissing neemt (79). De term die voor de consultatieve bevoegdheden is gebruikt is participatie en dit wordt gezien als een onderdeel van een wijder begrip coöperatie. Door coöperatie moeten werknemersvertegenwoordigers en werkgever tot overeenstemming (pogen) te komen. De ondernemer neemt wanneer geen overeenstemming wordt bereikt, de definitieve beslissing (80).

Het adviesrecht kan ook versterkt worden, doordat het gepaard gaat met instemmingsbevoegdheden of onderhandelingsrechten opondernemingsniveau op aangrenzende gebieden. Materieel kan het adviesrecht als "bargaining chip" dan een rol gaan spelen in het geheel van overleg tussen werkgever en werknemersvertegenwoordigers. Die instemmings- of onderhandelingsrechten kunnen worden uitgeoefend worden door dezelfde vertegenwoordigers die geconsulteerd moeten worden, waardoor onderhandeling in het geheel van medezeggenschapsverhoudingen mogelijk wordt. Het is ook mogelijk dat een verdeling wordt gemaakt naar het orgaan dat specifieke consultatieve bevoegdheden heeft en vertegenwoordigers die alleen onderhandelingsbevoegdheden hebben. Bij zo'n scheiding van bevoegdheden zal een versterking van het adviesrecht minder snel kunnen gebeuren.

In Frankrijk zijn de bevoegdheden van de ondernemingsraad beperkt tot consultatie. Er wordt daarbij een uitdrukkelijk onderscheid gemaakt naar consultatie op economisch (81) en sociaal gebied. Voor economische

78. Artikell 26 WOR.

79. Het gaat hierbij niet alleen om specifiek economische aangelegem theden, zo vallen eronder: beroepsopleidingen in de onderneming, instelling van flexibele (arbeids) schema's, invoering vain van systemen voor het organiseren, dan wel controleren van de arbeid, invoering van betalings- dan wel classificatiesystemen, functie-evalluatie en collectieve wijzingingen in arbeidsvoorwaarden. Daarnaast vallen er economische aangelegenheden onder als: herstructurering van het personeelsbestand, gedeeltelijke of definitieve bedrijfsbeeindiging met de daarbij behorende afvloeiing en arbeidstijdverkorting, fusies en andere veranderingen in de juridische status wan de onderneming, voor zover dit inwloed heeft op de
werkgelegenheid in de onderneming (artikel 64 Werknemersstatuut).

80. De ondernemingsraad heeft de meer algemeen geformuleerde coöperatie bewoegdheid voor maatregelen om de productie van de onderneming voort te zetten of uit te breiden.

81. De consultatiebevoegdheden liggen op het terrein van de interne organisatie van de onderneming, de externe organisatie, voor zover deze betrekking heeft op de interne organisatie (bijwoorbeeld veranderingen binnen een dochteronderneming of dependance),
fusie of afscheiding van een deel van de onderneming, overneming van een andere
onderneming, het financieel beleid, werkg onderneming, het financieel beleid, werkgelegentheid binnen de onderneming, nieuwe technologieën, eventuelle participatie in overwinsten, het gebruik maken van tijdelijke arbeidskrachten in ruime zin, en interne reglementen $0 . m$. op het gebied van buitenlandse 
aangelegenheden heeft de ondernemingsraad een algemeen recht geconsulteerd te worden, een consultatierecht dat, zowel geldt voor de gang van zaken in de onderneming, als voor elke bijzondere beslissing van de ondernemer. De plicht tot het consulteren van de ondernemingsraad door de werkgever hangt samen met het informatierecht: na het geven van informatie door de ondernemer moet over die informatie met de ondernemingsraad van gedachten gewisseld worden, hetgeen de kwaliteit van de informatie waarborgt (82). Daarnaast zijn er voorschriften over het tijdstip waarop de informatie verstrekt moet worden in het licht van de consultatiebevoegdheden (83).

Op het gebied van sociaal beleid heeft de Franse ondernemingsraad voornamelijk toezichthoudende bevoegdheden (84). Op zichzelf blijven ook voor dit terrein beslissingen voorbehouden aan de werkgever, de ondernemingsraad heeft wel een ruime bevoegdheid vragen betreffende dit beleid aan de orde te stellen. Dit ruime initiatiefrecht heeft tot gevolg dat het functioneren van het sociaal beleid afhangt van de opstelling en mate van activiteit van de ondernemingsraad. Het initiatiefrecht wordt gestimuleerd doordat de ondernemingsraad op grond van de Code du Travail over een eigen budget beschikt, hetgeen de mogelijkheid voor uitwerking van voorstellen op een aantal gebieden die exclusief tot de bevoegdheden van de ondernemingsraad behoren, kan vergroten (85). De mate waarin dit kan gebeuren hangt uiteraard wel van de grootte van dit budget af.

Ook in de Luxemburgse constellatie kent men een scheiding tussen de personeelsdelegatie die alleen consultatiebevoegdheden heeft en de ondernemingsraad die medebeslissingsbevoegdheden op een aantal gebieden kent (86). Het verschil met het Franse systeem is, dat in Luxemburg de mogelijkheid tot onderhandelen zich binnen de ondernemingsraad afspeelt en niet is overgelaten aan vakbondsvertegenwoordigers.

werknemers.

82. G.H. Camerllynck c.s., a.w. (noot 16), p. 777.

83. De consultatie moet op een zodanig tijdstip geschieden dat het van invloed kan zijn voor de besluitworming, ten aanzien van de informatie die voor het overleg werstrekt dient te worden zijn in de Code du Travail gedetailleerde bepalingen opgenomen. Bovendien moeten zowel informatie en consultatie qua tijdstip het comite de mogelijkkeid bieden zelf onderzoek te verrichten naar eventuele alternatieve oplossingen.

84. Hier moet met name de controlebevoegdheid ten aanzien van de medische dienst en sociale dienst van de arbeid genoemd worden.

85. Op sociaal gebied heeft het comité een anderssoortige taak dan de werknemersvertegenwoordiging in andere landen: het bevorderen door de ondernemingsraad van maatregelen die ten voordele strekken van de werknemers moet worden opgevat in de zin van het ontwikkelen van voorstellen dan in een instemmingsrecht tem aanzien van voorstellen van de ondermemer. Onder sociaal beleid wordt in de Code ook een cultureel beleid begrepen.

86. C. Docksey, a.w. (noot 23), p. 40-41. 
In Duitsland (87) en Belgie (88) zijn consultatie, instemmingsbevoegdheden en onderhandelingsbevoegdheden op nog iets verwarrender wijze over de verschillende vertegenwoordigers in de onderneming gespeid.

De samenwerking ten aanzien van economische zaken in Duitsland loopt normaal gesproken via de Wirtschaftsausschuss; deze overlegt met de ondernemer, waarna de ondernemingsraad geïnformeerd wordt. Tenminste eén ondernemingsraadslid is altijd lid van de Wirtschaftsausschuss, hetgeen een garantie moet bieden voor de kwaliteit van de verstrekte informatie (89).

In Belgie is de ondernemingsraad in beginsel het orgaan dat geconsulteerd wordt; de vakbondsafvaardiging onderhandelt in de onderneming. Dit onderscheid is echter niet helemaal zuiver, omdat ook de ondernemingsraad op een gering aantal punten het instemmingsrecht heeft, en bovendien de vakbondsafvaardiging bij ontstentenis van de ondernemingsraad de bevoegdheden van dit laatste orgaan overneemt. Hierop wordt in de volgende paragrafen nog teruggekomen.

Een andere mogelijkheid is dat de consultatierechten enerzijds en de instemmings- of onderhandelingsrechten aan hetzelfde orgaan of aan dezelfde vertegenwoordigers toekomen. Dit is het geval in Griekenland (90), Spanje, Nederland, Italië, Groot Brittannië, en Ierland en tot op zekere hoogte in Denemarken (91) het geval. In Denemarken zijn de consultatieen onderhandelings en instemmingsbevoegdheden verdeeld over shop stewards, samenwerkingscommissie en veiligheidsdeskundigen, die in het systeem ieder hun eigen rol spelen. Voor Italië, Groot Brittannië en Ierland geldt overigens dat de consultatieve bevoegdheden die ten aanzien van

87. De Wirtschaftsauschuss wordt op basis van paragraaf 106 BetrVG geconsulteerd over die economische maatregelen die niet tot veranderingen (Betriebsänderungen) in de zin van paragraaf 11 BetrVG leiden. Hier gaat het ook om een zuiver consultatierecht.

88. De Belgische ondernemingsraad adviseert de ondernemer onder meer bij het opstellen en vaststellen van de jaarrekening, overheidssteun, onderdelen van het tewerkstellingsbeleid, collectieve ontslagen, wachtgelden, arbeidswoorwaarden, arbeidsorganisatie en personeelsbaleid (R. Blanpain, a.w. (noot 22), para. 282). Dit adwiesrecht is alleen een recht om gehoord te worden; worden de adviezen genegeerd, dan heeft de ondernemingsraad geen
mogelijkheid daar iets aan te doen.

89. Deze garantie wordt nog versterkt doordat de ondernemingsraad het recht geconsulteerd te worden over de aanstelling van de andere leden van de Wirtschaftsausschuss.

90. De ondernemingsraden hebben de bevoegdheid te adviseren over met name collectieve ontslagen, in die gevallen waarin geen vakbond in de onderneming aanwezig is. Of hier sprake is van een zuivere consultatie moet echter worden betwijfeld. Zie: A Kardaras, Der Einfluss des Europarechts auf das Griechische Arbeitsrecht, in FIDE-report vol. II,

91. Voor de Deense samenwerkingscommissie worden twee soorten van medezeggenschapsbevoegdheden onderscheiden, te weten medebeïnvloeding en medebepaling. Medebeinvloeding is een recht op consultatie dat voorschrijt dat de ondernemer de samenwerkingscommissie goede mogelijkheden geeft om met hen gezichispunten uit te wisselen, voor het besluit genomen is, zo, dat het overleg daadwerkelijk van invloed kan zijn op het te nemen besluit. Naast de medebepalende bevoegdheden heeft ook de shop steward participatiebevoegdheden in de vorm van een recht tot onderhandelen over een gelimiteerd aantal
onderwerpen. 
veiligheids- en gezondheidsaangelegenheden bestaan, niet per definitie door shop stewards hoeven te worden uitgeoefend, echter in de praktijk is dit wel vaak het geval.

Waar op ondernemingsniveau onderhandeld kan worden, of het consultatierecht verbonden is aan een instemmings- of medebeslissingsrecht hebben de werknemers een extra, informele mogelijkheid, om de consultatie enige inhoud te geven. Die inhoud hangt dan wel samen met de machtspositie waarin die werknemers in de onderneming verkeren, de mate van scheiding tussen consultatief en onderhandelend orgaan, en de mate waarin consultatie en instemmings- of onderhandelingsbevoegdheden in de regeling gescheilden zijn.

\subsection{Instemming}

Wettelijke regelingen, waar het instemmingsrecht op ondernemingsniveau het belangrijkste beïnvloedingsinstrument is zijn te vinden in Duitsland (92) waar dit recht in zijn meest uitgebreide vorm te vinden is, Nederland, Luxemburg, Griekenland en voor enkele aangelegenheden België.

De Duitse ondernemingsraad heeft een geclausuleerd recht tot instemming in zowel een aantal economische als een aantal sociale aangelegenheden. Men moet hier een verschil maken tussen de omvang van het begrip economische aangelegenheden dat in de BetrVG en dat in artikel 25 van de Nederlandse WOR gehanteerd wordt. In Duitsland gaat het om een beperkter begrip, en omvat het niet de economische en de bedrijfsorganisatorische zaken, die artikel 25 WOR wel omvat. Volgens Van der Wulfften Palthe loopt Nederland met zijn ruime invulling van het begrip voorop in de medezeggenschap van werknemers inzake economische aangelegenheden. Wanneer men echter in aanmerking neernt dat in Duitsland werknemersvertegenwoordigers in de bestuursstructuur zijn opgenomen, en via die weg kunnen meebeslissen, kan men zich afvragen of deze stelling juist is (93).

Het beperkte instemmingsrecht bij economische aangelegenheden ziet op de sociale gevolgen van die economische zaken die tot veranderingen in de onderneming leiden (94). Het is geclausuleerd omdat de werkgever bij het

92. Naast instemmingsrechten op economisch en socialal gebied heeft de Duitse ondernemingsraad enkele bijzondere medebeslissingsrechten die werknemers betreffen namelijk over te nemen maatregelen wanneer werknemers door veranderingen in arbeidsplaatsen en arbeidsomgeving op bijzondere wijze belast worden (paragraaf 91 BetrVG), en ower "Personelle Einzelmassnahmen" (paragraaf 99 BetrVG). Ten aanzien van beroepsopleidingen binnen en buiten de onderneming (paragraaf 96 BetrVG), gewone ontslagen (paragraaf 102 BetrVG), planning op het gebied van o.m. arbeidsplaatsen en technische zaken heeft de ondernemingsraad het recht geconsulteerd te worden (paragraaf 90 BetrVG).

93. J. Van der Wulfften Palthe, Industriële medezeggenschapsrechten in rechtswergelijkend verband, Eindhoven 1986, p. 459; zie in dit werband ook L. Timmerman, a.w. (noot 2).

94. Paragraaf 112 BetrVG. 
ontbreken van de instemming van de ondernemingsraad de beslissing kan afdwingen bij de Einigungsstelle. Deze arbitrage-instantie kan echter alleen beslissen over zaken die tot de competentie van de ondernemingsraad behoren; over de vraag of een bepaalde kwestie daar tot die competentie behoort zal bij de rechter (Arbeitsgericht) moeten worden geprocedeerd (95).

Wat betreft sociale aangelegenheden (96) voorziet de BetrVG in een vergelijkbare regeling. De ondernemingsraad heeft een instemmingsrecht (de werkgever kan niet besluiten zonder overeenstemming met de ondernemingsraad) over een aantal sociale onderwerpen. Wordt die overeensteming niet bereikt, dan beslist de Einigungsstelle, wier beslissing in de plaats van het besluit van ondernemer en ondernemingsraad treedt. Het overleg wordt echter door de ondernemer met de ondernemingsraad gevoerd, er is geen tussenschakel in de vorm van een verplichte bijzondere Ausschuss. Dit neemt echter niet weg dat de ondernemingsraad het overleg kan delegeren naar de commissies.

De Nederlandse ondernemingsraad heeft instemmingsrecht (97) op het gebied van bepaalde onderwerpen van het sociaal beleid (98). Ook voor het instemmingsrecht geldt dat voor de beslissing van de ondernemingsraad over de betrokken aangelegenheid tenminste eenmaal overleg is gevoerd. Weigert de ondernemingsraad zijn instemming dan kan de ondernemer zich tot de kantonrechter wenden (99). De goedkeuring van de kantonrechter treedt in de plaats van de instemming van de ondernemingsraad.

Ondanks de sterke overeenkomsten met de regeling in de BetrVG zijn er enkele verschillen in formulering op te merken. Zo is het in de WOR voor ondernemer en ondernemingsraad geen verplichting om tot overeenstemming te komen. Materieel is dit natuurlijk wel de bedoeling van het gebruiken van het instemmingsrecht en van aan het besluit voorafgaande overleg, maar het hoeft niet. De kantonrechter beslist niet in de plaats van de ondernemingsraad en de ondernemer gezamenlijk. Hij toetst alleen het voorgenomen besluit van de ondernemer en niet eventuele amendementen die de ondernemingsraad tijdens het overleg heeft gesuggereerd. In

95. Vgl. K. Fitting c.s., a.w. (noot 18), p. 1303.

96. Het begrip sociale aangelegenheden is ruim: eronder vallen naast zaken die met arbeidlsen rustijden, uitbetaling van loon, en verlofregelingen ook zaken die met weiligheid gezondheid en welzijn te maken hebben, loonsystemen en het verhuwr van dienstwoningen.

97. Naast de consultatie- en instemmingsrechtenrechten heeft de ondermemingsraad nog een geclausuleerd vetorecht bij de benoeming van commissarissen in structuurvennootschappen (Vgl. P. van Schilfgaarde, De beroepsprocedure bij de benoeming van structuurcommissarissen, De naamloze vennootschap, 61(1983)6, p. 106-109) en een recht om
geconsulteerd te worden bij benoeming of ontslag van bestuurders.

98. Het gaat hier om een in artikel 27 WOR gelimiteerd aantal onderwerpen. Vergeleken met de Duitse regeling ligt de grens in de Nederlandse mijns inziens nog iets sterker in het criterium dat het moet gaan om regelingen die de werknemers direct raken.

99. Wetsontwerp ter wijziging van de Wet op de Ondernemingsraden en de Arbeidsomstandighedenwet, TK. 1988/89, 20583 , no 11 , p. 8-9. 
Duitsland kan de Einigungsstelle deze amendementen wel meenemen, en kan de mening van de ondernemingsraad over het besluit, de beslissing van de Einigungsstelle beïnvloeden. Anderzijds biedt de mogelijkheid tot enkele goed- of afkeuring van de kantonrechter wel de garantie dat ondernemer en ondernemingsraad weten waar zij aan toe zijn: het gaat om een geschreven voorgenomen besluit, en niets anders dan dat. In Duitsland kan de beslissing van de Einigungsstelle een kunstmatig compromis zijn tussen de standpunten van ondernemer en ondernemingsraad zodat deze van te voren niet precies weten wat zij te verwachten hebben.

Een ander verschil tussen beide landen, is dat in Nederland een besluit dat is genomen zonder dat de vereiste instemming verkregen is, nietig is, indien de ondernemingsraad tegenover de werkgever een beroep op nietigheid heeft gedaan. Dit moet gebeuren binnen een maand nadat de werkgever mededeling van het besluit heeft gedaan of indien de ondernemingsraad merkt dat het besluit wordt uitgevoerd of toegepast (100). De Nederlandse ondernemingsraad hoeft in eerste instantie dus niet naar de rechter. De BetrVG, schrijft voor, dat in een dergelijk geval de rechter beslist. Besluiten zijn dan, afhankelijk van de omstandigheden vernietigbaar (101).

Het laatste en niet onbelangrijkste verschil is dat de Duitse ondernemingsraad, in tegenstelling tot zijn Nederlandse pendant, ten aanzien van een aantal sociale aangelegenheden, met inbegrip van een deel van de arbeidsbeschermende maatregelen, een afdwingbaar recht van initiatief heeft. De ondernemingsraad kan voorstellen doen, waarover de werkgever verplicht is met de ondernemingsraad te onderhandelen (102). Indien nodig kan via de Einigungsstelle afgedwongen worden dat er een regeling getroffen wordt (103). Daar het initiatiefrecht wordt gezien als onderdeel van het participatierecht van paragraaf 87 BetrVG, is het recht daar ook door beperkt: alleen voor zaken waarover de Betriebsrat in het kader van dat artikel kan beslissen kan het initiatiefrecht gehanteerd worden; hiermee is uitgesloten dat de ondernemingsraad zijn competentie uitbreidt tot buiten het wettelijke kader. Het initiatiefrecht is daarmee een wapen tegen een eventuele "non-decision policy" van de ondernemer, hetgeen wanneer het om een aantal sociale zaken en zeker om arbeidsomstandigheden gaat belangrijk is. Stilzitten levert juist in die zaken vaak verslechteringen op.

Het initiatiefrecht van de Nederlandse ondernemingsraad zoals geformuleerd in artikel 23 WOR geeft de ondernemingsraad wel de bevoegdheild om voorstellen te doen omtrent aangelegenheden die de onderneming betreffen, maar biedt slechts de verplichting tot overleg over die voorstellen. Indien de ondernemer de voorstellen niet overneemt, heeft de ondernemingsraad

100. TK. $1988 / 89,20583$ no. 11 p. 9.

101. O.m. G. Etzel, Betriebsverfassungsrecht, Neuwied/Darmstadt 1987, p. 177.

102. Paragraaf 74 jo. 87 BetrVG. Zie K. Fitting c.s. a.w. (noot 18), p. 943-944.

103. G. Etzel, a.w. (noot 101), p. 173-174. 
geen recht van beroep (104). Op dit punt is de regeling dus aanmerkelijk lichter dan de Duitse.

In Griekenland heeft de ondernemingsraad alleen bij gebreke van een vakbond in de onderneming (105), het recht samen met de werkgever te beslissen en te onderhandelen over een aantal de werknemers direct aangaande maatregelen, waaronder veiligheids- en gezondheidsaangelegenheden (106). Komen de ondernemingsraad en de werkgever niet tot overeenstemming dan kan de ondernemingsraad van het genomen besluit in beroep bij de lokale afdeling van de arbeidsinspectie. Weliswaar kan de werkgever dus eenzijdig een besluit nemen, tegen dat besluit kan wel wat ondernomen worden.

De Luxemburgse ondernemingsraad heeft op een aantal gebieden waaronder arbeidsomstandigheden, instemmingsrechten (107). Het systeem lijkt op het Belgische omdat ook hier de ondernemingsraad gemengd is samengesteld. Werknemersvertegenwoordigers beslissen mee, maar de ondernemer kan niet overstemd worden. Ingeval het niet tot overeenstemming komt is voorzien in een arbitrageprocedure. De werkgever kan de ondernemingsraad dus niet negeren.

Hoewel de Belgische ondernemingsraad over enkele sociale aangelegenheden (108) instemmingsbevoegdheid heeft met eenparigheid van stemmen, vallen veiligheids- en gezondheidsaangelegenheden hier niet onder. Op dit laatste gebied kan voor de benoeming en het ontslag van de bedrijfsarts instemming van de ondernemingsraad vereist zijn, namelijk in het geval dat de ondernemingsraad in de plaats treedt van het veiligheidscomité (109). Geschillen tussen ondernemingsraad en werkgever kunnen voor de arbeidsrechtbanken worden gebracht. Dit zijn speciale rechtbanken die kennis nemen van in beginsel alle arbeidsrechtelijke geschillen. Ook individuele werknemers kunnen geschillen omtrent de OR bij deze rechtbanken aanbrengen. De Belgische werknemersmedezeggenschap zou erg zwak zijn, als niet naast de ondernemingsraad de vakbondsvertegenwoordiging in de onderneming een grote rol speelde. Deze heeft onderhandelingsbevoegdheden op ondernemingsniveau waardoor het totaal van instrumenten de relatieve zwakte van die instrumenten, die aan de ondernemingsraad toekomen, weer kan goedmaken.

104. A.J.C.M. Geers, a.w. (noot 7), p. 178.

105. Wet op de Ondernemingsraden, no. 1767 van 6 april 1988 (Griekenlland), zie ook Social and Labour Bulletin, p. 305.

106. Voorts vallen maatregelen betreffende reglementen $m$.b.t. het werk, beroepsopleidingen i.v.b. nieuwe technologieën, vakantiedagen, herintreding van werknemers na ongevallen en vrijtijdsactiviteiten voorzien voor de werknemers hieronder.

107. Artikel 7 Wet op de Comite's Mixte et la Participation des travailleurs, van 6 mei 1974.

108. Zoals ten aanzien van het opstellen en wijzigen van het arbeidsreglement, maatstaven voor ontsiag en wederindienstneming, vakantieregelingen en het beheer van sociale werken.

109. G. Magrez-Song, La loi du 23-1-1975, en matiére de conseils d'entreprise et de comité"s de sécurité et hygiéne, Journal des tribunawx de travail, 31 maart 1975 , no. 100, p. 88. 
De Deense samenwerkingscommissie heeft een, aan het Centraal Akkoord, ontleend recht tot "medebepaling" van het beleid, dat doet denken aan de instemmingsbevoegdheden van de Duitse ondernemingsraad. Bij medebepaling is er een verplichting om tot overeenstemming te komen. Medebepalende bevoegdheden hebben met name betrekking op het afspreken van grondbeginselen op een aantal sociale gebieden, waaronder arbeidsomstandigheden (110) en met betrekking tot de hoofdzaken tot taakuitoefening van de samenwerkingscommissie (111). De gezamenlijke beslissingsbevoegdheid heeft alleen betrekking op die vaststelling van beginselen. De beslissingsbevoegdheid over concrete besluiten blijft in handen van de werkgever, waarbij hij zich uiteraard moet laten leiden door de beginselen (112). leder van de partijen kan de afgesproken beginselen opzeggen, en eisen om in de samenwerkingscommissie opnieuw te gaan onderhandelen over andere beginselen. Men kan dus stellen dat de samenwerkingscommissie voor zover het de ideëen over haar eigen taakuitoefening gaat een betrekkelijk grote stem heeft. De bevoegdheid betekent meer dan het op het eerste gezicht lijkt, wanneer deze bezien wordt in het licht van de aan de samenwerkingscommissie toegekende taken.

Wanneer één van de partijen de afspraken niet nakomt bestaat de mogelijkheid een boete op te leggen. Deze mogelijkheid is in de technologieovereenkomst in 1981 vastgelegd, en in 1986, toen de technologieovereenkomst in de Samenwerkingsovereenkomst werd geïncorporeerd, overgenomen (113). Worden ondernemer en samenwerkingscommissie het niet eens, dan hebben zij de mogelijkheid steun te vragen bij de bedrijfscommissie (samarbejdsnaevnet), die eventueel met steun van de vakbonden en werkgeversverenigingen bemiddelt. Wanneer dan nog geen overeenstemming bereikt wordt kan de bedrijfscommissie, op verzoek van één van de partijen een scheidsgerecht instellen. De samenwerkingscommissie kan niet zonder meer genegeerd worden; de blokkade die zij tegen een besluit (regeling) van de werkgever opwerpt kan echter wel doorbroken worden.

Een recht op initiatief is niet met zo veel woorden geregeld. De taakomschrijving van de samenwerkingscommissie, die praktisch zelf de beginselen vaststelt, en waarin in hoge mate initiërende bevoegdheden zijn opgenomen, duidt er echter op dat de samenwerkingscommissie zelf ook de

110. De grondbeginselen die door de samenwerkingscommissie worden vastgesteld zien op o.m. de werkomgewing op ondernemingsniveau en personeelsbeleid, opleiding, m.n. in verband met nieuwe technologie, en het opvragen, opslaan en gebruik van persoonlijke gegevens in de onderneming.

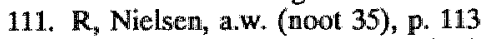

112. Zie ook: P. Jacobson, (bewerkt door M. Smith), Denmark, in International Encyclopedia for Labour Law and Industrial Relations, (supplement 33), Deventer 1983, para. 595.

113. Denemarken kent cen systeem waarin belangrijke overeenkomsten op centraal niveau tussen de sociale partners worden afgesloten. Zo kent men de Hovedaftalen, uit 1960, een kaderovereenkomst waarin onder andere de positie wan de shop steward is geregeld, de Samarbejdsaftalen uit 1970, recentelijk vernieuwd en marginaal gewijzigd in 1986. In 1981 werd in verband met de ontwikkelingen in de automatisering de Teknologi-aftalen gesloten, die alleen voor dit beperkte gebied bedoeld was. Met de wijziging van de Samarbejdsaftalen is de Teknologi-aftalen in de eerstgenoemde opgegaan. 
bevoegdheid heeft om wijzigingen in die beginselen voor te stellen en in onderhandeling te brengen.

Het verschill tussen Denemarken en België enerzijds en Luxemburg anderzijds zit met name in de rol die de vakbonden in het geheel spelen. In Denemarken is het recht van medebepaling ontleend aan het vrijwillige systeem van arbeidsverhoudingen, hetgeen de vakbonden al invloed op de inhoud van de regeling geeft; daarnaast hebben in de samenwerkingscommissie ook shop stewards zitting. In België hebben de vakbonden eveneens een grote invloed op de samenstelling van de raad, en, indien er geen ondernemingsraad is, neemt de vakbondsdelegatie ook zijn bevoegdheden over. Dit is in Luxemburg niet het geval. Vakbonden kunnen slechts indirect invloed op de gang van zaken uitoefenen en dan met name via de personeelsdelegaties, wier bevoegdheden bij collectieve overeenkomst uitgebreid kunnen worden. Dit gezet naast de onderhandelingsbevoegdheden van de Belgische vakbonden op ondernemingsniveau geeft een vrij significant beeld van het verschil tussen beide systemen.

\subsection{Onderhandelingsrechten}

Een ander instrument om besluiten te beïnvloeden is de mogelijkheid van werknemersvertegenwoordigers overeenkomsten af te sluiten met de werkgever. Hierbij wordt gedacht aan het collectief onderhandelen op ondernemingsniveau, zoals dat in Italië en Groot Brittannië bekend is. Onderhandelingsrechten komen in de meeste lid-staten toe aan vakbonden of hun vertegenwoordigers en niet aan de ondernemingsraad. Een uitzondering zijn Duitsland, Spanje en tot op zekere hoogte Griekenland. Deze landen bieden een wettelijke basis voor het onderhandelingsrecht, evenals Frankrijk.

In Duitsland heeft de ondernemingsraad de mogelijkheid bedrijfsovereenkomsten (Betriebsvereinbarungen) af te sluiten met de ondernemer. Deze bevoegdheid van de ondernemingsraad en ondernemer gezamenlijk ziet op algemene regelingen die de onderneming en medezeggenschapsrechtelijke vragen kunnen betreffen (114), waaronder preventievoorschriften voor ongevallen begrepen worden (115). De grenzen van de overeenkomstsluitende bevoegdheid zijn de wet en de collectieve overeenkomsten met de vakbonden. Bedrijfsovereenkomsten werken in de verhouding tussen ondernemer en werknemers zonder meer door en worden geacht dwingend te zijn. Wel worden zij voor de individuele werknemers beheerst door het gunstigheidsbeginsel (116).

114. G. Etzel, a.w. (noot 101), p. 332.

115. Paragraaf 88 BetrVG.

116. BAG 16-9-1986, Der Betrieb, 1986, p. 2026. Zie i.h.a. A.T.J.M. Jacobs, Het recht op collectief onderhandelen in rechtsvergelijkend en Europees perspectief, Alphen aan den Rijn/Brussel 1986, p. 334-336. 
In Spanje is de ondernemingsraad expliciet bevoegd overeenkomsten met de ondernemer af te sluiten op een aantal de werknemers direct of indirect rakende gebieden (117). De wet stelt enige beperkingen aan de bevoegdheid tot onderhandelen van de ondernemingsraad: de gebieden moeten tot de bevoegdheden van de ondernemingsraad behoren, en er moet overleg plaatsvinden met de syndicale vertegenwoordigers in de onderneming. De eerste voorwaarde betekent dat eventueel over de uitvoering van en het toezicht op veiligheids- en gezondheidsaangelegenheden kan worden onderhandeld (118). Het biedt de ondernemingsraad mogelijkheid om, zonder een specifieke bevoegdheid daartoe het initiatief tot besluitvorming te nemen. Wanneer de ondernemer het recht op onderhandelingen, of het resultaat van die onderhandelingen zelf (de overeenkomst dus) negeert kan de ondernemingsraad een procedure aanspannen bij de arbeidsrechter. Indien een ondernemingsraad ontbreekt kunnen de personeelsgedelegeerden de onderhandelingsbevoegdheid overnemen. Hierin is de bevoegdheid van de gedelegeerden praktisch gelijk aan die van de ondernemingsraad. Alleen hebben de gedelegeerden niet de mogelijkheid om, hoewel zij de werknemers vertegenwoordigen als persoon en niet als college, zonder medewerking van de andere gedelegeerden de werknemers bindende overeenkomsten af te sluiten. Voor het collectief van gedelegeerden is dit volgens de doctrine wel toegestaan (119). Vakbondsafgevaardigden zijn slechts in bepaalde gevallen gemachtigd collectieve overeenkomsten op ondernemingsniveau af te sluiten.

Het Griekse systeem geeft het prerogatief aan de vakbonden waar het gaat om rechten tot beïnvloeding op ondernemingsniveau. Indien een vakbond in de onderneming optreedt heeft deze het recht, over de aangelegenheden waarin anders de ondernemingsraad een instemmings- of adviesrecht heeft, een collectieve overeenkomst af te sluiten. De taak van de ondernemingsraad wordt dan heel marginaal; deze functioneert dan als overlegorgaan met de vakbonden. Het resultaat is dan dat de mogelijkheid voor beleidsbeinvloeding door middel van vertegenwoordiging door niet-vakbondsleden, veel kleiner wordt. Dit spreekt temeer daar alleen onderhandeld wordt met de meest representatieve vakbonden. De kans dat de nog zeer jonge wet op de ondernemingsraden een grote rol gaat spelen in de verhoudingen op ondernemingsniveau is, gezien de Griekse structuur van arbeidsverhoudingen (120) groot. Hoewel met de Trade Union Democracy Act de mogelijk-

117. De ondernemingsraad heeft de bewoegdheid tot onderhandelen (artikel 87 werknemersstatuut) over collectieve verandering van arbeidswoorwaarden, tijdelijke neerlegging van werk of beeindiging van arbeidsovereenkomsten in verband met technologische of economische redemen, vakantieregelingen voorstellen voor alle werknemers.

118. Artikel 64 Werknemersstatuut geeft de ondernemingsraad de bevoegdheid toezicht uit te oefenen op het arbeidsomstandighedenbeleid in de onderneming. Hierover kan op basis wan artikel 87 onderhandeld worden.

119. J.A. Sagardoy, a.w. (noot 63), p. 250 , p. 546.

120. Van oudsher speelde met name de nationale collectieve overeenkomst de grootste rol, D. Th. Tsatsos, Die Koalitionsfreiheit des Arbeitnehmers in Griechenland, in The Freedom of the Worker to Organize, Berlin 1980, p. 335. 
heden voor contracten op ondermingsniveau vergroot wordt daarmee de gegroeide gecentraliseerde structuur niet opgeheven. In het geval het proces van collectief onderhandelen faalt kan een beroep gedaan worden op een arbitrage-instantie (121). Collectieve contracten op alle niveaus zijn rechtens bindend, zij kunnen worden afgedwongen voor de rechter.

In Frankrijk en België zijn de rollen tussen ondernemingsraden en vakbondsvertegenwoordigers verdeeld, hoewel dat in Frankrijk duidelijker het geval is dan in België. In België heeft dit mede te maken met het tweesporensysteem van medezeggenschap op ondernemingsniveau: een wettelijk (ondernemingsraden) en een vrijwillig (de vakbondsafvaardiging) spoor. Onderhandelingsbevoegdheden op ondernemingsniveau in Frankrijk komen sedert 1982 exclusief aan de (representatieve) vakbonden toe. De werkgever is verplicht jaarlijks te onderhandelen (122), een verplichting die afdwingbaar is door de vakbonden (123). Daarnaast hebben zij het recht zitting te nemen in de ondernemingsraad met een adviserende stem. De daardoor ontstane mogelijkheid tot communicatie over en weer kunnen in de onderhandelingen weer een rol spelen. In deze zin hebben zij binnen de medezeggenschapsstructuur een speciale rol. Dit spreekt temeer daar de vakbondsvertegenwoordigers als specifieke taak hebben de collectieve en individuele belangen van personen, voorzien in de wet, te verdedigen (124).

De Belgische vakbondsafvaardiging heeft niet op grond van een wettelijke regeling maar op basis van Centraal Akkoord nummer 5 (125), ten opzichte van de werkgever, een aantal bevoegdheden gekregen. Zo kan zij eisen stellen aan, en overleggen en onderhandelen met de ondernemer. In beginsel is het niet de bedoeling, volgens Blanpain (126), dat afgevaardigden bevoegd zijn om rechtens bindende collectieve overeenkomsten af te sluiten, hoewel het wel mogelijk is (bijvoorbeeld op grond van gewoonte). De vakbondsafvaardiging heeft het recht door de ondernemer ontvangen te worden wanneer er een collectief geschil ontstaat. Hoewel de vakbondsvertegenwoording door de opgelegde belemmeringen een vrij zwak instituut lijkt te zijn is dit in de praktijk toch anders. Om te beginnen zijn er een aantal wetten die de bevoegdheden van de vakbondsvertegenwoordiging

121. De arbitrage instantie bestaat uit cen werkgevers- en een werknemersvertegenwoordiger, een ambtenaar van het Ministerie van Arbeid en een beroepsrechter. Men kan wan het besluit in beroep gaan.

122. Artikel L 132-27 van de Wet van 13 november 1982 legt deze verplichting op ten aanciem van het aantal gesalarieerden, de omvang en de organisatie van de uren.

123. J. PElissier, a.w. (noot 69), p. 43 .

124. Artikel L. 411-1 Code du Travail, ingevoerd bij wet van 28 oktober 1982.

125. Overeenkomst nummer 5, vastigesteld op 24 mei 1971 in de Nationale Raad voor de Arbeid.

126. R. Blanpain, a.w. (noot 22), para. 225. 
hebben uitgebreid (127). Daarnaast moet de wisselwerking tussen de door de vakbond gedomineerde ondernemingsraad en de syndicale afvaardiging niet onderschat worden.

De Deense shop steward ontleent zijn rechten aan het Centraal akkoord en aan de collectieve overeenkomsten in de bedrijfstak en/of de onderneming waar hij is aangesteld. De shop steward heeft een bemiddelende taak, naast zijn algemene taak tot belangenbehartiging. Dit impliceert dat de ondernemer actief moet meewerken aan de taakuitoefening van de shop steward, en hem dus moet horen over de zaken die werknemers aangaan. De shop steward heeft de mogelijkheild tot onderhandelen met de ondernemer op een aantal gebieden (bijvoorbeeld het wijzigen van een loonsysteem), maar in het algemeen is hij de vertegenwoordiger van de vakbond op ondernemingsniveau, en in die zin een verschaffer van inlichtingen aan de vakbond, waar deze in onderhandelingen rekening mee kan houden. Voorts bemiddelt hij bij klachten. Dit is ook de rol die hij binnen het veiligheids- en gezondheidsbeleid speelt, naast hun al eerdergenoemde rol in de samenwerkingscommissies. De Deense shop steward is daarmee aanzienlijk minder autonoom dan zijn Britse en Italiaanse tegenhangers.

In Italië, Groot Brittannië en Ierland hadden (en hebben vaak nog steeds) de shop stewards praktisch exclusief de medezeggenschapsbevoegdheden op ondernemingsniveau en deze worden niet of nauwelijks ontleend aan een expliciete wettelijke basis. Pas in de jaren zeventig zijn in Groot Brittannië veiligheidsvertegenwoordigers gekomen, die een wettelijke basis hebben in de onderneming. In Ierland is dit nog later. Hun positie wordt verderop besproken.

Het Italiaanse shop steward systeem vindt sedert 1970 zijn wettelijke basis in het al eerder genoemde Werknemersstatuut; de uitwerking daarvan is echter geregeld in zowel nationale als sectoriële collectieve contracten. De shop stewards (van de representatieve vakbonden) zijn de onderhandelaars van de vakbonden op ondernemingsniveau, zowel over de arbeidsomgeving en arbeidsorganisatie, maar ook en vooral over op de onderneming toegesneden arbeidsvoorwaarden. Het recht op onderhandelen, van de shop stewards verenigd in de "consigli di fabricca", op grond van art 19 Werknemersstatuut kan worden afgedwongen via artikel 28 , de bepaling betreffende anti-syndicaal gedrag (128). Artikel 28 biedt een eenvoudige procedure bij de pretore die onmiddellijk uitvoerbaar is (129). Het artikel

127. Zoals de bevoegdheid mee te werken aan voorstellen voor werkreglementen (Wet van 8 april 1965), instemmingsrecht ingeval van vergunningen vor overwerk; maast de bevoegdheden van de ondernemingsraad kan de vakbondsvertegenwoordiging onder omstandigheden ook de bevoegdheden wan het comité voor veiligheid, gezondheid en werfraaiing van de werkplaatsen overnemen, en de vakbondswertegenwoordiging heeft rechten onder het Talen Decreet van 19 juli 1973.

128. Zie T. Treu, a.w. (noot 61), para. 361-365.

129. Indien partijen in beroep gaan moet de uitspraak wan de pretore worden nageleefd, tot in beroep is beslist. 
wordt veel gebruikt, ook ingeval van een conflict omtrent de collectieve onderhandelingen hoewel het daarvoor eigenlijk niet geschreven is. De enige voorwaarde voor de procedure is dat het gedrag van de werkgever de rechten van de vakbonden beïnvloedt. Het gebruik van artikel $28 \mathrm{om}$ collectieve onderhandelingen af te dwingen is overigens niet onomstreden, mede omdat Italie geen expliciete verplichting tot onderhandelen kent (130). Collectieve contracten zelf zijn wel afdwingbaar door de vakbonden bij de rechter.

In Groot Brittannië is wel een aantal wettelijke regelingen tot stand gekomen die de positie van de shop steward in de onderneming begeleiden, zoals de al eerder genoemde bepalingen omtrent informatieverstrekking en een zekere mate van bescherming bij ontslag. De grondslag voor zijn bevoegdheden is echter geheel gebaseerd op vrijwilligheid. Erkende vakbonden hebben de mogelijkheid te onderhandelen met de ondernemer, er is echter geen plicht tot onderhandeling voor de werkgever, hoewel er wel regelingen in de wet te vinden zijn waaruit een dergelijk recht af te leiden is (131). Eén probleem bij het Britse systeem is dat bereikte resultaten over niet onbelangrijke zaken alls loon, werktijden, en vakanties, maar ook over arbeidsomstandigheden, niet direkt in rechte afdwingbaar zijn, noch door vakbonden noch door individuele werknemers. Collectieve contracten zijn in beginsel niet juridisch afdwingbaar (132). De contracten hebben naast arbeidsvoorwaarden in het algemeen procedurele voorzieningen voor het proces tot onderhandelen tot voorwerp, waarin voor het geval dit proces vastloopt, conciliatie- en arbitrage voorzieningen in zijn opgenomen.

\subsection{Uitbreiding en beperking van de bevoegdheden van vertegenwoordigers op ondernemingsniveau}

Consultatie en participatiebevoegdheden (maar ook informatierechten) van vertegenwoordigers op ondernemingsniveau kunnen zowel uitgebreid als beperkt worden door hogere regelingen. In eerste instantie moet gedacht worden aan (met name ILO) verdragen en EEG-regelingen. Van ILOverdragen is wel betoogd dat deze werken tussen werkgever en werknemers (133). Dit zou voorvloeien uit de tripartite samenstelling van de

130. T. Trew, a.w. (noot 61), para. 406-407; S. Sciarra, The rise of the. Italian shop steward Industrial Law Journal 1977 , p. 40 .

131. Vgl. om. de matregelen die genomen zijn om collectief onderhandelen te bevorderen, zoals deze in de verschillende wetten zijn opgenomen (de disclosure of information bepaling in de EPA bijvoorbeeld, en de oprichting van de ACAS), Zie B. Hepple, United Kingdom in The right of the Worker to Organize, Berlin 1980, p. 1006; ook A.T.J.M. Jacobs, a.w. (noot 116), p.360-363.

132. Hierover: P. Davies, M. Freedland, Kahm-Freumds. Labour and the Law, London 1983, p. $158-166$

133. E.A. Alkema, De internationale sociale rechten en het Nederlandse recht, in Het Europees Sociaal Handvest (J.J.M. van der Ven, ed.) Nijmegen 1982, p. 46; zie ook conclusie van Alkema bij de uitspraak van de Europese Commissie voor de rechten van de Mens 3-5- 
ILO (134). Jacobs stelt echter dat in het algemeen geen rechtstreekse werking van ILO-verdragen wordt aangenomen (135). Toetsing aan ILOverdragen komt wel, zij het sporadisch, voor (136). EEG-richtlijnen kunnen eveneens invloed hebben op rechten op ondernemingsniveau. Invloed vanuit het EEG-recht loopt in beginsel via het instrument van nationale wetgeving (137). Voorts kunnen dwingende wettelijke bepalingen de bevoegdheden van de werknemersvertegenwoordigers, met name wanneer die worden uitgeoefend in een vrijwillig systeem van medezeggenschap, beperken. Anderzijds kunnen wettelijke bepalingen van aanvullend recht, de mogelijkheid bieden dat bevoegdheden van vertegenwoordigers op ondernemingsniveau worden beperkt en/of uitgebreid door middel van collectieve overeenkomst (138).

Dit laatste is in Nederland en Duitsland het geval. Het instemmingsrecht van de Duitse ondernemingsraad kan worden beperkt door collectieve overeenkomsten met de vakbonden. In het geval dat deze in een regeling voorzien, gaat de collectieve overeenkomst voor op het instemmingsrecht van de ondernemingsraad. Eenzelfde regeling is te vinden in de Nederlandse wet op de ondernemingsraden ten aanzien van het instemmingsrecht. Een collectieve overeenkomst die ten aanzien van een sociale aangelegenheid een inhoudelijke regeling geeft kan niet door een gezamenlijke actie van ondernemer en ondernemingsraad opzij gezet worden. Dit kan leiden tot een zekere mate van rivaliteit tussen vakbonden en ondernemingsraden, met name als er sprake is van een ondernemingscao. Looise (139) stelt dat de meeste klachten van ondernemingsraden hieromtrent voorkomen in grotere ondernemingen met een eigen cao. Nederland kent bovendien de SERfusiegedragscode, ten aanzien van informatie die in verband met het adviesrecht aan de ondernemingsraad verstrekt moet worden, de betrokken vakorganisatie het recht toe het moment van die informatieverstrekking, mede te bepalen (140). Dit beperkt de rechten van de ondernemingsraad

9183, NJ. '84-268.

134. Deze redenering werd gevolgd door de A-G Mok in zijn conclusie bij het arrest HR. 303-1984, NJ' $85-350$.

135. A.T.J.M. Jacobs, De rechtstreekse werking van internationale normen in het socialal recht, Preadvies Vereniging voor Arbeidsrecht 1985.

136. Zie A.W. Heringa, Sociale grondrechten, hun plaats in de gereedschapsikist van de rechter, 's-Gravenhage 1989, p. 267-268. Het ging hier overigens niet om rechistreckse werking wan het ILO-verdrag, matar on verdragsconforme vitleg.

137. Enkele van bovengenoemde wettelijke regelingen zijn tot stand gekomen onder de invloed van EEG-richtlijnen, zoals s. 99 uit de EPA in Groot Brittannië en de Wet Melding Collectief onslag, en de artikelen 1639 aa ev. in Nederland. Zie voor een overzicht de nationale rapportages in The effect of Community Law on national employment law, FIDE-reports wol. 2, Thessaloniki 1988.

138. Ower de verhouding tussen autonoom en heteronoom recht, zie A.T.J.M. Jacobs, a.w. (noot 116), p. 297-300.

139. J.C. Looise, Vakbeweging en vertegenwoordligend overleg in veranderende arbeidswerhoudingen, Alphen a/d Rijn 1989, p.162-163.

140. Artikel 18, SER-besluit fusiegedragsregels 1975, Mededelingen blad SER, 9 december 1975, laatstelijk gewijzigd bij SER besluit van 16 maart 1979. 
formeel niet, maar kan wel invloed op de uitoefening van die rechten hebben.

Anderzijds biedt in Nederland de WOR de mogelijkheid dat de bevoegdheden van ondernemingsraden worden uitgebreid door middel van een besluit van de Sociaal Economische Raad (141), een besluit van de ondernemer waarvoor instemming van de ondernemingsraad vereist is (142), of collectieve overeenkomst (143). In Duitsland is dit niet expliciet het geval (144): wel kan volgens de BetrVG bij collectieve overeenkomst een andere organisatiestructuur worden vastgelegd dan die waar de BetrVG toe verplicht, indien dat een betere samenwerking tussen werkgever en werknemers zou opleveren. In de jurisprudentie is echter aangenomen dat een uitbreiding van de bevoegdheden (met name op sociaal gebied) van de ondernemingsraad toelaatbaar is (145).

Ook in België en Luxemburg bestaat de mogelijkheid de competentie van de ondernemingsraden respectievelijk personeelsdelegaties uit te breiden. In België is een ontwikkeling in het begin van de jaren zeventig gestart om de ondernemingsraden extra faciliteiten te bieden door middel van interindustriële collectieve overeenkomsten (146).

In Spanje waar de ondernemingsraad bevoegd is te onderhandelen is een specifiek probleem aan de orde. Nu ondernemingsraden niet formeel aan vakbonden gebonden zijn, vinden hun bevoegdheden hun begrenzing in beginsel slechts in de wet. Vertegenwoordigers hoeven zich op bij deze onderhandelingen niet te storen aan collectieve overeenkomsten op sectorieel of nationaal niveau, hetgeen op ondernemingsniveau tot hogere eisen zou kunnen leiden dan die door de vakbond in de algemene onderhandelingen zijn gesteld. Het probleem is echter meer theoretisch dan dat het in werkelijkheid bestaat (147), gezien het feit dat de vakbonden zelf een vrij sterke invloed hebben in de ondernemingsraden (148).

141. Artikel 32 WOR. Een daartoe strekkende SER-verordening behoeft goedkeuring van de Minister van Sociale Zaken.

142. Artikel 32a lid 2 WOR. Een dergelijk besluit moet medegedeeld worden aan de bedrijfscommissie.

143. Artikel 32a lid 1 WOR.

144. K. Fitting c.s., a.w. (noot 18), p. 97.99.

145. Zie W. Daübler, a.w. (noot 50), p. 85-94; S. Wiedemann, H. Stumpf, Tarifsvertragsgesetz, München, 1977 , p. 167 en p. 244-245; S. Simitis, Von den institutionalisierten zur Problembezogenen Mitbestimmung, Arbeit und Recht, 1975, p. 328.

146. Zie R. Blanpain, a,w. (noot 22), para 247.

147. Daarnaast doet zich de situatie voor dat ook collectieve overeenkomsten met erga omnes werking kunnen worden gesloten door vakbondsvertegenwoordigers in de onderneming indien door de vakbond meer dan $50 \%$ werknemers als lid heeft. Zie: M. Rodrigues Piñero en S. Del Rey Guanter, Workers Representative Bodies and bangaining at the Workplace: Notes on the recent Evolution in Western Europe, The International Journal of Comparative Labour Law and Industrial Relations, 1985 , p. 77.

148. ILO-report, Trade Unions and Industrial Relations in Spain, Geneva 1985, p. 66. 
De onderhandelingsbevoegdheden van syndicale afgevaardigden worden in praktisch alle lid-staten (uitgezonderd Groot Brittannië) begrensd door collectieve overeenkomsten van een hoger (sectoriêel of nationaal) niveau. Dit is overigens niet overal altijd zo geweest. In Italië waar de onderhandelingsvrijheid lang even groot was als in Groot Brittannië, wordt pas sedert 1983 getracht een dergelijke begrenzing te effectueren (149). Franse akkoorden op ondernemingsniveau moeten in overeenstemming zijn met "hogere" overeenkomsten, met dien verstande dat een ouder akkoord op ondernemingsniveau voor een latere sectoriële of nationale overeenkomst gaat, in elk geval voor zover het gunstiger rechten voor de werknemers inhoudt (150).

Aan de onderhandelingsbevoegdheid van de Britse shop steward kunnen in beginsel geen grenzen door hogere overeenkomsten gesteld kunnen worden (151). De grens is gelegen in de zaken die zich voor onderhandeling tussen ondernemer en vakbond lenen en waartoe zij door de vakbondsleden gemachtigd worden. Wettelijke of andere formele voorwaarden aan hetgeen onder de onderhandelingscompetentie van de shop stewards valt zijn er niet, uitgezonderd de hierboven genoemde (152). Dit impliceert wel dat de grenzen van de mogelijkheden van shop stewards flexibel zijn. Door het ontbreken van enige onder of bovengrens aan de bevoegdheden, zullen shop stewards in periodes van volledige werkgelegenheid meer onderwerpen ter tafel kunnen brengen, en hogere eisen kunnen stellen, dan in tijden van recessie.

3.5 Consultatie, instemming en onderhandeling inzake veiligheids- en gezondheidsaangelegenheden

Consultatie en participatiebevoegdheden op ondernemingsniveau inzake veiligheid en gezondheid zijn in praktisch alle EG lid-staten vastgelegd in wettelijke bepalingen. Slechts in Italië ligt dit anders. In een aantal landen zijn de bevoegdheden op dit terrein toebedeeld aan de algemene vertegenwoordigend organen. In andere heeft men speciale commissies inzake veiligheids- en gezondheidsaangelegenheden in het leven geroepen. Deze commissies hebben in het algemeen geen participatie bevoegdheden, maar meer een adviserende functie naar het algemene vertegenwoordigende orgaan. Wel hebben deze comité's soms specifieke eigen verantwoordelijkheden inzake de contrôle van veiligheids- en gezondheidsmaatregelen en bij situaties van ernstig (dreigend) gevaar.

149. S. Sciarra, Plant Bargaining The Impact of Current Deregulative trends in Italy, Comparative Labor law Journal, 1987, Vol. 8 p. 132.

150. De verhouding in Frankrijk is gecompliceerd, zie hierover: M. Despax, a.w. (noot 5), p. $15-1.6$.

151. Lord Wedderburn, a.w. (noot 60), p. 273-276.

152. Dit leidde tot de jaren tachtig tot wildgroei in het onderhandelingscircuit; echter nadien zijn juist weer meer sector overeenkomsten tot stand gekomen. 
In Nederland en Luxemburg heeft de wetgever de medezeggenschapsbevoegdheden inzake veiligheids- en gezondheidszaken primair toebedeeld aan de algemene vertegenwoordigende organen. Dit betekent overigens niet niet dat zij deze bevoegdheden niet kunnen delegeren aan gespecialiseerde commissie. De Duitse regeling laat de uiteindelijke medezeggenschap verlopen via de ondernemingsraad, maar de al eerder genoemde Ausschusse op wettelijke basis spelen een grote rol in het gehele veiligheids- en gezondheidsbeleid.

In Luxemburg bestaat een medebeslissingsbevoegdheid ten aanzien van veiligheids- en gezondheidsbeleid. De rollen van personeelsvertegenwoordiging en ondernemingsraad zijn gescheiden inzake veiligheids- en gezondheidsaangelegenheden. De personeelsdelegatie moet hierover geconsulteerd worden en heeft het recht voorstellen te doen. Het behandelen van deze voorstellen door werkgever en/of ondernemingsraad is overigens niet juridisch af te dwingen. De ondernemingsraad heeft medebeslissingsrecht over maatregelen die als zodanig de veiligheid en gezondheid van werknemers betreffen.

In Nederland berusten specifieke consultatierechten voor de ondernemingsraad op de Arbeidsomstandighedenwet (153). Tot voor kort had de ondernemingsraad ook een instemmingsrecht inzake alle veiligheids- en gezondheidsaangelegenheden. Dit vloeide voort uit zowel de WOR als de Arbowet. Voor de ondernemingsraad was dit geregeld in de WOR (zie hierboven) voor de Arbocommissie in de Arbowet, met een verwijzing naar het instemmingsrecht uit artikel 27 WOR. De wetswijziging die de opheffing van de samenloopbepalingen tussen WOR en Arbowet ten doel had, heeft het instemmingsrecht echter sterk beperkt (154). Voor besluiten inzake veiligheids- en gezondheidsaangelegendheden is (artikel 27 lid 1 sub e WOR) geen instemming meer vereist voor zover terzake een aanwijzing kan worden gegeven, of een eis kan worden gesteld door de arbeidsinspectie. De zin van deze (vergaande) beperking ontgaat mij geheel. Uiteraard zou het niet zo mogen zijn, dat een eis (of aanwijzing) van de arbeidsinspectie door het gebruik van het instemmingsrecht opzij zou kunnen worden gezet. Dit vloeide echter al uit de oude regeling voort (155). Nu de nieuwe formulering de instemming bindt aan de mogelijkheid tot het geven van

153. Recht om advies te geven heeft de ondernemingsraad over het ondernemingsbeleid voor zover dit van aanwijsbare invloed kan zijn op de veiligheid, de gezondheid en het welzijn van de werknemers, het jaarplan (artikel 4 lid 4) het arbeidsveiligheidsrapport (artikel 5 lid 6), benoeming en ontslag van de mentor (artikel 8 lid 5) en van de deskundigen in de Daarnaast heeft de ondernemingsraad een aantal (artikel 18 lid 5 en artikel 19 lid 5) overbeid (zie A.J.C.M. Geers, a.w. (noot 7), 189).

154. TK. 1988/89, no. 20 583,

583 , no. 11 p. 8, inwerkingtreding 1-4-1990.

instemmingsrecht van de Leijnse, TK. $1989 / 90,20583$ no. 18, waarin hij, om het woorden "kan worden" te wijzigen in "is". Dit annodig te beperken, voorstelde de verworpen. 
aanwijzingen of het stellen van eisen door de arbeidsinspectie, gaat het instemmingsrecht voor het overgrote deel van de in de Arbeidsomstandighedenwet geregelde materie verloren. Wat overblijft is een recht van overleg, waarin de onderhandelingspositie van de ondernemingsraad versterkt wordt door de mogelijkheid de arbeidsinspectie in te schakelen. De uiteindelijke invloed op het te nemen besluit is echter wel afhankelijk van de inschatting van het probleem door de arbeidsinspectie.

Ook op arbeidsomstandighedengebied bestaat er geen gesanctioneerd initiatiefrecht voor de werknemersvertegenwoordiging. Hiervoor is bij de totstandkoming van de Arbowet wel gepleit (156), in die zin dat een afwijzing van initiatief van de OR een afwijzend besluit van de ondernemer zou zijn geweest, waarop beroep zou moeten openstaan. Het voorstel werd afgewezen met de motivering dat daaraan geen behoefte zou bestaan, aangezien een afwijzing van een binnen het kader van de wet noodzakelijk geacht voorstel van de ondernemingsraad ondervangen zou kunnen worden via een beroep op de arbeidsinspectie (157). Dit laatste argument is natuurlijk vreemd in het licht van de strekking van de Arbowet. Deze wet wordt toch geacht meer te omvatten dan alleen hetgeen absoluut noodzakelijk is voor de veiligheid en de gezondheid. Het valt te betwijfelen of de Arbeidsinspectie altijd kan en zal reageren op verzoeken om wetstoepassing die gaan om voorstellen op bijvoorbeeld de gebieden van welzijn of ergonomie. Bovendien heeft een beroep op de arbeidsinspectie een vrij conflictueuze impact, terwijl dat niet voor ieder voorstel noodzakelijk moet worden geacht. Een mogelijkheid tot beroep zoals hierboven genoemd, zou de slagvaardigheid van de ondernemingsraad vergroot hebben, zonder dat het het overleg als geheel aan banden zou hebben gelegd.

De Nederlandse ondernemingsraden hebben, zo blijkt, tot dusver zowel veel belangstelling getoond (158) voor veiligheids- en gezondheidsaangelegenheden, als succes geboekt. Volgens Geers handelde de ondernemer in bijna $100 \%$ van de gevallen volgens de wens van de ondernemingsraad (159).

De Duitse situatie, waarin Sicherheitsausschuss of Arbeitsschutzausschuss optreden is veel gecompliceerder. De ondernemingsraad kan over elke maatregel die niet is opgevuld door een wettelijke regeling of collectieve overeenkomst omtrent de preventie van arbeidsongevallen en beroepsziekten meebeslissen (160). Daarnaast moet de aanstelling van Sicherheitsbeauftragten tot stand komen met medewerking (Mitwirkung) van de ondernemingsraad (161). De ondernemer moet over zowel het aantal Beauftragten, voor

156. TK. 13 mei 1980 , wo. 14497 , p. 4685 .

157. T.K. 13 mei 1980 , wo 14497 , p. 4686-7. Volgens de minister zou de OR in dat geval een verzoek tot wetstocpassing kunnen doen op basis van artikel 40 Arbowet.

158. J.C. Looise, J.Z. Heijink, De OR en zijn bevoegdheden, Nijmegen 1986, p. 47.

159. A.J.C.M. Geers, a.w. (noot 7), p. 201.

160. Paragraaf 87 Abs. 1 BetrVG; zie ook G. Etzel, a.w. (noot 101), p. 196-197.

161. Paragraaf 719 Reichsversicherungsordnung. 
zover dit niet door de Reichsversicherungsordnung vastgesteld is, als over de personen die als zodanig worden aangesteld en over de vraag waar zij in de onderneming worden aangesteld, tijdig met de ondernemingsraad overleggen (162). Procedures betreffende de Mitwirkung kunnen worden. aangespannen bij het Arbeitsgericht. Deze bevoegdheid van de ondernemingsraad is niet van bellang ontbloot. De ondernemingsraad heeft weliswaar een aantal instemmingsrechten op het gebied van veiligheids- en gezondheidsmaatregelen, maar ten aanzien van het arbeidsbeschermingsbeleid slechts het recht geconsulteerd te worden en te overleggen (163). De Sicherheitsbeauftragten (dan wel Sicherheitsausschuss/Arbeitsschutzausschuss) zijn belangrijke informatiekanalen van de ondernemingsraad, en bovendien wordt een deel van het overleg met de ondernemer door de Beauftragten daadwerkelijk gevoerd. Door nu invloed te kunnen uitoefenen op met name de personen, die voor deze taak geworven worden, is de kans groter dat diegenen aangesteld worden, die door de ondernemingsraad het vertrouwen waard worden geacht.

In Spanje is in beginsel ook de ondernemingsraad het orgaan dat zich met veiligheids- en gezondheidsaangelegenheden bezighoudt. Hij heeft echter geen expliciete consultatie-, onderhandelings- of instemmingsrechten maar alleen de mogelijkheid tot het uitoefenen van toezicht. Zoals in paragraaf IV.3.1. werd opgemerkt is de ondernemingsraad wel in staat hierover te onderhandelen, maar een verplichting daartoe is niet gegeven.

In Frankrijk, België, Denemarken, Griekenland, en Ierland kent men specifieke veiligheidsvertegenwoordigers die in meer of mindere mate een eigen verantwoordelijkheid hebben in het samenspel met de andere vertegenwoordigende organen.

De Franse CHSCT heeft het recht geconsulteerd te worden over elke maatregel die een wijziging brengt in regelingen met betrekking tot arbeidsomstandigheden in het algemeen, de veiligheid en de hygiëne in het byzonder. Daarnaast moet de ondernemer de CHSCT om advies vragen als het om matregelen ten aanzien van speciale groepen werknemers gaat: bijvoorbeeld slachtoffers van ongelukken op het werk, oorlogsinvaliden, of andere gehandicapten. Tenminste éénmaal per jaar vraagt de ondernemer advies in het algemeen over de arbeidssituatie, op basis van een jaarverslag en een jaar-programma ter voorkoming van ongelukken en ter bevordering van de arbeidsomstandigheden.

Naast deze verplichte consultatierechten, heeft de CHSCT het recht ieder voorstel te doen op het gebied van preventie van beroepsrisico's en voorkoming van ongevallen. Als de ondernemer dergelijke voorstellen verwerpt, moet hij zijn afwijzing motiveren. De CHSCT is niet het enige orgaan dat

162. K. Fitting, c.s. a.w. (noot 18), p. 1075 .

163. Paragraal 89 BetrVG, schrijft woor dat de ondernemingsraad zich woor de uitwoering van de arbeidsbeschermende maatregelen moet inzetten. Voorts biedt het artikel een recht op deelname aan het overleg tussen werkgever, vakkrachten en Sicherheitsbeauftragten. Een instemmingsrecht biedt dit artikel echter niet. 
zich met veiligheids- en gezondheidszaken bezighoudt; de ondernemingsraad en de personeelsgedelegeerden behouden dit recht ook als er een CHSCT bestaat (164). Echter door de wijze waarop het CHSCT verkozen wordt, is de kans groot dat het orgaan de taken van van de twee andere vertegenwoordigingen overneemt.

In Frankrijk kunnen mogelijk de vakbondsvertegenwoordigers het punt in de onderhandelingen brengen; het behoort echter niet tot de onderwerpen waarover jaarlijks, verplicht, onderhandeld moet worden.

Op het gebied van veiligheid en gezondheid hebben de Belgische comités voor veiligheid, gezondheid en verfraaiing van de werkplaatsen weliswaar een groot aantal gedetailleerde bevoegdheden, maar van instemmings- of medebeslissingsrechten is ook hier geen sprake. Wel heeft het comité een gekwalificeerde adviesbevoegdheid, die er op neer komt dat van adviezen van het comité betreffende gevaarssituaties die unaniem zijn uitgebracht, alleen gemotiveerd mag worden afgeweken. Echter ook hier geldt weer dat de ondernemer zelf deel uitmaakt van het comité; het risico dat er een besluit wordt genomen dat van zijn standpunt (in ernstige mate) afwijkt, is dus klein.

Ten aanzien van aanstelling van een bedrijfsarts of de aansluiting bij een gezamenlijke (medische) dienst van meer ondernemingen heeft het comité een adviesbevoegdheid, ten aanzien van het ontslag van de bedrijfsarts een instemmingsbevoegdheid. Bovendien heeft het comité de mogelijkheid het initiatief te nemen tot het ontslag van de bedrijfsarts. Daarnaast heeft het comité nog een belangrijke bevoegdheid: het heeft beslissingsmacht ten aanzien van maatregelen voor opvang, informatie en scholing van werknemers op het gebied van veiligheid en gezondheid. Wanneer de ondernemer zich niet aan zijn verplichtingen tegenover het comité houdt, kunnen werknemers zich tot de arbeidsrechter wenden. Daarnaast is het niet oprichten van van een veiligheidscomité, en het belemmeren van zijn werkzaamheden een strafbaar feit.

De Griekse veiligheids- en gezondheidscommissie heeft een voornamelijk informerende en adviserende taak naar werknemers en werkgever toe. Informatie dient verkregen te worden in het proces van samenwerking met de bedrijfsartsen en veiligheidsdeskundigen. Instemmings- of onderhandelingsbevoegdheden heeft de commissie niet; deze berusten bij ondernemingsraad of vakbondsvertegenwoordiging. Wel heeft de commissie bevoegdheden in geval van dreigend en ernstig gevaar; in dat geval overlegt de commissie rechtstreeks met de werkgever over de te nemen maatregelen.

Ook in systemen waar de algemene vertegenwoordiging een vrijwillige basis heeft is de vertegenwoordig inzake veiligheids-en gezondheidszaken veelal bij wet geregeld.

164. Cour de cassation (Crim.) 7 december 1982, Jur. Soc. 1983, no. 55 . 
Veiligheidsvertegenwoordigers in Denemarken hebben het recht om geconsulteerd te worden over alle zaken die met hun taakuitoefening te maken hebben. De werkgever hoeft hun adviezen niet op te volgen, maar dan moet hij een afwijkende beslissing binnen drie weken motiveren, zodat dit in een volgende vergadering van de gezamenlijke veiligheidsvertegenwoordigers (veiligheidscommissie) besproken kan worden. Een medebeslissingsrecht voor de veiligheidscommissie ontbreekt; wel heeft de commissie het recht op overleg, zowel geïnstitutionaliseerd (énmaal per kwartaal), als incidenteel (wanneer tenminste twee vertegenwoordigers daarom verzoeken). Bovendien hebben zij het recht om voorstellen te doen aan de ondernemer over veiligheids- en gezondheidsproblemen. Deze voorstellen kunnen zowel een tijdsplanning als een prioriteitenlijst inhouden. De structuur van de medezeggenschap op veiligheidsgebied ziet er in Denemarken als volgt uit: de samenwerkingscommissie stelt de algemene beginselen van het veiligheidsbeleid vast, en heeft daaromtrent medebeslissingsrecht. Bij ernstige meningsverschillen met de ondernemer loopt de procedure via de bedrijfscommissie en (eventueel) arbitrage. De veiligheidsvertegenwoordigers, al dan niet verzameld in een veiligheidscommissie, concentreren zich, met een uitgebreide taakstelling, op de uitvoerende maatregelen en de dagelijkse gang van zaken. Op deze commissies is overigens wel kritiek. Volgens Rieper zijn de veiligheidscomité's niet erg effectief, wanneer de problemen die behandeld moeten worden gecompliceerd zijn. Zij zijn daar door het ontbreken van de know how in het algemeen niet voor toegerust (165).

Individuele klachten kunnen worden behandeld en besproken door shop stewards. De vakbond heeft geen specifiek eigen recht in dit systeem, maar wanneer problemen die door shop stewards worden aangebracht zo groot zijn, kunnen zij in een bemiddelingsprocedure bij de bedrijtscommissie worden betrokken, en hun shop steward steunen.

In Ierland heeft het veiligheidscomité eveneens consultatieve bewoegdheden. Instemmingsrechten of expliciete onderhandelingsbevoegdheden komen deze commissie niet toe, evenmin als haar eerdergenoemde collega-commissies in andere lid-staten. Dit betekent concreet dat deze bevoegdheden ofwel bij de algemene medezeggenschapsorganen liggen zoals het geval is Griekenland waar de ondernemingsraad een instemmingsbevoegdheid heeft ten aanzien van veiligheid en gezondheid, en tot op zekere hoogte Denemarken waar de beginselen met instemming van de werknmers moeten worden vastgelegd, ofwel dat er op het veiligheids- en gezondheidsgebied geen participatie bevoegdheden zijn (of alleen een zeer beperkte zoals in België).

In Ierland (zie boven), Groot Brittannië en Italië liggen de bevoegdheden op het gebied van veiligheid en gezondheid niet expliciet bij de algemene

165. O. Rieper, Styring af Arbejdsmiljøet, Kopenhagen 1985, p. 169. 
werknemersvertegenwoordigers, maar over het algemeen komen zij daar wel terecht.

Britse veiligheidsvertegenwoordigers ontlenen hun bevoegdheden aan de HSWA 1974. Zij hebben een recht om geconsulteerd te worden over de ontwikkeling en uitvoering van veilige werkmethoden. Voorts overleggen zij met de werkgever. In dit overleg worden zij ook geacht de in de onderneming levende problemen in te brengen. De bedoeling wan overleg en consultatie is, dat overeenstemming over te nemen maatregelen ontstaat, en de oplossing van problemen wordt gevonden in afspraken tussen veiligheidsvertegenwoordigers en ondememer.

De structuur van vertegenwoordiging en overleg op veiligheids- en gezondheidsgebied, sluit aan op de algemene structuur van de vertegenwoordiging van de shop stewards. Volgens de Health and Safety Commission, een overkoepelend orgaan ingesteld bij de HSWA 1974, moet het afdwingen van de afspraken verlopen via de normale procedure voor het oplossen van problemen binnen de collectieve arbeidsverhoudingen (166).

Of het achteraf bezien een goede zaak is geweest de bevoegdheden inzake veiligheid en gezondheid zo sterk te koppelen aan de structuur van "industrial relations" kan men zich afvragen. Op zich was het codificatie van een bestaande praktijk, zij het dat de vakbonden door middel van hun vertegenwoordigers op ondernemingsniveau nu een aantal wettelijke (en dus ononderhandelbare) rechten kregen toegekend. De aansluiting bij het shop steward-systeem is vaak verdedigd met het argument dat het ontnemen van weiligheids- en gezondheidsaangelegenheden aan de vakbonden een verzwakking van hun positie in de onderneming zou opleveren (167). Wilson stelt echter dat veiligheid en gezondheid in Groot Brittanniè nauwelijks aandacht van de vakbonds-"officials" krijgt, en dat er weinig expertise bij de kaderleden is (168). Dit heeft uiteraard zijn weerslag op het functioneren van de commissies. Juist nu shop stewards en veiligheidsvertegenwoordigers vaak in eên persoon verenigd zijn, lijkt de koppeling niet altijd even gelukkig, omdat veiligheid en gezondheid dan als "bargaining chips" in de onderhandelingen kunnen worden gezien. De gemakkelijke wijze waarop de Britse vakbonden erkennen dat de mate van veiligheid die men in een onderneming kan verwachten gekoppeld is aan het redelijkheidscriterium wijst daar ook op (169).

In Italië zijn de werknemerswertegenwoordigers zelfs geen expliciete wettelijke consultatie of participatiebevoegdheden toegekend, er is slechts het recht van toezicht van artikel 9 Werknemersstatuut. Desalniettemin is veiligheid en gezondheid in Italie voorwerp van onderhandeling op

166. Lord Wedderburn, a.w. (noot 60), p. 423.

167. Commission on Industrial Relations, Worker Participation and Collective Bargaining in Europe, London HMSO 1975, p. 143.

168. G.K. Wilson, The Politics on Safety and Health, Oxford 1985, p. 114.

169. G.K. Wilson, a.w (noot 168), p. 127. 
ondernemingsniveau, zonder dat daar verder een wettelijke bepaling aan ten grondslag ligt.

Indien de werknemerswertegenwoordigers van artikel 9 en de vakbondswertegenwoordigers van artikel 19 Werknemersstatuut niet in dezelfde persoon verenigd zijn, kunnen de laatsten in beginsel geen beroep doen op de procedure van artikel 28 Werknemersstatuut om hun bevoegdheden af te dwingen. Zij zijn dan aangewezen op het gewone contractenrecht en dan met name op artikel 700 wetboek van burgerlijk procesrecht (dat de mogelijkheid tot een onmiddellijke voorziening biedt op grond van ernstig en onherstelbaar nadeel) eventueel in combinatie met artikel 2087 van het burgerlijk wetboek. Dit laatste artikel schrijft voor, dat de werkgever ter bescherming van de fysieke integriteit en morele persoonlijkheid van de werknemers alle maatregelen moet nemen die noodzakelijk zijn in het licht van de ervaring en de techniek. Van dit artikel wordt echter niet zonder meer aangenomen dat werknemersvertegenwoordigers er, voor wat betreft hun rechten onder het Werknemersstatuut (in relatie met artikel 700), een beroep op kunnen doen. Zangari neemt aan dat deze verplichting alleen ten opzichte van individuele werknemers geldt en niet in verband kan worden gebracht met collectief optreden (170). Echter ook indien artikel 28 wel inroepbaar is, vind het zijn beperking in de voorwaarde dat het moet gaan om een schending van de rechten van vakbonden.

Algemene bevoegdheden die de shop stewards al dan niet verenigd in "consigli di fabricca" of andere werknemersvertegenwoordigers (in sommige collectieve overeenkomsten worden aparte commissies voor arbeidsomstandigheden ingesteld) worden toegekend zijn met name inspectie- en informatierechten en documentatiebevoegdheden. Daarnaast hebben zij vaak de mogelijkheid voorstellen te doen aan de werkgever en de hierboven al genoemde onderhandelingsmogelijkheden.

\subsection{Tussenconclusie}

Wanneer men de formele regelingen in ogenschouw neemt dan komen de Duitse, de Luxemburgse en de Deense er het best af, zeker waar het gaat om medezeggenschap inzake veiligheids- en gezondheidsaangelegenheden. In deze landen kan de werkgever in beginsel geen besluit op dat gebied nemen respectievelijk geen beleid vaststellen, zonder instemming van de werknemersvertegenwoordigers. De Nederlandse ondernemingsraad had sterke medezeggenschapsrechten, maar na de wetswijziging is de regeling met name voor wat betreft de medezeggenschap inzake veiligheids- en gezondheidsaangelegenheden een stuk zwakker de drie bovengenoemde. De Griekse regeling is met zijn instemmingsrecht eveneens als sterk te kwalificeren. Dit geldt alleen wanneer geen vakbond in de onderneming aanwezig is. Is dit wel het gevall dan resteert een onderhandelingsrecht, dat niet volledig de besluitvorming van de werkgever blokkeert.

170. G. Zangari, a.w. (noot 38), p. $196 \mathrm{ev}$. 
Onderhandelingsrechten in de lid-staten gaan zelden gepaard met een verplichting tot overeenkomst te komen. Een onderhandelingsverplichting is op zichzelf een stap in de goede richting maar levert niet zoveel op als een instemmingsrecht, althans formeel niet. De mogelijkheid de onwil van de zijde van de werkgever te breken via een eenvoudige procedure, zoals deze in Italie en Spanje bestaat, biedt materieel bijna dezelfde mogelijkheden als de bovenstaande regelingen. Wat in deze landen echter ontbreekt is de verplichting over specifieke zaken (als veiligheids- en gezondheidsaangelegenheden) te onderhandelen. Het zal dus van de wil van zowel vertegenwoordigers als de werkgever afhangen of er onderhandeld wordt over deze zaken. Dit betekent dat de situatie waarin de onderneming verkeert (bijwoorbeeld de concurrentiepositie, of de financiële situatie), van grotere invloed kan zijn dan in de bovengenoemde systemen. Daardoor zijn zij toch als iets zwakker te kwalificeren.

In de meeste lid-staten vallen veiligheids en gezondheidsaangelegenheden voor wat betreft consultatie- en onderhandelings-of instemmingsbevoegdheden onder de competentie van de algemene werknemersvertegenwoordigers, of dit nu shop stewards of ondernemingsraden zijn. Uitgezonderd Frankrijk en Spanje kennen de medezeggenschapssystemen de werknemersvertegenwoordigers op een of andere wijze, expliciet instemmings- of onderhandelingsrechten toe, hoe beperkt deze soms ook zijn. Mogelijkheden tot medezeggenschap voor andere werknemers komen in deze systemen niet voor, hoewel de meeste wetten wel regelingen voor scholing, vorming en overleg vormen op afdelingsniveau kennen. Op dit aspect zal in een volgend hoofdstuk worden teruggekomen (171).

De specifiek voor veiligheids en gezondheidsaangelegenheden in het leven geroepen vertegenwoordigers of organen hebben onder gewone omstandigheden een adviserende rol, die echter van veel meer belang kan worden indien er van dreigend gevaar sprake is, of ingeval er sprake is van een bedrijfsongeval. Daarop wordt in een volgend hoofdstuk teruggekomen (172).

In praktisch alle medezeggenschapssystemen zijn de bevoegdheden van de werknemersvertegenwoordigers afdwingbaar. Een aantal lid-staten kent de vertegenwoordigers een beroep op rechter of arbiter toe om hun bevoegdheden op zichzelf af te dwingen, of als scheidsrechter ter oplossing van een geschil; in andere landen maakt het beroep op de rechter deel uit van het proces ter ondersteuning van het collectief onderhandelen op ondernemingsniveau. De afdwingbaarheid is van belang voor de mogelijkheid de bevoegdheid te effectueren. Daarom alleen al verdienen deze procedures nadere aandacht.

171. Zie paragraaf V.6.

172. Zie paragrafen V.3 en V.5.. 
De mogelijkheid om in geval van een onoplosbaar conflict een uitspraak van een onpartijdige instantie te verkrijgen, om zo een oplossing in een geschil te forceren, is onontbeerlijk voor werknemersvertegenwoordigers om medezeggenschapsregelingen te effectueren. Wanneer vertegenwoordigers instemmingsrechten hebben, of een verplichting tot contracteren bestaat, is de mogelijkheid een beroep te doen op een geschillenbeslechtende instantie echter voor de ondernemer noodzakelijk om een onderneming te kunnen besturen; de ondernemer kan immers niet meer zelf een besluit nemen.

In deze paragraaf zullen de verschillende mogelijkheden worden bekeken om naar een geschillenbeslechtende instantie te gaan, wat er getoetst kan worden en hoe er getoetst wordt. Zowel de verschillende soorten rechters als arbitragemogelijkheden worden hierbij betrokken. Het gaat hierbij om geschillen over naleving van de regels op zichzelf, over de naleving van het resultaat van de medezeggenschap (het concrete besluit) en geschillen die ontstaan tijdens het proces van besluitvorming, waarmee het proces van collectief onderhandelen, c.q. het niet overeenstemming bereiken over een besluit waarvoor instemming nodig is. Naast arbiters en rechters kan ook een toezichthoudende instantie als de arbeidsinspectie geschillen beslechten. De rol van de arbeidsinspectie wordt in het volgende hoofdstuk besproken (173).

\subsection{Geschillen over naleving}

Werknemersvertegenwoordigers hebben indien conflicten ontstaan over de uitleg en de toepassing van hun rechten, uitspraken nodig over de interpretatie van de regels waarop die rechten berusten. Bovendien moeten zij ingeval van schending van die rechten een gebod of verbod gericht aan de ondernemer kunnen verkrijgen, zodat de schending van die rechten ophoudt. Voor een procedure in het laatste geval is de snelheid waarmee de uitspraak verkregen kan worden van belang: indien een ondernemer bijvoorbeeld weigert informatie te verstrekken die door een medezeggenschapsorgaan van belang geacht wordt, dan is het natuurlijk prettig om een jaar na dato in het gelijk gesteld worden, maar in de concrete zaak zal dat veelal te laat zijn.

In de meeste lid-staten is de scheiding tussen naleving van de regels en conflicten over de inhoud van de op basis van die regels te nemen besluiten terug te vinden in het soort procedures dat over die conflicten gevoerd kunmen worden. In Nederland was deze scheiding tot voor kort vrij helder; door de recente wetswijziging is deze minder duidelijk geworden. Hier hebben ondernemingsraad en de ondernemer beiden de mogelijkheid naleving van de wet te vorderen bij de kantonrechter, voor zover die

173. Zie paragraaf V.5. 
naleving van de ander te vorderen is. Dit betekent dat indien de ondernemer bijvoorbeeld weigert de ondernemingsraad informatie (174) te verstrekken, dan wel de uitoefening van consultatie- of instemmingsrechten belemmert de ondernemingsraad op deze wijze actie kan ondernemen. De geschillen worden volgens de WOR aangemerkt als geschillen uit arbeidsovereenkomst, geschillen waarvoor in Nederland in het algemeen de kantonrechter bevoegd is. In verband met consultatiebevoegdheden is er nog een andere mogelijkheid dan vordering tot naleving, namelijk de al eerder besproken weg via de Ondernemingskamer (175). Hierbij is een procedure met betrekking tot de inhoud van een genomen besluit mede een mogelijkheid geworden de naleving van de regel te bewerkstelligen.

De naleving van het instemmingsrecht kan overigens zonder rechterlijke tussenkomst afgedwongen worden. Wanneer een ondernemer een besluit waarvoor instemming is vereist, uitvoert of toepast, kan de ondernemingsraad binnen een maand nadat hem daarvan gebleken is zich op die nietigheid schriftelijk beroepen tegenover de ondernemer. Mocht de ondernemer menen dat dat beroep ten onrechte is gedaan dan kan hij een beslissing aan de kantonrechter vragen, die alleen in cassatie getoetst kan worden. De ondernemingsraad kan zelf ook het initiatief nemen (bijvoorbeeld doordat de ondernemer, ondanks het beroep op nietigheid het besluit toch uitvoert) en bij de kantonrechter een verbod tot uitvoering van het besluit vorderen (176).

In Duitsland worden geschillen over de naleving voorgelegd aan de Arbeitsgerichte, zowel over de naleving zelf, als voor de vraag of de Einigungstelle, het orgaan dat zich met de inhoud van de besluiten bij geschil bemoeit, competent is. Paragraaf 23 abs. 3 BetrVG, dat de basis biedt voor een nalevingsvordering, spreekt echter van "groben Verstösse" van de werkgever, hetgeen in eerste instantie een probleem opleverde. Deze term moet zo opgevat worden dat naleving gevorderd kan worden wanneer het gaat om de plichten van de werkgever "im Rahmen der Betriebsverfassung". In beginsel gaat het om alle gedragingen; deze hoeven niet aan de persoon van de werkgever verwijtbaar te zijn. Verplichtingen "im Rahmen der Betriebsverfassung" kunnen uit de BetrVG zelf voortvloeien, maar bijwoorbeeld ook uit andere met de BetrVG gerelateerde wetten, of uit Collectieve Overeenkomsten die zich binnen dit kader bevinden. Ook het niet-naleven van verplichtingen uit bedrijfsovereenkomsten kan tot de "groben Verstösse" behoren, wanneer deze verplichtingen hun grondslag in de wet vinden. Het moet wel steeds het gedrag van de werkgever als "Betriebsverfassungsorgan" betreffen (177).

174. Over het soort informatie dat moet worden verstrekt beslist de bedrijfscommissie.: H.L. Bakels, Schets van het Nederlandse arbeidsrecht, Deventer 1987, p. 235.

175. Artikel 26 WOR. De Ondermemingskamer toetst of de ondernemer bij het afwegen van de betrokken bellangen in redelijkheid tot zijn besluit had kunnen komen.

176. HR. 27 september 1985 , NJ 1986, 339.

177. K. Fitting c.5., a.w. (noot 18), p. 328-329. 
Geschillen over toepassing van de veiligheidswetgeving kunnen in België zowel door de ondernemer, werknemers en werknemersvertegenwoordigers in ondernemingsraad en het comité voor veiligheid, gezondheid en ter verfraaiing van de werkplaatsen, als de vakbonden steeds worden voorgelegd aan de arbeidsrechtbank. Het gaat hier met name om procedures tegen het nalaten van de ondernemer of werknemers bepaalde maatregelen te nemen, respectievelijk goed uit te voeren. Voor de individuele werknemers betreft het in het algemeen de eigen veiligheidssituatie (zij moeten een bijzonder belang hebben) en mogelijk geschillen over die informatie waarop individuele werknemers recht hebben.

De vakbonden kunnen informatie- en consultatierechten van de ondernemingsraad en het comité afdwingen en daarnaast opkomen in verband met de naleving van de wet, voor wat betreft instelling van raad en comité zelf. De vertegenwoordigers van beide comité's kunnen naar de arbeidsrechtbank voor naleving van de aan hen toekomende rechten; de procedure impliceert tevens dat een uitspraak over de omvang van die rechten wordt gedaan.

De Franse ondernemingsraad heeft rechtspersoonlijkheid, en kan mede om die reden zelfstandig naleving van zijn rechten vorderen. Deze mogelijkheid is aanwezig bij schending van de consultatie en informatierechten, maar bijvoorbeeld ook op het nietig laten verklaren van besluiten of reglementen, die genomen c.q. ontwikkeld zijn zonder daarover de ondernemingsraad geraadpleegd te hebben (178).

De CHSCT kan naleving slechts via de arbeidsinspectie afdwingen. Op de door haar te volgen procedures wordt in een later stadium teruggekomen (179).

In Spanje (180) komen zaken over de naleving van voorschriften in beginsel voor het arbeidsgerecht. Het gaat hier om zaken tegen de de administratie en arbeidszaken waarwoor gespecialiseerde rechters in het leven geroepen zijn, die georganiseerd zijn op eenzelfde basis als de gewone rechterlijke organisatie. De reden hiervoor is, dat het in deze zaken gaat om een bijzondere tak van het (civiele) recht (181) dat is afgescheiden van het gewone civiele recht. Een proces in arbeidszaken verloopt als volgt: in eerste instantie is er een verplichte hoorzitting voor een bestuursorgaan, het Institudo de Mediación, Arbitraje y Conciliación (IMAC). De bedoeling van deze hoorzitting is tot een schikking te komen. De arbeidsgerechten, die in iedere provinciehoofdstad en in andere grote steden zijn gevestigd, zijn, na

178. Zie G. Lyon-Caen, J. Pélissier, a.w. (noot 56), p. 817-819.

179. Zie paragraaff V.5.

180. De Spaanse rechterlijke organisatie heeft, hoewel zijn wortels in de megentiende eeuw liggen, bij inwoering van de Grondwet van 1978 een nieuwe en overzichtelijke structuur gekregen. De structuur van de civiele rechtspraak is opgebouwd volgens het territoriale principe, met een Hooggerechtshof, dat woor de eenheid in het recht zorgt.

181. E. Guttiérrez de Cabiedes gebruikt in Judicial Structures and legal Proceeding, Spanish business Law (Gen. ed. B.M. Cremades), Deventer 1985, de term 'a special branch of civil llaw', hetgeen voor het administratieve recht in het Nederlands geen adequate omschrijwing
zou zijn. 
de verplichte hoorzitting bewoegd in eerste instantie te oordelen in alle zaken die betrekking hebben op arbeidsrecht. In steden waarin geen arbeidsgerecht gevestigd is kunnen aan het Districtsgerecht (normaal gesproken oordelend in 'gewone' civiele geschillen) voorbereidende taken gedelegeerd worden in zaken waarin de vordering minder bedraagt dan 1500 peseta's, in geval het arbeidsgerecht dit passend vindt. De procedure kent een eenvoudige en mondelinge behandeling. Van de beslissing kan in (vol) beroep gekomen worden bij het Centrale arbeidsgerecht, waarvan de jurisdictie nationaal is (182).

Het Werknemersstatuut voorziet niet in een aparte procedure in het geval dat de consultatiebevoegdheden van de ondernemingsraad worden geschonden. Niettemin is aannemelijk dat de arbeidsgerechten (183) hier bevoegd zullen zijn om vorderingen wegens schending van de wet te ontvangen. Voor wat betreft de naleving van de Collectieve Overeenkomsten zijn de arbeidsgerechten bevoegd.

Ook in lid-staten waar medezeggenschap in hoofdzaak is gebaseerd op vrijwilligheid zijn de collectieve contracten waarin dat is geregeld, zowel als de collectieve contracten die worden afgesloten door de onderhandelaars op ondernemingsniveau in het algemeen afdwingbaar. Dit geldt voor Denemarken, Italië, Griekenland en Frankrijk. In deze landen zijn procedures bij de (arbeids)rechter mogelijk.

Alleen in Groot Brittannië en, tot op zekere hoogte Ierland (184) ligt dit anders. De Britse collectieve overeenkomsten zelf zijn niet in rechte afdwingbaar, de enige manier om ze af te dwingen is via "industrial action" (lees staking). Dit betekent dat ook door shop stewards op lokaal niveau bereikte resultaten met name dan effectief zijn, indien ofwel de ondernemer zelf ook belang heeft bij uitvoering van de overeenkomst, of de shop steward binnen de onderneming genoeg macht heeft de uitvoering af te dwingen via dreiging met "industrial action" (185). Overigens kan in geval van staking wel degelijk naar de rechter worden gestapt door de ondernemer, waarbij schadevergoeding uit onrechtmatige daad (tort), kan worden

182. Het Centrale arbeidsgerecht is bevoegd in zaken tot 1.000.000 peseta's. Bij het Hooggerechtshof is de zesde kamer gespecialiseerd in arbeidszaken. Deze kamer is cassatierechter in zaken waarin de wordering de 1.000 .000 peseta's te boven gaat, en in gevallen bijj wet oorzien, beroepsrechter (vol beroep) ten aanzien van het eindoordeel van de arbeidsgerechten. Bowendien kan bij het Hooggerechtshof cassatie in het belang der wet ingesteld worden ten aanzien van beslissingen van het Centraal arbeidsgerecht, in zakem. waarin de motivering van het Centraal arbeidsgerecht (prejudicial) is.

183. Ten aanzien van vorderingen betreffende onregelmatigheden bij ondernemingsraadsverkiezingen en ontslag in verband met ondernemingsraadslidmaatschap of toegebracht nadeel aan ondernemingsraadsleden zijn de arbeidsgerechten eveneens in eerste aanleg bevoegd.

184. Zie A.T.J.M. Jacobs, a.w. (noot 116), p. 204; M. Redmond, a.w. (noot 40), para. 438, 439.

185. Zie hierover $M$. Terry, How do We know if Shop Stewards are getting Weaker, British Journal of Industrial Rellations 1986, p. 172-173; ook P.K. Edwards, The Pattern of Collective Industrial Action, in G.S. Bain, Industrial Relations in Britain, Oxford, 1983, p. 223. 
gevorderd (186). De naleving van de HSWA 1974 en de daarin aan werknemersvertegenwoordigers toegekende rechten verloopt vooral via de strafrechtelijke weg.

\subsection{Geschillenbeslechting tijdens het besluitvonningsproces}

Geschillen die optreden tijdens het proces van besluitvorming of onderhandeling hebben in het algemeen betrekking op het niet instemmen met een voorgelegd besluit door de ondernemingsraad, of een vastlopen van het proces van onderhandelen op ondernemingsniveau. In de meeste lid-staten, uitgezonderd Spanje is daarvoor in een arbitrageprocedure voorzien, al dan niet voorafgegaan door een bemiddelingspoging.

In de Duitse BetrVG is de Einigungstelle voor dit soort geschillen de belangrijkste geschilsbesllechtende instantie (187). Het is in beginsel een ad hoc arbitrage-orgaan in de onderneming, dat bij iedere geschilsoplossing opnieuw wordt samengesteld, hoewel het op basis van de wet mogelijk is dat bij bedrijfsovereenkomst een permanente Einigungsstelle wordt geïnstalleerd. Het orgaan bestaat uit een onafhankelijke voorzitter en een gelijk aantal door ondernemer en ondernemingsraad benoemde leden. Indien over het aantal leden of over de persoon van de voorzitter een conflict ontstaat, kunnen zowel ondernemer als ondernemingsraad aan het Arbeitsgericht hierover een beslissing vragen.

De Einigungsstelle beslist over geschillen tussen ondernemer en Betriebsrat. $\mathrm{Zij}$ beslist na een mondelinge behandeling, die niet openbaar is, met volstrekte meerderheid van stemmen, de voorzitter heeft de beslissende stem indien de stemmen staken.

In het geval dat in een uitspraak van de Einigungstelle de verzoening tussen (c.q. de beslissing van) ondernemingsraad en ondernemer wordt beoogd, kan ieder der partijen de zaak aanzwengelen bij de Einigungstelle. De partij die het niet gewenst vindt dat een beslissing gevraagd wordt, kan dit niet tegengaan door geen leden te benoemen: indien eén partij geen leden benoemt, wordt er alleen met de wel benoemde leden een beslissing genomen, hetgeen de partij die een beslissing vraagt ongetwijfeld een overwinning op zal leveren.

Als één van beide partijen een uitspraak kan vragen, hetgeen bij de meeste typische medezeggenschapsonderwerpen, waaronder het sociaal beleid, het geval is (188) toetst de Einigungstelle het besluit volledig, maar moet daarbij zowel de belangen van de ondernemer als die van de betrokken werknemers afwegen naar billijkheid. Dit impliceert onder meer dat de Einigungstelle rekening dient te houden met hetgeen door ondernemingsraad en ondernemer overeen is gekomen. Het billijkheidscriterium is de grens van het handelen van de Einigungsstelle; meent é́n der partijen dat

186. Zie over dit onderwerp onder meer. K.S. Wedderburn, R. Lewis, J. Clark, Labour Law and Industrial Relations, Oxford 1983, p. 200-296.

187. Paragraaf 76 BetrVG.

188. Zie hierover K. Filting c.s., a.w. (noot 18), p. 817 . 
de grens van het oordeel naar billijkheid is overschreden dan kan tegen het besluit van de Einigungsstelle binnen twee weken na de uitspraak bij het Arbeitsgericht in beroep worden gekomen. Het Arbeitsgericht kan bij overschrijding van de billijkheidsgrens de uitspraak van de Einigungstelle "opheffen", indien uit de uitspraak duidelijk blijkt dat geen redelijke belangenafweging heeft plaatsgevonden. Hoewel het Arbeitsgericht de uitspraak niet in volle omvang toetst, lijkt mij deze formulering toch verder gaan dan een willekeurtoetsing zoals deze in Nederland door de Ondernemingskamer toegepast wordt (189).

In de gevallen waarin de Einigungsstelle alleen kan optreden op verzoek van beide partijen (als een scheidsrechter in de ware zin des woords) is het noodzaak dat beide partijen verklaren de uitspraak na te zullen leven. Indien de Einigungsstelle verzocht wordt een uitspraak te doen over een aangelegenheid die een individuele werknemer betreft, dan sluit de uitspraak niet de weg naar het Arbeitsgericht voor de individuele werknemer af.

Op basis van een uitspraak van de Einigungsstelle kan een bedrijfsovereenkomst worden gesloten. Conflicten over een overeenkomst komen echter bij het Arbeitsgericht "im Beschlussverfahren" (een verzoekprocedure bij het Arbeitsgericht die sneller is dan een gewone procedure). Dit geldt ook voor gewone bedrijfsovereenkomsten, voor conflicten over zowel de naleving als conflicten over de inhoud van de overeenkomst is het Arbeitsgericht competent.

In Nederland werden geschillen over de inhoud van de rechten tot voor kort voorgelegd aan de bedrijfscommissie. $\mathrm{Na}$ de hierboven genoemde wetswijziging tot vereenvoudiging van de geschillenregelingen is de de kantonrechter bevoegd. Het is mogelijk dat de toetsing door deze wijziging inhoudelijk gaat verschillen van die van de bedrijfscommissie. Daarom zal aan beide procedures aandacht worden besteed.

In de oude regeling kon de ondernemer, wanneer de ondernemingsraad wanneer zijn instemming (o.g.v. artikel 27 WOR) weigerde, vervangende instemming vragen aan de bedrijfscommissie. De bedrijfscommissie toetste het verzoek van de ondernemer vol. Indien vervangende instemming werd verleend kon de ondernemingsraad binnen een maand in beroep gaan bij de Minister van Sociale Zaken. Mocht deze zijn goedkeuring ook verlenen, dan was onder omstandigheden beroep mogelijk krachtens de wet AROB (190).

$\mathrm{Na}$ de wetswijziging moet de kantonrechter vervangende toestemming geven. Hij kan dit slechts (nadat bemiddeling van de bedrijfscommissie zonder resultaat is gebleven) wanneer de beslissing van de ondernemingsraad niet in te stemmen, onredelijk is, of wanneer het voorgenomen besluit van de ondernemer gevergd wordt door zwaarwegende bedrijfsorganisatorische,

189. Vgl. L. Pünnel, Die Einigungsstelle des BetrVG, Neuwied/Darmstadt, 1985.

190. H.L. Bakels, a.w. (noot 174), p. 240. 
bedrijfseconomische of bedrijfssociale redenen. Met deze formule wordt vollgens de Memorie van Toelichting aangesloten op de criteria die in de jurisprudentie van de Minister van Sociale Zaken, worden gehanteerd (191). Van der Heijden (192) meent echter dat het toetsingscriterium in de ministeriele jurisprudentie oorspronkelijk veel marginaler was dan die in het wetsontwerp, en pas na 1984 naar een redelijkheidstoetsing is verschoven. De toetsing tot 1984 sloot aan bij de toetsing die de Ondernemingskamer verrichtte in het kader van de artikel 26 WOR-procedure. Dit was een toetsing die het instemmingsrecht als zodanig het volle pond gaf. Of het nieuwe toetsingscriterium tot een wijziging in de nu bestaande praktijk zal leiden is nog onduidelijk. Van der Heijden sluit dit niet uit (193).

Het aantal verschillende instanties die de ondernemingsraad bij het uitoefenen van zijn informatie- en consultatiebevoegdheden kan tegenkomen wordt door de wetswijziging drastisch ingekrompen. Dat is maar goed ook want een grote hoeveelheid verschillende procedures leidt tot even zovele mogelijkheden op een bepaald moment niet-ontvankelijk verklaard te worden. Dit was niet direct bevorderlijk voor de taakuitoefening van een orgaan, dat formeel in elk geval geen steun heeft van een vakbondsapparaat.

Er is er echter nog én procedure die nog niet genoemd is. Als een spoedeisende beslissing noodzakelijk is, kan de ondernemingsraad in Kort Geding een voorzlening vragen, indien het gaat om een procedure waartoe de ondernemingsraad bij wettelijke voorziening procespersoonlijkheid is verleend. De ondernemingsraad is geen rechtspersoon en heeft slechts beperkte proces-persoonlijkheid (194).

In België is er slechts voor het medebeslissingsrecht inzake de aanstelling en ontslag van de bedrijfsarts een speciale geschillenprocedure. Op zich zelf is het medebeslissingsrecht van ondernemingsraad of comité voor veiligheid, gezondheid en verfraaiing van de werkplaatsen bedoeld als beschermende bepaling voor de bedrijfsarts. Niettemin kunnen ook de ondernemingsraad of het comite het ontslag aanzwengelen indien geen vertrouwen (meer) bestaat in de bedrijfsarts, hetgeen aan de beschermde positie van de bedrijfsarts weer wat afdoet (vanuit zijn oogpunt dan). Indien binnen het comité geen overeenstemming over het (onvrijwilige) ontslag van een bedrijfsarts wordt bereikt, dan wordt de kwestie voorgelegd aan de erkenningscommissie van geneeskundige diensten, waarnaast nog een procedure bij de bevoegde rechter kan plaatsvinden.

191. TK $1988 / 89$, no. 20583 , p. $27-28$.

192. P.F. van der Heijden, Een nieuwe geschillenregeling in de WOR, TVVS 1989, p. 9.

193. P.F. van der Heijden, a.w. (noot 192), p. 11.

194. Zie o.m. J.B. Huizink, De Ondernemingsraad: Rechtspersoon?, TVVS 1983, no. 83/11, p. 297-302. Zie ook Afd. Rp., 18 februari 1982, B. Geersing, P.F. van der Heijden, Rechispraak medezeggenschapsrecht 1981-1982, Deventer, no. 74. waarin de Afdeling Rechtspraak van de Raad van State de status van procespersoon enigzins heeft uitgebreid door rechtspersoonlijkheid aan te nemen als dat noodzakelijk is om in administratief beroep te gaan. 
In Luxemburg schrijft de wet, indien men het in de ondernemingsraad niet eens kan worden over een besluit waarbij medebeslissingsrecht van de raad bestaat, een conciliatieprocedure voor (195). Eventueel kan een arbitrageprocedure in gang worden gezet, waarbij het Office National de Conciliation als arbiter optreedt. De uitspraken van dit bureau, dat is ingesteld bij een besluit in 1945 (196) treden in de plaats van de beslissing van de ondernemingsraad (197).

In Griekenland wordt de conciliatie-activiteit tussen werkgever en werknemersvertegenwoordigers tijdens het besluitvormingsproces veelal verricht door een ambtenaar van het Ministerie van Arbeid. Deze is ook betrokken bij het arbitragetribunaal, dat daarnaast bestaat uit werkgevers- en werknemersleden, en een beroepsrechter (198).

In de lid-staten waar de medezeggenschap op vrijwillige basis is geregeld bestaat er meestal een mogelijkheid tot conciliatie en arbitrage ingeval het proces van onderhandelen stukloopt. Soms worden voor de conciliatietaken speciale commissies voor in het leven geroepen. In België is deze taak toebedeeld aan het paritaire comité, dat voor de conciliatiefase gebruik maakt van een een daartoe in het leven geroepen conciliatiecomité (199). Ook de Deense bedrijfscommissie (samarbejdsnaevnet) heeft een in eerste instantie bemiddelende taak. Pas nadat deze mislukt is, wordt een arbitrageinstantie in het leven geroepen. Wanneer Deense vakbondsvertegenwoordigers in conflict raken met de ondernemer kunnen beiden het conflict voorleggen aan een bipartite samengesteld arbitrage college. Indien het conflict om de persoon van de shop steward gaat zal dit het geval zijn indien er al met ontslag gedreigd is.

In lidstaten zonder al te veel regulering van het proces van collectief onderhandelen, zoals Italie is een procedure omtrent geschillen veelal te vinden in de collectieve overeenkomsten zelf; in elk geval voorzien de nationale overeenkomsten in het algemeen in conciliatie- en arbitrageprocedures (200).

In Groot Brittannie is het proces van collectief onderhandelen wel onderworpen aan enkele ondersteunende regels, waarin onder meer arbitrage en conciliatie mogelijkheden zijn geschapen. In de de Employment Protection Act 1975 werd de Advisory, Conciliation and Arbitration Service (ACAS) in het leven geroepen, een lichaam dat 'Codes of Practice' kan

195. Groenboek, Medezeggenschap van de werknemers en de structuur van de vennootschap in de Europese Gemeenschap, bulletin EEG, supplement $8 / 75$, p. 98.

196. Arreté grand-ducal van 6 oktober 1945 .

197. R. Schintgen, La liberte syndicale des salariés au Grand Duche de Luxembourg, in The Freedom of the Worker to Organize, Berlijn 1980, p. 487.

198. A.G. Karakatsanis, Labor Law, in Introduction to Greek Law, Athens 1988 (K.D. Keramus, P.J. Kozyris, eds.) p. 224.

199. R. Blanpain, a.w. (noot 22), para. 310.

200. T. Treu, a.w. (noot 61), para. 450 . 
uitgeven, die weliswaar geen wet zijn, maar door de rechters en het Central Arbitration Committee (CAC) bij hun uitspraak in de owerwegingen moeten worden betrokken. Deze beide organen hebben een taak in het bevorderen van het collectief onderhandelen en de daarmee samenhangende rechten van de vakbonden. Tot 1982 voorzag de EPA 1975 in een arbitrageprocedure, waarin erkende vakbonden konden klagen bij de al eerder genoemde CAC, wanneer de werkgever zijn plicht "to bargain reasonably", niet naleefde. Deze procedure is bij de Employment Act van 1982 ingetrokken (201). Arbitrage moet nu op geheel vrijwillige basis plaatsvinden.

Arbitrageuitspraken treden in tegenstelling tot rechterlijke uitspraken, in een aantal lid-staten in de plaats van, of gaan deel uitmaken van de collectieve overeenkomst. Dit betekent dat zij bij een nieuwe onderhandelingsronde vatbaar zijn voor wijzigingen. Dit is het geval in Griekenland, Frankrijk maar ook in Luxemburg. In feite is dit in Duitsland, hoewel het daar niet gaat om collectief onderhandelen in de enge zin van het woord, eveneens het geval.

In Spanje voorziet de wet niet in bepalingen met betrekking tot arbitrage en conciliatie in geval van collectief conflict. In het Economisch en Sociaal Akkoord ten aanzien van collectief onderhandelen 1985/1986 (202), werd deze ommissie geconstateerd en werden criteria gesteld voor een omtrent dit onderwerp te omntwerpen overeenkomst.

De belangen van ondernemers bij bovengenoemde actiesoorten zijn niet altijd even groot; weinigen zullen hun besluiten graag inhoudelijk getoetst zien, zelfs maar marginaal, en ook op formele punten zullen de meesten niet graag tot de orde geroepen worden; het kan de slagvaardigheid alleen maar verkleinen (203). Voor wat betreft naleving van besluiten c.q. overeenkomsten ligt het in die zin anders, dat belangen van de ondernemer bij naleving minstens even groot zo niet groter kunnen zijn dan voor werknemers.

Er zijn echter meer belanghebbenden wanneer een besluit genomen wordt, dan alleen ondernemer en de werknemersvertegenwoordigers. Individuele werknemers kunnen belang hebben bij de toetsing van een besluit, bijvoorbeeld als zij door een besluit nadelig getroffen worden, of wanneer zij voor hun klachten geen gehoor vinden. Zij kunnen een ander besluit, of juist helemaal geen besluit wensen. Bovendien kunnen individuele werknemers veel last ondervinden indien de ondernemer op bepaalde punten geen poging om tot besluitvorming te komen onderneemt.

In de lid-staten waar medezeggenschap op vrijwillige basis plaatsvindt hebben individuele werknemers in beginsel weinig mogelijkheden om in het

201. Lord Wedderburn, a.w. (noot 60), p. 288.

202. Spanish Economic and Social Agreement tussen de Werkgevers federaties CEOE en CEPYME en de vakbond UGT, Engelse tekst EIRR 132, January 1985.

203. J. van der Wulffen Palthe, a.w. (noot 93), p. 457, 464. 
geweer te komen tegen besluiten genomen na overleg/onderhandelling tussen werkgever en werknemersvertegenwoordigers. Een uitzondering zou gevormd kunnen worden door collectieve contracten die doorwerken in de arbeidsovereenkomsten van de werknemers; echter dan gaat het met name om verkregen rechten op andere gronden, hetgeen in dit verband geen voorwerp van onderzoek is. Invloed uitoefenen op het besluitvormingsproces moet verlopen via pressie op de vertegenwoordigers zelf. In de meeste systemen is dit overigens betrekkelijk eenvoudig te bereiken, omdat de shop steward behoort tot de groep van werknemers die hij vertegenwoordigt. Hier doen zich twee problemen voor die elders in dit boek ook al gesignaleerd zijn: om te beginnen is de shop steward een vakbondsvertegenwoordiger en vertegenwoordigt dus in beginsel alleen vakbondsleden (zelfs als er een algemeen kiesrecht is zoals in Denemarken en Italië blijft de shop steward vakbondsvertegenwoordiger) en daarnaast worden slechts de leden van de "representatieve" bonden vertegenwoordigd, omdat in de meeste lidstaten slechts zij onderhandelingen kunnen voeren.

Dit kan acceptabel zijn als de onderhandelingen concrete arbeidsvoorwaarden tot voorwerp hebben, die de niet-leden niet in hun individuele overeenkomsten voelen, zodat zij geen last ( maar ook geen voordeel) hebben van hetgeen in de onderhandelingen bereikt wordt. Maar dat wordt al anders wanneer zaken als veiligheid, gezondheid, welzijn, arbeids- en rusttijden en de arbeidsorganisatie, kortom de meer algemeen door te voeren maatregelen tot het onderhandelingsterrein van de shop stewards behoren. Een algemeen kiesrecht zou dan het minste zijn waaraan democratische arbeidsverhoudingen zouden moeten voldoen.

In die systemen die op wettelijke basis geschoeid zijn zijn de mogelijkheden evenmin ruim. In Nederland (204) en in Spanje heeft de individuele werknemer, indien de opstelling van ondernemingsraad hem miet zint, praktisch geen mogelijkheid daar iets aan te doen. Slechts als een besluit genomen wordt, waarin een maatregel hem persoonlijk betreft, kan dit anders liggen, op basis van het gewone contractenrecht.

In Duitsland zijn de mogelijkheden iets ruimer. Om te beginnen zijn contacten met de achterban door de eerder besproken Betriebsversammlungen sterker geïnstitutionaliseerd dan in bijvoorbeeld Nederland, waardoor het beleid en de stellingname van de ondernemingsraad gemakkelijker beïnvloed kunnen worden.

Voorts kan in Duitsland de individuele werknemer, als hij zich benadeeld voelt in de onderneming, zijn bezwaren tegen besluiten van de ondernemer bij de daartoe geëigende instituties in de onderneming ("zuständigen Stellen des Betriebes") kenbaar maken. Hij kan zich daarbij laten vergezellen door een lid van de ondernemingsraad als steun of als bemiddelaar. Het gaat

204. Alleen in het geval een ondernemingsraad ontbreekt kan in Nederland een meerderheid van de belanghebbende werknemers o.g.v. de Arbowet een verzoek tot wetstoepassing doen. 
hier ook om individuele benadeling, niet om een actio popularis. Niettemin geeft de ruime formulering uit paragraaf 84 aan dat het niet gaat om maatregelen die specifiek voor of tegen de klagende werknemer zijn gericht: indien een algemene maatregel een individuele werknemer benadeelt, dan heeft die werknemer het Beschwerderecht. Bezwaren tegen de ondernemingsraad zelf, zijn overigens niet-ontvankelijk; in geval werknemers bezwaar hebben tegen bepaalde ondernemingsraadsleden geeft paragraaf 231 BetrVG een aparte weg.

De ondernemingsraad kan ook bezwaren behandelen en deze de ondernemer voorleggen, om op deze wijze tot een oplossing te komen. Indien een bezwaar door de ondernemingsraad behandeld wordt, en dit leidt tot een verschil van mening met de ondernemer, dan kan de zaak aangezwengeld worden bij de Einigungsstelle.

Voor het Beschwerderecht geldt dat, wanneer een bezwaar in het overleg behandeld wordt en dit niet tot een voor de werknemer positief resultaat leidt, dit niets afdoet aan het recht van een werknemer zijn zaak bij het Arbeitsgericht aanhangig te maken.

De Nederlandse werknemer heeft in tegenstelling tot zijn Duitse collega (nog (205)) geen op de wet gebaseerd individueel klachtrecht of recht van bezwaar in de onderneming. Ook een klacht gedeponeerd bij de ondernemingsraad (of arbeidsinspectie (206)) over een bepaalde gang van zaken draagt het karakter van een petitie. Deels heeft dit te maken met het feit dat de ondernemingsraad minder dan de Duitse Betriebsrat besluiten neemt in individuele gevallen (ontslagbescherming loopt in de BRD voor een deel via de ondernemingsraad) deels met de Nederlandse tradititie die individuele bescherming meer heeft gekoppeld aan het individuele arbeidsovereenkomsten- en ontslagrecht. Wel kan de individuele werknemer, evenals de vakbonden naleving van de wet eisen waar het gaat om de ontslagbescherming van leden, aspirant- en voormalige leden van de ondernemingsraad. Bovendien kunnen individuele kiesgerechtigde werknemers naleving vorderen op het gebied van instelling van een $O R$, het vaststellen van het voorlopig reglement van de $O R$, de kandidaatstelling, en bekendmakingen in verband met de $O R$, door de ondernemer of de ondernemingsraad zelf. Dit laatste vorderingsrecht komt ook toe aan de vakbonden.

Tot voor kort had de individuele werknemer de mogelijkheid bij de kantonrechter de niet-uitvoering of -toepassing van een nietig besluit te vorderen (207). Deze mogelijkheid is na de wetswijziging verdwenen.

In de meeste lid-staten kunnen bij geschillen tussen ondernemingsraad en werkgever in beginsel zowel arbiter (tijdens de besluitvorming) als rechter

205. Een wetsontwerp met betrekking tot het individueel klachtrecht in de onderneming ligt bij de Raad van State. Zie over het klachtrecht in het algemeen A.J.C.M. Geers, a.w. (noot
7), p. $316-323$.

206. Artikel 34. Arbowet.

207. Artikel 36 lid 3 , $2 \mathrm{e}$ zin WOR. 
(over de naleving van een genomen besluit) betrokken worden. In Nederland is na de wetswijziging de rol van de arbiter (bedrijfscommissie) geheel een bemiddelende geworden; knopen worden alleen nog door rechters doorgehakt. Of dit een voordeel is zal de praktijk moeten uitwijzen, het is in elk geval een goede zaak dat het aantall geschillenbeslechtende instanties, die de ondernemingsraad kan tegenkomen fors verminderd is.

Individuele werknemers moeten het in de lid-staten hebben van invloed op de vertegenwoordigers en niet of veel minder van juridische procedures om iets te bereiken binnen de medezeggenschapssystemen. Het zal mede afhangen van de wijze waarop de vertegenwoordiging binnen de onderneming georganiseerd is en van de voorwaarden welke het recht stelt aan die organisatie, of werknemers in dit opzicht voldoende mogelijkheden hebben hun bezwaren en wensen kenbaar te maken. De organisatie in Duitsland maakt in elk geval beïnvloeding door de achterban als geheel wel mogelijk. Dit is niet op gelijksoortige wijze geformaliseerd in andere lid-staten met een wettelijk stelsel van medezeggenschap. In lid-staten waar shop stewards op de werkvloer de werknemers vertegenwoordigen ligt dit in zoverre anders dat zij dagelijks met hun achterban in contact komen; beïnvloeding kan daar op zichzelf al gemakkelijker plaatsvinden. In alle gevallen geldt dat resultaten niet afdwingbaar zijn en dat ongenoegen slechts achteraf consequenties kan hebben.

Voor de individuele werknemers, maar niet woor hen alleen is dan ook de vraag van belang op welke andere wijze zij werkgever en ondernemingsraad gezamenlijk, of de werkgever alleen kunnen dwingen rekening te houden met wat zij menen dat in hun belang is. Daarmee komt de vraag naar de directe sancties aan de orde.

\section{Directe sancties}

De laatste en meest ultieme mogelijkheid om invloed uit te oefenen op het ondernemingsbeleid is het overgaan tot direct tegen de werkgever gerichte acties binnen de onderneming door werknemers. Met directe sancties doel ik op de mogelijkheden die werknemers hebben om zowel individueel als collectief het werk stil te leggen, totdat het beleid dusdanig is beïnvloed dat werknemers zich tevreden kunnen achten. De mogelijkheid om het werk individueel stil te leggen is met name van belang in verband met veiligheid en gezondheid, en minder in verband met meer algemene problemen. Dit is dan ook de reden dat dit recht in het volgende hoofdstuk behandeld zal. worden in samenhang met het recht om bij dreigend en ernstig gevaar, collectief het werk stil te leggen.

De andere directe sanctie, de collectieve actie in de onderneming, met name in de vorm van staking wordt in het algemeen gekoppeld aan collectieve onderhandelingen tussen werkgever en werknemersvertegenwoordigers. Er wordt daarbij niet in de eerste plaats gedacht aan de situatie van 
overleg en samenwerking met de werkgever en werknemersvertegenwoordigers in een orgaan, als een ondernemingsraad, dat juist met een samenwerkingsdoelstelling is ingesteld. Zoals eerder is gesteld (208), zijn naar mijn mening overleg en onderhandelingssituaties niet strikt te scheiden: wat als het ene begint kan uitlopen op het andere. Patstellingen zijn mogelijk, en situaties waarin oplossingen moeilijk zo niet onmogelijk worden kunnen daarin voorkomen. Hoe meer juridische wegen openstaan (mogelijkheden tot arbitrage, toegang tot de rechter voor de werknemersvertegenwoordigers), kortom hoe meer medezeggenschapsinstrumenten zijn versterkt met additionele rechten, hoe minder noodzaak zal bestaan tot collectieve actie over te gaan.

Met de term staking sluit ik mij an bij de definities die in het algemeen in het arbeidsrecht gebruikt worden (209). Hierbij wordt uiteraard niet gedoeld op een bij de wet toegestane actievorm voor een specifiek (en mogelijk evident) geval. Het zelfstandig direct actie ondernemen, staken of op andere wijze collectief actie voeren (stiptheids-, speerpuntacties e.d. (210)), is het oudste middel tot beïnvloeding van de werkgever in het arbeidsrecht. De staking is echter veelal gebruikt om ondernemers tot concessies te dwingen bij het sluiten van collectieve overeenkomsten, die weliswaar ook de arbeidsomstandigheden (konden) omvatten, maar waarbij de regulering daarvan niet altijd de eerste prioriteit had (211). De vraag die hier dan ook rijst is of een actievorm, die zozeer gebonden is aan het recht op collectief onderhandelen overgeplant kan worden naar een gebied dat veel meer gereguleerd is door wettelijke bepalingen (212). Dit geldt vooral voor de landen waarbij collectief onderhandelen en medezeggenschap streng gescheiden zijn.

Het stakingsrecht zal in deze paragraaf bekeken worden op zijn mogelijkheden als directe actievorm voor werknemers inzake aangelegenheden die tot overwegende tot de competentie van de medezeggenschapsorganen behoren. De nadruk ligt hierbij op veiligheids- en gezondheidsaangelegenheden. Deze beperking impliceert dat hier niet het stakingsrecht in het algemeen besproken zal worden. Voorts zal ik mij voor een aantal lid-staten, noodgedwongen moeten beperken tot de formele regelingen met betrekking

208. Zie paragraaf IV.1. 209. Zie de definitie bij H.L. Bakels, a.w. (noot 174), p. 194, die ontleend is aan de algemene
literatuur ${ }_{j}$ en volgens de auteur de meest gangbare is

210. Deze andere vormen van acties worden buiten beschouwing gelaten. Wel moet hierbij opgemerkt worden dat niet in alle lid-staten deze andere vormen op dezelfde wijze in het
stakingsrecht zijin "opgenomen"..

211. Verwevenheid van arbeidsomstandigheden en arbeidsvoorwaarden (hoger loon i.v.m. slechte werkomstandigheden is well een bekend fenomeen) een recent voorbeeld zijn de acties in 1989 van het verplegend en verzorgend personeel in Nederlland voor een $5 \%$ loonswerhoging waarbij de eis mede gebaseerd was op het feit dat de werkomstandigheden
zeer zwaar waren. 212. Zie hierover i.h.a. R. Blanpain (ed), Comparative Labour Law and Industrial Relations,
Deventer 1985 , p. 399-424. 
tot staking. Vooral in die lid-staten waar de competenties van ondernemingsraad en vakbonden gescheiden zijn is relatief weinig aandacht aan de staking binnen het medezeggenschapsrecht besteed. Alleen Nederland wordt in dit verband wat uitgebreider besproken.

In het internationale recht, en met name het Europees Sociaal Handvest (213) wordt het stakingsrecht gekoppeld aan collectief onderhandelen (214). Ook het Gemeenschapshandvest voor Sociale Grondrechten legt deze koppeling (215). Kan men nu werknemersvertegenwoordigers op ondernemingsniveau per definitie zien als collectieve onderhandelaars, of juist in het geheel niet. Een ondernemingsraad die weliswaar instemmingsbevoegdheden binnen de onderneming op een aantal terreinen heeft, maar geen expliciete onderhandelingsbevoegdheden, kan zoals gesteld wel feitelijk een onderhandelend orgaan worden, maar formeel hoeft hij dat niet te zijn. In dat geval kan men betogen dat, bij verschil van mening tussen ondernemingsraad en werkgever een mogelijkheid tot staking uitgesloten is. Als een ondernemingsraad een van de vakbonden onafhankelijk orgaan is, is een door de raad uitgeroepen staking een wilde staking hetgeen eveneens consequenties heeft voor de mogelijkheid tot staken in een aantal lid-staten.

De definitie van wat collectief onderhandelen is en wie daartoe bevoegd zijn, is dus van belang voor de vraag of ondernemingsraden een staking kunnen uitroepen. In Duitsland wordt het begrip collectief onderhandelen strikt gekoppeld aan vakbonden. In beginsel zijn stakingen alleen geoorloofd indien zij uitgeroepen zijn door de vakbonden (216). Wilde stakingen komen overigens wel voor, maar kunnen alleen hun onrechtmatigheid kwijtraken doordat de vakbonden de actie overnemen; in dat geval wordt de actie met terugwerkende kracht rechtmatig, indien de staking tenminste de toetsingscriteria die voor stakingen, door vakbonden georganiseerd, gelden, kan doorstaan.

Voor zaken die onder de competentie van de ondernemingsraad vallen (onder meer veiligheid en gezondheid), zal indien werknemers het werk stilleggen om een bepaald doel te bereiken, dit als een (onrechtmatige) wilde staking beschouwd worden, tenzij de vakbonden interveniëren. Echter, in dit laatste geval is het nog maar de vraag, of de staking de rechtmatig-

213. $\mathrm{Nu}$ in het Gemeenschapsrecht een afdwingbare catalogus voor (sociale) grondrechten ontbreekt en er dus geen gemeenschappelijk stakingsrecht in die zin bestaat, zal voor de mogelijkheid tot staking aangeknoopt worden bij het Europees Sociaal Handvest als "dichtstbijzijnde" internationale norm die voor dit geheel relevant is.

214. Zie artikel 6 lid 4 ESH. Voor definities in andere verdragen, ze $\mathrm{L}$. Betten, The Right to Strike in Community law, North Holland 1985, p. 190-193.

215. Gemeenschapshandvest voor Sociale Grondrechten, COM (89) 471 def. (tekst na aanvaarding nog miet gepubliceerd, zic ook NJCM-bulletin 1990, 15-1, p. 20-29, artikel 11.

216. A. Hueck, H. Nipperdey, Lehrbuch des Arbeitsrechts, II/2, Berlin Frankfurt, 1970 p. 1002, concluderen uit het verbod van acties in arbeidsconflicten van de Betriebsrat, een verbod dat de partijen bij een collectieve overeenkomst niet raakt, a contrario dat alleen vakbonden een staking mogen organiseren. 
heidstoets kan doorstaan aangezien in de Bondsrepubliek een staking als uiterste middel wordt beschouwd.

Ondernemingsraden zelf mogen niet tot wilde stakingen oproepen (217). Artikel 74 BetrVG verklaart acties uit het collectieve arbeidsrecht tussen werkgever en ondernemingsraad in een arbeidsconflict ontoelaatbaar. Dit verbod dat niet geldt indien het gaat om conflicten tussen "tariffahiger Parteien" betekent dat het arbeidsomstandighedenconflict dan ook een conflict tussen vakbond en werkgever moet zijn. Dit betekent dat het verschil maakt of vakbonden en werkgevers de arbeidsomstandigheden in een collectieve overeenkomst hebben geregeld. Als dit niet het geval is, is het nog maar de vraag of vakbonden een staking zullen ondersteunen; het gaat dan om een materie die zij nu juist uitdrukkelijk hebben overgelaten aan de ondernemingsraad. Indien de vakbonden zich inhoudelijk in de CAO bemoeid hebben met bijvoorbeeld veiligheidsbeleid, of indien juist het conflict ontstaat tijdens de onderhandelingen over een dergelijk onderwerp, dan zal dit mogelijk anders liggen.

Een andere mogelijkheid die aangegrepen kan worden is het Zurückbehaltungsrecht van paragraaf $273 \mathrm{BGB}$. Dit is het recht van een schuldeiser zijn deel van de overeenkomst niet uit te voeren, wanneer de wederpartij in gebreke blijft. Voor werknemers betekent dit dat zij het werk neer kunnen leggen, indien de werkgever zijn wettelijke verplichtingen, ook met betrekking tot beschermende maatregelen, niet nakomt (en ook alleen dan) (218). Hoewel het hier om een individueel recht gaat kàn het collectief uitgeoefend worden; er kunnen dan wel problemen ontstaan met betrekking tot de afgrenzing met het stakingsrecht.

Het onrechtmatig gebruiken van het Zurückbehaltungsrecht kan leiden tot ontslag.

De rigide uitleg van het begrip "collectief" zoals dat in Duitsland toegepast wordt -namelijk dat alleen vakbonden als "collectief" dat een staking kunnen uitroepen, andere "collectieven" zijn uitgesloten- vindt men elders ook terug (in Denemarken en Griekenland bijvoorbeeld).

In Nederland is de situatie al iets minder strak geregeld dan in Duitsland (219). Om te beginnen is het recht een staking uit te roepen (220)

217. Dat wordt gezien als een Grosse Plichtverletzung van de ondernemingsraadsleden in de zin van paragraaf 23 (1) BetrVG, K. Fitting c.s. a.w. (noot 18), p. 320 .

218. G. Schaub, Arbeitsrechtshandbuch, München 1987, p. 562, 1016.

219. Rigide in de zin van wettelijke stakingsverboden. De praktijk is dat rechters in Kort Geding oordellen over stakingen en daarbij de toegebrachite schade toetst aan de redelijksheidlsgrenzen. Het gevolg van deze toetsing is dat veel stakingen op die grond onrechtmatig worden geoordeell. Hierop is door de FNV nogal wat kritiek geleverd, zie: Collectieve Actie een recht, een FNV beschouwing over enige knelpunten in het collectieve actierecht, Amsterdam 1988 , p. $25-29$.

220. Tot op 30 meil 1986 de rechtstreekse werking van art 6 lid 4 Europees Sociaal Handvest werd aangenomen (HR. 30 mei 1986 NJ 1986, 688), kende Nederland geen wettelijke bepaling die een recht van staking regelde ; in de jurisprudentie was een stakingsrecht wel erkend. Zie over dit onderwerp o.m. M.G. Rood, Naar een stakingswet?, Dewenter 1978; H. van den Berg, P. Fortuyn, T. Jaspers, De ontwikkeling van het stakingsrecht in Nederland, SUN, Nijmegen 1978; M.G. Rood, Over collectieve werknemers actie of: De 
niet volledig het prerogatief van de vakbonden. Hoewel wilde stakingen ook in Nederland weliswaar eerder onrechtmatig zijn dan georganiseerde, hoeft onrechtmatigheid niet per definitie het geval te zijn (221). Bovendien maakt, het in Nederland rechtstreeks werkende artikel 6 lid 4 Europees Sociaal Handvest (ESH), geen onderscheid tussen wilde en georganiseerde stakingen. Het ESH spreekt over werknemers die collectief optreden, niet over vakbonden als (enige) collectiviteiten die namens hun leden acties organiseren of ondersteunen (222). De wilde staking in een onderneming is dus op zich zelf mogelijk.

Blijft over de vraag of gestaakt kan worden voor een doel dat tot de competentie van een medezeggenschapsorgaan behoort. Op zichzelf is een ondernemingsraad een collectief in de zin van artikel 6 lid 4 ESH te noemen. Deze zou mogelijk bij conflict een staking uit kunnen roepen, indien hij bij de werkgever na veelvuldig overleg geen gehoor vindt en geen mogelijkheden openstaan zijn eisen via de rechter af te dwingen. Op veiligheids- en gezondheidsgebied heeft dit probleem door de wetswijziging een nieuwe dimensie gekregen. Nu de ondernemingsraad geen instemmingsrecht meer heeft voor het overgrote deel van het arbeidsomstandighedenbeleid, moet hij, om maatregelen af te dwingen terugvallen op de arbeidsinspectie. Tot deze zich over het probleem heeft uitgesproken lijkt een staking mij niet in de rede te liggen. In het geval de arbeidsinspectie geen maatregelen wil nemen, ligt dit anders. Dit kan zijn oorzaak vinden in het feit dat de arbeidsinspectie meent dat maatregelen (nog) niet nodig zijn, of dat de maatregelen uitgaan boven hetgeen waartoe wettelijke voorschriften verplichten. In dat geval staat er voor de ondernemingsraad geen weg meer open om de werkgever tot actie te dwingen. Dit spreekt te meer omdat de ondernemingsraad geen gesanctioneerd adviesrecht heeft. Ik kan mij voorstellen dat een door de ondernemingsraad uitgeroepen (wilde) staking onder die omstandigheden rechtmatig kan zijn.

Daarnaast is er het probleem van de andere werknemers. Zoals ik elders al eens betoogd heb (223), meen ik dat een staking om betere arbeidsomstandigheden af te dwingen mogelijk is, indien Nederlandse werknemers met hun klachten bij de ondernemer, de ondernemingsraad of de arbeidsinspectie geen gehoor vinden en er geen andere mogelijkheid is tot het overleg door te dringen.

HR terug van weggeweest, NJB 1987 , p. 301.

221. Zie Ktr. Rotterdam 29 juni 1978, NJ 1978, 682; Pres. Rb Groningen, 3 mei 1977, NJ 1978, 14.

222. Rood bekritiseert dan ook de opvatting van de Duitse regering dat artikel 6 lid 4 slechts het oog zou hebben op acties gericht op het tot stand brengen van een CAO en stelt dat deze opvatting ook is verworpen door het Comité van Deskundigen, M.G. Rood, Over de betekenis van het Europees Sociaal Handvest voor het stakingsrecht en het onderhandelingsrecht in de private en publieke sector, in Het Europees Sociaal Handvest, (I.J.M. van der Ven, ed), Nijmegen 1982, p. 61.

223. E. Steyger, De Arbeidsomstandighedenwet en het stakingsrecht, NJB 1987, p. 563-566. 
Hoewel de ondernemingsraad een de werknemers vertegenwoordigend orgaan is in de onderneming, kan het gebeuren dat de ondernemingsraad zich van die taak onvoldoende kwijt, door geen aandacht te schenken aan arbeidsomstandigheden die weliswaar geen ernstig en onmiddellijk gevaar opleveren, maar niettemin op de lange duur lichamelijke schade toebrengen. Indien de betreffende werknemers deze klachten onder de aandacht van de ondernemingsraad brengen, en desondanks genegeerd worden, kunnen zij m.i. het werk neerleggen en, naar analogie van de erkenningsstaking, proberen op deze wijze af te dwingen dat aan hun klachten aandacht wordt besteed. Het verschill met een gewone erkenningstaking zit hem dan hierin dat niet de werknemers zelf toegang krijgen tot het overleg, maar dat het door de wet voorziene medezeggenschapsorgaan de klachten in het overleg betrekt.

Trekt men deze lijn door, dan kan gesteld worden dat, wanneer het gaat om een zaak waarbij de ondernemingsraad actie kan ondernemen (door middel van het inschakelen van de arbeidsinspectie), het bij ontbreken van actie, af zal hangen van het gedrag van zowel de ondernemingsraad (heeft de ondernemingsraad gehoor gegeven aan klachten van werknemers) en van de werknemers zelf (hebben zij de klachten onder aandacht van de ondernemingsraad gebracht) of een staking rechtmatig geacht kan worden.

Bij bovenbeschreven stakingen bestaat uiteraard wel het probleem van de betaling. Wilde stakers hebben in het algemeen geen stakingskas en de werkgever hoeft geen loon door te betalen. Een dergelijke staking zal dus ook geen lang leven beschoren zijn. $\mathrm{Nu}$ is het de vraag of dat nodig is: een ochtend staken, kan gezien de kosten die dat voor de werkgever met zich meebrengt al effectief genoeg zijn om in het vervolg gehoor te vinden voor de problemen.

Naast het bovenbeschrevene bestaat nog de mogelijkheid dat een collectieve overeenkomst inhoudelijk voorziet of gaat voorzien in inhoudelijke regels betreffende het omstreden onderwerp. In dat geval wordt het instemmingsrecht (voor zover het nog bestaat) van de ondernemingsraad gepasseerd en wordt het een zaak van collectieve onderhandelingen waarvoor actie gevoerd zou kunnen worden. Zowel voor een staking waar de competentie van de ondernemingsraad in het geding is, als een staking waar het gaat om. collectief onderhandelen, geldt dat de (on)rechtmatigheid afhankelijk is van de normale toetsing met betrekking tot stakingen die in Nederland gebruikelijk is.

In Griekenland kent men een op zichzelf bijna even rigide situatie als in Duitsland: slechts de vakbonden zijn gerechtigd een staking uit te roepen (het grondrecht op staking als voorzien in artikel 23 lid 2 van de Constitutie is in ditzelfde artikel al op die wijze ingeperkt). Dit zijn in beginsel alle vakbonden, hoewel bepaalde solidariteitsstakingen slechts door organisaties van het derde niveau (de landelijke confederaties) mogen worden 
uitgeroepen (224). Zolang de vertegenwoordigende rol door vakbonden op ondernemingsniveau wordt vervuld, is hier dus geen probleem, aangezien de redenen waarom gestaakt mag worden in de Trade Union Democracy Act betrekkelijk ruim geformuleerd zijn (preserving and promoting the economic, labour, trade union and social security rights and interests (...) and as a means of expressing solidarity for these goals). Anders wordt het echter wanneer er geen vakbond in de onderneming is, en de vertegenwoordigende rol op basis van de wet van 1988 wordt vervuld door ondernemingsraden. In beginsel lijkt dan het recht op staking niet aanwezig te zijn, althans als de (eventueel sectoriële) bonden zich buiten het conflict houden. Het valt te bezien hoe de jurisprudentie hiermee om zal gaan.

Belgische werknemers kunnen een staking uitroepen om hun arbeidsomstandigheden te verbeteren. Het stakingsrecht, dat in de jurisprudentie is uitgewerkt, is hier niet onderworpen aan veel voorwaarden vooraf; stakingen hoeven niet door vakbonden georganiseerd te worden om rechtmatig te zijn, en de reden van de staking is een zaak tussen werknemers en werkgevers (225). Bovendien spelen de rechters in het stakingsrecht een kleine rol (226). Dit betekent dat de mogelijkheid tot staken vooral afhangt van de positie van de groep werknemers in de onderneming die staakt, de steun van de syndicale afvaardiging en daarmee de vakbond, en de conjunctuur in het algemeen. Slechts voor bepaalde soorten werknemers is thet stakingsrecht ingeperkt, daarnaast kan het aan beperkingen worden gebonden. Dit laatste zou in verband met veiligheid van andere werknemers dan wel omwonenden het geval kunnen zijn bij een arbeidsomstandighedenstaking in een onderneming, maar dat geldt uiteraard voor iedere soort staking.

In Luxemburg is in 1952, in een beslissing van het Constitutionele Hof uitgemaakt, dat artikel 11 lid 5 , dat de vrijheid van vakvereniging waarborgt, impliciet het stakingsrecht inhoudt (227). Het recht is niet beperkt tot georganiseerde stakingen, echter wilde stakingen vallen niet binnen de garantie van de constitutie (228). Dit betekent dat een wilde staking, en (dus) een staking omtrent issues die onder de competentie van de ondernemingsraad vallen, mogelijk niet verboden is, maar well dat onrechtmatigheid eerder het geval zal zijn.

In Spanje, Frankrijk en Italië is het recht op staking een constitutioneel recht dat aan de werknemers toekomt, en waar de uitoefening ervan geen

224. Greek Trade Union Democracy Act, artikel 19 lid 1 sub b, Engelse tekst, EIRR 1982, p. 28.

225. L. Betten, a.w. (noot 214) p. 142.

226. R. Blanpain, aw. (noot 22), para. 381 .

227. R. Schintgen, a.w. (noot 197 ), p. 478.

228. A. Kayser, Grève et Lock-out en droilt Luxembourgeois, no. 6, in Grève et Lack-out, Deel $V$ wan de E.C.S.C. Publications on Labour Law, Labour Law in the European Communities, Luxembourg 1961. 
specifiek prerogatief van de vakbonden is. In Spanje hebben naast de vakbonden ook de werknemers (rechtstreeks, nadat er een geheime stemming over is geweest) en de personeelsgedelegeerden (bij gewone meerderheid van stemmen) het recht een staking uit te roepen. De motieven voor een staking moeten gerelateerd zijn aan het domein van arbeidsverhoudingen (229). Dit omvat meer issues dan alleen die, die in verband staan met collectieve onderhandelingen. Hieronder worden ook zaken begrepen, die onder de competentie van de ondernemingsraad vallen. Doordat de Spaanse wetgeving een procedure kent voor de werknemers om het werk stil te leggen in geval van dreigend gevaar zal een specifieke arbeidsomstandighedenstaking minder snel noodzakelijk zijn dan in die landen waar een dergelijk recht niet aanwezig is. Desondanks kan dit het geval zijn. Indien aan de voorwaarden voor het stilleggen van het werk niet voldaan is of indien geen overeenstemming over het stilleggen van het werk bereikt wordt, kan er alsnog een staking uitgeroepen worden, om een veilige situatie af te dwingen. Een staking zoals hierboven omschreven, wordt op de gebruikelijke wijze getoetst, waarbij gekeken wordt naar proportionaliteit, doel en of de staking in uitvoering rechtmatig is. Ingeval de wettelijk voorgeschreven mogelijkheid via de "formele" weg van het stilleggen van het werk niet aanwezig is, kan dit gevolgen hebben voor de rechtmatigheid van de staking.

Ook volgens het Franse Cour de Cassation (230) hoeft het grondwettelijk gegarandeerde stakingsrecht niet per definitie in vakbondsverband te worden uitgeoefend. Ook kan een staking in een onderneming worden uitgeroepen, terwijl slechts een deel van de werknemers aan de staking deelneemt. Als slechts een minderheid van de werknemers deelneemt, impliceert dit niet per se onrechtmatigheid van de staking (231).

Het criterium voor rechtmatigheid is, dat het moet gaan om een zgn. "professioneel belang" een criterium dat ruim wordt uitgelegd, en meer omvat dan alleen loon en arbeidsvoorwaarden (232). Volgens de Franse jurisprudentie (233) moet daar ook de verbetering van de arbeidsomstandigheden onder worden begrepen (234).

229. M. García Fernàndez, La Liberté syndicale des salariés en Espagne, in The Freedom of the Worker to Organize, Berlin 1980, p. 887.

230. Cour de cassation (Soc) 21 juni 1967, Dalloz 1967, p. 753 .

231. Cour de cassation (Soc.) 3 october 1963, Dalloz 1964, p. 3.

232. Als voorbeeld: In 1951 werd een solidariteitsstaking in verband met het ontslag van een lid van het ondernemingsraad (comité d'entreprise) rechtmatig geacht; het Cour de Cassation overwoog hierbij dat de staking gericht was op verdediging van vakbondsrechten in het algemeen en rechten van werknemersvertegenwoordigers in het bijzonder. De link met vakbondsrechten lijkt hier een noodzakelijke woorwaarde te zijn om de staking rechtmatig te achten. (Cour de cassation, 21 juli 1951, Droit Social 1952, p. 11.).

233. Cour de cassation (Soc.) 3 oktober 1963, Dalloz 1964, p. 3. Hier wordt gesteld dat gezamenlijke actie het werk te stoppen "dans le but d'obtenir une amélioration des conditions de travail" mogelijk is.

234. Zie ook Rood n.a.w. de term professioneel doel in M.G. Rood, a.w. (noot 222), p. 59 ev. 
In Italie is de stakingsvrijheid tamelijk onbeperkt (235). Een staking ter verbetering van de arbeidsomstandigheden behoort tot de mogelijkheden. In Italie is het stakingsrecht opgenomen in de Constitutie als werknemersrecht. In de rechtspraak is uitgemaakt dat rechtmatigheid van de staking niet afhankelijk is van vakbondsbemoeienis (236). Een wilde staking (237) kan rechtmatig zijn als deze maar georganiseerd wordt om een gezamenlijk belang te verdedigen (238). Dit geldt zowel voor een staking om redenen van het eigen belang van een groep werknemers als in geval van een solidariteitsstaking. Het gezamenlijke belang moet wel een professioneel doel dienen (ook wel economisch-contractueel belang) (239). Voor Italië geldt dat juist de materiële arbeidsomstandigheden voorwerp van collectief onderhandelen zijn, en dat een staking tot de mogelijkheden behoort.

In die landen waar medezeggenschap wordt uitgeoefend door vakbondswertegenwoordigers is niet de vraag interessant of het stakingswapen het vakbondsprerogatief is, maar veeleer of op ondernemingsniveau beperkingen aan het stakingswapen zijn gekoppeld, al dan niet op vrijwillige basis.

Deense shop stewards zijn in hoge mate beperkt door het Centraal Akkoord in hun mogelijkheid tot het uitroepen van een staking. Evenals in Duitsland hebben in Denemarken alleen de vakbonden het recht stakingen uit te roepen en is het stakingsrecht sterk gerelateerd aan het onderhandelen over een nieuwe collectieve overeenkomst; bovendien is een conciliatieprocedure vereist (240). Shop stewards die stakingen uitroepen, die in strijd zijn met de collectieve overeenkomst lopen het risico ontslagen te worden (241). Sterker nog, zij moeten pogen stakingen in de onderneming die in strijd zijn met de CAO, te doen ophouden. Een staking om betere arbeidsomstandigheden af te dwingen ligt niet voor de hand, aangezien dit gebied op basis van collectieve overeenkomst tot de competentie van de samenwerkingscommissie als geheel behoort. Een staking is dus dan alleen mogelijk als er een onderhandelingsronde voor een nieuwe overeenkomst bezig is, waarbij de betreffende arbeidsomstandigheden voorwerp van onderhandeling zijn, conciliatieprocedures gehouden zijn en geen soelaas hebben geboden, en bovendien het omstreden onderwerp niet normatief bij wet geregeld is. In de praktijk zijn stakingen om deze redenen dus niet mogelijk.

235. Op 5 juni 1990 is in Italie voor de eerste keer de staking bij wet gereguleerd. Deze informatie kwam voor mij) echter op een te laat tijdstip om nog te verwerken (zie NRCHandelsblad, bijlage economie van 6 juni 1990 ).

236. Corte di Cassazione, 7 juni 1952 , no. 1628, Giurisprudenza Italiana 1952, p. 624.

237. Deze komen overigens zelden voor, T. Treu, a.w. (noot 61), para. 466.

238. Er zijn overigens wel beperkingen aan de uitoefening van het stakingsrecht gesteld, zoals een zekere mate wan evenredigheid tussen schade en opoffering van de stakers, en zorgvuldigheïd.

Zie T. Treu, Itally a.w. (noot 61), para. $495,496$.

239. L. Mengoni, Grève et lock out en droit Italien, in Grève et lock-out, Part V. van de ECSC Publications on Labour Law in the European Communities, Luxemburg 1961, no. 32.

240. P. Jacobson, Denmark, a.w. (noot 112), para. 672 .

241. R. Nielsen, a.w. (noot 35), p. 105. 
Heel anders is het in Groot Brittannië. Werknemersvertegenwoordigers in hebben daar wel het stakingswapen tot hun beschiking. Dit geldt zowel voor stakingen die georganiseerd worden door veiligheidsvertegenwoordigers als voor wilde stakingen georganiseerd door de werknemers zelf. Een staking hoeft niet door een vakbond georganiseerd te zijn, om een niet-onrechtmatige staking te zijn (242) (hetgeen overigens alleen tot gevolg heeft dat geen "immunities" worden verleend (243)).

Sedert de invoering van de Employment Act 1982 (244), is de mogelijkheid tot solidariteitsstakingen beperkt tot gevallen waarin werknemers in conflict zijn met hun eigen werkgever. Het conflict moet geheel of voornamelijk gerelateerd zijn aan zaken die voorwerp zijn van collectief onderhandelen (245). Deze inperking lijkt weinig gevolgen te hebben voor stakingen georganiseerd door werknemers om een claim voor verbetering van de arbeidsomstandigheden van collegawerknemers, in de eigen onderneming, te ondersteunen. In Groot Brittannië zijn veiligheids- en gezondheidszaken nu eenmaal voorwerp van collectieve onderhandelingen.

Het Ierse stakingsrecht is grotendeels gebaseerd op het Britse ook al zijn er in de wetgeving en jurisprudentie beperkingen aangebracht op de stakingsvrijheid. Alleen die vakbonden die een "negotiation licence" hebben verkrijgen "immunities" (246). Dit betekent concreet dat bij het uitroepen van wilde stakingen, de stakers meer risico's lopen op sancties.

Uit het bovenstaande blijkt dat in een deel van de lid-staten van de gemeenschap het stakingswapen gebruikt kan worden om in medezeggenschapsverhoudingen een bepaalde beslissing af te dwingen. In Denemarken is de mogelijkheid het meest beperkt en bestaat deze alleen onder zeer specifieke omstandigheden die zich overigens zelden zullen voordoen. In Duitsland is de wettelijke ruimte iets groter, maar materiëel is dat nauwelijks het geval. Wanneer we kijken naar de wijze waarop het stakingsrecht in het ESH (247) is verwoord, dan is het inperken van de mogelijkheid tot staken in deze landen, waar het gaat om issues die op ondernemingsniveau in overleg/onderhandeling met de werkgever geregeld moeten worden te sterk.

242. Zie o.m. T. Elias, B. Napier en P. Wallington, Labour Law, Cases and Materials, London 1980, p. 214.

243. Zie over het systeem van immunities in het Britse arbeidsrecht o.m.: O Kahn Freund and B. Hepple, Laws against Strikes, London 1972; Lord Wedderburn, The Law and Industrial Conflict in Great Britain, in Labour Relations and the Law, (O. Kahn-Freand, ed.) London 1965 , p. $127-153$.

244. Zie over de imperkingen die sedert 1980 door de conservatieve regering zijn aangebracht op de stakingsvrijheid, waardoor de wakbonden en stakers voor de rechter aansprakelijk kunnen worden gesteld: A.T.J.M. Jacobs, a.w. (noot 116), 1986, p. 161-162; J. Clark, B. Wedderburn, Modern labour law - Problems, Functions, Policies, in Labour Law and Industrial Relations (Wedderburn, Clark, Lewis, eds.), Oxford 1983, p. 136-144, p. 156 -
164 , p. 199-206.

245. Zie hierover o.m. L. Betten, a.w. (noot 214), p. 169.

246. A.T.J.M. Jacobs, a.w. (noot 116), p. 110, p. 116-117, p. 163.

247. Beide landen zijn partij bij het ESH. 
De vraag of om issues die met medezeggenschap op ondernemingsniveau, en in het bijzonder veiligheid en gezondheid, in die landen waar dat mogelijk is, daadwerkelijk veel gestaakt wordt, valt nauwelijks te beantwoorden. De oorzaak van stakingen is vaak een complex van factoren waarvan lonen een belangrijk deel uitmaken, maar waarbij ook andere zaken (waaronder de arbeidsomstandigheden) in het algemeen een rol spelen (248). Daarnaast wordt in veel (landellijke) statistieken maar een zeer globaal onderscheid gemaakt naar oorzaken die stakingen hebben, waardoor het aantal stakingen dat specifiek terug te voeren is op meningsverschillen over arbeidsomstandigheden niet meer te achterhalen valt (249). De meeste stakingen hebben overigens meningsverschillen over lonen als oorzaak (250).

Uit in Groot Brittannië verricht onderzoek, waarbij wel gedetailleerd onderscheid werd gemaakt naar oorzaken, bleek dat in de periode 1953-1973 slechts $4 \%$ van de stakingen in de onderzochte ondernemingen direct betrekking had op veiligheidsissues en arbeidsomstandigheden (251).

Het aantal arbeidsdagen dat verloren gaat door staking in de lid-staten, is het grootst door stakingen die betrekking hebben op looneisen (252). Het aantal arbeidsdagen dat door stakingen omtrent arbeidsomstandigheden in de ruime zin van het woord (als ze al als aparte oorzaak in de statistieken verschijnen) verloren gaat, is in het algemeen laag (253).

In Nederland wordt weinig gestaakt (254) maar wanneer op ondernemingsniveau gestaakt wordt, heeft dit in veel gevallen wel te maken met issues waarvoor de ondernemingsraad competent is (met name economische aangelegenheden als sluiting of verplaatsing van een deel of de gehele onderneming). Een dergelijke staking wordt echter meestal geïnitieerd door de vakbonden (255), of het is een wilde actie zonder formele bemoeienis van de ondernemingsraad.

248. P. K. Edwards, a.w. (noot 185), p. 232-233.

249. K. Walsh, Strikes in Europe and the United States, New York 1983, p. 32-33.

250. K. Walsh, a.w. (noot 149), p. 170.

251. E. Batstone, I. Boraston, S. Frenkel, The Social Organization of Strikes, Oxford 1978, p. 48.

252. Dit hoeft niet per se te betekenen dat dit veruit de meeste stakingen oplevert, maar kan ook betekenen dat die stakingen langer duren.

253. K. Walsh, a.w. (noot 149), p. 72 (België), 104 (Ierlland), 123 (Nederland), 134 (Groot Brittannie).

254. Collectieve Actie: een recht, Een FNV-beschouwing over enige knelpunten in het collectief actierecht, Amsterdam 1988, p. 12

255. Van den Heuvel beschrijft hoe de verhoudingen tussen OR en vakbond in dit "spel" verdeell zijn, G.A.A.J. van den Heuvel, Industrieel burgerschap als uitnodiging, Deventer 1983, p. 197-222. 


\section{Slotopmerkingen}

Medezeggenschapsbevoegdheden op ondernemingsniveau zijn, zo blijkt, in de lid-staten van de Europese gemeenschap in de wetgeving of praktijk overal te vinden. In elk land is wel een vorm van medezeggenschap, zowel voor wat betreft informatie- en consultatie-, als participatiebevoegdheden te vinden. Deze vormen van medezeggenschap verschillen in de zin dat zij veelal vanuit een andere basis tot stand gekomen zijn.

In de meeste lid-staten hebben de vakbonden of vakbondsvertegenwoordigers de meest vergaande medezeggenschapsbevoegdheden. In Groot Brittannië, Italië, Ierland en Frankrijk hebben de vakbondsvertegenwoordigers exclusief de onderhandelingsrechten op ondernemingsniveau; in landen waar participatiebewoegdheden door andere vertegenwoordigers worden uitgeoefend (Nederland, Duitsland, België en Spanje) hebben de vakbonden ofwel de mogelijkheid de bevoegdheden te beperken of uit te breiden, ofwel zelf de zaak over te nemen door een inhoudelijke regeling af te spreken en op die wijze de ondernemingsraden buiten spel te zetten. In Griekenland is de wettelijke regeling slechts een vangnet voor het geval geen vakbond in de onderneming aanwezig is. Denemarken is in deze zin een uitzondering dat weliswaar in de samenwerkingscommissies leden kunnen zitten die geen vakbondslid zijn, maar zij oefenen in samenwerking met shop stewards de participatiebevoegdheden van de commissie uit, op basis van een collectieve overeenkomst. Slechts in Luxemburg hebben vakbonden een zeer marginale invloed op de (wettelijke geregelde) medezeggenschapstructuur. Vakbonden kunnen dus in de meeste lid-staten binnen de onderneming een rol spelen, en in een aantal lid-staten doen zij dat ook.

Informatie- en consultatiebevoegdheden hebben in het algemeen vooral een wettelijke grondslag; slechts in enkele lid-staten zijn werkgevers en vakbonden op vrijwillige basis op deze punten tot overeenstemming gekomen (Denemarken en Italië, hoewel de uitwerking daar slechts in een deel van de sectoren tot stand is gekomen) In de meeste lid-staten waar informatie en consultatie een wettelijke basis hebben, hebben deze instrumenten het doel werknemers informatie te verschaffen en te horen over economische aangelegenheden en over maatregelen die de werknemers niet direct in hun belang raken. In die landen waar medezeggenschap vooral op vrijwillige basis plaatsvindt, wordt een informatieverplichting van de werkgever (al dan niet op wettelijke basis, dit laatste is in Groot Brittannië het geval) gezien als een ondersteunende maatregel voor de collectieve onderhandelingen.

De meest restrictieve norm voor informatieverstrekking is te vinden in Groot Brittannië waar informatie aan de werknemers op vrij vergaande wijze onthouden kan worden en slechts onder specifieke omstandigheden verstrekt hoeft te worden. In de Health and Safety Act 1974, is een wat ruimere mogelijkheid tot informatieverstrekking opgenomen. De andere lid-staten 
gaan in het algemeen wat verder in de mogelijkheid voor werknemers informatie te verwerven.

Instemmingsbevoegdheden (en tot op zekere hoogte ook onderhandelingsrechten) hebben in tegenstelling tot informatie- en consultatierechten vooral betrekking op maatregelen die werknemers direct raken. Dit heeft te maken met de bevoegdheden die de vertegenwoordigers in de wet zijn toegekend, of met de medezeggenschapsstructuur in de systemen op vrijwillige basis. Voor deze laatste systemen geldt dat in "hogere" collectieve overeenkomsten de aangelegenheden betreffende indirect rakende maatregelen kunnen zijn geregeld, maar ook als dit niet het geval is is de kans groot dat op ondernemingsniveau de aandacht van de onderhandelaars in elk geval uit zal gaan naar direct rakende maatregelen.

In die landen waar shop stewards verenigd zijn in ondernemingscommissies (zoals de Italiaanse consigli di fabbrica) zal de aandacht voor indirect raken maatregelen nog het sterkst tot uitdrukking komen, aangezien in die commissies een uitwisseling van kennis, ervaring en informatie over de gehele onderneming zal plaatsvinden. Echter in Groot Brittannië en in lerland waar shop stewards in eerste instantie vertegenwoordigers van de werkplek zijn (en zij ook op die werkplek gekozen worden) zal belangenbehartiging ook in eerste instantie op die werkplek betrekking hebben.

Wanneer men de uitwerking van de medezeggenschapsbevoegdheden inzake veiligheid en gezondheid goed bekijkt, dan valt op dat de mogelijkheden voor invloeduitoefening niet heel sterk verschillen. Het scala van rechten varieert van (wettelijke) consultatierechten eventueel gecombineerd met onderhandelingsrechten op vrijwillige basis, en instemmingsrechten (all dan niet op wettelijke basis). Ook de mogelijkheden naleving van besluiten af the dwingen vertonen tussen de lid-staten grote overeenkomsten. Voor wat betreft het afdwingen van invloed op het ondernemingsbeleid wanneer werkgevers weigeren op redelijke wijze overleg te voeren verschillen de instrumenten per lid-staat wel vrij sterk. Inhoudelijke toetsing van besluiten, door rechter of arbiter komt in de meeste lid-staten voor. Echter een groot verschil is, dat in de ene lid-staat wel, en de andere praktisch niet gestaakt. kan worden ter beïnloeding van dat beleid.

De uiteindelijke verschillen tussen de mogelijkheden voor werknemers te onderhandelen, of besluiten direct te beïnvloeden zijn materieel genomen niet zo groot. Op instrumenteel niveau kan men wanneer het gaat om veiligheids- en gezondheidsaangelegenheden nawwelijks meer verdedigen dat de verschillen tussen de systemen zo groot zijn dat zij niet, en nooit op één (harmonisatie)lijn te brengen zouden zijn. De verschillen die er bestaan liggen vooral op het ideologische vlak: wie oefent de medezeggenschap uit, en op welke wijze kan de vakbond haar invloed (nog) uitoefenen? Wanneer dat eenmaal beslist is, blijkt dat de vertegenwoordigers in grote lijnen hetzelfde instrumentarium ter beschikking staat, al zijn er uiteraard gradaties te onderkennen in de wijze waarop aan werknemersvertegenwoor- 
ders waarborgen geboden worden. Ik ben van mening dat die ideologische verschillen niet zo belangrijk zijn dat zij zouden voorkomen dat er een harmonisatierichtlijn tot stand zou kunnen komen.

Wanneer men de verschillende soorten medezeggenschap inzake veiligheid en gezondheid, voor wat betreft de invloed op de beslissingen van de werkgever, tegen elkaar afweegt moet vastgesteld worden dat de systemen die met een wettelijk opgetuigd kader van participatiebevoegdheden binnen de onderneming het zwaarst zijn. In Duitsland en Luxemburg kan de werkgever in beginsel geen besluit nemen op een aantal terreinen (waaronder een groot deel van de veiligheids- en gezondheidsmaatregelen) zonder dat de ondernemingsraad instemt. In Nederland was dit tot voor kort ook het geval, maar het instemmingsrecht in veiligheids- en gezondheidsaangelegenheden is door de wijziging van de WOR en de Arbeidsomstandighedenwet sterk beperkt. In Duitsland kan de werkgever de instemming doorbreken door middel van een uitspraak van de Einigungsstelle. De Einigungsstelle kan op dit moment echter niet gemakkelijk om het standpunt vande ondernemingsraad heen. Het grote verschil tussen Luxemburg en Duitsland is te vinden in de samenstelling van de ondernemingsraad: in Duitsland is de werkgever geen lid. De Griekse ondernemingsraad is op eenzelfde wijze met een instemmingsrecht bedacht.

Het Deense systeem komt er het best af van die lid-staten waar de medezeggenschap overwegend (niet helemaal) op collectieve onderhandelingen is gebaseerd. De samenwerkingscommissie heeft een grote, en niet gemakkelijk doorbreekbare invloed op, onder meer het veiligheids- en gezondheidsbeleid als geheel. De samenstelling van de samenwerkingscommissie zwakt deze invloed mogelijk iets af; het feit dat de werknemersleden de vakbond achter zich hebben brengt dat weer in evenwicht.

Of bovengenoemde systemen er op het geheel van veiligheids- en gezondheidsbeleid er ook het beste afkomen kan in dit stadium nog niet beantwoord worden. Daarvoor zal eerst gekeken moeten worden naar de andere instrumenten die op dit terrein de onderneming gebruikt kunnen worden. Deze komen in een volgend hoofdstuk aan de orde.

De andere medezeggenschapsystemen of ze nu op wettelijke of op vrijwillige basis tot stand zijn gekomen, moeten het vooral van de vakbondsinvloed hebben, omdat participatiebevoegdheden als het recht op onderhandelen in geen van die landen voorzien zijn van een verplichting om tot een overeenkomst te komen. Wel hebben enige landen als Frankrijk (expliciet), Spanje en Italië (impliciet) een afdwingbare onderhandelingsverplichting respectieveli $j k$ procedures tegen anti-syndicaal gedrag die de vrijheid van de ondernemer in hoge mate aan banden kunnen leggen. Deze verplichting c.q. procedures zien echter miet specifiek op veiligheids- en gezondheidsaangelegentheden. Door de afwezigheid van een duidelijk verplichting om mee te beslissen dan wel overeenkomsten te sluiten over deze zaken, moeten deze systemen toch als lichter gekwalificeerd worden. 
Instemmingsbevoegdheden zijn er niet, of zij zijn slechts voor zeer kleine deelgebieden in wetten of collectieve overeenkomsten opgenomen. Dit betekent niet per definitie dat de werknemersvertegenwoordigers zwakker zijn dan in de eerstgenoemde lid-staten, (men moet het enkele feit dat een vertegenwoordiger een vakbond achter zich heeft staan niet onderschatten); het betekent wel dat hun beïnvloedingsmogelijkheden meer afhankelijk zijn van externe factoren als de economische situatie en de wijze waarop de industriële structuur zich ontwikkelt. Juist deze systemen zijn kwetsbaar in een periode waarin inter- en multinationalisering van het bedrijfsleven aan de orde is, en door de ontwikkelingen in de Europese gemeenschap beworderd wordt.

Wat betekent dit voor de toekomst waarin meer grootschaligheid verwacht kan worden? Om te beginnen geldt dat in die landen waar informatie- en consultatieverplichtingen gekoppeld zijn aan het collectief onderhandelen over maatregelen die werknemers direct raken, werknemers en hun vertegenwoordigers in een achterstandspositie raken. Wanneer ondernemingen grootschaliger worden,en besluiten (met name waar het gaat om financiering van, ook sociale en dus direct rakende activiteiten) op hoger niveau komen te liggen, hebben de werknemersvertegenwoordigers tot dat hogere niveau geen toegang.

De bevoegdheden blijven dan weliswaar hetzelfde (op nationaal) niveau, maar stilstand leidt tot achteruitgang in geïnformeerdheid. De oplossing die de Nederlandse ondernemingskamer bood ten aanzien van informatieverstrekking binnen concerns zal dit niet kunnen tegengaan. Het ging in deze zaak om een dochter van een in het buitenland gevestigde moeder. De dochter had informatie waartoe zij in het kader van de WOR verplicht was, niet verstrekt. Dit kwam volgens de dochter omdat zij niet over die informatie beschikte. Dit verweer werd niet geaccepteerd. Volgens de Ondernemingskamer was het niet verstrekken van de informatie een grond om een ondernemersbesluit te vernietigen (256). Materiëel is hiermee wel voorzien in de verstrekking van de verplichte informatie, echter het gaat dan nog alleen om die informatie die ten aanzien van de nationale "poot" van het concern verstrekt moet worden (257). Andere informatie binnen het concern kan echter wel degelijk ook de nationale poot raken, maar die kan op basis van deze uitspraak niet verkregen worden.

De mogelijkheid tot beïnvloeding gaat nog veel sterker achteruit. Beïnvloeding zelfs in consultatieve zin van de concerntop is niet meer mogelijk. Een concept als het Vredeling-Richard voorstel had voor wat deze problemen aangaat (gedeeltelijk) uitkomst kunnen bieden. Voor wat betreft instemmings- en onderhandelingsbevoegdheden had ook het Vredeling-Richard voorstel geen oplossing. Hoe grootschaliger een onderneming wordt, hoe hoger het beslissingsniveau komt te liggen over allerlei ondernemingsaange-

256. Hof Amsterdam OK, 10 december 1981, NJ 1983, 24; zie ook Hof Amsterdam, 23 juni 1983, NJ 1984, 571.

257. Zie ook L. Timmerman, a.w. (noot 2), p. 126-127. 
legenheden, ook waar het gaat om die aangelegenheden die, in uitwerking de werknemers direct zullen raken. Of instemmings- en onderhandelingsbevoegdheden op het niveau van de onderneming (of nationale "poot" van een concern) nog zin hebben, hangt mede af van de mate van zelfstandigheid van de dochters c.q. groep van dochters. Onderhandelen met een bestuur van een dochter, die op zichzelf geen zeggenschap heeft over de grootte van het te besteden budget, omdat daar de moeder, al dan niet in de vorm van een holding, of een in een andere lid-staat gevestigde onderneming over beslist, levert uiteindelijk betrekkelijk weinig op.

In die lid-staten waar ondernemingsraden van een concern, concern- of groepsondernemingsraden kunnen oprichten kan de schade nog beperkt blijven, echter alleen als het centrum wan de besluitvorming zich in die lidstaat bevindt. Als dit niet het geval is, kan men op die wijze hooguit via de nationale groep pogen het besluitvormingscentrum onder druk te zetten maar van de directe invloed, die toch in de (wettelijke) maatregelen bedoeld was te bereiken blijft dan weinig over.

Is een dergelijke uitholling van rechten onontkoombaar? In het licht van de nationale medezeggenschapsregelingen en praktijken lijkt dit niet het geval. Als in alle lid-staten (hetgeen het geval is) op êen of andere wijze medezeggenschap in de praktijk is geîncorporeerd, valt te verdedigen dat het algemene idee, dat werknemers op die zaken die hen direct aangaan direct invloed moeten kunnen uitoefenen in de Gemeenschap geaccepteerd is.

De grote problemen met een regeling op communautair niveau, zo bleek uit hoofdstuk II zijn te vinden in het bezwaar van een aantal lid-staten dat door een wettelijke regeling het evenwicht tussen werkgevers en werknemers, dat op vrijwillige basis tot stand kwam verstoord wordt. Wanneer blijkt dat medezeggenschap door schaalvergroting die gestimuleerd wordt door andere Europese regelgeving op aangrenzende gebieden, achteruit gaat, valt niet meer vol te houden dat het evenwicht vrijwillig tot stand komt. Het evenwicht is al verstoord doordat ondernemingen meer keuze krijgen in rechtsvorm en wijze van vestiging, en op deze wijze de onderhandelingsruimte kunnen beinvloeden. Van vrijwillig tot stand gekomen evenwicht is dan geen sprake meer.

De vraag hoe dat geregeld zou moeten worden is een andere kwestie, die in een latere fase aan de orde zal komen (258). Eerder is al gesteld dat minimumregelingen die vasthouden aan de laagste norm van een enkele lidstaat niet de meest wenselijke zijn. Ten slotte hebben lid-staten op een bepaald punt een minimumnorm (of zelfs helemaal geen norm) omdat dat in dat specifieke systeem past (of omdat het toevallig in een politieke constellatie de meest wenselijke werd geacht). Als men aanneemt dat die

258. Zie paragraaf VI.2.2. 
constellatie aan het veranderen is, moet men ook bekijken welke normering daarbij hoort, ook al vallen de verschillende medezeggenschapsculturen, zoals boven beschreven daarbij te respecteren. 

Veiligheid- en gezondheidsaangelegenheden; instrumentarium van specifiek belang voor dit terrein.

In de vorige twee hoofstukken zijn de verschillende soorten werknemersvertegenwoordigers en de instrumenten die zij kunnen hanteren ter beïnvloeding van het ondernemingsbeleid aan de orde gekomen. Het bleek dat de verschillen tussen de wijze waarop vertegenwoordiging in de lid-staten is geregeld (of juist niet is geregeld) voornamelijk het gevolg zijn van tradities en ideologische verschillen binnen de lid-staten. Kan men deze bestaande verschillen voor zover het gaat om de institutionele kant van de zaak mogelijk als zo essentiëel beschouwen, dat harmonisatie niet tot de mogelijkheden behoort, dit is niet meer het geval als het gaat om het soort instrumentarium dat de werknemersvertegenwoordigers kunnen gebruiken bij de uitoefening van hun taak. De verschillen tussen de instrumentaria in de lid-staten zijn gradueel, met name waar het de instrumenten betreft die betrekking hebben op maatregelen die de werknemers in het algemeen direct raken.

De verschillen tussen de lid-staten voor wat betreft de rechten van de vertegenwoordigers inzake veiligheids- en gezondheidsaangelegenheden betreft bleken nog kleiner. In praktisch alle lid-staten (behalve tot op zeer grote hoogte Italië) heeft de vertegenwoordiging op dit gebied een wettelijke basis, en geen vrijwillige. Op het gebied van veiligheid en gezondheid kan praktisch geen van de lid-staten zich enigszins realistisch mett een beroep op de tradities, en de historisch gegroeide situatie verzetten tegen harmonisatie van wetgeving in Europees verband.

Uit het voorgaande bleek dat op veiligheids- en gezondheidsgebied in de meeste landen de werknemers de mogelijkheid hebben invloed op het beleid uit te oefenen door middel van een recht geconsulteerd te worden, door te onderhandelen met de werkgever, of door het al dan niet instemmen met een voorgenomen besluit van de werkgever. Van de drie rechten kan het instemmingsrecht als sterkste gekwalificeerd worden, de andere twee zijn zwakker. Voorts bleek dat praktisch alle systemen in de mogelijkheid voorzien de naleving af te dwingen bij arbiter en rechter. Geconstateerd werd ook dat die mogelijkheid in zijn algemeenheid is 
woorbehouden aan de werknemersvertegenwoordigers en niet aan de andere werknemers.

In dit hoofdstuk staan centraal: de veiligheids- en gezondheidsaangelegenheden als deelgebied van het sociale ondernemingsbeleid en het daarmee samenhangende instrumentarium voor werknemers en hun vertegenwoordigers de veiligheid en gezondheid van de werknemers te beschermen. Een deel daarvan is al besproken in de voorgaande hoofdstukken. Er zijn echter enkele instrumenten die specifiek van belang zijn als het gaat om veiligheid en gezondheid, hoewel zij ook daarbuiten in veel gevallen toegepast kunnen worden en zeker hun belang hebben. Tot die instrumenten kunnen worden gerekend: het recht op toezicht door de werknemers op de naleving van wettelijke maatregelen en daarmee samenhangend het recht externe en interne deskundigen te consulteren en de mogelijkheid tot het afdwingen van die naleving door de arbeidsinspectie.

Voor de individuele werknemer is de mogelijkheid tot beïnvloeding van de vertegenwoordigers van belang. Hierbij komt de vraag aan de orde of medezeggenschap per definitie de beste oplossing is waar het om de positie van de individuele werknemer ten aanzien van veiligheids- en gezondheidsaangelegenheden gaat.. In dit verband wordt het recht van en de mogelijkheid bij (dreigend) ernstig gevaar individueel of collectief het werk stil te leggen, zonder dat daar sancties aan verbonden kunnen worden behandeld. Daarnaast wordt ingegaan op het democratische gehalte van de medezeggenschapssystemen in de lid-staten, waar het gaat om veiligheids- en gezondheidsaangelegenheden. Dit laatste is vooral ook belangrijk voor die werkenden die om formele redenen, bijvoorbeeld omdat zij op andere wijze aan de onderneming verbonden zijn dan de "gewone full-time" werknemers, of om materiële redenen niet in het medezeggenschapscircuit (kunnen) meedraaien.

Medezeggenschap kan een wettelijke basis hebben, maar zoals uit het voorgaande bleek is dit op zichzelf niet nodig. Veiligheids- en gezondheidsbeleid, en de organen die al dan niet samen met de werknemersvertegenwoordigers hierop controle uitoefenen hebben praktisch altijd een wettelijke basis. Vandaar dat aan de rol van de wet in veiligheids- en gezondheidsaangelegenheden in eerste instantie (zij het niet uitputtend) aandacht wordt besteed.

\section{.1 De rol van de wet in veiligheids-en gezondheidsaangelegenheden}

Traditioneel heeft de wet een grote rol gespeeld in de bescherming van werknemers in veiligheids- en gezondheidsaangelegenheden. Wetgeving ter bescherming van de veiligheid en gezondheid van de werknemers is in de meeste lid-staten in het midden van de vorige eeuw tot stand gekomen en heeft zich in de loop van deze eeuw ontwikkeld. De zich in Europa in verschillende fasen afspelende, industriële revolutie was een belangrijke drijfveer om tot wetgeving op dit gebied te komen. Een deel van de 
wetgeving was specifiek ter bescherming van kinderen, jonge werknemers en vrouwen (1); een ander deel had tot doel het publiek in het allgemeen, en slechts in mindere mate specifiek werknemers, te beschermen tegen de gevaren die bepaalde categorieën ondernemingen met zich meebrachten (2). In eerste instantie richtte beschermende wetgeving zich overwegend op zaken als werktijden en fysieke bescherming, pas later splitste dit laatste terrein zich in de regelgeving af van het eerste (3).

In Groot Brittannië dateren de vroegste wetten uit het begin van de $19 \mathrm{e}$ eeuw; deze waren er met name op gericht enige bescherming te bieden aan kinderen en jonge werknemers (4). In $1844 \mathrm{kwam}$ een eerste (serieuze) Veiligheidswet tot stand die veiligheidsomheining van gevaarlijke machines vereiste en het schoonmaken van werkende machines verbood. Deze wet was met name gericht op de bescherming van vrouwen, die door hun kleding zeer kwetsbaar waren. De in de wet gestelde eisen werden overigens al snel gematigd, onder druk van de National Association of Factory Occupiers (5).

Frankrijk en Duitsland volgen omstreeks dezelfde tijd (6), ook al had de wetgeving in die landen niet per definitie de bescherming van werknemers, maar veeleer de algemene bescherming van de onderneming tot doel. België (7), Denemarken en Nederland (8) behoren tot de categorie landen waar wat later dan in de rest veiligheidswetgeving tot stand komt.

In de zuidelijke Europese landen liepen de ontwikkelingen ongeveer gelijk op. Spanje kreeg zijn eerste beschermende wet met betrekking tot de arbeidsuren en -omstandigheden van kinderen in 1873, een wet die de arbeidsuren van volwassenen regelde volgde in 1919 (9). In Italië kwam in 1898 een algemene veiligheidswet in de vorm van een delegatiewet tot stand die de overheid machtigde per decreet maatregelen te nemen voor een aantal sectoren. In Griekenland duurde het tot na de invoering van de

1. Th. Ramm, Laissez-faire and State Protection of Workers in The Making of Labour Law in Europe, (B. Hepple, ed.) London 1986, p. 89-99.

2. Th. Ramm, a.w. (noot 1), p. 103.

3. Zie. o.m. I. Nahnsen, Bemerkungen zum Begriff und zur Geschichte des Arbeilsschutzes, in Arbeitssituation, Lebenslage und Konfliktpotential (Heruitgave, M. Osterland), Frankfurt, 1975.

4. Zie o.m. de wet van 29 augustus 1833 die tot doel had "to Regulate the Labour of Children and Young Persons in the Mills and Factories of the United Kingdom", een uittreksel is te vinden in The Making of Labour Law in Europe, London 1986, p. 368-376.

5. Zie Redgrave"s Health and Safety in Factories, (II. Fife and E. Machin eds), Londen, 1982 (2e. druk) p. 703-1580.

6. Voor de ontwikkeling in deze landen zie: J.K.M. Gevers, Zeggenschap van werknemers inzake gezondheid en veiligheid in bedrijven, Deventer $1982_{\text {, p. }} 29$ ev..

7. M. Sojcher-Rousselle, Droit de la sécurité et de la santé de l'homme au travail, Bruxelles 1979 , p. 83-92.

8. Hierover AJ.C.M. Geers, Recht en humanisering wan de arbeid, Deventer 1988, p. 17-89.

9. M. Alonso Olea, F. Rodriguez-Sañudo, Spain, Encyclopedia for Labour Law and Industrial Relations, Deventer 1988 (supplement 85 ), para. 48. ev. 
grondwet van 1911 voor de eerste beschermende wet tot stand kwam. Voor 1911 was het zelfs omstreden of de overheid wel kon ingrijpen in de arbeidsverhoudingen. In de periode van 1911 tot 1917, de periode die Koniaris de periode wan de individuele bescherming noemt (10), kwamen wetten tot stand met betrekking tot arbeidshygiëne, veiligheid en de werkuren (1911), vrouwen- en kinderarbeid (1912) en op het gebied van arbeidsongevallen (1915).

De meeste van deze wetten hadden een regelstellend karakter en legden de verantwoordelijkheid voor het veiligheidsbeleid overwegend bij de werkgever. Volgens Gevers werden werknemers in veel gevallen beschouwd als een een te beschermen object, hij spreekt dan ook van wetgeving met een legalistisch en paternalistisch karakter (11). Voor een verklaring daaromtrent haalt hij onder meer Sojcher-Rouselle aan, die stelt dat de de rol van de staat op het gebied van de arbeidsveiligheid mede voort kwam uit traditionele optreden van de overheid als "protecteur" (12). Ramm legt er daarentegen de nadruk op, dat de wetgeving wel degelijk ook gerelateerd werd aan de ontwikkelingen die in de collectieve organisatie van de arbeidsverhoudingen speelden, zowel op als buiten de werkplek. Hij gebruikt als voorbeeld een bepaling uit de Belgische wet, waarin de regering was gemachtigd de noodzakelijke maatregelen voor te schrijven nà hoorzittingen waar de industriële raden, de provinciale raden, de Koninklijke Academie, de Hoge Raad voor Arbeid en Gezondheid en ook 'indien noodzakelijk' de werknemers in de industrie en handel waren gehoord (13). Sojcher-Rouselle stelt over deze bepaling uit de wet van 1899 echter dat hij praktisch onopgemerkt is gebleven en bij herziening van de wet van 1952 niet is uitgebreid. De staat beperkte zich veel meer tot een normstellende en politionele vorm van regelgeving dan dat men de mogelijkheid tot samenwerking gebruikte (14).

In de meeste lid-staten werden eind negentiende, of begin twintigste eeuw publiekrechtelijke instanties opgericht, met meer of minder politionele bevoegdheden, die tot taak hadden toe te zien op de naleving van de bij wet of decreet gestelde normen. Ook hier liep Groot Brittannië voor op de andere lid-staten: het oudste inspectoraat in dit land, de Fabrieksinspectie dateert al van 1833 .

Een ander aspect dat de veiligheids- en gezondheidswetten in de diverse lid-staten gemeen hadden was dat ze veelal differentieerden naar verschillende sectoren. Dit gebeurde ofwel door het maken van verschillende

10. T.B. Koniaris, M. Smith, Greece, in International Encyclopedia for Labour Law and Industrial Relations, Deventer 1982 (supplement 28), para. 36.

11. J.K.M. Gevers, a.w. (noot 6), p. 33 .

12. M. Sojcher-Rouselle, a.w. (noot 7), p. 108-109.

13. Th. Ramm, a.w. (noot 1), p. 104.

14. M. Sojcher-Rouselle, a.w. (noot 7), p. 103-104. 
wetten voor verschillende bedrijfstakken (15), ofwel door de splitsing naar sectoren binnen één meer algemene wet (16), of door het uitzonderen van een aantal sectoren in de algemene wet. In een aantal lid-staten (17) werd landbouw uitgezonderd hetgeen tot gevolg had dat in het agrarische Europa een groot deel van de bevolking geen bescherming genoot.

Een mogelijke verklaring voor deze gesplitste en daardoor versnipperde wetgeving is dat de Staat pas interveniëerde in het arbeidsbestell als gebleken was dat de arbeidsomstandigheden niet te negeren ongelukken of grote wantoestanden opleverden. De Britse Mijnwet van 1842 die ondergronds werk voor vrouwen en kinderen verbood was mede een gevolg van een onderzoek van de Royal Commission of Inquiry into the Employment of Children and Young Persons; in Nederland maakte de Arbeidsenquéte van 1887 (18) naar de toestanden in fabrieken en werkplaatsen een dermate diepe indruk, dat niemand meer twijfelde aan de noodzaak van overheidsingrijpen (19).

De versnippering van de wetgeving was in de jaren zestig één van de redenen in bijna alle EG lid-staten om tot herziening van de veiligheidswetgeving over te gaan (20). De huidige wetten hebben dan ook, veel meer dan haar voorgangers een algemeen karakter, uitzonderingen kunnen wel gemaakt worden, evenals speciale regelingen voor bepaalde bedrijfssectoren of bijzondere groepen, maar algemene toepassing is in beginsel de regel.

Een ander gemeenschappelijk kenmerk van de huidige wetgeving is het feit dat op één of andere manier werknemersvertegenwoordigers betrokken zijn bij de besluitvorming rond veiligheids- en gezondheidsaangelegenheden of bij de controle op de uitvoering van de maatregelen. De roep om medezeggenschap op dit gebied ontstond vooral in de jaren zestig; het werd bij de herziening van de wetgeving in de meeste landen in de jaren zeventig verwerkt.

15. De wetgeving omtrent mijnbouw is hier een voorbeeld van: deze werd veclal in aparte wetten geregeld en kwam mede, doordat men al vroeg bet nut van controle bevoegdheden voor werknemers inzag, sneller tot ontwikkeling dan de algemene veilligheidswetgeving, zic o.m. woor Groot Brittannië: R.W.L. Howells, Worker Participation in Safety, 1 The Development in Legal Rights, Industrial law Journal 1974, p. 91-92; voor Nederland: J.E.W. Koomen, K.J.M. Tercic, Het mijnreglement 1906 en hoe het tot stand kwam, Economisch en Socaal-Historisch Jaarboek, 's-Gravenhage 1979, p. 223-238, p. 255-271; voor Duitsland: G. Boldt, Bundesberggesetz und Arbeitsrecht, Recht der Arbeit 1981, Heft I.

16. Zie o.m. de Nederlandse Veiligheidswet 1934 die gesplitst was in vier bedrijfissectoren: Industrie, landbouw, binnenvaart en de rest, A. Geers, Veilig en wel, Allphen a/d Rijn, 1984 , p. 14.

17. Zoals Griekenland, zie o.m. T.B. Koniaris, a.w. (noot 10), p. 49.

18. Zie: Een kwaad leven, Heruitgave wan de Arbeidsenquete van 1887, Nijmegen, 1981.

19. A.J.C.M. Geers, a.w. (noot 8), p. 39.

20. J.K.M. Gevers, a.w. (noot 6), p. 13. 
Dit patroon gaat niet helemaal op voor Franknijk en België. In deze landen bestonden al eerder zowel algemene medezeggenschapsorganen als (overwegend technisch georiënteerde) veiligheidscomités. In beide landen kregen deze laatste overigens veel kritiek, hetgeen én van de redenen was voor de Franse wetgever om eerst in 1976, en daarna in 1982 de wetgeving te herzien. Bij deze laatste herstructurering van het (gehele) systeem werd het "comité d'hygiéne, de sécurité et des conditions des travail" (CHSCT) in het leven geroepen, dat de twee bestaande commissies moest vervangen (21).

Ook in de landen die begin jaren zeventig tot een drastische herziening van bestaande of invoering van nieuwe wetgeving overgingen, waren al eerder veiligheidsdeskundige werknemers die zich met deze zaken bezighielden. Hun taak was echter eerder een toezichthoudende (22) dan een beleidsbeinvloedende (laat staan een beleidsmakende). Zo kenden de Britse mijnen van oudsher werknemersinspecteurs (23), in Duitse ondernemingen waren al langer Sicherheitsbeauftragten werkzaam (24). De ontwikkeling naar medezeggenschap in de zin van beleidsbeïnvloeding werd in Duitsland in gang gezet door de herziening van de Betriebsverfassungsgesetz in 1972, en de invoering van de Arbeitssicherheitzgesetz van 1973. Door de herziening, respectievelijk invoering van deze wetten kreeg de mogelijkheid van beleidsbeïnvloeding handen en voeten door de aansluiting van de Ausschusse op de ondernemingsraad. Dit laatste orgaan kon al coördinerend zijn medebeslissingsrecht waarmaken. In Nederland kwam de uitbreiding van de bevoegdheden eveneens in eerste instantie uit de algemene regeling betreffende medezeggenschap, de Wet op de Ondernemingsraden. Bij de wijziging van de WOR in 1979 preludieerde men weliswaar op de Arbeidsomstandighedenwet, de argumentatie ervoor werd al in 1973 door de toenmalige minister-president Den Uyl verwoord. Volgens hem was de wetgeving verouderd, en was er een behoefte aan nieuwe medezeggenschapsstructuren ontstaan, die zich overal manifesteerde (25).

De argumenten voor het instellen van een werknemersvertegenwoordiging in de Britse Health and Safety Act 1974 kwamen, hoewel de vakbonden later het exclusieve recht kregen veiligheidsvertegenwoordigers te benoemen, in eerste instantie niet uit de vakbondshoek. Het Donovanreport (26) besteedde geen bijzondere aandacht aan veiligheids- en gezondheids-

21. G. Lyon-Caen, J. Pélissier, Droit du travail, Paris 1988, p. 515. Zie ook: New French Safety law, EIRR, 1976 , no. 35 , p.2.

22. Zie ook paragraaf III.2.3.

23. Op grond wan de Coal Mines Regulations Acts 1872.

24. Zoals de Reichswersicherungsordnung, op basis waarvan na de herziening in 1963 Sicherheitsbeauftragten moesten worden aangewezen.

25. J.M. den Uyl, Socialisme en vrije ondernemingsgewijze produktie, in Inzicht en uitzicht, opstellen over economie en politiek, Amsterdam 1978, p. 190.

26. Report of The Royal Commission on Trade-unions and Employers Associations 1965/1986 (voorzitter Lord Donovan). 
aangelegenheden. Het Robensreport (27) stelde een apart vertegenwoordigingssysteem op dit gebied voor, met het argument dat velligheids- en gezondheidsaangelegenheden voorwerp van gezamenlijke regulering door werknemers en werkgevers moesten zijn (28). Doordat de bevoegdheden van de veiligheidsvertegenwoordigers zelf relatief zwak zijn, en de koppeling met vakbonden is gelegd in de wet, zijn deze zaken nu wel beland in het systeem van arbeidsverhoudingen (29).

In Italiè was de invoering van artikel 9 Werknemersstatuut 1970, dat een wettelijke recht van toezicht voor werknemersvertegenwoordigers schiep op veiligheids- en gezondheidsmaatregelen, vooral een bevestiging van een recht dat in de praktijk gegroeid (en bevochten) was, en een bescherming van die bestaande praktijk. In dezelfde periode dat de wetgever met voorstellen kwam tot herziening van de veiligheids- en gezondheidswetgeving in moderne zin (30), waren in Italiaanse ondernemingen al samenwerkingsverbanden tussen shop stewards ontstaan die zelf veiligheids- en gezondheidscommissies instelden (31). De vorm van werknemersbemoeienis op dit terrein die uiteindelijk opgenomen werd in het Werknemersstatuut, biedt slechts het controlerecht op de toepassing van normen. De bedoeling was dat andere vormen van veiligheids- en gezondheidsbeleid zouden worden voorzien bij een nieuwe wet, die de structuur van de organisaties die zich met veiligheid en gezondheid bezighouden, zou herzien. Deze wet is in 1978 aangenomen (32). Het controlerecht werd in vakbondskringen gezien als het natuurlijk tegenwicht tegen de werkgever, die de bepalende stem heeft bij de keuze van de technische arbeidsmiddelen, terwijl deze keuze slechts een gepretendeerde objectiviteit zou bezitten (33). Dit controlerecht moest dan wel naast een onderhandelingsrecht over de te gebruiken arbeidsmiddelen bestaan.

Zowel de in de late jaren zestig en de jaren zeventig totstandgekomen wetgeving, als de wetgeving die in jongere EG lid-staten in een later stadium werd aangenomen, schrijft voor dat op enigerlei wijze werknemers betrokken moeten worden bij het beleid.

De invoering en regulering van medezeggenschap op dit terrein heeft echter een aantal niet altijd voorziene gevolgen. Medezeggenschap in het algemeen vereist het nodige van de werknemers die eraan deelnemen. Aan werkne-

27. Safety and Health at Work, Report of the Robens Committee 1970-1972 HSMO Londen 1972 .

28. Ook B. Perryns, Trade Union Law, London 1985, p. 245.

29. A. Broadhurst, The Health and Safety Act in Practice, London 1978, p. 5.

30. Voor cen overzicht: J.K.M. Gevers, a.w. (noot 6) p. 138-139.

31. P.G. Cella, T. Treu, Relazioni Industriali. Manuale per l'analisi della espirienza Italiana, Bologna 1982, p. 114; D. Weiss, La democratie industrielle; cogestion ou controle ouvrier, Paris 1978, p. 137-138.

32. Wet op de Riforma Sanitaria no. 833.

33. G. Marri, Conditions de travail et organisation du travail, le valeur de l'expinience ouwrie're, in Le syndicat et l'organisation du travail, Paris 1978, p. 134-136. 
mers(vertegenwoordigers) worden impliciet eisen van mondigheid en kennis gesteld. Dit geldt echter nog vele malen meer wanneer het gaat om medezeggenschap bij specifieke veiligheids- en gezondheidskwesties. Weliswaar hebben werknemers vaak de kennis van de concrete situatie, voor beleidsbeïnvloeding is dat niet genoeg. De werknemersvertegenwoordiger die in overleg met de werkgever diens beleid wil/moet beïnvloeden ten aanzien van risico's die op het werk bestaan, moet in staat zijn die risico's te identificeren en in te schatten. Hoe meer regelgeving teruggrijpt op medezeggenschap als mogelijkheid tot regelstellend concept, hoe meer eisen aan de competentie van de veiligheidsvertegenwoordiger, c.q. de algemene werknemersvertegenwoordiger gesteld worden. Men kan zich afvragen of aan die eisen te voldoen is. Tenslotte: veiligheidsvertegenwoordigers in de meeste systemen zijn (en blijven) amateurs; het is redelijkerwijs niet te verwachten dat amateurs zich de benodigde kennis altijd meester kunnen maken (34).

Een tweede probleem dat kan ontstaan wanneer normen op veiligheids- en gezondheidsgebied alleen of in belangrijke mate door middel van het medezeggenschap bereikt worden, is dat de kans bestaat dat er een zekere mate van slordigheid in de regelgeving en -naleving (op ondernemingsniveau) sluipt. De kans bestaat dat, omwille van de onderneming, werknemersvertegenwoordigers meer risico's zullen accepteren dan zij eigenlijk zouden moeten doen. Deze kans bestaat overigens ook zonder dat regels tot stand komen op basis van overleg tussen werkgever en werknemers. Ook regels door de overheid gesteld kunnen, omwille van economische argumenten, genegeerd worden, niet alleen door de werkgever maar $66 \mathrm{k}$ door de werknemers (35). Echter daar valt door middel van staatscontrole tegen op te treden; wanneer werknemersvertegenwoordigers en de werkgever regels stellen waarbinnen risico's groter zijn dan verantwoord is, is het aanvechten daarvan via controle een moeizame zaak. Met name waar het gaat om niet direct levensgevaarlijke, maar op termijn schadetoebrengende zaken is dit een risico.

Een derde probleem bij medezeggenschapsregelingen bij veiligheid en gezondheid is de bescherming van bijzondere groepen werknemers. Dit waren vroeger met name kinderen, jongeren en vrouwen. Tot de nieuwe bijzondere groepen zou men nu eventueel ook buitenlandse werkne-

34. Zie ook: A. Broadhurst, a.w. (noot 29), p. 2; O. Rieper, Styring af arbejdsmiljøet,
Kopenhagen 1985, p. 169.

35. Als voorbeeld kan de Rijtijdenwet ( 1936, Stb. 802$)$ worden aangehaald, die het tegengaan van oververmoeidheid van bestuurders van motorvoetuigen zowel in verband met arbeidsbescherming als de verkeersveiligheid beoogt. Het daarop gebaseerde Rijtijdenbesluit (1977, Stb. 547) bevat regels over dienst-, rij- en rusttijden. Deze regelingen die ter bescherming van de werknemers werden opgesteld, werden grof overtreden door de werknemers zelf. De invoering van een controlemiddel, de tachograaf, stuitte op verzet bij
de chauffeurs. 
mers (36), en inleenkrachten kunnen gaan rekenen. Deze laatste groeperingen zijn tenslotte diegenen die vaak voor het vieze en zware werk ingehuurd worden.

De nieuwe veiligheidswetgeving voorziet tot op zekere hoogte wel in bescherming van bijzondere groepen. Veelal hebben jonge werknemers meer rechten op specifieke informatie en opleiding. Aan vrouwen, als bijzondere groep, wordt in een deel van de wetten nog extra bescherming ten aanzien van zwangerschap en moederschap geboden. Hier doet zich echter het merkwaardige fenomeen voor dat gelijke behandelingsvoorschriften, zoals deze onder meer uit EEG-richtlijnen voortvloeien, in het nadeel van vrouwen gaan werken (37). Zo worden met een beroep op de gelijkheid in een aantal lid-staten bestaande verboden op nachtarbeid voor vrouwen opgeheven. Argument daarvoor is dat de bescherming tegen nachtarbeid vrouwen in een nadeliger positie brengt (voor wat de toegang tot de arbeil betreft) dan mannen (38). Hoewel dit op zichzelf juist is, zou men dit nadeel niet per se hoeven te bestrijden door middel van de redenering: even slecht is ook gelijk.

In Nederland is in de wet ter opheffing van nachtarbeid voor vrouwen (39) zelfs geen algemene uitzondering voor zwangere vrouwen opgenomen, hoewel richtlijn 76/207 (40) die mogelijkheid uitdrukkelijk openlaat. Zwangere werkneemsters die geen nachtarbeid willen verrichten zullen zelf een verzoek om een andere functie moeten doen, waarbij het districtshoofd van de arbeidsinspectie, op de naleving zal moeten toezien. Het is mogelijk dat deze vorm van bescherming die wel zeer zwak is, voortkomt uit een slordige behandeling van de wet door de Tweede Kamer die haast had met de wet (41). Desalniettemin geeft het een aanwijzing voor de veranderende wijze waarop tegen de positie van vrouwen in de arbeidsbeschermende wetgeving aangekeken wordt.

36. De beschrijving van de arbeidsomstandigheden van Turkse werknemers in Duitsland door de journalist Günther Walraff in het boek "Ganz Unten" (Keulen 1987) (zie ook de oratie gethouden in 1987 van A.T.J.M. Jacobs, Ali en het arbeidsrecht, uit te komen in 1990) stemt wat de "gelijkberechtiging" van buitenlanders in Duitsland aangaat niet hoopvol, en het is niet onwaarschijnlijk dat de situatie in andere West-europese landen daar veel op lijkt. Buitenlanders die "illegaal" zijn hebben het al helemaal moeilijk.

37. J. Conaghan, L. Chudleigh, Women in Confinement: Can Labour Law deliver the Goods? Journal of Law and Society, Vol. 14, no. 1 spring 1987.

38. M. Monster, Bescherming moederschap, Nemesis 1988, p. 93.

39. Wet tot wijzing van de Arbeidswet 1919 m.b.t. het verrichten van nachtarbeid door vrouwen in fabrieken of werkplaatsen en het opheffen van de overige naar geslacht onderscheiden bepalingen, van 12-4-1989, Stb. 1989, 95 (Kamerstukken 20 689).

40. Richtlijn betreffende de tenuitwoerlegging van het beginsel van gelijke behandeling van mannen en vrouwen tten aanzien van de toegang tot het arbeidsproces, de beroepsopleiding en de promotiekansen en ten aanzien van de arbeidsvoorwaarden, $\mathrm{Pb} .1976, \mathrm{~L} 39$, p. 40.

41. Zie het commentaar van W.C. Monster, Nachtarbeld voor zwangere wrouwen, NJB 1989, $\mathrm{p}_{\text {. }}$ 453-455. 
Vrouwen hebben kennelijk veel meer dan jongeren en (uiteraard) kinderen de status van bijzonder beschermenswaardige groep verloren, en nemen binnen die wetgeving minder een aparte positie in. Dit geldt in elk geval voor de wetgeving met betrekking tot arbeidsuren, maar het is niet uitgesloten dat hun positie, en ook de positie van andere bijzondere groepen als buitenlandse werknemers ook door andere veranderingen in de beschermende wetgeving onder druk komt te staan. Deze druk kan ontstaan wanneer in de regulering de nadruk te sterk op normering in de onderneming via samenwerking en overleg alleen komt te liggen. Het lidmaatschap van medezeggenschapsorganen, of de mogelijkheid zijn collega-werknemers te vertegenwoordigen is niet voor iedereen weggelegd. Met name uit paragraaf III.2. bleek al dat het passieve en actieve kiesrecht voor de leden van vertegenwoordigende organen of vertegenwoordigers van de werknemers in een aantal lid-staten aan voorwaarden gebonden is. Aan deze voorwaarden voldoen een aantal groepen als part-timers flexibele arbeidskrachten en thuiswerkers in een aantal lid-staten niet. Kortom deze groepen draaien niet mee in het medezeggenschapscircuit en hebben dus minder of geen mogelijkheden om hun specifieke eisen en verlangens kenbaar te maken. In deze groepen bevinden zich relatief veel vrouwen, hetgeen gezien de bovengeschetste tendens voor hen een extra nadeel op kan leveren.

Indien medezeggenschap (in belangrijke mate) in de plaats komt van normering door de overheid zal dit effect zich nog veel sterker voordoen. Een nieuwe groep van personae miserabiles ontstaat dan, weliswaar sexe-neutraal gedefinieerd, maar men zal in hun kringen met name de vroegere beschermenswaardige groepen aantreffen, plus de (relatief) nieuwe categorieën van buitenlandse werknemers en inleenkrachten. Formeel zijn dleze groepen (uitgezonderd de laatste) binnen het arbeidsrecht in de meeste landen gelijkberechtigd, maar materieel vallen zij er buiten, mede door de gehanteerde regels, die uitgaan van "gewone" full time werknemers.

$\mathrm{Nu}$ is het niet zo dat normering volledig afhankelijk is van wat vertegenwoordigers in ondernemingen doen. Minimumveiligheidsnormen in wetgeving of daarop gebaseerde regelingen vormen nog steeds een groot bestanddeel van de regelgeving omtrent arbeidsomstandigheden (42). En ook de relatief nieuwe, van de Europese Gemeenschap komende, regulering bevat op dit moment voornamelijk absolute minimumnormen en grenswaarden.

Deze laatste regelgeving biedt echter niet met zekerheid een kader waar bijzondere groepen als thuiswerkers en flexibele arbeidskrachten een beroep

42. Hierbij moet worden aangetekend dat de lid-staten daarin verschillen. Een aantal lidstaten (waaronder Duitsland) hebben naast hun medezeggenschapssysteen hoge minimumnormen gehandhaafd, terwijl andere (waaronder Nederland) de strategie van normering door middel van medezeggenschap veel meer heeft laten prevaleren; $L$. Parmegiani, State of the Art, Recent Legislation on Workers Health and Safety, Internationall Labour Review, vol 121, no. 3,1982 , p. 27 - p. 285. 
op kunnen doen. Tot dusver heeft de beschermende sociale EEG-wetgeving veelal aangeknoopt bij de begrippen die het nationale recht hanteert ten aanzien van de werkingssfeer van arbeidsrechtelijke regelingen (43). Minimumnormen die binnen de onderneming gelden zullen daarom wel toepasbaar zijn op flexibele arbeidskrachten, maar voor thuiswerkers (44) is niet uitgesloten dat andere regime's gelden. Bescherming voor deze zeer kwetsbare categorie werknemers -overigens worden zij lang niet altijd geacht werknemers te zijn in de zin van de nationale wetgeving-, is niet altijd aan gemeenschapsnormering te ontlenen, indien de nationale wetgeving daar niet in voorziet.

Voor deze oude en "nieuwe" kwetsbare groepen, is dus meer nodig dan meer zeggenschap en betere zeggenschap. Voor hen kan "paternalistische en legalistische" wetgeving wel degelijk een uitkomst zijn, ook al zal veel afhangen van de mogelijkheden tot handhaving van de normen. Voor deze groepen is het vooral van belang dat de verantwoordelijkheid van de werkgever een grote en duidelijke blijft, en dat deze niet door allerlei in algemene arbeidsomstandighedenwetten opgenomen samenwerkings- en onderhandelingsverplichtingen verschuift naar de werknemers zelf. Het zou echter aan te bevelen zijn dat de Gemeenschap, nu de nationale wetgeving op dit punt nog wel eens in gebreke blijft zelf actie onderneemt ten opzichte van dit soort kwetsbare groepen.

In dit verband kan de ontwerp-richtlijn betreffende minimumvoorschriften voor veiligheid en gezondheid met betrekking tot het werken met beeldschermapparatuur (45) als voorbeeld genoemd worden. Tele-workers zijn in veel mindere mate dan andere werknemers gebonden aan de onderneming als werkplek, en hebben de mogelijkheid thuis, of in elk geval op een geheel andere plaats dan de onderneming, te werken. Dit kan hen, binnen de arbeidsbeschermende regelgeving, een even nadelige plaats opleveren als thuiswerkers (46). De ontwerp-richtlijn nu zal (als hij richtlijn wordt in deze vorm) van toepassing zijn op "alle werkplekken met een beeldscherm". Onder werkplek wordt, volgens het ontwerp, verstaan: het geheel gevormd door beeldscherm, toetsenbord, de bijkomende apparatuur met inbegrip van de printer, het manuscript met de gegevens, de stoel en de werktafel; alsmede de onmiddellijke werkomgeving. Door op deze wijze in concrete gevallen begrippen te herdefiniëren wordt de regelgeving van toepassing op werknemers, die op grond van de nationale regelgeving buiten de beschermende regelgeving zouden kunnen blijven.

43. Zie E. Steyger, De gemeenschappelijke arbeidsmarkt en het sociale beleid van de Gemeenschap; over discriminatie, distorsies en ingebakken dispariteiten, NJB, 1988, p. 251.

44. De bescherming van de veiligheid en gezondheid van thuiswerkers was in Denemarken en Duitsland voor de oorlog voorwerp van regulering. Ook Nederland kende een een wet uit 1933 hieromtrent, maar deze is een dode letter gebleven. (Th. Ramm, a.w. (noot 1), p. 99).

45. COM (88) 77 def., Pb. 1988, C 113 .

46. Zie ook: Y. Kravaritou-Manitakis, New Forms of Work, Luxemburg 1988, p. 76 en 113114. 


\section{Werknemerstoezicht en deskundigeninformatie}

Het oudste instrument dat aan werknemers toekwam is het recht op controle op de uitvoering van de voorgeschreven maatregelen in de onderneming (47). Met dit recht hangt samen het recht deskundigen te raadplegen, al geldt ook daar weer voor dat het ook voor andere zaken (men kan met name denken aan het recht om financiële controle uit te oefenen) wan belang is.

\subsection{Het recht toezicht te houden}

Het recht van werknemers toezicht te houden op de uitvoering van wettelijke of overeengekomen weiligheidsvoorschriften binnen de onderneming, biedt werknemers een handvat waarmee zij greep kunnen krijgen op de veiligheidssituatie binnen de onderneming. Zij kunnen hiermee tevens kennis verwerven en informatie verkrijgen over die veiligheidssituatie waarmee zij bij de besluitvorming invloed kunnen uitoefenen. Het is een recht waarmee het oude prerogatief van de werkgever de controle over de onderneming te hebben wordt doorbroken.

Het recht toezicht te houden neemt in kracht toe indien werknemers ten aanzien van de uit te voeren en uitgevoerde controles deskundigen kunnen raadplegen, een toezichthoudende instantie kunnen inschakelen en/of zelf direct actie kunnen ondernemen, wanneer bij de inspecties blijkt dat wettelijke of overeengekomen voorschriften niet worden uitgevoerd of worden overtreden. Deze laatste twee aspecten van het recht toezicht te houden komen verderop nog aan de orde, het recht deskundigen te raadplegen zal in paragraaf V.2.2. behandeld worden.

Het recht toezicht te houden kan zowel aan de "algemene" werknemersvertegenwoordigers toekomen, als aan daartoe specifiek in het leven geroepen organen als veiligheids- en gezondheidscommissies of veiligheidsvertegenwoordigers.

De Britse veiligheidsvertegenwoordigers ontlenen hun inspectierecht aan de op de HSWA 1974 gebaseerde Regulations (48). In de Regulations wordt een onderscheid gemaakt tussen inspectie en onderzoek. Dit laatste is in tegenstelling tot wat de terminologie suggereert, een meer algemeen en ruimer begrip: onder "onderzoek" vallen ook onderzoekingen naar toekomstige gevaren, gevaarlijke situaties, en naar oorzaken van ongelukken en klachten, hetgeen het inspecteren van de werkplek, het interviewen van

47. Het aan werknemers toegekende recht om controle uit te oefenen stamt, in bepaalde sectoren, al uit de vorige eeuw. De Britse Coal Mines Regulations Aat 1872 voorzag in een recht "workmen's inspectors" te benoemen die de verplichting hadden de veiligheidsvoorschriften in de gaten te houden.

48. Safety Representatives and Safety Committees Regulations 1977, S.I. 1977, no. 500. 
betrokkenen, deskundigen en getuigen vereist (49). In de Regulations is de wijze waarop de bevoegdheden van de veiligheidsvertegenwoordiger moeten worden uitgeoefend geregeld, de wijze waarop de werkgever moet worden ingelicht, en hetgeen waarover met deze overeenstemming moet worden bereikt. Wie de vertegenwoordigers moet c.q. mag vergezellen bij de inspecties blijkt niet duidelijk uit de Regulations; ook niet of de vertegenwoordigers hun inspecties kunnen uitvoeren zonder dat een vertegenwoordiger van de bestuur van de onderneming aanwezig is. Hierover kunnen vertegenwoordigers met de werkgever per onderneming afspraken maken (50).

De Ierse veiligheidsvertegenwoordiger heeft praktisch geen expliciete rechten om toezicht te houden. Hij heeft slechts het recht de arbeidsinspecteur te vergezellen bij zijn tocht door de onderneming. Dit recht geldt niet automatisch indien het gaat om inspectie met betrekking tot het onderzoeken van ongevallen (51).

In Denemarken hebben de veiligheidsgroepen (veiligheidsvertegenwoordigers plus afdelingschef) controlletaken. In die ondernemingen waar meer veiligheidsgroepen zijn wordt een veiligheidscommissie gekozen. De veiligheidsgroepen of de commissie houdt toezicht op de veiligheidsactiviteiten in de onderneming, en op de onderzoeken die worden gedaan ter opsporing van de oorzaak van arbeidsongevallen (52). Overigens blijkt uit een onderzoek van de vakbondsfederatie LO uit 1983 dat deze controletaak, met name waar het gaat om de te verrichten onderzoeken feitelijk geen belangrijk deel uitmaakt van de dagelijkse bezigheden van de veiligheidsvertegenwoordigers (53).

In Italie is het recht van toezicht op veiligheids- en gezondheidsaangelegenheden in feite het enige de werknemers op dit gebied wettelijk toegekende recht. Artikel 9 van het Werknemersstatuut schrijft voor dat de werknemers het recht hebben de uitvoering van wettelijke voorschriften met betrekking tot het voorkomen van arbeidsongevallen en beroepsziekten door middel van hun werknemersvertegenwoordigers te inspecteren. Op basis van dit artikel zijn talloze nationale en bedrijfstaksgewijze overeenkomsten tot stand gekomen met betrekking tot veiligheid en gezondheid in de onderneming, die de aanwijzing en de bevoegdheden van de werknemersvertegenwoordigers ex artikel 9, de positie van externe deskundigen en de documentatie van arbeidsrisico's regelen (54).

49. R. Benedictus, Safety Representatives, in Law at Work London, 1980, p. 58.

50. R. Benedictus, a.w. (noot 49 ), p. 58.

51. M. Redmond, Ireland, in International Encyclopedia for Labour Law and Industrial Relations, Deventer 1986 (supplement 71), para. 183.

52. De taken staan gedletailleerd omschreven in paragraaf 9 van de ministerièle bekendmaking van 1978 (no. 392).

53. LO, Sikkerhedsarbejdet. Vilkar og muligheder, Kopenhagen 1983, p. 12.

54. O.m. J.K.M. Gevers, a.w. (noot 6), p. 150. 
De Spaanse voorziening op het gebied van toezicht lijkt bijzonder veel op het Italiaanse artikel 9 Werknemersstatuut. Artikel 19 lid 3 Werknemersstatuut biedt de werknemers een recht van toezicht op de materie die in de wetgeving voorzien is, en op de maatregelen waarin de werkgever verplicht is te voorzien. Dit recht van toezicht wordt uitgeoefend door de in de in de wet voorziene werknemersvertegenwoordigers of de in veiligheids- en gezondheidsaangelegenheden gespecialiseerde organen of instituties. Tot de werknemersvertegenwoordigers wordt in elk geval de ondernemingsraad gerekend (artikel 64 lid 8 sub b) maar er kunnen dus ook anderen zijn. Dit zal slechts het geval zijn bij ontbreken van de ondernemingsraad. Specifieke uitwerking van de bevoegdheden met betrekking tot toezicht wordt in het Werknemersstatuut niet gegeven.

Op zichzelf is deze gelijkenis tussen de Italiaanse en de Spaanse regeling eigenaardig, aangezien de Italiaanse bepaling valt in een praktisch geheel vrijwillig gereguleerd systeem, terwijl de Spaanse medezeggenschapsorganen een stevige wettelijke basis compleet met informatie- en onderhandelingsbevoegdheden hebben. Een verklaring kan zijn dat de Spaanse ondernemingsraad toch meer gezien wordt als een onderhandelend orgaan en daarmee tegenover de ondernemer staat, dan als een orgaan dat binnen de onderneming participeert en mede een taak tot samenwerking met de ondernemer heeft (55).

In het Spaanse Centraal Akkoord van 1984 (56) is het voornemen van de contractspartners opgenomen om mogelijkheden voor een nieuw juridisch raamwerk te bezien, waarin de organisatie van veiligheids- en gezondheidsbevorderende maatregelen op de werkplek, veiligheidstechnieken, opleidingen maar ook verplichtingen en verdeling van verantwoordelijkheden zouden worden ingepast. Om dit raamwerk te ontwerpen is een "comitê mixto", opgericht waarin de belanghebbende partijen zitting hebben. De in het werknemersstatuut voorziene vrijheid zou op deze wijze op vrijwillige basis gereguleerd worden. Ik heb echter niet kunnen constateren dat deze overeenkomst er ook is gekomen.

De Griekse veiligheidsvertegenwoordigers hebben een minimaal controlerende taak: zij hebben de verplichting ingeval van zware ongevallen of dergelijke voorvallen de zaak te volgen en voorstellen ter verbetering te doen. Overige controletaken zijn voornamelijk opgedragen aan intern in het bedrijf werkzame deskundigen. De veiligheidsvertegenwoordigers houden wel toezicht op de participatie van de werknemersvertegenwóordigers (vakbondsvertegenwoordigers of ondernemingsraden) in veiligheids- en gezondheidsaangelegenheden (57).

55. Zie o.m. ILO, The Trade Union Situation and Industrial Relations in Spain, Geneva 1985, p. 86. 56. Spanish Economic and Social Agreement, Part one, van 9 oktober 1984, Engelse tekst,
EIRR, 131, p. 25 .

57. Artikel 2 (a) en (b) Wet no 1568 (Workers health and safety). 
De Franse CHSCT heeft vergaande inspectiebevoegdheden. Zij heeft de bevoegdheid tenminste vier maal per jaar inspecties in de onderneming uit te voeren ten aanzien van de uitvoering van wettelijke en reglementaire voorschriften, en onderzoekt en analyseert de beroepsrisico's in de onderneming. Bovendien heeft zij het recht arbeidsongevallen en de oorzaken van beroepsziekten te onderzoeken. Wanneer bij een dergelijk onderzoek een ernstig risico ("risque grave") wordt geconstateerd mag zij op kosten van de ondernemer een deskundige raadplegen. Indien de werkgever de noodzaak van deze raadpleging of de keuze van de deskundige betwist, kan de CHSCT een beroep doen op de rechter in een spoedprocedure (58).

Hun Belgische collega's van het comitê voor veiligheid, gezondheid en ter verfraaiing van de werkplaatsen hebben een bevoegdheid tot het opsporen van zaken die de veiligheid en gezondheid van de werknemers kunnen schaden, en het opsporen van gevallen waarin de arbeid niet aan de mens is aangepast (59). Een, tenminste, jaarlijkse inspectie samen met het hoofd van de veiligheids- en gezondheidsdienst en de verantwoordelijke chef van iedere afdeling van de onderneming is voorgeschreven, om met name aan de laatstgenoemde opdracht te voldoen. Daarnaast kan het comité een vertegenwoordiger benoemen om ingeval er gevaar dreigt voor ernstige ongelukken, technische incidenten of vergiftiging onmiddellijk een onderzoek uit te voeren. Deze onderzoeken moeten in elk geval plaatsvinden nadat zich een dergelijke situatie heeft voorgedaan en wanneer een derde van de werknemersvertegenwoordigers daarom verzoekt. Het comité benoemt de werkgevers- en werknemersvertegenwoordigers die de arbeidsinspecteur bij zijn bezoeken aan de onderneming vergezellen.

In Luxemburg behoort het controlerecht tot het domein van de personeelsgedelegeerden, niet tot dat van de ondernemingsraad. Hiertoe kunnen zij wekelijkse inspecties uitvoeren (60).

In Duitsland en Nederland zijn de bevoegdheden met betrekking tot veiligheid en gezondheid in hoofdzaak in handen van de ondernemingsraden. De Duitse rechten om toezicht te houden aangaande de veiligheidsregelgeving zijn vervat in een bijzondere verplichting over de uitvoering van arbeidsbeschermende voorschriften te waken, naast een meer algemene waakplicht ten aanzien van werknemersbegunstigende voorschriften (61). Algemene visitaties aan, evenals onaangekondige steekproefsgewijze inspecties in, de onderneming behoren tot de rechten die de ondernemingsraad heeft om aan deze verplichting inhoud te geven. Hiertoe behoort zelfs

58. G.H Camerlynck, G. Lyon-Caen, J. Pelissier, Droit du Travail, Paris 1984, p. 503.

59. Artikel 337 Algemeen Reglement voor de Arbeidsbescherming.

60" C. Docksey, Employee Information and Consultation Rights in the Member States of the European Communitic:s, Comparative Labor Law 1985, p. 41.

61. K. Fitting, F. Auffarth, H. Kaiser, F. Heither, Betriebsverfassungsgesetz, Handkommentar, München 1987, p. 1069. 
het recht afdelingen te bezoeken die onder normale omstandigheden tot verboden terrein behoren. De Sicherheitsbeauftragten hebben eveneens het recht tot visitatie van de onderneming binnen de gebruikelijke arbeidsuren $(62)$.

In Nederland is het recht om toezicht te houden wel aanwezig, maar minder expliciet in de wet opgenomen dan in een aantal andere lid-staten (zoals Frankrijk en België). De Wet op de Ondernemingsraden spreekt van "het zoveel als in zijn vermogen ligt bevorderen van de naleving van de voorschriften". Specifieke inspectiebevoegdheden komen de ondernemingsraad of arbocommissie niet toe, uitgezonderd het recht de ambtenaren wan de arbeidsinspectie bij hun tocht door de onderneming te vergezellen en zilch met hen buiten tegenwoordigheid van anderen te onderhouden. $\mathrm{Na}$ de wetswijziging is daaraan het recht tot een aantal vrijgestelde uren, waarin van de arbeidomstandigheden in de onderneming kennis kan worden genomen, bijgekomen (63). Of de ondernemingsraad zelf de bevoegdheid heeft inspecties uit te voeren is niet uit de wet te lezen. Men zou uit de wetgeschiedenis kunnen afleiden dat hij, of een uit zijn midden ingestelde veiligheids- en gezondheidscommissie dat eventueel wel zou mogen (64). Of de afwezigheid van specifieke onderzoeksbevoegdheden de controlerende taak van de ondernemingsraad/arbocommissie zal belemmeren is de vraag. Op zichzelf dient de werkgever de ondernemingsraad/arbocommissie alle informatie te verschaffen waarover hijzelf beschikt; daarnaast hebben de commissies het recht op informatie van andere betrokkenen (veiligheidsdeskundigen, arbeidsinspectie en afdelingschefs). Bovendien hebben zij het recht kennis te nemen van de arbeidsomstandigheden in de onderneming en kunnen zij zich daartoe onderhouden met in de onderneming werkzame personen. Materieel lijken de voorzieningen van de ondernemingsraad/arbocommissie voldoende te zijn om effectief toezicht uit te kunnen oefenen. De problemen kunnen echter ontstaan indien de ondernemingsraad/arbocommissie naar aanleiding van arbeidsongevallen of ziektegevallen in de onderneming onafhankelijk een onderzoek wil instellen. In dat geval kan het ontbreken van een specifieke bevoegdheid de commissie tegengeworpen worden.

Inspectiebevoegdheden variëren in de verschillende lid-staten van strak omschreven verplichtingen al dan niet voorzien van specifieke bevoegdheden tot binnentreden en rechten op onderzoek, tot de pure constatering in de wet dat het recht (of de plicht) bestaat. In de landen waarin medezeggenschap voornamelijk een wettelijke basis heeft vallen Spanje en Nederland met hun weinig uitgewerkte controlerechten/verplichtingen enigszins uit de boot. Dit betekent overigens niet dat in die landen alles verboden is, wat

62. Paragraaf 13 Arbeitssicherheitsgesetz.

63. Gewijzigd artikel 18 WOR, Zie E.K. 89/90, 20 583, no. 11, invoering per 1 april 1990.

64. Artikel 28 van de WOR 1971 gaf de ondernemingsraad de opdracht toezicht te houden op de naleving van woorschriften. In de MVT werden dergelijke inspecties ter witvoering van deze taak gesuggereerd, T.K. 1969-1970, 10335 no. 3, p. 24. 
in de andere uitdrukkelijk is toegestaan. Echter zodra het in deze landen gaat draaien om precaire situaties waarin de medezeggenschapsorganen zelfstandig onderzoek willen uitvoeren, terwijl de wet in die bevoegdheid niet voorziet, kunnen de ondernemingsraden in deze landen, meer gehinderd worden bij het uitoefenen van hun taak dan hun collega-organen in andere lid-staten, die een meer uitgewerkt recht hebben.

\subsection{Het inschakelen van externe deskundigen als steun}

Het recht informatie in te winnen bij of raad te vragen aan externe deskundigen is een recht, dat de verwezelijking van meer rechten dan het recht toezicht te houden op de uitvoering van wettelijke voorschriften op het gebied van veiligheid en gezondheid alleen, vergemakkelijkt. Ook op andere gebieden kan de materie die de vertegenwoordigers moeten beoordelen te moeilijk of multi-interpretabel zijn. Daarnaast kan een algemeen recht om deskundigen te raadplegen dienen om het recht op consultatie en mogelijkheden van werknemers in te stemmen met besluiten, of te onderhandelen, mede inhoud te geven. De bevoegdheid van een medezeggenschapsorgaan advies te geven over, dan wel in te stemmen met een gecompliceerde of omstreden zaak, wint aan waarde indien het medezeggenschapsorgaan bij twijfel of gebrek aan kennis zelf de mogelijkheid heeft gehad, de zaak voor te leggen aan onafhankelijke deskundigen. Voorts levert het een mogelijkheid op de door de werkgever verstrekte informatie te controleren op juistheid en consistentie.

In relatie tot het contrôlerecht ten aanzien van uitvoering van wettelijke maatregelen inzake veiligheids- en gezondheidsaangelegenheden kan het recht deskundigen te raadplegen nog een extra betekenis hebben. Dit geldt met name waar het gaat om voorschriften, zoals die in veiligheids- en gezondheidsregelingen nu eenmaal veel voorkomen, waarbij men bij uitstek deskundig moet zijn op zeer specifieke gebieden.

Wanneer een geschil ontstaat over de mate van gevaar die een situatie oplevert -hierboven is gebleken dat in die omstandigheden, controle en onderzoeksrechten in een aantal lid-staten een belangrijke rol spelen- heeft de werkgever in beginsel een voorsprong. Hij kan immers altijd een deskundige raadplegen en juist dat advies dat voor hem het best uitkomt gebruiken in het geschil. Voor werknemers is het veel moeilijker, gezien kosten en mogelijkheden, een onafhankelijk advies te verkrijgen. Juist waar het gaat om zaken als de uitvoering van wettelijke voorschriften en te nemen maatregelen ter voorkoming van ongelukken, is een zo groot mogelijke kennis van de vertegenwoordigers van belang.

Bij de bevoegdheid deskundige hulp in te roepen rijzen wel enkele vragen, zoals: tot hoever gaat de bevoegdheid? wie betaalt de kosten die aan het inroepen van externe deskundigen verbonden zijn? moet de ondernemer instemmen met een vraag om informatie? kan de ondernemer invloed uitoefenen op de persoon van de deskundige die om informatie verzocht 
wordt? Met name voor medezeggenschapsorganen die geen eigen budget hebben, of geen zelfstandige rechtspersoonlijkheid hebben zijn de antwoorden op deze vragen van belang.

Wanneer de vakbond zelf door middel van shop stewards de vertegenwoordiging op ondernemingsniveau levert, liggen de problemen iets anders. In dat geval zal het minder van belang zijn of een ondernemer toestemming voor het inwinnen van advies geeft, maar of de vakbond c.q. shop steward de voor het advies benodigde gegevens kan verkrijgen. Het recht deskundigen te raadplegen hangt dan meer samen met een recht op informatie voor de werknemersvertegenwoordigers zelf. Bovendien is het niet onmogelijk dat in die gevallen, de vakbond zelf in staat is een apparaat te onderhouden dat onafhankelijk van de ondernemer de werknemersvertegenwoordigers van meer en gedetailleerde informatie kan voorzien.

In Duitsland, Nederland, en Frankrijk zijn er specifieke regelingen die voorzien in de mogelijkheid deskundigen te raadplegen. In Duitsland heeft de ondernemingsraad, om zijn taak te verlichten, een recht deskundigen te raadplegen, wanneer de materie waarover hij zich moet buigen te gecompliceerd is. Het recht is beperkt tot zaken waarover de ondernemingsraad door de ondernemer geconsulteerd moet worden, dan wel waarin de ondernemingsraad instemmingsrechten heeft. Voor de Wirtschafts-ausschuss geldt een vergelijkbare regeling. Dit betekent dat aangaande zaken waarover de ondernemingsraad het controlerecht heeft niet per definitie een deskundige om advies gevraagd kan worden. In veel gevallen zullen er tussen het recht om toezicht te houden en consultatie- en instemmingsrechten (en dit is voor veiligheids- en gezondheidsaangelegenheden het geval) wel overlappingen zijn. De deskundigen kunnen zowel uit de onderneming als van buiten afkomstig zijn.

Het recht deskundigen te raadplegen is beperkt tot specifieke onderwerpen (65). In de concrete situatie wordt gekeken naar de noodzaak deskundig advies in te roepen, hoewel aangenomen mag worden dat in die gevallen waarin een ondernemingsraad zeer eenzijdig is samengesteld en bepaalde deskundigheden ontbreken, over zaken die daarmee te maken hebben, praktisch altijd advies kan worden ingewonnen (66).

De Nederlandse Wet op de Ondernemingsraden biedt de ondernemingsraad, zowel als zijn commissies, gelegenheid, deskundigen uit te nodigen op de vergadering om inlichtingen of advies te geven over een bepaald onderwerp. In de Arbeidsomstandighedenwet bestaat een vergelijkbare bepaling (67). Daarnaast kunnen buiten de vergadering schriftelijke adviezen uitgebracht

65. Landesarbeitsgericht Frankfurt, 26-2-1985, Arbeit und Recht, 1986, p. 124.

66. Vgl. o.m. Landesarbeitsgericht Düsscldorf, 9-11-1983, Arbeit und Recht 1984, p. 191, Landesarbeitsgericht Berlin, 30-7.1985, Landesarbeitsgerichts Entscheidung (LAGE) paragraaf 80 , BVG 1982 no. 4 .

67. Artikel 14 lid 11. Daarnaast biedt artikel 14 lid 10 ook de mogelijkheid tot raadpleging van niet in het bedrijf of de inrichting werkzame personen. 
worden. De beperking tot een bepaald onderwerp voorkomt met name dat een ondernemingsraad een algemeen adviseur aanstelt (68). Het recht is in tegenstelling tot het in Duitsland geregelde niet beperkt tot onderwerpen waarover de OR advies moet geven dan wel instemmingsrecht heeft. De uit te nodigen personen kunnen zowel bestuurders of commissarissen van de onderneming zijn als deskundigen van buitenaf.

Voor de Franse ondernemingsraden zijn in de Code du Travail eveneens bepalingen opgenomen die voorzien in de mogelijkheid deskundigen te raadplegen voor limitatief omschreven situaties. Deze mogelijkheid staat open voor het controleren van het financiële jaarverslag en het bestuderen van ontslagen om economische redenen. In deze gevallen heeft de ondernemingsraad de vrije keus voor wat betreft de persoon van de deskundige, wel is deze gebonden aan de omschreven adviesopdracht en moet zijn onderzoek plaatsvinden op basis van dezelfde documenten die ook de gemachtigden bij het verslag ("commissaires au comptes") ter beschikking staan.

Sedert $1982(69)$ is, wanneer de introduktie van een nieuwe technologie in een onderneming van meer dan 300 werknemers voorzien wordt, het mogelijk een expert te raadplegen. Voorwaarde voor de raadpleging is, dat van het technologieprojekt verwacht wordt dat dit op de werkgelegenheid, de (werk)classificatie, de beloning, of de arbeidsomstandigheden invloed zal hebben. Ook moet de ondernemer (of het bestuur van de onderneming (chef d'entreprise)) met de onderzoeksopdracht en de persoon van de deskundige akkoord gaan. Doe hij dit niet dan is beroep op de rechter mogelijk. Over de vraag het technologieprojekt van voldoende belang is om het raadplegen van een deskundige te rechtvaardigen, is nogal wat jurisprudentie (70). Voor beide soorten deskundigen geldt dat het honorarium wordt betaald door de onderneming.

Voor de voorbereiding van de werkzaamheden in het algemeen kan de ondernemingsraad beroep doen op deskundige begeleiding. De beloning van de expert in het laatste geval kan, indien de werkgever niet akkoord gaat, voor rekening van het ondernemingsraad komen (71). Tot deze werkzaamheden behoort ook het adviseren over veiligheids- en gezondheidsaangelegenheden.

Het recht deskundigen te raadplegen voor de CHSCT is hierboven al aangestipt. Bij ernstig gevaar op veiligheids- en gezondheidsgebied mag de CHSCT een deskundige laten komen op kosten van de werkgever. De

68. Dit blijkt o.m. uit een uitspraak van de Bedrijfscommissie voor het Verzekeringsbedrijf, 19 april 1984 (niet gepubliceerd).

69. Wet van 29 oktober 1982, JORF, p. 262 (art. L 432-2 CdT).

70. Cour. de Cassation, (Soc.) 2 juli 1987, Bull. V.438; Cour de Cassation (Soc) 15 october 1987, Bull. V 569. Lyon-Caen en. Pélissier noemen in hun noot in Droit du travail, Paris 1988 , p. 877 , ook jurisprudentie aangaande de vraag of de invoering van bepaalde zaken als "projet" in de zin wan art. L. 432-2 CdT moet worden gezien en feitelijke vragen over de inhoud van het begrip nieuwe technologie.

71. J. Rivero, J Savatier, Droit du travail, Paris, 1984, p. 249 ev. 
werkgever kan in beginsel tegen de persoon van een deskundige geen bezwaar maken.

De kosten van de deskundigen komen in Nederland en Duitsland net als in Frankrijk in het algemeen voor rekening van de onderneming. In Frankrijk wordt de beloning vastgelegd in een akkoord, of door beslissing van de voorzitter van de ondernemingsraad. Bij geschillen over de kosten treedt de president van de rechtbank als arbitrage-instantie op. Daarnaast heeft de ondernemingsraad de mogelijkheid uit zijn eigen budget advies van deskundigen te bekostigen. De beslissing over de kosten wordt in dat geval in de raad genomen, waarbij de werkgever zich onthoudt van stemmen (72).

In Nederland komen in beginsel alle kosten van de ondernemingsraad en zijn commissies ten laste van de ondernemer, maar voor het raadplegen van deskundigen geldt, dat deze kosten pas door de ondernemer hoeven te worden gedragen wanneer hij vooraf van de te maken kosten in kennis is gesteld. In de oude regeling moest de ondernemingsraad, indien de ondernemer niet akkoord ging met het dragen van deze kosten, de zaak aan de bedrijfscommissie voorleggen. Slechts indien de ondernemingsraadsleden zoveel waarde aan het raadplegen van een deskundige hechtten dat zijzelf bereid waren de kosten te dragen, was dit anders. Op deze wijze werd de mogelijkheid voor de ondernemer om invloed uit te oefenen op de persoon van de deskundige dan wel op de vraag of verdergaande informatie nodig was, een mogelijkheid die in de wet niet expliciet opgenomen was, via de kostenregeling binnengehaald.

Want hoewel de procedure bij de bedrijfscommissie alleen ging over de eventuele vergoeding van de kosten, kon hierbij een toetsing van het belang dat een $O R$ bij een deskundigenadvies zou hebben aan de orde komen (73). Daarmee kon in extreme gevallen de weigeringsbevoegdheid van de ondernemer bij te dragen in de kosten, tot een verkapt toestemmingsvereiste worden. Deze mogelijkheid is door het inwerkingtreden van het wetswijziging ter herziening van de geschillenregelingen van de WOR en de Arbowet vervallen (74). De kennisgeving is voortaan genoeg om de kosten die redelijkerwijze aan het raadplegen van een deskundige verbonden zijn voor rekening van de ondernemer te laten komen. Geschillen over het uitnodigen van een deskundige behoren nu tot de bevoegdheid van de kantonrechter.

De ondernemingsraad kan in overeensteming met de ondernemer de kosten van te voren vaststellen op een bepaald bedrag. De ondernemingsraad kan het vastgestelde bedrag naar eigen inzicht besteden, onder meer voor het raadplegen van deskundigen. In dat geval is weliswaar toestemming nodig van de ondernemer voor kosten waardoor het bedrag overschreden wordt, echter zolang de kosten binnen het budget blijven kan de ondernemer geen

72. G. Lyon-Caen, J. Pélissier, a.w. (noot 21), p. 872-874. 73. Dit blijkt uit een uitspraak van de Bedrijfscommissie voor de Groothandel van 7 juni 1984

74. T.K. $205831988 / 89$, no. 11, p. 7. 
invloed uitoefenen op de persoon van de deskundige of de vraag of er überhaupt wel advies noodzakelijk is.

De Arbeidsomstandighedenwet voorziet in een gelijksoortige regeling die echter op enkele punten verschilt. Gaat de WOR er van uit dat de kosten door de ondernemer worden betaald na kennisgeving, behoudens weigering, in de Arbowet staat expliciet dat de ondernemer (werkgever in de terminologie van de Arbowet) toestemming moet geven voor de uitnodiging, indien aan de uitnodiging kosten verbonden zijn. De werkgever is gehouden toestemming te geven als die kosten redelijkerwijs nodig zijn voor de vervulling van de taak van de Arbocommissie. Geeft de werkgever geen toestemming, dan kan de Arbocommissie in beroep bij de kantonrechter met hoger beroep op de Ondernemingskamer (75).

Het expliciete toestemmingsvereiste in de Arbowet gaat verder dan de regeling die in de WOR gegeven is, en geeft de ondernemer een grotere mogelijkheid invloed uit te oefenen op onder meer de persoon van de deskundige en de vraag over welke kwesties de adviesaanvraag mag gaan (76). Bovendien kan de ondernemer door toestemming te weigeren voorkomen dat een deskundige faciliteiten verkrijgt om advies uit te brengen.

De regelingen in de gewijzigde wetten staan naast elkaar. De ondernemingsraad baseert zijn uitnodiging op de artikelen in de WOR, de Arbocommissie op de artikelen uit de Arbeidsomstandighedenwet. Dit betekent dat de Arbocommissie gebonden is aan "zwaardere" voorwaarden dan de ondernemingsraad, namelijk de (expliciete) toestemming vooraf. Doordat de ondernemer bezwaar kan maken tegen een door de ondernemingsraad uitgenodigde deskundige, en procedures hieromtrent op basis van beide wetten bij de kantonrechter gevoerd moeten worden, zal het verschil materieel mogelijk klein zijn.

De Duitse ondernemingsraad heeft de mogelijkheid een overeenkomst te sluiten met de werkgever over de wijze waarop het recht deskundigen te raadplegen wordt uitgeoefend. Daarin kunnen bijzonderheden over de persoon van de deskundige, de hoogte van de kosten en het tijdstip van raadpleging worden geregeld. De invloed van de ondernemer is met deze regeling afhankelijk gemaakt van de hoeveelheid macht die een ondernemingsraad binnen een onderneming heeft. Bij geschillen over de in de overeenkomst te regelen aangelegenheden kan de Einigungsstelle op basis van paragraaf 76 abs. 6 BetrVG gevraagd worden. Weigert de ondernemer een overeenkomst te sluiten omdat hij meent dat het raadplegen van een deskundige niet nodig is, dan kan de ondernemingsraad een beslissing vragen aan het Arbeitsgericht (im Beschlussverfahren) op grond van de Arbeitsgerichtsgesetz. Daarbij staat de vraag van de noodzaak tot het

75. Artikel 14 lid 9 Arbeidsomstandighedenwet zoals gewijzigd per 1 april 1990.

76. Tijdens de totstandkoming van de Arbowet zijn stemmen opgegaan om een mogelijkheid tot bezwaar van de ondernemer tegen de persoon van de deskundige expliciet in de wet op te nemen. Vgl o.a. het advies van de Raad van Bestuur in Arbeidszaken over de arbeidsomstandighedenwet van 29 mei 1979 , p.8. 
raadplegen van een deskundige centraal (77). Raadpleegt de ondernemingsraad, ondanks een weigering van de ondernemer een overeenkomst te sluiten, toch een deskundige, dan kan de ondernemingsraad geen vergoeding van de kosten eisen.

Het woord overeenkomst is in dit verband trouwens nogal verwarrend: het betreft hier geen bedrijfsovereenkomst (Betriebsvereinbarung) die de ondernemingsraad op een aantal punten met de ondernemer kan sluiten (78). Daarom hoeft de overeenkomst niet aan de voor de bedrijfsovereenkomst vereiste voorschriften te voldoen, en kan deze bovendien ook door een commissie van de ondernemingsraad worden gesloten.

In beginsel zijn de kosten die het raadplegen van een deskundige met zich mee brengen, voor rekening van de ondernemer. Deze vallen onder de kosten die het uitoefenen van de taak door de ondernemingsraad met zich brengen. Niettemin heeft de ondernemer wel invloed op de hoogte van die kosten via het sluiten van bovengenoemde overeenkomst.

Over een eventuele invloed van de ondernemer op de persoon van de deskundige rept de BetrVG niet, aangenomen mag worden dat de ondernemer deze wel kan uitoefenen tijdens het sluiten van de overeenkomst. Geraadpleegde deskundigen hebben dezelfde geheimhoudingsplicht als de leden van de ondernemingsraad.

De ondernemingsraad kan de mogelijkheid tot het raadplegen van deskundigen delegeren aan zijn commissies; wanneer commissies algemene gedelegeerde bevoegdheden hebben zijn zij automatisch

gerechtigd tot het sluiten van overeenkomsten met de ondernemer hieromtrent.

De Belgische regeling voor raadpleging van deskundigen dateert uit 1985 (79). In deze lid-staat is, in plaats van de incidenteel te raadplegen deskundige voor een bepaald geval, gekozen voor een systeem waarin adviseurs en deskundigen een geïntegreerd onderdeel uitmaken van het functioneren van de ondernemingsraad.

Voor economische en financiële informatie is een permanente adviseur in de ondernemingsraad aanwezig wiens taak het onder meer is het waarheidsgehalte en compleetheid van de door de ondernemer verstrekte informatie te verifiëren $(80)$. Op het gebied van veiligheid en gezondheid bestaat een dergelijke regeling hooguit in die zin dat het comité zijn taken verricht in zeer nauwe samenwerking met de dienst voor veiligheid en gezondheid (81) en de bedrijfsarts, die eveneens als deskundige kan gelden. Door het al eerder genoemde zeggenschapsrecht bij aanstelling of ontslag van deze

77. K. Fitting c.s., a.w. (noot 61), p. 900 .

78. K. Fitting c.s., a.w. (noot 61), p. 899.

79. Bij wet van 22 januari, in werking getreden op 21 februari 1985 is de regeling omtrent ondernemingsraden gewijzigd, Engelse tekst, International Encyclopedia for Labour Law and Industrial Relations, Legislation, vol. I, Deventer 1986, no. 36.

80. Voor zijn overige taken, zie R. Blanpain, Belgium in International Encyclopedia for Labour Law and Industrial Relations, Deventer 1988, (supplement 93) para. 285.

81. R. Blanpain, a.w. (noot 80 ), para. 296. 
functionaris is de onafhankelijkheid van de informatie door deskundigen versterkt en in elk geval tot op zekere hoogte gewaarborgd. Nadeel van deze regeling is wel dat het van de positie van de deskundige in de onderneming afhangt, hoe onafhankelijk zijn oordeel zal zijn.

De Griekse veiligheids- en gezondheidswet hanteert eenzelfde soort systeem. Hoewel de veiligheidsvertegenwoordigers, zoals eerder bleek, weinig eigen specifieke contrólebevoegdheden hebben, oefenen zij hun algemeen adviserende en consulterende bevoegdheden in nauwe samenwerking uit met de interne veiligheidskundige en/of de bedrijfsarts. Zij kunnen alleen maar met instemming van de werkgever externe deskundigen raadplegen (82). Over de kosten is in de wet geen regeling opgenomen. Men mag aannemen dat de werkgever deze moet dragen, gezien het instemmingsvereiste. Geschillen over de noodzaak van de inschakeling van een deskundige kunnen op basis van de wet bij de rechter worden aangekaart.

De Spaanse ondernemingsraad heeft geen wettelijk recht om deskundigen te raadplegen aangaande kwesties waar onduidelijkheid over is. In het Werknemersstatuut is hierover geen regeling opgenomen, evenmin als een regeling over eventuele kosten die aan het functioneren van de ondernemingsraad verbonden zijn.

Overigens is hiermee niet gezegd dat de mogelijkheid deskundigen te raadplegen voor de ondernemingsraad volledig uitgesloten is. De Spaanse ondernemingsraad heeft in tegenstelling tot zijn Nederlandse en Duitse tegenhanger meer binding met de vakbond, waaruit eventueel experts om advies gevraagd kunnen worden. Bovendien heeft hij de mogelijkheid om over de aangelegenheden die tot zijn competentie behoren met de werkgever te onderhandelen, zodat men ook een overeenkomst over kosten van het functioneren van de ondernemingsraad in het algemeen en het raadplegen van experts en de kosten daaromtrent kan afsluiten. Dit vereist uiteraard wel een relatief "machtige" ondernemingsraad hetgeen tot verschillen tussen de verschillende ondernemingen kan leiden.

In de Ierse, Britse en Italiaanse (83) wetgeving zijn geen regelingen omtrent het raadplegen van deskundigen opgenomen. Dit heeft vermoedelijk mede te maken met het feit dat de wettelijke regeling op deze gebieden als aanvullend op de onderhandelingstaken beschouwd wordt (84). Het raadplegen van deskundigen door shop stewards in lerland en Groot Brittannie kan wel geschieden binnen de vakbond waarvan zij vertegenwoor-

82. Artikel 2 B lid f. Wet no. 1568 .

83. P.G. Cella, T. Trew, a.w. (noot 31), p. 105.

84. Hoe diep het gevoel zit dat collectief onderhandelen de enige manier is om zaken tussen werkgever en werknemers te regelen blijkt o.m... uit de visie op de, sedert 1979 op de Wages Councils Act 1979 gebaseerde, maar al eerder bestaande tripartite Wages Councils, die tot taak hadden collectief onderhandelen zowel, indien nodig, te vervangen, als te bevorderen: zij werden gezien als "statutory props to the system", Lord Wedderburn, The Worker and the Law, Harmondsworth 1986, p. 352-353. 
diger zijn; deze is soms in staat deskundige hulp te bieden (85). Op het gebied van veiligheid en gezondheid zijn er echter wel mogelijkheden om deskundige hulp in te roepen, zij het dat het gaat om informatie die door arbeidsinspecteurs wordt verschaft. Zij zijn verplicht feitelijke, op de werkomgeving toegespitste informatie die behoort tot het gebied van de veiligheidsvertegenwoordiger (86), te verstrekken. Op deze adviserende taak wordt in een latere paragraaf teruggekomen.

In Italie wordt de mogelijkheid experts van buitenaf te raadplegen in het algemeen geregeld in de verschillende collectieve contracten (87).

De scheiding tussen informatieverstrekking in het algemeen en het advies door deskundigen lijkt in Denemarken niet zo scherp te liggen. Dit is ten dele het gevolg van het feit dat shop stewards hun informatie ofwel via de vakbonden krijgen, ofwel via de samenwerkingscommissie. De samenwerkingscommissie heeft, zoals in paragraaf IV.2. geschetst, altijd de mogelijkheid om via de Bedrijfscommissie (samarbejdsnaevnet) aan deskundig advies te komen. De Bedrijfscommissie speelt hier een actieve rol in, ofwel door de informatie zelf te verstrekken, ofwel deze op andere wijze te verzorgen. De veiligheidscommissies hebben met name zelf de taak om informatie te verschaffen. Zij kunnen te dien einde een beroep doen op deskundigen van de landelijke organisatie die zich met veiligheid en gezondheid bezighoudt.

In hoeverre een beroep op deskundigen in de praktijk voorkomt is niet duidelijk op te maken uit het materiaal dat voorhanden is. Veel van de bestaande wetten zijn te kort in werking om een duidelijk beeld op te leveren. In onderzoeken naar de bevoegdheden van medezeggenschapsorganen, zowel algemene als specifiek op medezeggenschap bij veiligheids- en gezondheidsaangelegenheden gerichte organen, wordt weinig (tot geen) aandacht aan deze bevoegdheid besteed. Het aantal zaken waarin een beroep op arbiter of rechter wordt gedaan verschilt nogal per lid-staat. In Frankrijk is met name over de noodzaak van het raadplegen van technologie-experts de nodige jurisprudentie ontstaan, hetgeen er op wijst dat met name in dit verband van de bevoegdheid gebruikt gemaakt wordt (88). In Nederland zijn weinig uitspraken van de bedrijfscommissie over de kostenregeling omtrent experts te vinden (89). Het gebrek aan gegevens maakt het moeilijk over de werking van deze bevoegdheid in de praktijk, iets te zeggen.

85. B. Perryns, a.w. (noot 28), p. 3

86. A. Broadhurst, a.w. (noot 29), p. 45.

87. N. Messina, Ambiente di lavoro, IPSOA, Milano 1979, p. 90.

88. G. Lyon-Caen, J. Pélissier, a.w. (noot 21), p. 877-878.

89. In de periode 1979-1985 kwamen 3 zaken hieromtrent bij de verschillende Nederlandse bedrijfscommissies. 
3 Het recht van werknemerswertegenwoordigers een deel van de onderneming stil te leggen

Wanneer geconcludeerd wordt dat in een onderneming de situatie zo onveilig of ongezond is geworden dat er iets aan moet gebeuren, is er een aantal mogelijkheden. In eerste instantie kunnen werknemers- of veiligheidsvertegenwoordigers met de werkgever overleggen, over hetgeen hen te doen staat. Daarnaast kunnen zij de arbeidsinspectie waarschuwen. Voorts is het van belang wat de vertegenwoordigers zelf kunnen ondernemen. Met andere woorden hebben de werknemersvertegenwoordigers zelf het recht de onderneming, of een deel van de onderneming stil te leggen?

Slechts in twee landen namelijk Denemarken en Spanje hebben de werknemersvertegenwoordigers dit recht nadrukkelijk en volledig.

In Denemarken kan de veiligheidsgroep (veiligheidsvertegenwoordiger(s) en afdelingschef) bij ernstig en onmiddellijk gevaar de onderneming stilleggen. Dat kan echter alleen indien er geen tijd is om de bedrijfsleiding of de voorzitter van van de veiligheidscommissie te waarschuwen. Deze nemen de beslissing over maatregelen of hervatting van de werkzaamheden. Als werknemers na een beslissing tot hervatting van de werkzaamheden menen dat het gevaar nog aanwezig is, en om die reden geen gehoor geven aan de beslissing, kunnen zij de arbeidsinspectie waarschuwen. Deze heeft eveneens de bevoegdheid het werk stil te leggen. Indien de arbeidsinspectie constateert dat het werk hervat moet worden, lopen werknemers die deze beslissing negeren het risico ontslagen te worden wegens werkweigering. De bevoegdheid van de veiligheidsgroep is relatief vergaand. Oorspronkelijk waren de vakbonden overigens tegen toekenning van deze bevoegdheid, zij wilden deze bij voorkeur zelf uit kunnen oefenen $(90)$. Zij hebben doordat shop stewards gekozen kunnen worden als veiligheidsvertegenwoordigers en als zodanig deel uitmaken van de veiligheidsgroep, niettemin invloed op de mogelijkheid de onderneming stil te leggen.

In Spanje voorziet artikel 19 lid 5 Werknemersstatuut in een procedure bij ernstig en direct gevaar. De werknemers kunnen, wanneer een dergelijk gevaar zich voordoet, ofwel via een beslissing van de competente organen op het gebied van veiligheid en gezondheid, ofwel bij een stemming onder de personeelsvertegenwoordigers met een meerderheid van $75 \%$, het proces in de onderneming stopzetten. De beslissing moet onmiddellijk meegedeeld worden aan "de onderneming" en aan de autoriteit van de arbeid (bedoeld wordt vermoedelijk de arbeidsinspectie, dan wel een provinciale inspectie). De autoriteit van de arbeid moet binnen vierentwintig uur de beslissing bekrachtigen, dan wel hem ongedaan maken. Over dit twistpunt kan uiteraard weer naar de rechter gestapt worden.

90. L. Iversen, Arbejderklassen og arbejdsmiljøet, Kopenhagen, 1978 ( 2 e druk) p. 16-17. 
In andere landen bestaan wel rechten tot stillegging, maar deze zijn nog meer dan hierboven gekoppeld aan het inschakelen van de arbeidsinspectie.

Zo is voor de Franse CHSCT in 1982 een vrij sterke positie gecreëerd in geval van dreigend gevaar. In de regeling die in 1976 werd ingevoerd kreeg de Franse arbeidsinspectie, in tegenstelling tot de vergelijkbare organisaties in de meeste andere Europese landen, geen wettelijke bevoegdheid het werk stil te leggen bij direct en ernstig gevaar. Wel kon zij een bevel daartoe aan de rechter vragen. $\mathrm{Al}$ in 1982 is deze regeling, onder invloed van de toen aangetreden socialistische regering Mitterand, in zoverre gewijzigd, dat bij ernstig en direct gevaar de personeelsgedelegeerden of de CHSCT een procedure kunnen initiëren om het gevaar te stoppen. Indien éen van de vertegenwoordigers of leden van de CHSCT de ondernemer waarschuwt dat er sprake is van een gevaarlijke situatie, dan is hij verplicht onmiddellijk een onderzoek in te stellen en de noodzakelijke maatregelen te nemen. De CHSCT kan het werk na dit onderzoek als noodzakelijke maatregel tijdelijk stilleggen. In geval van verschil van mening over de aanwezigheid van gevaar, of over de wijze van aanpakken ervan, wordt de CHSCT in spoedzitting bijeengeroepen, tesamen met de arbeidsinspecteur. Op basis van dit overleg worden de noodzakelijke maatregelen getroffen (91). Die maatregel kan een bekrachtiging van de stillegging door de CHSCT inhouden.

In Griekenland geeft de Veiligheids- en gezondheidswet uit 1985 de veiligheidscommissies het recht om in geval van ernstig en onmiddellijk gevaar eisen te stellen om de noodzakelijke maatregelen te nemen. Deze eisen kunnen het stilleggen van machines of het produktieproces inhouden. Echter de wet is niet duidelijk of de veiligheidscommissie dit ook zelf kan doen. Op het eerste gezicht lijkt de formulering slechts het stellen van de eis op zich in te houden, waarbij aan de werkgever de beslissing bljjft voorbehouden. Het enkele feit dat de mogelijkheid uitdrukkelijk in de wet is opgenomen, kan de positie van de veiligheidscommissie, indien de werkgever weigert de noodzakelijke maatregelen te nemen, versterken.

In de andere landen is geen wettelijk recht tot het stilleggen van de onderneming door werknemersvertegenwoordigers voorzien en is alleen de arbeidsinspectie daartoe bevoegd. Wel bestaat in aantal landen een individueel recht tot stillegging bij dreigend ernstig gevaar. In een enkel geval kan dit recht ook collectief uitgeoefend worden. Óp dit individuele recht van werknemers wordt in paragraaf V.6.1. uitgebreid teruggekomen.

In Groot Brittannië en Italië zijn well in enkele collectieve overeenkomsten rechten tot stillegging voor veiligheidsvertegenwoordigers opgenomen.

91. J. Rivero, J. Savatier, a.w. (noot 71), p. 622. 
In Groot Brittannië waar de vakbonden dit recht voor hun vertegenwoordigers geëist werd bij de behandeling van de HSWA 1974, heeft de General and Municipal Workers Union in 1979 een modelovereenkomst opgesteld. Volgens deze overeenkomst krijgen veiligheidsvertegenwoordigers het recht om de onderneming stil te leggen bij schending van een Regulation of de mogelijkheid van gevaar en risico voor personen (92).

4 Interne en externe ondersteunende instanties bij het voeren van een veiligheids- en gezondheidsbeleid

Ter ondersteuning van het veiligheids- en gezondheidsbeleid in de onderneming en de samenwerking van werknemers en werkgever vervullen min of meer onafhankelijke instanties en personen zowel binnen als buiten de onderneming een belangrijke rol. De noodzaak van deze diensten wordt niet alleen, al van oudsher, op nationaal (93) niveau ingezien, maar ook op internationaal niveau. In 1985 is in de ILO een Conventie opgesteld met betrekking tot bedrijfsgeneeskundige diensten, als uitwerking van een eerder bestaande aanbeveling (94). Bij dergelijke instanties kan men denken aan veiligheidsdiensten in de onderneming die voor scholing zorgen of bedrijfsartsen (interne vakkrachten, maar ook aan door de overheid gënitieerde en gesubsidieerde diensten met meer of minder vergaande bevoegdheden (95)). Het is overigens niet de bedoeling alle externe organisaties met een top-downstructuur (zoals nationale veiligheids- en gezondheidsraden) die er in de verschillende lid-staten zijn, te bespreken, maar alleen dan wanneer zij gedecentraliseerde (of gedeconcentreerde) organen hebben tot wier taak het behoort, op lokaal niveau werknemers(vertegenwoordigers) van advies te dienen.

De taak van de interne en externe deskundigen is onder meer de samenwerking te versoepelen, als intermediair op te treden bij dreigende conflicten en oplossingen te bedenken en aan te bieden ingeval de samenwerkende partijen er niet meer uit komen. Daarnaast hebben de deskundigen in de onderneming veelal een aantal andere, meer concrete taken. In deze paragraaf zullen interne en externe ondersteunende organisaties aan bod komen, die geen politionele bevoegdheden hebben ten aanzien van de naleving van bestaande voorschriften; daarmee wil echter

92. EIRR 1979 , no. 61 , p. 20 .

93. De eerste bedrijfsartsen c.q. bedrijfsgezondheidsdiensten deden hun intrede in de onderneming tussen 1833 (Groot Brittannië) en 1930 (Denemarken). Wettelijke regelingen kwamen vooral in de jaren vijftig en zestig tot stand (Bron CISME, D.G. 86. C.2., 13 januari 1986).

94. Convention concerning Occupational Health Services, (no. 161) Geneva 1985, mede gebaseerd op de Occupational Health Services Recommendation, van 1959 (no. 112) International Labour Organization Conventions and Recommendations, 1966 and supplements; de conventie is nog niet in werkinggetreden.

95. Conventie no. 161 laat de ratificerende staten de ruimte te kiezen voor zowel interne diensten, als door de overheid gefinancierde diensten. 
niet gezegd zijn dat inspecteurs die wel politionele bevoegdheden hebben geen ondersteunende rol zouden kunnen vervullen.

Indien conflicten tot uitbarsting komen worden deze instanties geacht met behulp van hun bevoegdheden de zaak op te lossen. En mocht dit niet gebeuren dan moeten zij in eerste instantie een besluit nemen over hoe een probleem aangepakt moet worden.

Dit levert met name voor de interne vakkrachten, een rol met verschillende kanten op. Dit is zeker het geval als zij binnen de onderneming zelf werken en te maken hebben met enerzijds belangen (en eisen) van werknemers en anderzijds de economische mogelijkheden van de onderneming waartoe zij behoren. Daarnaast hebben zij te maken met het feit dat de onderneming niet alleen een te examineren component is, maar tevens hun werkgever is. Hoe onafhankelijker hun positie binnen een onderneming is (met wettelijke of CAO-garantie omgeven) hoe objectiever en minder belast zij te werk kunnen gaan. Kortom de positie van ondersteunende instanties is er op zijn best éen van relatieve zelfstandigheid en onafhankelijkheid.

Ten opzichte van de werknemers heeft met name de bedrijfsarts een dubbele rol. Hij is in het algemeen ook keuringsinstantie, voor de geschiktheid van de werknemer voor zijn baan. Als zodanig heeft de bedrijfsarts ook in hoge mate rekening te houden met de belangen van de werkgever, tegenover die van de gekeurde werknemer. Deze van oudsher aan de bedrijfsarts toekomende taak kan, gezien de samenwerking met de werknemers of hun vertegenwoordigers, problematisch zijn.

In de meeste lid-staten zijn in de wettelijke regelingen omtrent veiligheid en gezondheid voorschriften opgenomen over vakkrachten op dit gebied. Zij worden in het algemeen geacht hun werkzaamheden met die van de veiligheidsvertegenwoordigers te coördineren en hen bij hun werkzaamheden te ondersteunen. Hierdoor wordt het veiligheidsbeleid deels in deskundige handen gelegd, zozeer zelfs dat, zoals uit de vorige paragraaf bleek dat in België en Griekenland additionele deskundige informatie in elk geval niet strikt noodzakelijk wordt geacht.

In Griekenland is de aanstelling van een veiligheidsdeskundige en een bedrijfsarts verplicht in bedrijven die gemiddeld per jaar meer dan 50 werknemers in dienst hebben. Beide deskundigen hebben zowel adviserende taken ten opzichte van de werkgever en zijn de belangrijkste toezichthouders op het gebied van veiligheid en gezondheid (96). $\mathrm{Zij}$ participeren in de aan werknemers te geven opleidingen en en hebben een aantal specifieke verantwoordelijkheden. Naast de werkgever zijn de vakkrachten de voornaamste adviseurs van de commissie op dit gebied. Griekse deskundigen hebben ontslagbescherming, maar tot hoever deze reikt is niet

96. Wet no. 1568, Workers Health and Safety, Engelse tekst, EIRR 144, January 1986, p. 28-
30 . 
duidelijk. Ten aanzien van een meningsverschil omtrent de verantwoordelijkheden van de deskundigen is ontslag verboden, maar de deskundigen mogen wel (en slechts) ontslagen worden wegens gerechtvaardigde redenen. Deze ontslagbescherming is minder vergaand dan die de Griekse wet kent voor vakbondsvertegenwoordigers en ondernemingsraadsleden: voor hen geldt een ontslagverbod. De nog jonge Griekse veiligheidswet wordt op punt van de aanstelling van vakkrachten beter nageleefd dan voor wat betreft het instellen van veiligheidscommissies, althans in de grotere ondernemingen (met meer dan 150 werknemers). In 1987 had $85 \%$ van deze ondernemingen een veilligheidskundige en $75 \%$ een bedrijfsarts in dienst (97). Over kleinere ondernemingen is (in verband met de gefaseerde invoering van de wet) nog niet gerapporteerd.

In België is het aanstellen van een bedrijfsarts verplicht bij meer dan 50 werknemers, indien er minder zijn moet worden aangesloten bij een gemeenschappelijke medische dienst (98). Het comitế voor veiligheid, gezondheid en verfraaiing van de werkplaatsen heeft een instemmingsrecht bij de aanstelling. Ingeval er een gezamenlijke bedrijfsarts wordt aangesteld wordt een adviesraad van de vertegenwoordigers van de meest representatieve vakbonden ingesteld aan wie dit instemmingsrecht toekomt. De verschuiving van de bevoegdheid van comité naar de vakbonden komt mij overigens vreemd voor: men zou ook vertegenwoordigers van de verschillende comite's kunnen afvaardigen. De Belgische bedrijfsarts heeft naast zijn adviserende en zijn, in samenwerking met het comité, controlerende taak ook zeer specifieke taken in de onderneming, die er met name op zien dat werknemers in die banen terechtkomen die passen bij hun capaciteiten. Uit onderzoek blijkt dat deze laatste rol nog al wat weerstand tegen de bedrijfsarts heeft opgeroepen (99).

Deze laatste rol wordt ook gespeeld door de Franse medische dienst (100). Deze kan indien nodig voorstellen doen zowel voor individuele maatregelen als voor mutaties of transformaties in meer algemene zin met het oog op de gezondheid van de werknemers. Dit is overigens een bron van conflicten met de werkgever omtrent wat genoemd wordt: "l'autorité patronale" (101). Indien men in zo'n conflict niet tot overeenstemming komt beslist de arbeidsinspecteur na advies van een arts. De dienst verricht zowel keuringsactiviteiten als acties op het gebied van het arbeidsmilieu. Op dit laatste gebied adviseert de dienst zowel de werknemersvertegenwoordigers

97. Commissie van de Europese Gemeenschappen, Verslag over de sociale ontwikkeling 1987, Brussel Luxemburg 1988, p. IX-6.

98. Decreet van 16 aprill 1965.

99. M. Sojcher-Rousselle, a.w. (noot 7), p. 224-225.

100. In 1958 is uitgesproken dat de oprichting een verplichting is voor alle ondernemingen (Cass. crim. 30 april 1958, Bulletin, no. 369, p. 682), kleine ondernemingen kunnen een "service interentreprises" oprichten.

101. G.H. Camerlynck c.s., a.w. (noot 58), p. 769. 
als de ondernemer. Daarnaast heeft de dienst een eerste hulp taak bij ongevallen en het opmaken van rapporten over gebeurde bedrijfsongevallen. De ondernemingsraad heeft een adviserende bevoegdheid bij het aanstellen van de bedrijfsarts en moet instemmen met de voordracht van een kandidaat en het ontslag van de arts, maar heeft zelf geen recht kandidaten voor te dragen voor de functie. Deze adviesbevoegdheid moet mede de onafhankelijkheid van de bedrijfsarts garanderen. Evenals zijn Belgische collega's heeft de bedrijfsarts een slechtere ontslagbescherming dan de ondernemingsraadsleden. Ook houdt de raad toezicht op het functioneren van de arts.

De Nederlandse en Duitse wetgeving kennen beide een uitgebreide regeling omtrent vakkrachten en hun taken binnen de onderneming. In beide landen hebben de vakkrachten op het gebied van veiligheid en gezondheid zowel een adviserende en probleemoplossende taak als een taak als keuringsinstantie.

In Duitsland is de regeling hieromtrent te vinden in de Arbeitssicherheitsgesetz. Bedrijfsartsen en andere vakkrachten (Sicherheitsingenieure, -techniker, -meister) moeten worden aangesteld, indien dit noodzakelijk is met het oog op de aard van de onderneming en de daarmee voor de werknemer verboden gevaren, het aantal werknemers (een minimumaantal wordt in de wet echter niet genoemd) en de samenstelling van de werknemersbevolking, de organisatie van de onderneming in het bijzonder met het oog op het aantal en de aard van de voor de arbeidsveiligheid en de ongeval-preventie verantwoordelijke personen. Zowel bedrijfsartsen als veiligheidskrachten hebben de taak met de ondernemingsraad samen te werken. Zij moeten de ondernemingsraad voorlichten over belangrijke aangelegendheden met betrekking tot arbeidsbescherming en de ongevalpreventie, zij moeten de inhoud van de voorstellen die zij de werkgever doen aan de ondernemingsraad meedelen en moeten op verzoek van de ondernemingsraad deze adviseren over arbeidsbescherming en ongevalpreventie. De strakke omschrijving van de taken van de vakkrachten in relatie tot die van de ondernemingsraad is overigens wel voorwerp geweest van kritiek. Kühn (102) meent dat de invulling van de wijze waarop de ondernemingsraad zijn taak met betrekking tot veiligheid en gezondheid uitoefent in (te) vergaande mate beïnvloed wordt door de "professionals". Hun doelen, en de belangen van de werknemers, die door de ondernemingsraad vertegenwoordigd worden, zijn niet altijd dezelfde. De enige wijze waarop de ondernemingsraad tegenwicht kan bieden, is door te zorgen dat hij zelf specialisten op dit gebied in huis heeft. Deze ondernemingsraadsleden zijn dan wel voor een deel onttrokken aan het algemene ondernemingsraadswerk. 102. H. Kühn, Betriebliche Arbeitsschutzpolitik und Interessen-vertretung der Beschäftigten,
Frankfurt am Main 1982, p. $57-58$. 
De artsen en veiligheidsdeskundigen hebben een aantal specifieke taken met betrekking tot ongevalpreventie, planning en bijzondere gevaren (103). De bedrijfsartsen moeten de werknemers onderzoeken, keuren en adviseren ten aanzien van de onderzoeksuitslagen. Voorts moeten de vakkrachten de uitvoering van arbeidsbeschermende en ongevalpreventieve maatregelen bevorderen en daarmee in samenhang de onderneming (die Arbeitsstätten) onderzoeken op leemtes in de bescherming en deze aan de werkgever voorleggen, op het gebruik van beschermingsmiddelen toezien en onderzoek doen naar de oorzaken van ziekten. De taak van de bedrijfsarts ten opzichte van de werknemers is een adviserende, een controlerende en een stimulerende, die met name gericht is op het effectueren van de invoering en uitvoering van beschermende maatregelen.

De vakkrachten moeten naast de bovenstaande taken de bedrijfsonderdelen en technische arbeidsmiddelen, voor de invoering in de onderneming, uitproberen op veiligheidsaspecten. Ook moeten zij leemtes in de veiligheidsmaatregelen opsporen en deze met de werkgever bespreken, en hebben een stimulerende en toezichthoudende taak ten opzichte van de werknemers voor zover het veiligheidsmaatregelen betreft.

De onafhankelijkheid van bedrijfsartsen en veiligheidskrachten is als garantie opgenomen in de Arbeitssicherheitsgesetz, maar wordt niet versterkt door bijvoorbeeld een bijzondere ontslagbescherming.

Hun Nederlandse collega's die als leden van deskundige diensten in de onderneming werken hebben wel een bijzondere ontslagbescherming, ook al was de mate van bescherming die nodig werd geacht, bij de totstand koming van de Arbeidsomstandighedenwet een punt van discussie (104). De regeling is nu dat het ontslag van een lid van een dienst getoetst wordt door de kantonrechter; bovendien moet de ondernemingsraad voor het ontslag in de gelegenheid gesteld worden advies uit te brengen.

Bedrijfsgezondheidsdiensten en veiligheidsdiensten moeten in, bij AmvB aangewezen categorieën ondernemingen, worden opgericht. De bedrijfsgezondheidsdienst is overigens geen nieuw fenomeen, de instelling hiervan was al onder de Veiligheidswet voor een aantal eveneens bij AmvB aangewezen ondernemingen verplicht (105). Naast deze algemene regulering kan de

103. Het gaat hierom adviezen aan de werkgever en de Sicherheitsbeauftragten omtrent:

- planning, de uitvoering en het onderhoud van bedrijfsgedeelten en sociale en sanitaire inrichtingen,

- het gebruik van technische arbeidsmiddelen en de invoering van arbeidsmethoden en stoffen,

- de keuze van en het testen van lichaamsbeschermingsmateriaal,

- fysische, psychologische en arbeidshygiënische wragen (alleen bedrijfsartsen), zowel als ergonomische wraagstukken die te maken hebben met het arbeidsritme, de arbeidstijd, pauzeregelingen en de organisatie en de omgeving van de arbeid.

104. Een voorstel om de ontsllagbescherming van de deskundigen analoog te regelen aan die van ondernemingsraadsleden werd door CDA en VVD overmatig zwaar geacht. Zie o.m. Hand. TK. 13 maart 1980, 14497 , p. 4657-4658.

105. Besluit Verplichtstelling Bedrijfsgeneeskundige Diensten Stb. 1974, 740. 
Direkteur-Generaal van de Arbeid gezondheidsdiensten voor individuele ondernemingen verplicht stellen.

De verschillende diensten hebben voor een deel elkaar overlappende taken, die betrekking hebben op het geven van adviezen op het gebied van gezondheid en welzijn in het algemeen, en het meewerken aan voorlichting en onderricht en ongevalpreventie in het bijzonder (106). Daarbij gaat het met name om het adviseren van de werkgever, de ondernemingsraad c.q. Arbocommissie en de werknemers. Deze adviezen komen ter kennis van alle partijen, en in het geval er geen ondernemingsraad of Arbocommissie is, moet de werkgever er voor zorgen dat de adviezen ter kennis van de belanghebbende werknemers komen.

Daarnaast hebben de bedrijfsgezondsheidsdiensten de taak nieuwe werknemers te keuren en perodiek onderzoek te verrichten onder werknemers die door hun werk bijzondere risico's lopen.

De bedrijfsgezondheidsdiensten kunnen bij AmvB taken krijgen ter bevordering van het welzijn in de onderneming. Ook de wijze van uitoefening van de taken wordt bij AmvB nader ingevuld evenals de uitrusting en bemanning en de eisen waaraan artsen en ander personeel van de dienst moeten voldoen.

De veiligheidsdienst is op de in de Arbowet geregelde wijze wel een nieuw instrument. Weliswaar zijn er al in vele ondernemingen veiligheidsfunctionarissen aan het werk, maar hun taken verschillen per onderneming, van politioneel tot adviserend, preventief en organisatorisch (107). Deze laatste taken worden de dienst in de Arbowet met name toebedacht (108).

106. De taken van de bedrijfsgezondheidsdienst zijn o.m.

- kennis verzamelen van de arbeidsomstandheden, met name waar het gaat om schadelijke invloeden die van het werk, de werktijden het arbeidsmilieu en het arbeidstempo kunnen uitgaan.

- het onderzoeken, analyseren van en rapporteren over met beroepsziekten samenhangende omstandigheden, het melden van vermoedens hieromtrent aan de werkgever en doen van aanbevelingen ter voorkoming van beroepsziekten.

- het meewerken aan: goede arbeidswerhoudingen binnen de onderneming, verrichten van een arbeidsanalyse, het verrichten van werkzaamheden en maatregelen ter beperking van het ziekteverzuin.

De veiligheidsdiensten richten zich meer op het analyseren en het opstellen wan een preventief beleid met betrekking tot arbeidsongevallen maar deels overlapt deze activiteit die van de bedrijfsgezondheidsdiensten.

107. A. Geers, a.w. (noot 16), p. 73.

108. Zo vallen hicronder:

- het meewerken aan het voorkomen en bestrijgden van ongevallen, en het doen van aanbevelingen hierover, aan het weren en bestrijden van schadelijke invloeden waaraan de werknemer in verband met het werk kan zijn blootgesteld, zoals schadelijke dampen, gassen stof, schadelijk of hinderlijk. geluid of andere trillingen, of schadielijke stralingen, - het verlenen van bijstand bij het tot stand komen van veiligheidsrapportage,

Beide bovengenoemde diensten hebben bovendien een taak met betrekking tot het meewerken en opstellen aan het jaarverslag. ook woor de veiligheidsdienst geldt dat hij moet samenwerken met de $O R$, Arbocommissie en de werkgever, en dat verstrekte adviezen ook aan de andere partij ter hand dienen te worden gesteld. 
De oorspronkelijke bedoeling van de wet (109), dat er op den duur gecombineerde Arbodiensten tot stand komen, is sedert 1988 afgezwakt. De oprichting van een Arbodienst is facultatief; men kan ook volstaan met aansluiting bij gezamenlijke of gecombineerde diensten (110).

Het door Kühn (111) geschetste probleem met betrekking tot het overwicht van de vakkrachten in de invulling van het veiligheids-en gezondheidsbeleid, zoals dat in Duitsland gebeurt, en de daardoor noodzakelijkerwijs verschuiving van de competenties binnen de raad, zal zich mogelijk ook kunnen gaan voordoen binnen het Nederlandse stelsel. Ook hier is de samenwerking tussen ondernemingsraad en deskundigen voorgeschreven, zij het dat de Nederlandse regelling meer een kader voor samenwerking biedt, dan strakke samenwerkingsprocedures zoals de Duitse regeling. Uit een onderzoek naar de praktijk van de arbeidsomstandighedenwet in Nederland tot dusver, blijkt voorlopig niet dat de vakkrachten zich een overwichtspositie ten aanzien van het beleid hebben verworven. Dit komt echter niet doordat de ondernemingsraden door hun eigen optreden het overwicht hebben behouden, maar door een gebrek aan contact tussen de instanties. Wat er aan contacten is tussen ondernemingsraad en vakkrachten (en dan met name de bedrijfsgezondheidsdienst) is hooguit incidenteel (112). De beïnvloeding van het beleid van de ondernemingsraad komt door dit slechte functioneren van de regeling niet tot stand. Als de Arbeidsomstandighedenwet langer in werking is, en dus meer gemeengoed wordt voor ondernemingsraden en deskundige diensten, kan dit beeld veranderen.

Luxemburg kent een zeer beperkte vorm van bedrijfsgeneeskunde, de artsen houden zich daar alleen bezig met keuringen, medisch toezicht van jeugdigen, en toezicht op werknemers die blootgesteld zijn aan bijzondere risico's, met name met diegenen met de kans op loodvergiftiging en silicose (113).

De bestaande Spaanse regeling biedt niet veel meer dan de Luxemburgse. Een uit 1959 daterend en in 1982 herzien decreet schrijft bedrijfsgeneeskundige diensten voor, voor ondernemingen met meer dan 100 werknemers. Kleine ondernemingen kunnen aangesloten zijn bij regionale diensten. De bevoegdheden van de bedrijfsartsen hebben met name betrekking op keuringen en toezicht op werknemers, hoewel de bepalingen daaromtrent niet erg uitgebreid zijn. In collectieve contracten worden deze voorschriften well aangevuld. Nieuwe wetgeving is nog in woorbereiding; deze moet de

109. TK. 77-78, 14497 , no. 4 , p. 30; TK. $78-79,14497$, no. 9 p. 16.

110. A.J.C.M. Geers, a.w. (noot 8), p. 222.

111. $H_{3}$ Kühn, a.w. (noot 102), p. 57-58.

112. T.J.M. Reubsaet, P.A.M. De Boer, P.C.J. Sweere, H.J.M. van den Tillaart, De Arbowet in uitwoering; een onderzoek naar de ervaringen in de praktijk onderzoek door het Instituut voor toegepaste Sociale Wetenschappen (ITS), in opdracht van het Ministerie van Sociale Zaken en Werkgelegenheid, Den Haag 1988, p. 58 .

113. La médecine du travail Francaise et L'Europe, rapport van der Association des membres Francais de la Commission Internationale de Médecine du Travail, Paris 1988, p. 24. 
bestaande situatie volledig herstructureren. De bedoeling is dat een nieuwe wet duidelijke voorschriften geeft voor het toezicht op werknemers die beroepsrisico's lopen, en bovendien naast bedrijfsgeneeskundigen, voor een aantal ondernemingen ook veiligheidsdeskundigen gaat voorschrijven (114).

De kritiek op de binnen het bedrijf werkzame vakkrachten is in alle bovengenoemde lid-staten gelijkluidend (115): de krachten zijn te weinig getraind in die aspecten van het werk die niet draaien om de directe veiligheid en gezondheid, zoals ergonomische aspecten, of problemen met nieuwe technologie. Ook blijken de vakkrachten vaak niet getraind om in samenwerking met de werknemersvertegenwoordigers hun werk te doen. Een ander aspect is de zichtbaarheid van de vakkrachten in de onderneming, hier ontbreekt het nog wel eens aan. Voor wat betreft bedrijfsartsen heeft dit mede te maken met het aantal artsen op het aantal werknemers. Hieronder volgt een staatje (116).

Als grootste probleem wordt echter de niet-onafhankelijkheid van de vakkrachten ervaren. Zelfs wanneer er ontslagbeschermende regelingen bestaan, zijn deze vaak niet voldoende om de onafhankelijkheid te waarborgen. Dit afhankelijkheidsprobleem speelt zowel bij krachten behorend bij de onderneming (hetgeen voor de hand ligt) als bij vakkrachten die bij samenwerkende diensten in dienst zijn. In dit laatste geval blijkt de concurrentie tussen de verschillende diensten een slechte zaak voor het

114. Rapport Wan de Association des membres Francais de la Commission Internationale de Médecine du travail, a.w. (noot 113), Paris 1988. 115. Zie o.m. Noël Pardon, Prospective de la médecine du travail dans le CEE, Luxemburg
1986 . 116. Brow Rapport wan de Association des membres Francais de la Commission Internationale
de Medecine du travail, a.w. (noot 113), Paris 1988. 
Tabel II: Aantal (beschermde) werknemers ten opzichte van het aantal bedrijfsartsen.

Land. Aant. wn. Aant. besch. werkn.

Aantal aantal. wn artsen per arts

Du. $\quad 22.330 .000$

12.000 .000

14,000

858

Ned. $\quad 4.548 .000$

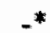

690

6592

Fra. 18.130 .000

12.000 .000

5.987

2004

Bel. $\quad 3.280 .000$

1.250 .000

Lux. $\quad 137.000$

Sp. $\quad 12.000 .000$

1.991 .326

3472

• 574

Gr.@

Den. $\quad 2.091 .000$

365.846

125

2927

It. $\quad 15.239 .000$

2641

5770

GB. 25.500 .000

2820

9042

Ir. $\quad 868.000$

450

1928

NB. De systemen boven en onder de lijn gaan uit van verschillende uitgangspunten.

* Geen gegevens beschikbaar.

@ Situatie sedert laatste gegevens radicaal gewijzigd.

onafhankelijk oordeel van de vakkrachten (117).

In een aantal lid-staten wordt de medische deskundigheid vanuit door de overheid geïnitieerde instanties verstrekt. Deze is dan ondergebracht in

117. Safety and Health at the Workplace, ondierzoek wan het Europees Instituut voor de

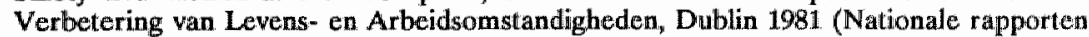
1980). Deze gegevens zijn enigzins verouderd, maar de kritielk wordt in later onderzork grotendeels bevestigd. Zie F. Naschold, Dynamics without structural change, The Case of the Federal Republic of Germany, in Work and Health in the $1980^{\prime} \mathrm{s}_{\mathrm{s}}(\mathrm{S}$. Bagnara, R. Misiti, H. Wintersberger, eds), p. 240-241; A.J.C.M. Geers, a.w. (noot 8), p. 213-216. 
instituten, die al dan niet binnen een "top-down" organisatie, op lokaal niveau adviseren en de vertegenwoordigers ondersteunen.

In Denemarken kent men, als ondersteunende organisatie met name de Bedrijfsgezondheidsdienst (Bedriftssundhedstjenesten; BST). Dit is een grote professionele organisatie, die met name de laatste vijftien jaar aan belang heeft gewonnen (118). Voor een aantal branches is aansluiting bij de BST verplicht, maar ook voor ondernemingen waarbij dit niet het geval is, komt aansluiting meer en meer voor. De BST kan ondernemingsinterne "units" hebben, veelal staan zij echter apart van de onderneming.

De BST is het adviserende orgaan voor de veiligheidsorganisatie (in beginsel de veiligheidscommissie) in de ondernemingen, en (indien deze er niet is) voor de gezamenlijke werknemers. De BST heeft in de ministeriële bekendmakingen (119) een ruime opdracht gekregen, waardoor deze dienst drie typen van medewerkers kan hebben: personeel opgeleid voor gezondheidsaspecten (waaronder ook ergotherapeuten begrepen worden), technisch opgeleid personeel (zoals ingenieurs, laboranten, arbeidshygiënisten) en psychologen.

De taken van de BST zijn onder te verdelen in vier categorieën (120). Deze zijn te onderscheiden in advisering (121), diagnostische taken (122), behandeling van ziektegevallen en specifieke onderrichtstaken die er op gericht zijn zowell individueel als collectief arbeidsmilieuproblemen te beheersen (123).

De BST heeft met name invloed op de diagnostische capaciteit van de veiligheidscommissie, die door de medewerking van de BST in een eerder stadium dan voorheen gevaarlijke of problematische situaties kan onderkennen en maatregelen kan nemen. Over de wisselwerking tussen BST en werknemersvertegenwoordigers in het algemeen is volgens Rieper nog weinig bekend-(124). Wel bleek uit een onderzoek in 1986 dat de

118. O. Rieper, a.w. (noot 34), p. 139.

119. Arbejdsminusteriets bekendtgorelse no. 288 van 22 juni 1978.

120. H.E. Jensen, P. Langa, N. Møller, Dansk Bedriftssund-hedstjeneste, Kopenhagen 1983, p.
49.

121. Zo is er een adviestaak op technisch hygiënisch gebied, in verband met bestaande technologie in de ruime zin van het woord (het gebruik van omstreden stoffen valt er ook onder) en naar aanleiding van gepland technologiegebruik en de geplande arbeidsorganisa-
tie.

122. Deze hebben te maken met gezondheidsonderzoeken in de onderneming, individueel advies en gezamenlijke therapie (samtaleterapi) die uit kan draaien op behandeling wan
kwalen (sygdomsbehandling).

123. Het gaat hierbij om onderricht met betrekking tot uiteenlopende zaken als inrichting van aanpak van arbeidsmilieuproban persoonlijke beschermingsmiddelen; voor de collectieve dighedenaanpak in de onderneming, de hierbij te aan organisatie van de arbeidsomstanonderrichtstaak moet aansluiten bij de uitvoerij te gebruiken methoden en strategieên. De een metamodel (metaplan)). 124. O. Rieper, aw. (noo 34), p. 152-155; zie ook D. Bunnage, C. Nørregaard, The
Occupational Health Service in Denmark, Kopenhagen 1987, p. 52 . 
gezondheidsdiensten door de werkgevers in steeds ernstiger mate in hun werkzaamheden worden gedwarsboomd (125)

Het Deense model is mogelijk vergelijkbaar met de in Nederland voorgestelde Arbo-instituten (126) die met name voor kleinere bedrijven, als zelfstandige organisaties een ondersteunende rol moeten gaan vervullen.

In Italie en Groot Brittannië is de werkgever niet verplicht vakkrachten in dienst te nemen of zich aan te sluiten bij een bedrijfsgezondheidsdienst. Dit was de reden dat in Italië, in de jaren zeventig collectieve overeenkomsten uitgebreide afspraken over externe deskunigen gemaakt werden. Hierbij werd niet alleen geregeld welke externe deskundigen kunnen worden geraadpleegd, maar ook werden regels gesteld ten aanzien van hun mogelijkheden binnen te treden, onderzoekingen te verrichten en wie de mogelijkheid heeft hen daartoe uit te nodigen. In 1978 werd de regulering in collectieve overeenkomsten vereenvoudigd door de inwerkingtreding van de Wet op de riforma sanitaria (127). Deze wet legt een gedecentraliseerde structuur van bedrijfs-gezondheidsdiensten op. Hierdoor werd de deskundigheid bijeengebracht en werd het daardoor gemakkelijker advies in te winnen.

De lokale gezondheidsunits zijn de organen die met name contacten onderhouden (of moeten onderhouden) met de vertegenwoordigers op ondernemingsniveau. Tussen het centrale orgaan en de lokale units bevinden zich administratieve eenheden op regionaal niveau (er zijn twintig regio's). Deze worden geacht zich vooral bezig te houden met training en het ontwikkelen van onderzoek met name naar de gezondheidssituatie op de werkplek (128).

De implementatie van de Italiaanse wetgeving levert echter problemen op. Zowel op organisatorisch als op politiek en economisch vlak zijn er problemen met het opzetten van de gezondheidsdiensten. Het systeem functioneert als geheel dan ook niet echt goed (129). Over, met name, de lokale gezondheidsunits die wel functioneren bestaat een vrij grote tevredenheid (130).

In het Britse model wordt de ondersteunende taak inzake bedrijfsgezondheid praktisch geheel uitgeoefend door de Employment Medical Advisory Service (EMAS), die sedert de wet van 1974 is geïntegreerd in de Health and Safety Executive (HSE) en wordt gecontroleerd door de Health and

125. Commissie van de Europese Gemeenschappen, Verslag van de, sociale ontwikkeling 1986, Brussel Luxemburg 1988, p. IX-3.

126. Zie: A.J.C.M. Geers, a.w. (noot 8), p. 223.

127. Wet no. 833 .

128. N. Pardon, a.w. (noot 115), rapport 6 Italy.

129. R. Misiti, S. Bagnara, Participation in Health Control at the Workplace, the Italian experience, in Work and Health in the 1980's, (S. Bagnara, R.Misiti, H. Wintersberger eds.), Berlin 1985, p. 41.

130. G. Marri, C. Stanzani, The Struggle against Health Hazards at the Workplace in Italy from 1968 onwards, in Health and Work in the 1980's (S. Bagnara. R Misiti, H Winterberger eds.), Berlin 1985, p. 69. 
Safety Commission (HSC). De EMAS heeft een gedecentraliseerde structuur, en heeft naast adviserende, preventieve en onderzoekstaken een belangrijke taak in verband met wettelijk vereiste keuringen van werknemers (131). De integratie van de EMAS in de structuur van de HSE is een constructie die eigenaardig is, omdat de HSE ook een inspecterende taak heeft. De aan de EMAS verbonden artsen hebben slechts een puur ondersteunende functie.

Meer dan in de andere landen zijn in Groot Brittannië ondersteuning, toezicht en naleving met elkaar verweven. De ondersteuning vindt voornamelijk plaats door het voorzien van de betrokkenen (werkgever en veiligheidsvertegenwoordigers/ commissies) van passend materiaal, ook vanuit HSE en HSC; echter zodra de HSE zich in persoon met de onderneming gaat bemoeien, is er al gauw sprake van een probleem omtrent interpretatie en naleving van normen.

In Ierland is men eveneens bezig een organisatie met een gedecentraliseerde structuur op te zetten, waarbij de nadruk zal liggen op training van werknemers (132) (hoever men hiermee gevorderd is, is mij niet bekend).

Het verschil tussen de systemen, die met een verplichte interne vakkrachten of aansluiting bij een gemeenschappelijke dienst is voor de Europese Gemeenschap niet onbelangrijk. Een zware verplichting tot het aanstellen van vakkrachten kost de werkgever geld, hetgeen concurrentieverstorend kan werken. Op zichzelf is daar niet zoveel tegen, tenzij de verschillen tussen de lid-staten te groot worden. Dit zou niet hoeven te gebeuren wanneer daar, waar geen interne deskundigheid is, voor externe deskundigheid zoals hierboven geschetst, door de werkgever betaald moet worden. In Italië is dit niet per dienst het geval. De gezondheidsdiensten worden als geheel betaald uit bijdragen van werknemers en werkgevers (133). In Denemarken. worden de diensten voor ongeveer 50 tot $75 \%$ gefinancierd uit bijdragen van die werkgevers die aangesloten zijn bij de BST. De werknemers betalen hieraan niet mee (134).

Het is uiteraard wel zo dat het in dienst hebben van deskundigen in het algemeen duurder uitvalt, dan het betalen voor extern te verlenen diensten, of zoals in bovenstaande lid-staten het geval is een bijdrage leveren aan het totaal van kosten van instandhouding van een gezondheidsdienst. Dit geldt temeer als geen verplichting bestaat dergelijke externe deskundigen te raadplegen of te zijn aangesloten bij een gezondheidsdienst (135). Gezien het bovenstaand staatje kan gesteld worden dat in Duitsland de meeste ondernemingen hoge kosten moeten maken om aan de verplichtingen te
voldoen.

131. A. Broadhurst, a.w. (noot 29), p. 79 ev. 132. Commissie van de Europese Gemeenschappen, Verslag over de sociale ontwikkeling 1985 ,
Brussel Luxemburg 1986 , p. IX-9 en IX-10.

133. N. Pardon, a.w. (noot 115), rapport no. 6 Italy.

134. N. Pardon, a.w. (noot 115), rapporten no. 2 (Danemark) en no. 6 (Italy).
135. N. Pardon c.s., a.w. (noot 115). 


\section{De mogelijkheid een beroep te doen op de arbeidsinspectie}

Een belangrijke rol bij het handhaven van regelingen omtrent veiligheidsen gezondheidsaangelegenheden wordt vervuld door de arbeidsinspectie. De arbeidsinspectie is in de meeste lid-staten een publiekrechtelijke instantie, die belast is met het toezicht op arbeidsrechtelijke regelgeving, zowel op veiligheids- en gezondheidsgebied als op een ruimer gebied van verplichtende regelgeving waaronder onder meer kinderarbeid, en arbeidsurenregelingen vallen.

De arbeidsinspectie is, zoals in paragraaf V.1.2. bleek, in Europa al cen betrekkelijk oud instituut, de meeste lid-staten kennen een dergelijke, met politionele bevoegdheden uitgeruste, instelling sedert de vorige eeuw of het begin van deze eeuw. Het internationale recht voorziet reeds enige tijd in verplichtingen hieromtrent. De ILO-conventie omtrent Labour inspection dateert van 1947 (136). Deze conventie is overigens de enige op veiligheidsen gezondheidsgebied die door alle EG lid-staten is geratificeerd (137). Naast hun politionele bevoegdheden hebben arbeidsinspecteurs een stimulerende en een bemiddelende rol; soms hebben zij de plicht te adviseren over te nemen maatregelen, en kunnen zij voorzien in corrigerende maatregelen. In die rol zijn zij een instantie die de samenwerking tussen werkgever en werknemers(vertegenwoordigers) kan versoepelen.

In deze paragraaf staat de vraag centraal op welke wijze en door wie de arbeidsinspectie ingeschakeld kan worden, welke maatregelen deze kan nemen, en in hoeverre zij verplicht zijn op verzoeken tot ingrijpen in te gaan. Het is een vraag die zowel ziet op de bemiddelende functie van de arbeidsinpectie als op de politionele: waar een verzoek om gebruikmaking van de politionele bevoegdheden wordt gedaan, kan de arbeidsinspectie soms volstaan met bemiddeling, maar verzoeken om bemiddeling kunnen met evenveel gemak uitlopen op ingrijpende maatregelen in de onderneming. In verband met de overzichtelijkheid zullen de politionele (en administratieve) bevoegdheden eerst besproken worden. Daarna zall op de relatie tussen arbeidsinspecteurs en werknemersvertegenwoordigers worden teruggekomen.

Voor wat de politionele en administratieve bevoegdheden betreft ontlopen de verschillende lid-staten elkaar niet al te veel. Alle arbeidsinspecties

136. ILO-convention concerning Labour Inspection in Industry and Commerce, 1947, International Labour Organization Conventions and Recommendations, 1919-1966, Geneva 1966, p. 611.

137. Groot Brittanniê ratificeerde als eerste in 1949, Portugal in 1962 als Jaatste. List of Ratifications of Conventions (as at 31 december 1987), International Labour Office, Geneva 1988. 
hebben ambtshalve de bevoegdheid tot binnentreden (138) hoewel hier en daar aan die bewoegdheid beperkingen zijn aangebracht waar het gaat om ondernemingen die in woonhuizen zijn gevestigd, of wanneer het gaat om nachtelijke bezoeken zoals in Frankrijk (139). Daarnaast hebben de meeste inspecties de bevoegdheid om eisen te stellen, regels of aanwijzingen te geven en eventucel sancties op te leggen. Slechts in Spanje legt de arbeidsinspecteur niet zelf de sanctie op, maar wordt dit gedaan door het betreffende departement van het Arbeidsministerie.

De sancties kunnen in een aantal landen, waaronder lerland, ook de werknemers treffen, zij kunnen beboet worden. In lerland spelen hierbij naast de "gewone" arbeidsinspecteurs ook de lokale autoriteiten een rol (140). Ook in andere lid-staten hebben lokale autoriteiten in de arbeidsinspectie een inbreng. Dit geldt voor Groot Brittannië (141), maar ook voor Spanje (142). In dit laatste land wordt in de wet steeds gesproken over de "bevoegde autoriteit", hetgeen meer is dan alleen de arbeidsinspectie (143). De bevoegdheid om de onderneming of een deel van de onderneming stil te leggen bij dreigend gevaar komt praktisch alle inspectoraten toe. In Italie is bovendien het inspectoraat van de mijnen bevoegd het werk stil te leggen als niet in overeenstermming met de voorschriften wordt gewerkt.

Naast deze taken hebben de inspecteurs veelal nog additionele taken. Zo hebben in een aantal landen de inspecteurs een taak in verband met de sociale verzekering (o.m. Italië). In Frankrijk heeft de arbeidsinspecteur

138. De Britse Inspectors hoeven zich owerigens niet door alle bepalingen uit andere wetgeving in hun werk te laten te laten belemmeren, tot hun "overige bevoegdheden behoort in beginsel het doorbreken daarvan. Zie, o.m. C.D. Drake, F.B. Wright, Law of Health and Safety at Work, the New Approach, London, 1983, p. 129-130.

139. Nachtelijke bezoeken zijn in Frankrijk verboden; verder mogen inspecteurs mogen die ruimten die behalwe werkruimten ook woonruimten zijn, allieen betreden met toestemming van de bewoners. De werkgever die het bezoek belemment of poogt te verhinderen kan gestraft worden.

140. Onder meer in de Office Premises Act, waar het afdwingen van veiligheids- en gezondheidsnormen vooral de taak is van de "sanitary inspectors" van de lokale autoriteiten.

141. Naast de inspectoraten zijn ook de lokale overheden belangrijk voor bet toezicht op arbeidsonstandigheden: in de Offices, Shops and Railway Premises Act 1963 is de handhaving wan deze wet aan lokale autoriteiten opgedragen, terwijl de vergunningverlening aan de handel in explosieven en petroleum installaties, die toezichtsuitoefening in zich draagt, in de Explosives Acts 1875 en 1923, en de Petroleum (Consolidation) Act 1928 is geregeld.

142. M. Alonso Olea, F. Rodriguez-Sañudo, a.w. (noot 9), para. 80-81..

143. Het gaat hier in elk geval om de arbeidsinspecteurs die deel vitmaken van het Minüsterie van Arbeid. Anderen die onder de term "bevoegde autoriteit" begrepen kunnen worden zijn het Nationaal Instituut voor Veiligheid en Hygiëne op het werk (Instituto Nacional de Seguridad e Higiene en el Trabajo) een aan het Arbeidsministerie gelièerde publiekrechtelijke instantie dat onderzoeksbevoegdheden heeft naar arbeidsongevallen en beroepsziekten, en de provinciale organem van de Autonome gebieden die bevoegd zijn op het gebied van arbeidsverhoudingen. 
naast zijn veiligheids- en gezondheidstaak de controle op het interne ondernemingsreglement (144), met name waar het gaat om de discretionaire bevoegdheden van de werkgever (145).

De relatie tussen de arbeidsinspecteurs en de werknemersvertegenwoordigers op ondernemingsniveau is in verband met het veiligheids- en gezondheidsbeleid van bijzonder belang. Arbeidsinspecteurs hebben in het algemeen de verplichting om adviezen te geven. Voorts kan er een verplichting bestaan tot het reageren op klachten, of procedures tot het gezamenlijk oplossen van klachten.

De contacten tussen de Britse en lerse arbeidsinspecteurs en de vertegenwoordigers op ondernemingsniveau zijn betrekkelijk vrijblijvend. De Britse Health and Safety Commission (146) en de Health and Safety Executive (147), beiden ingesteld bij de HSWA 1974, zijn verplicht te adviseren inzake veiligheids- en gezondheidsaangelegenheden. Het is deze rol die in Groot Brittannië als het belangrijkst wordt ervaren (148). De organisaties doen dit in algemene zin door Codes of Practice (149)(HSC) te publiceren, en kunnen ook adviezen in de onderneming geven. De inspecteurs van de HSE zijn verplicht volgens sectie 28 (8) HSWA 1974, de veiligheidsvertegenwoordigers op de hoogte te houden over zaken die hun veiligheid gezondheid of welzijn aangaan.

144. J. Savatier, Le contrôle administratif du règlement intérieur, Droit Social 1987, p. 645 ev.

145. Een voorbeeld is te vinden in Conseil d'Etat, 1 februari 1980 , Sociétée "Peintures Corona", A.J.D.A. 1980, nr, 7-8, p. 439. (De zaak ging om een werkgever die een praktisch onvoorwaarde-lijk alcoholverbod in zijn interne reglement had opgenomen, hetgeen werd beschouwd als indruisend tegen de rechten van de mens).

146. De HSC is met name het adviserend en deels regelgevend orgaan. De voorzitter van de HSC wordt benoend door de secretary of State, evenals de overige leden (niet minder dan zes, niet meer dan negen), over de benoeming van deze leden worden werkgevers- en werknemersorganisaties geconsulteerd. Naast werk-gevers en werknemersleden zijn de andere leden vertegenwoordigers van mogelijk andere belanghebbende organisaties.

147. Zie over de organisatie van HSE en HSC o.m. G.K. Wilson, The Politics of Safety and Health, Oxford 1985, p. 112-149.

148. National Report Safety and Health at the Workplace, United Kingdom, Dublin 1980.

149. De HSC publiceert Codes of Practice, regelgeving, die onder meer in strafrechtelijke procedures (bijvoorbeeld bij ongevallen) meegenomen worden en tot een verplichting voor het leveren van bewijs voor de ondernemer kunnen leiden indien hij zich moet verdedigen in een zaak waarin twijfels ower een jusite wetstoepassing zijn. Voorts kan de HSC de Executive bevelen een onderzoek in te stellen, een speciaal rapport op te maken over ellke zaak waarwoor zijn sectie angewezen is. De HSC is daarbij niet gebonden aan de Executive, zij kan de bevoegdheden ook aan een andere persoon, of organisatie delegeren. Bovendien kan de HSC een aanklacht bevelen in een bepaalde zaken, dat kan echter alleen met instemming van de Secretary of State. De secretary heeft, zoals. blijkt uit section 12 van de HSWA 1974 ruime controlerende bevoegdheden ten aanzien van de HSC. Hierin wordt namelijk geregeld dat de Secretary of State de HSC bewoegdheden kan delegeren, elke keer als hij meent dat dit nodig is, gezien het functioneren, inclusief nieuwe bevoegdheden (hoewel die beperkt zijn door het consistentievereiste tussen de verschillende opdrachten van de Secretary of State zelf). 
De Ierse situatie lijkt vrij sterk op de Britse. Ook daar heeft de arbeidsinspectie een adviserende en politionele taak. De eerste taak heeft volgens Redmond aanzienlijk aan belang gewonnen, mede door de nieuwe wetgeving en de regulering van de Europese Gemeenschap op veiligheidsen gezondheidsgebied (150). Evenals in Groot Brittannië kunnen de veiligheidsgedelegeerden de inspecteurs verzoeken om op te treden, maar deze zijn niet verplicht aan dit verzoek te voldoen.

Voor Griekenland en Italië geldt een gelijksoortige situatie; de band tussen werknemerswertegenwoordigers en arbeidsinspectie is er niet veel sterker. In Griekenland (151) heeft het Inspectoraat voor Arbeidsrecht de taak contact te onderhouden met werknemersvertegenwoordigers. Het Inspectoraat werkt gedeconcentreerd maar valt direct onder het Arbeidsministerie. Het inspectoraat waakt over de toepassing van arbeidswetten en collectieve contracten. Daarnaast moet het inspectoraat reageren op klachten tegen de werkgever of tegen werknemers. Een expliciete verplichting te reageren bestaat niet, en zou volgens Koniaris ook niet kunnen worden nagekomen, gezien de onderbemanning en het slechte functioneren van de dienst (152).

De arbeidsinspectie, die ook in Italie een gedeconcentreerde structuur heeft, heeft de bevoegdheid de onderneming te bezoeken en te inspecteren. Inspecteurs kunnen, bij het constateren van een schending van de beschermende wetgeving, een aanwijzing geven met een termijn waaraan de werkgever zich heeft te houden. Bovendien kunnen zij eisen stellen, waartegen beroep openstaat bij de hiërarchisch hogere instanties (153). Hoewel er, juist ook door de controlerende rol van de vakbonden binnen de onderneming contacten bestaan met de arbeidsinspectie is er geen verplichting van deze laatste instantie te reageren op klachten.

Bij onenigheid over de toepassing van de voorschriften in Belgische ondernemingen wordt advies van de arbeidsinspecteurs (154) ingewonnen. Dit advies, dat past in de algemene adviserende bevoegdheid van de arbeidsinspectie kan in principe zowel door het comité voor veiligheid, gezondheid en verfraaiing van de werkplaatsen (of ondernemingsraad) en de vakbondsafvaardliging, als door de ondernemer gevraagd worden. De arbeidsinspectie kan als reactie op dit verzoek de noodzakelijke maatregelen nemen (155). De arbeidsinspectie is echter niet verplicht op elke klacht te reageren,

150. M. Redmond, a.w. (noot 51), para. 176 .

151. Hier valt de Arbeidsinspectie uiteen in Centrale Diensten en Periphere Diensten. De Centrale inspectie heeft subdivies voor de controle van veiligheids- en gezondheidsnormen te controleren, het voorkomen van arbeidsongevallen en voor de arbeidsorganisatie. Daartoe behoren ook ergonomische aspecten.

152. T. Koniaris, a.w. (noot 10), para. 80 .

153. $\mathbf{T}$. Treu, Italy in International Encyclopedia for Labour Law and Industrial Relations, Deweneter 1985, (supplement 58) para. 40.

154. België kent meer soorten inspecteurs; gezondheid en veiligheid vallen onder verschillende dienstem.

155. Zie M. Sojcher-Rousselle, a.w. (noot 7), p. 293-294 (no. 233) 
hoewel nu juist klachten vaak een reden zijn om een onderzoek in te stellen (156). Bovendien kan het comiteé onder alle omstandigheden, en met name in spoedgevallen aan de chef van de interne veiligheidsdienst vragen èen onderzoek in te stellen. Deze is verplicht te rapporteren aan het comite (in niet spoedeisende gevallen eens per maand) op basis waarvan het comité kan overleggen met de ondernemer. Ook de vakbondsvertegenwoordiging heeft het recht om de chef van de veiligheidsdienst te verzoeken een onderzoek in te stellen.

Het comité kan de arbeidinspecteur spreken en deelnemen aan de opsporing van gezondheidsrisico's. De vakbondsafvaardiging heeft dit laatste recht niet, maar wel kan zij van het comiteé eisen dat zij een onderzoek instelt (waarbij dan weer een beroep op de arbeidsinspectie kan worden gedaan).

Naast de hierboven genoemde bevoegdheden heeft de arbeidsinspectie het recht proces-verbaal op te maken in de onderneming. Deze laatste bevoegdheid heeft de Luxemburgse arbeidsinspectie ook; voordat dit gebeurt overlegt de inspecteur met de bedrijfsarts. Bovendien kan de arbeidsinspectie in Luxemburg overleggen met de personeelsvertegenwoordigers. In dat geval is de inspecteur wel verplicht mededeling te doen aan de werkgever (157).

In de andere EG lid-staten is de relatie tussen werknemersvertegenwoordigers iets meer gereguleerd. Voor een aantal landen geldt dat er procedures zijn die specifiek zien op situaties van dreigend en ernstig gevaar.

In Spanje bepaalt het Werknemersstatuut dat in geval van ernstig en onmiddellijk gevaar de binnen de onderneming competente organen (158) met de ondernemer in overleg treden over de te nemen maatregelen. Indien de ondernemer weigert maatregelen te nemen, dan kan de ondernemingsraad (na vier dagen) de 'bevoegde autoriteit' waarschuwen, die indien de aanvraag is gegrond, de werkgever bij gemotiveerde beslissing kan opleggen, passende maatregelen te memen. De formulering van dit artikel in het Werknemersstatuut is zo imperatief, dat het vermoeden rijst dat de 'bevoegde autoriteit' een verplichting tot reageren op de klacht heeft.

Daarnaast kan de 'bevoegde autoriteit' op basis van specifieke technische rapporten, de onmiddellijke stillegging van het werk gelasten, of de verwijdering van het gevaar veroorzakende materiaal van de plaats waar gewerkt wordt.

Het Werknemersstatuut spreekt in deze paragraaf overigens niet van de ondernemingsraad maar van de bevoegde interne organen in de onderneming op het gebied van veiligheid' die een dergelijk verzoek kunnen doen. Daartoe behoort ook de ondernemer, gezien zijn verplichtingen op het

156. Safety and Health at the Workplace in the European Community, Consolidated Report, Dublin 1981.

157. R. Schintgen, La législation du travail en Grand Duché de Luxembourg, Luxembourg 1977 , p. 180.

158. Dat kunnen zijm de ondernemingsraad of een door deze ingestelde veiligheidscommissic met door de ondernemingsraad gedelegeerde bevoegdheden, maar colk de vakbondswertegenwoordigers indien in de onderneming geen ondernemingsraad aanwezig is. 
gebied van veiligheid en gezondheid. De vakbonden kunnen middels hun vertegenwoordiging in de ondernemingsraad, die slechts adviserende bewoegdheden heeft een verzoek tot inmenging van de bevoegde autoriteit niet afdwingen. De vakbondsvertegenwoordigers hebben wel de mogelijkheid tot een verzoek, indien geen ondernemingsraad in de onderneming aanwezig is.

De Franse CHSCT kan de arbeidsinspectie waarschuwen in geval van een conflict over de toepassing van de veiligheids- en gezondheidsbepalingen. De verplichting om te reageren is bij de arbeidsinspectie niet altijd aanwezig, de CHSCT heeft slechts een getrapte manier om de arbeidsinspectie in geval van conflict uitspraak te laten doen: de interne medische dienst kan bij een conflict over een individuele maatregel of geval de arbeidsinspectie vragen uitspraak te doen. Daar de medische dienst een overlegorgaan is met de werknemers, en ook verplicht is het belang van de werknemers te behartigen en niet dat van de ondernemer (159), hebben de vertegenwoordigende organen, personeelsgedelegeerden, ondernemingsraad en de CHSCT ieder de mogelijkheid de medische dienst te doordringen van de noodzaak een bepaalde maatregel te betwisten. Daarmee hebben zij de mogelijkheid een uitspraak van de arbeidsinspectie te verkrijgen. Een dergelijke constructie is niet altijd mogelijk; in de jurisprudentie zijn beperkingen aangelegd voor het geval dat het conflict de staat van gezondheid van individuele werknemers betreft, of indien de individuele matregel die ten aanzien van de werknemer (bijvoorbeeld overplaatsing of ontslag) met die staat van gezondheid samenhangt, omdat de arbeidsinspectie zich in dat geval zou mengen in de bepalingen van het arbeidscontract, hetgeen de bevoegdheden van de inspectie te buiten gaat (160).

$\mathrm{De}$ personeelsgedelegeerden hebben een wettelijke bevoegdheid de arbeidsinspectie te waarschuwen, daarmee is niet gezegd dat zij een uitspraak in een concreet conflict kunnen verkrijgen.

De relatie tussen Deense veiligheidsvertegenwoordigers en de Arbeidsinspectie heeft meer betrekking op de algemene gang van zaken. De arbeidsinspectie bezoekt de onderneming, indien daarom door leidende of daartoe opgeleide personen in de onderneming gevraagd wordt, met name in verband met storingen (161). Onder daartoe opgeleide personen worden de veiligheidsvertegenwoordigers, de veiligheidsgroep of de veiligheidscommissie verstaan. Ook als de arbeidsinspectie ambtshalve de onderneming bezoekt, heeft zij de verplichting de veiligheidsvertegenwoordigers of de commissie te waarschuwen. Bij het bezoek kan de arbeidsinspectie zowel bemiddelen, adviseren en voorlichten als een aanwijzing geven in een concreet geval. Overtreding van aanwijzingen van de arbeidsinspectie kan strafrechtelijk worden vervolgd. Bovendien heeft de arbeidsinspectie de

159. J. Rivero, J. Savatier, a.w. (noot 71), p. 630.

160. J.P. Poupon, Le droit des services autonomes de médecine du travail, Droit social, april 1980 (numéro speciall: La médecine du travail et le droit).

161. O. Rieper, a.w. (noot 34), p. 63. 
bevoegdheid de wet ingeval van een concreet geschil te interpreteren. De arbeidsinspectie heeft tijdens het bestaan van de Arbejdsmiljølovet overigens weinig gebruik gemaakt van haar bevoegdheden tot wetstoepassing. Of dit nu komt doordat ondernemers de wet juist uitvoeren, of omdat conflicten meestal in het overleg opgelost worden is uit onderzoek daarnaar niet gebleken (162).

Andere werknemersvertegenwoordigers hebben geen bevoegdheid de arbeidsinspectie te verzoeken in te grijpen. De samenwerkingscommissie bijvoorbeeld heeft geen expliciete bevoegdheden de arbeidsinspectie te waarschuwen indien er een conflict over de toepassing van de wet met het risico van gevaar ontstaat. Dit vloeit voort uit het feit dat, op basis van het Centraal Akkoord de samenwerkingscommissie (163) slechts de beginselen van het veiligheidsbeleid vastlegt. Dit heeft tot gevolg dat, hoewel aan de Bedrijfscommissie (164) om informatie op veiligheids- en gezondheidsgebied gevraagd kan worden, deze commissie, zelfs als zij een scheidsgerecht instelt, niet in beslissingen in het concrete geval kan voorzien. Zij is slechts bevoegd te oordelen in geschillen ten aanzien van de op te stellen beginselen. In concrete geschillen kan alleen de arbeidsinspectie een oordeel geven, en deze hoeft niet per se te reageren op een verzoek van de samenwerkingscommissie. Overigens levert deze mogelijke discrepantie in het systeem niet echt problemen op, angezien al in relatief kleine ondernemingen (meer dan 19 werknemers) veiligheidsvertegenwoordigers moeten worden verkozen.

Ook de Duitse en Nederlandse arbeidsinspecties hebben naast hun politionele taak, een taak binnen de medezeggenschapssystemen gekregen. De Duitse regelingen op het gebied van de bemoeienis van de arbeidsinspectie (Gewerbeaufsichtämter) hebben echter meer dan hun Nederlandse pendanten het karakter van conflictregelingen behouden (165). De algemene regeling is te vinden in de Gewerbeordnung; deze is uitgewerkt in nadere regels van de Länder. Daarnaast geven overigens bepaalde bedrijfsreglementen aan de interne veiligheidsdiensten bevoegdheden tot het nemen van maatregelen (166).

Ook de externe organisaties hebben, net als de interne vakkrachten de plicht de ondernemingsraad bij alles wat met arbeidsveiligheid en ongevalpreventie samenhangt te betrekken. Dit betekent m.i. enerzijds dat de inspectiediensten (Gewerbeaufsichtämter, Gesundheitsämter, Staatliche Gewerbeärzte) de plicht hebben, indien hen klachten bereiken over de veiligheid, voor zij aan het nemen van maatregelen toekomen, de ondernemingsraad moeten raadplegen en anderzijds, dat zij met de ondernemings-

162. O. Rieper, a.w. (noot 34), p. 69-71.

163. Zie paragraaf III.2.1..

164. Zie paragraaf IV.4.2.

165. H. Kühn, a.w. (noot 102), p. 161.

166. A. Mertens, De Wet op de Arbeidsveiligheid in de Duitse Bondsrepubliek, De Veiligheid 54 (1978), deel II p. 5711 . 
raad moeten overleggen, indien deze zelf met klachten komt, waar in het overleg met de ondernemer niet meer uit te komen valt.

Meningsverschillen over de toepassing van de veiligheidswetgeving en ongevalpreventieregelingen, kunnen zowel door de ondernemingsraad als door de werkgever voorgelegd worden aan het Arbeitsgericht (im Beschlussverfahren). Dit geldt zowel voor geschillen tussen ondernemer en ondernemingsraad als voor geschillen tussen ondernemingsraad en Berufsgenossenschaften (die optreden als ongevalverzekeraars), vakkrachten en Sicherheitsbeauftragten. De voorschriften met betrekking tot ongevalpreventie worden door technische Aufsichtbeamte van de Berufgenossenschaften getoetst.

De verhouding tussen de Nederlandse ondernemingsraad en de arbeidsinspectie is weliswaar minder op conflictoplossing gericht, dan in Duitsland maar conflictoplossing blijft in de praktijk de belangrijkste rol van de inspecteurs (167). De inspecteurs kunnen bovendien altijd reageren op klachten van individuele werknemers vanuit de onderneming. $\mathrm{Zij}$ kunnen om een onderzoek in te stellen naar aanleiding wan die klacht gebruik maken van de ambtshalve bevoegdheden tot binnentreden en onderzoekingen te verrichten. De arbeidsinspectie is echter niet verplicht op individuele klachten te reageren.

Anders is het wanneer de ondernemingsraad de hulp van de arbeidsinspectie inroept. Artikel 40 Arbeidsomstandighedenwet geeft aan de ondernemingsraad c.q. Arbocommissie, maar ook aan de werkgever de mogelijkheid een verzoek tot wetstoepassing te doen aan de arbeidsinspectie. Wanneer in een onderneming geen ondernemingsraad of Arbocommissie aanwezig is, dan is ook een meerderheid van de belanghebbende werknemers, dan wel een in de onderneming als zodanig werkzame vakbond bevoegd een dergelijk verzoek te doen. Over dit laatste is bij de beschouwingen over deze wet nogal wat te doen geweest. De FNV meende dat een spontane meerderheid van werknemers niet bereikt kan worden en pleitte dus voor een algemeen recht van vakbonden een verzoek te kunnen doen. De werkgeversorganisaties waren juist tegen een recht van vakbonden om een verzoek te mogen doen, aangezien dit 'over de hoofden van de werknemers heen" zou kunnen gebeuren (168). Ook in de Kamer werd door de enkele partijen (m.n. CDA en klein-rechts) bezwaar gemaakt tegen een sterke rol van de vakbond. Zelfs het nu in de wet opgenomen compromis werd al te vergaand geacht (169).

Het verzoek moet schriftelijk bij de arbeidsinspectie worden ingediend, de andere belanghebbenden in de onderneming (degenen die ook bevoegd zijn tot het doen van een verzoek) moeten worden ingelicht. De arbeidsinspectie stelt de belanghebbenden in de gelegenheid hun visie kenbaar te maken

167. A.J.C.M. Geers, a.w. (noot 8), p. 244.

168. Zie FNV, schriftelijk commentaar op het ontwerp-arbeidsomstandighedenwet, 8 september 1977, pag. 2; Raad van de Centrale Ondernemingsorganisaties, Commentaar wetsontwerp 14 497, Arbowet (nadler gewijzigd ontwerp en amendementen).

169. Hand. T.K., OCV 19 maart 1980, pag 1455; zie ook T.K. 13 mei 1980, pag. 4660. 
alvorens te beslissen op het verzoek. De beslissing kan een aan de ondernemer gestelde eis of aanwijzing tot naleving zijn.

De anwijzing tot naleving is bedoeld om de wetsbepalingen te interpreteren dan wel de wijze van toepassing te verduidelijken. Het gaat daarbij met name om de meer algemene bepalingen, terwijl de eis tot naleving vooral van belang is in concrete situaties, zoals de specifieke verplichtingen gebaseerd op art. 24 Arbowet. Bovendien kan alleen de ondernemingsraad, de Arbocommissie of een meerderheid van de belanghebbende werknemers de Directeur van de Arbeid verzoeken om een aanwijzing te geven voor een veilligheidsrapport of het instellen van de interne deskundige organisaties, een bevoegdheid die de werkgever niet toekomt.

Voor de meeste bepalingen op veiligheidsgebied geldt dat de aanwijzing door de arbeidsinspectie ambtshalve gegeven kan worden. Voor enige specifieke welzijnsbepalingen ligt dit anders: daar moet een verzoek tot wetstoepassing aan vooraf zijn gegaan. Dit betekent dat een aanwijzing op die gebieden dus niet kan worden gegeven, indien de arbeidsinspectie ambtshalve de omstandigheden binnen een onderneming bekijkt, dan wel op grond van een klacht van een individuele werknemer. De eis tot naleving kan altijd ambtshalve gesteld worden.

Aan de relatie tussen werknemersvertegenwoordigers en arbeidsinspectie wordt veel waarde gehecht. Zoals hierboven blijkt wordt daar door de lidstaten op verschillende wijze invulling aan gegeven. Tabel III geeft een overzicht.

Uit het bovenstaande kan voor het eerst een scheiding tussen 'noordelijke' en 'zuidelijke' EG-lid-staten worden waargenomen, die het vooroordeel dat het in het noorden allemaal veel beter geregeld is, lijkt te bevestigen. In Nederland, Duitsland en Denemarken zijn er tot op zekere hoogte bepalingen die contacten tussen arbeidsinspectie en werknemersvertegenwoordigers institutionaliseren, en daardoor de arbeidsinspectie van politioneel orgaan (waar ook werknemers nog wel eens moeite mee hebben) tot adviserend en belangenbehartigend orgaan van de werknemers maken. Hetzelfde geldt voor Spanje hoewel een zuidelijk land, een land met een relatief jonge en moderne wetgeving. Ook in de Britse, Franse en Belgische situatie, lijken de condities voor dergelijke contacten (ofwel doordat de inspecties behoren tot een orgaan met een adviserende taak, ofwel omdat het contact verloopt via de vakkrachten, die eveneens een beschermende tak hebben) aanwezig. In Griekenland en Italië is niets van dit alles, en heeft de arbeidsinspectie vooral zijn karakter van politioneel instituut behouden. In tegenstelling tot de mogelijkheden tot beleidsbeïnvloeding door werknemersvertegenwoordigers waar, voor zover het om instrumentarium ging slechts graduele verschillen te constateren waren, blijkt dat als het om het handhaven van regels gaat, grotere verschillen te bestaan.

Wanneer men naar het functioneren van de arbeidsinspecties in de verschillende landen kijkt wordt dit beeld weliswaar bevestigd, maar blijkt ook dat in die landen waar men de voorwaarden voor interactie tussen inspectie en vertegenwoordigers wel heeft geschapen, dit niet voldoende is 
Tabel III: Verplichtingen arbeidsinspectie ten opzichte van werknemersvertegenwoordigers.

land

Du.

Ned.

Bel.

Fra.

Lux.

Sp.

Gr.

It.

Den.

$\mathrm{Gr} \cdot \mathrm{Br}$

Ierl.

$$
\begin{aligned}
& \text { Verplicht te } \\
& \text { reageren op } \\
& \text { klacht verteg. }
\end{aligned}
$$

$$
\mathbf{x}
$$

$\mathbf{x}$

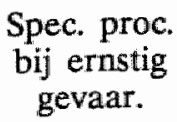

* Volgens een getrapte procedure.

geweest.

On te beginnen kennen niet alleen de inspecties in zuidelijke landen (zoals voor Griekenland hierboven werd opgemerkt), maar in alle lid-staten van de Europese Gemeenschap een gebrek aan personeel (met name inspecteurs) (170). Dit was de overwegende klacht tien jaar geleden al in de meeste lid-staten (171), en uit meer recent onderzoek blijkt dat daarin in elk geval in een aantal lid-staten niet veel veranderd is. Daarmee handelen

170. Een overzicht van de het aantal inspecteurs gerelateerd aan het aantal werknemers in de lid-staten, bleek niet te geven, aangezien de aantallen arbeidsinspecteurs in de werschillende lid-staten niet te achterhalen waren.

171. Safety and Health at the Workplace in the European Communities, Consolidated Report, Dublin 1981, p. 66-67. 
de lid-staten overigens in strijd met de eerdergenoemde ILO-conventie die voorschrijft dat het aantal inspecteurs "sufficient" moet zijn (172). Het mag duidelijk zijn dat goede wettelijke voorschriften met betrekking tot de verhouding tussen inspecteurs en werknemerswertegenwoordigers tot niets leiden, indien er niet voldoende menskracht is om die verhouding in te vullen. Voldoende inspecteurs is een eerste voorwaarde om het gezamenlijke handhavingssysteem te doen werken. Uit Brits onderzoek blijkt dat met name het tekort aan Factory Inspectors (173) er toe leidt dat, als alle plaatsen waarop arbeid wordt verricht bezocht zouden worden, elke plaats slechts eenmaal in de vier jaar bezocht zou worden (174).

Ook uit recent Nederlands onderzoek blijkt dat onderbemanning een probleem is. Dit werd al onderkend bij de behandeling van de Arbeidsomstandighedenwet. De regering stelde toen, uit te gaan van een uitbreiding van het uitvoerend apparaat van de inspectie met ongeveer 200 plaatsen (175). Deze uitbreiding is er echter, volgens het onderzoek dat de Algemene Rekenkamer verrichte naar de arbeidsinspectie, niet gekomen (176). Voor zover er al uitbreiding is gekomen (pas na 1986) heeft deze ook niet de noodzakelijke uitbreiding van de buitendienst (inspecteurs) opgeleverd, maar is deze ten goede gekomen aan de centrale afdelingen van het Directoraat-Generaal van de Arbeid. Het gevolg is dan ook dat het voorgenomen beleid, om meer aandacht voor kleine ondernemingen te besteden, volgens de Rekenkamer niet van de grond is gekomen (177). Uit het rapport van de Rekenkamer over de arbeidsinspectie in Nederland blijkt dat, wanneer alle ondernemingen bezocht worden, de theoretische inspectiekans ligt op énmaal in de zeven à acht jaar.

Het gevolg van deze tekorten aan mankracht, is dan ook dat inspecteurs prioriteiten moeten stellen. Dit gaat vaak ten koste van de bezoeken aan kleinere (en minder in het oog lopend gevaarlijke bedrijven) (178). Grote en erkend risicovolle bedrijven worden vaker bezocht; deze besteden echter al relatief veel aandacht aan veiligheid en gezondheid, terwijl dat bij de kleinere waar minder aandacht aan wordt besteed, vaak minder het geval is (179).

172. Artikell 10 Convention no. 81.

173. In Groot Brittannië zijn inspectoraten gespecialiseerd in verschillende sectoren. Er zijn 135 Mines Inspectors, 700 Factory Inspectors, 70 Nuclear Safety Inspectors en 44 Agricultural Safety inspectors en Inspecteurs van lokale overheden (houdt zich m.m. bezig met detailhandel en kantoren). De Factory Inspectors zijn degenen met de meest ruime bevoegdheden.

174. G.K. Wilson, a.w. (noot 147), p. 129-131.

175. TK. $1978 / 79,14497$, no. 5 en no. 9; TK. $1979 / 80,14497$, no. 11.

176. TK $1988 / 89,21283$, no. 1-2, p. $22-23$.

177. TK 1988/89, 21283 , nrs. 1-2, p. 23.

178. Rapport Rekenkamer, TK. 1988/89, 21283 , no. 1-2, p. 23.

179. T. Wilthagen, Hoe werkt de Engelse arbeidsinspectie, Sociaal Recht 1989, p. 8. 
Voorts lijden de contacten tussen vertegenwoordigers onder de verschillende rollen wan de inspectie. De meeste lid-staten benadrukken het belang van de adviserende taken in de relatie tussen arbeidsinspectie en vertegenwoordigers op ondernemingsniveau (180). De arbeidsinspecteurs hebben daardoor naast hun politionele rol een adviserende (en daarmee preventieve) taak gekregen. Deze verschuiving van de rol (en taak) van de arbeidsinspecteurs is niet altijd even goed ontvangen. Rosenbrock wijst deze ontwikkeling aan als eén van de oorzaken waardoor volgens hem de veiligheids- en gezondheidssystemen in een crisis zijn geraakt (181). De vermenging van taken creëert een spanningsveld, zowel binnen de inspectieorganisatie zelf, als in de verhouding met de werkgever en werknemersvertegenwoordigers in de onderneming. De preventieve adviserende taak vereist een zekere beoordelingsvrijheid, en beleidsruimte voor de inspecteurs, waar de politionele rol juist sterke regulering en gedetailleerde normstelling vereist (182).

De Britse inspectie is meermalen bekritiseerd omdat zij niet "tough" genoeg was. Zij gaf werkgevers die in strijd met de wet handelden eerst een aantal adviezen, voordat er zelfs maar met vervolging werd gedreigd (183). Bovendien bleek de HSE met name de werkgever te adviseren, en bij klachten lang niet altijd contact op te nemen met de veiligheidskundige of de veiligheidsvertegenwoordiger (184). In Nederland kritiseerde de Rekenkamer de arbeidsinspectie omdat de beleidsvrijheid leidde tot noninterventie bij problemen en verschillen in beleid tussen de districten (185). Anderzijds moet gezegd worden dat in beide landen de vakbondsorganisaties, ondanks het feit dat zij ook deze kritiek geuit hebben tegelijkertijd ambivalent blijken te staan tegen al te hard optreden van de arbeidsinspectie (186).

De ambivalente rol van de arbeidsinspectie heeft zijn invloed op de interactie tussen inspectie en werknemersvertegenwoordigers. Verzoeken tot optreden aan de arbeidsinspectie vanuit de Britse veiligheidscommissies

180. Safety and Health at the Workplace in the European Communities, Dublin 1981, p. 65-66.

181. R. Rosenbrock, Industrial Health Policy in a Crisis, Regressive Tendencies and New Tasks for The Professionals, in Work and Health in the 1980's, (S. Bagnara, R. Misiti, H. Wintersberger eds.) Berlin 1985, p. 336.

182. Rapport Rekenkamer, TK. $1988 / 89,21283$ no. 1-2, p. 37; zie over de wijze waarmee met deze bevoegdheden omgegaan wordt het onderzoek dat door het empirische onderzoek van onderzoekers Centre for Socio-Legal Studies te Oxford (1988) is gedaan naar de effectiviteit van de veiligheids- en gezondheidswetgeving.

183. P. Kinnerslley, The Hazards of Work and how to Fight them, London 1974, p. 224.

184. T. Wilthagen, a.w. (noot 179), p. 9.

185. Rapport Rekenkamer, T.K. $1988 / 89,21283$ no. 1-2, p. 37-38. Geers stelt echter in zijn proefschrift dat de kritiek op de inspectie belangrijk minder geworden is, en voortkamt uit de ambivalentie in de rol van de inspectie; A.J.C.M. Geers, a.w. (noot 8), p. 243-244.

186. G.K. Wilson, a.w. (noot 147), p. 136; A.J.C.M. Geers, a.w. (noot 8), p. 244. 
komen zelden voor (187). Hetzelfde beeld ziet men in Denemarken (voor wat betreft de inspecterende rol) (188). Hier wordt de arbeidsinspectie met name wel geconsulteerd in verband met de werkwijze van de veiligheidsorganisatie. Nederland (189) levert voor wat betreft de verzoeken tot wetstoepassing eenzelfde beeld op, hoewel dit vertekend kan zijn door de gefaseerde invoering van de de Arbowet. In Duitsland waar de arbeidsinspectie meer dan in deze drie landen een conflictbeslechtende rol heeft behouden wordt in grote ondernemingen wél in toenemende mate een beroep op de inspectie gedaan (190).

Hoe de contacten in andere lid-staten verlopen is niet bekend. Sedert de invoering van de wetten Auroux in Frankrijk in 1982 is de de situatie omtrent veiligheids- en gezondheidsissues zozeer gewijzigd dat ouder onderzoek nauwelijks een goed beeld kan leveren van de praktijk van vandaag. Ook is er nauwelijks recent rechtssociologisch onderzoek naar de Italiaanse en Belgische situatie te vinden. Wel blijkt dat in Italië, de arbeidsinspectie slechts door ongeveer zeven procent van de werknemers gezien wordt als instituut dat verbeteringen in arbeidsomstandigheden kan brengen (191). De lerse, Griekse en Spaanse wetgeving is te jong om reeds tot conclusies tot de verhouding tussen vertegenwoordigers en arbeidsinspectie te kunnen leiden.

De individuele werknemer komt, noch in de lid-staten met een verplichting van de arbeidsinspectie te reageren op klachten, noch in de lid-staten zonder een dergelijke regeling specifiek in beeld. Hij heeft in het algemeen wel recht om te klagen, maar hooguit als recht van petitie. Hij kan in geen enkel geval erop rekenen dat de arbeidsinspectie actie onderneemt. Uit onderzoek in Groot Brittannië blijkt dat, wanneer het niet gaat om direct waarneembare gevaarssituaties, de inspectie pas reageert op series identieke gezondheidsklachten (192).

Het is niet uitgesloten dat in die landen waar de arbeidsinspectie verplicht is te reageren op klachten van werknemersvertegenwoordigers de individuele werknemer in een nadeliger positie is dan in de andere landen (193). Juist dan kan een arbeidsinspecteur zich gaan afvragen, of de klacht serieus genoeg is, als de werknemersvertegenwoordigers niet de moeite hebben genomen om hem in te schakelen. Geers constateert in dit verband dat de

187. J. W. Leopold, Worker Participation and Joint Union-Management, Health and Safety Committees in the United Kingdom, in Work and Health in the 1980's, $(S$. Bagnara, $\mathbb{R}$. Misiti, H. Wintersberger, eds.) Berlin 1985, p, 263.

188. O. Rieper, a.w. (noot 34), p. 103.

189. T.J.M. Reubsaet c.S., a.w. (noot 112), p. 85.

190. H. Kühn, a.w. (noot 102), p. 162.

191. R. Raimondi, Health and Working Environment 1971-1982, Workers' Opinions, in Work and Health in the 1980's, (S. Bagnara, R. Misiti, H. Wintersberger, eds.) Berlin 1980, p. 93.

192. T. Wilthagen, A.W. (noot 179), p. 9.

193. Zie ook H. Kühn, a.w. (noot 102), p. 161. 
bevoegdheden van de ondernemingsraad als alibi kunnen gaan dienen in de relatie van de inspectie tot de individuele werknemer. Volgens Geers heeft de arbeidsinspectie deze opvatting voor een goed deel in haar uitvoeringsbeleid geincorporeerd. Of dit ook expliciet geldt voor het beleid met betrekking tot klachten vermeldt hij overigens niet, maar hij sluit verschraling van het petitierecht niet uit (194).

Nederlandse schrijvers wijzen in dit verband op de beantwoordingsplicht, c.q. de behandelingsplicht die in de praktijk (als beginsel van behoorlijk bestuur) aan het (grondwettelijk) petitierecht is gekoppeld (195). Een verzoek aan, of een klacht bij de arbeidsinspectie zou gelijk te stellen zijn aan een petitie. In beginsel moet op "redelijke" verzoekschriften met tenminste een antwoord gereageerd worden (196). In Nederland is het overigens niet helemaal uit te sluiten dat een negatieve (of geen) reactie van de de arbeidsinspectie op een verzoek van de individuele werknemer een (weigering c.q. fictieve weigering van een) beschikking is in de zin van de wet AROB. Dit zou het geval kunnen zijn, indien de werknemer de arbeidsinspectie (expliciet) verzoekt een eis te stellen, of een aanwijzing te geven (197) op grond van de Arbowet, en de arbeidsinspectie feitelijk op geen andere wijze zou kunnen reageren, dan door aan dit verzoek gehoor te geven (198). Of de werknemer ontvankelijk zou zijn in een beroep tegen een dergelijke fictieve weigering, is overigens niet zeker (199). Het voert te ver om hier in dit verband uitgebreid op in te gaan.

De praktijk zoals die gehanteerd wordt ten aanzien van petities levert in beginsel geen (of een zeer beperkte) reactieverplichting op. Werknemers hebben bijzonder weinig mogelijkheden in beroep te komen, wanneer geen reactie komt, of het antwoord slechts een voorgedrukte bevestiging van ontvangst is. Mijns inziens zou tenminste een reactie van de arbeidsinspectie (in de vorm van eèn antwoord op de klacht) verplicht moeten zijn, als de

194. A.J.C.M. Geers, a.w. (noot 8), p. 333 en p. $280-283$.

195. H. van Maarseveen, Petitierecht, Grondrechten commentaar op hoofdstuk 1 van de herziene grondwet, (Jeukens-bundel) Nijmegen 1982, p. 140; A.J.H. van Lymden, De individuele werknemer in het arbeidsomstandighedenrecht, SMA 1984, p. 499; H.J. van Zwarm, Veranderingen in het Arbeidsomstandighedenrecht, Deventer 1983, p. 56.

196. Zie ook het rapport van de Nationale Ombudsman, 20 juli 1989, no. 89/R475, AB 1989, no. 489.

197. Een aanwijzing en cen eis kunnen als beschikking in de zin van de Wet Arob worden gekwalificeerd. Werkgever en ondernemingsraad/arbocommissie kunnen volgens de in de wet gegeven procedure bezwaar maken, de indiwiduele werknemer niet.

198. Zie hierover O.m. F.A.C.M. Michiels De AROB beschikking, 's" Grawenhage 1987, p. 7478 , p. 106-111.

199. Het probleem schuilt hem in het feit dat er all een andere administratieve procedure openstaat, ook al heeft de individuele werknemer geen recht van procederen. Het is mogelijk dat de AROB-rechter tot niet-ontvankelijkheid komt o.g.v. de redenering dat de wetgever kennelijk niet bedloeld heeft een procedure voor de individuele werknemer te openen. Het tegenovergestelde kan overigens ook nl. dat ontvankelijkheid juist wel wordt aangenomen ondat de bestaande procedure geen mogelijkheden biedt. Zie J.G. Steenbeek, Wet administratieve overheidsbeschikkingen 's-Gravenhage 1984, p. 163-166. 
klacht niet kennelijk onredelijk is. Een verdergaande reactieverplichting, bijvoorbeeld een verplichting voor de arbeidsinspectie de klager uit te nodigen de klacht mondeling te komen toelichten, waarna een onderzoek wordt ingesteld als de klacht redelijk is, is eventueel ook denkbaar. Een zwaardere verplichting zou voor Nederland in samenhang met het (in de volgende paragraaf te bespreken) recht op werkweigering bij dreigend en onmiddellijk gevaar te verdedigen zijn. De individuele werknemer heeft binnen de onderneming weinig mogelijkheden iets te doen aan gevaar dat niet ernstig en onmiddellijk is. Geers toont aan dat ook de verplichtingen van de deskundigen in de onderneming ten opzichte van de individuele werknemer nauwelijks sanctioneerbaar zijn (200) via de arbeidsinspectie. Een zware reactieverplichting $\mathrm{kan}$ in de gevallen dat een individuele werknemer nauwelijks respons krijgt op zijn klachten soelaas bieden.

Of een dergelijke verplichting mogelijk is hangt mede af van het aantal klachten dat individuele werknemers indienen en de mogelijkheid van de arbeidsinspectie daarop in te gaan. Hierboven werd al gesteld dat het aantal arbeidsinspecteurs nu al praktisch in alle EG lid-staten onvoldoende is. Hoeveel klachten per jaar op het gebied van schending van de arbeidsomstandighedenwetgeving worden ingediend is niet bekend. Het gerniddeld aantal klachten dat in Nederland tussen de jaren 1979-1989 door werknemers werd ingediend bedraagt 440 (201). Dit aantal dekt klachten over alle wetgeving (uitgezonderd het Buitengewoon Besluit Arbeidsverhoudingen 1945) terzake waarvan de arbeidsinspectie competent is. Het valt op basis van deze gegevens niet na te gaan hoeveel daarvan precies betrekking hebben op arbeidsomstandigheden. Mogelijk is dit aantal klachten voor de arbeidsinspectie derdaad "behapbaar".

Daarnaast is het nog maar de vraag of de werknemers zelf een zware reactieverplichting wenselijk achten. Uit de jaarverslagen van de arbeidsinspectie blijkt dat een groot deel van de klachten die de inspectie bereiken anoniem zijn (202). Het is, denk ik, niet uitgesloten dat onder deze anonieme klagers zich ook werknemers bevinden die, ondanks de verplichting van de inspectie hun identiteit te verzwijgen, toch bang zijn dat hun naam in de onderneming waar zij werken bekend wordt. Met een zwaardere reactieverplichting in de vorm van een uitnodigingsplicht zou deze angst kunnen toenemen. Als dan anderzijds, de uitnodiging van de arbeidsinspectie de klacht te komen toelichten een soort voorwaarde voor verdere actie wordt, zou een zwaardere reactieverplichting contraproductief kunnen gaan werken.

200. A.J.C.M. Geers, a.w. (noot 8), p. 286-287.

201. In 1980666 , in 1981488 , in 1982294 , in 1983405 , in 1984491 , in 1985521 , in 1986382 , in 1987377 en in 1988331 . (Jaarverslagen arbeidsinspectie van 1982 (met gegevens ower 1980 , 1981 en 1982) van 1985 (met gegevens over 1983, 1984 en 1985), en van 1988 (met gegevens over 1986, 1987 en 1988).

202. Zie noot 201 . Uit de jaarverslagen blijkt dat het ower de jaren $1980 \mathrm{t} / \mathrm{m} / 1988$ gemiddeld 279 klagers anoniem hun klacht indienden. 
Vooralsnog lijkt dan ook een verplichting tot beantwoording mij de meest haalbare mogelijkheid. Dat antwoord kàn zijn een onderzoek, maar dat hoeft niet het geval te zijn. Is dit niet het geval dan zal het antwoord de redenen waarom geen actie wordt ondernomen moeten bevatten. Een dergelijke beantwoordingsplicht verplicht de arbeidsinspectie in elk geval de klachten te lezen en ze te toetsen (al is het marginaal). Blijft over de vraag wat de sanctie moet zijn indien de arbeidsinspectie niet reageert, of ongemotiveerd klachten afwijst.

Er zijn daarvoor weinig effectieve oplossingen te bedenken. Een beroepsrecht is niet realistisch, omdat dan ook een een beroepsrecht (voor de werkgever) bij een besluit tot wél-optreden gecreëerd zou moeten worden. De reactieverplichting zou bewaakt kunnen worden door een ombudsman, maar dat levert hooguit publiciteit achteraf op (en dan nog alleen effectief als de inspectie haar taken echt ernstig zou verwaarlozen), in het concrete geval lost het niets op. Wat dan overblijft is een procedure wegens onrechtmatige daad; echter als het zo erg is dat de werknemer bereid is een dergelijke procedure aan te spannen, is procederen tegen de werkgever om direct iets aan de arbeidsomstandigheden te doen vermoedelijk wel zo effectief (en goedkoop).

Kortom, hoewel het petitierecht in de praktijk een optreden van de inspectie kàn opleveren, moet de individuele werknemer niet verwachten van een publiekrechtelijke instantie als de arbeidsinspectie, dat deze een effectieve rol kan spelen als het gaat om niet direct gevaarlijke omstandigheden. Desalniettemin zou een verplichting tot reageren van de arbeidsinspectie deze situatie enigszins kunnen verbeteren.

De individuele werknemer, op wiens positie in een volgende paragraaf nog wordt teruggekomen, heeft in elk geval niet meer en meestal minder mogelijkheden om met betrekking tot de naleving van veiligheidsnormen de arbeidsinspectie in te schakelen dan de werknemersvertegenwoordigers. Het is dus zaak na te gaan welke mogelijkheden dan wel openstaan voor het geval de individuele

werknemer in een onveilige of ongezonde situatie komt te werken.

6 De individuele werknemer in medezeggenschapssystemen $\mathbf{m}$.b.t. veiligheidsen gezondheidsaangelegenheden

De individuele werknemer, zo blijkt uit de voorgaande hoofdstukken, komt er in de medezeggenschap nogal bekaaid af. Hij heeft in het algemeen geen, of slechts een beperkt, eigen recht op informatie; hij heeft weinig mogelijkheden "in te breken" in besluiten, ook als die ingaan tegen zijn belangen, en hij heeft in de lid-staten weinig kans besluiten aan te vechten bij de rechter. Voor medezeggenschapsregelingen omtrent veiligheids- en gezondheidsaangelegenheden geldt dit eveneens in vrij sterke mate. De individuele werknemer heeft in veel gevallen recht op opleiding en training met betrekking tot veiligheid en gezondheid waar het zijn eigen arbeids- 
plaats aangaat. Voor meer algemene informatie is hij echter in de meeste landen afhankelijk van de werknemersvertegenwoordigers, die soms een plicht hebben informatie door te geven (Griekenland, Denemarken, Duitsland) en soms de mogelijkheid dit te doen.

Steun kan die individuele werknemer mogelijk vinden bij de vakkrachten voor veiligheid en gezondheid. Hierover moet opgemerkt worden dat hun bevoegdheden ten aanzien van werknemers, veelal gekoppeld zijn aan die van veiligheids- of werknemersvertegenwoordigers. Hoewel hun formele taak daarnaast een andere is, is hun materiële taak valk zeer ingebed in de relaties tussen werkgever en werknemersvertegenwoordigers.

Tenslotte heeft de individuele werknemer, al dan niet tezamen met collega's in sommige landen wel, mar meestal niet de mogelijkheid goede arbeidsomstandigheden af te dwingen door directe acties. Slechts wanneer het gevaar levensbedreigend wordt, bestaan er in de lid-staten rechten om direct iets te ondernemen, maar dan is de vraag wat de positie van de individuele werknemer is. In deze paragraaf komen de mogelijkheden voor de individuele werknemer iets te doen aan zijn arbeidsomstandigheden aan de orde. Als eerste zal het recht het werk neer te leggen bij dreigend gevaar besproken worden; daarna zal ingegaan worden op de mogelijkheid klachten in de onderneming in te dienen. Tenslotte zal de positie van de groep werknemers die niet tot de reguliere categorieën werknemers gerekend worden, zoals thuiswerkers en afroepcontractanten besproken worden.

\subsection{Het recht het werk neer te leggen bij dreigend gevaar}

In alle lid-staten is de verplichting voor de werknemer bevelen uit te voeren van meerderen, één van de hoofdelementen van het arbeidscontract. Weigert de werknemer, dan kan in beginsel ontslag (op staande voet) volgen. Een dergelijke verplichting kan echter opgeschort worden onder bijzondere omstandigheden. Eén van die omstandigheden is dreigend en onmiddellijk gevaar.

Om te beginnen kan een recht om het werk neer te leggen bij dreigend en onmiddellijk gevaar afgeleid worden uit grondwettelijke (203) en verdragsrechtelijke (204) bepalingen omtrent het recht op fysieke integriteit. Het hangt er echter van af of de grondrechten een horizontale werking hebben en daarmee contracten tussen burgers onderling beinvloeden of het grondrecht 'bruikbaar' is in de praktijk (205).

203. Bijvoorbeeld: Nederland artikel $10 \mathrm{en} 11 \mathrm{GW}$, Italië artikel $2 \mathrm{CI}$, Spanje artikel $15 \mathrm{CE}$, Duitslland paragrafen 2 en $10 \mathrm{GG}$.

204. Art. 3 Universele Verklaring wan de Rechten wan de Mens, artikel 8 ECRM, etc.

205. In Nederland is de horizontale werking van grondrechten waaronder artikel 10 en 11 tot op zekere hoogte geaccepteerd., ook al wordt deze in de jurisprudentie gekoppeld aan vage termen zoals o.m. "dringende reden tot ontslag". (HR 30-3-1984 AB 1984, 366. Zie ook 
Daarnaast bestaat een recht van werkweigering bij dreigend en onmiddellijk gevaar op basis van het contractenrecht. In de EG lid-staten is de werkgever op grond van het burgerlijk recht (206) of common law (207), verplicht zorg te dragen voor een veilige werkomgeving. Doet de werkgever dit niet dan is hij aansprakelijk voor de gevolgen. Omgekeerd kan men stellen dat wanneer een werkgever niet aan deze verplichting voldoet, de werknemer gerechtigd is zijn prestatie op te schorten (208). Dit betekent dat indien een werkgever de wettelijke veiligheids- en gezondheidsvoorschiriften overtreedt, de werknemer in beginsel het werk mag weigeren. Dit gaat verder dan een expliciet recht bij dreigend en acuut gevaar.

In een aantal lid-staten is het recht het werk neer te leggen, of het nu wel of niet expliciet in de wet is opgenomen op deze wijze uitgewerkt.

Het Duitse Zurückbehaltungsrecht (209) is op basis van jurisprudentie in verband met veiligheids- en gezondheidsaangelegenheden tot een vrij uitgebreid werkweigeringsrecht geëvolueerd. Het werk hoeft niet te worden aangevangen of worden voortgezet, wanneer wettelijke of Unfallverhütungsvoorschriften (dus ook die van de Berufsgenossenschaften) worden overtreden (210). Dit betekent dat, ook als er voorschriften worden overtreden die geen direct en onmiddellijk gevaar opleveren individuele werknemers de mogelijkheid hebben het eigen werk stil te leggen om op deze wijze naleving van de voorschriften af te dwingen. Hierbij gaat het echter alleen om een stilleggingsrecht voor zover het de eigen werkzaamheden betreft; de mogelijke collectieve uitoefening van dit recht makkt dat niet anders.

De Griekse wet kent eveneens een regeling die het de werknemer mogelijk maakt het werk neer te leggen. Dit recht geldt voor die situaties waarin de werkgever contractbreuk pleegt; contractbreuk kan zich ook voordoen in andere situaties dan het niet doorbetalen van loon. In de jurisprudentie is uitgemaakt dat indien een werkgever opdrachten verstrekt die de waardigheid of de gezondheid van de werknemer kunnen schaden dit recht uitgeoefend kan worden. Dit laatste geldt echter niet wanneer het werk op zichzelf ongezond is (211). In dit laatste geval wordt de werknemer

C.A.J.M. Kortmann, De Grondwetsherzieningen 1983 en 1987, Deventer 1987, p. 48-50, P.W.C. Akkermans, De Grondwet een artikelsgewijs commentaar, Zwolle 1987, p. 227 en p. 246. Men kan eventueel ook aan open termen dlenken als het goed werkgeverschap uit artikel $1638 \mathrm{zWW}$.

206. Vgl. o.m. Nederland: $1638 \times \mathrm{BW}$; Italiê: $2087 \mathrm{CC}$; Duitsland: Paragraaf $618 \mathrm{BGB}$.

207. J.V. Coleman ${ }_{n}$ An Employers Duties at Common Law in Ireland, Dublin 1961.

208. F. Agnelli, Principe e norme generale, in Codice della prevenzione infortuni e dell' igiene dell lavoro (V. Varese ed.) Roma 1978, Vol. I, p. 48-49.

209. Paragraaf 273 BGB; G. Schaub Arbeitsrechtshandbuch, München 1987, p, 562, zie ook paragraaf IV.5.

210. O.m. G. Wiese, Zur rechtlichen Bedeutung der Rechtlinien der Berufgenossenschaften, Recht der Arbeit, 1978 , Heft 2. p. $72-73$.

211. T.B. Koniaris, a.w. (noot 10), para. 159. 
kennelijk geacht akkoord te zijn gegaan met de omstandigheden waaronder hij moet werken, en kan hij niet op die grond werk weigeren. Wel kan hij afdoende bescherming verlangen.

In de Italiaanse jurisprudentie zijn (individuele) werkonderbrekingen om redenen van dreigend en ernstig gevaar (212) en in verband met het overtreden van veiligheidsvoorschriften door de werkgever (213) als rechtmatig geaccepteerd. In de wet ontbreekt ieder spoor van verwijzing naar een dergelijk recht.

In Groot Brittanniê en Ierland is het recht op werkonderbreking gebaseerd op common law. De veiligheids- en gezondheidswetten in beide landen (noch de Codes of Practice in Groot Brittannië) voorzien in een recht voor de individuele werknemer het werk te onderbreken in geval van dreigend ernstig gevaar. Normaal gesproken wordt in Groot Brittannië werkweigering beschouwd als contractbreuk (wanprestatie) en is ontslag mogelijk; enige garantie dat ernstig en acuut gevaar gezien wordt als een rechtvaardiging van deze wanprestatie is niet aanwezig. Niettemin is ook hier door enkele lagere rechters, de "industrial tribunals", geaccepteerd, dat het ontslaan van een werknemer omdat hij weigert werk te doen dat hem in in gevaar brengt als een 'unfair dismissal' beschouwd kan worden (214). Ook ingeval het gevaar niet ernstig in de zin van levensbedreigend is kan een werkonderbreking gerechtvaardigd zijn, aangezien de ondernemer door het niet voorzien in deugdelijke werkomstandigheden contractbreuk kan plegen (215).

Hierbij wordt dan wel aangetekend dat de werknemer zelf niet een gevaarlijke situatie mag laten ontstaan, bijvoorbeeld door apparaten die gevaar opleveren aan te laten. In dat geval is een ontslag gerechtvaardigd. Niet iedereen is met deze uitspraken even gelukkig, omdat het gevaar gesignaleerd wordt dat werknemers op ieder moment voor elke grief het werk zouden kunnen onderbreken (216), ook al wordt erkend dat bij de toetsing van een ontslag veiligheids- en gezondheidszaken als relevante factoren moeten worden meegenomen.

Op het bovenstaande valt nog iets af te dingen: bij 'unfair dismissal' zaken gaat het in het algemeen om de verstrekking van een mogelijke schadevergoeding; herstel van dienstbetrekking is wel mogelijk, maar ongebruikelijk.

De Ierse opvatting van het weigeringsrecht stemt hier vrij sterk mee overeen; ook hier wordt het weigeringsrecht afgeleid van de zorgplicht van

212. Vgl. T. Treu, a.w. (noot 153), para. 116 en 208.

213. F. Agnelli, a.w. (noot 208), Vol. I p. 48-49.

214. Zie 0.m. D. Lewis, The Health and Safety at Work Act 1974; New Opportunities for Worker Participation in Safety at Work, Centre for socio-legal studies, Oxford 1977, p. 32.

215. Dit was het geval in de zaak Graham Oxley Tool Steels vs Firths (1980) Industrial Relations Law Reports, 135, p. 137, waar het ontslag van een werkneemster, die het werk onderbroken had in verband met de koude op haar werk, unfair geacht werd, ondat de ondernemer in dit geval voor voldoende verwarming had moeten zorgen.

216. C.B. Drake, F.D. Wright, a.w. (noot 138), p. 24-25. 
de werkgever. In lerland is in de jurisprudentie echter wel sterk de nadruk gelegd op de door de werkgever gegeven voorlichting voor de aanvang van het werk, en de mate van vrijwilligheid van de werknemer bij het aanvaarden van de opdracht (217). Dit laatste betekent dat de werknemer minder snel een weigeringsrecht zal toekomen als hij weet en accepteert dat het werk op zichzelf gevaarlijk is. In dit opzicht doet de jurisprudentie aan die van de Griekse rechters denken.

Ook het Spaanse Werknemersstatuut voorziet niet expliciet in een recht voor de individuele werknemer het werk neer te leggen in geval van ernstig en onmiddellijk gevaar, ofschoon een dergelijk recht wel afgeleid kan worden uit artikel 4 van het Statuut. In dit artikel worden onder de fundamentele rechten van de werknemer binnen het kader van zijn arbeid, het recht op fysieke integriteit en op een veiligheids- en gezondheidsbeleid naar tevredenheid gebracht. Dit wordt echter niet uitgewerkt in een specifiek recht het werk neer te leggen. Het ontslaan van een werknemer omdat hij het werk onderbreekt in verband met ernstig en dreigend gevaar zal vermoedelijk wel een schending van artikel 4 Statuut opleveren en om die reden illegaal geacht worden (artikel 56 Werknemersstatuut).

In Frankrijk werd vóor 1982 dreigend en acuut gevaar in de rechtspraak eveneens als rechtvaardigingsgrond voor werkweigering geaccepteerd, zonder dat dit recht expliciet in de wet was toegekend. Werkweigering was toegestaan als een ongeval dreigde bij de uitvoering van taken (218), maar ook wanneer een opdracht van de werkgever niet in overeenstemming was met de staat van de gezondheid van de werknemer (219).

Sedert 1982 (220) hebben Franse werknemers ook een wettelijk recht het werk neer te leggen indien zij naar hun redelijk oordeel onmiddellijk ernstig gevaar voor hun leven of hun gezondheid mogen aannemen. Ze moeten tezelfdertijd de werkgever waarschuwen, en zijn verplicht er op toe te zien dat hun werkonderbreking niet een nieuwe gevaarlijke situatie doet ontstaan. De werkgever mag geen sancties opleggen aan de werknemer, en al evenmin van hem eisen dat hij het werk weer hervat zolang het gevaar nog bestaat. Het probleem zit hier in de bewijslast indien de ondernemer en werknemer over de ernst en onmiddellijkheid van het gevaar van mening verschillen. Daar het hier om een rechtvaardingsgrond voor de werknemer (bij werkweigering) gaat, zal het van de van de wijze waarop rechter de attitude van de werknemer inschat, afhangen of de werkonderbreking al dan gerechtvaardigd is. Overigens blijkt uit de jurisprudentie sedert 1982 dat rechters alle elementen van de zaak meewegen om vast te stellen of de werknemer redelijkerwijs kon aannemen dat het op zijn post blijven onmiddellijk en dreigend gevaar met zich mee zou brengen (221).

217. J.V. Coleman, a.w. (noot 207).

218. Soc. 20 maart 1956, OP 1956, 601.

219. Soc. 11 juni 1958, QP 1958, 919 en Soc. 7 januari 1960, QP 1960, 1008.

220. G.H. Camerlynck c.s., a.w. (noot 58), p. 498.

221. G. Lyon-Caen, J. Pélissier, a.w. (noot 21), p. 520. 
In Nederland is het recht het werk neer te leggen eveneens, al voor de inwerkingtreding van de arbeidsomstandighedenwet in de rechtspraak geaccepteerd. De wijze waarop de Hoge Raad (222) dit recht destijds invulde heeft wel kritiek gekregen. De werknemer mag, zelfs indien hiij 'steekhoudende bezwaren' tegen de opdracht heeft, alleen weigeren, wanneer hij daarbij met het belang van de werkgever in redelijke mate rekening houdt. Geers (223) meent dat geen ruimte voor een dergelijke rechtvaardigingsgrond van de werkgever, of voor een belangenafweging van de rechter achteraf mag bestaan, gezien de bewoordingen van artikel $1639 \mathrm{q}$ lid 2 onder 9.

Het bestaan van het werkweigeringsrecht op basis van het contractenrecht was in Nederland, bij de behandeling van de arbeidsomstandighedenwet dan ook reden om te betogen dat een specifiek recht op werkweigering bij gevaar niet nodig was (224). Het probleem is echter dat zolang een dergelijk recht niet expliciet is ingevuld men met vragen blijft zitten omtrent de bewijslast, en ook wat als acuut en dreigend gevaar moet worden gezien. Daarnaast blijft, als er geen expliciet wettelijk recht is, ook de vraag open, of de werknemer met het mindere had kunnen volstaan, terwijl hij het meerdere heeft gedaan.

Dat het civiele recht niet altijd bruikbaar is, bleek in een Nederlandse zaak. Nog in 1979 werd een ontslag op staande voet door de Hoge Raad gesanctioneerd, waarbij de overweging, dat het enkele feit van de weigering van een havenarbeider wegens de gevaarlijke omstandigheden waaronder het werk moest gebeuren een dringende reden tot ontslag kon zijn, gelet op de voorzieningen die de werkgever had getroffen de werkzaamheden geen ernstige moeilijkheden voor de betreffende werknemer hadden kunnen opleveren, niet in strijd met het recht werd bevonden (225). De Hoge Raad liet in deze zaak het bewijs helemaal over aan de werknemer. Had hij, zoals de Arbeidsomstandighedenwet sedert 1983 voorschrijft, de bewijslast op de werkgever gelegd, dat was het niet uitgesloten geweest dat hij in dit geval tot een andere conclusie was gekomen (226).

Sedert 1983 is in Nederland het recht tot werkonderbreking bij dreigend en acuut gevaar expliciet in de wet opgenomen. Artikel 38 Arbeidsomstandighedenwet lijkt op het eerste gezicht enigszins diffuus geformuleerd: de werknemer is bevoegd het werk te onderbreken en die onderbreking voort te zetten, indien en zolang naar zijn redelijk oordeel gevaar voor personen als bedoeld in artikel 37 le lid aanwezig is en naar zijn redelijk oordeel het gevaar zo onmiddellijk dreigt dat de arbeidsinspectie niet tijdig kan optreden. Artikel 37 le lid spreekt over "werkzaamheden (...) die een

222. HR. 24 juni 1966 , NJ $1966,457$.

223. A.J.C.M. Geers, a.w. (noot 8), p. 272-273.

224. TK., 13 mei 1980, w.0. 14497 , p. 4661.

225. HR. 24 jumi 1979 , NJ 1979, 629.

226. Zie ook: M.M. Olbers, Opdracht in strijd met de wet, SMA 1984, P. 16; A.J.C.M. Geers, a.w. (noot 8), p. 278 . 
ernstig gevaar opleveren voor personen". Deze laatste term is in de wet verder niet uitgewerkt. Men kan zich afvragen of ook omstandigheden die op den duur (ernstige) lichamelijke schade toebrengen, zoals bijvoorbeeld gehoorstoornissen of rugklachten, maar niet direct levensbedreigend zijn hieronder begrepen worden. Dit lijkt niet het geval te zijn, omdat daarvoor de hierboven beschreven procedures bestaan, waardoor de arbeidsinspectie werzocht kan worden op te treden (227). Wanneer echter zo'n verzoek tot optreden wordt gedaan door de individuele werknemer is er geen verplichting voor de arbeidsinspectie actie te ondernemen.

Olbers (228) is van mening dat onder omstandigheden, ook dan van het recht tot werkonderbreking gebruik gemaakt kan worden. Hoewel, volgens de doctrine de situatie wararin de werkgever zijn verplichting wettelijke veiligheidsregels na te leven niet nakomt, niet onder de criteria van artikel 38 valt (229), zou dit in zijn visie anders zijn wanneer het niet-naleven van die regels "ernstig en onmiddellijk" gevaar oplevert. Olbers redeneert dat bij overtreding van de wettelijke voorschriften, de wetgever een geobjectiveerd oordeel heeft uitgesproken over het gevaar dat aan het werken zonder inachtneming van de in de wet gestelde voorschriften kleeft. In dat geval mag een werknemer, volgens hem, redelijkerwijs aannemen dat het werken zonder naleving van die voorschriften ernstig gevaar oplevert.

Het probleem is dat het uittesten van deze redenering door een werknemer, hem wel eens op ontslag wegens dringende redenen kan komen te staan (230). Dit is de mogelijke sanctie die aan het weigeren van werk in het algemeen kan kleven. Het werkweigeringsrecht moet nu juist voorkomen dat werknemers uit angst voor ontslag door blijven werken onder zeer gevaarlijke omstandigheden (231).

Overigens wordt het bovenstaande wel genuanceerd door het in artikel 38 geformuleerde criterium dat de werknemer "naar zijn redelijk oordeel"

227. TK. 1979-1980, 14497 no. 11, nota naar aanleiding van het eindverslag, p. 14.

228. M.M. Olbers, a.w. (noot 226), p. 161 .

229. De FNV wenste ook deze situatie onder artikel 38 begrepen te zien. Commentaar van 8 september 1977 i.v.m. W.O. 14497 van de Federatie Nederlandse vakbeweging, p. 10. Zie ook J. Bloemarts, Op weg naar een drie partijenmodel voor het social beleid in de onderneming, De FNV over het ontwerp Arbeidsomstandighedenwet, SMA 1978, p. 590 ev, en A.J.C.M. Geers en J.K.M. Gevers, Arbeidsomstandighedenrecht, Alphen a.d. Rijn 1974 , p. 153.

230. Geers beschrijft in een overigens zeer gecompliceerde casws, waarin een volgens hem niet honorabel beroep op artikel 38 werd gedaan, de situatie, waarin een werkmemer terecht kan komen indien hij onder gevaarlijke doch niet levemsbedreigende omstandigheden werkt en daar iets tegen wil ondernemen. Geers concludeert dan ook dat de werknemer "(....) de levende illustratie (is) van mujn betoog dat de individuele werknemer bij zijn pogingen om zijn arbeidsomstandigheden te verbeteren zowel juridisch al feitelijk in hoge mate afhankelijk is van anderen binnen de onderneming en wooral van de werkgever ${ }^{*}$ AJ.C.M. Geers, a.w. (noot 8), p. 337-349.

231. M. Driessen en M. Rennenberg wijzen er in de FNV-brochure 'Veilig en gezond op karwei" overigens op dat ontslag, ook indien de werknemer in het gelijk gesteld wordt toch kan plaatswinden wegens de verslechterde verhouding (en dus veranderde onstandigheden) tussen werkgever etn werknemer. Dit relativeert de versterking wan de positie van de werknemer, die door de omker"ung wan de bewijslast wordt bereikt nog iets meer (Veilug en gezond op Karwei, Industriebond FNV, Amsterdam 1988, p. 33). 
ernstig gevaar moet kunnen aannemen. Indien een werknemer het werk onderbreekt omdat hij meent dat er sprake is van gevaar, zal de werkgever moeten bewijzen dat de werknemer dit gevaar "naar zijn redelijk" oordeel niet kon aannemen. Dit betekent dat ook de individuele kennis van de omstandigheden die zich voordoen, in de overweging moet worden betrokken.

Een andere nuancering van het gevaar wan ontslag wegens dringende redenen zit hem in artikel 38 zelf, aangezien bij een werkonderbreking onmiddellijk de arbeidsinspectie gewaarschuwd kan worden. In dat geval beslist de arbeidsinspectie over de ernst van het gevaar en neemt een beslissing. Dit kan zijn het stilleggen van de machines, maar ook het stellen van een eis waardoor het ergste gevaar geweken is. Door een beschikking van de arbeidsinspectie eindigt de bevoegdheid van de werknemer het werk te onderbreken.

\subsection{Klachtenprocedures binnen de onderneming}

De positie van de individuele werknemer kan ook versterkt worden, door procedures in de onderneming die het mogelijk maken dat hij, zonder daarbij het risico van benadeling te lopen, over zijn eigen situatie klachten kenbaar kan maken.

Een dergelijke wettelijke voorziening bestaat op dit moment alleen in Duitsland (232). De BetrVG voorziet in het recht van de individuele werknemers bij de "zustandigen Stellen des Betriebs" bezwaar te maken wanneer hij zich door de werkgever of door zijn collega-werknemers benadeeld acht of onrechtmatig behandeld meent, zonder daarvan nadeel te ondervinden. Een lid van de ondernemingsraad mag ter ondersteuning of bemiddeling bij de behandeling van het bezwaar aanwezig zijn.

De procedure voorzover deze op de werkgever betrekking heeft hangt samen (233) met het informatierecht van de werknemer en het recht gehoord te worden (234). Dit laatste recht geldt voor die ondernemingsaangelegenheden die de werknemer in persoon betreffen. Hij heeft tevens het recht hieromtrent voorstellen in te dienen bij de werkgever. Ook ten aanzien van de beoordeling van zijn werkzaamheden en de mogelijkheden zich verder beroepsmatig te ontwikkelen heeft hij een recht geconsulteerd te worden. Het gaat hier niet om een algemeen hoorrecht; het is steeds beperkt tot die zaken waar de individuele werknemer zelf bij betrokken is.

In andere lid-staten zijn niet zulke duidelijke procedures in het leven geroepen, hoewel de mogelijkheid tot het doorgeven van klachten met waarborgen tegen benadeling hier en daar wel gegeven is. In Frankrijk hebben werknemers sedert 1982 het "droit d'expression" in de onderne-

232. Paragraaf 84 BetrVG.

233. K. Fitting c.s., a.w. (noot 61), p. 922.

234. Paragrafen 81 en 82 BetrVG. 
ming (235). Het wettelijk recht is niet meer dan het recht klachten, suggesties en meningen bij de leiding naar voren te brengen zonder dat dit voor de werknemer nadelen met zich meebrengt. Rechters hebben dit laatste ruim uitgelegd en de werknemers met name voor hun uitspraken in de groupes d'expression immuniteit verleend. In collectieve overeenkomsten op ondernemingsniveau) kunnen procedures worden geregeld (het "droit d'expression" behoort tot de zaken waarover verplicht met de representatieve vakbonden onderhandeld dient te worden). Dit is in de praktijk ook gebeurd (236). Van een echt individueel klachtrecht is echter geen sprake.

In andere landen heeft het klachtrecht als het al aanwezig meer het karakter gekregen van een arbitrageprocedure om geschillen op te lossen. Zo voorziet de Italiaanse wet (237) in geschillen procedures waarin tripartite commissies (waarvan ook een ambtenaar van de lokale afdelingen van het ministerie van Arbeid lid is) bemiddelen in of onderhandelen over individuele conflicten. De bedoeling daarvan is het geschil buiten de formeel juridische kaders op te lossen, zodat de arbeidsverhoudingen (misschien) niet al te erg verstoord raken (238). Eenzelfde soort regeling geldt in België waar bij individuele problemen in beginsel wordt bemiddeld door de vakbondsafvaardiging, en als men er niet uitkomt er beroep mogelijk is op het paritair comite (239). In Ierland kent alleen de Unfair Dismissals Act een klachten-procedure (240).

Dergelijke arbitrageregelingen veronderstellen echter al een enigszins uit de hand gelopen conflict; een klachtenprocedure zou juist ingesteld kunnen worden om conflicten te voorkomen.

De andere lid-staten hebben geen wettelijke klachtenprocedures. Wel is het met name in die lid-staten waar shop stewards als voornaamste vertegenwoordiger van de werknemers optreden gebruikelijk dat deze ook bemiddelen bij conflicten, en de doorgever van klachten naar de werkgever zijn. Individuele werknemers hebben hier echter geen aanspraak op.

In Nederland kwam bij de behandeling van de de Arbowet in de Tweede Kamer wel ter sprake dat een klachtenprocedure wenselijk zou zijn (241), er is echter niet in voorzien. De vakbonden hebben in collectieve overeenkomsten soms wel een individueel klachtrecht gecreëerd; een vorm is het instellen van een een algemene ombudsman, of een ombudsman voor specifieke onderwerpen (242). Een wettelijke regeling omtrent een

235. Artikel L. 461-1 ev. CdT, ingevoerd bij Wet van 4 augustus 1982, Droit Social 1983, p. 571, herzien bij wet no. 86-1 van 3 januari 1986.

236. G. Lyon-Caen, J. Pélissier, a.w. (noot 21), p. 449-456.

237. Wet no. 533 uit 1973 .

238. T. Treu, a.w. (noot 153 ), para. 257-264.

239. R. Blanpain, a.w. (noot 80), para. 172.

240. M. Redmond, a.w. (noot 51), para. 333.

241. TK. 1978-1979, 14 497, no. 9 p. 20 (Eindverslag), zie ook TK. 1979-1980, 14 497, no. 11, p. 25 (Nota naar aanleiding van het Eindverslag).

242. Zie 0.m. Y. Konijn, Kroniek Arbeidsrecht, Nemesis 2(1985)5, p. 221. 
individueel klachtrecht voor wat betreft gewetensbezwaren is overigens wel aangekondigd (243). Bovendien is aan de Raad van State advies gevraagd over een wettelijke regeling van het klachtrecht. Dit zou dan moeten gebeuren via een wijziging of aanvulling van artikel $1638 \mathrm{z}$ BW (244).

\subsection{De randgroepwerknemers: het democratieprobleem}

All in hoofdstuk III is opgemerkt dat in landen met wettelijke regelingen mogelijkheid tot het kiezen van vertegenwoordigers niet openstaat voor alle werknemers. De meeste wetten kennen restricties die gebonden zijn aan het aantal maanden dat men in dienst is en leeftijd; bovendien kan het feit of men al dan niet een werknemer in de zin van de betreffende wet van belang zijn.

In landen met een op vrijwillige basis geregeld systeem is in het algemeen het vakbondslidmaatschap het bepalend criterium. Dit levert op zichzelf al een beperking van het democratisch gehalte van de medezeggenschap op (wie geen lid is wordt niet vertegenwoordigd) dat in beginsel alleen door een closed shop kan worden doorbroken. Bovendien kunnen de bonden bepaalde categorieën werknemers, ook indien zij wel lid zijn van de vakbond, uitsluiten van democratische besluitvorming binnen de bond. Volgens Kidner kunnen Britse vakbonden aan bepaalde categorieën leden waaronder werklozen, en degenen die op afroep werken het stemrecht ontnemen (245).

Daarnaast beperkt het representativiteitsvereiste het aantal bonden dat aan de onderhandelingen deel kan nemen. In de meeste lid-staten is het zo, dat de werkgever slechts onderhandelingen voert met de meest representatieve vakbonden in de onderneming (246). Welke die bonden zijn hangt af van de praktijk of de wetgeving hieromtrent in de lid-staten. Het representativiteitsvereiste betekent wel dat andere bonden geen recht tot onderhandeling kunnen doen gelden, en daarmee hun mogelijkheid tot beïnvloeding van het ondernemingsbeleid kwijt zijn.

Nu kan men zeggen dat de werknemers die dààronder lijden, er dan verstandig aan doen lid te worden van de meest representatieve bond. Dat kan echter alleen wanneer die bonden deze werknemers ook toelaten. Met name in het gevall vakbonden veeleer beroepsbonden zijn dan bedrijfsbonden kan dit problemen geven.

243. Een wetsontwerp ter regeling van een beperkt indiwidueel klachtrecht is wel aangekondigd in de notitie Gewetensbezwaarden in dienstbetrekking, TK. 1985-1986, 19377 nrs. 1 en 2.

244. Zie ook het advies van de Stichting van de Arbeid, een commentaar daarop is opgenomen in Sociaal Recht 1990 p. 75; (Zie ook TK. 1989/90 21300, no. 15 (Antwoord wan de minister van Sociale zaken en Werkgelegenheid op kamervragen no. 64 en 72).

245. R. Kidner, Trade Union Democracy: Election of Trade Union Officers, Industrial Law Journal 1984, p. 200.

246. A.T.J.M. Jacobs, Het recht op collectief onderhandelen, Alphen a/d Rijn 1986, p. 112-117. 
In een aantal lid-staten is voor wat betreft de vertegenwoordiging inzake veiligheids- en gezondheidsaangelegenheden dit probleem opgelost door deze specifieke vertegenwoordigers in de vigerende wetgeving los te koppelen van de vakbonden. Dit is met name in Griekenland, Ierland en Denemarken het geval, al geldt ook hier dat onderhandelingstaken meestal aan de vakbondsvertegenwoordigers toekomen (247).

Zowel in Italle (248) als in Groot Brittannie zijn veiligheidsvertegenwoondigers gebonden aan de vakbonden (249). In Groot Brittannië zijn de taken van veiligheidsvertegenwoordigers overigens wel vastgelegd $(250)$, dit in tegenstelling tot de taken van de "gewone" shop stewards.

In beide landen is een deel van het democratieprobleem opgelost door het feit dat shop stewards (die veelal de rol van veiligheidsvertegenwoordigers op zich nemen) werken op de afdeling die zij vertegenwoordigen. Men kent ze dus, en de verantwoording aan hun achterban wordt zeer direct afgelegd. Het niet goed vertegenwoordigen van de werknemers heeft hiermee directe gevolgen (met name wanneer er verkiezingen worden gehouden (251)).

Aan de werknemers die geen lid van een vakbond kunnen of willen worden biedt deze oplossing overigens geen soelaas. Er kunnen verschillende redenen zijn waarom werknemers geen lid kunnen worden: ofwel, het is al eerder gezegd, omdat zij niet als werknemer in de traditionele zin worden beschouwd (bijvoorbeeld omdat zij een relatief grote zelfstandigheid hebben en formeel niet in een gezagsrelatie tot de onderneming staan), ofwel omdat registratie als lid van een organisatie als een vakbond zou kunnen leiden tot uitzetting uit het land in geval van illegaliteit. Andere werknemers zullen mogelijk om praktische of ideologische redenen geen lid van een bond willen worden. Deze laatste groepering behoort op zilchzelf niet tot de randgroep-werknemers. Desondanks hebben ook zij geen mogelijkheid invloed uit te oefenen via vertegenwoordiging zolang die vertegenwoordiging geheel aan de vakbonden wordt overgelaten.

\subsection{Vertegenwoardiging door homogene groepen als steun aan de individuele werknemer}

De zwakke positie van de individuele werknemer in de systemen van medezeggenschap in het algemeen, wordt van meer belang naarmate de vertegenwoordigers verder van de individuele werknemer afstaan. Indien de

247. O. Rieper, a.w. (noot 34), p. 123; LO, a.w. (noot 53), p. 42 .

248. Zie paragraafi II.2.3.

249. Slechts erkende bonden hebbem het recht veiligheidsvertegenwoordigers te benoemen: C.D. Drake, F.B. Wright; a.w. (noot 138), p. 193.

250. Safety Representatives and Safety Committee Regulations 1977, S.I. 1977, no. 500, gezamenlijk gepubliceerd met een Code of Practice, in geval er en veiligheidscommissie wordt gevormd liggen de taken vast in Guidance Notes.

251. Zie hierover o.m. S. Sciarra, The Impact of Juridification on Current Deregulative Trends in Italy, Comparative Labor Journal, Vol 8, no.2, 1987, pag. 129. 
individuele werknemer de vertegenwoordigers niet kan overtuigen van de ernst van de gevaren voor veiligheid en gezondheid in de omstandigheden waaronder hij moet werken, heeft hij weinig kans, gezien de afhankelijkheid van de vertegenwoordigers, zijn problemen onder de aandacht van de werkgever te krijgen. Zolang de vertegenwoordigers zelf deel uitmaken van de groep die zij vertegenwoordigen en bovendien verkozen worden door die groep, bestaat er gerede kans dat dit probleem geen ernstige vormen aanneemt. De beïnvloeding kan dan nog op vrij informele, maar effectieve wijze plaatsvinden, en (niet onbelangrijk), de vertegenwoordiger ondervindt de problemen van diegenen die hij vertegenwoordigt aan den lijve. Dit kan minder worden naarmate de vertegenwoordigers verder van de werknemers afstaan, maar ook wanneer zij minder met hen gemeen hebben. Een fulltime werknemer kent de problemen van part-timers en thuiswerkers (als hij ze al kent) in beginsel alleen van horen zeggen, voor een mannelijke werknemer geldt hetzelfde met betrekking tot de problemen van vrouwelijke werknemers die op typische "vrouwenafdelingen" als type-kamers zitten. De beïnvloeding van de vertegenwoordigers door deze laatste groepen (die om formele of materiële redenen vaak niet vertegenwoordigd zijn) kan alleen al om deze redenen aanzienlijk moeilijker verlopen.

Een oplossing voor met name de zwakkere groepen, maar ook voor anderen binnen de structuur van de medezeggenschap kan derhalve zijn de vertegenwoordiging te laten kiezen binnen homogene groepen, zoals dat in Italië en Groot Brittannië gebeurt. In een aantal wetten in Europa is dit probleem in die zin geregeld dat ook daar per groep vertegenwoordigers gekozen worden (Spanje en tot op zekere hoogte België en Frankrijk). Voorwaarde voor dergelijke homogene groepen is mijns inziens echter wel, dat zij niet per definitie aan de vakbond gebonden moeten zijn. Een systeem als het Spaanse, waar de ondernemingsraad verkozen wordt naar (homogene) groep, en de leden banden (kunnen) hebben met de vakbond, maar waar het kiesrecht binnen de onderneming niet specifiek aan de vakbond gebonden is, verdient mijns inziens dan ook de voorkeur. Een probleem hiermee is natuurlijk dat er geen exact criterium is waaraan gemeten kan worden of een groep homogeen is. Het door mij aangehaalde voorbeeld van vrouwelijke werknemers is daar een voorbeeld van: zijn vrouwen binnen de onderneming altijd een homogene groep? Of zijn zij dat alleen als er typische "vrouwenafdelingen" bestaan. En die vrouwen die op andere afdelingen werken, worden hun belangen dan wel afdoende vertegenwoordigd? Eenzelfde redenering kan worden gevolgd als men het woord vrouw vervangt door "buitenlandse werknemer". Mijns inziens neemt dit definitieprobleem niet weg dat vertegenwoordiging gekozen binnen zo homogeen mogelijke groepen, een grotere betrokkenheid van de individuele werknemers kan bewerkstelligen.

Voor zover die speciale zwakke categorieën als werknemers met flexibele arbeidscontracten, thuiswerkers en buitenlandse werknemers niet altijd binnen de werkingssfeer van de betreffende medezeggenschapswetten vallen, of geen mogelijkheid hebben hun stem te laten horen binnen de vak- 
bond (252), zou men moeten zoeken naar andere wegen om hen in te schakelen. Een oplossing voor deze categorieën werknemers zou kunnen zijn dat een regeling wordt getroffen waarin zij eigen vertegenwoordigers zouden kunnen afvaardigen (als zij beschouwd kunnen worden als een homogene groep) zodat deze de belangen in verband met de werkomstandigheden naar voren zou kunnen brengen in het overleg met de werkgever. Deze vertegenwoordiging zou geformaliseerd kunnen worden, bijvoorbeeld, wanneer het gaat om een van de onderneming gescheiden groep als thuiswerkers, deze als aparte categorie in de wet op te nemen of als speciale groep in de betreffende bedrijfsbond te laten participeren.

Ik ben van mening dat de oplossing voor de zwakke categorieëen werknemers eerder in overheidsinterventie dan in oplossingen op vrijwillige basis gezocht moet worden. Enerzijds kan men hen beschermen met een algemene hoge standaard in de normering (253). Deze standaard geldt voor iedereen en niet alleen van de zwakke categorieën werknemers. Voor deze latste groepen geldt wel dat de controle op de naleving van die standaard scherper moet zijn, juist omdat zij de groepering zijn wier rechten gemakkelijker met voeten getreden kan worden en juist omdat zijzelf vaak niet in de positie verkeren hun stem te verheffen indien de normen overtreden worden. Anderzijds is bescherming te vinden in een aparte normering in aanvulling op de bestaande structuren van medezeggenschap. De reden hiervoor is dat groepen die een dermate zwakke positie hebben in de onderneming het risico lopen -en dit blijkt ook wel uit het voorgaande- dat zij eenzelfde zwakke positie binnen de vakbonden innemen, en dus met die positie niet geholpen zijn. Het arbeidsbeschermende recht moet ten opzichte van deze groepen dus een speciale functie vervullen.

Het bovenstaande is een pleidooi voor overheidsinterventie in veiligheidsen gezondheidsaangelegenheden, in vrij vergaande mate. Dit is het soort oplossing dat weerstanden oproept en waarvan wordt gevreesd dat dit te vergaande consequenties voor het systeem van arbeidsverhoudingen kan hebben. Sommige Britse auteurs menen dat overheidsinterventie en daarmee, juridifisering van de industriële verhoudingen, op zichzelf de positie van de vakbonden (en dus de werknemers) verzwakt. Juridifisering zou ingrijpen in het proces van autonomie en de vrijheid van de vakbonden limiteren omtrent datgene te onderhandelen dat zij belangrijk achten. Aldus zou het resultaat van een ingrijpen door de overheid een verzwakking van de vakbond over de hele linie kunnen betekenen (254). En, het zij toegegeven, juist in Britse verhoudingen zou een dergelijke overheidsinterventie vrij vergaande consequenties hebben.

252. Zie als woorbeeld R. Lewis, B. Simpson, Striking a balance? Employment law after the $1980 \mathrm{Act}$, Oxford 1981, p. 107-113.

253. Zie paragraaf $\mathrm{V} \cdot 1.1$

254. J. Clark, The Juridification of Industrial relations, A Review Article, The Industrial Law Journal, 1985, p. 78 . 
Echter wanneer het proces van collectief onderhandelen geen zorg kan dragen voor effectief beschermende maatregelen van individuen of speciale categorieën werknemers, valt te verdedigen dat staatsinterventie gerechtvaardigd is: In feite is die op het veiligheids- en gezondheidsgebied, ook in die landen waar men de grootst mogelijke bezwaren tegen interventie heeft wel geaccepteerd. Ook in Denemarken en Groot Brittannië kent men wettelijke normering op dit terrein, al is de juridifisering van de onderhandelingen op ondernemingsniveau voor het overige niet geregeld. Desondanks zijn het niet altijd alleen de vakbonden die zich tegen interventie verzetten (255). De Nederlandse regering concludeerde in 1986, dat de arbeidsomstandigheden van bijvoorbeeld thuiswerk(st)ers slecht zijn, vastgestelde normen niet of zelden worden nageleefd, en er geen sprake is van van een organisatie die met de werkgevers kan onderhandelen. Toch meende de regering dat de verbetering van die omstandigheden moest worden gezocht in zelfregulering. De regering zag haar taak als een ondersteunende en stimulerende (256). Mijn inziens is deze houding te danken aan een te sterk verlangen naar zelfregulering, terwijl de actoren in dit proces daartoe niet in staat zijn. Juist in een dergelijk geval moet mijns inziens de overheid wel degelijk ingrijpen.

De vraag die dan nog overblijft is hoever die interventie mag gaan. Clark (257) schetst met een citaat van Simitis (258) het dilemma waar, met name regulering met betrekking tot veiligheid en gezondheid, in vervat is: "State intervention, is at one and the same time, a necessary reaction in the interests of improving the living conditions of employees and an unavoidable beginning of an occupation of their life-world". Interventie zou, zo kan men uit deze uitspraak afleiden niet verder mogen gaan dan strikt noodzakelijk is, om te bereiken dat de belangen van individuele werknemers, ten opzichte van het systeem van collectief onderhandelen en daarbinnen, behartigd worden, zonder dat het gehele systeem er van doortrokken wordt.

Regulering van belangenbehartiging voor die werknemers die er in de gewone medezeggenschapsstructuren of ze nu een wettelijke basis hebben of een vrijwillige, (en dan met name voor wat betreft die laatste, in de eerste heeft de staatsinterventie tenslotte al plaatsgehad) er niet aan te pas komen, zou ook in die redenering te rechtvaardigen zijn. Wanneer de gebruikelijke arbeidsverhoudingen die bescherming niet kunnen bieden mag, en wat mij betreft, moet de overheid ingrijpen. Anderzijds indien het

255. Het Steunpunt. Thuiswerk van de Vrouwembond FNV meemt het standpunt in dat thuiswerk niet onder de arbeidsomstandighedenwet zou moeten worden gebracht, aangezien dit arbeidsplaatsen zou kosten (zie Balans van thuiswerk, Hengelo, Stichting Steunpunt Thuiswerk Vrouwenbond FNV, oktober 1988),

256. Ministerie van Sociale Zaken en Werkgelegenheid, (Concept) Nota herintredende wrouwen, Den Haag 1986, p. 26-27.

257. J. Clark, a.w. (noot 254), p. 78.

258. F. Kübler, W. Schmidt, S. Simitis, Mitbestimmung alls Gesetzgebungspolitische aufgabe, Baden-Baden 1978. 
industriele systeeem zichzelf zodanig herstructureert dat de bescherming wel geboden kan worden, zal de overheid moeten terugtreden.

Voor regulering als vangnet, voor het geval onderhandelingen niet werken, dus met name in de vorm van hoge standaarden, geldt hetzelfde "En eveneens valt mijns inziens te verdedigen dat staatsinterventie in de vorm van controle op (wettelijk gegeven of overeengekomen) normen, als noodzakelijk zou kunnen worden beschouwd. Ook als de medezeggenschap wel werkt kunnen werknemers en werkgevers gezamenlijk een belang hebben bij het negeren van die normen (hetgeen bij wettelijke standaarden mogelijk vaker zal voorkomen).

7 Conclusies met betrekking tot het totaal aan instrumentarium van de vertegenwoordigers in de lid-staten

Uit de voorgaande hoofdstukken was al gebleken dat alle lid-staten op éên of andere wijze een medezeggenschapsstructuur in de arbeidsverhoudingen geîncorporeerd hebben. Of deze nu op wettelijke of vrijwillige basis is gestoeld, alle regelingen hebben de mogelijkheid voor werknemersvertegenwoordigers om

a. informatie te ontvangen van de werkgever, ten aanzien van meer of minder ruim omschreven punten

b. geconsulteerd te worden, in te stemmen met, of te onderhandelen over de besluiten. Dit laatste geldt met name ten aanzien van sociale aangelegenheden waaronder veiligheids- en gezondheidsaangelegenheden moeten worden begrepen,

c. deze rechten af te dwingen bij arbiter, rechter of door middel van directe actie.

In een aantal lid-staten bestaat daarnaast de mogelijkheid de genomen beslluiten inhoudelijk te laten toetsen.

Voor wat betreft de veiligheids- en gezondheidsregelingen kan daar het volgende aan worden toegevoegd. In praktisch alle lid-staten heeft de medezeggenschap aangaande veiligheid- en gezondheid een wettelijke basis. Zelfs in Groot Brittannië en Denemarken waar de "gewone" medezeggenschap praktisch geheel een vrijwillige basis heeft, is in specifieke wetten een structuur van medezeggenschap bij veiligheids- en gezondheidsaangelegenheden in het leven geroepen, die deels geincorporeerd is in de algemene structuur, en deels een aantal specifieke rechten voor werknemersvertegenwoordigers op dit terrein in het leven heeft geroepen. Slechts Italie heeft op dit gebied maar én specifiek wettelijk recht, namelijk het recht van toezicht. De wettelijke faciliteiten voor de vakbondsvertegenwoordiging in de onderneming zijn echter zodanig, dat men ook hier van een, zij het magere, wettelijke basis kan spreken.

In alle lid-staten is contact met deskundigen (intern of extern) en arbeidsinspectie mogelijk, en bestaan er mogelijkheden om al dan niet gesteund door de arbeidsinspectie of interne deskundigen bij ernstig (dreigend) gevaar 
maatregelen te nemen, die in de meeste lid-staten kunnen uitlopen op het stilleggen van het gehele of een deel van het productieproces.

De zwaarte van de systemen verschilt wel. In het vorige hoofdstuk werd geconcludeerd dat de Deense, het Luxemburgse en het Duitse systemen als sterkste konden gekwalificeerd, voor wat betreft de inhoud van de aan de vertegenwoordigers toegekende rechten. Op basis van de aan de werknemersvertegenwoordigers toegekende rechten die specifieke inzake veiligheids- en gezondheidsaangelegenheden van belang zijn, lijkt dit beeld te worden bevestigd. In Denemarken bestaan weliswaar minder minder mogelijkheden om deskundigen te raadplegen, de Deense veiligheidsvertegenwoordigers hebben wel het recht het werk stil te leggen. De Franse, Nederlandse, Duitse, Deense en de Spaanse werknemersvertegenwoordigers hebben ten opzichte van de arbeidsinspectie de sterkste positie, al wordt deze in alle lid-staten ondergraven door een tekort aan inspecteurs.

De meest opvallende conclusie, in het licht van de mogelijkheid om tot een Europese regeling te komen, is echter dat de rechten elkaar uiteindelijk onderling niet veel ontlopen. In onderstaande tabel wordt het instrumentarium van de vertegenwoordigers in de lid-staten schematische weergegeven.

Deze feiten, zo sec bekeken, lijken er op te wijzen dat er praktisch geen probleem zou hoeven te zijn om een medezeggenschapsregeling op gemeenschapsniveau te creëren waarin op verdergaande wijze geharmoniseerd wordt dan alleen de koppeling met de bestaande systemen van medezeggenschap te maken. Alle lid-staten hebben immers al de nodige instrumenten; en de verschillen, in elk geval voor wat het te gebruiken instrumentarium aangaat, zijn gradueel.

Een deel van de weerzin om tot verdergaande maatregelen dan een enkele koppeling met de bestaande systemen te komen, heeft te maken met de rol van de vakbonden in de verschillende systemen van medezeggenschap. Niet zozeer het instrumentarium van medezeggenschap verschilt, maar het feit dat de vakbond als enige die medezeggenschap uitoefent in een aantal lidstaten is het essentiële verschil. Men kan erover discussiëren of deze staten, vanuit hun nationale praktijk gegroeide medezeggenschapsvormen daarin gelijk hebben of niet: het is uiteraard niet altijd wenselijk een op vrijwillige basis vormgegeven structuur te doorbreken met wettelijke maatregelen.

Voor wat betreft een Europese regeling voor medezeggenschap inzake veiligheids- en gezondheidsaangelegenheden gaat dit argument echter niet of nawwelijks meer op. Zoals gezegd zijn hier in praktisch alle lid-staten wettelijke medezeggenschapsregelingen aanwezig, al hebben deze regelingen in een aantal lid-staten (Groot Brittannië, Frankrijk) consultatie van werknemers en niet instemming of onderhandeling als verstgaande wettelijke medezeggenschapsvorm. Echter deze regelingen maken onderhandelingen niet onmogelijk, zij bieden daar slechts geen wettelijk recht op. Er kan in deze landen wel degelijk over veiligheids- en gezondheidsaangelegenheden 
Tabel IV: Medezeggenschapsinstrumenten van de werknemersvertegenwoordigers inzake veiligheid en gezondheid in de lid-staten.

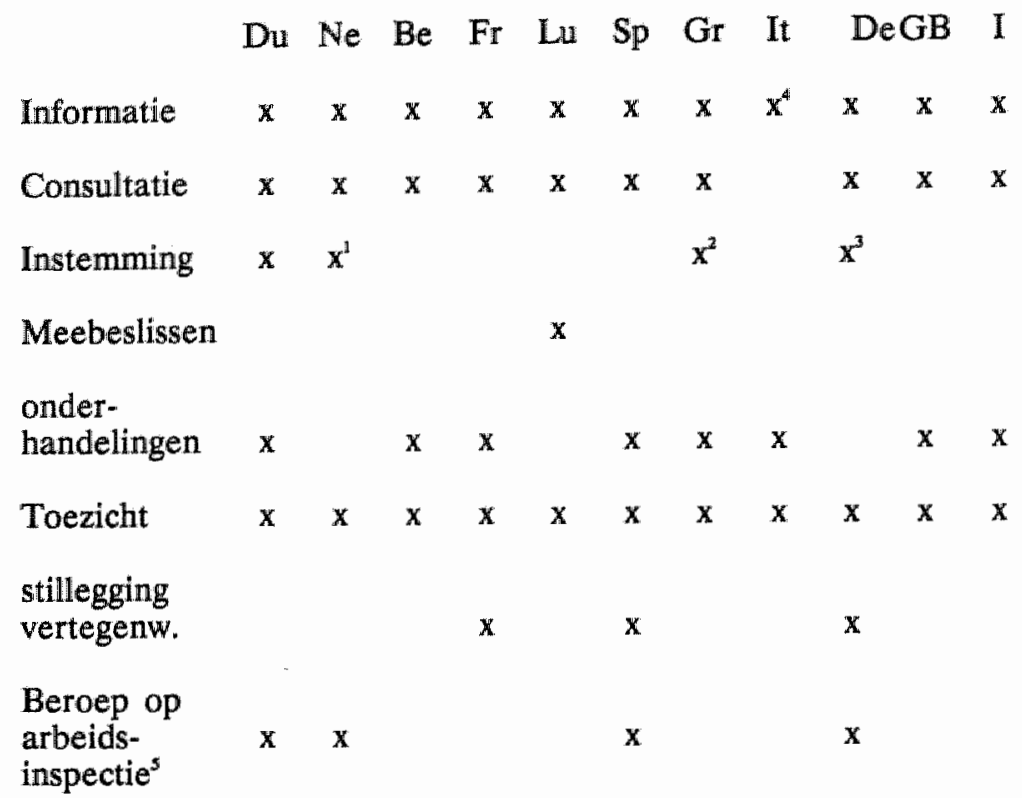

1. Door de wetswijziging zeer beperkt.

2. Komt alleen toe aan de ondernemingsraad indien geen vakbond in de onderneming vertegenwoordigers heeft.

3. Alleen met betrekking tot de beginselen van het veiligheids- en gezondheidsbeleid.

4. Impliciet bij het recht om toezicht te houden, voorts geregeld in Collectieve Overeenkomst van 1983.

5 . Inclusief de verplichting te reageren.

onderhandeld worden. Een Europese medezeggenschapsregeling voor het specifieke veiligheids- en gezondheidsgebied, die verder gaat dan het voorschrijven van een consultatieverplichting zou mijns inziens heel goed mogelijk zijn. Deze regeling zou dan ofwel een instemmingsrecht ofwel de verplichting om tot een overeenkomst te komen met de vertegenwoordigers in de besluitvorming inzake veiligheids- en gezondheidsaangelegenheden moeten voorschrijven.

Het probleem van een dergelijke regeling (in de vorm van een richtlijn) zou zijn dat, zelfs als een dergelijk verdergaand instrumentarium er in opgenomen zou zijn, de medezeggenschap opnieuw gebonden zou zijn aan de nationale grenzen. Er zou geen medezeggenschap gecreëerd worden indien 
de moedermaatschappij zich in een andere lid-staat bevindt. Dit lijkt in eerste instantie niet vreemd. Het gebruik van medezeggenschapsinstrumenten ten aanzien van veiligheid en gezondheid heeft veelal betrekking op situaties die in de directe arbeidsomgeving ontstaan, en waar met de besturen in de vestiging in eerste instantie overleg gevoerd zal moeten worden over onveilige of ongezonde situaties. Dit neemt echter niet weg dat er situaties kunnen ontstaan waarin juist medezeggenschap bij de (zich in het buitenland bevindende) moedermaatschappij van belang kan zijn.

Een andere vraag is wat in een dergelijke regeling de plaats zou moeten zijn van de individuele werknemer en van de groepen die geen mogelijkheid hebben binnen de nationale wetgeving in medezeggenschapsstructuren te functioneren. De positie van de individuele werknemer is zwak binnen praktisch alle nationale regelingen en praktijken, en de positie van de groepen wier status als werknemer twijfelachtig is, is zo mogelijk nog zwakker. Moet een Europese regeling zich om hen bekommeren, of die bekommernis nu juist aan de nationale praktijk overlaten. Een vraag die zeker gezien de tendenzen tot arbeidsflexibilisering in geheel Europa, aan de orde moet komen.

Hierboven concludeerde ik dat voor deze categorieën werknemers een vertegenwoordiging op basis van homogene groepen in de medezeggenschapsorganen een aanzet tot een oplossing zou kunnen bieden. Men kan zich afvragen of niet de gehele samenstelling op basis van homogene groepen, kortom een soort van shop steward systeem, maar dan zonder verplichte vakbondsachtergrond de meest effectieve wijze van vertegenwoordiging zou kunnen opleveren. Recente wetswijzigingen in Duirsland (259) en België (260) tenderen wel enigszins in die richting.

259. Gesetz über Sprecherausschüsse der Leitende Angestellten, van 20 december 1988, BGBIl. I.S. 2312; zie K.P. Martens, Die Neuabgrenzung der leitende Angestellten und die begrenzte Leistungsfähigkeit moderner Gesetzgebung, Recht der Arbeit 1989, p. 73-88.

260. De Wet van 1985 in Belgiè constitueerde cen aparte kiessector voor "cadres", zie R. Blanpain, a.w. (noot 80), para. 245bis. 


Naar een europese regeling voor medezeggenschap inzake veilig-
heids- en gezondheidsaangelegenheden

\section{Inleiding}

$\mathrm{Na}$ de uitstap naar de wetgeving in de lid-staten, wordt het tijd om terug te keren naar de mogelijkheden die de Europese Gemeenschap heeft een medezeggenschapsregeling te maken, op basis van hetgeen de lid-staten al geregeld hebben. Uit het rechtsvergelijkende deel van dit onderzoek trek ik de conclusie dat de overeenkomsten tussen de lid-staten op het gebied van medezeggenschapsregelingen met name inzake veiligheids- en gezondheidsaangelegenheden groot genoeg zijn, om als basis te dienen voor een regeling op gemeenschapsniveau die een eigen inhoud geeft aan, en voorwaarden stelt aan medezeggenschap.

Tot dusver is de Gemeenschap, ondanks de opdrachten daartoe in het EEG-verdrag, met name in de artikelen 117 en 118, steeds zeer terughoudend geweest in het zich bemoeien met die delen van het sociale beleid, die raken aan de tradities van de lid-staten in de collectieve arbeidsverhoudingen. Deels is deze terughoudendheid terecht; de bevoegdheid van de Commissie op basis van artikel 118 is voornamelijk een coördinerende. De opdracht in artikel 117 legt echter well een duidelijke verplichting op tot harmonisatie van het sociale beleid.

De terughoudendheid komt overigens niet geheel voort uit de bevoegdheidsverdeling. Om te beginnen ging men er in de jaren zestig vanuit dat het naar elkaar toe groeien van de sociale wetgeving zou volgen uit de economische groei (1). Ook het feit dat nogal wat voorstellen voor harmonisatierichtlijnen op sociaal terrein van de Commissie sneuvelden in de Raad, maakte dat het sociale beleid niet van de grond kwam (2). Als voorbeeld kunnen de pogingen om tot een medezeggenschapsrichtlijn op

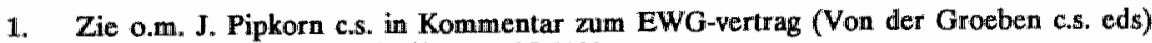
Baden-Baden 1983 (3e druk), p. 1985-2089.

2. Voor een overzicht hiervan: zie L. Betten, Prospects for a Social Policy of the European Community and its impact on the Functioning of the European Social Charter (p. 106110) en D. Curtin, Prospects for a European Social Policy, (p. 144) in L. Betten ed. The Future of European Social Pollicy, Deventer 1989. 
multinational niveau te komen, dienen (3). Richtlinen die het wel haalden in de Raad, reguleerden veelal een beperkt terrein, en sloten voor wat betreft de "gevoelige issues" in hoge mate aan op de in de lid-staten bestaande regelingen en praktijken (en zaten wat normering betreft daar niet zelden nog wat onder) (4).

Voor de bescherming met betrekking tot veiligheid en gezondheid van werknemers ligt dit iets anders. Sedert 1977 is een aantal harmonisatierichtlijnen op dit gebied tot stand gekomen, die artikel 100 EEG-verdrag als basis hebben. Daarnaast heeft de Commissie een groot aantal voorstellen gedaan voor njeuwe richtlijnen op dit terrein. Bovendien is, door middel van de Europese Akte in 1987, artikel 118A aan het EEG-verdrag toegevoegd, dat een grondslag biedt voor meer richtlijnen, die op een eenvoudiger manier dan via de procedure van artikel 100 kunnen worden vastgesteld.

Met andere woorden: terwijl het moeizaam is gebleken een materie, die in tenminste een aantal lid-staten door collectieve onderhandelingen beheerst wordt, te harmoniseren kon met betrekking tot de bescherming van werknemers op het gebied van veiligheid en gezondheid voortvarender worden opgetreden. Dit roept de vraag op waarom de lid-staten wel maatregelen op het ene gebied accepteren, terwijl op het andere kennelijk absoluut geen overeenstemming is te verkrijgen?

Het is niet uitgesloten dat de lid-staten (en met betrekking tot de invoering van artikel $118 \mathrm{~A}$ ook de respectieve nationale parlementen) ervan overtuigd zijn dat de bescherming op het gebied van veiligheid en gezondheid van werknemers zodanig belangrijk is dat harmonisatie van wetgeving en bestuursrechtelijke maatregelen op dit terrein noodzakelijk is; zo noodzakelijk dat de harmonisatie een specifieke rechtsgrondslag in het verdrag. behoeft (5). Voor wat de invoering van artikel 118A aangaat, is het echter ook denkbaar dat men meende dat enige concessies op het gebied van het sociale beleid (met name om de ergste sociale dumping te voorkomen) noodzakelijk waren, indien op de andere terreinen de interne markt 'echt' tot stand zou komen (6).

Een minder politiek geïnspireerde reden waarom op dit specifieke gebied van het arbeidsrecht wél en op andere gebieden geen overeenstemming in de Raad mogelijk is, kan zijn dat de bescherming met betrekking tot veiligheid en gezondheid traditioneel veel meer door wettelijke regelingen

3. Zie paragraaf II.4.2.A. ev.

4. Met name $\mathrm{RI}$. 75/129/EEG Pb 1975, L48, collectief ontslag; R1. 77/187/EEG Pb. 1977, $L 61$, rechten van werknemers bij overgang van ondernemingen.

5. Zie ook P.J.G. Kapteyn en P. VerLoren van Themaat, Inleiding tot het recht der Europese Gemeenschappen, Deventer 1987, p. 416.

6. E. Vogel-Polsky, L"Acte Unique ouvre-t-ill l'espace social europeen, Droit Social 1989, p. 183. 
dan door collectieve overeenkomsten is gereguleerd. Harmonisatievoorschriften van gemeenschapswege, in ieder geval voorzover zij betrekking hebben op concrete normstelling ten aanzien van specifieke gebieden, grijpen niet of maar zeer ten dele in de industriële machtsverhoudingen van de verschillende lid-staten in. In elk geval grijpen deze voorschriften niet meér in, dan men al op de nationale niveau's geaccepteerd heeft (7).

Of dit ook nog zo zal zijñ wanneer een richtlijn normen stelt over de mate van invloed die werknemers (eventueel door middel van hun vertegenwoordigers) ten aanzien van het veiligheids- en gezondheidsbeleid in de onderneming kunnen gaan uitoefenen is nog maar de vraag. Lange tijd heeft de Gemeenschap aan medezeggenschap inzake veiligheid en gezondheid slechts heel impliciet eisen gesteld.

Deze normstelling behoort tot de mogelijkheden. Artikel 118A schrijft slechts voor dat minimumnormen moeten worden vastgesteld, maar het artikel is zodanig open geredigeerd (de term minimumnormen is tenslotte al voor meer interpretaties vatbaar), dat het, ook in institutionele zin, verdergaande consequenties kan hebben.

Het is niet uitgesloten dat dit gebeurt. De eerste richtlijn die de Raad heeft aangenomen op basis van artikel $118 \mathrm{~A}$ is er éen die niet voorziet in harmonisatie van standaarden, maar veeleer in harmonisatie van procedures op ondernemingsniveau inzake veiligheids- en gezondheidsaangelegenheden (8). Deze richtlijn raakt wel aan het gebied van medezeggenschap, dat op zijn minst omstreden kan worden genoemd. Als aangenomen mag worden dat medezeggenschap bij veiligheids- en gezondheidsaangelegenheden onder artikel artikel $118 \mathrm{~A}$ valt, is niet uit te sluiten dat de Commissie de mogelijkheden van artikel $118 \mathrm{~A}$ ten volle zal gaan uitbuiten, zoals zij dat eerder bij andere verdragsartikelen waarbij de lid-staten dat misschien niet verwacht hadden, heeft gedaan (9). Dit zou kunnen betekenen dat de vastgelopen medezeggenschapsdiscussie langs de weg van artikel $118 \mathrm{~A}$ mogelijk opengebroken zou kunnen worden, met een betere en duidelijker grondslag dan die van artikel 100 of die van artikel 235 .

7. Zie B. Bercusson, Fundamental Social and Economic Rights, Report to the European Economic Community, Florence 1989, p. 94.

8. R1. 89/391, van 12 juni 1989 , Pb. 1989 L 83; richtlijn betreffende de tenuitvoerlegging van maatregelen ter bevordering van de verbetering van de weiligheid en de gezondheid van de werknemers op het werk.

9. Ik denk hierbij aan de richtlijnen op het gebied van gellijke behandeling van mannen en vrouwen, die op zichzelf niet voortkomen uit artikel 119 EEG-verdrag, maar waar dat artikel in hoge mate toe inspireerde, zie bijv. de preambulle van RI. 86/378/EEG (gelijke behandeling van mannen en vrouwen in ondernemings- en sectoriele regelingen inzake sociale zekerheid). Ook kan men eraan twijfelen of een artikel als 119 EEG-verdrag voor alle lid-staten acceptabel zou zijn geweest, als men geweten had dat het Hof rechtstreekse werking van dit artikel zou aannemen. Zie thierover o.m. S. Prechal, Gelijke behandeling in de rechtspraak wan het Europese Hof van Justitie, Nemesis 1(1984/5)4, p. 167. 
Wanneer men echter constateert dat, gezien de wettelijke maatregelen in de lid-staten, een harmonisatierichtlijn op het veiligheids- en gezondheidsgebied in elk geval tot de juridische (zij het dan mogelijkerwijs niet tot de politieke) mogelijkheid behoort, dan moet men zich ook buigen over de wraag op welke wijze deze dan in een richtlijn ingevuld zouden moeten worden. Legt de term minimumnormen een verplichting op om hooguit alls vangnet voor de wettelijke regelingen in de lid-staten te fungeren? In dat geval kan een harmonisatieregeling op dit moment niet veel verder gaan, dan een consultatieverplichting. In elk geval kan de bepaling dan geen medezeggenschapsvorm in concernverhoudingen opleveren zolang dergelijke woorschriften niet vanuit de lid-staten worden geinitieerd. De term minimumnorm kan echter ook een communautaire inhoud krijgen: dan kan men vaststellen dat werknemersparticipatie in de beslunttvorming een minimumvoorwaarde is, voor een goed veiligheids- en gezondheidsbeleid in de onderneming.

In dit hoofdstuk zullen in de eerste plaats de mogelijkheden voor een. regeling op Europees niveau besproken worden die, gezien de regelgeving op nationaal niveau voor het veiligheids- en gezondheidsbeleid juridisch haalbaar zijn. Hierbij zal met name gekeken worden naar de institutionele en materiële consequenties van artikel $118 \mathrm{~A}$. Voorts zullen achtereenvolgens de richtlijnen en de voorgestelde ontwerprichtlijnen op dit terrein getoetst worden aan de normatieve criteria zoals deze afgeleid kunnen worden uit de beginselen die de lid-staten gemeenschappelijk hebben. Daarnaast zal bekeken worden in hoeverre de bestaande mogelijkheden hun weerslag kunnen hebben op de gebieden die aan de bescherming van werknemers met betrekking tot de bescherming van veiligheid en gezondheid zijn gerelateerd.

2 Een op de wetgeving en praktijk van de lid-staten te baseren concept voor een medezeggenschapsregeling inzake veiligheids- en gezondheidsaangelegenheden

Sedert 1977 is een aantal richtlijnen totstandgekomen op het gebied van veiligheid en gezondheid van werknemers. Het betreft hier onder meer de richtlijn over veiligheidssignalering op de werkplaats (10), de richtijin ter bescherming van de gezondheid van werknemers die aan vinylchloridemonomeer zijn blootgesteld (11), de richtlijnen met betrekking tot metallisch lood, asbest en lawaai (12), de algemenere raamrichtlijn betreffende bescherming van werknemers tegen risico's van blootstelling aan chemische, fysische en biologische agentia op het werk (13), en zeer recent de raamrichtlijn de uitvoering van maatregelen ter bevordering van de

110. RI. 77/576, Pb. 1977 L 229.

11. RI. $78 / 610$, Pb. 1978 , L 197.

12. RI. 82/605 Pb. 1982, L 247 (Metallisch lood); 83/477, Pb. 1983, L 263 (Asbest); RI 86/188, Pb. 1986 L 137 (Lawaai).

13. RL 80/1107, Pb. 1980, L 327 . 
verbetering van de veiligheid en gezondheid van werknemers op het werk (14).

Deze eerste richtlijnen zullen, gezien de vele voorstellen door de Commissie gedaan en die bij de Raad liggen, slechts een begin vormen van een veel uitgebreider stelsel van harmonisatieregels op het gebied van de arbeidsomstandighedenbescherming. De voortschrijdende integratie en de (mogelijke) voltooiing van de interne markt in en na 1993 (15) heeft zowel bij de Commissie als bij het Europese Parlement ongerustheid doen ontstaan over de bescherming van werknemers. In verschillende resoluties verzoekt het Europees Parlement de Commissie voorstellen te doen om "dumping" op sociaal gebied tegen te gaan, normverlaging te voorkomen en zowel een programma op te stellen dat concrete maatregelen voorstelt als een maatregel vast te stellen omtrent fundamentele sociale rechten (16). Daarnaast wijst het Parlement erop dat ook werkgevers en vakbonden in deze verantwoordelijkheden hebben in zaken als voorlichting, raadpleging en onderhandeling op het gebied van veiligheids- en gezondheidsbescherming.

Ook de Commissie heeft actie ondernomen met het oog op "1992" en heeft een programma opgesteld van concrete uitvoeringsmaatregelen van artikel $118 \mathrm{~A}$, waarin zij onder meer vast heeft gesteld dat de term "veiligheid en gezondheid" van werknemers ook maatregelen op het vlak van de ergonomie voor zover deze noodzakelijk is ter bescherming van die veiligheid en gezondheid van werknemers omvat (17). De Raad heeft met dit programma door middel van een resolutie ingestemd (18).

Dit programma kan worden gezien als een voortzetting en uitbreiding van eerdere actieprogramma's van de Commissie op arbeidsomstandighedengebied, die eveneens door resoluties van de Raad werden ondersteund (19). Deze eerdere actieprogramma's zagen op de etiologie van de arbeidsongevallen, beroepsziekten, bescherming tegen gevaarlijke stoffen, de voorkoming van gevaren en van schadelijke effecten van machines, en de toezicht, de inspectie alsmede de verbetering van het menselijk gedrag. Het nieuwste programma draait in principe om alle soorten van risico's op het gebied van veiligheid en gezondheid.

14. $89 / 391$, Pb. 1989, L 183 .

15. Artikel 8A EEG-werdrag, dat door middel wan de Europese Akte is ingevoerd schrijft voor dat op 31 december 1992 de interne markt tot stand moet zijn gebracht. Deze interne markt omvat cen ruimte zonder binnengrenzen waarin het vrije verkeer van goederen, personen, diensten en kapitaal is gewaarborgd.

16. Resolutie Europees Parlement over veiligheid en gezondheid op het werk, doc B2-1703/87, Pb 1987 C 68 p. 100, Resolutie over de totstandkoming van de interne markt in 1992 en de bescherming van werknemers, doc. B2-1704/87, Pb 1987 C 68, pag. 101, doc. B2 1708/87, Pb C 68/102, doc B2-1709/87, Pb 1987 C 68 pag. 101.

17. $\mathrm{Pb} .1988 \mathrm{C} 28$ p. 3 .

18. Resolutie van de Raad, 21 december 1987, Pb. 1988 C 28 p. 1.

19. Resolutie van 29 juni $1978 \mathrm{~Pb}$. 1978, C 165, en van 27 februari 1984, Pb. 1984, C 67. 
Het feit dat de Raad het programma met een resolutie ondersteunt is niet helemaal zonder betekenis. Resoluties hebben in beginsel weliswaar geen rechtsgevolgen, en niet nakoming levert geen verdragsschending op (20); de ondersteunende resolutie kan wel als de politieke wil van de Raad uit het programma uit te voeren gezien worden (21). Bovendien kan het op den duur als hulpmiddel gezien worden bij interpretatie van rechtshandelingen van de instellingen van de Gemeenschap en een bron voor onderzoek en richtlijnvoorstellen van de Commissie zijn.

De ondersteuning van de Raad van het programma bij resolutie zou erop kunnen wijzen dat richtlijnwoorstellen door de Commissie gedaan, tot betrekkelijk weinig problemen in de Raad en dus tot snelle acceptatie aanleiding zullen geven. Deze verwachting is niet geheel terecht. Instemming met een programma dat in betrekkelijk algemene termen is gesteld, blijkt toch vaak een politiek gekleurde handeling te zijn, waarbij, als het op concrete maatregelen aankomt die consequenties hebben voor de nationale wetgeving en het nationale beleid, gas terug wordt genomen (22).

De bestaande richtlijnen ten aanzien van veiligheids- en gezondheidsbeleid hebben als grondslag artikel 100, hetgeen betekent dat zij werden gezien als zijnde rechtstreeks van invloed op de instelling of de werking van de gemeenschappelijke markt. Deze formulering is niet geheel open. De termen "gemeenschappelijke markt", "rechtstreeks" en "invloed" beperken de mogelijkheden ten aanzien van hetgeen de Gemeenschap wil regelen op deze basis. Volgens Lauwaars en Maarleveld betekent dit dat artikel 100 van toepassing kan zijn op (onder meer) het sociale beleid van de lidstaten (23), voor zover de te harmoniseren wetgeving betrekking heeft op de vier vrijheden en indien deze nodig is om tegen te gaan dat de mededinging ernstig wordt vervalst (24). De term rechtstreeks ziet op de wijze waarop de gemeenschappelijke markt wordt beïnloed: volgens

20. Dit kan wel het geval zijn als een bepaald rechtsgevolg met de resolutie is beoogd, en de bevoegdheid rechtsgevolgen aan resoluties te geven bij of krachtens het EEG-verdrag is gegeven. Dat is hier niet het geval.

21. Zaak $59 / 75$, Jur. 1976 , p. 102 (Manghera).

22. Als voorbeeld kan het New Community Action Programme on the Promotion of Equal Oppurtunities for Women 1982-1985 dienen, dat eveneens door een resolutie van de $\mathbb{R}$ aad ondersteund werd. Uit het implementatierapport bleek dat Nederland, hoewel het de resolutie ondersteund had, geen grote veranderingen in zijn wetgeving had aangebracht, terwijl daar blijkens het rapport wel aamleiding toe was geweest (zie Report on the implementation of the New Community Action Programme on the Promotion of Equal Opportunities for Women, 1982-1985).

23. R.H. Lauwaars, J.M. Maarleweld, Harmonisatie van wetgeving in Europese organisaties, Amsterdam 1987, p. 104.

24. Zie ook zaak 91/79, Jur 1980, p. 1106, (Commissie vs Italië). In deze zaak die betrekking had op de grondslag van milieumaatregelen overwoog het Hof (r.o. 8), dat "Bepalingen die door gezondheids- of milieuoverwegingen worden ingegeven (....) zeer wel een belasting (kunnen) vormen voor de ondernemingen waarop zij wan toepassing zijn en bij gebreke van harmonisatie van nationale bepalingen terzake zou de mededinging daardoor ernstig
kunnen worden vervalst". 
bovengenoemde schrijvers is harmonisatie slechts geboden voor zover zij publiek- of privaatrechtelijke verkeersbelemmeringen opheft, dan well de functionering van de gemeenschappelijke markt verbetert (25). Over de inhoud van de term "invloed" verschillen de meningen nogal: Bleckmann (26) en Timmermans (27) verdedigen de opvatting dat er sprake moet zijn van een negatieve invloed op de gemeenschappelijke markt. Deze laatste schrijver concludeert dat harmonisatie op grond van artikel 100 dan niet verder mag gaan dan het neutraliseren van de schadelijke effecten. Lauwaars en Maarleveld staan een interpretatie van de term invloed voor die ook het geval omvat "waarin harmonisatie van wetgeving positief aan de effectiviteit van deze markt bijdraagt" (28). In een dergelijke ruime opvatting speelt de politieke wil van de lid-staten tot regulering een grotere rol dan in de eerste.

Het grondslagprobleem is belangrijk, omdat artikel 100 gezien zijn beperkingen (zeker wanneer de meest beperkte interpretatie wordt gehanteerd) nauwelijks kan voorzien in een adequate grondslag voor een eigen invulling door de gemeenschap van de medezeggenschapsbepalingen inzake veiligheids- en gezondheidsaangelegenheden. Het zal moeilijk aan te tonen zijn, dat de verschillen in dergelijke bepalingen een zodanige rechtstreekse negatieve invloed op de werking van de gemeenschappelijke markt hebben, dat harmonisatie pur sang noodzakelijk is. Weliswaar zou, in het geval artikel 100 niet bruikbaar is als grondslag, teruggegrepen kunnen worden op artikel 235 EEG-verdrag, maar dat heeft voor een deel dezelfde nadelen als artikel 100 .

Daarom is het van belang dat harmonisatie van veiligheids- en gezondheidsmaatregelen een eigen grondslag gekregen heeft, die niet zo rigide aan bovengenoemde criteria gebonden is. Voor ik overga tot het formuleren van de criteria waaraan mijns inziens een communautaire regeling zal moeten voldoen, zal ik dan ook eerst artikel 118A, dat de grondslag van een dergelijke richtlijn zal moeten vormen, bespreken.

\subsection{Antikel 118A: een rechtsgrondslag voor minimumvoorschriften}

Artikel 118A is als onderdeel van de Europese Akte in het EEG-verdrag beland. De Europese Akte is een verdrag dat zowel een wijziging van het EEG-verdrag bewerkstelligt als een eigen inhoud die betrekking heeft op de Europese samenwerking op het gebeid van het buitenlands beleid (29). De Akte wijzigt bestaande bepalingen en procedures, zoals de raadplegings-

25. R.H. Lauwaars, J.M. Maarleveld, a.w. (noot 23), p. 108.

26. A. Bleckmann, Europarecht, Köln, Berlin, Bonn, München, 1985, p. 441.

27. C.W.A. Timmernans, Harmonisatie van wetgeving en Nederlands recht, beeld van bewogen beweging, R.M. Themis, 1980, p. 411.

28. R.H. Lauwaars, J.M. Maarleveld, a.w. (noot 23), p. 107.

29. Titel HI (artikel $30 \mathrm{ev.}$.) van de Europese Akte is geen onderdeel geworden van het EEGverdrag, maar leidt een zelfstandig bestaan. 
procedure van het Europees Parlement, en de mogelijkheid om een gerecht toe te voegen aan het Hof van Justitie dat in eerste aanleg behoudens hoger beroep kennis neemt van bepaalde categorieën van beroepen ( 30 ).

Voorts zijn er wijzigingsbepalingen van de harmonisatiegrondslag met betrekking tot de gemeenschappelijke markt in het verdrag opgenomen. Het gaat hier met name om het de artikelen $8 \mathrm{~A}$ en volgende en $100 \mathrm{~A}$. Artikel $8 \mathrm{~A}$ voorziet in de vorming van een interne markt die geleidelijk tot stand gebracht moet worden en in 1992 voltooid moet zijn; een datum die overigens geen automatische rechtsgevolgen zou scheppen (31). Deze interne markt zou moeten omvatten het vrije verkeer van goederen, personen, diensten en kapitaal. Dit artikel wordt gerelativeerd door artikel $8 \mathrm{C}$, dat in een tijdelijke uitzonderingsmogelijkheid voorziet in het geval een lid-staat niet in staat is door een achterstand in ontwikkeling volledig aan de bepalingen met betrekking tot de interne markt te voldoen. Op de vorming van de interne markt is kritiek geweest. Pescatore stelt dat de interne markt niets meer biedt dan de gemeenschappelijke markt en dat deze dus al gerealiseerd had moeten zijn in 1970. Hij ziet in de datum van 31 december 1992 alleen maar uitstel van de verwezenlijking van de gemeenschappelijke markt, en dan ook nog een uitstel waaraan geen rechtsgevolgen verbonden zijn (32).

Om de interne markt te bewerkstelligen is een vereenvoudigde harmonisatieprocedure opgenomen in het verdrag, te weten artikel 100A. Dit artikel geeft ter verwezenlijking van de doeleinden van artikel $8 \mathrm{~A}$ de mogelijkheid dat de Raad van Ministers besluiten hieromtrent met gekwalificeerde meerderheid van stemmen neemt. Het vrij verkeer van personen en de bepalingen inzake rechten en belangen van werknemers zijn van deze procedure uitgezonderd. Dit heeft mede te maken met de bestaande procedures op het gebied van vrij verkeer van personen, waarin besluiten niet met eenparigheid van stemmen hoeven te worden genomen (33). Voor

30. Op 25 juli 1988 is een Raadsbesluit genomen tot oprichting van een Gerecht wan eerste aanleg dat bevoegd zall zijn voor ambtenarenzaken, mededingingsgeschillen en EGKSheffingen, NJB $1988_{4}$, p. 1069.

31. Verklaring gehecht aan de slotakte die samen met de tekst van de Europese Akte werd vastgesteld op 9 september 1985 . Wat met deze tekst bedoeld wordt is niet helder. Uit de formulering dat geen "automatische rechtsgevolgen" uit de bepalingen voortvloeien is $\mathrm{m}$.i. af te leiden dat de bedoeling is dlat het artikel op den duur wel degelijk rechtsgevolgen kan hebben, en dat het slechts de bedoeling is de Gemeenschap te behoeden woor rechtstreekse werking zonder meer, vanaf 31 december 1992 (behoeden woor baldadige rechters in de terminologie van het NRC Handelsblad (25 juli 1988)).

32. P. Pescatore, Some critical remarks on the 'Single European-Act', C.M.L.Review 1987, p. 9.

33. Oorspronkelijk voorzag artikel 49 EEG-verdrag in een procedure waarbij met volstrekte meerderheid van stemmen beshiten konden worden genomen. Deze procedure is, door het invoegen van de samenwerkingsprocedure met het Europees Parlement verworden tot een procedure met gekwalificeerde meerderheid van stemmen. Vanuit communautair perspectief dus een achteruitgang, hoewel daarbij aangetekend moet worden dat de oude procedure praktisch niet gebruikt werd en altijd met unanimiteit besloten werd. Bij andere 
maatregelen met betrekking tot rechten van werknemers pur sang blijft de procedure van artikel 100 (of, indien dit artikel om bovengenoemde redenen niet toepasbaar is, de procedure van artikel 235) gelden.

Naast de wijzigingsbepalingen zijn door middel van de akte nieuwe beleidsgebieden aan het verdrag toegevoegd, namelijk milieu-beleid, economische en sociale samenhang, en onderzoek en technologische ontwikkeling. Deze nieuwe beleidsgebieden hebben te maken met de noodzaak voor de Gemeenschap zich op meer terreinen, met name het sociale en regionale terrein en op milieugebied te manifesteren. De nieuwe artikelen geven de gemeenschap de bevoegdheid maatregelen te nemen op deze terreinen. Tot dusver kon dit (bijna) alleen op basis van artikel 235 EEG-verdrag. Bovendien meende men dat met het invoeren van een interne markt de kans op verslechtering van arbeidsvoorwaarden en arbeidsomstandigheden in de moeilijke regio's, met een uitstralende werking naar de gemeenschap als geheel met zich mee zou kunnen brengen (34).

Toch is het hoofdstuk met betrekking tot de sociale politiek nauwelijks uitgebreid. Slechts twee artikelen, het al genoemde artikel 118A en een artikel 118B, dat de sociale dialoog tot onderwerp heeft zijn aan het EEGverdrag toegevoegd.

Artikel 118A is voorzichtig geformuleerd. De lid-staten krijgen een algemene verplichting opgelegd zich te beijveren om de verbetering van het arbeidsmilieu te bevorderen, teneinde de veiligheid en gezondheid van de werknemers te beschermen, en zich de harmonisatie bij de verbetering van de op dit gebied bestaande omstandigheden, ten doel te stellen. De Raad kan op voorstel van de Commissie in samenwerking met het Europees Parlement minimurn voorschriften vaststellen, die geleidelijk zullen worden toegepast met inachtneming van de in elk van de lid-staten bestaande omstandigheden en technische voorschriften.

Is de beperking tot minimumvoorschriften al aan de magere kant, de in het artikel ingebouwde mogelijkheid tot geleidelijke toepassing van die minimumvoorschriften maakt dat het artikel sterk op een lege huls lijkt. Nog verder relativerend is de clausule dat de richtlijnen vermijden zodanige administratieve bepalingen op te leggen dat zij oprichting en ontwikkeling van middelgrote en kleine ondernemingen zou kunnen hinderen. In de slotakte (35) is weliswaar een verklaring opgenomen dat de clausule niet ten doel heeft de werknemers in kleine en middelgrote ondernemingen achter te stellen indien daarvoor geen objectieve gronden aanwezig zijn; het

rechten en belangen van werknemers kan men denken aan medezeggenschap, harmonisatie van (collectief) arbeidsrechtelijke zaken.

34. Zie o.m. het rapport Dury (doc. A2 177/86) over internationale arbeidsnormen, en handelingen Europees Parlement van 20-2-1987, nr. 2-348/296.

35. .Slotakte van de Europese Akte, vastgesteld op 9 september 1985. 
is echter wel voorstelbaar dat een dergelijke clausule uitgebuit kan worden om minimumnormen lager te stellen dan strikt noodzakelijk.

\section{A De reikwijdte van artikel $118 \mathrm{~A}$}

De interpretatie van artikel $118 \mathrm{~A}$ is een belangrijk punt. De reikwijdte is met name van belang in verband met de procedure van besluitvorming van het artikel. Artikel 118A maakt besluitvorming met gekwalificeerde meerderheid mogelijk (36). Het stemmen bij gekwalificeerde meerderheid betekent dat indien een aantal lid-staten, wier gewogen stemmenaantal uitkomt boven de 54 stemmen, voor een richtlijnvoorstel stemt, het voorstel is aangenomen (artikel 148 EEG-verdrag). Dit impliceert dat nadrukkelijke tegenstanders van (onder meer) medezeggenschapsnormen op gemeenschapsniveau tot dusver, zoals Groot Brittannië en Denemarken overstemd kunnen worden, indien de Commissie een voorstel voor dergelijke normen zou doen. Dit wordt overigens wel enigzins gerelativeerd, zowel door de onderhandelingscultuur die in de Raad is ontstaan, als doordlat lid-staten zich nog altijd kunnen beroepen op het feit dat voor hen vitale belangen in het spel zijn (37).

Het is dus de vraag wat op basis van artikel 118A geregeld mag worden en wat tot de overige rechten en belangen van werknemers in de zin van artikel $100 \mathrm{~A}$ behoort. Dit laatste artikel zondert, zoals gezegd, de besluitvorming over rechten en belangen van werknemers van zijn werking uit, waardoor deze alleen maar kan geschieden op basis van de artikelen 100

36. Deze mogelijkheid is niet nieuw. In het EEG-verdrag was reeds sinds 1957 sprake van besluiten die met volstrekte dan wel gekwalificeerde meerderheid kunnen worden genomen. Dit leidde echter in het midden van de zestiger jaren tot een "constitutionele crisis' waarna stemmingen, in de Raad werden vermeden, en veell meer een onderhandelingspolitiek werd gevoerd. In het begin van de jaren tachtig kwam daar werandering in, hetgeen onder meer veroorzaakt werd door de uitbreiding van de Gemeenschappen van zes tot twaalf landen. In 1986, werd de mogelijkheid tot stemmen met gekwalificeerde meerderheid opnieww verruimd door een wijziging in het Reglement van Orde van de Raad. Daarnaast werd door middel van de Europese Akte voor besluiten op basis van een aantal artikelen stemming bij gekwalificeerde meerderheid in plaats van unanimiteit mogelijk gemaakt. Zie hierover: P.J.G. Kapteyn, De politieke verschraling van de Europese gemeenschappen; De EEG een politiek verschijnsel?, Int. Spect. 1966, p. 51 ev, PJ.G. Kapteyn en P. VerLoren wan Themaat, a.w. (noot 5), p. 175, 176.

37. Het Akkoord van Luxemburg gesloten op de bijzondere zitting van de Raad op 28 en 29 januari 1966, (Bulletin EEG no 3-1966 blz 5 e.v.) werd gesloten om de 'constitutiomele crisis' van 1965 te bezweren. Het Akkoord, dat voornamelijk een agreement to disagree bevat, bepaalt in sub 1 onder $b$ : Wanneer in het geval van besluiten die met meerderheid van stemmen kunnen worden genomen op voorstel van de Commissie zeer gewichtige belangen van een of meer partners op het spel staan, zullen de leden van de Raad tracliten binnen redelijke termijn tot oplossingen te komen, die door alle leden van de Raad kunnen worden aanwaard, onder eerbiediging van hun wederzijdse belangen en die der Gemeenschap, overeenkomstig artikel 2 van het Verdrag. In sub 2 onder $b$ is bepaald: Met betrekking tot het voorgaande punt meent de Franse delegatie dat, wanneer het om zeer gewichtige belangen gaat, de discussie voortgezet zal moeten worden totdat men algemene overeenstemming heeft bereikt.

Deze bepalingen zijn niet herroepen. 
en 235 (of eventueel op basis van een specifieke rechtsgrondslag). De reikwijdte van artikel $118 \mathrm{~A}$ zal afhangen van de interpretatie van twee termen uit dit artikel. Om te beginnen is de term minimumvoorschriften van belang, en in de tweede plaats speelt met name het begrip arbeidsmilieu een rol in de afgrenzing met artikel 100A. Beide problemen worden achtereenvolgens behandeld.

Op basis van artikel 118A kunnen alleen maar minimumvoorschriften worden vastgesteld. Dit zou kunnen betekenen dat voorschriften die boven dit minimum uitgaan, ook al betreffen zij de verbetering van het arbeidsmilieu in beginsel een andere rechtsgrondslag dan artikel 118A zouden moeten hebben (38). In dat geval zou deze andere rechtsgrondslag (in verband met de uitzondering van artikel $100 \mathrm{~A}$ ) die van artikel 100 of van artikel 235 moeten zijn (39). Het gevolg is dan dat voorschriften die boven het minimum uitgaan niet met gekwalificeerde meerderheid maar met eenparigheid van stemmen moeten worden vastgesteld. Het hangt dus van de inhoud die aan de term "minimumvoorschriften" gegeven wordt af, wat er op basis van artikel $118 \mathrm{~A}$ aan regelingen mogelijk is.

Het begrip "minimumvoorschriften" in artikel 118A is niet ingevuld. Het is, gezien het gebied dat het bestrijkt, een wat krenterig aandoende term zeker wanneer men deze vergelijkt met alle tamtam die gemaakt wordt omtrent de voltooiing van de interne markt, en de maatregelen die op basis van artikel $100 \mathrm{~A}$ kunnen worden genomen. Slechts voor het milieubeleid lijkt de Gemeenschap met nóg vagere termen en bevoegdheden te zijn toegerust.

In eerste instantie lijkt de term minimumvoorschriften te zien op het stellen van strikte technische normen op minimumniveau ter bescherming van werknemers met betrekking tot de fysieke veiligheid en gezondheid, waaraan ondernemingen zouden moeten voldoen. Dit zou af te leiden zijn uit het tweede deel van de zin, waar het gaat om de technische mogelijkheden van de lid-staten.

$\mathrm{Er}$ is meer dan één reden om te veronderstellen dat het begrip een communautaire en een verdergaande inhoud toe te kennen is.

Om te beginnen kan men uit de verschillende wetten en regelingen en praktijken in de lid-staten zelf afleiden dat de inhoud van het begrip minimumvoorschriften verder kan gaan dan enkel technische voorschiften. Indien in de lid-staten medezeggenschapsrechten van werknemers, in elk

38. Zo ook A.M. Huntjens van het VNO die tijdens het ARBO-congres 1990 (Amsterdam). Hij stelde dat door middel van artikel 11 wan $\mathrm{rl}$. 89/391 (gebaseerd op artikel 118A) medezeggenschap via een sluipweg weer op de agenda is geplaatst, terwijl dit niet uit artikel 118A zou voortvloeien (A.M. Huntjens, De sociale dimensie van Europa, ARBOcongres 1990, 6 juni 1990).

39. De mogelijkheid van het baseren van voorstellen op artikel 54 moet in dit verband als praktisch onmogelijk worden gezien. Zie ook paragraaf II.3.2.2.1.. 
geval op het niveau van informatie en consultatie, als woorwaarde gezien worden voor verbetering van de veiligheids- en gezondheidssituatie, kunnen deze rechten heel goed onder de term minimumvoorschriften begrepen worden. Men heeft immers het beginsel dat medezeggenschap bij veiligheilds- en gezondheidsaangelegenheden hoort al gemeenschappelijk. Harmonisatie van deze voorschriften op minimumniveau kan dan leiden tot het vestigen van medezeggenschapsrechten zonder afbreuk te doen aan de mogelijkerwijs veel hogere medezeggenschapsniveaus die in de lid-staten bereikt zijn. Op deze wijze zou men dan een minimum aan verplichte medezeggenschap kunnen bewerkstelligen, dat zich in elk geval op het laagste niveau bevindt.

Ik wil echter nog een stap verder gaan. Want wanneer men slechts de norm uit de wetgeving zou mogen toepassen zou men alleen maar op een zeer laag niveau kunnen harmoniseren. Een communautair beleid, in de vorm van regelgeving op basis van artikel $118 \mathrm{~A}$ kan ook een eigen communautair minimum bieden, in plaats van het absolute minimum van de minst ontwikkelde lid-staat. Tenslotte biedt vrijwel iedere harmonisatieregelling in de vorm van een richtlijn minimumvoorschriften, het is de lid-staten in praktisch alle gevallen toegestaan is om een hogere bescherming te bieden. Volgens Timmermans is de toevoeging in richtlijnen dat het om minimumregelingen gaat, in veel gevallen dan ook overbodig (40). Ten aanzien van de term minimumvoorschriften in artikel 118A kan daar wel tegen in gebracht worden, dat wanneer nu juist het verdrag spreekt van "minimum", de hoogte van de bescherming die in de op het bewuste verdragsartikel gebaseerde richtlijn geboden wordt, nooit meer dan "minimum" in de zin van het verdragsartikel kan zijn.

De communautaire inhoud van het begrip minimum kan op twee wijzen geïnterpreteerd worden: de eerste is, dat bij harmonisatie een laag niveau aangehouden wordt, maar wel een niveau dat op communautair niveau wordt vastgesteld; de tweede is, dat het begrip minimum slechts betekent dat hoe hoog het niveau ook is, de lid-staten altijd een verdergaande bescherming mogen bieden. Deze laatste interpretatie zou aansluiten bij de in het sociaal recht gebruikelijke regel, dat van wettelijke voorschriften praktisch altijd in voor de werknemers gunstige zin mag worden afgeweken. De term minimum heeft dan geen relatie meer met de beschermingsniveaus die in de wetgeving van de lid-staten geboden wordt, maar slaat slechts op de bevoegdheidsverdeling tussen Gemeenschap en lid-staten. Wanneer voor deze interpretatie gekozen wordt kan de Gemeenschap een eigen veiligheids- en gezondheidsbeleid bij de arbeid ontwikkelen, waarvoor de regelgevende bevoegdheid uitdrukkelijk is verleend.

Voor deze opvatting is wel steun te vinden in de rechtspraak van het het Hof ten aanzien van de begrippen in een communautaire aangelegenheid

40. C.W.A. Timmermans, a.w. (noot 27), p. 421. 
als het vrij werknemerswerkeer. Ook hier komen begrippen voor die ook al hebben ze op nationaal niveau een eigen inhoud, op communautair niveau een andere (en met name ruimere inhoud) kregen. Men kan hierbij denken aan de ruimere interpretatie die hier Hof aan het werknemersbegrip gaf ten opzichte van het Nederlandse recht op dit punt, in de zaken Levin (41) en Kempf (42). Dat artikel 118A deel uitmaakt van de sociale politiek, waar het Hof tot dusver wat minder scheutig is geweest met het toekennen van een communautaire inhoud aan begrippen speelt in dit verband geen rol, omdat het hier nu juist, evenals in artikel 48 EEG-verdrag, om een verdragsartikel gaat (43). De interpretatie van een verdragsartikel kan wel degelijk ruimer zijn, en met deze ruimere interpretatie een hoger beschermingsniveau bieden, dan een aan het beschermingsniveau van de lid-staten gerelateerde interpretatie.

Kortom het begrip minimum kan, en moet mijns inziens, zo worden uitgelegd: enerzijds kan, door vast te stellen dat de lid-staten in hun respectievelijke wetten werknemersmedezeggenschap kennelijk als minimumvoorziening beschouwen, dit ook op gemeenschapsniveau gebeuren; anderzijds, doordat de term minimum in een verdragsartikel is opgenomen, heeft de Gemeenschap een eigen bevoegdheid te bepalen wat zij als noodzakelijke minimumvoorwaarden beschouwt.

Het tweede punt in de afgrenzing met artikel $100 \mathrm{~A}$ is de term arbeidsmilieu. Artikel 118A is alleen rechtsgrondslag voor besluiten ter verbetering van het arbeidsmilieu. Het is dus zaak te bepalen waar de begrippen arbeidsmilieu en daarmee samenhangend veiligheid en gezondheid uit artikel $118 \mathrm{~A}$ op zien.

Het begrip arbeidsmilieu wordt aangetroffen in de Deense wetgeving. Die wet legt het begrip aldus uit dat niet alleen gelet moet worden op de gebruikelijke veiligheids- en gezondheidszaken als bedrijfsongevallen en beroepsziekten maar op alle factoren die op de lange duur schadelijk kunnen zijn voor de lichamelijke en geestelijke gezondheid (44). Dit is al aanzienlijk ruimer dan bijvoorbeeld het begrip "welzijn" (45) in de

41. Zaak $83 / 81$, Jur. 1982 , p. 1035 (Levin).

42. Zaak 139/85, Jur. 1986, p. 1741-1752 (Kempf).

43. Hierover: E. Steyger, De gemeenschappelijke arbeidsmarkt en het sociale beleid in de gemeenschap; over discriminatie, distorsies en ingebakken dispariteiten, NJB 1988, p. 249 ew.

44. O. Rieper, Styring af Arbejdsmiljpet, Kopenhagen 1985, p. 39. Zie ook J.K.M. Gevers, Zeggenschap van werknemers inzake gezondheid en veiligheid in bedrijven, Deventer 1982, p. 193.

45. Artikel 1 lid 7 Arbowet beperkt de welzijnswerplichtingen tot enkele specifiek arbeidsorganisatorische zaken, zoals de inrichting van werkplaatsen, taakinhoud van werknemers, en het rekening houden met eigenschappen wan de werknemer bij het toewijzen van taken. 
Nederlandse arbeidsomstandighedenwet en de interpretatie die door de staatssecretaris van sociale zaken daaraan is gegeven (46).

Voor de term arbeidsmilieu in het EEG-verdrag zou ik een in elk geval geen engere interpretatie dan de Deense willen verdedigen. Volgens VogelPolsky (47) zijn drie interpretaties mogelijk. In de eerste interpretatie ziet het artikel alleen op pure arbeidsbescherming, in de tweede op alle arbeidsomstandigheden en arbeidsvoorwaarden die effect kunnen thebben op veiligheid en gezondheid van werknemers, en in de derde interpretatie omvat het artikel alle arbeidswoorwaarden waaronder de veiligheids en gezondheidsbescherming. Dit laatste lijkt mij een te grote uitbreiding van de werkingssfeer van artikel $118 \mathrm{~A}$.

Mijns inziens zou het begrip arbeidsmilieu moeten worden uitgelegd als direct betrekking hebbend op die zaken die in de arbeidsomgeving de psychische en fysieke gezondheid van de werknemers kunnen beïnvloeden. Dit betekent dat zaken als arbeidsduur, organisatie van en inhoud van de arbeid, er onder zouden vallen, maar ook arbeidstijden en de verhoudingen binnen de onderneming. Bij dit laatste kan men denken aan zaken als sexuele pesterijen (48) en de mogelijkheid voor een klachtrecht binnen de onderneming. Alleen op die gebieden die een overwegend economisch karakter hebben zoals beloningsaspecten en werk- classificatiesystemen zou op basis van artikel 118A geen regeling te treffen zijn.

Deze afgrenzing sluit vrij dicht aan op, hetgeen het Europees Parlement heeft gesteld omtrent de uitleg van artikel 118A. Volgens het Parlement moet het begrip zo geïnterpreteerd worden dat het in elk geval ook de duur, inhoud en organisatie van de arbeid omvat (49). Jacobs gaat nog verder bij het onderschrijven van een ruime interpretatie; volgens hem kunnen met enige fantasie zaken als flexibele arbeid en deeltijdarbeid eronder begrepen worden (50). Een dergelijke uitleg zou de regeling van, tot dusver op Britse tegenwerking gestrande initiatieven als de voorstellen omtrent part-time en tijdelijk werk, mogelijk maken. Curtin stelt daarentegen dat onder artikel 118A eventueel de bescherming van het moederschap en sexuele pesterijen (als zijnde een deell van het psychische en fysieke arbeidsmilieu) kunnen vallen, maar zij ziet niet in hoe op arbeidsrechtelijke

46. Zie ook het antwoord van Staatssecretaris de Graaf wan Sociale zaken aan de Commissie gelijke behandeling van mannen en vrouwen bij de arbeid van 18 mei 1987, waarin werd gesteld dat ongewenste intimiteiten niet onder het welzijnsbegrip konden vallen in verband met de beperkte reikwijdte van deze term.

47. E. Vogel-Polsky, Welke juridische instrumenten zijn nodig voor een sociaal Europa, SMA 1990, p. $67-68$.

48. Zie ook E. Steyger, Van vrouwenprobleem tot Gemeenschapszaak in Ongewenste intimiteiten, gewenste rechten, Alphen a/d Rijn 1990, p. 214-218; M. Rubinstein, The dignity of Women at Work, Brussel 1987, (doc. V/412/1/87-EN def.) p. 100-101.

49. Hand. EP, 21 oktober 1988, doc. A2-226/88.

50. A.T.J.M. Jacobs, De arbeidsrechtelijke aspecten van de voltooing van de Europese binnenmarkt, NJB 1989 , p. 838. 
onderwerpen als deeltijd- en tijdelijke arbeid, de unanimiteitsregel kan worden ontlopen (51).

De Britse regering heeft al gezegd, dat in haar visie op basis van artikel $118 \mathrm{~A}$ geen maatregelen kunnen worden genomen die de rechten van individuele werknemers tot voorwerp hebben, zelfs als deze rechten de werkomstandigheden betreffen (52). Volgens Vogel-Polsky hanteren ook de Raad en de Commissie ten opzichte van de reikwijdte van artikel 118A de meest restrictieve interpretatie. Daarnaast zouden zij voor de reikwijdte van de uitzondering van artikel $100 \mathrm{~A}$ lid 2 (rechten en belangen van werknemers) de meest extensieve interpretatie hanteren. Onder rechten en belangen van werknemers zou de gehele arbeidsreglementering worden verstaan (53). Ik vind de conclusie van Vogel-Polsky met betrekking tot de interpretatie van Commissie en Raad overigens voorbarig. Het artikel is pas sedert 1 juli 1987 in werking, en nu al liggen er enkele richtlijnen op veiligheids- en gezondheidsgebied die meer omvatten dan puur technische arbeidsbeschermende maatregelen. Daarnaast heeft de Commissie aangekondigd dat richtlijnvoorstellen omtrent atypische (zoals flexibele en deeltijd) arbeid en de ordening van de werktijden gebaseerd zullen worden op de artikelen $118 \mathrm{~A}$ en $100 \mathrm{~A}(54)$. Het is voorstelbaar dat in de toekomst meer en ruimere voorstellen worden gedaan. Men kan mijns inziens de Commissie niet verwijten dat zij, op basis van dit artikel niet in eerste instantie voorstellen heeft gedaan die de reikwijdte van artikel 118A zwaar op de proef stellen. Met het aannemen van de raamrichtlijn met betrekking tot veiligheid en gezondheid is in elk geval duidelijk geworden dat voorschriften omtrent verplicht voorgeschreven informatie- en consultatieprocedures op basis van artikel $118 \mathrm{~A}$ kunnen worden vastgesteld.

Indien de begrippen uit artikel $118 \mathrm{~A}$ eng uitgelegd worden, zal een groter aantal besluiten omtrent veiligheids- en gezondheidsaangelegenheden op de basis van artikel 100 moeten worden genomen. Dit artikel vereist eenparigheid van stemmen, eén heeft de bovengeschreven beperkingen. Hoe ruimer de interpretatie van de termen minimumvoorschriften en arbeidsmilieu, hoe ruimer de bevoegdheidsgrondslag is, die in artikel 118A geboden wordt. Dan bestaat minder kans dat richtlijnen, waarin meer geregeld wordt dan het laagste niveau van technische voorschriften, wegens de verkeerde bevoegdheidsgrondslag vernietigd zullen worden (55).

51. D. Curtin, aw. (noot 2), p. 144; Zie ook de bijdrage van E. Steyger a.w. (noot 48).

52. NRC-Handelsblad 14 september 1989.

53. E. Vogel-Polsky, a.w. (noot 47), p. 68.

54. Europe, Agence Internationale d'Information pour la Presse, 13 januari 1990, nr. 51.71, p. 8.

55. Sedert meer met gekwalificeerde meerderheid van stemmen besloten wordt (m.n. og.v. artikel $110 \mathrm{~A}$ ), is het aantal verzoeken tot nietigverklaring o.g.y. artikel 173 in verband met de keuze van de rechtsgrondslag toegenomen. Als woorbeeld kan dienen de recente zaak $131 / 86$ (23-2-1988; nog niet gepubliceerd), waarin de vernietiging van een rïchtlijn die minimumnormen ter bescherming van kippen in legbatterijen (gebaseerd op artikel 43 EEG-verdrag) bood werd verzocht, omdat naast doelstellingen op het vlak van de landbouw ook onderlinge aanpassing van de nationale wetgeving werd beoogd. Hoewel het 
Voor deze ruime interpretatie zijn argumenten te vinden, onder meer in de plaats van het artikel in het verdrag en in de formulering die in artikel 118 EEG-verdrag is gehanteerd. Dit laatste artikel kan gezien worden als een instructienorm aan de Commissie. Deze norm geeft weliswaar de Commissie de bevoegdheid, én legt haar de verplichting op, onderhandelingen tussen werknemers en werkgevers te bevorderen, maar laat de bevoegdheden van de lid-staten onverlet, voor zover deze niet deel uitmaken van andere in het verdrag geregelde bevoegdheden (56). Ook artikel $118 \mathrm{~B}$ dat uitdrukkelijk de Commissie opdracht geeft met betrekking tot de dialoog tussen de sociale partners op Europees niveau te bevorderen (57) is een instructienorm, die vooralsnog geen rechtsgevolgen lijkt te hebben (58). Gezien deze artikelen lijkt het niet vergezocht, de Gemeenschap voor een beleidsgebied waarvoor, voor de te regelen materie, een aparte rechtsgrondslag wordt geboden een ruime armslag te bieden om ook werkelijk beleid te maken.

Een argument voor enig optimisme ten aanzien van de uitleg van artikel $118 \mathrm{~A}$, is de ruime interpretatie die het Hof an andere (sociaal-politieke) verdragsartikelen heeft gegeven zoals artikel 128 EEG-verdrag. Dit artikel ziet slechts op een zeer beperkt gebied en vereist volstrekte meerderheid van stemmen. Het Hof van Justitie heeft in zijn recente jurisprudentie dit artikel zo ver opgerekt als maar mogelijk is (59).

Een resultaat van een ruime interpretatie zou kunnen zijn dat de discussie over medezeggenschap op gemeenschapsniveau weer opengebroken wordt. Het is niet onmogelijk dat zelfs die lid-staten die zich tot dusver het felst verzetten (60) tegen harmonisatie van dergelijke bepalingen in het algemeen, die zij zien als inbreuk op het systeem van collectieve arbeidsver-

Hof op deze grond niet vernietigde owerwoog het dat het werschil van mening over de rechtsgrondslag niet van louter formele betekenis is, juist in verband met het wereiste van eenparigheid van stemmen in artikel 100.

56. Zaak 126/86, Jur. 1987, p 3697-3718, (Gimenez Zaera ws Instituto Nacional de la Seguridad en Tsesoria de la Seguridad Social).

57. Artikel 118 legt de Commissie de verplichting op de samenwerking tussen de lid-staten te bevorderen waar het gaat om onder andere het recht zich te organiseren in vakverenigingen en collectieve onderhandelingen tussen werkgevers en werknemers. Artikel 118B verplicht de Commissie zich te beijveren "de dialoog tussen de sociale partners op Europees niveau verder te ontwikkelen; als deze laatsten zulks wenselijk achten kan dit tot contractuele betrekkingen leiden".

58. P.J.G. Kapteyn en P. VerLoren van Themaat, a.w. (noot 5), p. 417.

59. Het gaat hier om een recente uitspraak omtrent de grondslag van artikel 128 voor het creëren van onderwijsprogramma's. Voor het Erasmusprogramma had de Commissie alls grondslag artikel 128 genomen (eenvoudige meerderheid), de Raad had echter artikel 235 als grondslag toegevoegd, aangezien het programma de kaders van 128 te buiten ging en zelfs geheel nieuw beleid creëerde. De Commissie vocht deze grondslag voor het Hof aan, en hoewel zij verloor kwam dit alleen doordat het Hof oordeelde dat de grondslag van 235 nodig was in verband met de onderzoekscomponent van het programma. Indien het programma alleen uit een onderwijscomponent had bestaan, had het Hof genoegen genomen met artikel 128 als grondslag, daarmee dit wat vage artikel een ruime uitleg gevend. Zaak 242/87, 12 juni 1989, nog niet gepubliceerd (Commissie vs Raad).

60. Zie paragraaf II.4.2.A. 
houdingen, minder grote bezwaren zouden hebben tegen harmonisatie waar het gaat om bepalingen met betrekking tot veiligheid en gezondheid van werknemers.

Het openbreken van die discussie en regulering vanuit de Gemeenschap zouden kunnen betekenen dat niet alleen de nationale medezeggenschapsregelingen inzake veiligheids- en gezondheidsaangelegenheden worden geharmoniseerd, maar dat ook medezeggenschap op multinationaal niveau wordt gecreëerd met betrekking tot dit gebied. Dit is echter alleen te verdedigen wanneer van een ruime interpretatie van artikel $118 \mathrm{~A}$ uitgegaan wordt.

Anderzijds is de kans groot dat juist de tegenstanders, en vooral de Britse regering, zich in hoge mate zullen verzetten tegen een interpretatie die de termen "minimumnorm" en "arbeidsmilieu" in hun meest bekrompen uitleg te boven gaat (61). Mede daarom stelt Vogel-Polsky voor dat de vertegenwoordigers van die lid-staten die een ruime interpretatie voorstaan of het Europees Parlement een actie wegens nalaten, op basis van artikel 175 EEG-verdrag beginnen (62). Het resultaat van een dergelijke actie zou duidelijkheid omtrent de interpretatie van de termen uit artikel $118 \mathrm{~A}$ kunnen bieden. Mijns inziens zou zo'n actie op dit moment niet tot resultaat kunnen leiden, omdat op basis van artikel $118 \mathrm{~A}$ nu juist wel maatregelen genomen zijn (63).

\subsection{Een concept voor een communautaire regeling geïnspireerd op de nationale} praktijken

Wanneer de hierboven voorgestelde uitleg van artikel 118A wordt geaccepteerd kan de de gemeenschap een eigen invulling geven aan de regulering van het veiligheids- en gezondheidsbeleid zoals dat in de onderneming gevoerd zou moeten worden. Er is overigens geen reden om bij die regulering niet aan te sluiten bij datgene dat de lid-staten al in hun wetgeving en praktijk verwerkt hebben. Sterker nog, om redenen van politieke haalbaarheid, sociale acceptatie en effectieve verwerking in de wetgeving van de verschillende lid-staten is het eerder wijs om dat wel te doen (64).

61. In een op 20 september 1988 te Brugge gehouden rede liet de Britse premier Thatcher, er geen misverstand ower bestaan dat zij zo weinig mogelijk sociale regulering uit "Brussel" wenste.

62. E. Vogel-Polsky, a.w. (noot 47), p. 69.

63. In zaak 13/83, Jur. 1985, p. 1513 (Europees Parlement vs Raad) kon het Hof tot haar conclusie dat van schending van het verdrag sprake was onder meer komen op grond van het feit dat de omvang van de verplichting op het gebied van het vervoersbeleid in het verdrag woldoende nauwkeurig was bepaald (ro. 64,66), en op grond van het feit dat er in het verdrag een duidelijke termijn was gesteld v66r wamneer er maatregelen zouden moeten worden genomen.

64. Zie ook B. Bercusson, a.w. (noot 7), p. 95. 
Aansluiten bij de wetgeving en praktijk van de lid-staten, het is hierboven al betoogd, hoeft niet te betekenen dat het laagste niveau van bescherming wordt aangehouden. Het niveau wan medezeggenschap kan zo hoog zijn als de Gemeenschap noodzakelijk acht, het kan als het vast te stellen resultaat van de richtlijn gelden. De uitvoering zal in hoge mate aan de lid-staten zelf moeten worden overgelaten, de middelen moeten dus vrij zijn.

Institutionele regulering is alleen al om die reden ongewenst. Al in hoofdstuk II bleek dat de institutionele benadering van medezeggenschap in minstens een aantal lid-staten op grote bezwaren stuitte, zodat deze vorm van regulering politiek niet haalbaar moet worden geacht. Maar ook om redenen van verwerking van de medezeggenschap binnen de nationale systemen is een institutioneel voorstel minder geslaagd, omdat in dat geval het risico van een richtlijn die slechts een dode letter wordt groot is.

De voorkeur zou dus uitgaan naar een instrumentele regeling, naar het voorbeeld van het Vredeling-Richard voorstel. Nu valt op dat voorstel aan te merken dat dit tot dusver ook niet haalbaar is gebleken. Dat kan liggen aan het feit dat Vredeling-Richard voorzag in informatie- en consultatiebevoegdheden in het algemeen. Hier zou het gaan om medezeggenschapsinstrumenten op een heel beperkt gebied, een gebied waarvoor in de meeste lid-staten een wettelijke grondslag al is gecreëerd. De vraag blijft dan wel of een speciale richtlijn verder zou kunnen gaan dan het VredelingRichard voorstel (dat in zijn laatste versie ook voorzag in informatie en consultatie inzake veiligheids- en gezondheidsaangelegenheden) aangezien een aantal nationale wetten de medezeggenschapsbevoegdheden niet verder gaan dan consultatiebevoegdheden. Noch in Denemarken noch in Groot Brittannië geven respectievelijk de Arbejdsmiljølovet en de HSWA 1974, de werknemersvertegenwoordigers meer dan consultatie bevoegdheden. Hier zou, indien een richtlijn een verdergaand resultaat dan consultatie voorschrijft, een probleem kunnen ontstaan.

Juist echter, omdat de richtlijn slechts een zo beperkt gebied zou omvatten zou een verdergaande medezeggenschapsvorm mogelijkerwijs wel aanvaardbaar kunnen zijn, zolang deze de nationale praktijken niet al te veel geweld aandoet.

Het aansluiten bij de nationale praktijk levert evenwel een ander, in het vorige hoofdstuk gesignaleerd probleem op. Daar werd geconstateerd dat de individuele werknemer in de nationale systemen in het algemeen een uiterst zwakke positie inneemt, en gezien de democratische lacunes in een aantal systemen zelfs in het geheel niet meetelt. Juist hier kan een richtlijn een eigen begrippenapparaat introduceren die in elk geval een deel van dit probleem zou kunnen wegnemen. Een tweede probleem is dat door pure aansluiting bij de nationale praktijk opnieuw geen medezeggenschap aan de top van concerns, met name bij multinationale organisaties kan worden bereikt. Ook hier zou een richtlijn, naar analogie van de pogingen van het Vredeling-Richard voorstel in moeten voorzien. Voordat ik tot een oplossing 
voor deze beide problemen kom zall ik eerst het niveau van de verschillende medezeggenschapsinstrumenten aan een nadere beschouwing onderwerpen.

Het eerste instrument dat in een richtlijn zou moeten worden opgenomen is het recht op informatie. In de meeste lid-staten, bestaat er, zoals eerder bleek een recht op informatie in het algemeen en een bijzonder recht op informatie ten aanzien van veiligheids- en gezondheidsaangelegenheden. Het laagste niveau is in feite het Britse waar, hoewel veiligheidsvertegenwoordigers recht hebben op informatie met betrekking tot die aangelegenheden, de vraag blijft bestaan of zij deze ook kunnen krijgen. Zodra deze informatie relevant is, of kan zijn in verband met collectieve onderhandelingen, heeft de werkgever immers het recht een beroep te doen op het belang van de onderneming om die informatie achter te houden (65). Dit recht van de ondernemer is, hoewel niet volledig, terug te vinden in het Vredeling-Richard voorstel en het ontwerp-Statuut SE (66).

Een richtlijn ten aanzien van veiligheid en gezondheid zou niet zo ver hoeven gaan. Voor wat betreft de informatie kan een algemene bepaling worden opgenomen dat de vertegenwoordigers van de werknemers alle informatie ter beschikking krijgen die zij in verband met hun functie nodig hebben, gevoegd bij een aantal specifieke bepalingen met betrekking tot gevaarlijke stoffen, machines, ergonomische aspecten, organisatie van de arbeid, gevaarlijke situaties en arbeidsongevallen. Op de (in verband met collectief onderhandelen vermeende) noodzaak van een geheimhoudingsparagraf kom ik nog terug.

Het afdwingen van de informatie zou in eerste instantie kunnen verlopen via de arbeidsinspectie, van wier adviezen, beroep zou moeten openstaan op arbiter of rechter. Welke keuze in dit verband wordt gemaakt moet mijns inziens overgelaten worden aan het nationale recht; wel zal duidelijk zijn dat de bewuste arbitrale of rechterlijke colleges hierover prejudiciële vragen aan het Hof van Justitie moeten kunnen stellen.

Met name voor arbitrale colleges ligt hier een probleem. In beginsel zijn arbiters niet gerechtigd om prejudiciële vragen te stellen (67). Slechts indien zij voldoen aan vijf voorwaarden worden zij gezien als rechterlijke instantie die vragen kan stellen aan het Hof. Deze voorwaarden zijn betrekkelijk vergaand. Om te beginnen moet de arbitrage voorzien zijn binnen het raamwerk van het recht. Daarnaast moeten de arbiters volgens het recht (en dus niet volgens billijkheid) oordelen. De uitspraak moet het res judicata hebben en moet afdwingbaar zijn. De partijen moeten ofwel

65. C.D. Drake, F.B. Wright, Law of Health and Safety at Work, the New Approach, London 1983 , p. 189.

66. Zie paragraaf II.4.1.B.. en II.4.2.A..

67. G. Bebr, Arbitration Tribunals and article 177 of the EEC Treaty, C.M.L.Review, 1985, p. $489-504$. 
volgens het recht, ofwel feitelijk verplicht zijn zich tot de arbiter en niet tot de rechter te wenden, en de arbitrage moet op éen of andere wijze ondersteund worden door de publieke autoriteiten (68). De geschillenbeslechtende instanties met betrekking tot het informatierecht voldoen in meeste lid-staten aan dit criterium (69); voor instanties aan wie zaken tijdens het besluitvormingsproces (en die daarmee ook deels de inhoud van de medezeggenschapsrechten toetsen) is dit twijfelachtig (70). Het is zaak dat bij uitwerking van de richtlijn hierop gellet wordt.

De hamwraag bij een te maken richtlijn zal zijn tot hoever de medezeggenschap moet gaan. Moet deze een minimumvoorziening geven van slechts consultatieve bepalingen of kan de richtlijn ook verdergaande verplichtingen opleggen. De wettelijke voorzieningen in een aantal lid-staten gaan niet verder dan consultatierecht op veiligheids- en gezondheidsgebied (zie het schema in paragraaf V.8.) maar laten de mogelijkheid onverlet dat over dit onderwerp onderhandeld wordt en dat er collectieve overeenkomsten op ondernemingsniveau over afgesloten worden.

$\mathrm{Er}$ is dan ook gezien de nationale regelingen en praktijken niet echt een reden om slechts consultatie als uitgangspunt te nemen, en geen instemmingsrecht of onderhandelingsrecht voor te schrijven. Het geven van instemming en/of het voeren van onderhandelingen vinden al plaats en kunnen al plaatsvinden in de overgrote meerderheid van de lid-staten. Daar waar de gemeenschap een grondslag heeft voor een eigen beleid zou zij ook een minimum vast moeten stellen woor de participatie van werknemers in het veiligheids- en gezondheidsbeleid.

De wraag is dan wel hoe zo'n participatieverplichting er uit moet komen te zien. Een institutionele oplossing waarin werknemersvertegenwoordigers een raamwerk van regels opgelegd krijgen lijkt, gezien de tegenstand die er tegen alle voorstellen die tot dusver zo"n raamwerk beoogden bestond, niet wijs. Een richtlijn zou kunnen aansluiten bij het Deense systeem van samenwerking tussen werknemerswertegenwoordigers en werkgever bij het vaststellen van de beginselen van veiligheid in de onderneming. In dat geval kan de richtlijn volstaan met bepaling die voorschrijft dat de werkgever en de werknemersvertegenwoordigers gezamenlijk het algemene ondernemingsbeleid ten aanzien van veiligheid en gezondheid en de arbeidsorganisatie in de onderneming vaststellen.

68. Zaak 61/65, Jur. 1966 , p. 274-275 (G. Vaassen-Goebbels tegen het bestuur van het beambtenfonds voor het mijnbedrijf), zaak 246/80, Jur. 1982, p. 2326-2328 (C. Broekmeulen vs. Huisarts Registratie Commissie r.o. 8-17), Zaak 102/81, Jur. 1982, p. 1109-1110; ( $r, 0.7-13)$ (Nordsee II).

69. De Britse CAC kan in dit verband mogelijk problemen opleveren.

70. Voor de Deense vakbondsarbitrage zie zaak $109 / 88$ van 17 oktober 1989 , nog niet gepubliceerd (Handels og Kontor-funktionaerernes Forbund i Danmark vs Dansk Arbejdsgiwer-foreming). Zie voorts paragraaf IV.4.2. 
Een tweede lid kan dan voorzien in de wijze waarop dit kan gebeuren: door middel van een (eventueel periodieke) verplichting aan werkgevers en werknemersvertegenwoordigers op dit gebied een collectieve overeenkomst af te sluiten, door middel van een instemmingsrecht van de werknemersvertegenwoordigers, of door middel van medebeslissingsrechten. Deze formulering duidt er op dat een instemmingsrecht sec overigens aan de magere kant is: wanneer men over beginselen vaststellen spreekt, moeten deze beginselen al voor de vaststelling bespreekbaar zijn. Hoe het nationale recht dit ook aitwerkt, het algemene veiligheidsbeleid is op deze wijze in elk geval niet meer geheel in handen van de werkgever: hij zal ten aanzien van het algemene beleid het fiat van de werknemersvertegenwoordigers moeten hebben.

Ten aanzien van concrete maatregelen is hier geen instemmings- of onderhandelingsrecht mee gegeven. Naar mijn mening is dit om twee redenen niet nodig. Om te beginnen zullen deze niet in strijd mogen zijn met het algemene ondernemingsbeleid, waarbij al participatierechten bestaan. Concrete maatregelen zijn dus toetsbaar. Ten tweede, maar daar kom ik later op terug, ben ik van mening dat de individuele werknemer een klachtrecht bij de arbeidsinspecteur moet krijgen, indien concrete maatregelen zijn veiligheid en gezondheid persoonlijk bedreigen. Ook hier is dus een mogelijke toets ingebouwd. Lid-staten kunnen overigens de medezeggenschap naar concrete maatregelen uitbreiden.

Ik ben mij ervan bewust dat medezeggenschap bij het algemene beleid een zware eis aan de werknemersvertegenwoordigers stelt. Al te algemene richtlijnen voor dat beleid zullen veel ruimte laten voor afwijking waar het concrete maatregelen betreft. Een beleidsplan dat slechts "voor de veiligheid en tegen de onveiligheid" is, zal door middel van concrete maatregelen geheel onderuitgehaald kunnen worden. Het is dan ook aan de werknemersvertegenwoordigers het plan inhoud te geven met een zekere mate van concreetheid gericht op de onderneming.

Door het opleggen van een verplichting aan de werkgevers in die systemen waar medezeggenschap door middel van collectieve overeenkomst geregeld wordt, een overeenkomst af te sluiten op dit specifieke gebied, ontstaat een gelijke verplichting die informatie, die noodzakelijk is in verband met de onderhandelingen, ter beschikking te stellen. In dat verband is de geheimhoudingsparagraaf uit het Britse systeem van belang: die zou voor deze onderhandelingen niet meer kunnen worden ingeroepen. Hoewel ongetwijfeld conflicten zullen ontstaan over de grenzen van de ter beschikking te stellen informatie, wordt deze paragraaf in elk geval door de verplichting op zichzelf doorbroken.

Naleving van de verplichting kan worden afgedwongen door de bovenbeschreven rechterlijke of arbitrale colleges. Hiervoor geldt hetzelfde als bij het informatierecht: men zal prejudiciële vragen moeten kumnen stellen, in verband met de basisbegrippen uit de bepaling. 
Over de inhoud van het beleid zal eveneens een rechter of arbiter zich moeten kunnen buigen, hier liggen overigens prejudiciële vragen minder voor de hand, omdat het om pure geschillenbeslechting zal gaan. Deze instanties zullen zich ook moeten buigen over de verenigbaarheid van concrete maatregelen met het vastgestelde algemene beleid. Dit betekent een beroepsmogelijkheid van de werknemersvertegenwoordigers (eventueel als collectief) tegen door de werkgever genomen concrete maatregelen.

Het zal duidelijk zijn dat in deze benadering een directe sanctie als staking een betrekkelijk marginale plaats inneemt in het geheel van middelen dat werknemers kunnen aanwenden tegen een weigerachtige werkgever. In eerste instantie kunnen de vertegenwoordigers hun heil bij rechter of arbiter zoeken. Echter dit aspect kan het beste aan de lid-staten overgelaten worden, een richtlijn op basis van artikel $118 \mathrm{~A}$ is niet de geëigende plaats om hier iets over te regelen. Ook een ruime interpretatie van een artikel kent haar grenzen.

Een recht voor de werknemers om toezicht te houden zou alleen als oningevulde bepaling gegeven moeten worden, waarbij hooguit expliciet het recht in verband met dat toezicht deskundigen te raadplegen wordt erkend. De verschillende praktijken in de lid-staten, waar de controle ofwell op zichzelf staat, ofwel verloopt in samenwerking met medische en veiligheidsdiensten in de onderneming ofwel in samenwerking met de arbeidsinspectie moeten niet worden doorkruist, hooguit worden verbeterd. Wel kan zo'n recht op toezicht voorzien worden van een nalevingsbepaling, waarbij de richtlijn bepaalt dat het nationale recht voorziet in een adequate rechtsgang, bij schending van het recht om toezicht te houden.

Een recht voor de werknemersvertegenwoordigers een beroep te doen op de arbeidsinspectie, of andere bevoegde autoriteiten, moet weer wel expliciet in de richtlijn worden opgenomen, met een verplichting voor die bevoegde instantie binnen een bepaalde termijn te reageren. Men kan hier denken aan het verzoek tot wetstoepassing zoals dat in Nederland bestaat. Deze bevoegde instantie zou dan ook het recht moeten hebben, al dan niet in samenwerking met de werknemersvertegenwoordigers, de onderneming stil te leggen indien dit noodzakelijk is. Of de werknemersvertegenwoordigers zelf dit recht ook moeten krijgen lijkt mij, gezien de voorschriften hieromtrent in de lid-staten discutabel. Volgens Bercusson is dit recht, gezien recente overzichten, wel uit de wetgeving af te leiden, en hij concludeert dan ook dat dit recht als fundamenteel recht in een Communautair instrument voor de bescherming van fundamentele rechten moet worden opgenomen (71). Volgens mij is dit een te optimistische inschatting van de wetgeving in de lid-staten. Uit paragraaf V.3 blijkt dat die mogelijkheid slechts in enkele lid-staten bestaat; in andere is dit uitsluitend een bevoegdheid van arbeidsinspecteurs of daarmee vergelijkbare autoriteiten.

71. B. Bercusson, a.w. (noot 70), p. 96. 
Een richtlijn zou daarin mijns inziens niet moeten voorzien. Wel zou de richtlijn een verplichting tot overleg hieromtrent met de werknemersvertegenwoordigers op kunnen nemen, waardoor de mogelijkheid een beroep te doen op de arbeidsinspectie, naast een verplichting van dit orgaan te reageren op voorstellen, meer inhoud krijgt.

Tot zover de instrumenten die de werknemersvertegenwoordigers mijns inziens zouden moeten toekomen, op basis wat uit de verschillende nationale wetten kan worden afgeleid. Hier zitten nog wel enkele problemen in. Om te beginnen is daar het probleem van de uitvoering van de richtlijn. Uitvoeringswetgeving door de lid-staten, zal in een aantal lid-staten weinig problematisch zijn, aangezien zij al aan de in de richtlijn gestelde minimum-voorwaarden voldoen of met een simpele wetswijziging aan kunnen voldoen. Voor alle duidelijkheid: mijns inziens voldoen de Nederlandse Arbeidsomstandighedenwet en WOR niet aan de bovengenoemde vereisten. Invloed op het beleid als geheel door middel van het afsluiten. van een overeenkomst, of het instemmingsrecht staat niet gelijk aan het in deze wetten geregelde instemmingsrecht met besluiten. Dit geldt temeer na de wetswijziging van de WOR en Arbowet. Het instemmingsrecht, dat voor het overgrote deel van besluiten op het veiligheids-, gezondheids- en welzijnsgebied is afgeschaft, biedt aanzienlijk minder dan hetgeen hierboven wordt voorgesteld.

In een aantal andere lid-staten ligt de problematiek anders. Een wettelijke regeling als bovengeschetst gaat uit boven hetgeen bijvoorbeeld de Italiaanse, Deense en Britse wetgeving bieden. Weliswaar staat het niet haaks op de daar geldende praktijk maar wel op de wijze waarop de wet zich er mee bemoeit. Een mogelijkheid waar al eerder (72) op is gewezen is uitvoering van richtlijnen bij collectieve overeenkomst. De Deense regeling, waarop met name de hier voorgestelde participatieregeling op leunt is een collectieve. Op zichzelf is er geen overwegend bezwaar om een dergelijke uitvoeringsregeling bij collectieve overeenkomst te laten bestaan mits er maar een wettelijk vangnet is voor die personen en bonden, die in het nationale recht buiten de overlegstructuur vallen. Daarnaast moet de collectieve regeling voldoen aan de eisen die door het Hof van Justitie in dit verband zijn gesteld (73) en voorts moeten lokale overeenkomsten ondergeschikt zijn aan de (nationale) collectieve overeenkomst. Is dit laatste niet het geval, en dat geldt in elk geval voor Groot Brittannië, dan zal een aanvulling op de betreffende veiligheids- en gezondheidswet noodzakelijk zijn. Daarmee wordt direct ingegrepen vooral in de eerdergenoemde drie landen, in het traditionele systeem van arbeidsverhoudingen. De enige hoop dat dit een haalbare kaart is, is dat de regeling een beperkt gebied betreft, dat toch al door wettelijke maatregelen wordt gedekt.

72. Zie paragraaf II.5.

73. Zie paragraaf II.5. 
In het vorige hoofdstuk kwam ook de positie van de individuele werknemer ter sprake. Het instrument dat in een nieuwe richtlijn voor individuele werknemers in elk geval moet worden opgenomen, is een expliciet recht het werk neer te leggen bij onmiddellijk dreigend gevaar. Dit recht is een wettelijk recht in enkele van de lid-staten (Nederland, Griekenland, Frankrijk) en in de andere lid-staten in elk geval in de civielrechtelijke jurisprudentie geaccepteerd (74). In elk geval zou een formulering zoals in de Nederlandse arbeidsomstandighedenwet, met betrekking tot de bewijslast in de richtlijn moeten worden opgenomen.

Voor wat betreft de andere problemen omtrent de positie van de individuele werknemer, het democratieprobleem en de mogelijkheid van medezeggenschap inzake veiligheids- en gezondheidsaangelegenheden op concernniveau, zou een richtlijn ook voorzieningen moeten geven. Aangezien het daar, veel meer dan bij het bovenstaande, gaat om nieuw te creëren beleid, dan een beleid dat als uitvloeisel van hetgeen de lid-staten op nationaal niveau al geregeld hebben, zal dit verderop in dit hoofdstuk worden besproken. Eerst zullen de bestaande regelingen, en vooral de op basis van artikel $118 \mathrm{~A}$ gedane voorstellen aan de bovenstaande minimumvoorzieningen worden getoetst.

\section{Beleid, richtlijnen en richtlijnvoorstellen}

Het beleid van de gemeenschap op het gebied van veiligheid en gezondheid bij de arbeid dateert uit de jaren zeventig, en voor wat betreft EGKS en Euratom nog eerder; in het EGA-oprichtings-verdrag is bepaald dat basisnormen betreffende de bescherming van werknemers en de bevolking tegen stralingsgevaar moeten worden vastgesteld (75).

In de jaren zestig bestond dit beleid voornamelijk uit (niet-bindende) aambevelingen die later gevolgd werden door normstellende maatregelen die betrekking hadden op de veiligheidsaspecten van bepaalde producten (76). Deze richtlijnen werden vastgesteld in het kader van het vrij goederenverkeer, en hadden het opheffen van technische handelsbelemmeringen tot doel (77). In de jaren zeventig kwam ook de oprichting van de Europese Stichting voor Levens- en Arbeidsomstandigheden tot stand (78), die zich bezig houdt met onderzoek zowel op het gebied van arbeidsomstandigheden

74. Zie paragraaf V.6.1..

75. Artikell 30 EGA-verdrag. Zie ook Pb. 1980, L 246.

76. Onder meer de richtlijn die classificatie, verpakking en het merken van gevaarlijke stoffen voorschrijft (oorspronkelijk daterend uit 1967, gewijzigd in $1979 \mathrm{~Pb} .1979 \mathrm{~L}$ 259) en de richtlijn betrekking met betrekking op het gebruik van electrische apparatuur ( $\mathrm{Pb}$ 1976, L. 24 en Pb. 1979 L 43).

77. Een deel werd genomen in het kader van het Algemeen Programma voor opheffing van technische handelsbelemmeringen, 28 mei $1969, \mathrm{~Pb} .1969, \mathrm{C} 76$.

78. Vo. 1365/75, Pb. 1975, L 139. 
sec (79), als op het veel ruimere gebied van milieu en de verhouding tussen arbeids- en levensomstandigheden in het algemeen (80). Daarnaast werd het Raadgevend Comité voor veiligheid, hygiëne en gezondheidsbescherming op de arbeidsplaats bij verordening ingesteld, een tripartite samengesteld advieslichaam van de Commissie (81). In deze jaren kwam bovendien een actieprogramma tot stand (82), dat in 1984 door een tweede (83) en in 1987 door een derde (84) werd gevolgd.

Ter uitvoering van beleid op veiligheids- en gezondheidsgebied heeft de Raad een richtlijn vastgesteld betreffende een informatieprocedure (tussen lid-staten en Commissie) op het gebied van technische normen en voorschriften; deze procedure omvat mede de gezondheid, veiligheid en hygiëne op het werk (85). De Commissie wordt bij de verwerking van de informatie sedert 1988 ondersteund door een groep van deskundigen uit de lid-staten (86).

De eerste richtlijnen waren geinspireerd door het eerste actieprogramma en er tot op zekere hoogte op gebaseerd. Een meer uitgebreid overzicht van de ontwikkeling in de Gemeenschap is onder meer te vinden bij Gevers (87).

\subsection{Richtlijnen en richtlijnvoorstellen daterend van vóór de invoering van artikel $118 \mathrm{~A}$}

De bestaande richtlijnen zijn onder te verdelen in drie soorten: richtlijnen die dwingend (minimum)normen voorschrijven die in het nationale recht moeten worden overgenomen en in de ondernemingen moeten worden toegepast, richtlijnen die voorwaarden scheppen voor een beleid met betrekking tot veiligheid en gezondheid, waaraan in de nationale wetgeving op eigen wijze kan worden vormgegeven, en richtlijnen die zowel aan werknemers als aan andere betrokkenen bescherming moeten bieden tegen gevaren die bij het werken in een onderneming kunnen ontstaan.

Tot de eerste soort behoren de richtlijn (88) inzake veiligheids-signalering op de werkplaats, de richtlijn ter bescherming van de gezondheid van

79. Zie o.m. het wierjarenprogramma van de stichting waarin onderzoeksterreinen voor de jaren 1992 worden vastgesteld, $\mathrm{Pb} .1989 \mathrm{C} 75$.

80. M. van Blijswijk, $H$. van Doorneveld-Luuring, EG-nieuwe stijl moet ook leiden tot verbetering arbeidsomstandigheden, Arbeidsomstandigheden (64) 1988, no. 9 p. 541 .

81. Vo. 74/325, Pb. 1974 L. 185.

82. Actieprogramma inzake veiligheid en gezondheid op de arbeidsplaats, Resolutie van 29 juni 1978, Pb 1978, C 165.

83. Resolutie van 27 februari 1984, $\mathrm{Pb}$ 1984. C 65.

84. Resolutie van 21 december 1987, Pb. 1988, C 28.

85. Pb. 1983, L 109.

86. Beschikking van 24 februari 1988, Pb. $1988 \mathrm{~L} 183$.

87. J.K.M. Gevers, a.w. (noot 44), p. 275-280; D. Collins, The European Communities, the Social Policy of the first Phase, Vol. II, The EEC 1958-1972, London 1975, p. 90 ev.

88. R1. 77/576, Pb. 1977 L 229, gewijzigd bij Rl. 79/640. 
werknemers die aan vinylchloridemonomeer (89) zijn blootgesteld (90) en de, op de raamrichtlijn ter bescherming van werknemers tegen chemische, fysische en biologische agentia gebaseerde, bijzondere richtlijnen (91).

De richtlijn inzake veiligheidssignalering op de werkplaats is een "pure" harmonisatierichtlijn, althans in opzet. Het beoogt de in de lid-staten gebruikelijke signalering te uniformeren, zodat werknemers die de taal van een bepaalde lid-staat niet machtig zijn, de waarschuwingen en aanwijzingen toch kunnen begrijpen en gebruiken. Volgens de preambule is de richtlijn noodzakelijk in het kader van de werking van de gemeenschappelijk markt. De richtlijn is een "pure" harmonisatie richtlijn in die zin dat lid-staten worden geacht hun wettelijke en bestuursrechtelijke bepalingen aan te passen; in beginsel is het invoeren van nieuwe bepalingen die niet ter vervanging van de oude dienen, niet nodig. Materiëel kan dat uiteraard toch noodzakelijk zijn: van lid-staten die op dit punt geen of onvoldoende voorschriften hadden, wordt invoering van nieuwe regelingen verlangd.

De richtlijn ter bescherming van de gezondheid van werknemers die werken met vinylchloridemonomeer, lijkt eveneens een zuivere harmonisatiemaatregel, hoewel hier meer een sociaal aspect naar voren komt. De richtlijn heeft, meer dan dan bovengenoemde richtlijn, een ruimere doelstelling dan het enkele harmoniseren van wetgeving. Dit blijkt met name uit de formulering van de preambule. De richtlijn beoogt preventieve maatregelen voor te schrijven, ter voorkoming van het vinylchloridemonomeersyndroom, een syndroom dat naast "beroepsacro-osteolyse", aandoeningen van de huid en stoornissen van de leverfunctie tot gevolg kan hebben. In de preambule wordt onder meer overwogen dat ".....hoewel de arbeidssituatie reeds opmerkelijke verbetering vertoont ten opzichte van de vroegere omstandigheden, waaronder vorenvermeld syndroom optrad, bij vergelijking van de door de lid-staten genomen beschermende maatregelen verschillen aan de dag treden; dat met het oog op een evenwichtige economische en sociale ontwikkeling die nationale wetgevingen moeten worden geharmoniseerd en verbeterd welke directe invloed op de werking van de gemeenschappelijke markt hebben". Daarnaast stelt de preambule: "...dat vooreerst op de huidige stand van de wetenschappelijke kennis afgestemde technische maatregelen tot preventie en bescherming moeten worden genomen, ten eind de concentratie van vinylchloridemonomeer in de atmosferische lucht van de bedrijven tot uiterst geringe waarden te verlagen."

89. RI. $78 / 610$, Pb. L. $1978,197$.

90. In Nederland zijn deze richtlijnen geïmplementeerd door invoeging van bepalingen in het Veiligheidsbesluit voor fabrieken en werkplaatsen 1938, het Electrotechnisch veiligheidsbesluit 1938, het Veiligheidsbesluit Loodwit, het Landbouw-veiligheidsbesluit en het Veiligheidsbesluit-Stuwadoorswet, zie Stb. 1982, 52 en Stb. 1982, 433.

91. R1. 82/605 (Metallisch lood), Pb. L 247, R1. 83/477, Pb. L 263, (Asbest), RL 86/188, L 137 (Lawaai); R1 88/364, Pb. L 179 (verbod van specifieke agentia). 
Wanneer men deze motieven tot regelgeving vergelijkt met die van de richtlijn over veiligheidssignalering dan spreekt hier een significant verschil uit. De directe invloed op de gemeenschappelijke markt waar het daar om gaat, is het probleem van werknemers die de taal c.q. de signalen niet begrijpen. Ondernemers kunnen om die reden weigeren onderdanen van andere lid-staten in dienst te nemen (en hebben daar tot op zekere hoogte misschien gelijk in). Bij de tweede richtlijn is de relatie met de gemeenschappelijke markt aanzienlijk minder duidelijk, zij komt ook minder duidelijk in de preambule naar voren; er wordt alleen aan gerefereerd door middel van een algemene overweging. Het lijkt er op dat harmonisatie in verband met de directe invloed op de gemeenschappelijke markt, tenminste mede, is gebruikt om een noodzakelijk geachte verbetering van de in de lid-staten geldende minimumnormen tot stand te brengen. Van pure uniformering van normen is geen sprake.

De richtlijn schrijft de minimumwaarden, en het controlesysteem van die waarden voor vinylchloridemonomeer voor, de situaties waarin individuele beschermingsmaatregelen moeten worden genomen, en bepalingen over medische controle en registratie. Daarnaast wordt de ondernemer de verplichting opgelegd aan (individuele) werknemers voor zij aangenomen worden, of voor de aanvang van de werkzaamheden en geregeld nadien te wijzen op de gevaren van vinylchloridemonomeer en de te nemen voorzorgen. Voorts schrijft de richtlijn voor dat de werknemer het recht moet hebben de over hem geregistreerde gegevens in te zien.

De raamrichtlijn ter bescherming van werknemers tegen de risico's van blootstelling aan chemische, fysische en biologische agentia (92), daterend uit 1980 , op het werk heeft een ander karakter dan de twee voorgaande en behoort tot de tweede soort. Deze richtlijn beoogt voorwaarden voor bescherming van werknemers te scheppen. De waarde van deze richtlijn is door het aannemen van de nieuwe richtlijn overigens sterk verminderd. De invulling geschiedt zowel door regelingen op gemeenschapsniveau (bijzondere richtlijnen) en (voorlopig) op nationaal niveau.

Het sociale karakter van de richtlijn komt hier uit de preambule heel duidelijk naar voren. Ook hier wordt met een algemene formule verwezen naar het belang voor de gemeenschappelijke markt van de harmonisatie. De richtlijn voorziet in een aantal voorwaarden die de lid-staten in acht moeten nemen bij het vaststellen van beschermingsmaatregelen tegen schadelijke agentia. De voorwaarden bevatten zowel individuele als collectieve beschermingsmaatregelen, (zowel preventieve als absolute) voorlichting, uitoefenen van medisch toezicht en (in hoofdstuk II besproken) informatie en consultatie van werknemers. Er is hier strikt gesproken geen harmonisatie van wetgeving in de zin van uniformering van voorschriften, hooguit van

92. RI. $80 / 1107$, Pb. 1980, L 327; wijzigingsvoorstel ingediend in $1986, \mathrm{~Pb} .1986, \mathrm{C} 164$. 
het stellen van minimumeisen aan wettelijke en bestuursrechtelijke matregelen in het algemeen.

Hoewel in de preambule gesproken wordt over het nader tot elkaar brengen van de wettelijke en bestuursrechtelijke bepalingen op de weg van de vooruitgang, is het niet zeker of dat in dit geval ook gebeurt: het enige dat duidelijk is, is dat excessen worden bestreden, daarvoor zorgen de minimumeisen. Dit open karakter wordt wel enigszins gematigd doordat in de richtlijn bepalingen zijn opgenomen, waaruit blijkt dat de richtlijn op concreet niveau kan worden ingevuld; in de bijlage worden agentia genoemd waarvoor bij bijzondere richtlijn grenswaarden op gemeenschapsniveau zullen worden vastgesteld. De richtlijn is in zoverre beperkt dat de voorwaarden voor nationale regelingen alleen betrekking hebben op chemische, fysische en biologische agentia (waarvan in de begripsomschrijving slechts gesteld wordt "dat deze de gezondheid (kunnen) schaden")

Dit betekent dat schadelijke invloeden die op andere wijze dan door genoemde agentia ontstaan, of schadelijke invloeden van agentia die in het algemeen de gezondheid niet, maar in specifieke individuele gevallen wel, schaden buiten het kader van de richtlijn vallen. Toetsing van nationale wetgeving aan de richtlijn kan dus alleen met betrekking tot het beperkte kader van de genoemde agentia plaatsvinden. Dit betekent concreet dat een werknemer die bijvoorbeeld meent recht te hebben op informatie ten aanzien van een agens dat alleen door de specifieke omstandigheden van die werknemer, voor hem mogelijkerwijs schadelijk kan zijn, en waar in de nationale wetgeving geen informatievoorziening is getroffen, geen mogelijkheid tot beroep op het gemeenschapsrecht heeft. De richtlijn legt alleen verplichtingen op met betrekking tot die agentia die in het algemeen worden geacht de gezondheid te schaden.

De eerste richtlijn ter uitwerking van de raamrichtlijn (93) is de richtlijn betreffende bescheming van de werknemers tegen de risico's van blootstelling aan metallisch lood en zijn ionverbindingen op het werk (94) die in 1982 tot stand kwam. De richtlijn voorziet in gebodsbepalingen met betrekking tot preventie en medische controle voor het geval dat het loodgehalte bepaalde maximumwaarden overschrijdt, bepalingen die betrekking hebben op medische controle meer in het algemeen, en algemene en bijzondere preventiemaatregelen. De belangrijkste en meest concrete bepaling in de richtlijn is artikel 10, waarin een aantal maatregelen staat opgesomd die het werken met lood moeten begeleiden. Dit artikel legt de ondernemer een aantal verplichtingen op in verband met kantineruimten, het ter beschikking stellen van (niet-besmette) dranken in die gevallen waarin de werknemers veel moeten drinken, en passende en adequate werkkleding en sanitaire

93. Rl. 80/1107, Pb. 1980, L 327, zie voor de bespreking van de in die richtlijn opgenomen medezeggenschapsverplichting paragraaf II.4.2.C.

94. RI. 82/506/EEG, 28 juli 1982, Pb. 1983, L 247. 
voorzieningen, verplichtingen die niet op de werknemer mogen worden verhaald.

In de richtlijn zijn grenswaarden opgenomen, waarvan de waarde echter relatief is, omdat geen absoluut verbod bestaat voor het werken in ruimten waar die grenswaarden overschreden worden. De grenswaarden zijn indicatoren voor verscherpt toezicht en een aantal preventieve maatregelen, waardoor de situatie verholpen kan worden. Indien deze maatregelen niet meteen de situatie verbeteren, levert dat nog geen verbod op om in de ruimte te werken, maar slechts een verplichting voor de werkgever passende persoonlijke beschermingsmiddelen ter beschikking te stellen. Deze situatie mag volgens de richtlijn geen blijvend karakter dragen. Alleen bij "incidenten die kunnen leiden tot een aanzienlijke toeneming van de blootstelling aan lood' moeten de werknemers onverwijld uit de betrokken zone worden verwijderd. Deze toevoeging maakt de waarde van de richtlijn twijfelachtig, met name doordat de term "aanzienlijk" niet duidelijk is. Indien deze term gerelateerd is aan eventuele hoge waarden van het loodgehalte, lijkt het een vrijbrief voor zo ongeveer alles.

Wanneer in een onderneming werkzaamheden plaatsvinden, waarbij overschrijding van de grenswaarden verwacht kan worden, en waarbij preventieve beschermingsmaatregelen redelijkerwijs niet uitvoerbaar zijn, moeten door de werkgever in overleg met de werknemersvertegenwoordigers maatregelen worden getroffen ter bescherming van die werknemers.

Naast deze verplichting bestaat er voor de ondernemer een informatieplicht ten opzichte van zowel de werknemers als hun vertegenwoordigers met betrekking tot gevaren en de hygiënische en andere preventieve maatregelen. Daarnaast hebben werknemersvertegenwoordigers inzage in de metingsresultaten van de loodmetingen in de lucht en de statistische resultaten van het biologische toezicht op de werknemers. Indien uit de metingen van het loodgehalte in de lucht blijkt dat grenswaarden overschreden zijn, moeten de werknemersvertegenwoordigers geconsulteerd worden over te nemen maatregelen, of in noodsituaties geinformeerd worden over de genomen maatregelen.

Deze medezeggenschapsbepalingen zijn te beschouwen als concrete invulling van de in artikel 6 lid 1 van de raamrichtlijn gegeven medezeggenschapsverplichting. De lid-staten hebben overigens op alle punten, dus ook op dit punt het recht om verder te gaan in hun eigen wetgeving.

De richtlijn ter bescherming van werknemers tegen de gevaren van asbest uit 1983 (95) is eveneens een uitwerking van de raam-richtlijn. Asbest is een stof die in bijlage I van de raam-richtlijn is opgenomen, en waarvan artikel 8 van de raamrichtlijn voorschrijft dat afzonderlijke richtijnen zullen

95. RL. $83 / 477$, Pb. 1983, L. 263. 
voorzien in grenswaarden en andere specifieke voorschriften. Ook hier geldt dat deze specifieke voorschriften, voor zover nodig en mogelijk, onderworpen zijn aan de in de raamrichtlijn voorgeschreven medezeggenschapsbepaling. De richtlijn voorziet, naast grenswaarden, in een meldingsplicht van en technische bepalingen over het gebruik en controle van het gebruik van asbest in het licht van de grenswaarden. Daarnaast voorziet de richtlijn in een aantal bepalingen voor de wijze waarop werknemers beschermd dienen te worden. Het gaat hier om verplichtingen met betrekking tot persoonlijke beschermingsmiddelen, gezondheidscontrole en -dossiers, voorlichting en onderricht van werknemers en verplichtingen met betrekking tot de duur en de omstandigheden waaronder het werken met asbest is toegestaan.

De richtlijn verplicht zowel tot het verstrekken door de werkgever als het dragen door de werknemer van een persoonlijke beschermingsuitrusting. Bovendien zijn ook in deze richtlijn verplichtingen opgenomen met betrekking tot sanitaire voorzieningen en tot onderhoud van, en controle op het onderhoud van de persoonlijke beschermingsuitrusting, waarvan de kosten niet op de werknemers verhaald mogen worden. Ook voor de medische controle en de procedures daaromtrent zijn bepalingen opgenomen. Daarnaast is er een verplichting tot het aanleggen van een persoonlijk gezondheidsdossier van werknemers.

Een belangrijke bepaling is m.i. te vinden in artikel 15 van de richtlijn, wanneer men deze combineert met de raamrichtlijn. Deze bepaling heeft betrekking op de keuring. Werknemers moeten drie-jaarlijks gekeurd worden zollang zij met asbest werken. De keuring kan tot resultaat hebben dat een werknemer niet langer aan asbest mag worden blootgesteld. De richtlijn stelt dat de werknemer recht heeft op herziening van de keuring volgens de nationale wetgeving van de lid-staten. De bepaling geeft niet aan wat er verder moet gebeuren, indien de werknemer wordt afgekeurd. Echter artikel 6, tweede gedachtenstreepje van de raamrichtlijn stelt dat de werknemer die volgens de nationale praktijk tijdelijk wordt onttrokken aan blootstelling aan de werking van een agens voor zover mogelijk, ander werk moet krijgen. Indien de afkeuring maar tijdellik is, is er dus een duidelijke plicht van de werkgever tegenover de werknemer. Dit is in beginsel niet het geval wanneer de afkeuring voor het werken met asbest definitief is. Echter het valt te verdedigen dat -indien de ondernemer mogelijkheden heeft om de werknemer van ander werk te voorzien, waarbij hij niet in aanraking komt met asbest- uit de bepaling van artikel 6 tweede gedachtenstreepje van de raamrichtlijn, ook dan een dergelijke plicht kan worden afgeleid.

Artikel 15 van de richtlijn is overigens een wel heel zwakke afspiegeling van het oorspronkelijk door de Commissie voorgestelde artikel (96). Daarin werd het verboden werknemers aan asbest bloot te stellen indien dit risico, volgens een medische keuring onaanvaardbaar moet worden geacht. De

96. Voorstel door de Commissie ingediend op 26 september 1980, Pb. 1980, C 262. 
keuring had jaarlijks moeten plaatsvinden en moeten omvatten: '(...) een klinisch onderzoek van de borstkas, keuringen op de ademhalingsfuncties (waaronder de vitale capaciteit) en een röntgenfoto van de borstkas op standaardformaat' (97). Lid-staten zouden moeten voorzien in een beroepsprocedure voor beslissingen op grond van deze keuring. Hier zat dan ook een probleem omdat uit het voorstel niet duidelijk werd of datgene dat in de keuring moest worden onderzocht een minimumeis was of een standaardeis. Met andere woorden: kon op basis van de formule uit het voorstel iemand afgekeurd worden voor het werken met asbest doordat de keuring in een lid-staat uitgebreider is dan het door de richtlijn verplichte onderzoek?

Uit artikel 15 lid 2 van het voorstel had men kunnen afleiden, dat het om standaardeisen ging. In dit artikel werd, met een verwijzing naar artikel 10 van de raamrichtlijn een verplichting opgelegd de procedure voor medische onderzoeken aan te passen in overeenstemming met de technische vooruitgang. In artikel 10 werd een procedure gegeven, waarbij een comité van vertegenwoordigers van de lid-staten in samenwerking met de Commissie een advies geeft over de te nemen maatregelen, waarna de Commissie maatregelen vaststelt. Indien er geen advies tot stand gekomen was, of de maatregelen niet in overeenstemming waren met het advies van de Commissie, doet de Commissie een voorstel aan de Raad over de te nemen maatregelen. De verwijzing met betrekking tot de keuring, naar deze procedure van artikel 10 wees erop dat de keuringseisen artikel 15 lid 1 sub b standaardeisen zijn, en alleen gewijzigd kunnen worden door middel van deze procedure.

Niettemin zou ook dan het probleem zijn blijven bestaan, dat medische keuringen op zichzelf niet gereguleerd worden door gemeenschapsrecht (98). Dit betekent dat keuringen, ook in gevallen waar met asbest gewerkt wordt, altijd ruimer kunnen zijn dan datgene dat het voorstel voor zou hebben geschreven, ook al zou de test met betrekking tot asbest niet ruimer mogen zijn geweest dan hetgeen artikel 15 lid 1 sub b voorschreef. In dat geval zou het echter wel de vraag zijn geweest of de werknemer dan op grond van de richtlijn (t.z.t.) een recht op een beroepsprocedure had kunnen claimen, als die er voor andere keuringen dan op asbest in de eigen lidstaat niet bestaat. Het lijkt mij dat dit wel het geval zou zijn geweest, omdat anders een werknemer die, op andere gronden dan de in het voorstel aangegeven verplichte tests zou worden afgekeurd, terwijl zijn

97. Ook met betrekking tot deze formule is de richtlijn veel zwakker: artikel 15 lid 1 stelt dat 'deze keuring (.....) een specifiek van de borstkas (dient) te omvatten'. De gebezigde formule uit het voorstel wordt slechts in een bijlage aan de lid-staten aanbewolen als testcriterium.

98. Zie T. Morehead Dworkin, E. Steyger, AIDS Victims in the European Community and the United States: Are they protected from Unjustified Discrimination, Texas International Law Journal, Spring 1989, Vol 24, no. 2. p. 322. Keuringen zijn onderworpen aan regels van nationaal recht, en komen slechts in strijd met het gemeenschapsrecht, als EGonderdanen gediscrimineerd worden ten opzichte van eigen onderdanen. 
afkeuring in relatie zou staan tot het werken met asbest in een te nadelige positie zou komen te verkeren. De consequentie van deze redenering zou zijn geweest dat beroepsrechten bij keuringen, indien ze in relatie tot het gebruik van asbest staan, zouden zijn uitgebreid, althans in die lid-staten die niet in beroep tegen beslissingen op grond van medische onderzoeken voorzien.

Door de formulering in de richtlijn, waarin herziening van de keuring overeenkomstig de nationale wetgeving kan worden gevraagd is dit niet het geval. Indien de nationale wetgeving niet in herzienings- c.q. beroepsprocedures met betrekking tot keuringen voorziet valt er ook geen herziening aan te vragen. Een uitbreiding of invoering van beroepsmogelijkheden met betrekking tot keuringen op basis van het gemeenschapsrecht is daarmee dus van de baan.

In de richtlijn zijn specifieke informatie- en consultatie verplichtingen voor de werknemers en hun vertegenwoordigers opgenomen. Informatieverplichtingen ten opzichte van de werknemers zijn er met betrekking tot de gevaren van asbest, met betrekking tot de signalering en de keuring. Consultatie van werknemersvertegenwoordigers moet plaatsvinden in die situaties waarin te verwachten valt dat de grenswaarden overschreden worden, maar preventieve maatregelen niet uitvoerbaar zijn. Bovendien hebben de werknemersvertegenwoordigers recht op inzage in de metingsresultaten, en moeten zij geraadpleegd worden in het geval zij menen dat deze onjuist zijn, of dat er veranderingen in de situatie hebben plaatsgevonden. Ook deze medezeggenschapsverplichtingen staan slechts naast die uit de raamrichtlijn. In de raamrichtlijn (artikel 6 eerste gedachtenstreepje (99)) wordt ook een recht op informatie en eventueel consultatie toegekend voor de toepassing van de door de lid-staat op basis van de richtlijn genomen maatregelen in de onderneming. Dit recht wordt door de richtlijn inzake asbest niet opzij gezet.

De derde bijzondere richtlijn in de zin van de raamrichtlijn is de richtlijn ter bescherming van werknemers tegen de risico's van blootstelling aan lawaai op het werk (100). In de preambule van de richtlijn wordt al de ontmoedigende conclusie getrokken dat de situatie in de lid-staten vooralsnog niet de vaststelling van een maximumwaarde toelaat op een zodanig niveau, waaronder zich geen gevaar meer zal voordoen voor het gehoor van de werknemers. Dit betekent dat ook hier de grenswaarden er alleen toe

99. Deze bepaling luidt: "De lid-staten zorgen ervoor dat de werknemers- en werkgeversorgamisaties worden geraadpleegd voordat de bepalingen ter uitvoering van de in artikel 3 bedoelde maatregellen worden aangenomen en dat de vertegenwoordigers van de werknemers in de ondernemingen en bedrijven waar dergelijke vertegenwoordigers bestaan, zich over de toepassing van deze bepalingen kunnen vergewissen of erbij kunmen worden betrokken".

100. Rl. 86/188/EEG, Pb. 1986, L 137. 
dienen het moment te bepalen waarop additionele beschermende maatregelen moeten worden genomen.

De richtlijn legt een verplichting op aan de ondernemer dat de gevaren aan blootstelling van geluid zo laag moeten worden gehouden als redelijkerwijs mogelijk is. Indien de blootstelling aan geluid de maximumwaarde overschrijdt, moet naast de bijzondere beschermingsmaatregelen, de ondernemer een programma van maatregelen van technische of organisatorische aard opstellen en uitvoeren om de blootstelling aan lawaai van werknemers te verminderen, indien dit redelijkerwijs haalbaar is. Werknemersvertegenwoordigers worden wel ingelicht over het programma maar hoeven op grond van de richtlijn niet geconsulteerd te worden (101). Dit laatste is een omissie, juist doordat voor het op te zetten programma een tweede 'redelijkerwijs' clausule is opgenomen. Bovendien, consultatie bij organisatorische maatregelen lijkt mij bijna een voorwaarde om tot effectieve maatregelen te komen: werknemers hebben veelal een betere kijk op de organisatie van het werk en de problemen bij het reorganiseren daarvan dan de werkgever.

Andere medezeggenschapsbepalingen in de richtlijn hebben betrekking op informatie en controlerechten bij de metingen van het geluid, en inzagerecht in de bewaarde gegevens met betrekking tot de metingen. Bovendien is de medezeggenschapsbepaling uit de raamrichtlijn (artikel 6, eerste gedachtenstreepje) in haar geheel in de richtlijn overgenomen. In feite is deze bepaling mijns inziens hier ten overvloede. Zoals hierboven al gesteld zou de bepaling ook van toepassing zijn geweest, indien deze niet op deze wijze in de bijzondere richtlijn was opgenomen.

De vierde (102) en tot dusver laatste bijzondere richtlijn is de richtlijn ter bescherming van werknemers door een verbod van bepaalde specifieke agentia en/of bepaalde werkzaamheden (103) uit 1988. Door middel van een amendement op de preambule uit 1987 is deze richtlijn de eerste geworden die gebaseerd is op artikel 118A (104). Het voorstel is voor het overige bedoeld als bijzondere richtlijn op basis van de ramrichtlijn ter bescherming tegen gevaren van chemische, fysische en biologische agentia. De grondslag van de raamrichtlijn zelf is overigens niet uitdrukkelijk gewijzigd (105).

101. Artikel 5 lid 2, sub a en sub b RL. 86/188.

102. In feite dateert deze richtlijn al van na de imwoering van artikel $118 \mathrm{~A}$, het voorstel is echter wit 1984 (Pb. 1984, C 270).

103. Rl $88 / 364$, Pb. 1988, L 179.

104. Voorstel ingediend op 12 november $1987, \mathrm{~Pb} .1988, \mathrm{C} 3$.

105. Zie ook P.J.G. Kapteyn, P. VerLoren van Themaat, a.w. (noot 5), p. 416. Zij vragen zich af of het de bedoeling is of richtlijn 80/1107 onder deze nieuwe rechtgrondslag wordt gebrachit. 
De richtlijn verbiedt het gebruik van bepaalde in een bijlage genoemde agentia (106). De bijlage kan met gekwalificeerde meerderheid van stemmen herzien worden, met name om agentia toe te voegen. Daarnaast geeft de richtlijn de grenzen aan van eventuele vrijstellingsregimes aan. Vrijstellingen kunnen onder meer verleend worden voor onderzoeksdoeleinden, voor werkzaamheden waarbij de agentia als tussenprodukt wordt gebruikt en voor werkzaamheden met als doel de agentia in de vorm van afvalprodukten te verwijderen. Vrijstellingen kunnen alleen gegeven worden, indien de werkgever een aantal procedures naleeft die betrekking hebben op voorzorgsmaatregelen ter bescherming van de gezondheid en de veiligheid van de werknemers en informatieverstrekking aan de bevoegde instantie. De lid-staten mogen bovendien voorzien in een vergunningenstelsel.

Werknemers hebben een bijzonder recht op informatie, namelijk de inzage in de aan de bevoegde autoriteit verstrekte stukken. Deze stukken moeten alle inlichtingen bevatten die de werknemersvertegenwoordigers nodig hebben om volledig op de hoogte te zijn zowel van de gevaren voor de veiligheid en gezondheid die verbonden zijn aan het agens waarmee zij werken als de maatregelen die genomen zijn ter bestrijding van de gevaren.

De richtlijn inzake de risico's van zware ongevallen bij bepaalde industriële activiteiten (107) is een op zichzelf staande richtlijn van de derde soort; de richtlijn moet naast werknemers ook aan derden bescherming moet bieden tegen gevaren die bij het werken in een onderneming kunnen ontstaan. $\mathrm{Zij}$ is zowel gebaseerd op artikel 100 als op artikel 235. Dit komt omdat de richtiijn volgens de preambule zowel harmonisatie beoogt als een (kennelijk zelfstandige) actie van de Gemeenschap ter verwezenlijking van én van de doelstellingen van het verdrag. De harmonisatie van wetgeving heeft betrekking op de bepalingen die in de lid-staten van toepassing zijn, dan wel in voorbereiding zijn ten aanzien van de preventie van zware ongevallen en de beperking van de gevolgen daarvan voor mens en milieu. De verschillen in deze bepalingen tussen de lid-staten kunnen concurrentievervalsend werken, en harmonisatie wordt daarom rechtstreeks van belang geacht voor de werking van de gemeenschappelijke markt. Voor dit deel is de grondslag dus artikel 100 .

De bijkomende grondslag van artikel 235 is nodig omdat met de richtlijn specifieke maatregelen worden beoogd op het gebied van de milieubescherming en de veiligheid en gezondheid van het werk. Het verdrag voorziet niet in de vereiste bevoegdheden deze maatregelen zonder meer te nemen;

106. Het gaat hier om 2-naftylamine en de zouten daarvan, 4-aminodifenyl en de zouten daarvan en 4-nitrodifenyl, afzonderlijk of alls preparaat. Het verbod geldt niet indien deze agentia in de vorm van onzuiverheden, bijprodwkten, of bestanddeel van afvalprodukten worden gebruikt, mits de concentratie ervan een bepaalde grenswaarde niet overschrijdit.

107. RI. 82/501 EEG, 24 juni 1982, Pb 1982, L 230/1, wijzigingsvoorstel van de Commissie aan de Raad, Pb. 1988, C 119. 
de aanvullende grondslag van artikel 235 dient om in deze leemte te voorzien.

De richtlijn is op meer gericht dan alleen bescherming van werknemers; zij beoogt ook bescherming te bieden aan het milieu en aan derden. De richtlijn heeft dan ook veel minder een ingrijpend karakter in de ondernemingen zelf: weliswaar worden voorzieningen gegeven die aan ondernemers (in deze richtlijn: "fabrikant") verplichtingen opleggen, maar deze verplichtingen zijn veel algemener dan die in de andere veiligheids- en gezondheidsrichtlijnen. Bovendien hebben ze voornamelijk betrekking op informatie-verstrekking aan de bevoegde (publiekrechtelijke) instanties en aan hen die mogelijk getroffen zouden kunnen worden door een industrieel ongeval. Een specifieke informatieplicht voor ondernemers ten opzichte van werknemers is niet opgenomen.

De richtlijn voorziet in een aantal bepalingen die de Lid-Staten verplichten zorg te dragen voor controle op de ondernemers met betrekking tot preventiemaatregelen in de onderneming, passende veiligheidsmaatregelen, veiligheidsvoorlichting, -training en -uitrusting van het personeel. Deze controle dient te worden uitgevoerd door een zonodig in het leven te roepen instantie met publiekrechtelijke bevoegdheden die onder meer het recht op het verkrijgen van benodigde gegevens inhoudt en die bovendien over de deskundigheid beschikt om de gegeven te bestuderen en in staat is de genomen maatregelen te beoordelen.

De fabrikant moet de verplichting worden opgelegd om de bevoegde instanties de kenmis te geven van een aantal situaties die in de richtlijn omschreven staan. Aan welke voorwaarden een dergelijke kennisgeving moet voldoen staat in de richtlijn omschreven. Ook in geval van wijziging van een industriële activiteit geeft de richtlijn voorschriften voor het optreden van de lid-staten. Bovendien schrijft de richtlijn een aantal maatregelen voor voor het geval zich een zwaar ongeval voordoet.

Naast deze verplichtingen legt de richtlijn een verplichting op de lid-staten om er op toe te zien dat personen die getroffen kunnen worden door een zwaar ongeval ten gevolge van een industriële activiteit waarvan op de in de richtlijn voorgeschreven wijze kennis is gegeven, op passende wijze worden ingelicht over de genomen veiligheidsmaatregelen en over de wijze waarop zij zich ingeval van een ongeluk moeten gedragen.

De meest opvallende bepalingen in de richtlijn zijn gewijd aan de rapportage verplichting aan de andere lid-staten en aan de Commissie. De bedoeling hiervan is ervoor te zorgen dat met name in grensgebieden onderdanen van andere lid-staten op dezelfde passende wijze worden voorgelicht over risico's en veiligheidsmaatregelen als eigen onderdanen. Daarnaast is door de rapportageverplichting van ervaringen bij zware ongevallen de mogelijkheid ontstaan dat verschillende lid-staten profiteren 
van deze (al dan niet goede) ervaringen, zodat gelijksoortige of juist geheel andere maatregelen kunnen worden genomen.

Hoewel in de preambule van de richtlijn veel nadruk wordt gelegd op de bescherming van de veiligheid en gezondheid van werknemers, is het duidelijk dat de richtlijn meer beoogt bescherming van milieu en bevolking in het algemeen te bieden dan werknemersbescherming (108). Dit blijkt met name uit het ontbreken van specifieke informatie en consultatierechten van werknemers of hun vertegenwoordigers: hierover is in de gehele richtlijn niets terug te vinden. Dit is in mijn ogen een omissie niet alleen omdat juist voor deze specifieke categorie van bedreigingen van veiligheid en gezondheid van werknemers tot dusver in geen enkele richtlijn een voorziening is getroffen maar ook omdat informatie aan werknemers, onder geheimhouding verstrekt, reëel kan bijdragen aan zowel grotere bescherming van werknemers als aan grotere bescherming van milieu en bevolking.

Informatieverstrekking aan werknemers als specifieke verplichting is een minimumvoorwaarde om de bepalingen die uit een richtlijn als deze voortvloeien, effectief te laten werken. Daarnaast zou de mogelijkheid voor werknemersvertegenwoordigers om geconsulteerd te worden over zowell veiligheidsmaatregelen als de actuele kennisgeving de effectiviteit van de richtlijn en de controlemogelijkheden van lid-staten kunnen vergroten.

De waarde van de richtlijn wordt overigens ook op andere wijze gerelativeerd: onder de bedrijfstakken die worden uitgezonderd vallen zowel kerninstallaties en installaties voor de behandeling van radioactieve stoffen en materialen, militaire activiteiten, winnings- en andere mijnbouwactiviteiten als de fabricage en de afzonderlijke opslag van springstoffen, kruit en munitie. Waar het gaat om grensoverschrijdende risico's kan worden aangenomen dat juist deze bedrijfstakken gevaar op kunnen leveren.

In 1988 is een wijzigingsvoorstel voor de richtlijn naar de Raad gegaan, dat naast andere wijzigingen een betere informatievoorziening beoogt. Het wijzigingsvoorstel is gedaan met het oog op artikel 130S EEG-verdrag (109).

A Opmerkingen over de medezeggenschapsbepalingen bezien in het licht van het eerdengenoemde concept

Als de belangrijkste bepaling met betrekking tot medezeggenschap inzake veiligheids- en gezondheidsaangelegenheden kan de bepaling in de raamrichtlijn ter bescherming van werknemers tegen chemische, fysische en biologische agentia worden beschouwd. Deze biedt het kader waarbinnen

108. Zie ook de opmerkingen van de behandeling in het Europees Parlement van zowel het richtlijnvoorstel (17 juni 1980, doc. 1-220/80) als het wijzigingsvoorstel (19 februari 1987, doc. 2-348/203).

109. Artikel $130 \mathrm{~S}$ is ến wan de artikelen die door middel van de Europese Akte in het verdrag is opgenomen, en die deel uitmaakt van de bepalingen met betrekking tot milieubeleid. 
in de, op deze richtlijn gebaseerde, bijzondere richtlijnen, specifieke verplichtingen gerealiseerd moeten worden.

In de eerste echte beschermingsrichtlijn, de richtlijn ter bescherming van werknemers tegen vinylchloridemonomeer, wordt de werknemer nog geheel gezien als een te beschermen object. Medezeggenschapsbepalingen in de hierboven genoemde zin komen in de richtlijn niet voor, slechts de individuele werknemer heeft recht op informatie en het controlesysteem wordt geheel in handen gelegd van werkgever en overheid.

De raamrichtlijn kent een medezeggenschapsbepaling die geheel aansluit bij de nationale praktijk. Artikel 6 lid 1 schrijft voor dat de werknemersvertegenwoordigers (indien aanwezig (110)) zich van de toepassing van de in de onderneming te nemen maatregelen moeten kunnen vergewissen of erbij betrokken worden. Dit laat de wijze waarop dit dient te gebeuren open: minimaal gebiedt het tot het verstrekken van van informatie. Een verplichting tot het consulteren van de werknemers kan men er echter niet zonder meer in lezen, hoewel de bepaling daar wel naar tendeert.

Deze informatieverplichting staat naast een specifieke informatieverplicliting met betrekking tot de situatie bij overschrijding van de grenswaarden en de daarop gerichte maatregelen, en algemene informatie ter vermeerdering van de kennis van de gevaren. Hieruit zou afgeleid kunnnen worden dat "het zich kunnen vergewissen" van de uitvoeringsmaatregelen uit artikel 6 lid 1 van de richtlijn meer betekent dan een informatieverplichting. Voorts kent de richtlijn een meer algemene informatieverplichting aan alle werknemers toe. De laatste verplichting kan overigens niet overgenomen worden door de vertegenwoordigers. Het gaat hier om specifieke, op de individuele werknemers afgestemde informatie over de gevaren van het werken met de in de onderneming aanwezige agentia.

Daarnaast heeft de richtlijn een verplichting tot het opnemen in de nationale wet voor een mogelijkheid tot controle door de werknemersvertegenwoordigers op de resultaten van de metingen die in de onderneming naar bepaalde agentia zijn verricht. Dit moet gebeuren door de werknemers toegang te verlenen tot die (anonieme) resultaten.

Al met al zijn dit nogal magere voorschriften. Nu moet men deze richtlijn wel zien in de tijd waarin deze gemaakt is. Het voorstel van de Commissie dateert uit 1979 (111), en dus uit de tijd dat de discussie rond de Vredeling-richtlijn woedde, en veel weerstanden opriep. De pragmatische benadering van volledige aansluiting bij de nationale praktijk en slechts enige voorschriften op het gebied van informatieverstreking en controle kan om die reden gekozen zijn.

110. Zie paragraaf I1.4.2.D.

111. Pb. 1979, C 89. 
In de richtlijn ter bescherming van werknemers tegen metallisch lood, is de bepaling van artikel 6 lid 1 uitgewerkt in een consultatieverplichting. Het raamwerk van de richtlijn wordt daarmee ingevuld op een wijze die iets verder gaat dan wat de raamrichtilin biedt. De informatie en controleverplichtingen zijn vrijwel gelijk aan die van de raamrichtlijn en slechis ingevuld voor het concrete terrein. Voor de richtlijn ter bescherming tegen asbest geldt praktische hetzelfde.

De richtlijn ter bescherming van werknemers tegen lawaai beperkt de werking van artikel 6 lid 1 van de raamrichtlijn zelfs nog iets, tenminste dat kan zo uitpakken. Hierboven werd al opgemerkt dat werknemers over de door de werkgever op te stellen programma's voor technische en organisatorisch maatregelen ter vermindering van het lawaai, wanneer dat een bepaalde grens overschrijdt, in de onderneming wel geïnformeerd maar niet geconsulteerd hoeven te worden. Waar de raamrichtlijn de mogelijkheid tot consultatie over de toepassing van de in onderneming te nemen maatregelen (praktisch) voorschrijft, komt deze laatste richtlijn met een bepaling waarin consultatie niet voorgeschreven is voor.... in de onderneming te nemen maatregelen in een specifiek geval. Dit wijst er dan toch weer op dat ofwel artikel 6 lid 1 niet zo ruim is bedoeld dat consultatie er per definitie onder valt, ofwel dat het mogelijk is de raamrichtlijn bij bijzondere richtlijn te beperken.

Geen van de bestaande richtlijnen opent de mogelijkheid tot de verdergaande medezeggenschapsbepalingen zoals in het door mij gesuggereerde concept voorgesteld. Zoals opgemerkt: het kan aan de tijd liggen waarin zij gemaakt zijn. Naast de eerdergenoemde discussies, zijn tenslotte een groot deel van de wetten op dit terrein die de werknemerswertegenwoordigers verdergaande rechten geven dan consultatieve van de jaren na de totstandkoming van de richtlijnen. Slechts voor de richtlijn ter bescherming tegen lawaai -die nu juist op een bepaald punt restrictiever lijkt te zijn dan de raamrichtlijn geldt dit niet- deze dateert uit 1986.

Andere dan de hierboven genoemde rechten, zoals de mogelijkheid van ingrijpen door de arbeidsinspectie worden in de richtlijn niet geboden, hoewel in veel gevallen de wetten in de lid-staten al voorzieningen daaromtrent hadden opgenomen. De reden daarvoor kan gelegen zijn in het feit dat men dergelijke bepalingen tot de nationale competentie rekende, en dat harmonisatie in het kader van de gemeenschappelijke markt een dergelijke bepaling niet nodig maakte.

\section{$B$ De richtijnvoorstellen}

Naast de bestaande richtlijnen is er een aantal richtlijn-voorstellen met betrekking tot veiligheid en gezondheid van werknemers ingediend bij de Raad van Ministers. Het gaat zowel om voorstellen die specifieke gevaren betreffen, als om voorstellen die gericht zijn op meer algemene bescherming. 
Uit 1980 dateert het voorstel van de Commissie voor een richtlijn tot vaststelling van basisnormen voor de bescherming van de gezondheid wan de werknemers en de bevolking tegen de aan microgolven verbonden gevaren (112). De richtlijn zou geënt moeten worden op artikel 100 met verwijzing naar de artikelen 117 en 118 EEG-verdrag. Harmonisatie van voorschriften voor de fabricage en het gebruik van toestellen die microgolven uitzenden wordt direct in het belang van de gemeenschappelijke markt geacht, een nadere motivering wordt daar overigens niet voor gegeven.

Hoewel het voorstel niet alleen bedoeld is ter bescherming van werknemers maar ook van de bevolking in het algemeen blijkt zowel uit deze grondslag als uit de preambule dat de Commissie met deze richtlijn in het bijzonder de bescherming van de werknemers op het oog heeft. De bredere basis die de richtlijn beoogt, zou men althans voor wat betreft de preambule af kunnen leiden uit de aansluiting op de EEG-richtlijn die de harmonisatie van wettelijke voorschriften inzake elektrisch materiaal bestemd voor gebruik binnen bepaalde spanningsgebieden (113) ten doel heeft, en op de Euratom-richtlijn die basisnormen voor de bescherming van de bevolking en van de werknemers tegen de aan ioniserende straling verbonden gevaren (114).

Het voorstel bevat twee hoofdlijnen. De eerste is te vinden in de titel III, 'limieten van de blootstelling aan microgolven'. Daar wordt naast de vaststelling van een absolute maximumnorm bepaald, dat: "de blootstelling van personen aan microgolven (....) zo gering (moet worden gehouden) als redelijkerwijs mogelijk is" (115). In hoeverre een dergelijke bepaling effectief kan zijn, hangt af van de waarde van de maximumnorm. Indien deze hoog is, hebben lid-staten meer vrijheid om de term 'redelijkerwijs' ruim te interpreteren (116).

De tweede hoofdlijn, titel VI, betreft de principes van operationele bescherming. Hierin worden bepalingen gegeven ten aanzien van medisch toezicht op werknemers die blootgesteld zijn aan microgolven, specifieke voorschriften ter bescherming van werknemers die "bewust aanvaard blootgesteld" zijn aan niveaus die hoger liggen dan de maximumnormen, en voorlichting en onderricht van werknemers. Ter bescherming van personen zijn er bepalingen opgenomen met betrekking tot de afbakening voor het publiek en signalering van gecontroleerde (en dus risicovolle) zones.

112. Voorstel door de Commissie bij de Raad ingediend op 26 junï 1980, Pb 1980, C 249.

113. R1. 73/23/EEG, Pb. 1973, L 77 .

114. Rl. 76/579/Euratom, Pb. 1976, L 178.

115. Voorstel voor de richtlijn, art. 3 lid 1.

116. Gezien mijn onbekendheid met de materie, en het feit dat het voor de juridische implicaties daarvan van weinig belang is of deze norm inderdaad als 'boog' dan well 'laag' moet worden beschowwd, wil ik er hier niet op ingaan. 
Met betrekking tot het medisch toezicht bepaalt het voorstel alleen in het algemeen dat, en in welke gevallen er medisch toezicht nodig is. Voor werknemers die bewrust aan hogere niveaus dan de in titel III worden blootgesteld moet een "geëigende dienst" beschikbaar zijn. Over bevoegdheden en status van deze dienst wordt niets bepaald, zodat aannemelijk is dat een bedrijfsgeneeskundige dienst als een "geëigende dienst" in de zin van het woorstel kan worden beschouwd.

Tenslotte bevat het voorstel bepalingen met betrekking tot controle en onderhoud van apparaten die microgolven uitzenden, waarbij zowel aan de lid-staten als aan de fabrikanten van de apparaten verplichtingen worden opgelegd. Voor deze laatsten betreft het met name een plicht tot verstrekking van informatie met betrekking tot de apparatuur (117).

In het voorstel zijn geen verplichtingen aan de lid-staten opgenomen tot het opnemen van een medezeggenschapsvoorziening in hun nationale wetgeving; er is evenmin sprake van een bepaling als in andere veiligheids- en gezondheidsrichtlijnen die voorschrijft dat medezeggenschap moet plaatsvinden naar de wettelijke voorschriften of de praktijk in de lid-staten. Dit kan zijn oorzaak vinden in het feit dat de richtlijn een zeer specifiek deel van de arbeidsbescherming behandelt. Een formulering waarin echter een vage term als "redelijkerwijs" gebruikt wordt, waar het gaat om een zo laag mogelijk blootstelling aan microgolven, vereist mijns inziens de mogelijkheid van medezeggenschap van werknemers, om de invulling van de term in het concrete geval, zo goed mogelijk tot zijn recht te doen komen.

De medezeggenschapsbepaling zou ingevuld zijn, indien het voorstel als uitwerking van de (oude) raamrichtlijn, zou worden beschouwd. Uit het voorstel blijkt niet dat dat de bedoeling is. Het voorstel is ouder dan de raamrichtlijn, en de preambule bij het voorstel maakt van de (komende) raamrichtlijn geen melding. Ook is niet zeker of microgolven tot de, door de raamrichtlijn, te beschermen agentia behoren. Anderzijds zou, nu het voorstel nog steeds niet de status van richtlijn heeft bereikt, een nu aan te nemen richtlijn op dit terrein heel goed als uitwerking van de raamrichtlijn beschouwd kunnen worden. Daarmee zou de medezeggenschapsbepaling van de raamrichtlijn van toepassing zijn op het voorstel. Indien de richtlijn een aparte status verkrijgt zou het aanbeveling verdienen alsnog een medezeggenschapsbepaling op te nemen.

Het voorstel is al oud en nog steeds niet door de Raad geaccepteerd. Dit is des te schrijnender als men in gedachten houdt dat reeds in 1973 het Parlement een resolutie aannam waarin de Commissie tot het stellen van normen op dit terrein uitnodigde (118).

117. Artikel 11 van het voorstel verplicht de fabrikant direct tot het verstrekken van voldoende informatie om de apparatuur veilig te kumnen installeren, te onderhouden en te bedienen.

118. Hand. EP, 19 juni 1981, p. 312. 
Ook een ander voorstel, dat de vijfde bijzondere richtlijn van de raamrichtlijn 80/1107 moet worden, heeft de richtlijnstatus nog niet weten te bereiken. Het gaat hier om het voorstel voor een richtlijn ter bescherming van de werknemers tegen de risico's verbonden aan de blootstelling aan benzeen op het werk (119). Het voorstel bevat voorschriften met betrekking tot de wijze waarop met benzeen en dampen van benzeen moet worden omgegaan. Het gaat om het reduceren van de kwantiteiten van benzeen, tot zo laag mogelijke waarden en het afzuigen van dampen daar waar zij vrij komen, voor zover deze maatregelen redelijkerwijs mogelijk zijn. In bijlagen. worden de te nemen maatregelen gespecifeerd.

Het voorstel bevat bijzondere voorschriften voor informatierechten met betrekking tot het gebruik en de grenswaarden in de onderneming, de algemene (anonieme) gegevens die er over de blootstelling worden bijgehouden en, in het geval dat grenswaarden worden overschreden. Daarnaast bevat het voorstel een specifiek recht op toezicht voor de werknemers op de wijze waarop de richtlijnvoorschriften worden toegepast. Bovendien hebben zij recht op uitleg ten aanzien van de door de ondernemer verschafte informatie over de bijzonderheden van het werken met benzeen. Of dit laatste bedoeld was om het raadplgen van (externe) deskundigen mogelijk te maken blijkt niet expliciet uit het voorstel, maar gezien het uitdrukkelijke recht op uitleg, zou dit er in gelezen kunnen worden.

Naast deze voorstellen ligt er nog een aantal richtlijn-voorstellen van latere datum. Deze stammen bijna allemaal uit 1988; zij zijn van na de invoering van artikel $118 \mathrm{~A}$.

\subsection{Richtlijnen en richtlijnvoorstellen op basis van artikel 118A}

Op basis van artikel 118A is al in 1988 een aantal richtlijn-voorstellen gedaan met betrekking tot bescherming van veiligheid en gezondheid van werknemers in het algemeen, en op een aantal specifieke gebieden. Het gaat hier om voorstellen voor bescherming van de veiligheid en gezondheid van werknemers op gebieden die niet door de raamrichtlijn ter bescherming van werknemers tegen de gevaren van fysische, chemische en biologische agentia bestreken werden. Een aantal van deze voorstellen is inmiddels door de Raad van Ministers geaccepteerd, andere zitten nog in de pljplijn.

Deze nieuwe richtlijnen en voorstellen zullen in de navolgenda paragrafen besproken worden. Bij de bespreking van de raamrichtlijn zal worden aangegeven van welke lid-staten de wetgeving gewijzigd of op andere wijze geïnterpreteerd zal moeten worden, om aan het resultaat van de richtilijn te voldoen. De (op vrijwilligheid gebaseerde) nationale praktijken blijven hierbij buiten beschouwing, omdat in beginsel implementatie van richtlijnen

119. Pb. 1985, C 349. 
door middel wan wettelijke of bestuursrechtelijke maatregelen dient te geschieden.

\section{A De nieuwe raamrichtlijn}

De eerste en belangrijkste richtlijn die tot standgekomen is is een nieuwe raamrichtlijn betreffende de uitvoering wan maatregelen ter bevordering van de verbetering van de veiligheid en gezondheid van werknemers op het werk (120). Deze richtlijn is veel algemener van aard dan de "oude" raamrichtlijn die zich beperkte tot het beschermen van gevaren tegen specifieke agentia. De nieuwe richtlijn komt niet in de plaats wan de 'oude' raamrichtlijn, maar moet er een bestaan naast leiden en zal op een aantal aspecten als aanvulling kunnen dienen (121).

In de preambule wordt meteen ingegaan op het medezeggenschapsaspect. Hier wordt aangegeven dat het ter waarborging van de hoogst mogelijke graad van bescherming noodzakelijk is, dat werknemers geïnformeerd worden, en dat het ook volstrekt noodzakelijk is dat zij er via een evenwichtige deelneming overeenkomstig de nationale wetten en/of praktijken toe kunnen bijdragen dat de nodige beschermingsmaatregelen kunnen worden genomen. Daarnaast wordt het ontwikkelen van de dialoog en evenwichtige deelneming inzake veiligheid en gezondheid tussen werkgever en werknemers en hun vertegenwoordigers met behulp van het instrumentarium dat in de lid-staten al wordt gebruikt van belang geacht. Op de vraag wat "evenwichtige deelneming" kan zijn wordt verderop nog teruggekomen.

Deze formuleringen hebben een lange weg afgelegd. Het eerste voorstel (122) sprak alleen over het versterken van de samenwerking tussen werkgever en werknemers op dit terrein. Later werd, na het advies van het Parlement in het gewijzig voorstel (123),gesproken over de dialoog en de onderhandelingen op dit terrein. Het woord onderhandelingen is vervangen door het diffusere evenwichtige deelneming.

De richtlijn geeft algemene beginselen met betrekking tot beroepsmatige gevaren, algemene regels over de wijze waarop de werkgever en de werknemers zich dienen te gedragen en bevat algemene bepalingen met betrekking tot training, informatie, consultatie en blijkens artikel 1 van de richtlijn ook evenwichtige deelneming van werknemers. Bovendien bevat de richtlijn algemene regels met betrekking tot de implementatie van de beginselen. De

120. Rl. $89 / 391$, van 12 juni 1989 Pb. 1989 , L 183 .

121. In de preambule wordt steld dat de bepalingen van de onderhavige richtlijn op de eerdere raamrichtlijn 80/1107 van toepassing zijn, zonder overigens afbreuk te doen aan stringentere communautaire maatregelen. Het oorspronkelijk voorstel sprak slechts over de nieuwe richtlijn als "globale sociale aanvulling" op eerdere richtlijnen.

122. Oorspronkelijk voorstel (Com(88) 73 def.) ingediend op 25 februari 1988 door de Commissie, Pb. 1988, C 141.

123. Gewijzigd voorstel (Com(88) 8-02 def) n.a.v. advies wan het Europees Parlement van 16 november 1988 ingediend op 5 december 1988, $\mathrm{Pb} .1989 \mathrm{C} 30$. 
nieuwe richtlijn bepaalt expliciet dat zij geen afbreuk doet aan verdergaande communautaire en nationale bepalingen die op het moment van inwerkingtreding van de richtlijn van kracht zijn. Met name de toevoeging voor wat. betreft het nationale recht is, gezien artikel 118A overbodig, maar wel zinvol in verband met de aanzuigende werking van (minimum)richtlijnbepalingen (124).

De werkingssfeer van de richtlijn is ruim. $\mathrm{Zij}$ is van toepassing op alle particuliere en openbare sectoren. Slechts bijzondere aspecten die inherent zijn aan bepaalde activiteiten in overheidsdienst mogen van haar werkingssfeer worden uitgezonderd. Hierbij moet men denken aan activiteiten in het leger, de politie of in het kader van de bevolkingsbescherming. Voor andere in de nationale wetgeving uitzonderde sectoren moet specifieke regelgeving in eenzelfde resultaat voorzien als in de richtlijn is voorgeschreven (125). Dit betekent voor de Nederlandse Arbeidsomstandighedenwet dat de toegelaten uitzonderingen op basis van artikel 2 (uitgezonderd lid 5) slechts mogen worden gemaakt, indien voor de uitgezonderde sectoren bijzondere regels zijn of worden gesteld.

De richtlijn geeft de werkgever een ruime verantwoordelijkheid voor de veiligheid en gezondheid van zijn werknemers, namelijk in alle met het werk verbonden aspecten. Ook indien bij een probleem de in de onderneming werkzame veiligheids- of gezondheidsfunctionarissen te hulp worden geroepen, of externe deskundigen worden geconsulteerd, behoudt de ondernemer de volle verantwoordelijkheid; de verantwoordelijkheden van de werknemers kunnen dit beginsel ook niet aantasten.

124. Een mooi voorbeeld hiervan is de gang van zaken in Nederland rond de vraag of richtlijn $77 / 187$ (behoud van rechten van werknemers bij owergang van ondernemingen)ook toepasselijk is in geval van faillissement. Nadat cerst aangenomen was dat dit wel het geval zou zijn, aangezien niet-toepassing bij faillissement misbruik en daarmee strijd met dle richtlijn op zou leveren, (zie o.m. de brief van 22 september 1982 van de Minister van Sociale Zaken en Werkgelegenheid aan de vaste Commissies van de Tweede Kamer voor Justitie en Sociale Zaken en Werkgelegenheid, TK 1982-1983, 17.600, p.11) werd deze visie verlaten doordat "... (....) de praktijk (heeft) geleerd dat de toepassing van die wet (art. 1639 aa e.v. ES) bij overneming van cen gefailleerde onderneming (.....) aan zulk een onderneming (bedoeld is vermoedelijk overneming, ES) in de weg staat, althans ernstig bemoeilijkt" (Brief van de Minister van Justitie van 6 april 1983 aan de Voorzitter van de Tweede Kamer). De conclusie in deze brief was dat de op de richtlijn gebaseerde wetsartikelen niet van toepassing zouden zijn in geval van faillissement of sursesance van betaling. In de zaken Abels vs Bestuur van de Bedrijfsvereniging voor de Metaalindustrie en de Electrotechnische Industrie (zaak 135/83) en Industriebond-FNV vs Staat der Nederlanden (179/83) (Arresten van 7 januari 1985, Jur. 1985 resp. p. 469 4n p. 511) bepaalde het Hof dat richtlijn niet van toepassing bij faillissement hoefde te zijn, doch wel bij surséance van betaling; echter het staat de lid-staten vrij om de richtlijin ruimer toe te passen.

125. Zie in dit verband ook paragraaf 17 van de Duitse ArbSichG, die alleen niet van toepassing is op bepaalde sectoren indien in specifieke regelegving woorzien is. 
In het oorspronkelijke voorstel was deze verantwoordelijkheid nog ruimer geformuleerd: een te verwachten clausule die de ondernemer de veramtwoording liet dragen, "voorzover dit redelijkerwijs mogelijk is", was niet opgenomen (126). Vergeleken met de verplichtingen van de werkmemers (artikel 12; nu artikel 13), waar de "redelijkerwijsformule" wel was opgenomen (werknemers hebben de plicht tijdens de werkuren behoorlijke (nu "naar vermogen") (127) zorg voor hun eigen veiligheid en die van anderen te dragen, voor zover deze anderen geraakt worden door het doen of nalaten van die werknemers) ging dit ver. Het belang van het al dan niet hanteren van een "redelijkerwijsclausule" ten opzichte van de verplichtingen van de ondernemer strekt verder dan alleen de zorgplicht binnen de onderneming, in tenminste een aantal lid-staten zou een dergelijke verstrekkende verantwoordelijkheid gevolgen kunnen hebben voor de privaatrechtelijke aansprakelijkheid van de ondernemer ingeval van schade aan de gezondheid (128). Deze zeer vergaande consequentie heeft de Commissie er toe aangezet een nieuw lid 4 in dit artikel op te nemen. De formulering is $\mathrm{nu}$, dat de richtlijn geen belemmering vormt de verantwoordelijkheid van de werkgevers uit te sluiten of te verminderen voor feiten die te wijten zijn aan abnormale en onvoorzienbare omstandigheden buiten de wil van de werkgever of buitengewone gebeurtenissen, indien de gevolgen ondanks alle zorgvuldigheid niet hadden kunnen worden voorkomen. Deze ietwat vage aanvulling zal in de nationale wetgeving moeten worden geconcretiseerd.

De verplichtingen van de werkgever zijn te splitsen in specifieke zorgplichten en overlegverplichtingen met de werknemers of hun vertegenwoordigers. De zorgplicht heeft betrekking op preventieve principes als risico's bestrijden bij de bron, het aanpassen van het werk aan de mens, rekening houden met de ontwikkeling van de techniek en planning, waarin elementen als techniek, organisatie van het werk, arbeidsomstandigheden, menselijke

126. Bijwoorbeeld: de Nederlandse Arbeidsomstandighedenwet legt de ondernemer zowel een aantal zorgplichten op die gerelativeerd worden door de 'redelijkerwijsformule' zoals de verplichting het ondernemingsbeleid mede te richten op een '....zo groot mogelijke veiligheid, een zo goed mogelijke bescherming van de gezondheid en het bevorderem van het welzijn van de werknemer....'Deze formulering ziet op aanzienlijk minder, dan de nietgerelativeerde verantwoordelijkheid van de ondernemer uit het voorstel (zie over de waarde van de zorgplicht van de werkgever ook: A.C.J.M. Geers, Recht en humanisering van de arbeid, Deventer 1988, p. 115, 116). Ook de Britse Health and Safety at Work Act 1974 (section 2) clausuleert de algemene zorgplicht van de ondernemer met de woorden "so far as reasonably practible".

127. In de Engelse tekst (vindplaats HSIB 148, 29 March 1988) "reasonable care" een terminologie die nog dichter' tegen de 'redelijkerwijsformule' aanhangt.

128. Bijwoorbeeld in Nederland. In de MvT bij de Arbowet, werd gesteld dat de verplichting van de werkgewer op grond van de Arbeidsomstandighedenwet in feite een publiekrechtelijke uitwerking betreft van datgene waartoe de werkgever op grond wan artikel $1638 \mathrm{x}$ reeds verplicht is (TK 1976-1977, 14.497 no 3 (MvT) p.12. Hier wordt de link naar het privaatrecht, inclusief de mogelijkheid tot schadeclaims gelegd. De verantwoordelijikheid wan de werkgever zoals geformuleerd in het voorstel zou de mogelijkheid tot schadevergoeding voor de werknemer aanzienlijk hebben kunnen uitbreiden. 
relaties en invloed van de omgevingsfactoren op het werk worden geïntegreerd.

Daarnaast zijn er nog specifieke verplichtingen met betrekking tot het evalueren van risico's, integratie van beschermende maatregelen in het gehele pakket activiteiten van de onderneming, en integratie van maatregelen die betrekking hebben op de specifieke capaciteiten van werknemers en de organisatie van het werk voor zover dit redelijkerwijs uitvoerbaar is. Planning en invoering van nieuwe technologieën moet geschieden in overleg met de werknemers of hun vertegenwoordigers, waarbij niet alleen de veiligheid en gezondheild in enge zin van deze technologieën aan de orde moeten komen, maar ook andere aspecten zoals de invloed van omgevingsfactoren.

De werkgever krijgt de verplichting opgelegd, samen met andere ondernemers de acties ter preventie van beroepsrisico's te coördineren, indien op een bepaalde plaats meer ondernemingen werken (129). Voor die gevallen is er een specifiek aan de werkgever opgelegde plicht tot het informeren van de werknemers.

Dit zijn niet de enige medezeggenschapsbepalingen uit de richtlijn. Artikel 10 schrijft voor dat de werkgever passende maatregelen moet nemen zodat de werknemers of hun vertegenwoordigers in de onderneming of vestiging adequate informatie krijgen over de risico's en genomen preventiemaatregelen in de onderneming in het algemeen en voor iedere werknemer betreffende zijn werkplek en of functie in het bijzonder. Voorts bestaat deze verplichting ten aanzien van genomen maatregelen met betrekking tot ernstig gevaar, op basis van artikel 8 , het artikel dat voorschriften geeft voor ernstig gevaarlijke situaties. Deze voorlichting moet ook aan tijdelijke en ingeleende werknemers worden gegeven. De voorlichting moet gegeven worden volgens de in de lid-staten geldende praktijken. De reden hiervan is dat dan rekening kan worden gehouden met de grootte van de ondernemingen, een toevoeging die kennelijk terugslaat op de in artikel 118A opgenomen beperking dat de in richtlijnen gegeven minimum-voorschriften aan kleine en middelgrote ondernemingen niet zodanige administratieve en andere verplichtingen worden opgelegd dat zij deze in hun oprichting of ontwikkeling zouden kunnen belemmeren.

Naast deze algemene informatieplicht is er een plicht tot het verschaffen van specifieke informatie aan die werknemers of werknemersvertegenwoordigers, die zich speciaal bezig houden met de bescherming van de veiligheid en de gezondheid van werknemers. Het gaan hier om informatie over ongevallen en beroepsziekten, analysegegevens over genomen maatregelen en informatie vanuit de bevoegde instantie. Deze werknemers kunnen zowel.

129. Artikel 30 van de Nederlandse arbeidsomstandighedenwet regelt een soortgelijke verplichting. 
vertegenwoordigers van de werknemers uit de onderneming zijn (130), of specifiek als veiligheidsdeskundige aangestelde werknemers, die geen werknemersvertegenwoordigers zijn. De richtlijn verplicht de werknemer om dergelijke vertegenwoordigers aan te wijzen; indien daarvoor de mogelijkheden niet bestaan mag de werkgever ook op deskundigen van buiten de onderneming een beroep doen (131). De lid-staten bepalen bij welke grootte een onderneming in staat moet worden geacht uit zijn kader veiligheidsdeskundigen aan te wijzen.

In de meeste lid-staten voldoet de wetgeving in grote lijnen aan de in de richtlijn voorgeschreven informatieverplichting. Ontbrekende details zouden eventueel door middel van richtlijnconforme interpretatie van de bestaande informatieverplichting zoals in Nederland, België en Frankrijk kunnen worden opgevangen. Dit geldt vooral voor die lid-staten waar de vertegenwoordiging inzake veiligheids- en gezondheidsaangelegenheden een wettelijke basis heeft. In Italië en mogelijkerwijs Groot Brittannië zou de informatiebepaling tot een wijziging in de wetgeving moeten leiden. In Italië is dit mijns inziens zeker het geval, aangezien de wettelijke voorschriften op veiligheidsen gezondheidsgebied geen expliciet recht op informatie in zich bergen. Weliswaar wordt dit ten dele opgevangen door sectoriële collectieve contracten en de raamovereenkomst van 1976 (132), maar dit is indachtig de jurisprudentie van het Hof met betrekking tot het uitvoeren van richtlijnen bij collectieve overeenkomst niet genoeg (133). Voor Groot Brittannië zit het probleem meer in de wettelijke beperkingen die aan de informatieverstrekking gesteld kunnen worden (134). Deze beperkingen zijn mogelijk via richtlijnconforme interpretatie weg te werken, zodat wetswijzigingen niet nodig zouden zijn. Ook in Denemarken zou een wetswijziging nodig kunnen zijn. De veiligheidsvertegenwoordigers hebben in beginsel een beperkter recht op informatie dan de (op het Centraal Akkoord gebaseerde) samenwerkingscommissie. Naar de letter van de richtlijn valt te verdedigen dat een verschuiving van het informatierecht moet plaatsvinden naar de veiligheidsvertegenwoordigers. Anderzijds zou men kunnen volhouden dat, wanneer de het Centraal Akkoord op zichzelf voldoet aan de criteria van het Hof met betrekking tot uitvoering van een richtlijn bij collectieve overeenkomst, het resultaat van de richtlijn op dit punt bereikt is. In dat geval zou alleen een wettelijke vangnetbepaling nodig zijn voor die ondernemingen waar geen samenwerkingscommissie functioneert.

Het voor dit boek belangrijkste artikel uit de richtlijn is artikel 11, dat als kopje "Raadpleging en deelneming van de werknemers" draagt. Artikel 11

130. Men denke aan de Deense veiligheidsvertegenwoordigers, de Duitse Sicherheitsaussschuss of de Britse Health and Safety Representatives.

131. Artikel 7. Men kan hier ook denken aan een constructie van gezamenlijke gezondheidsen veiligheidsdiensten, waarin een aantal van de nationale wetten in voorzien.

132. Zie paragraaf IV.2.

133. Zie paragraaf Il.5.

134. Zie paragraaf IV.2. 
schrijft voor dat de werkgever de werknemers en/of vertegenwoordigers moeten raadplegen en het recht moeten geven deel te nemen aan de behandeling van vraagstukken die betrekking hebben op de veiligheid en de gezondheid op het werk. Volgens het tweede lid van dit artikel houdt deze deelneming het volgende in: een consultatieverplichting, het recht van werknemers voorstellen te doen, en evenwichtige deelneming volgens de in de lid-staten geldende praktijken en/of wetgevingen.

De tekst van dit artikel heeft een interessante voorgeschiedenis. In het oorspronkelijke voorstel was de Commissie uitgegaan van een consultatieverplichting alleen. Verdergaande verplichtingen waren in geen enkele vorm voorzien. $\mathrm{Na}$ advies van het Europees Parlement werd een nieuw artikellid toegevoegd in het gewijzigde voorstel dat voor tweede lezing (135) naar de Raad ging, waarin een verplichting tot samenwerking tussen werknemers en werkgevers was opgenomen. Deze samenwerking werd geconcretiseerd door de verplichting tot "inspraak van de werknemers(vertegenwoordigers) volgens de in de lid-staten geldende praktijken en/of wetgevingen".

Deze formulering had redelijk verstrekkende consequenties kunnen hebben als de volgende uitleg zou zijn gehanteerd. Inspraak gaat in beginsel verder dan het recht op consultatie en kan zowel instemming betekenen, als het recht op onderhandelen (en, eventueel, tot een overeenkomst te komen). In het vorige hoofdstuk is geconstateerd dat alle lid-staten een vorm van inspraak in hun wetgeving of praktijk hebben geïncorporeerd. Men had de bepaling zo kunnen lezen, dat de werkgever verplicht zou zijn geweest veiligheids- en gezondheidsaangelegenheden aan de volgens de nationale praktijk geldende inspraak- (dus instemmings of, en vooral, onderhandelings) procedure te moeten onderwerpen. Een richtlijn kan echter een werkgever niet rechtstreeks verplichtingen opleggen (136). De inspraakverplichting van de richtlijn zou dus een verplichting niet aan de werkgever, maar voor de lid-staten zijn geweest te zorgen dat deze nationale praktijk ook daadwerkelijk zou worden nageleefd. De wijze waarop de lid-staten dit resultaat hadden moeten bereiken zou aan henzelf overgelaten zijn, maar een in de

135. Artikel 118A schrijft besluitworming voor met in achtneming van de sanenwerkingsprocedare tussen Raad en Europees Parlement wan artikel 149 EEG-Verdrag. Deze procedure kent twee lezingen. In de eerste lezing neemt de Raad op basis wan het voorstel van de Commissie (na een eerste advies van het parlement) een gemeenschappelijk standpunt in. Dit gemeenschappelijk standpunt gaat naar het parlement dat drie mogelijkheden heeft. a) $\mathrm{Ze}$ is het er mee eens, warna het voorstel in de Raad wordt vastgesteld. b) $\mathrm{Ze}$ verwerpt, en dan kan de Raad het voorstel alleen nog met unanimiteit aanmemen. c) ze amendeert het voorstel. Deze amendementen gaan naar de Commissie, die ze kan overnemen. In dat geval mag de Raad alleen met unanimiteit van het geamendeerde voorstel afwijken. Anderzijids kan de Commissie de amendementen ook niet overnemen, in dat geval kan de Raad ze alleen nog met unanimiteit aanvaarden. Dil alles is aan strakke termijnen gebonden. Overschrijdt de Raad zijn laatste termijn, dan wordt het voorstel geacht te zijn verworpen.

136. Zaak 152/84, Jur. 1986, p. 723-751 (Marshall); zaak 80/86, 8 oktober 1987 nog niet gepubliceerd (Kolpinghuis). 
wetgeving opgenomen verplichting of een wettelijke mogelijkheid onderhandelingen af te dwingen, zou niet ondenkbaar zijn geweest.

Op basis van dit voorstel nam de Raad van Ministers op 16-17 december 1988 een gemeenschappelijk standpunt in, waarin de term "inspraak" was gewijzigd in "evenwichtige deelneming". Deze term, die in de richtlijn is beland, betekent eveneens meer dan alleen een consultatieverplichting. Hij is namelijk naast de verplichting tot consultatie in de richtlijn opgenomen. Men kan ook hierbij denken aan de in een aantal lid-staten voorkomende verplichting tot instemming bij besluiten, of het recht op dit terrein met de werkgever een overeenkomst te sluiten. Mijns inziens schrijft de richtlijn niet voor een verplichting tot instemming met besluiten of het sluiten van een overeenkomst in de nationale wetgeving of praktijk op te nemen.

Ik heb daar twee argumenten voor. Om te beginnen slaat de term "deelneming", wolgens artikel 11 eerste zin, niet terug op deelneming aan de besluitvorming, maar op deelneming aan de behandeling van vraagstukken aangaande veiligheid en gezondheid. De term "deelneming aan de behandeling" zegt niets over het besluit dat als gevolg van die behandeling moet worden genomen. Kortom wat de richtlijn biedt is een overlegverplichting. De richtlijn verplicht nu dit element van "deelneming aan de behandeling", in de nationale wetgeving op te nemen. Dit wil zeggen dat, voor zover de lid-staten nog geen overlegverplichting aangaande veiligheid- en gezondheid bezaten, zij deze nu in hun wetgeving of praktijk moeten incorporeren. Met betrekking tot het resultaat van dit overleg, legt de bepaling geen verplichting op.

In de tweede plaats moet de "deelneming" van de eerste zin een "evenwichtige" zijn, gekoppeld aan de praktijk of wetgeving in de lid-staten. In lidstaten als Groot Brittannië en Italië is onderhandelen over veiligheids- en gezondheidsaangelegenheden mogelijk een deel van de nationale praktijk te noemen, maar niet wettelijk voorgeschreven. $\mathrm{Nu}$ is het denkbaar dat in verband met economische omstandigheden, de onderhandelingen over juist dit onderwerp worden gelaten voor wat zij zijn, omdat er dringender (loonshoogte, ontslagen etc.) aangelegenheden zijn. Mijns inziens kan men dan slechts constateren dat, jammer maar helaas, in de praktijk niet over dit onderwerp onderhandeld wordt. Kortom het evenwicht tussen werkgevers en werknemers laat op dat specifieke moment niet meer toe dan een overleg, waarin de werknemers hun mening naar voren kunnen brengen (uitgebreide consultatie), maar geen invloed uitoefenen op de uitkomst van dat overleg (het te nemen besluit) door middel van het afsluiten van een overeenkomst.

In het licht van het advies van het Europees Parlement heeft de richtlijn een nogal verwaterde medezeggenschapsbepaling, namelijk een enkele 
overlegverplichting van de werkgever met de werknemers(vertegenwoordigers) gekregen (137).

Een verplichting de werknemers of hun vertegenwoordigers die zich speciaal bezighouden met veiligheid en gezondheid deel te laten nemen (op bovenbeschreven wijze) of te consulteren bestaat voor alle maatregelen die van wezenlijke invloed kunnen zijn op dit gebied. Onder deze maatregelen worden onder meer begrepen: de aanwijzing van deskundigen, en werknemers die belast zijn met het geven van eerste hulp en het nemen van dergelijke maatregelen, het beroep op deskundigen van buitenaf, de opzet en organisatie van opleiding op het gebied van veiligheid en gezondheid, en de aanwijzing van personen voorzien in artikel 8 lid 2 , die moeten optreden in geval van ernstig gevaar. Bovendien hebben de vertegenwoordigers het recht om voorstellen te doen over, en te verzoeken om alle passende maatregelen die erop gericht zijn alle risico's voor de werknemers te ondervangen en bronnen van gevaar uit te schakelen.

Ook hier geldt dat de wetgeving van de meeste lid-staten in overeenstemming is met de richtlijn. Zowel aan consultatie gekoppeld overleg, als een recht op overleg dat eventueel is gekoppeld aan verdergaande mogelijkheden als instemming zijn mijns inziens voldoende. De meeste lid-staten hebben een dergelijk recht op (al dan niet periodiek) overleg in hun wetgeving opgenomen. Mogelijk zouden de onderwerpen waarover overleg dient te worden gevoerd op detailpunten moeten worden bijgesteld; in de meeste wetgeving kan dit geschieden door richtlijnconforme interpretatie. Slechts wanneer het consultatierecht een puur formele aangelegenheid is, waaraan geen overleg vooraf gaat, zou een wetswijziging of een interpretatiewijziging van bestaande wetgeving noodzakelijk zijn. Voor wat de wetgeving betreft die consultatieverplichtingen oplegt, is dit mijns inziens nergens het geval. Italië valt ook hier weer uit de boot. De buitengewoon magere wetgeving op dit punt zal herzien moeten worden door in elk geval een consultatieverplichting in de wetgeving op te nemen (138). Het valt te betwiffelen of de hierboven gesignaleerde problemen met de uitvoering door middel van collectieve overeenkomsten op dit punt niet zouden bestaan. Voorts is niet uit te sluiten dat Spanje zijn consultatieverplichting iets moet aanscherpen, hoewel de mogelijkheden die in praktijk aanwezig zijn, aan de richtlijn voldoen. De Nederlandse wetgeving voldoet, ondanks de recente sterke beperking van het instemmingsrecht inzake veilligheids- en gezondheidsaangelegenheden, wel aan de richtlijn. Een recht op overleg op dit terrein bestaat immers nog steeds (139).

De werknemers of hun vertegenwoordigers hebben volgens de richtlijn het recht om zich overeenkomstig de nationale wetten of praktijk te wenden tot de bevoegde autoriteit op het gebied van de veiligheids- en gezondheidsbe-

137. Zie ook B. Bercusson, a.w. (noot 7), p. 94 .

138. Zie ook paragraaf IV.3.5..

139. Zie paragraaf IV.3.5. 
scherming te wenden, indien zij van oordeel zijn dat de door de werkgever genomen maatregelen onvoldoende zijn. Naast dit beroep op de arbeidsinspectie kent de, er op volgende, bepaling de werknemersvertegenwoordigers een recht toe de arbeidsinspectie hun opmerkingen voor te leggen tijdens bezoeken en inspecties. Dit is een verzwakking ten opzichte van eerdere voorstellen waarin werknemersvertegenwoordigers het recht kregen, de arbeidsinspectie te vergezellen bij bezoeken en inspecties. Slechts in Italië zal deze laatste verplichting tot een wetswijziging of een interpretatiewijziging van bestaande bepalingen moeten leiden.

Voorts schrijft de richtlijn beschermende maatregelen met betrekking tot mogelijke benadeling van de werknemers- en werknemersvertegenwoordigers voor, en verplicht het de werkgever tot het verstrekken van faciliteiten om aan hun verplichtingen als vertegenwoordiger te voldoen. De benadelingsbepaling in de richtlijn is conform het oorspronkelijke voorstel van de Commissie. Een advies van het parlement om bescherming voor alle werknemers en hun vertegenwoordigers die zich met veiligheids- en gezondheidsaangelegenheden bezighouden, of zij een specifieke taak hebben op dit gebied of niet, te bieden, haalde de richtlijn niet.

De richtlijn bevat voorts bepalingen over opleiding van werknemers in het algemeen en van werknemersvertegenwoordigers die zich speciaal bezighouden met de bescherming van de veiligheid en gezondheid in het bijzonder, opleidingen die niet ten laste van de werknemers mogen komen, zowel wat tijd als kosten betreft. Met betrekking tot ingeleende werknemers is de verplichting zwakker: de werkgever hoeft zich er slechts van te vergewissen dat dat zij passende instructies hebben ontvangen in verband met de risico's waaraan zij in zijn bedrijf bloot kunnen staan. Ook hier is een verzwakking te constateren ten opzichte van het gewijzigde voorstel. Daarin werd ook een opleiding voor tijdelijke werknemers voorgeschreven, over hen wordt in de richtlijn niet meer gerept. Bovendien had in het gewijzigde voorstel de werkgever de plicht ervoor te zorgen dat de ingeleende werknemers een opleiding of in elk geval passende instructies kregen. De Nederlandse arbeidsomstandighedenwet is door zijn definities van werkgever en werknemer in beginsel in overeenstemming met dit voorschrift.

De richtlijn geeft specifieke voorschriften voor situaties die ernstig gevaar opleveren (artikel 8). Het gaat hier om algemene organisatorische voorzienigen met betrekking tot brandpreventie, eerste hulp, evacuatie van werknemers, en de werknemers die de organisatie hiervan tot taak krijgen. Voorts verplicht de richtlijn de werkgever tot het nemen van maatregelen, waardoor de werknemers in staat gesteld worden bij niet te vermijden ernstig en onmiddellijk gevaar de werkplek te verlaten. Deze maatregelen moeten zo spoedig mogelijk worden meegedeeld aan alle werknemers die zijn of kunnen worden blootgesteld aan een risico van ernstig dreigend gevaar. 
De bepalingen met betrekking tot de individuele werknemer zijn met name in dit artikel te vinden. Om te beginnen bevat artikel 8 lid 4 een individueel werkweigeringsrecht. In dit artikel wordt bepaald dat een werknemer die, in geval van niet te vermijden dreigend en onmiddellijk gevaar de werkplek en/of een gevaarlijke zone verlaat daarvan geen nadeel mag ondervinden, en overeenkomstig de nationale wetten of praktijken beschermd moet worden tegen alle ongerechtvaardigde nadelige gevolgen daarvan. Hoewel impliciet geformuleerd, kan men hierin een werkweigeringsrecht voor de individuele werknemer lezen (140). De angel zit overigens in de verwijzing naar het nationale recht, ondat uit het vorige hoofdstuk bleek dat niet zozeer het recht om te weigeren het probleem was, maar de bewijsrechtelijke positie achteraf. Daaraan verandert het artikel mijns inziens niets (141).

Volgens artikel 8 lid 5 moet de werkgever ervoor zorgen dat de werknemer, wanneer een ernstig en onmiddellijk gevaar voor zijn eigen veiligheid of die van anderen dreigt en het onmogelijk is om contact op te nemen met de bevoegde hiërachieke chef, passende maatregelen kan nemen (rekening houdend met zijn technische kennis en middelen) om de gevolgen van een dergelijk gevaar te voorkomen. Deze bepaling heeft iets omslachtigs en dubieus. Hij zou gelezen kunnen worden als een recht van de werknemers een deel van de onderneming (of het produktieproces) stil te leggen, indien dat noodzakelijk is om de gevolgen van het gevaar te vermijden. Dit zou men kunnen afleiden uit de formulering "rekening houdend met zijn technische kennis en middelen". Het artikellid is echter zo impliciet geformuleerd dat het afleiden van een dergelijk recht misschien iets te ver gaat: toetsing van een nationale wet die dit recht niet biedt, lijkt mij niet tot strijdigheid te leiden, indien de nationale wet in andere mogelijkheden woorziet ter vermijding van gevaren. Bovendien wijst de geschiedenis van de bepaling niet op een dergelijke uitleg. Het advies van het parlement voegde aan het voorstel een bepaling toe, die voorschreef dat de werkgever maatregelen moest nemen de werknemers in staat te stellen onmiddellijk de werkplek te verlaten in geval van niet te vermijden ernstig gevaar. Het niet overnemen van dit deel van het gewijzigde voorstel, en het handhaven van de gematigder bepaling van het oorspronkelijke voorstel van de Raad wijst erop, dat een expliciet stilleggingsrecht niet beoogd is. Het optreden van de werknemer in het kader van dit artikel leidt niet voor hem tot enig nadelig gevolg, tenzij hij ondoordacht heeft gehandeld of zich schuldig heeft gemaakt aan grove nalatigheid.

Een ander aspect in het voordeel van de individuele werknemer, en dan met name de in de nationale medezeggenschapswetgeving of -praktijk uitgesloten werknemers is het in het voorstel gehanteerde werknemersbe-

140. Spaanse, Britse, Belgische, Duitse en Deense werknemers hebben geen expliciet recht helf werk neer te leggen voor zower dit miet uit het burgerlijk recht voortvloeit, voor hen zou een uit een richtlijn woortvloesend recht een verbetering van positie kunnen betekenen.

141. Zie paragraaf V.6.1. 
grip. De richtlijn gebruikt als definitie van werknemer: "iedere persoon die door een werkgever wordt tewerkgesteld, alsmede stagiairs en leerlingen, met uitzondering van huispersoneel". Op zich is deze vrij ruime definitie niet zo verwonderlijk, omdat in nationale wetgevingen, daar waar het gaat om arbeidsomstandigheden, veelal ook een ruimere definitie wordt gehanteerd dan in de andere arbeidsrechtelijke wetgeving. Voor een richtlijn is deze eigen definitie wel nieuw, tot dusver werd de koppeling met arbeidsovereenkomst of arbeidsverhouding zoals deze in het nationale recht bestaan, wel gemaakt (142). Het Hof van Justitie interpreteerde het werknemersbegrip in richtlijnen zelf niet, maar nam het begrip zoals dat in het nationale recht gehanteerd werd als uitgangspunt (143). Deze jurisprudentie had overigens wel betrekking op de richtlijn ter bescherming van rechten van werknemers bij overgang van ondernemingen, en die koppeling was, hoewel misschien niet noodzakelijk (144), niet onlogisch. Het werknemersbegrip zoals hier gegeven zal een communautaire inhoud moeten krijgen, hetgeen betekent dat onder deze definitie veel meer personen kunnen vallen dan diegenen die een arbeidsovereenkomst hebben.

Het gevolg van zo'n ruime definitie is, dat wanneer alle werknemers geraadpleegd dienen te worden indien de richtlijn dit voorschrijft ook die werknemers die normaal gesproken buiten beschouwing blijven daaronder vallen. Thuiswerkers behoren tenslotte ook tot de werknemers op grond van deze definitie. Eventueel zou uit de ruime omschrijving kunnen worden afgeleid dat ook de groepen die nu nog buiten de medezeggenschapsregelingen of -praktijken op het nationale niveau vallen het recht hebben specifieke vertegenwoordigers inzake veiligheids- en gezondheidsaangelegenheden te kiezen. De rechten van deze vertegenwoordigers kunnen echter niet verder gaan dan consultatie; voor de "deelnemings" bepaling is in het voorstel nu juist weer wel de koppeling met de nationale wetgeving en praktijk gemaakt. Of een zo vergaande conclusie is te trekken is overigens niet zeker. De richtlijn geeft tenslotte geen voorschriften over wie de vertegenwoordigers van de werknemers zijn, en door wie deze gekozen worden.

Voor Nederland, waar in de arbeidsomstandighedenwet het werknemersschap aan het gezagscriterium wordt gekoppeld (artikel 1 lid 2 arbeidsomstandighedenwet) zou de definitie van de richtlijn tot een verruiming van de definitie in de wet kunnen leiden. Tewerkgesteld zijn impliceert niet per definitie dat men onder iemands gezag in de zin van het Nederlandse

142. Rl. $77 / 178$ ( $\mathrm{Pb} .1977 \mathrm{~L} 61$ ) ter bescherming van werknemers bij overgang van ondernemingen hanteert de termen "arbeidsovereenkomst en arbeidsverhouding" evenals RI. 80/987 ( $\mathrm{Pb} 1980 \mathrm{~L} 283)$, ter bescherming van werknemers bij insolventie van de werkgever.

143. Zaak 19/83, Jur. 1985, p. 462 (Wendelboe); zaak 105/84, Jur. 1985, p. 2639 (Mikkelsen ws Danmols).

144. E. Steyger, a.w. (noot 43), p. 251-252. 
arbeidsrecht werkt (145). Ook voor andere lid-staten, met name Groot Brittannië zou de definitie van werknemer tot een uitbreiding in de wetgeving moeten leiden, al kan daar geen recht op verkiezing van vertegenwoordigers uit afgeleid worden (146).

Of het ruime werknemersbegrip voor wat betreft de medezeggenschap meer is dan een cosmetische oplossing (voor wat betreft het gebruik van de bovenstaand recht tot het verlaten van de werkplek lijkt mij dit wel het geval) waarvan "randgroepwerknemers" in de praktijk geen gebruik kunnen maken omdat de nationale wetgeving of praktijk daaraan in de weg staat is een kwestie van afwachten.

Artikel 15 van de richtlijn, tenslotte, schrijft voor dat bijzonder kwetsbare risicogroepen beschermd moeten worden tegen voor hen specifieke gevaren. Men kan hier denken aan zwangere vrouwen en zogende moeders. In het gewijzigde voorstel werden deze groeperingen ook met name genoemd, dit is echter in de richtlijn geschrapt. Toch kan deze bepaling met name interessant voor Nederland worden, waar het de wijziging van de regeling betreffende nachtarbeid (147). Wanneer het artikel inderdaad bedoeld is om deze groepen specifieke bescherming te bieden, zou de "egalitaire" Nederlandse regeling op dit punt wel eens discutabel kunnen zijn, gezien de minimumvoorschriften die de richtlijn biedt. Echter, zeker in de formulering die de richtlijn nu biedt is het artikel zo vaag dat de mogelijkheid om de regeling met betrekking tot nachtarbeid op die grond aan te vechten als niet realistisch moet worden beschouwd

$B$ De richtlijn bekeken in het licht van het uit de nationale regelingen en praktijken afgeleide concept

Op het eerste gezicht brengt de richtlijn het nodige nieuws in elk geval op gemeenschapsniveau. Om te beginnen creëert de richtlijn medezeggenschapsverplichtingen die verder gaan dan de verplichtingen op grond van de bestaande richtlijnen. Niet de nationale wetgeving of praktijk op medezeggenschapsgebied wordt volledig tot uitgangspunt genomen, zodat het van de nationale praktijk afhangt of de medezeggenschapsrechten kunnen worden verwezenlijkt (148), maar het recht op medezeggenschap zelf, al dan niet via vertegenwoordigers van werknemers of op andere wijze aangewezen deskundige werknemers. Op deze wijze waarborgt de richtlijn veel meer dan eerdere richtlijnen, dat de voorgeschreven medezeggenschap op onderne-

145. Zie over het gezagscriterium: HR. 17 november 1967, Nj. 1968, 163; CRvB 6 april 1972, RSV $1972,214$.

146. De HSWA 1974 geeft geen definitie van het begrip werknemer, en de positie van o.m. thuiswerkers is in het Biritse recht allerminst duidelijk. Zie: Y. Kravaritou-Manitakis (ed), New Forms of Work, Labour Law and Social Security Aspects in the EEC, Luxemburg 1988 , p. $80-81$.

147. Zie paragraaf V.1.1..

148. Zie para. IV.3.2. In de richtlijn ter bescherming tegen biologische, chemische en fysische agentia wordt door de formulering van de medezeggenschapsverplichting het recht op medezeggenschap onmogelijk gemaakt indien in een onderneming geen werknemersvertegenwoordigers aanwezig zijn. 
mingsniveau in alle lid-staten, ongeacht hun wetgeving of praktijk tot stand zal komen. Daarmee werd voor het eerst (na alle pogingen rondom het gestrande Vredeling-voorstel) een maatregel genomen die op gemeenschapsniveau een medezeggenschapsverplichting (zij het in dit geval binnen de nationale grenzen) in ondernemingen creeert waarvan de uitvoering niet geheel afhankelijk is van het feit of werknemersvertegenwoordigers al in de lid-staten aanwezig zijn.

Ten aanzien van het meest heikele punt biedt de richtlijn echter weinig nieuws. De enige nieuwe verplichting die de richtlijn oplegt is een verplichting tot overleg. De mogelijkheden van werknemers(vertegenwoordigers), om door middel van instemmingsrecht of onderhandelen deel te nemen aan de besluitvorming, zijn opnieuw afhankelijk gemaakt van de nationale procedures en de nationale praktijk. De richtlijn legt geen verplichtingen op die mogelijkheden te creëren. Wat dit betekent in die lidstaten waar de invloed afhankelijk is van de onderhandelingen tussen de sociale partners, en waar deze dus onder invloed staat van economische factoren beschreef ik hierboven al.

Voor lid-staten met een wetgeving die verder gaat dan de richtlijn geldt dit in mindere mate, echter ook de graad van bescherming in de wetgeving is aan economische invloeden onderhevig (149), en deze graad wordt door het voorstel niet veiliggesteld. De preambule stelt "(...) dat de onderhavige richtlijn geen rechtvaardiging mag zijn voor een eventuele verlaging van de in iedere lid-staat reeds bereikte beschermingsniveau's". De lid-staten worden er uitdrukkelijk op gewezen, dat zij zich krachtens het EEG-verdrag erop moeten toeleggen de op dit gebied bestaande omstandigheden te bevorderen. Desalniettemin laat de richtlijn de mogelijkheid open, dat het niveau van bescherming (i.c. het niveau van de inspraak) verlaagd wordt. Bovendien, zoals Bercusson stelt, nodigt de richtlijn met haar verwijzing naar het nationale recht ertoe uit de discrepantie tussen de standaarden in rechten van werknemersvertegenwoordigers op dit terrein, als vaststaand te accepteren. Het belang van hun bemoeienis met dit terrein is, gezien de invloed die dit heeft op de fysieke en psychische gezondheid van individuele werknemers, groot. Volgens Bercusson zou de intensiteit van die bemoeienis niet mogen afhangen van het rechtssysteem waaraan de vertegenwoordigers onderworpen zijn (150).

De enige wijze waarop de Gemeenschap een verplichting tot deelname aan de besluitvorming door middel van instemming of onderhandeling kan verwezenlijken, is zo'n verplichting in de richtlijn zelf op te nemen, en deze niet afhankelijk te maken van de nationale wetgever. Men kan zelfs besluiten tot een procedure van geleidelijke invoering van een dergelijke verplichting (de termijn die nu wordt voorgesteld is tot 1 januari 1991),

149. G. Lyon-Caen, Quel avenir pour quel droit social ? in Cent ans de droit social Belge, Brussel, 1986 p. $879-887$.

150. Zie B. Bercusson, a.w. (noot 7), p. 95. 
voor die lid-staten die instemming of onderhandelingsrechten op dit terrein nog niet in hun wetgeving opgenomen hebben.

Een ander en mogelijk nog belangrijker punt waarop kritiek geuit kan worden is de wijze waarop de verplichtingen gereguleerd en afdwingbaar zijn in het voorstel. Met andere woorden: wat zijn de sancties die de nationale wetgever moet inbouwen voor het geval werkgevers niet aan hun informatie- en consultatieverplichtingen voldoen, en wat zijn de mogelijkheden om bij het slechts formeel voldoen aan deze verplichtingen (dit speelt met name bij consultatie) anderssoortige besluiten af te dwingen. De vraag zou beter kunnen luiden: waar zijn de sancties. Die zijn er niet. Weliswaar schrijft artikel 4 van de richtlijn voor dat de lid-staten de nodige maatregelen nemen om te verzekeren dat de werkgevers, de werknemers en de werknemersvertegenwoordigers worden onderworpen aan de voorschiften die nodig zijn voor de uitvoering van de richtlijn, en bepaalt met name dat de lid-staten moeten zorgen voor voldoende controle en toezicht, maar dat is een wel heel algemene verplichting.

De richtlijn legt de lid-staten niet de verplichting op voor adequate procedures, in de vorm van arbitrage of beroep op een rechter te zorgen. Dit betekent dat de naleving van de verplichtingen uit het voorstel geheel zijn overgelaten aan de nationale wetgeving, en de sancties waarin deze voorziet (151). Het is dus mogelijk dat een verplichting onder het nationale recht kan worden afgedwongen, het is echter even goed mogelijk dat deze ongesanctioneerd en dus niet afdwingbaar is. Dit laatste zou overigens wel in strijd kunnen komen met het gemeenschapsrecht.

In het arrest Von Colson en Kamann (152) stelde het Hof van Justitie dat, ook al laat artikel 189 de lid-staten vrij in de keuze van vorm en middelen voor de uitvoering van richtlijnen, deze vrijheid niet afdoet aan de verplichting van elke lid-staat alle maatregelen te treffen die nodig zijn om de volle werking van de richtlijn overeenkomstig het ermee beoogde doel te verzekeren.

Dit betekent dat, ook al zijn er geen verplichtingen tot het opleggen van sancties opgenomen in de richtlijn, de lid-staten impliciet verplicht zijn deze wel in hun nationale wetgeving op te nemen, indien deze nodig zijn het door de richtlijn voorgeschreven resultaat te bereiken. In van Colson en Kamann ging het echter alleen om de naleving van de bepaling. Zoals eerder bleek is het juist in het medezeggenschapsrecht heel goed mogelijk een regel formeel na te leven, maar hem tegelijkertijd materiëel te negeren.

In de bovenstaande richtlijn wordt in een aantal bepalingen het resultaat zo mager omschreven dat sancties met betrekking tot de formele naleving, die impliciet voorgeschreven zijn, nog geen materiële naleving garanderen.

151. Zie paragraaf II.4.2.D.

152. Zaak 11/83, Jur. 1984, p. 1891-1896 (Von Colson en Kamann vs. Nordrhein-Westfalen). 
De gevolgen van deze magere bepalingen voor de waarde van de medezeggenschapsverplichtingen kan aan de hand van het initiatiefrecht van artikel 11 lid 1 verduidelijkt worden. De richtlijn legt aan de lid-staten op dat een recht voor de werknemers om voorstellen te doen in de nationale regeling wordt opgenomen. Op zichzelf is dat niet meer of minder dan een petitierecht bij de werkgever. De enige additionele eis die de richtllijn stelt is, dat is dat de voorsteller van zijn actie geen nadeel mag ondervinden. Meer wordt er in feite niet als resultaat gevraagd.

Het is echter de vraag wat werknemersvertegenwoordigers kunnen doen als hun uit het initiatiefrecht voortvloeiende rechten genegeerd worden. Op dit moment kan alleen in Duitsland in een dergelijk geval actie worden ondernomen. Daar bestaat een (impliciete) verplichting het voorstel te behandelen (153). In Frankrijk en Nederland hebben werknemersvertegenwoordigers al minder mogelijkheden, want in deze landen kan de werkgever volstaan met het gemotiveerd afwijzen van het voorstel. Na zo'n weigering van de werkgever is geen juridische mogelijkheid een doeltreffend overleg, of een onderhandelingssituatie over de voorstellen af te dwingen. Het initiatiefrecht als (afdwingbaar) recht stell in deze landen dan ook niet zoveel voor. Alle drie genoemde landen hebben een initiatiefrecht en voldoen daarmee (zelfs ruimschoots) aan de richtlijn. Zelis het enkele voorschrijven van het recht, zonder deze sanctionering was genoeg geweest. Het initiatiefrecht uit de richtlijn is daarmee in feite niet meer dan een verplichting tot een ideeënbus voor werknemersvertegenwoordigers. Door het ontbreken van een verplichting een sanctie in de wet op te nemen, houdt het recht niet veel in.

Hetzelfde geldt voor de andere rechten die in het voorstel zijn opgenomen. Evenmin als sancties voor het afdwingen van de verplichtingen, die dus aan het nationale recht worden overgelaten, is richting gegeven aan de wijze waarop geschillen over de inhoud van verstrekte informatie of de inhoud wan besluiten zouden moeten worden opgelost. Dit betekent concreet dat de inhoud van de consultatie- en deelnemingsverplichtingen weinig voorstellen: volgens de richtlijn kan de werkgever volstaan met het vragen van een pro-forma advies, of het houden van een pro-forma overleg, tenzij de nationale wetgeving of praktijk in procedures voorziet.

Voor de informatieverstrekking levert dit nog een extra probleem op. Op zichzelf is de interpretatie van de richtlijn als hij eenmaal tot stand is gekomen overgelaten aan het Hof van Justitie. Nationale rechterlijke instanties (in elk geval in laatste instantie) zouden hierover prejudiciële vragen moeten kunnen stellen. Zoals hierboven werd opgemerkt kan dit echter alleen door rechters; arbiters hebben in beginsel niet de mogelijkheid prejudiciële vragen te stellen, tenzij zij aan een aantal voorwaarden voldoen. Is dit niet het geval, dan blijft de interpretatie van de nationale wet aan de nationale arbiters, zonder dat de richtlijn op die interpretatie verder nog

153. Zie paragraaf IV.3.2. 
van invloed is. Een uit elkaar groeien van nationale wet en richtlijn op dit punt is dan niet uitgesloten. Dit kan toch niet de bedoeling zijn.

Het probleem zou eenvoudig op te lossen zijn geweest als het voorstel daar een enkele bepaling over had opgenomen, waarbij aangesloten werd op de nationale praktijk, maar de mogelijkheid tot stellen van prejudiciële vragen uitdrukkelijk werd geopend. Dit had kunnen gebeuren door dit element expliciet in de richtlijn op te nemen, of door aan de bewuste arbitragecolleges eisen te stellen, waardoor zij onder de door het Hof geformuleerde criteria zouden vallen. Nu moet men afwachten wat de praktijk gaat worden, in de hoop dat het Hof voor richtlijnen in verband hiermee zijn criteria bij zal stellen.

Een derde punt van kritiek, maar daar zal ik in een aparte paragraaf op terug komen, is de gebondenheid van het voorstel aan de nationale grenzen. Een richtlijnvoorstel dat beoogt verlaging van nationale normen te voorkomen, had ook de mogelijkheid tot grensoverschijdende medezeggenschap mee moeten nemen, aangezien het niet aanwezig zijn daarvan, nu juist tot normverlaging had kunnen leiden.

C Op artikel $118 \mathrm{~A}$ gebaseerde richtlijnen en richtlijn- voorstellen voor maatregelen op specifieke gebieden

Artikel 16 van de raamrichtlijn betreffende de tenuitvoerlegging van maatregelen in verband met veiligheid en gezondheid (richtlijn 89/391) bepaalt dat ter uitwerking van de raamrichtlijn, specifieke maatregelen genomen kunnen worden betreffende in een bijlage genoemde technische gebieden (154). De bepalingen van de raamrichtlijn zijn op deze bijzondere richtlijnen van toepassing, dit wordt nog eens uitdrukkelijk bevestigd in artikel 16 lid 2 . De bijzondere richtlijnen kunnen echter nog aanvullende bepalingen geven.

De vraag dient zich overigens aan of voor deze specifieke gebieden, waar het veelal om technische zaken als grenswaarden en vrij absolute normen gaat, niet veel beter met direct toepasbare verordeningen zou kunnen worden gewerkt, in plaats van met richtlijnen die weer omgezet moeten worden in nationale wet- of regelgeving, en daardoor tot een enorme proliferatie van rechtsregels leiden (155). Verordeningen hebben het voordeel dat zij als wetgeving werken in de lid-staten, en problemen met omzetting, maar ook met interpretatie zouden daarmee voorkomen kunnen worden. Dit geldt echter alleen voor bepalingen die geen nadere uitvoering behoeven. Aanvullende voorschiften, die ook nu in richtlijnen worden

154. Het gaat hier om 17 met mame genoemde gebieden als arbeidsplaatsen, machines, individuele beschermingsmiddelen beeldschermapparatuur, tijdelijke en mobiele werkplaatsen, visserij en landbouw en het hanteren van zware lasten welke risico wan lumbaal letsel opleveren. De formulering van artikel 16 sluit overigens bijzondere rïchtlijnen op andere gebieden niet uit.

155. Zie A.T.M. Jacobs, a.w. (noot 50), p. 837. 
gesteld en die niet zonder harmonisatie kunnen worden toegepast (vergelijk de keuringsvoorschriften die in de richtlijn ter bescherming van werknemers tegen de gevaren van asbest zijn opgenomen), zouden dan alsnog in een richtlijn geregeld moeten worden.

Het probleem is echter dat artikel 118A alleen maar een rechtsbasis biedt voor richtlijnen, en niet voor andere maatregelen zoals verordeningen. De grenswaarden zouden dan gebaseerd moeten worden op artikel $100 \mathrm{~A}$ lid 1, dat naast richtlijnen wel grondslag kan zijn voor verordeningen. Artikel $100 \mathrm{~A}$ sluit, zoals gezegd, maatregelen met betrekking tot rechten en belangen van werknemers uit. De enige redenering op basis waarvan men kan beweren dat dergelijke verordeningen op grond van artikel $100 \mathrm{~A}$ wel mogelijk zijn, is dat puur technische normen (als grenswaarden) niet zozeer de rechten en belangen van werknemers betreffen, maar vooral in het belang zijn van de verwezenlijking van de interne markt. Volgens VogelPolsky zouden maatregelen met betrekking tot de verwezenlijking van de interne markt, die verband houden met het arbeidsmilieu, mogelijk ook kunnen ressorteren onder artikel 100A lid 1 (156). Zij baseert deze conclusie op artikel 100A lid 3, waarin volgens haar voorgeschreven zou zijn dat de Commissie bij haar in lid 1 bedoelde voorstellen uit zou moeten gaan voor een hoog beschermingsniveau, ó́k op het gebied van het arbeidsmilieu (naast volksgezondheid, veiligheid, milieubescherming en consumentenbescherming). Dit berust op een misverstand. De term arbeidsmilieu is niet opgenomen in lid 3. Mijns inziens is de grondslag van artikel $100 \mathrm{~A}$ voor verordeningen op het gebied van technische veiligheidsen gezondheidsnormen voor werknemers, (daar waar het niet gaat om veiligheidseisen aan producten, maar om voorschriften bij het werk) gezien de expliciete uitzondering en de speciale rechtsbasis van artikel $118 \AA$ acceptabel.

Een andere optie zou mogelijk zijn de grondslag van artikel 235 . Op die basis kunnen eveneens verordeningen gemaakt worden. Daarvoor is echter wel eenparigheid van stemmen in de Raad nodig. Dat vereiste bezorgt ieder van de lid-staten ten aanzien van de grenswaarden een veto, en zou dus mogelijk tot lagere normering leiden om alle lid-staten tevreden te stellen. Het lijkt dan ook een weg die niet erg handig is. Een betere oplossing zou zijn, om bij een volgende verdragswijziging de term richtlijnen in artikel $118 \mathrm{~A}$ te vervangen door maatregelen, zodat op basis van dit artikel ook verordeningen kunnen worden vastgesteld.

Tot dusver heeft de Commissie op vijf van de in de richtlijn genoemde terreinen actie ondernomen. Een aantal van deze voorstellen zijn praktisch tegelijk met het voorstel voor een nieuwe raamrichtlijn ingediend. Drie ervan hebben inmiddels de richtlijnstatus bereikt. De eerste richtlijn betreft minimumvoorschriften inzake veiligheid en gezondheid voor arbeidsplaat-

156. E. Vogel-Polsky, a.w. (noot 47), p. 67. 
sen (157). Het gaat hier om een aantal voorschriften die betrekking hebben op het ontwerp, de bouw en de inrichting van gebouwen, vluchtwegen en hygiëne. Het voorstel is in eerste instantie van toepassing op gebouwen die na de inwerkingtreding van het voorstel als richtlijn worden gebouwd. Deze moeten aan een aantal in bijlage I voorgeschreven minimumvereisten voldoen. Voor bestaande en in gebruik zijnde arbeidsplaatsen geldt een ander regime: deze moeten uiterlijk drie jaar na inwerkingtreding voldoen aan de minimumvoorschriften uit bijlage II, voorschriften die aanzienlijk minder ver gaan en gedetailleerd zijn dan die uit bijlage I. Gebouwen die verbouwd, gewijzigd of uitgebreid worden na inwerkingtreding van de richtlijn, dienen waar het de uitgevoerde wijzigingen, uitbreidingen en verbouwingen betreft wel in overeenstemming te zijn met de eisen van bijlage I.

Voor de gezondheids- en veiligheidsaspecten uit de bijlagen bestaat een in het voorstel opgenomen bijzondere verplichting de werknemers of hun vertegenwoordigers te informeren en medezeggenschap te bieden overeenkomstig de raamrichtlijn. De voorschriften in de bijlagen hebben met name betrekking op de fysieke omstandigheden die op de arbeidsplaats heersen. Zo zijn voorschriften opgenomen over temperatuur, verlichting de staat van vloeren, muren en daken, ontspanningsruimten en sanitaire voorzieningen. Daarnaast zijn voorschriften opgenomen over voorzieningen voor dreigend gevaar zoals vluchtwegen, nooduitgangen, en brandmelding en -bestrijding. Tenslotte bevat de bijlage voorschriften voor werknemers die bijzondere faciliteiten nodig hebben als zwangere vrouwen, zogende moeders en gehandicapte werknemers.

De tweede richtlijn betreft minimumvoorschriften inzake veiligheid-en gezondheid bij het gebruik van arbeidsmiddelen door werknemers op de arbeidsplaats (158). De opzet van deze richtlijn lijkt op die van de eerste. Arbeidsmiddelen die na inwerkingtreding van de richtlijn in gebruik worden genomen dienen meteen aan een aantal in de bijlage voorgeschreven minimumeisen te voldoen, reeds in gebruik zijnde arbeidsmiddelen moeten vier jaar na de inwerkingtreding van de richtlijn aan deze minimumeisen voldoen. De richtlijn bevat een bijzondere informatieverplichting aan de werknemers. Informatie moet verstrekt worden over de omstandigheden waaronder de arbeidsmiddelen dienen te worden gebruikt, over voorzienbare abnormale situaties en over de conclusies die kunnen worden getrokken uit de bij het gebruik opgedanen ervaringen. De informatie en de gebruiksaanwijzingen moeten voor de betrokken werknemers begrijpelijk zijn. Dit is een verzwakking ten opzichten van het eerdere voorstel, waarin voorgeschreven was dat gebruiksaanwijzingen, bij voorkeur in de eigen taal

157. RI. 89/654, Pb. 1989, 391; Voorstel Pb. 1988, C 141/6, gewijzigd voorstel ingediend op 22 maart 1989, Pb. 1989, C 115, voorstel n.a.v. de tweede lezing van het Europees parlement, Pb. 1989, C 284.

158. RI. 89/655, Pb. L 393; Voorstel in Pb. 1988, C 114/3, gewijzigd voorstel Pb. 1989, C 106, Voorstel n.a.v. amendementen van het Europees parlement in tweede lezing $\mathrm{Pb}$. 1989, C 297. 
van de werknemer moesten worden verstrekt. De voorschriften in de bijlage betreffen met name de bediening, de mogelijkheid tot stillegging van apparaten, noodzakelijke veiligheidsinrichtingen voor specifieke apparaten, verlichting van werk- en onderhoudspunten, en bescherming tegen brand, ontploffing of aanraking met electriciteit. Een aan het oorspronkelijke voorstel toegevoegde bijlage waarin indicatieve voorschriften bij aanschaf van arbeidsmiddelen waren opgenomen, is in de richtlijn komen te vervallen.

De richtlijn met betrekking tot minimumvoorschriften voor het gebruik op de werkplek van individuele beschermingsmiddelen door werknemers (159) is de derde in de reeks. Deze richtlijn hangt samen met een recent voorstel dat de technische harmonisatie van persoonlijke beschermingsmiddelen (160) tot doel heeft. In dit laatste voorstel, dat is gebaseerd op artikel 100A, gaat het overigens voornamelijk om het opruimen van handelsbelemmeringen; het heeft niet de bedoeling vooruit te lopen op voorschriften inzake het gebruik wan persoonlijke beschermingsmiddelen, ook al stelt de preambule dat harmonisatie niet tot een verlaging van beschermingseisen mag leiden. Het voorstel voor minimumvoorschriften is volgens de preambule wel te zien als een sociale aanvulling op deze harmonisatierichtlijn.

De richtlijn stelt minimumvoorschriften vast voor persoonlijke beschermingsmiddelen, maar bepaalt dat deze slechts moeten worden gebruikt indien de risico's op andere wijze vermeden kunnen worden door collectieve technische beschermingsmiddelen, of met middelen, methoden of procédé's op het gebied van de arbeidsorganisatie. Deze andere wijzen genieten blijkens de preambule de voorkeur. De richtlijn geeft een aantall algemene voorschriften, waarvan de eis dat het beschermingsmiddel afgestemd moet zijn aan ergonomische vereisten en aan de vereisten van de gezondheid van de werknemers de meest saillante is. Deze bepaling is overigens wel een verzwakking van het oorspronkelijk voorstell, waarin bepaald werd dat de uitrusting aangepast moest zijn of kunnen worden, aan de individuele werknemer. Voorts moeten de lid-staten regels vaststellen, voor het geval meer werknemers van é́n beschermingsuitrusting gebruik maken en zorgdragen voor regels met betrekking tot gegevenswerstrekking over de beschermingsuitrusting in de onderneming. De uitrusting moet normaal gesproken gratis ter beschikking worden gesteld door de werkgever; deze heeft de zorg voor onderhoud en hygiëne. Van deze bepaling kan echter door de lid-staten worden afgeweken als de beschermingsmiddelen niet uitsluitend op het werk worden gebruikt. Artikel 5 geeft regels over de beoordelingsprocedure van de beschermingsmiddelen.

159. Rl. 69/656, L 393; Oorspronkelijk voorstel $\mathrm{Pb}$. 1988, C 161, gewijzigd voorstel ingediend op 20 maart 1989, $\mathrm{Pb}$. $1989, \mathrm{C} 115$, voorstel n.a.v. amendementen van het Europees parlement in tweede lezing, $\mathrm{Pb} .1989, \mathrm{C} 287$.

160. Pb. 1988, C 141/14. 
De bijlagen bij de richtlijn geven lijsten voor persoonlijke beschermingsmiddelen en een opsomming van situaties waarin het gebruik van persoonlijke beschermingsmiddelen noodzakelijk kan zijn. Deze lijsten zijn indicatief en niet volledig. In tegenstelling tot de eerste twee richtlijnen waarin duidelijke minimumvoorschriften zijn opgenomen, is hier een dergelijke (vrij dwingende) stap niet gemaakt. Voor wat betreft de activiteiten waarbij persoonlijke beschermingsmiddelen ter beschikking moeten worden gesteld is dit mijns inziens te betreuren. Weliswaar is een absoluut voorschrift mogelijk niet haalbaar geacht in verband met het in artikel 3 gegeven voorschrift dat persoonlijke beschermingsmiddelen pas in laatste instantie gebruikt mogen worden, dit neemt niet weg dat mijns inziens een dwingender lijst mogelijk was geweest.

Het voorstel voor een vierde specifieke richtlijn heeft betrekking op het werken met beeldschermapparatuur (161). Deze richtlijn sluit op richtlijn $83 / 198$ (162), de richtlijn die in een algemene informatieprocedure voorziet op het gebied van technische normen en regelingen. Het voorstel geeft een aantal minimumvoorschriften waaraan de werkplek moet voldoen, en schrijft voor dat over deze maatregelen de werknemers of hun vertegenwoordigers geconsulteerd moeten worden. De maatregelen zijn opvallend omdat zij naast specifieke voorschiften die betrekking hebben op fysieke aspecten (gezichtsvermogen en lawaai) ook voorschriften bevat voor de hoogte en soort werktafel en werkstoel. Deze laatste gebieden worden in het algemeen tot de ergonomie (en daarmee eerder tot welzijnsgebied) gerekend dan tot veiligheid en gezondheid in de strikte zin. In een van de gewijzigde voorstellen voor de raamrichtlijn werd voorgeschreven dat de ergonomie betrokken moet worden bij de organisatie van de veiligheid en gezondheid (163). Deze verplichting is er in het gemeenschappelijk standpunt van de Raad echter weer uit gehaald (164). Het is dan ook afwachten of dit soort vergaande concrete voorschriften de eindstreep halen. Hetzelfde geldt voor een andere bepaling waarin als minimumeis gesteld wordt, dat bij invoering van software rekening moet houden met psycho-sociale factoren.

Het vijfde voorstel bevat minimumvoorschriften voor het hanteren van zware lasten die lumbaal letsel kunnen opleveren (165). Het woorstel legt de lidStaten een algemene verplichting op te zorgen dat werkgevers zoveel mogelijk het hanteren van zware lasten zonder hulpmiddelen door werknemers vermijden. In het geval waarin dit niet mogelijk is moeten de werkgevers rekening houden met een aantal technische factoren die genoemd zijn in bijlage II, factoren die overigens nogal voor de hand lijken

161. Voorstel van 11 maart $1988, \operatorname{COM}(88) 77$ def. $\mathrm{Pb}, 1988, \mathrm{C} 113$.

162. RI 83/189, Pb 1983, L 109.

163. Artikel 5 lid 3 van gewijzigd voorstel van voorstel van 5 december $1988, \mathrm{~Pb}, 1989, \mathrm{C} 30$.

164. Gemeenschappelijk standpunt van de Raad, Pb. 1989, C 172.

165. Pb. 1988, C 141, gewijzigd voorstel ingediend op 22 maart 1989, Pb. 1989, C 115. 
te liggen (166). Daarnaast moet ook met de speciale kenmerken van de werknemers rekening worden gehouden, volgens een in bijlage III gegeven lijst. Ook deze lijst is niet spectaculair (167). Een consultatieverplichting bestaat met betrekking tot de toepassing van de regelingen door de ondernemer. Voorts bestaat er voor de ondernemer de verplichting de werknemers te informeren voor zover mogelijk, over het gewicht van de zware lasten en over het zwaartepunt indien het gewicht niet gelijk verdeeld is.

Het meest opvallend is het ontbreken van een maximumwaarde: een dergelijke waarde werd misschien niet vast te stellen geacht.

Twee andere voorstellen voor bijzondere richtlijnen die in eerste instantie voorgesteld werden als bijzondere richtlijnen in de zin van raamrichtlijn $80 / 1107$, krijgen (op basis van de gewijzigde voorstellen) eveneens als basis artikel $118 \mathrm{~A}$ mee en worden bijzondere richtlijnen in de zin van nieuwe raamrichtlijn $89 / 391$. Het gaat hier om voorstellen voor richtlijnen betreffende de bescherming van werknemers tegen de risico's van blootstelling aan carcinogene agentia op het werk (168) en betreffende bescherming tegen de risico's van biologische agentia op het werk (169). Het eerste voorstel omvat verplichtingen voor de ondernemer met betrekking tot het nemen van een mantal in de richtlijn opgesomde maatregelen, die moeten bewerkstelligen dat de blootstelling van werknemers tot een zo laag mogelijk peil te brengen. Jongeren, zwangeren en zogende moeders mogen volgens het gewijzigde voorstel in beginsel helemaal niet te worden tewerkgesteld op plaatsen waar zij in contact kunnen komen met carcinogene agentia. De opsomming bevat naast een aantal organisatorische maatregelen ook voorlichting van de werknemers en toezicht op de gezondheid van de werknemers. Voorts geeft het voorstel een aantal voorschriften met betrekking tot toegang tot zones, het doorgeven van informatie aan de bevoegde autoriteiten en voor maatregelen bij calamiteiten.

Het gewijzigde voorstel is voor wat de medezeggenschapsverplichtingen betreft aangesloten op de nieuwe raamrichtlijn. Het bevat bepalingen met voorschriften over voorlichting en training aan werknemers, of in voorko-

166. Het gaat bijvoorbeeld om de hoogte van de ruimte (sta-hoogte), effentheid van de werkvloer, plaats van de lasten en de mogelijkheid van de werknemer om deze te bereiken rust- en recuperatieperioden, draagafstanden. Men zou kunnen zeggen dat dit soort factoren zo gewoon zijn dat eenieder daar zonder meer rekening mee zou houden, en dus dat een richtlijn overbodig is; ik sluit echter niet uit dat dit niet het geval is.

167. Hierin staat o.m. dat werknemers risico lopen als zij fysiek niet in staat zijn de last the dragen (inclusief ziekte, handicap en zwangerschap), zij niet behoorlijk gekleed of getraind zijn. Ook hier geldt dat de regeling niet noodzakelijk zou moeten zijn, maar dat vermoedelijk wel is.

168. COM(87) 641 def, ingediend op 21 december 1987, PB. 1988, C. 34, gewijzigd voorstel ingediend op 2 augustus $1989, \mathrm{~Pb} 1989, \mathrm{C} 229$.

169. COM(88) 165 def, ingediend op 19 april 1988, $\mathrm{Pb}$. 1988, C 150 gewijzigd voorstel ingediend op 2 augustus $1989, \mathrm{~Pb} .1989, \mathrm{C} 218$. 
mend geval hun vertegenwoordigers in het algemeen over carcinogene argentia. Voorts bevat het een verplichting tot het verstrekken van informatie aan de werknemers over die carcinogene agentia en daarmee verband houdende recipiënten die in de onderneming in het bijzonder. Een bijzonder recht van toezicht voor werknemersvertegenwoordigers op de naleving van de bepalingen van de richtlijn is opgenomen. Eventueel moeten vertegenwoordigers bij de toepassing van de voorschriften actief worden betrokken, overigens zonder inbreuk te maken op de verantwoordelijkheden van de werkgever. Dit laatste wat cryptische zinnetje slaat vermoedelijk op de bepaling in de raamrichtlijn dat de deelneming van de werknemers, de werkgever niet van zijn verantwoordelijkheden ontheft. Informatie moet worden verstrekt bij calamiteiten; daarnaast hebben werknemersvertegenwoordigers het inzagerecht in de collectieve gegevens die over de blootgestelde werknemers door de ondernemer moet worden verzameld.

Het voorstel voor de richtlijn ter bescherming tegen de risico's van biologische agentia heeft met name betrekking op preventieve maatregelen, en wil naast preventie ook de verzameling van de gegevens bevorderen, hetgeen volgens de preambule een nauwkeuriger kennis van de gevaren kan opleveren. Het voorstel bevat dan ook een uitgebreid stelsel van maatregelen die zien op evaluatie van de gevaren van het werken met biologische agentia en op de registratie daarvan. Daarnaast worden algemeen preventieve maatregelen vergelijkbaar met die in andere voorstellen en richtlijnen voorgeschreven, en maatregelen met betrekking tot persoonlijke beschermingsmiddelen als kleding.

Medezeggenschapsverplichtingen anders dan informatieverplichtingen zijn in het voorstel niet opgenomen, opvallend genoeg ook niet waar het beschermende kleding betreft. Dit kan opgevangen worden door de bepalingen uit de raamrichtlijn en de richtlijn met betrekking tot persoonlijke beschermingsmiddelen, Een reden voor deze omissie zou gelegen kunnen zijn in het feit dat het voorstel weliswaar preventieve matregelen voorschrijft, maar dat tegelijkertijd nog niet altijd even duidelijk is hoe, waartegen en op welke wijze moet worden beschermd.

Andere voorstellen die nog in de pijplijn van het Actieprogramma sociale dimensie van de interne markt zitten zijn voorstellen voor veiligheidsvoorschriften in de sectoren vervoer en industriële bosbouw, voor medische assistentie op schepen, en voor informatiesystemen voor personen die zijn blootgesteld aan bepaalde gevaarlijke industriële agentia (170).

170. Europe, Agence Internationale d'Information pour la presse, 13 januair 1990, nr. 5171 p. 8. 
Op de nieuwe raamrichtlijn valt, zoals uit het voorgaande bleek nog wel het een en ander af te dingen. $\mathrm{Zij}$ bevat geen expliciete verplichting tot onderhandelen door of instemming van de werknemers bij besluiten, maar slechts een wage bepaling over "deelneming aan de behandeling van veiligheids- en gezondheidsvraagstukken", die als "evenwichtige deelneming" op de in de lid-staten bestaande situatie moet aansluiten, en die daardoor niet meer kan inhouden dan een verplichting tot overleg. Bovendien bevat de richtlijn een op te algemene wijze voorgeschreven handhavingsmechanisme, terwijl een strikter geformuleerd mechanisme juist ten behoeve van de werknemersvertegenwoordigers, maar ook van de individuele werknemers had kunnen werken. Dit laatste is een gemiste kans. In het vorige hoofdstuk constateerde ik immers al, dat de positie van de individuele werknemer in de nationale medezeggenschapssystemen zwak is. Het zou aan de richtlijn zijn daar lets aan te doen.

Een tweede omissie is de mogelijkheid om medezeggenschap bij de top van concerns te verkrijgen inzake veiligheids- en gezondheidsaangelegenheden. Deze twee aspecten, de mogelijke oplossingen daarvoor op gemeenschapsniveau en de verplichting die de Gemeenschap daar toe heeft zullen in deze paragraaf aan de orde komen.

Deze beleidsgebieden waarop de Gemeenschap bemoeienis heeft zijn, tot op zekere hoogte nieuw. Of in een richtlijn ter regulering van het instrumentarium van medezeggenschap deze zaken uitputtend aan de orde zouden moeten komen, of dat slechts de aanzet tot nadere regulering op termijn zou moeten worden gegeven is een nog niet beantwoorde vraag.

\subsection{De individuele werknemer in een te maken regeling}

Is het nodig in een voorstel voor een richtlijn met betrekking tot medezeggenschap inzake veiligheid en gezondheid iets te regelen met betrekking tot de positie van de individuele werknemer? Mijns inziens is dit wel het geval. Een richtlijn die het resultaat van nationale wetgeving voor moet schrijven, en zelf als (minimum)wetgeving gezien kan worden kan niet volstaan met het negeren van die positie, als die positie in de nationale wetgeving onvoldoende geregeld is. Dit geldt mijns inziens temeer wanneer de nationale wetgeving of praktijk groepen van werknemers in de medezeggenschapssystemen uitsluit.

Er zijn in elk geval twee zaken waarin een regeling zou moeten voorzien. In de eerste plaats kan de Gemeenschap niet langer meer volstaan met op de nationale praktijken aan te sluiten indien die praktijken medezeggenschap voorbehouden aan vakbonden en niet alle vakbonden in de onderneming vertegenwoordigd (kunnen) zijn, in verband met het representativiteitsbeginsel. Ten tweede heeft de Gemeenschap een specifieke verantwoordelijkheid voor die groepen van werknemers die, door de 
tradities van het nationale recht (of het ontbreken van nationaal recht op een aantal punten) van medezeggenschapsrechten verstoken zijn gebleven.

Tot het nemen van die verantwoordelijkheid is de Gemeenschap in elk geval op grond van de jurisprudentie van het Hof van Justitie verplicht (171). Medezeggenschap kan in een gemeenschapsregeling worden ondergebracht als alle werknemers, dus ook niet vakbondsleden daarvan kumnen profiteren. Een richtlijn zou dus een oplossing moeten bieden voor de lacune in het medezeggenschapsrecht van die lid-staten die de vertegenwoordiging inzake veiligheids- en gezondheidsaangelegenheden overlaten aan de vakbonden.

Een andere bron waruit men mogelijk een dergelijke verplichting zal kunnen halen is het in hoofdstuk II besproken Gemeenschaps-handvest van Sociale Grondrechten (172). Een van de rechten die in dit handvest zou moeten worden opgenomen, volgens het Economisch en Sociaal Comité (173) is het recht van alle werknemers ongeacht aard en kenmerken van hun arbeidsverhouding, collectief te onderhandelen met hun werkgevers. Zo uitgebreid is het recht echter niet in het Handvest terecht gekomen. Of de nu aangenomen tekst op den duur een bron kan zijn voor een dergelijke verplichting is een kwestie van afwachten.

Er zijn wel enkele oplossingen te bedenken voor het vertegenwoordigingsprobleem inzake veiligheids- en gezondheidsaangelegenheden. Zo kan een lid-staat, waar medezeggenschap in het algemeen wordt uitgeoefend door vakbondsvertegenwoordigers, voorschrijuen dat het actieve en passieve kiesrecht van vertegenwoordligers op dit gebied voor alle werknemers dient open te staan. Dit is de oplossing die in Denemarken is gekozen, waarbij moet worden aangetekend dat de samenwerkingscommissie, die het instemmingsrecht bij het vaststellen van de beginselen heeft, voor een groot deel uit shop stewards (dus vakbondsvertegenwoordigers) bestaat. Een andere mogelijkheid zou zijn dat vakbonden en andere werknemers gelijkelijk vertegenwoordigers kunnen aanwijzen respectievelijk kiezen. Een derde oplossing is een of meer vakbondsvertegenwoordigers qualitate qua als adviseur of lid toe te voegen aan de groep van vertegenwoordigers die met de werkgever over het algemene ondernemingsbeleid op het gebied van veiligheild en gezondheid samenwerkt, c.q. onderhandelt.

Het tweede probleem, dat $\mathrm{ik}$ in het vorige hoofdstuk het probleem van de randgroepwerknemers heb genoemd gaat een stukje verder. Hier betreft het

171. Zaak 91/81, Jur. 1982 p. 2133 (Commissie vs Italie) en zaak 143/83, Jur. 1985, p. 427 (Commissie ws Denemarken), zaak 215/83, Jur. 1985, p. 1039 (Commissie vs Belgie).

172. Ingediend op 13 juni bij de Raad der Europese Gemeenschappen, aangenomen op de Europese Raad te Staatsburg van 9 december 1989 door elf van de twaalf lid mtaten van de EEG. Zie ook B. Bercusson, a.w. (noot 7),

173. Advies van het Economisch en Sociaal Comité over de sociale grondrechten in de Europese gemeenschap, Pb. 1989, C 126. 
die werknemers die van oudsher geen kans hebben aan de medezeggenschapsstructuur deel te nemen, ofwel omdat zij om verschillende redenen in de wet of de praktijk van de lid-staten van deelname uitgezonderd zijn, ofwel omdat zij geen werknemers zijn in de zin van de wet. Uit een door de Gemeenschap geïnitieerd onderzoek naar werknemers op bijzondere contracten blijkt dat in enkele lid-staten bijzondere soorten werknemers door middel van arbeidsrechtelijke wetgeving bij het uitoefenen van collectieve rechten betrokken zijn. De meer algemene conclusie van het onderzoek luidt echter dat "Labour law in the member-states (....) mostly concerned with industrial workers and "surprised" by the pace of the recent developments, has not been able to develop and integrate systematically across the full range of the member-states, the (non-existent) union activities of those workers are weak. This means that workers on a nonpermanent employment contract, home-based workers, tele-workers, the fake self-employed workers and the parasubordinated workers (...) do not in principle enjoy the collective rights of workers having a typical employment contract" (174).

In de richtlijn is het probleem van deze groep benaderd met een zeer ruime definitie van het werknemersbegrip, ook voor wat betreft de medezeggenschap inzake veiligheids- en gezondheidsaangelegenheden. Dit zou kunnen betekenen dat die lid-staten waar tot dusver de vertegenwoordiging voorbehouden is aan speciale groepen een ruimere interpretatie moeten gaan hanteren. Men kan hierbij denken aan Groot Brittannië en Italië waar de aanwijzing van vertegenwoordigers in respectievelijk de HSWA 1974, en het Werknemersstatuut 1970 een recht van de vakbonden is c.q. wordt geacht te zijn, maar ook an die lid-staten waar wettelijke beperkingen aan het kiesrecht zijn verbonden. Bij de interpretatie van dit begrip zal de rechtspraak van het Hof mijns inziens een cruciale rol moeten spelen.

De bestaande rechtspraak ten aanzien van het werknemersbegrip inzake het vrij werknemersverkeer, zou mogelijk analoog kunnen worden toegepast. De definitie van het begrip uit de richtlijn nodigt al uit tot een ruimere interpretatie dan het Hof tot dusver aan dat begrip in richtlijnen heeft gegeven. Het is echter aannemelijk dat het werknemersbegrip in het richtlijn voorstel een uitwerking is van de term "werkenemers" die in artikel 118A EEG-verdrag wordt gehanteerd. Het Hof kan mijns inziens dan ook op basis van de term in het verdrag interpreteren en heeft dan minder te maken met het probleem van omzetting in nationale wetgeving, waarop tot dusver de koppeling aan het nationale werknemersbegrip is gebaseerd (175).

De kans dat een dergelijke oplossing slechts cosmetisch is, is helaas niet denkbeeldig. Want de eerdergenoemde randgroep-werknemers zitten

174. Y. Kravaritou-Manitakis (ed), a.w. (noot 146), p. 109-113.

175. Zie over de communautaire inhoud van in het verdrag gebruikte termen o.m. Zaak $75 / 63$, Jur. X p. 369 , (Unger), zie ook paragraaf VI.2.1.A. 
uiteraard niet voor niets in hun (in alle opzichten, maar voor met name het medezeggenschapsrecht) slechte positie. Zolang er verder geen flankerend beleid voor deze groepen van werknemers wordt ontwikkeld, wordt met een uitgebreid werknemers begrip in feite alleen bereikt dat zij het actieve kiesrecht verkrijgen. Het passieve kiesrecht blijft voor deze werknemers, hoewel zij formeel in de positie raken gekozen te kunnen worden, gezien de feitelijke omstandigheden vermoedelijk onbereikbaar.

In het vorige hoofdstuk werd erop gewezen dat vertegenwoordiging door homogene groepen een mogelijke oplossing zou kunnen bieden. Daardoor zouden deze werknemers de voor hen spelende belangen naar voren kunnen brengen. Bovendien door de vertegenwoordiging op deze wijze plaats te laten vinden, zouden zij verzekerd zijn van een vertegenwoordiger, en niet afhankelijk zijn, van een grotere bekendheid onder andere werknemers dan diegenen die in dezelfde positie verkeren. Hoe een dergelijke vertegenwoordiging van homogene groepen tot stand moet worden gebracht kan aan de lid-staten zelf over worden gelaten. In landen met een wettelijke regeling kan deze zo worden herzien dat daartoe mogelijkheden ontstaan. In landen met een vakbondsvertegenwoordiging kan men denken aan speciale groepen binnen de vakbond zelf waardoor plaatsen ontstaan, of eigen kleine bonden.

Een dergelijke oplossing brengt echter haar eigen problemen mee. Om te beginnen komt men dan aan de ook in het vorige hoofdstuk gesignaleerde vraag toe wat een homogene groep is. Werknemers op eenzelfde afdeling? Werknemers die onder dezelfde arbeidsomstandigheden werken? Werknemers met eenzelfde soort arbeidsverhouding met de onderneming? Daarnaast zijn er in de onderneming ook dwarsverbindingen te trekken van groepen met aparte belangen, zonder dat zij zich in dezelfde homogene groep bevinden: bijvoorbeeld vrouwen, buitenlandse werknemers, en gehandicapte werknemers. Voorts hoeven ook flexibele arbeidskrachten of thuiswerkers niet altijd in dezelfde homogene groep te zitten.

Kortom de criteria waarmee het begrip "homogene groep" moet worden vastgesteld zijn nog niet meteen gevonden. Dat neemt niet weg, dat een zekere mate van homogeniteit in de onderneming zelf wel vast te stellen is. Criteria moeten dus ook niet te zeer vastgelegd worden in een wettelijke regeling, en al helemaal niet in een regeling op gemeenschapsniveau. Het uitkristalliseren moet op ondernemingsniveau gebeuren, de op de richtlijn gebaseerde nationale regeling zal dan een mogelijkheid moeten bieden de, zich als homogene groep presenterende werknemers de kans te bieden een vertegenwoordiger te kiezen, en indien daarover geschillen zijn deze vertegenwoordiging af te dwingen.

Een andere weg om de positie van de individuele werknemer, en dan met name die van de randgroepwerknemers te verbeteren is het verbeteren van het bestaande petitierecht bij de arbeidsinspectie of andere bevoegde organen. Deze verbetering zou kunnen bewerkstelligen dat de individuele 
werknemer, wanneer hij werkzaamheden verricht die zijns inziens onveilig zijn of schadelijk zijn voor zijn gezondheid, via de bevoegde instantie de mogelijkheid heeft om de werkgever tot maatregelen te dwingen.

Dit idee voor een, zij het slechts ten dele gesanctioneerd, klachtrecht (zowel binnen de onderneming als bij de bevoegde instanties) is niet nieuw. Bij de totstandkoming van de Nederlandse arbeidsomstandighedenwet is het bijvoorbeeld ter sprake gekomen (176). In andere documenten, zoals de ILO Tripartite Declaration of Principles concerning Multinational Enterprises and Social Policy 1977 komt men het meer in zijn algemeenheid tegen (177).

Het klachtrecht zoals het mijns inziens in de richtlijn zou moeten worden opgenomen, zou de mogelijkheid moeten bieden aan de werknemer klachten te richten tot de arbeidsinspectie of bevoegde instantie, die verplicht zou zijn te reageren. Hiermee gaat het recht verder dan een petitierecht, maar minder ver dan een verzoek tot wetstoepassing zoalls de Nederlandse ondernemingsraad kan doen. De arbeidsinspectie zou immers op kennelijk ongegronde klachten slechts met een reactie hoeven in te gaan, maar is tot optreden niet verplicht. De verplichting tot reageren, zou de arbeidsinspectie in elk geval noodzaken de klacht te bestuderen. Toegegeven een dergelijk klachtrecht lost ongetwijfeld niet alles op (met name niet door het gebrek aan sancties tegen een niet-reagerende arbeidsinspectie) maar het biedt een ingang voor de individuele werknemer.

\subsection{Medezeggenschap op multinationaal niveau}

Een andere omissie uit het voorstel voor een raamrichtiijn is het ontbreken van medezeggenschap bij de concerntop, en op multinationaal niveau. Medezeggenschap inzake veiligheids- en gezondheidsaangelegenheden krijgt, hoewel het in eerste instantie vooral op vestigingsniveau van belang lijkt, steeds meer te maken met de verschuiving van beslissingscentra in de onderneming. Medezeggenschap op het niveau van de (nationale) groep, of het nationale concern (zoals de nationale regelingen in enkele lid-staten reeds hebben (178)) biedt om de daarmee samengaande problemen op te lossen niet altijd soelaas. Werknemersvertegenwoordigers kunnen wel onderhandelen over te nemen maatregelen op ondernemingsniveau, maar wanneer de financiële zeggenschap in handen is van de moeder van die onderneming (en die moeder zich ook nog in een andere lid-staat bevindt),

176. De Minister wan Sociale Zaken was daar tegen, en meende dat in de (oude) Veiligheidswet en nieuwe Arbeidsomstandighedenwet (artikel 34 lid 2) voorziene geheimhoudingsplicht in samenhang met het ook uit artikel $5 \mathrm{GW}$ voortvloeiende recht van petitie voldoende waarborg bood voor de individuele werkmemer (T.K. 1876/77, 14497 no. 3 p. 54 (MvT); zie ook T.K. 1979/80, 14497 , no.11, p. 45.)

177. Tripartite Declaration on Principles concerning Multinational Enterprises and Social Policy, 1977, opgenomen in International Encyclopedia for Labour law and Industrial Relations, (Codex) Deventer 1985 (supplement 57), p. 711.

178. Zie paragraaf III.2.1. 
dan kan het medezeggenschapsinstrumentarium hooguit aangewend worden om datgene waartoe de onderneming zelf financieel in staat is, te bereiken. Dit kan betekenen dat nieuwe maatregelen die additionele middelen vereisen, weliswaar door de werknemersvertegenwoordigers voorgesteld worden, maar dat het lokale bestuur, zelfs indien het die voorstellen steunt, deze eenvoudig niet kan honoreren, omdat het bestuur die middelen niet ter beschikking heeft en deze mogelijkerwijs ook niet zal krijgen.

In het extreme geval verwordt de medezeggenschap zo tot een controleinstrument op die maatregelen waartoe de werkgever toch al wettelijk verplicht is, maar houden participatie en initiatiefbevoegdheden waaruit een gezamenlijk beleid zou kunnen voortvloeien niets in.

Medezeggenschap op (bovennationaal) concernniveau is dus noodzakelijk om in het gehele concern een beleid op veiligheids- en gezondheidsgebied te voeren, waarin werknemersstemmen gehoord worden. Dat "horen" moet meer zijn dan het in ontvangst nemen van verzoeken vanuit de dochterondernemingen die met meer of minder welwillendheid kunnen worden aangehoord, maar waarover het concernbestuur zonder daar verder rekening mee te hoeven houden, zelfstandig beslist.

Geconstateerd hebbende dat er binnen de lid-staten, in elk geval tot op zekere hoogte communis opinio bestaat over wat er aan medezeggenschap inzake veiligheids- en gezondheidsaangelegenheden binnen de nationale grenzen aanwezig moet zijn, is er geen reden te bedenken, waarom dit opeens anders zou zijn als het om medezeggenschap op bovennationaal niveau zou gaan. Een regeling die medezeggenschap op bovennationaal niveau mogelijk maakt, zou de nationale praktijken van de lid-staten tot op zekere hoogte kunnen respecteren.

De raamrichtlijn voorziet niet in bovennationale medezeggenschap. Sterker nog, het feit dat het begrip onderneming in de uiteindelijke richtlijn helemaal niet is gedefinieerd wijst erop dat de interpretatie van het begrip volledig op nationaal niveau dient te gebeuren. Dit sluit in een aantal lidstaten medezeggenschap op hoger niveau dan de werkmaatschappij zelfs uit.

In de eerste voorstellen van de Commissie was nog wel een definitie van het begrip onderneming opgenomen. Deze luidde: de onderneming en/of vestiging is de tot de openbare of particuliere sector behorende eenheid welke met name een industriële, landbouw-, handels-, administratieve, dienstverlenende, educatieve, culturele of vrijetijdsactiviteit uitoefent (179). Uit deze definitie had men eventueel kunnen concluderen dat ook concerns tot het begrip zou behoren. Dit had slechts voor een aantal lid-staten het nodige uitgemaakt, namelijk voor die lid-staten, die geen medezeggenschap hebben op een hoger niveau dan de eigen vestiging. Echter dat nationale recht is nu eenmaal gebonden aan de nationale grenzen. Dus zelfs wanneer

179. Artikel 2 gewijzigd voorstel Pb. 1989, C 30 . 
de oorspronkelijke voorgestelde definitie mede concerns omvatte, zouden de medezeggenschapsbepalingen slechts hebben gegolden voor die concerns (of delen van concerns) die binnen de grenzen van die ene lid-staat vallen. Dit blijkt ook wanneer men deze definitie naast die uit het VredelingRichard voorstel legt, waar uitdrukkelijk gesproken wordt van moeder- en dochterondernemingen (180).

Alle richtlijnen die tot dusver van toepassing zijn in de gemeenschap hebben overigens deze beperking, die in het licht van de voortschrijdende integratie in verband met de uitvoering van de Europese Akte, inmiddels door de Commissie wel als problematisch wordt gezien (181). Het was dan ook hierom dat de Vredeling voorstellen enige ruimte moesten scheppen.

Indien met name het Vredeling-Richard voorstel het uiteindelijk toch nog tot richtlijn weet te brengen is het mogelijk dat daarmee de problematiek, zoals hij zich op dit moment voordoet voor een deel is opgelost. Dit laatste voorstel voorziet immers ook in een competentie voor vertegenwoordigers op het gebied van veiligheids- en gezondheidsaangelegenheden. Informatieverstrekking en consultatie door de top van het concern zou daarmee bereikt kunnen worden, de nieuwe raamrichtlijn zou daarnaast op nationaal niveau de bestaande medezeggenschapspraktijken niet frustreren. Aangezien het Vredeling-Richard voorstel wel in mogelijkheden voorziet weigerachtige werkgevers tot het verstrekken van informatie te bewegen zou in beginsel wel iets meer bereikt zijn dan tot dusver op dit terrein.

Maar het zou wel wat mager zijn. Het Vredeling-Richard voorstel kent ook zijn beperkingen, onder meer in de reeds besproken geheimhoudingsparagraaf. Daarnaast zou het niveau van de medezeggenschap bij de top niet meer zijn dan consultatie, en geen participatie. Met name als de nationale wetgeving of praktijk daar niet toe dwingt zou het gehele niveau van medezeggenschap met name bij de top van multinationals nog steeds relatief laag zijn. En wat nog meer zegt: het Vredeling-Richard voorstel is nog geen richtlijn, en de kans dat dat binnenkort wel het geval is is nog steeds niet groot (182).

Kortom datgene dat de niveaus van medezeggenschap het meest bedreigt, namelijk de vergroting van de slagvaardigheid van ondernemingen om door multinationalisering het centrum van besluitvorming op een plaats te vestigen waar (eventueel als neveneffect) de medezeggenschap op de vitale plaats in de onderneming ontweken wordt (183), wördt door datzelfde

180. Zie Pb 1983, C 217 .

181. Sociaal Europa, Thema nummer: De sociale dimensie van de interne markt, een uitgave van het Directoraat-Generaal werkgelegenheid, sociale zaken en onderwijs van de Commissie van de Europese Gemeenschappen, Luxemburg 1988, p. 104.

182. Zie paragraaf II.4.2.A.

183. Zie o.m. A.T.J.M. Jacobs, De ondermijning wan het sociaal recht, Sociaal Recht, 1989-2 p. 39 . 
richtlijnvoorstel in het geheel niet aan banden gelegd. En toch zou de raamrichtlijn een verlaging van dat niveau volgens zijn eigen preambule moeten tegenhouden. Ook het Gemeenschaps-handvest van Sociale Grondrechten en de adviezen daaromtrent verzetten zich tegen een verlaging van het beschermingsniveau. Volgens het Economisch en Sociaal Comité zou in verband de te hanteren standaarden van het handvest aansluiting bij het Europees Sociaal Handvest en ILO-verdragen gezocht moeten worden. Hierbij wordt onder meer verwezen naar de aanbevelingen die betrekking hebben op inspraak van de werknemers bij de vaststelling van de arbeidsvoorwaarden (184), en de Conventies die bescherming van veiligheid en gezondheid op de werkplek waarborgen (185).

Met name Conventie no. 155 geeft een aantal voorschriften op het gebied van samenwerking tussen werkgever en werknemersvertegenwoordigers, over informatieverstrekking, consultatie, de mogelijkheid van beroep op deskundigen en het recht op werkonderbreking. Het zal er vanaf hangen op welke wijze de uitwerking van het communautair sociaal handvest aan zal sluiten op de genoemde ILO-conventies. Wanneer die aansluiting toepassing betekent van de genoemde bepalingen in het gemeenschapsrecht, dan kunnen deze conventies een grote rol gaan spelen bij het concretiseren van sociale rechten in het gemeenschapsrecht, met name waar deze zijn uitgewerkt in een richtlijn. Echter zoals de zaak er nu voor staat kunnen de waarborgen ook als niet-toepasbare waarborgen worden beschouwd, bijvoorbeeld omdat de Gemeenschap, op basis van het ILO-statuut geen verdragspartij kan zijn (186).

Dit zou in beginsel geen belemmering voor toepassing in het gemeenschapsrecht te hoeven zijn: het Hof van Justitie gaat immers ook vrij ver in het toepassen van het ECRM, een verdrag waarbij de gemeenschap eveneens geen partij is (187). Echter de toepassing van het ECRM op het gemeenschapsrecht is mede gebaseerd op het feit, dat de lid-staten van de EEG wel verdragspartij bij het ECRM zijn; dit is niet het geval bij de genoemde ILO-conventies. Eind 1987 hadden bijvoorbeeld Spanje en Portugal als enige twee EEG-lid-staten Conventie no. 155 geratificeerd (188). De aantallen ratificaties van andere verdragen liggen niet veel hoger (189). Men kan dus

184. ILO Recommendation, nr. 94, Engellse tekst te vinden in International Encyclopedia for Labour Law and Industrial Relations, Codex, Deventer 1983, (supplement 32) p. 532; Rec. no. 113 , id. p. 541 en Rec. no 129 id. p. 582.

185. ILO conventions, nr. 155 (Engelse tekst, Encyclopedia for Labour law and Industrial Relations, Deventer 1983 (supplement 32). p. 324-330. en 161 (nog niet opgenomen).

186. Artikel 3 jo. 19 lid 5, Constitution ILO, 28-06-1919, laatstelijk gewijzigd 1 november 1974, Trb. 1975. Zie hierover ook E. Osieke, Constitutional Law and Practice in the International Labour Organisation, Dordrecht/Boston /Lancaster, 1985, p. 26-28, p. 152.

187. Zaak 136/79, Jur. 1980 p. 2033 (National Panasonic), zie colk paragraaf II.5.1.

188. List of ratifications of Conventions (as at 31 December 1987), International Labour Office, Geneva 1988.

189. Zie Commissie van de Europese Gemeenschappen, Sociaal Europa, (Speciaal nummer : De sociale dimensie van de interne markt), Luxemburg 1988, p. 107. 
niet stellen dat -indien de gemeenschap als geheel niet kan toetreden tot de verdragen, en de lid-staten dit zelf niet doen- deze conventies deel uitmaken van de in de lid-staten erkende waarborgen, die zonder meer toepasbaar zijn (190).

Een ander in dit verband interessant document is de hierboven genoemde Tripartite Declaration of Principles concerning Multinational Enterprises and Social Policy 1977 van de ILO. Deze verklaring wordt in de adviezen omtrent het communautaire handvest niet genoemd. Dit is niet zo verbazingwekkend want de declaratie heeft binnen de ILO niet dezelfde status alls een Verdrag of een Aanbeveling. Declaraties zijn slechts een afspiegeling van het beleid dat de ILO voert, maar hebben voor het overige weinig waarde. De doelstelling van de declaratie is een bijdrage te leveren aan het beleid van de ILO-leden ten aanzien van regulering met betrekking tot multinationals. Met betrekking tot veiligheid- en gezondheidsbeleid van deze ondernemingen stelt de declaratie dat multinationals samen zouden moeten werken met de werknemersvertegenwoordigers en dat met name informatie van de top verstrekt zou moeten worden aan vertegenwoordigers van de lokale ondernemingen. Waar dat mogelijk is zouden afspraken omtrent veiligheids- en gezondheidsaangelegenheden moeten worden geïncorporeerd in collectieve overeenkomsten (191).

Aan het Gemeenschapshandvest van Sociale Grondrechten zullen werknemers met betrekking tot de medezeggenschapsbepalingen van de vigerende richtlijnen geen rechten kunnen ontlenen (192). De meeste lid-staten menen dat het Handvest niet ver genoeg gaat (uitgezonderd Groot Brittannië dat tegen stemde omdat zij het te ver vond gaan) (193). De West-Duitse minister van sociale zaken meende bij aanvaarding van de Conclusies omtrent het Handvest in juni 1989 al dat hij : "meer zou hebben aan 10 centimeter concrete voorstellen dan aan meters plechtige verklaringen" (194). Het Handvest bestaat (zelfs als het een betere status binnen het gemeenschapsrecht krijgt dan nu het geval is (195)) uit instructienormen bestaan die op zichzelf geen automatische rechtsgevolgen met zich mee brengen (196). Voor wat medezeggenschap inzake veiligheids- en gezondheidsaangelegenheden betreft is het dan ook veiliger een oplossing te zoeken in nog te maken richtlijnen die meteen toepasbaar kunnen worden.

190. Zie over de toepasselijkheid van ILO-conventies in het gemeenschapsrecht ook L. Betten, Het Community Charter inzake fundamentele sociale rechten: een verwarrende Sinterklaas-surprise, NJCM 15-1 (1990), p. 12.

191. Declaration of Principles concerning Multinational Enterprises and Social Policy 1977, in International Encyclopedia for Labour Law and Industrial Relations, (Codex), Deventer 1985, (supplement 57), p. 702 .

192. Ook L. Betten, a.w. (noot 190), p. 12-13.

193. Zie paragraaf II.2.4...

194. Zie NRC-Handelsblad 13 juni 1989 , p. 16.

195. Zie paragraaf II.S.2.

196. Vergelijk de formulering uit artikel 117, waar het Hof in de zaak Gimenez Zaera, ook niet zonder meer rechtsgevolgen aan toekende (zaak 126/86, Jur. 1987, p. 3697-3718). 
Een oplossing voor het probleem kan zijn de definitie van het begrip onderneming in een te maken richtlijn zo te formuleren dat ook concerns daaronder begrepen kunnen worden. Dit zou voor het voorstel voor de raamrichtlijn dat hierboven besproken is overigens niet veel uitmaken. De informatieverstrekking door de top aan de werknemersvertegenwoordigers zou door zo'n ruime definiëring verplicht worden; de nationale procedures zouden op het afdwingen van die informatie van toepassing zijn, doordat bepalingen daaromtrent in richtlijn ontbreken. Concerns zouden acties bij de rechter of arbiter kunnen ontwijken door de top in die lid-staten te vestigen waar procedures daaromtrent zwak zijn, of buitengewoon lang duren. Bovendien blijft in het voorstel de medezeggenschap gebonden aan de nationale wetgeving of praktijk, en dus grensgebonden. Veel mér dan de Vredelingmethode zal men dus met een dergelijke uitbreiding niet bereiken, eerder minder.

Jacobs lanceert het idee om een richtlijn tot stand te brengen die multinationale ondernemingen zou verplichten bij de top van concerns een Eurocomité voor arbeidsveiligheidszaken te installeren (197). De concerndirectie zou direct met dit comité moeten onderhandelen over alle zaken die het arbeidsmilieu betreffen. Volgens Jacobs zou een dergelijke richtlijn niet alleen de rek van artikel 118A testen, maar ook een belangrijke stoot geven aan de totstandkoming van bovennationale zeggenschap, die zich op den duur van medezeggenschap over het arbeidsmilieu zou kunnen uitbreiden naar gebieden als lonen, winsten en sociale zekerheid (198).

Hoewel dit laatste mij niet zomaar zou lijken te gebeuren -werkgevers zouden een dergelijke uitbreiding van de competentie van zo'n Eurocomité te vuur, te zwaard en vooral voor de rechter bestrijden- is het idee van het Eurocomité op zichzelf een goede start. De vraag is alleen of daarvoor een aparte richtlijn nodig is. Om te beginnen kan een dergelijk Comitế op basis van een Collectieve Overeenkomst tot stand komen. Volgens Jacobs is via deze weg een Euro-ondernemingsraad, die veel meer beleidsterreinen tot zijn bevoegdheid zou kunnen rekenen mogelijk (199).

Daübler (200) ziet deze mogelijkheid ook, maar constateert dat er bij de uitvoering nog onopgeloste problemen zi.jn. Zo is daar om te beginnen de competentieverdeling tussen Euro-ondernemingsraad en gewone Concernondernemingsraden in die landen waar reeds wettelijk geïnstitutionaliseerde medezeggenschap bestaat. Daarnaast moet het probleem opgelost worden van die landen die meer dan één vakbeweging hebben, zeker als deze ook nog ideologisch van elkaar verschillen. Voorts blijft een moeilijkheid, zoals

197. A.T J.M. Jacobs, a.w. (noot 50), p. 839.

198. Zie ook B. Bercusson, a.w. (noot 7), p. 96.

199. A.T.J.M. Jacobs, Arbeitnehmervertretungen und ihre Möglichkeiten internationaler Zusammenarbeit nach niederländischem Recht, Arbeitsrecht im Betrieb 1989, p. 32.

200. W. Daübler, Gemeinschaftsrecht und grenzüberschreitende Interessenvertretung, Arbeitsrecht im Betrieb, 1989, p. 47-48. 
ook in hoofdstuk II gesignaleerd werd, dat een een juridisch kader op bovennationaal niveau ontbreekt.

Deze problemen zouden al minder groot zijn wanneer op Europees niveau een regeling voor een Eurocomité voor veiligheids- en gezondheidszaken zou worden overeengekomen. Op een dergelijk specifiek gebied spelen de verschillende ideologieën een minder grote rol, en bovendien kan dan veel gemakkelijker gebruik worden gemaakt van de competenties die in de meeste lid-staten al bestaan. De vraag is echter of ondernemers zo lang zij niet door de economische situatie gedwongen worden, bereid zijn op hoger niveau te contracteren. Enkele Franse ondernemingen zijn daartoe inmiddels overgegaan (201). In Nederland, waar op zichzelf die mogelijkheid ook zou bestaan wordt daar echter zelden gebruik van gemaakt (202).

Ook indien internationale Collectieve Overeenkomsten niet direct tot de mogelijkheden behoren is een aparte richtlijn voor een vorming van een Eurocomité inzake arbeidsveiligheid niet direct nodig. Een richtlijn die medezeggenschap in de vorm van onderhandeling, instemming of medebeslissingsrecht voorschrijft en deze uitbreidt tot zowel ondernemingen als concerns op alle niveaus, waarbij uitdrukkelijk in vertegenwoordiging vanuit ondernemingen die in een andere lid-staat gevestigd zijn dan de hoofdzetel wan het concern, zou al in de medezeggenschap voorzien.

Een richtlijn moet deze vorm van medezeggenschap uitdrukkelijk uitbreiden tot multinationals; de invulling van de medezeggenschap kan dan aan de lid-staten voorbehouden blijven, met dien verstande dat de mogelijkheden daartoe voor alle werknemers gewaarborgd blijven. De vorming van een apart comité dat onderling de eisen en verlangens afstemt en op den duur tot het door Jacobs gewenste comité evolueert, kan aan de vrijwilligheid van de vertegenwoordligers overgelaten worden. De kans dat zo'n comité op den duur gevormd wordt lijkt mij vanuit praktische overwegingen gezien reëel (203). De rek van artikel $118 \mathrm{~A}$ hoeft dan niet uitdrukkelijk getest te worden, hetgeen de politieke haalbaarheid van het idee wel eens zou kunnen vergroten.

201. Waaronder de onderneming Thomson-Grand Public, een staatsonderneming die op basis wan collectieve overeenkomt een Europese Ondernemingsraad samengesteld uit 26 gekozen werknemers-vertegenwoordligers uit vijf landen heeft geinstalleerd. Zie woorts M. Le Friant, Interessenvertretung in Multinationalen Unternehmen nach fransösischen recht, Arbeitsrecht im Betrieb, 1989, p. 35.

202. Multinationale ondernemingen met zetels in Nederland (waaronder Philips, Shell, Unilever en Akzo) zijn tot dusver slechts met mondjesmaat bereid geweest onderhandelingen te woeren op Europees niveau (zie o.m. J. Bloemarts, Het EVV over medezeggenschap in Europa, voordracht op de studiedag medezeggenschap in Europa, georganiseerd door het Nederlands Studiecentrum, 10 maart 1989, p. 19-20, en De FNV en Europa 1992, uitgave van de FNV, Amsterdam 1988 p. 19); A.T.J.M. Jacobs, a.w. (noot 199), p. 32.

203. Men vergelijke de ontwikkeling in Italie waar vakbondsvertegenwoordigers juist in verband met arbeidsomstandigheden zich verenigden tot consigli di fabbrica om meer te bereiken bij de ondernemer. 
Het beleid op het gebied bescherming tegen bedreigingen van veiligheid en gezondheid van werknemers is, voor wat betreft de regulering daarvan potentieel het meest ontwikkeld. De aparte rechtsgrondslag van artikel 118A biedt meer mogelijkheden tot communautaire wetgeving dan bepalingen als artikel 117,118 , en 118B die het vooral van coördinatie tussen de lid-staten en de nog niet aanwezige goodwill c.q. macht van de sociale partners moeten hebben (204).

De politieke haalbaarheid voor regulering op basis van artikel 118 A is vergroot door de besluitvormingsprocedure die in het artikel gegeven is, waarbij met gekwalificeerde meerderheid besluiten genomen kunnen worden. Deze vereenvoudigde procedure lost echter niet alles op: indien een besluit op tegenstemmers stuit is de kans aanwezig dat deze de grondslag van het genomen besluit zullen betwisten. De terminologie van artikel 118A, met name de termen arbeidsmilieu en minimumnormen zal daarbij het doel zijn waarop de pijlen gericht worden. De interpretatie van deze termen is in dit verband van bijzonder belang. Indien deze termen restrictief worden geïnterpreteerd zal weinig regulering buiten technische normering mogelijk worden.

Het is dus van belang deze termen ruim te nemen zodat medezeggenschap van werknemers als minimumvoorwaarde voor een veiligheids- en gezondheidsbeleid binnen de gemeenschap geaccepteerd wordt. Dat de lid-staten medezeggenschap als voorwaarde zien kan afgeleid worden uit de wetgeving van de verschillende leden. Het zou mijns inziens niet aangaan, als zij zich in de Raad ten opzichte van Europese regulering een andere mening zouden aanmeten. Daarbij moet natuurlijk wel gewezen worden op het feit dat een aantal van de wettelijke regels in de lid-staten ouder is, en gemaakt is onder regeringen van een andere signatuur dan die die er nu zitten. De Franse wetgeving komt uit de beginperiode van het presidentschap van Mitterrand, toen hij een socialistische regering naast zich had. De Britse HSWA 1974 is een produkt van Labour, het is nog maar de vraag of de huidige conservatieve regering op die basis van mening is dat daaraan enige grond voor verlangen naar Europese regulering mag worden ontleend. Anderzijds: de HSWA 1974 is ook na ruim tien jaar conservatief bewind nog intact.

De Gemeenschap heeft inmiddels de eerste stappen naar wetgeving door middel van richtlijnen op basis van artikel $118 \mathrm{~A}$ gezet. De wens van de Commissie en ook het Europees parlement is dat artikel 118A in elk geval zo ruim uitgelegd moet worden dat het meer omvat dan het enkele

204. De structuur van de vakbonden op Europees niveau, met name die van de ETUC (een confederatic), laat nauwelijks toe dat deze effectief kan onderhandelen met de werkgewers op het bovennationale niveau, laat staan dat zij de macht heeft die onderhandelingen af te dwingen, zie A.T.J.M. Jacobs, a.w. (noot 50), p. 839. 
opstellen van absolute veiligheidsnormen. Medezeggenschap inzake veiligheids- en gezondheidsaangelegenheden behoort volgens de recent tot standgekomen richtlijn tot de minimumvoorwaarden van wetgeving. Echter die medezeggenschap heeft vooral een beperkt karakter, en biedt niet meer dan rechten op informatie, consultatie, overleg, en toezicht. Op basis van de richtlijn krijgen de werknemers(vertegenwoordigers) geen directe invloed op de besluiten, zodat de richtlijn geen echt fundamentele veranderingen brengt. In Europees gesanctioneerde instemmings- en onderhandelingsrechten, mede op het niveau van multinationale concerns, waardoor op alle niveaus de verlangde inspraak kan worden verkregen, wordt door de richtlijn al helemaal niet voorzien.

En toch lijken zowel de meerderheid van de lid-staten als van de instellingen van de Gemeenschap van mening dat multinationale medezeggenschap er wel moet komen. De tekst omtrent het Gemeenschapshandvest voor sociale grondrechten en de adviezen van het Economisch en Sociaal Comité laten daarover geen misverstand bestaan. Of het Gemeenschapshandvest in dit verband iets kan gaan betekenen is nog maar de vraag. Zelfs als het Handvest uiteindelijk meer wordt dan intentieverklaring en proefballon (de laatste kwalificatie komt van Jacobs (205)), dan nog moeten de bepalingen concreet worden ingevuld. En toegegeven, die invulling kon nog well eens problemen geven.

Mijns inziens is de Commissie in 1988 met haar eerste voorstel al te voorzichtig geweest. $\mathrm{Zij}$ heeft, door het niet voorzien in instemmings- of onderhandelingsrechten en het niet stellen van eisen aan de sanctionering van de geboden rechten, te weinig mogelijkheden geboden voor de werkelijke ontwikkeling van Europese medezeggenschapsrechten inzake veiligheids- en gezondheidsaangelegenheden. Voorzichtige voorstellen verworden in de Gemeenschap in het algemeen tot nog voorzichter richtlijnen.

Het rechtsvergelijkend deel van dit onderzoek laat zien dat de Gemeenschap verder had kunnen gaan met haar eisen waar het het instrumentarium voor de werknemersvertegenwoordigers betreft: participatie had kunnen worden opgenomen in het voorstel, evenals een sanctieregeling. Daarnaast had de Commissie mijns inziens bij haar voorstel een duidelijke eerste poging kunnen wagen om een medezeggenschapsregeling bij multinationale concerns door middel van deze regeling te bewerkstelligen. Misschien had het voorstel het dan wel niet gehaald in de Raad; het was desalniettemin de moeite waard geweest om het te proberen. Anderzijds: misschien is de (impliciete) optie van Jacobs zo gek nog niet en is het zinvol om, nu deze richtlijn is aangenomen, het in een aparte richtlijn nog eens te proberen.

205. A.T.J.M. Jacobs, a.w. (noot 50), p. 836 . 
Hoewel veel op de richtlijn aan te merken is, kan men de Gemeenschap niet verwijten geen aandacht te hebben geschonken aan de positie van de individuele werknemer. De ruime definitie van het begrip werknemer, de bepalingen ten gunste van ingeleende arbeidskrachten (zelfs in de afgezwakte vorm waarin zij in de richtlijn zijn opgenomen) en de rechten voor werknemers bij situaties met dreigend en ernstig gevaar, gaan relatief ver. Het zijn deze rechten die mogelijk ook het meest inroepbaar zijn (met name het recht op informatie voor inleenkrachten), wanneer de nationale wet in gebreke blijft. "Inroepbaarheid" al dan niet in de zin van rechtstreeks werking kan veel aan de effectiviteit van de richtlijnbepalingen in de lidstaat zelf bijdragen. Dit geldt temeer omdat individuele werknemers zich veelal tot een rechter wenden in plaats van een arbiter. Deze is bevoegd tot het stellen van prejudiciële vragen. In het geval wanneer het gaat om het collectief afdwingen van of verzoeken tot geschillenoplossing omtrent medezeggenschapsrechten kan dit laatste problemen geven.

De nieuwe raamrichtlijn is te veel blijven hangen aan de regelingen in de lid-staten waar dit niet nodig is. Een regeling gebaseerd op de rechten die in de lid-staten bestaan waarbij meer recht zou zijn gedaan aan enerzijds de in die landen bereikte rechten (al dan niet in wetgeving), en anderzijds aan de multinationale dimensie waar de gemeenschap steeds meer mee te maken krijgt had tot de mogelijkheden behoord. In het volgende hoofdstuk zal ik het voorstel presenteren zoals het er gezien de rechten in de lidstaten, mijns inziens uit moet zien. 



\section{Conclusies}

$1 \quad$ Inleiding

Uit de voorgaande hoofdstukken is gebleken op welke wijze de Gemeenschap haar sociale politiek in het algemeen en de medezeggenschap van werknemers in het bijzonder heeft vormgegeven, of heeft gepoogd vorm te geven. Tot dusver zijn de resultaten hiervan als teleurstellend te kwalificeren.

In dit hoofdstuk zullen op basis van het hierboven weergegeven onderzoek conclusies getrokken worden ten aanzien van het beleid met betrekking tot de communautaire regelingen waarin medezeggenschap inzake veiligheid en gezondheid voorzien wordt.

Daarnaast zal op basis van deze conclusies een voorstel worden geformuleerd voor een richtlijn inzake medezeggenschap.

Voordat deze tekst zal worden geformuleerd zal ik echter enige (relativerende) opmerkingen maken over de effectiviteit van richtlijnen.

\section{De effectiviteit van richtlijnen}

Effectiviteit van richtlijnen is, ook al moeten richtlijnen zelf beschouwd worden als wetgeving, niet hetzelfde als effectiviteit van wetten. Over de definitie van effectiviteit van wetgeving verschillen de meningen trouwens ook nogal (1). Ik zou mij voor wat betreft dit proefschrift willen aansluiten bij de zeer praktissche definitie die Geers gebruikt en effectiviteit willen definiëren als de mate waarin het doel en uitgangspunten van de wet door de inhoud van de wet zelf kunnen worden bereikt (2). Daarmee is overigens niet alles gezegd, omdat een wet voor verschillende actoren op verschillende wijze effectief kan zijn.

1. Zie onder meer de definities van Griffiths in Is Law Important, Deventer 1978, (oratie, Groningen) en Blankenburg in Warum es so schwierig ist, die Wirksamkeit der Gesetzen zu erforschen, Vortrag anlasslich der Auflosung der Sozial-wissenschaftliche Forschungsgruppe an Max-Planckinstitut für auschlandisches und international Privatrecht, Hamburg, 30-2-1982, die onderling wel enige verschillen vertonen.

2. A.J.C.M. Geers, Recht en humanisering van de arbeid, Deventer 1988 , p. 350. 
Of een wet uiteindelijk het doel dient waarvoor zij gemaakt is, is bepaald niet alleen afhankelijk van het enkel opleggen van de in de wet voorgeschreven verplichtingen. Juridische factoren als handhavingsmogelijkheden en duidelijkheid van de wetstekst zijn een eerste vereiste om een zekere mate van effectiviteit te bereiken. Daarnaast spelen echter sociologische factoren als acceptabiliteit en bereidheid tot gehoorzaamheid een grote rol (3).

Voor de effectiviteit van richtlijnen ligt de zaak iets anders. Richtlijnen richten zich tot de lid-staten en leggen uitsluitend de lid-staten verplichtingen op (4). Het bereiken van doel en uitgangspunten van richtlijnen vereist om te beginnen uitvoeringswetgeving van de lid-staten. Formeel kan men stellen dat een richtlijn als effectief kan worden beschouwd wanneer de lidstaten voldoen aan de in de richtlijn gegeven verplichtingen, en hun wetgeving overeenkomstig de in de richtlijn gegeven resultaten aanpassen.

Met die formele effectiviteit van de drie "grote" arbeidsrechtelijke richtlijnen, nl, de richtlijnen ter bescherming van werknemers bij collectief ontslag, overgang van ondernemingen en insolventie van de werkgever is het niet zo slecht gesteld. De eerste richtlijn is niet op voldoende wijze door Italië uitgevoerd (5). Met betrekking tot de uitvoering van de richtlijn bij overgang van ondernemingen loopt op dit moment een procedure tegen Griekenland en deze is eveneens in Italië niet goed uitgewoerd (6) en met betrekking tot de richtlijn ter bescherming tegen insolventie van de werkgever loopt tegen deze beide landen een procedure. De andere landen hebben de richtlijn volgens de Commissie in elk geval wel op correcte wijze uitgevoerd (7).

Een dergelijke formele opvatting van effectiviteit van richtlijnen kan echter als niet beoogd gevolg hebben dat hoewel de lid-staat voorziet in de noodzakelijke wetgeving, deze zelf niet effectief is. Dit gevolg doet zich,

3. Hierover is het nodige geschreven, ik verwijs onder meer naar C.J.M. Schuyt, Rechtvaardigheid en effectiviteit in de verdeling van de levenskansen, een rechtssociologische beschouwing, Nijmegen 1973, oratie; A.A.G. Peters, Recht als Project, AA 28(1979), p. 245(881)-256(893), E. Blankenberg, a.w. (noot 1), M.V.C. Aalders, Industrie, milien en wetgeving Hinderwet tussen symboliek en effectiviteil, Amsterdam 1980 en de klassieke studie van V. Aubert, Enkele sociale functies van wetgeving, Proeven van rechtssociologie, Universitaire Pers Rotterdam 1971, p. 44-74, over de werking van de Wet op het Huishoudelijk Personeel in Noorwegen.

4. Zie zaak $152 / 84$, Jur. 1986 , p. $723-751$, (Marshall) en zaak $80 / 86$, Jur. 1987 , p. p. 3969 3988 (Kolpinghuis).

5. Zaak $91 / 81$ Jurr. 1982 , p. $2133 \mathrm{ew}$. (Commissie vs Italië).

6. Zaak 235/84, Jur. 1986, p. 2291 ev (Commissie vs Italië). Volgens Kardaras is de richtlijn in het Griekse recht overigems well uitgevoerd, zie A. Kardaras, Der Einfluss des Europarechts af das Griechische Arbeitsrecht, FIDE reports Vol.2, Thessalioniki 1988, p. 123-124.

7. Commissie van de Europese Gemeenschappen, Saciaal Europa, de sociale dimensie van de interne markt, Luxemburg 1988, p. 104. In Italië is inmiddels een wetsvoorstel ter implementatie van de drie richtlijnen ingediend. 
ondanks het feit dat noch het EEG-verdrag, noch het Hof een dergelijke opvatting ten volle hanteert wel degelijk voor. Nederland voldeed met zijn Wet Gelijk Loon voor mannen en vrouwen (8) aan richtlijn $75 / 117$, maar had om de naleving in een concreet geval te verwezenlijken een dermate ingewikkelde procedure in het leven geroepen, dat de effectiviteit van de wet nog wel wat te wensen overliet. Handhaving door een individuele werknemer gaf betrekkelijk grote problemen (9). Als men aanneemt dat een goed handhavingsmechanisme voorwaarde is voor de effectiviteit van de wet, kan gesteld worden dat het mede aan het ontbreken van dat mechanisme lag dat het doel van de wet (dat hetzelfde was als het doel van de richtlijn) niet volledig werd bereikt (10).

Kortom de effectiviteit van richtlijnen is een materieel gegeven. Niet alleen het aanpassen van de wetgeving aan de in richtlijn voorgeschreven tekst door de lid-staten is noodzakelijk, maar een zodanige aanpassing dat de nationale wet het doel van de richtlijn inderdaad bereikt. Dit stelt om te beginnen eisen aan de formulering van de richtlijn zelf. Hoe duidelijker en scherper de richtlijn het te bereiken resultaat omschrijft, hoe beter de lidstaten hun wetgeving conform de richtlijn kunnen aanpassen. Maar tegelijkertijd levert een duidelijke omschrijving een inperking van het te bereiken resultaat op, die ook een inperking van de ruimte van de lidstaten betekent hun wetgeving in te passen in het nationale systeem. Dit kan leiden tot wetgeving, die zodanig afwijkt van tradities op een bepaald terrein, dat de wet een ongebruikt buitenbeentje in het nationale stelsel wordt. Een al te gedetailleerd omschreven resultaat kan aldus de nationale wet weer ineffectief maken.

De wijze van formuleren van de richtlijn en de duidelijkheid die de richtlijn biedt, zijn dus basisvoorwaarden voor een grotere effectiviteit van de richtlijn. Echter dan nog geldt voor een richtlijn altijd dat er een getrapt systeem is om die effectiviteit te bereiken. Pas als de nationale wet aan de voorwaarden voor effectiviteit (voor zover deze al zijn te determineren) voldoet (men kan hierbij denken aan de lijst die Schuijt in zijn oratie biedt (11)), valt te bekijken of hetgeen de wet bereikt, gelijk is aan datgene wat met de richtlijn beoogd werd. Dat bekijken kàn gebeuren door middel van juridische toetsing: valt hetgeen dat de wet bereikt binnen het kader van de richtlijn. Is dit niet het geval, dan is de vraag of dat aan de wet zelf (m.a.w. is er sprake van strijdigheid met de richtlijn) ligt, of aan andere factoren. Wanneer geconstateerd wordt dat het aan andere factoren ligt,

8. Wet van 20 maart 1975, Stb. 129, laatstelijk gewijzigd bij de Wet van 1 maart 1980 , Stb. 86.

9. Zie o.m. T. van Vleuten, Zullen wij handhaven, Nemesis 1987, p 238-247.

10. Report on the implementation of the New Community Action Program on the Promotion. of Equal Opportunities for Women, 1982-1985, p. 31, Zie ook P.F. van der Heijden, Teruggeroepen naar de fabrick wegens defecten, NJCM-bulletin p. 340-346; J.J. Schippers, Beloningsdiscriminatie ten nadele van vrouwen: feiten en meetproblemen, in Beloningsdis'criminatie tegen vrouwen: normen, feiten, beleid, Utrecht 1988, p. 73-74.

11. . CJ.M. Schuijt, oratie a.w. (noot 3). 
dan zal het van het karakter van die factoren afhangen of er via het recht, iets aan de situatie veranderd kan worden.

De mogelijkheden voor een materiële toetsing van een wet aan een richtlijn in het concrete geval, is wederom afhankelijk van de formuleringen in de richtlijn. Hoe meer een richtlijn voldoet aan de criteria die daarvoor door het Hof geformuleerd zijn voor inroepbaarheid door de burger (12) (nauwkeurigheid, duidelijkheid, onvoorwaardelijkheid en een in elk geval duidelijk afgebakende beleidsmarge voor de lid-staat (13)) hoe beter er getoetst kan worden. Veel richtlijnbepalingen voldoen echter niet aan de criteria die gehanteerd worden voor inroepbaarheid. Is dit niet het geval dan wordt het al veel moeilijker de wet te toetsen aan de richtlijn.

De mogelijkheden om een toetsing te doen plaatsvinden zijn in het EGverdrag, vergeleken bij andere verdragen, groot door de prejudiciële procedure van artikel 177 . Effectuering van richtlijnen kan daardoor geschieden op instigatie van de burger. Om dit te kunnen doen, heeft die burger in elk geval een mationale rechtsgang nodig die de mogelijkheid biedt de bepaling in te roepen. De Commissie kan via de procedure die gegeven is in artikel 169 EEG-verdrag, een uitspraak van het Hof uitlokken en op deze wijze controle uitoefenen; de mogelijkheid voor diegenen voor wie de richtlijn (c.q. nationale wet) effectief moet zijn, is afhankelijk van een toegang tot een instantie via welke hij zelfstandig een uitspraak uit kan lokken. Daarvoor is toegang tot de rechter nodig, of tot een arbitragecollege dat aan de criteria van het Hof voldoet om prejudiciële vragen te kunnen stellen (14).

Het Hof heeft in de zaak Johnston vs Royal Ulster Constabulary (15) uitgemaakt dat het lid-staten niet zonder meer vrijstaat in een bepaald geval geen rechtsgang te openen, wanneer een richtlijn voorschrijft dat een dergelijke rechtsgang aanwezig moet zijn. In deze zaak, die ging om de weigering een nieuwe voltijdsbetrekking aan te bieden aan mevrouw Johnston -een weigering die volgens haar discriminatoir (op grond van sexe) was- deed de Chief Constable een beroep op een bepaling (art. 53 lid 1) in de Sex Discrimination Order. In dit artikel werd gesteld dat geen enkele van de in deze Order vórkomende bepalingen die discriminatie verbieden, de onwettigheid tot gevolg kan hebben van handelingen strekkende tot vrijwaring van de staatsveiligheid of tot bescherming van de openbare veiligheid of de openbare orde. Het tweede lid van dit artikel zegt dat een door of namens de minister ondertekend certificaat, inhoudende dat een

12. Zaak 41/74, Jur. 1974, p. 1331 (Van Duyn); zaak 8/81, Jur. 1982 p. 52 (Becker), Zaak $71 / 85$ Jur. 1986, p. 3855 (FNV vs Staat der Nederlanden), Zaak 152/84, Jur 1986, p. 723 751 (Marshall).

13. Zie P.J.G. Kapteyn en P. VerLoren van Themaat, Inleiding tot het recht van de Europese gemeenschappen, Deventer 1987, p. 237.

14. Zie para. VI.2.2.

15. Zaak 222/84, Jur. 1986, p. 1651-1694 (Marguerite Johnston vs Royal Ulster Constabulary). 
aldaar beschreven handeling tot een van de in lid 1 genoemde doelstelling strekt, het onweerlegbare bewijs vormt dat die handeling daartoe strekt. In dit geval was de Chief Constable in het bezit van zo'n certificaat dat verklaarde dat de weigering van een nieuwe voltijdsbetrekking aan mevrouw Johnston strekte tot de vrijwaring van de staatsveiligheid en de openbare orde. Kortom de mogelijkheid om haar rechten voor het gerecht te doen gelden, zoals richtlijn 76/207 voorschrijft was er slechts nog op papier; het onweerlegbare bewijs van de niet onwettigheid van de handeling van de Chief Constable was immers al gelleverd.

Het Hof grondde zijn beslissing op dit punt naast artikel 6 van de richtlijn op algemene rechtsbeginselen zoals vastgelegd in artikel 6 en 13 ECRM. Het Hof stelde dat indien artikel 6 van de richtlijn in het licht van deze algemene rechtsbeginselen wordt geïnterpreteerd, dit artikel niet anders kan betekenen dat dat een ieder het recht heeft om bij de bevoegde instanties een beroep in te stellen tegen handelingen waarvan hij/zij meent dat deze een inbreuk maken op het in richtlijn 76/206 neergelegde beginsel van gelijke behandeling. De lid-staten zijn verplicht een daadwerkelijke rechterlijk controle te verzekeren met betrekking tot de toepasselijke bepalingen van gemeenschapsrecht en van de nationale uitvoeringswetgeving. Een bepaling als artikel 53 van de Sex Discrimination Order die de bevoegde autoriteit in staat stelt de particulier deze mogelijkheid te ontnemen is derhalve in strijd met artikel 6 van de richtlijn.

Voor de mogelijkheid een beroep te doen op bepalingen van een richtlijn is het, met andere woorden, nodig dat de richtlijn zelf voorziet in een bepaling die de lid-staten de verplichting oplegt maatregelen te nemen dat justiciabelen hun rechten onder de richtlijn geldend kunnen maken bij een rechterlijke (of een onder de criteria van het Hof te accepteren arbitrage) instantie. Voorziet de richtlijn daarin, dan kan de lid-staat niet zonder meer die rechtsgang aan de justitiabele ontnemen. Voor de mogelijkheid tot effectiviteit van de richtlijn in het concrete geval is het dus wel zaak dat een dergelijke bepaling opgenomen wordt.

Dit geldt, mijns inziens, met name voor een richtlijn die medezeggenschapsregelingen betreft. Waar voor andere door gemeenschapsrecht gereguleerde zaken meestal op nationaal niveau wel een beroep op een rechterlijke instantie openstaat, is dat op het gebied van de collectieve arbeidsverhoudingen op ondernemingsniveau niet altijd het geval. We hebben al eerder gezien dat mogelijk niet alle arbitrage-instanties in de lid-staten, volgens de criteria die het Hof nu hanteert, gekwalificeerd hoeven te zijn prejudiciële vragen te stellen. Het is aan de gemeenschap te zorgen dat de lid-staten verplicht worden, te zorgen dat -al dan niet door middel van vrijwillige regelingen van de sociale partners- de mogelijkheid rechten geldend te maken en dus een beroep op een richtlijn te doen aanwezig is.

Gaat het hier om het effectief maken communautaire regelgeving op het concrete niveau, namelijk voor de rechtszoekenden, er zijn meer voorwaar- 
den voor effectiviteit van de op de richtlijnen gebaseerde regelgeving en daarmee voor de richtlijnen zelf. Wetgeving moet naast bovengenoemde factoren binnen het systeem van arbeidsverhoudingen passen, om überhaupt -en dat geldt zowel voor werkgevers als voor werknemers (en vakbonden)te kunnen aanslaan. Het lijkt in elk geval niet aan te raden om een geheel eigen soort van systematiek te bieden voor een specifiek onderwerp als medezeggenschap inzake veiligheids- en gezondheidsaangelegenheden dat niet aansluit op de overige wijze van regulering (al dan niet wettelijk).

Een richtlijn die wil voorzien in medezeggenschapsbepalingen inzake veiligheids- en gezondheidsaangelegenheden zal enerzijds de lid-staten de ruimte moeten laten de vorm en middelen te kiezen die aansluiten bij de nationale tradities, culturen en systemen, en anderzijds een afdoende handhavingsmechanisme moeten bieden om de effectiviteit in het concrete geval te waarborgen, zo dat de uiteindelijke interpretatie van de bepalingen komt te liggen bij het Hof van Justitie. Dat een dergelijke richtlijn op basis van de wettelijke regelingen in de lid-staten tot de mogelijkheden behoort mag duidelijk zijn; dat de in de richtlijn gekozen oplossingen tot flexibele uitvoeringswetgeving moeten kunnen leiden eveneens. Waar de werknemers in elk geval niet mee gebaat zijn, is dat die noodzaak tot flexibiliteit leidt tot onduidelijkheid en dubbelzinnigheid in de formuleringen van de richtlijn.

Desalniettemin zal een dergelijke richtlijn in een aantal lid-staten, en vermoedelijk voor elk van de lid-staten tot op zekere hoogte, nieuwe elementen in de regelgeving aanbrengen. Op zichzelf hoeft dat niet tot onbruikbaarheid van een richtlijn te leiden, als de vorm en de middelen die de lid-staten kunnen kiezen maar dermate aan het nationale systeem gebonden kunnen zijn dat die nieuwe elementen absorbeerbaar blijken en niet als vreemde elementen in de lucht blijven hangen. In dat laatste geval lijkt de kans dat een communautaire regeling een dode letter wordt en dus elke kans op effectiviteit verliest levensgroot.

\section{Conclusies ten aanzien van de probleemstelling}

In hoofdstuk I werd als probleemstelling gegeven:

Is het wenselijk en mogelijk om, gezien het in de lid-staten bestaande instrumentarium voor beleidsbeïnvloeding in de onderneming inzake veiligheids- en gezondheidsaangelegenheden, op communautair niveau een regeling te maken die voorziet in mogelijkheden voor deelneming aan de besluitvorming op alle ondernemingsniveaus, waarbij de kans dat deze bruikbaar is voor alle werknemers groot is:

Om tot een conclusie te komen werden de volgende deelvragen beantwoord:

- Wat is de politiek van de Gemeenschap tot dusver op het gebied van medezeggenschap (zowel ten aanzien van regelingen die binnen de 
nationale grenzen werken, als voor multinationale ondernemingen) geweest?

- Wat voor soort vertegenwoordigingssystemen kennen de lid-staten, en welke positie neemt de individuele werknemer daarin in?

- Over welk instrumentarium beschikken zij in het algemeen en meer in het bijzonder op veiligheids- en gezondheidsgebied?

- Welk beleid volgt de gemeenschap op veiligheids- en gezondheidsgebied?

- Zou een gemeenschappelijke regeling inzake veiligheids- en gezondheidsaangelegenheden ook ook in medezeggenschap in multinationale ondernemingen kunnen voorzien?

Om te beginnen werd de basis bekeken waarop medezeggenschap inzake veiligheids- en gezondheidsaangelegenheden geregeld is. In praktisch alle lid-staten heeft deze een wettelijke basis, ook als de algemene medezeggenschap een vrijwillige basis heeft. Op dit punt zijn de verschillen tussen de lid-staten bijzonder klein.

Met betrekking tot het aan de werknemers toekomende instrumentarium werden de wetgeving en de praktijk in de lid-staten onderzocht. De onderzochte instrumenten waren: het recht op informatie, het recht geconsulteerd te worden, het instemmingsrecht en het recht te onderhandelen, het recht toezicht te houden, het recht de onderneming stil te leggen en de mogelijkheid de arbeidsinspectie (of andere bevoegde instanties) in te schakelen. Van deze instrumenten werd ook bekeken of en hoe effectief zij konden worden afgedwongen en in hoeverre werknemersvertegenwoordigers steun bij interne en externe deskundigen konden vinden bij het gebruik van het instrumentarium.

Ten aanzien van de karakterisering naar sterkte en zwakte van de instrumenten in de lid-staten kan gesteld worden dat er verschillen zijn, maar dat deze over het geheel genomen als gradueel zijn te karakteriseren. Alle werknemersvertegenwoordigers hebben informatierechten; daarvan is het Britse het zwakste, omdat daar een vrij vergaande bevoegdheid bestaat informatie aan de werknemersvertegenwoordigers te onthouden. Met betrekking tot consultatie, instemmingsrechten en onderhandelingen, kunnen de Duitse, de Luxemburgse en het Deense als het sterkste worden gekaraktiseerd. De Nederlandse regeling kan sedert de inperking van het instemmingsrecht bij de recente wetswijzinging niet meer tot de sterkste gerekend worden. In de als sterkste gekwalificeerde lid-staten bestaat een instemmingsrecht op het gebied van veiligheids- en gezondheidsaangelegenheden. Het (collectief) onderhandelingsrecht, zoals dit in andere landen bestaat, is zwakker, omdat dit de werkgever waar het om besluitworming gaat geen absolute verplichting oplegt met de werknemers tot overeenstemming te komen. Als er een plicht tot onderhandeling bestaat, versterkt dit het recht wel, echter dan nog kan de werkgever eenzijdig een besluit nemen als de onderhandelingen mislukken. Materieel maakt het recht op onderhandeling deelname in de besluitvorming echter wel mogelijk. 
Harmonisatie van het instrumentarium kan dan ook met in achtneming van de verschillen tussen de lid-staten een niveau hebben waarbij deelname aan de besluitvorming wordt voorgeschreven.

De grootste verschillen tussen de lid-staten zijn echter te vinden in de uitoefening van de medezeggenschap. Hierbij gaat het er vooral om of medezeggenschap voorbehouden is aan de vakbonden of dat deze er juist van losgemaakt is. In enkele lid-staten is medezeggenschap losgekoppeld van vakbondsprerogatieven, in andere landen bestaat er een meer of minder sterke koppeling, en weer andere is de medezeggenschap geheel voorbehouden aan de vakbonden. Deze verschillen zijn wel als essentieel te karakteriseren en laten zich mijns inziens dan ook niet op gemeenschapsniveau harmoniseren.

De positie van de individuele werknemer in de verschillende systemen is, voor waar het de beïnvloeding van het beleid aangaande veiligheids- en gezondheidsaangelegenheden betreft, zwak. Voor een verbetering van zijn positie zou een gemeenschappelijke regeling een aantal specifiek op de individuele werknemer gerichte beginselen in acht moeten nemen. Om te beginnen moet een gemeenschappelijke regeling gepaard gaan met vastgelegde (hoge) standaarden. Daarnaast moet een regeling een expliciet recht op informatie voor andere werknemers dan vertegenwoordigers inhouden, een klachtrecht bij de arbeidsinspectie welke de verplichting heeft te reageren en een recht het werk neer te leggen bij dreigend gevaar, waarbij de positie van de werknemer versterkt dient te worden door een omkering van de bewijslast.

Het gemeenschapsbeleid inzake medezeggenschap in het algemeen en in het bijzonder in multinationale ondernemingen is nauwelijks van de grond gekomen. Medezeggenschapsvoorschriften bij de algemene arbeidsrechtelijke richtlijnen zijn voor waar het consultatie- en participatierechten aangaat praktisch geheel gekoppeld aan de nationale systemen. Voor wat betreft medezeggenschap inzake veiligheids- en gezondheidsaangelegenheden gaat de raamrichtlijn uit 1989 iets verder door een recht op overleg voor te schrijven. Het antwoord op de vraag wie uiteindelijk de beslissende stem heeft, blijft echter afhankelijk van de nationale bepalingen hieromtrent. Medezeggenschap bij multinationale ondernemingen is tot dusver in pogingen tot regelgeving blijven steken.

Medezeggenschap op multinationaal niveau is ook door deze laatste richtlijn niet bereikt. Ook hier blijven vertegenwoordigers vooralsnog afhankelijk van nationale wettelijke regelingen, en de eventuele bereidheid van werkgevers op dit punt internationale Collectieve Overeenkomsten af te sluiten. Dit is mijns inziens een gemiste kans in de nieuwe raamrichtlijn.

Een richtlijn voor medezeggenschap bij veiligheids- en gezondheidsaangelegenheden, die veel verder gaat dan de bestaande richtlijnen, lijkt op basis van de wetgeving in de verschillende lid-staten tot de mogelijkheden te 
behoren. Zonder veel revolutionaire wijzigingen in de verschillende nationale wetten en praktijken aan te brengen zou een dergelijke richtlijn op communautair niveau tot stand kunnen worden gebracht, zolang een dergelijke richtlijn maar flexibel genoeg geformuleerd zou zijn, om recht te doen aan de tradities waarin en waarbinnen de nationale medezeggenschapsvormen zijn ontstaan en gegroeid. Dit is de conclusie die uit het voorgaande getrokken kan worden.

Een bepaald niet onbelangrijk aspect van een dergelijke richtlijn zou moeten zijn, dat zo'n richtlijn de mogelijkheid biedt medezeggenschap te creëren op multinationaal niveau. Daar waar de gemeenschap faciliteiten creëert voor ondernemingen om de meest gunstige vestigingsplaats te kiezen voor hun productie, op alle terreinen, heeft de gemeenschap eveneens de taak medezeggenschap van werknemers evenredig met de overige faciliteiten te bewerkstelligen.

Artikel 118A biedt de mogelijkheid een dergelijke richtlijn vast te stellen met gekwalificeerde meerderheid van stemmen. Dit heeft het grote voordeel dat de meest hardnekkige tegenstanders kunnen worden overstemd bij het passeren van zo'n richtijin. Dit behoort slechts tot de mogelijkheden als de ruime uitleg van termen als minimumvoorschriften en arbeidsmilieu geaccepteerd worden.

\section{Een voorstel voor een richtlijn}

In paragraaf VI.2.2, zijn de eisen geformuleerd waaraan een richtlijnvoorstel, en ook een richtlijn, op basis van de wetgeving in de verschillende lidstaten zou moeten en kunnen voldoen. Het nieuwe element dat in de volgende tekst te vinden zal zijn, is dat de regeling ook zal moeten gelden voor ondernemingen wier moeder zich in een andere lid-staten bevindt. Helemaal nieuw is dat uiteraard niet; het Vredeling voorstel was hierop gericht. Hier gaat het echter om daadwerkelijke medezeggenschap bij de top, zij het op het beperkte gebied van veiligheids- en gezondheidsaangelegenheden.

Het voorstel zoals hier geformuleerd heeft alleen betrekking op het medezeggenschapsdeel van de veiligheids- en gezondheidsregulering. Het $\mathrm{zou}_{\text {, }}$ in deze vorm uiteraard niet alleen moeten staan maar naast andere organisatorische bepalingen, die verplichtingen van werkgevers en werknemers, medische diensten, deskundigen in het algemeen regelen, zoals deze zijn voorzien in raamrichtlijn $89 / 391$ (16)

Het voorstel dat de Commissie bij de Raad zou indienen zou als volgt kunnen luiden.

16. $\mathrm{Pb} .1989, \mathrm{~L} 183$. 


\section{COMMISSIE}

Voorstel voor een richtlijn ter harmonisatie van de voorschriften op het gebied van inspraakregelingen inzake veiligheids- en gezondheidsaangelegenheden.

\section{DE RAAD VAN DE EUROPESE GEMEENSCHAPPEN,}

Gelet op het verdrag tot oprichting van de Europese Economische Gemeenschap, inzonderheid op artikel 118A,

Gelet op het voorstel van de Commissie, opgesteld na overleg met het Raadgevend Comite voor voor de veiligheid de hygiëne en de gezondheidsbescherming op de arbeidsplaats,

Gezien het advies van het Economisch en Sociaal Comité,

In samenwerking met het Europese Parlement,

Overwegende dat in artikel 118A van het Verdrag wordt bepaald dat de Raad verplicht door middel van richtlijnen minimumvoorschriften vaststelt om de verbetering van met name de arbeidsomgeving te bevorderen, ten einde de veiligheid en de gezondheid van de werknemers te beschermen;

Overwegende dat artikel 118A eveneens aanbeveelt geen administratieve, financiële en juridische verplichtingen op te leggen welke de ontwikkeling van kleine en middelgrote ondernemingen zou kunnen hinderen;

Overwegende dat de Mededeling van de Commissie (17) over haar programma inzake de veiligheid de hygiëne en de gezondheid op het werk voorziet in de vaststelling van richtlijnen, gericht op het waarborgen van de veiligheid van de werknemers;

Overwegende dat de resolutie van de Raad van 21 december 1987 (18) betreffende de veiligheid de hygiëne en gezondheid op het werk vaststelt dat de sociale partners in de ondernemingen overeenkomstig de nationale wetten en gebruiken betrokken zullen worden bij het concipiëren wan het arbeidsmilieu ter bescherming van de veiligheid en gezondheid van de werknemers en bij de tenuitvoerlegging van voorzieningen ter bescherming van de werknemers;

Overwegende dat volgens het Gemeenschapshandvest voor Sociale Grondrechten (19), tot de communautaire grondrechten rekent: de gepaste ontwikkeling van voorlichting, raadpleging en deelneming van de werkne-

17. COM (87) 420 def; Pb. 1988 C 28.

18. Resolutie van de Raad van 21 december 1987, Pb. 1988, C 28.

19. Zie ook N.J.C.M. Bulletin 1990, 15-1, p. 22-29. 
mers, met name in ondernemingen of groepen met vestigingen of bedrijven in verscheidene lid-staten van de Europese Gemeenschap.

Overwegende dat het de taak van de lid-staten is om op hun grondgebied te zorgen voor de veiligheid, de gezondheid van personen en, in het bijzonder, van de werknemers;

Overwegende dat het ter waarborging van de hoogst mogelijke graad van bescherming welke redelijkerwijs bereikt kan worden, nodig is dat de werknemers op de hoogte gesteld worden van de risico's voor hun veiligheid en gezondheid en van de maatregelen die genomen moeten worden om deze risico's te kunnen verminderen, en dat het nodig is dat zij, al dan niet door middel van hun vertegenwoordigers reële en daadwerkelijke invloed kunnen hebben op de vorming van het beleid te dier zake, en de uitvoering van dit beleid kunnen controleren;

Overwegende dat de mogelijkheden van beïnvloeding van ondernemingsbeleid door werknemers, al dan niet door middel van werknemersvertegenwoordigers in de lid-staten uiteenlopen;

Overwegende dat inspraak en medezeggenschapsprocedures de nationale grenzen niet overschrijden, en dit leidt tot verschillende mogelijkheden van beïnvloeding van het ondernemingsbeleid inzake veiligheids- en gezondheidsaangelegenteden van de werknemers binnen één ondernemingen, indien deze onderneming vestigingen heeft in meer dan éen lid-staat, en daardoor leidt tot dispariteiten in de behandeling van die werknemers;

\section{HEEFT DE VOLGENDE RICHTLIJN VASTGESTELD}

\section{Doel}

Artikel 1.

1. De onderhavige richtlijn heeft ten doel minimumvoorschriften vast te leggen voor de (mogelijkheden tot) beïnvloeding van het ondernemingsbeleid inzake veiligheids- en gezondheidsaangelegenheden, op alle niveaus van de onderneming. $\mathrm{Zij}$ omvat algemene principes wat betreft de voorlichting, de raadpleging en de inspraak van werknemers op ondernemingsniveau, alsmede algemene voorschriften ten aanzien van de handhaving daarvan.

2. De onderhavige richtlijn doet geen afbreuk aan de nationale en communautaire bepalingen welke op het moment van kracht worden bestaan en gunstiger zijn voor de bescherming van de veiligheid en gezondheid op de werkplek. 


\section{Definities}

\section{Artikel 2.}

In de zin van de onderhavige richtlijn wordt verstaan onder:

- arbeidsplaats

iedere plaats waartoe de werknemer in de onderneming of vestiging toegang heeft, dan wel waar de, door het leveren van prestaties, aan de onderneming verbonden werknemer zijn werk voor de onderneming uitvoert;

- werknemer:

ledereen die ten opzichte van de werkgever om het even welke prestatie levert met inbegrip van stagiaires en leerlingen;

- werknemersvertegenwoordigers voor veiligheids- en gezondheidskwesties: de persoon of personen, die volgens de in de lid-staten bestaande wetgevingen en/of praktijken als gevolmachtigde voor veiligheids- en gezondheidsbeschermingsproblemen gekozen zijn door de werknemers.

- onderneming:

tot de openbare of particuliere sector behorende eenheid, met één of meer vestigingen in éen of meer lid-staten, welke met name een industriële, landbouw, handels, administratieve, dienstverlenende, educatieve of culturele activiteit uitoefent.

- vestiging:

iedere al dan niet in dezelfde lid-staat gevestigde eenheid die geografisch is afgescheiden van, maar niet juridisch onafhankelijk van de onderneming waar zij deel van uitmaakt.

- werkgever:

de instelling of persoon die verantwoordelijk is voor de onderneming en/of de vestiging;

- de bevoegde instantie:

De overheidsinstantie met de taak toezicht uit te oefenen op de naleving van wettelijke bepalingen met betrekking het arbeidsmilieu en de bescherming van de veilligheid en de gezondheid van de werknemers.

Artikel 3.

De lid-staten nemen de noodzakelijke maatregelen om ervoor te zorgen dat dat de werkgevers, de werknemers, de werknemersvertegenwoordigers en de bevoegde instanties de voor de uitvoering van de onderhavige richtlijn noodzakelijke juridische verplichtingen in acht nemen. 
Werknemersvertegenwoordigers voor veiligheids- en en gezondheidskwesties.

\section{Artikel 4.}

1. In ondernemingen met meer dan 50 werknemers worden vertegenwoordigers voor veiligheids- en gezondheidskwesties gekozen uit de werknemers, volgens de in de lid-staten geldende wetgeving of praktijk.

2. Alle werknemers worden in de gelegenheid gesteld actief en/of passief aan deze verkiezingen deel te nemen.

3. Zijn in ondernemingen met minder dan 50 werknemers vertegenwoordigers voor veiligheids- en gezondheidskwesties aanwezig, dan gelden de bepalingen ten aanzien van hen dienovereenkomstig; zijn er geen vertegenwoordigers dan gelden de bepalingen van deze richtlijn voor de werknemers.

4. De vertegenwoordigers van de werknemers mogen geen nadeel ondervinden van hun activiteiten op het gebied van de bescherming van de veiligheid en gezondheid; de lid-staat neemt de nodige maatregelen de werknemersvertegenwoordigers te beschermen tegen ontslag, dat een reactie van de werkgever zou kunnen vormen op de activiteiten van de werknemersvertegenwoordigers.

5. De werkgever moet de werknemersvertegenwoordigers met behoud van loon de benodigde tijd vrijstellen en hen de nodige middelen verschaffen om deze vertegenwoordigers in staat te stellen hun rechten uit te oefenen om zich van de uit de onderhavige richtlijn voortvloeiende taak te kwijten.

6. De lid-staat neemt de nodige maatregelen dat werknemers de hen in dit artikel toegekende rechten in rechte geldend kunnen maken.

Het recht op informatie.

\section{Artikel 5.}

1. De werkgever geeft de werknemersvertegenwoordigers alle informatie die zij voor het vervullen van hun functie nodig hebben.

Hieronder wordt in elk geval begrepen informatie omtrent:

a. het ondernemingsbeleid met betrekking tot veiligheids- en gezondheidsaangelegenheden inclusief het voor dat beleid begrootte en uitgegeven bedrag.

b. de analyses gemaakt over de risico's voor de veiligheid en gezondheid op de werkplek, de te nemen maatregelen en het te gebruiken beschermingsmateriaal. 
c. de door de werkgever bijgehouden lijsten over arbeidsongevallen en beroepsziekten waarvoor de werknemer meer dan drie dagen arbeidsongeschikt is geweest, en de rapportages over de oorzaken van arbeidsongevallen en beroepsziekten die een blijvende (gedeeltelijke) arbeidsongeschiktheid hebben veroorzaakt of zouden kunnen veroorzaken.

d. de preventie-activiteiten en de van de bevoegde instanties afkomstige informatie.

2. Indien een onderneming vestigingen in meer lid-staten heeft, draagt zij zorg voor het verstrekken van bovengenoemde informatie aan de werknemersvertegenwoordigers in deze vestigingen, zo nodig via het bestuur van die vestiging.

Medezeggenschap inzake veiligheids- en gezondheidsaanlegenheden.

Artikel 6.

1. De werkgever en de werknemersvertegenwoordigers stellen, op alle niveaus van de onderneming gezamenlijk het algemene ondernemingsbeleid inzake veiligheids- en gezondheidsaangelegenheden vast.

2. Deze vaststelling kan geschieden door middel van:

a. een collectieve overeenkomst tussen werkgever en werknemersvertegenwoordigers, die een looptijd heeft van ten hoogste twee jaar;

b. een formele instemming van de werknemersvertegenwoordigers met het algemeen ondernemingsbeleid, nadat zowel werkgever als werknemersvertegenwoordigers in de gelegenheid zijn gesteld voorstellen te doen;

c. een gezamenlijke beslissing van werkgever en werknemersvertegenwoordigers.

3. Het algemeen ondernemingsbeleid omvat in elk geval:

a. beginselen van het veiligheids- en gezondheidsbeleid zoals in de onderneming gevoerd;

b. alle acties die een belangrijke invloed kunnen hebben op de veiligheid en gezondheid;

c. de eventuele aanstelling van veiligheidsdeskundigen en bedrijfsartsen, of het eventueel gebruik maken van deskundige diensten en gemeenschappelijke medische diensten van buitenaf.

3. Indien een onderneming in meer lid-staten vestigingen heeft, geschiedt de vaststelling van het ondernemingsbeleid mede bij de hoofdzetel volgens de wetgeving of praktijk van de lid-staat waar de hoofdzetel zich bevindt. 
Bij de vaststelling hebben de werknemerswertegenwoordigers (of hun afgevaardigden) van de vestigingen inspraak volgens de in de lid-staat waar de hoofdzetel gevestigd is geldende procedure.

\section{Toezicht.}

\section{Artikel 7.}

1. De werknemersvertegenwoordigers hebben het recht de uitvoering van wettelijke of overeengekomen bepalingen alsmede de uitvoering van het algemeen ondernemingsbeleid te inspecteren.

2. De werknemersvertegenwoordigers worden betrokken bij alle door de bevoegde instantie uitgevoerde bezoeken en controles.

3. De werknemersvertegenwoordigers hebben het recht een beroep te doen op de op het gebied van veiligheids- en gezondheidsbescherming bevoegde instantie ter fine van controle en steun indien zij van oordeel zijn dat de door de werkgever genomen maatregelen niet voldoende zijn om de veiligheid en de bescherming van de gezondheid te verzekeren op de werkplek, dan wel op plaatsen buiten de onderneming of vestiging waar ten behoeve van de onderneming gewerkt wordt.

4. De bevoegde instantie is verplicht op de verzoeken van de werknemersvertegenwoordigers te reageren en de noodzakelijke maatregelen, inclusief een eventuele stillegging van de onderneming, al dan niet in samenwerking met de werknemersvertegenwoordigers, te nemen.

5. Indien dit door de werknemersvertegenwoordigers noodzakelijk geacht wordt, hebben zij de mogelijkheid onafhankelijke deskundigen te raadplegen. De onderneming betaalt de redelijkerwijze aan deze raadpleging verbonden kosten, tenzij de werkgever aantoont dat het raadplegen kennelijk overbodig kan worden geacht.

\section{Geschillen.}

Artikel 8.

1. De lid-staten nemen maatregelen opdat, indien over een van de van de in de artikelen 5, 6 en 7 geregelde materies geschillen ontstaan over de naleving van deze bepalingen, of over de inhoud van het vast te stellen beleid, toegang bestaat voor zowel werknemers als hun vertegenwoordigers, tot een rechterlijke of arbitrage instantie.

2. Ingeval gekozen wordt voor een arbiter neemt de lid-staat de maatregel dat, ten aanzien van de rechtmatigheidsaspecten van de beslissing, beroep open staat op een rechterlijke instantie. 
Verantwoordelijkheden van de werkgever en de werknemers.

Artikel 9.

De medezeggenschap van werknemers laat onverlet de verantwoordelijkheden die op werkgever en werknemers rusten in verband met de veiligheid en gezondheid op de arbeidsplaats.

Rechten van werknemers

Artikel 10.

1. Aan de werknemers wordt alle informatie verstrekt die nodig is in verband met:

a. de risico's voor de veiligheid en gezondheid alsmede over de preventiemaatregelen en -activiteiten betreffende de onderneming in het algemeen en voor iedere werknemer betreffende zijn werkplek en/of zijn functie.

b. het risico van ernstig en onmiddellijk dreigend gevaar, en van de terzake genomen maatregelen.

2. Werknemers hebben het recht een klacht in te dienen bij de bevoegde instanties op dit terrein, indien hun persoonlijke veiligheid en gezondheid op het werk onvoldoende beschermd is.

3. De bevoegde instanties zijn verplicht te reageren op een bij hen ingediende klacht tenzij deze klacht kennelijk ongegrond is.

4. De werknemers mogen geen nadeel ondervinden van het inbrengen van een klacht.

5. De werknemer die het werk onderbreekt of de werkplek verlaat omdat naar zijn redelijk oordeel sprake is van ernstig en onmiddellijk dreigend gevaar voor zijn leven of gezondheid mag hiervan geen nadelen ondervinden en dient overeenkomstig de in de betrokken lid-staat geldende wetgeving of praktijk beschermd te worden tegen alle schadelijke gevolgen.

Overgangs en slotbepalingen.

Artikel 11.

1. De lid-staten doen de nodige wettelijke en bestuursrechtelijke bepalingen in werking treden om uiterlijk op 1 januari (....) aan deze richtlijn te voldoen. Zij stellen de Commissie daarvan onverwijld in kennis. 
2. De lid-staten delen de Commissie de tekst mede van bepalingen van nationaal recht welke zij op het onder de richtlijn vallende gebied reeds vastgesteld hebben of vaststellen.

3. De lid-staten brengen de Commissie om de twee jaar verslag uit over de praktische tenuitvoerlegging van de bepalingen van de onderhavige richtlijn, met vermelding van de gezichtspunten van de sociale partners op nationaal niveau, en de Federaties van werkgevers- en werknemersverenigen op Gemeenschaps- dan wel Europees niveau.

4. De Commissie informeert hierover de Raad, het Europese Parlement het Economisch en Sociaal Comitê het Raadgevend Comité voor de veiligheid, de hygiëne en de gezondheid op de arbeidsplaats.

5. De Commissie legt periodiek de Raad, het Europese Parlement en het Economisch en Sociaal Comitê een rapport voor over de tenuitvoerlegging van de richtlijn.

Artikel 12.

Deze richtlijn is gericht tot de lid-staten.

\subsection{Toelichting}

Het hierboven ontworpen richtlijn voorstel zou een aantal van de in dit proefschrift gesignaleerde problemen van de medezeggenschap kunnen oplossen. Om enige helderheid te verschaffen in de gekozen formuleringen zal ik voor de belangrijkste artikelen aangeven welke motivering aan die keuze ten grondslag licht.

De definities van artikel 2 zijn voor een deel ontleend aan bestaande richtlijnen en eerdere voorstellen voor die richtlijnen. De begrippen werknemer, werknemersvertegenwoordiger in veiligheids- en gezondheidskwesties, werkgever en onderneming kwamen in praktisch dezelfde vorm voor in het oorspronkelijk voorstel voor de nieuwe raamrichtlijn $89 / 391$, ter bevordering van de veiligheid en gezondheid op het werk. Het begrip vestiging is praktisch geheel ontleend aan het Vredeling-Richard voorstel.

De definitie van werknemer is zo ruim dat zij ook thuiswerkers, part-timers en flexibele arbeidskrachten met een onduidelijke arbeidsovereenkomst omvat (men denke bij dit laatste aan nul-urencontracten). De definitie is in gewijzigde vorm in richtlijn 89/391 zelf terecht gekomen; daar wordt gesproken van personen die door de werkgever worden tewerkgesteld en wordt huispersoneel expliciet uitgezonderd. De nieuwe definitie heeft het bezwaar dat juist bij flexibele arbeidskrachten met vage contracten nog wel 
eens de vraag speelt of zij zijn tewerkgesteld. De ruimere definitie laat op dit punt geen twijfel.

Ook de definitie van werkgever is in richtlijn $89 / 391$ gewijzigd. Nu is deze: de natuurlijke of rechtspersoon die de wederpartij is in de arbeidsverhouding en die de verantwoordelijkheid draagt voor het bedrijf en inrichting. Deze dubbele vereisten zouden ten nadele kunnen werken van ingeleende krachten. De ruime definitie lijkt mij de meest praktische. Het lijkt erop dat deze definitie een ruime kring van privaatrechtelijk aansprakelijke personen (als werkgever) zou creëren. Dit is echter niet het geval: doordat de beslissing inzake concrete gevallen aan de werkgever blijft, zal alleen hij (als beslissingsbevoegde instantie) aansprakelijk in het concrete geval kunnen worden geacht.

Het begrip onderneming in deze definitie (ook ontleend aan het oorspronkelijke commissievoorstel voor richtlijn 89/391) omvat, door het onderscheid dat is gemaakt tussen onderneming en vestiging ook (gehele) concerns. Door nu vestiging te definiëren als hierboven worden zowel moeder- als dochterondernemingen door de richtlijn gedekt, ook als de dochter zich niet in dezelfde lid-staat bevindt. Het door mij ontworpen voorstel biedt echter geen oplossing voor de medezeggenschapsproblematiek voor het geval dat de hoofdzetel van een onderneming zich niet bevindt in een EG-lid-staat. In de raamrichtlijn is het begrip onderneming overigens niet gedefinieerd.

Het begrip werknemersvertegenwoordiger inzake veiligheids- en gezondheidskwesties is ook praktisch geheel ontleend aan de definitie uit het oorspronkelijke voorstel voor richtlijn 89/391 van de Commissie, al moet ik er bij aantekenen dat deze de mogelijkheid openhield van aanwijzing (door de werkgever) van die vertegenwoordigers. In mijn voorstel is deze laatste mogelijkheid komen te vervallen.

Artikel 4 schrijft het minimumaantal werknemers voor waarbij vertegenwoordigers inzake veiligheids- en gezondheidsaangelegenheden moeten worden gekozen. Ik heb dit minimum op vijftig gesteld omdat, zoals uit hoofdstuk III bleek, dit het getal is dat de meeste lid-staten als minimum aanhouden. Niets weerhoudt de lid-staten (of zelfs individuele ondernemingen) er overigens van dit getal lager te stellen. De ruime interpretatie van het begrip werknemer bewerkstelligt overigens wel dat bij deze vijftig ook stagaires, leerlingen, thuiswerkers en part-timers gerekend moeten worden.

Artikel 6 is het sleutelartikel in de richtlijn. Hierin wordt de medezeggenschap, zoals deze mijns inziens op basis van de bestaande wetgeving en praktijken in de lid-staten af te leiden is, vastgelegd op gemeenschapsniveau. Ik heb in mijn voorstel de lid-staten de keuze gelaten tussen drie mogelijkheden: het instemmingsrecht, het recht een overeenkomst te sluiten of een gezamenlijke beslissing. Deze keuzemogelijkheden zijn enkel pragmatisch: zij sluiten aan op datgene wat er in de lid-staten op dit moment aan medezeggenschapsvormen bestaat. Wat mijn voorstel toevoegt 
is een verplichting om die bestaande mogelijkheden aan te wenden voor veiligheids- en gezondheidsaangelegenheden.

De twee jaarstermijn voor collectieve overeenkomsten is eveneens een praktische keuze. Een verplichte heronderhandeling per jaar zou mogelijk teveel druk op de werknemersvertegenwoordigers kunnen leggen. Een tweejaarlijkse heroverweging van het gevoerde beleid leidt in elk geval tot een periodieke mogelijkheid veranderingen aan te brengen. Het legt met name de werkgever een plicht tot heronderhandelen van bestaande overeenkomsten op. Op nationaal niveau zowel als ondernemingsniveau kan overigens worden besloten deze termijn te bekorten.

Van artikel 10 kan worden verdedigd dat een dergelijke bepaling in een medezeggenschapsrichtlijn niet thuishoort. Rechten van individuele werknemers zouden op een andere plaats gegarandeerd moeten worden. Wanneer echter geconstateerd wordt dat in de nationale wetgeving op dit punt één van de problemen de verhouding tussen de rechten van vertegenwoordigers en die van de individuele werknemer is, denk ik dat een bepaling als artikel 10 als voorwaarde in een medezeggenschapsrichtlijn thuishoort. Daarmee vermijdt men op voorhand in elk geval enige competentieconflicten.

\section{$5 \quad$ Slotbeschouwing}

Toen de Europese Gemeenschap zich begin jaren zeventig boog over de mogelijkheid een regeling voor medezeggenschap te maken binnen de structuur van de vennootschap, strandden pogingen daartoe op meer dan én politiek argument. Niet alleen regeringen waren ertegen, maar ook de sociale partners, inclusief de vakbonden van verschillende lid-staten, die in beginsel voordeel zouden kunnen hebben van een goede regeling op Europees niveau.

Daar waren om te beginnen de tradities in de verschillende lid-staten die de gemeenschap parten speelde. Waar in lid-staten als Duitsland en Nederland op het punt van de verhouding tussen de sociale partners de wetgever een zekere mate van vertrouwen werd geschonken, bestond elders voornamelijk wantrouwen tegenover recht en wet.

Een wantrouwen dat niet uit het niets is ontstaan. Recht en het gebruik ervan door rechters hebben niet altijd een rol gespeeld waar werknemers voordeel van hebben gehad; integendeel, met name in Groot Brittannië was het (gebruikte) recht in hoge mate repressief. Wat door de wetgever met de ene hand werd gegeven, de afschaffing van het coalitieverbod in 1824 (20) bijvoorbeeld, werd door de rechter onder common law met de

20. Door middel vam de Combination Laws Repeal Act 1924, vervangen in 1925 door de meer beperkte Combination Laws Repeal Amendment Act. 
andere weer teruggenomen (21). In de vorige eeuw leidde dit tot beruchte zaken als die van de Tolpuddle Martyrs, die in 1834 tot zeven jaar deportatie naar Australie veroordeeld werden, in verband met het zweren van een "unlawfull oath" te weten het oprichten van een vakbond (22).

Ook in andere landen was de weg van repressie naar tolerantie er een die doorlopen moest worden voordat enig vertrouwen in de staat werd verkregen (23). Dit vertrouwen kon groeien doordat, althans in een aantal lid-staten, de wetgever het reguleren van collectieve arbeidsverhoudingen aan de sociale partners zelf overliet, en hooguit voorzag in procedurele en beschermende wetgeving.

De Gemeenschap moest binnen deze tradities haar weg naar regulering zien the vinden. En dat terwijl bij een deel van de lid-staten een grote afkeer heerste van bemoelenis van de wetgever, $60 \mathrm{k}$ de communautaire wetgever, met collectieve arbeidsverhoudingen, of deze zich nu op nationaal of ondernemingsniveau bevonden.

En wetgeving -all dan niet door middel van het relatief open instrument van de richtlijn- is het enige instrument dat de Gemeenschap ter beschikking stond. Een bepaling omtrent de sociale dialoog is pas sedert kort in het EEG-verdrag opgenomen. Wanneer men echter van mening is dat op een of andere wijze medezeggenschap tot verplichting dient te worden verheven, heeft de Gemeenschap alleen het instrument van wetgeving -zowel op communautair niveau als in beginsel op nationaal niveau- ter beschikking.

De Commissie valt, voor wat betreft de pogingen die zij heeft ondernomen, niets te verwijten. Zowel uit het eerste ontwerp van het Statuut SE, als de Vredeling-Richardvoorstellen en de ontwerpen vijfde richtlijn inzake de structuur van de venmootschap, blijkt dat de Commissie al vroeg inzag datt de wijzigingen op het gebied van medezeggenschap die door de effectuering van de gemeenschappelijke markt en het uitoefenen van het vestigingsrecht kon plaatsvinden, regulering van de medezeggenschap van werknemers noodzakelijk maakten. Het falen van deze pogingen is meer te wijten aan de al genoemde tradities, nationale politieke belangen en zelfs voor een deel aan koudwatervrees van de lid-staten, dan aan het optreden en initièren van de Commissie zelf. Het cynische resultaat is natuurlijk dat de

21. Enkele rechters stelden de bonden strafrechtelijk aansprakelijk, met de redenering dat zij zich schuldig maakten aan criminele samenzwering onder "common law". Ook nadat deze visie herroepen werd bleven rechters van mening dat het dreigen met staking molestatie yan de werkgever was, evenals het dwingen van andere werknemers aan een staking deel te nemen, bijwoorbeeld door niet gewelddadige "picketing lines". Zie o.m. B. Hepple, United Kingdom, in The Freedom of the Worker to Organize, Berlin, Heidelberg, New York 1980, p. 1014-1016.

22. Zie voor een mooie beschrijving van deze zaak R.G. Lee, The Tolpuddle Martyrs, Employee relations, Vol. 9 (1987), no. 1.

23. Zie A.T.J.M. Jacobs, Collective Self Regulation, in The Making of Labour law in Europe, (B. Hepple, ed.) London, 1986, p. 193-207. 
verordening over het Europees Economisch Samenwerkingsverband wel tot stand is gekomen, terwijl deze verordening nu juist geen medezeggenschapsparagraaf kent (24).

Inmiddels lijkt, vermoedelijk mede door de belangstelling die er voor de uitvoering van de Europese Akte, de publiciteit rond het magische jaar 1992 en de bewustwording van het praktisch ontbreken van de bijbehorende sociale regulering, het tij enigszins gekeerd. Onderwerpen als de bovengenoemde richtlijnvoorstellen en het Statuut SE zijn weer (met mondjesmaat) bespreekbaar, hoewel zij tot dusver niet tot concrete resultaten hebben geleid. Een Handvest dat communautaire economische en sociale grondrechten bevat is, hoewel het minder voorstelt dan wenselijk is, inmiddels vastgesteld. De dialoog tussen de sociale partners is in elk geval op gang gebracht (25) en op de verschillende topconferenties wordt daar tot op zekere hoogte aandacht aan besteed (hoewel de problematiek tot dusver veelal is overschaduwd door problemen omtrent de monetaire unie en de ontwikkelingen in Oost-Europa, maar dit terzijde). Ook al blijven resultaten nog uit, de stilte is in elk geval voorbij.

Deze aandacht voor de sociale kant van de Gemeenschap was wel nodig ook. Het sociale beleid van de Gemeenschap liep allang achter op hetgeen in de gemeenschappelijke markt bereikt werd. $\mathrm{Nu}$ de voltooiing van de interne markt naderbij komt, wordt deze achterstand zichtbaar. Hierdoor komt één van de doelstellingen van het EEG-verdrag, de verbetering van de levensstandaard in gevaar. Het optimisme dat het (interne) marktgebeuren vanzelf een verbetering brengt in, of zelfs maar een garantie vormt voor de levensstandaard van de werknemers is niet gerechtvaardigd. Zonder additioneel beleid wordt het Europa met een interne markt vooral het Europa van de ondernemers (26).

Op het specifieke gebied van de veiligheid en gezondheid is op gemeenschapsniveau meer bereikt dan op de andere gebieden. Dit heeft mijns inziens ten dele te maken met de relatieve ongevaarlijkheid van het beleidsgebied. Daannast is het te danken aan het feit dat ook in die lidstaten waar de arbeidsverhoudingen overwegend op vrijwilligheid van de partners zijn gebaseerd, de wet ofwel door het stellen van absolute normen, ofwel door het opleggen van een zekere mate van organisatiestructuur waarin werknemers rechten op informatie, consultatie, soms medezeggenschap en controle worden toegekend al een rol speelt.

24. Zie paragraaf II,4.3.

25. Zie o.m. J. van Rens, Wordt de Europese Gemeenschap een sociale unie, AA 1989 (themanummer Europa 1992), p. 176-182; Commissie van de Earopese Gemeenschappen, Sociaal Europa, speciaal nummer, Luxemburg 1988, p. 70 ev.

26. Zo ook bet socialistische EP-lid $H$. d'Ancona, tijdens de parlementaire behandeling van het Gemeenschapshandvest van Fundamentele Sociale rechten, Hand. EP 13-3-1989. 
De bestaande richtlijnen hebben echter betrekkelijk weinig nieuws gebracht, en voor de medezeggenschapskant niet of nauwelijks nieuwe rechten gecreëerd. De richtlijn betreffende de tenuitvoerlegging van maatregelen ter bevordering van de verbetering van de veiligheid en gezondheid van de werknemer op de werkplek, gebaseerd op artikel 118A, verbetert deze situatie enigszins, maar volgens mij te weinig.

De richtlijn is zeer weinig controversieel; de meeste lid-staten voldoen met hun wetgeving voor het overgrote deel aan de bepalingen van de richtlijn. Bovendien, zelfs als dit niet het geval is, of zou zijn, dan is de vraag of de richtlijn voor de werknemers, gezien de vaagheid van haar formuleringen veel kan opleveren. En als dat laatste niet het geval is, dan moet de lidstaat weliswaar wel aan de richtlijn voldoen, maar het enige werkelijke contrôle-instrument zijn de procedures die de Commissie kan voeren, procedures die voor de burgers zelf slechts indirecte consequenties kunnen hebben.

De geringe uitbreiding van rechten kan mede te wijten zijn aan een voorzichtige houding van de Commissie. Een optimistisch vermoeden dat nu met de nieuwe raamrichtlijn blijkt dat artikel 118A als grondslag kan dienen voor arbeidsorganisatorische maatregelen verdergaande (wijzigings) voorstellen worden gedaan, is misschien niet helemaal ongerechtvaardigd. $\mathrm{Nu}$ de lid-staten een dergelijke richtlijn onder artikel 118A geaccepteerd hebben zal het in een later stadium moeilijker hard te maken zijn, dat minimumvoorschriften over medezeggenschap inzake veiligheids- en gezondheidszaken met eenparigheid van stemmen moeten worden vastgesteld.

Het enige dat de richtlijn wel heeft gebracht is een voorzichtige verbetering van de positie van de individuele werknemer. De positie van de individuele werknemer in de regelingen en praktijken in de lid-staten is, over het geheel genomen zwak. Voor die werknemers die mondig genoeg zijn, om vertegenwoordigers of vertegenwoordigende organen naar zich te laten luisteren, is dit mogelijk niet zo'n probleem, voor werknemers die daar door positie in de onderneming, status of andere redenen niet toe in staat zijn is dit een slechte zaak.

Wanneer voor deze werknemers de voorwaarden worden geschapen iets te ondernemen ten aanzien van hen eigen situatie wanneer deze onveilig of ongezond is, is dit in een aantal lid-staten een vooruitgang. Het minste wat hen moet worden (en mogelijk wordt) geboden is in elk geval de mogelijkheid expliciet onveilige situaties te ontvluchten met een redelijke kans dat zij geen ontslag of andere benadeling in hun carriere te vrezen hebben. Ook hier blijft echter het probleem van de inroepbaarheid vooralsnog een rol spelen; het Hof zal dit moeten beoordelen.

Voor wat betreft de echte medezeggenschapsparagraaf is de richtlijn echter te mager. Deze sluit te zeer aan bij de nationale wetgeving. Daardoor 
ontstaat in die lid-staten waar geen medebeslissingsrecht, instemmingsrecht; of onderhandelingsrecht bestaat ten aanzien van veiligheids- en gezondheidsaangelegenheden, (of waar dat recht wel bestaat maar onder het nationale recht niet, of alleen onder gunstige (economische) condities afdwingbaar is) nog steeds geen recht op medezeggenschap in én van die drie vormen. Bovendien biedt de richtlijn op geen enkel ander front sancties waardoor geen garantie wordt geboden, dat de rechten geldend te maken zijn, en bovendien toetsbaar aan het Europese recht te maken zijn.

Het door mij opgestelde ontwerp biedt die mogelijkheden wel. Uit het gedane onderzoek blijkt dat het opgestelde ontwerp, althans voor zover het de praktijken en/of wetgeving in de lid-staten zelf betreft in beginsel haalbaar zijn. Die wetgeving en/of praktijken gaan praktisch alle veel verder dan wat tot dusver op gemeenschapsniveau tot stand is gekomen.

Het voorbeeld voor een Commissievoorstel betreffende minimumvoorschriften van medezeggenschap dat ik hierboven heb gegeven lost de in dit onderzoek gesignaleerde problemen niet allemaal op. Met name het democratieprobleem blijft in elk geval voor een deel bestaan, omdat, ook al laat een onderneming formeel alle werknemers toe tot verkiezingen, dit in de praktijk voor bepaalde groepen niet of nauwelijks zal werken.

Ook andere problemen blijven bestaan: zelfs indien medezeggenschap bij de hoofdzetel wordt bereikt, zelfs indien alle benodigde informatie wordt verstrekt en meebeslist kan worden over het algemene ondernemingsbeleid, blijven de machtsverschillen binnen de onderneming een rol spelen. Een werknemersvertegenwoordiger kan nog zo goed geïnformeerd zijn, de ondernemer is het vaak beter. De werknemersvertegenwoordiger kan nog zulke redelijke voorstellen doen, hij zal moeten opboksen tegen een werkgever die niet alles wil honoreren, aangezien deze rekening moet of wenst te houden met andere aspecten van ondernemingsbeleid. Een werknemersvertegenwoordiger kan nog zo vaak gelijk hebben: hij blijft degene die het tegenover de ondernemer zal moeten zien te krijgen.

De Gemeenschap staat met haar ambitieuze plannen voor wat betreft de interne markt voor de niet geringe taak ook het sociale beleid binnen die gemeenschap vorm te geven. Het risico van harmonisatie van wetgeving op een lager niveau dan een aantal lid-staten reeds hebben bereikt is aanwezig. Daarnaast bestaat het risico dat het nationale recht, dat mede dankzij een niet geringe sociale strijd tot stand is gekomen, wordt uitgehold, doordat communautaire regelgeving op sociaal gebied niet tot stand komt, terwijl ondernemers een grotere flexibiliteit krijgen nationale regelingen te ontwijken. Het is aan de Gemeenschap, maar ook aan de vakbonden op het multinationale niweau, die dreiging af te wenden.

Medezeggenschap op ondernemingsniveau is in dit verband voor de Gemeenschap van specifiek belang. Dankzij de bepalingen in het verdrag betreffende de liberalisatie van het vestigingsrecht, en de voortschrijdende 
harmonisatie van het vennootschapsrecht, is het vooral op het ondernemingsniveau, dat wijzingingen in de bestaande structuren en wijze van opereren van ondernemingen de veranderingen doordringen. Waar de Gemeenschap die mogelijkheden creëert en het gebruik ervan stimuleert, heeft zij ten aanzien van degenen die er nadeel van zouden kunnen ondervinden een specifieke verantwoordelijkheid. Met de Europese Akte is er op één sociaal gebied, het arbeidsmilieu, een extra expliciete rechtsgrondslag gekomen. Dat is weinig. Daarom is het van belang dat deze ene mogelijkheid zo goed mogelijk wordt benut, en dus zo ruim mogelijk wordt geïnterpreteerd.

Voor werknemers zal het belang van medezeggenschap op ondernemingsniveau toenemen, naarmate meer ondernemingen gebruik gaan maken van de grensoverschrijdende mogelijkheden. Beïnvloedings- en controlemogelijkheden nemen af naarmate de vrijheden van de ondernemers toenemen. Voor werknemers is het van belang dat zij van alle door de gemeenschap toegekende mogelijkheden gebruik gaan maken. Dit geldt zowel voor beïnwloeding door middel van vertegenwoordigers als door beinvloeding van de eigen veiligheids- en gezondheidssituatie.

Een goede medezeggenschapsregeling vanuit de gemeenschap is hiervoor een voorwaarde. Een voorwaarde, maar ook niet meer dan dat. Van een regeling zal door de werknemers gebruik moeten worden gemaakt. Zij zullen hun stem moeten laten horen binnen de medezeggenschapsorganen, en daarbuiten wanneer de medezeggenschapsorganen geen soelaas kunnen bieden. Geen enkele wettelijke regeling kan voor werknemers het door rabbi Hillel, inmiddels zo'n twee millennia geleden, gestelde overbodig maken: "If I am not for myself, who is for me?" (27).

27. Het volledige citaat, afkomstig uit het Traktaat Pirke Avoth (Vaderen) uit de Talmoed, luidt: "He used to say: -If I am not for myself, who is for me? and when I am for myself, what am I? and if not now when ?". Algemeen wordt aangenomen dat, hoewell de interpretatie verloren is gegaan, Hillel $(+10$ v.C. -10 na C. president van het Sanhedrin tesamen met rabbi Shammai, zie ook Čh. Potok, Wanderings, New York 1989, p. 297299) meent dat de mens niet op anderen moet vertrouwen voor datgene wat hem rechtens toekomt, en dat hij met het gebruik van zijn mogelijkheden niet moet wachten tot een toekomst die hij eventueel niet meer zal meemaken. Pirke Avoth is toegevoegd aan de Nezikien (het deel Rechtspraak) in de Mísjna (vastgelegde mondelinge leer). Zie R. Travers Herford, Pirke Avoth, the etics of the Talmud, New York 1962. 


\section{Coöperation and collective bargaining at plant level on safety and health issues}

Since the implementation of the Single European Act, the European Institutions and the member states of the European Communities show a growing awareness of the necessity for an effective European social policy. There is no consensus, however, about the form in which such a social policy should be achieved. Some member states seem to feel that a community social policy should not go beyond the adoption of the rules most necessary to ameliorate the social drawbacks of the completion of the internal market. Other member states and some of the institutions favour, as a counterpart to the economic policy, a more autonomous social policy. This book is written with this last vision in mind.

One of the community social policy issues which has occasioned controversies in the past is the issue of regulation of information, consultation and participation of workers at plant level. Up until now the member states could not reach agreement about several proposed directives on this subject. For this reason the proposed fifth directive on company structure and the proposed Vredeling-Richard directive were never accepted. In both directives the required worker-representation and information and consultation of workers proved to be insurmountable obstacles. Another Commission proposal, on the Societas Europea, which also contained provisions on worker-representation, was put in cold storage for nearly 20 years, and was only revived recently in a radically amended form. It seems that proposals which give an overall regulation for worker participation in any form are not acceptable to member states.

In some social policy directives which were accepted before the implementation of the Single European Act information and consultation provisions were included. These directives (RI. 75/129 on collective redundancies, Rl. $77 / 187$ on safeguarding employees rights in the event of transfers of undertakings, and RI, 80/1107 on the protection of workers from the risks relating to exposure to chemical, physical and biological agents in the workplace) covered only a part of labour law regulations and were never intended to regulate the situation more generally. The information and consultation provisions are linked to the national statutory representation systems. They do not create rights to information or to be consulted if no representation legislation or practice existed previously. However, if there 
exists worker-representation in any form, the provisions prescribe improvements in the national legislation or practice (depending on the standard in the member state). The directive-provisions did not affect the decisionmaking power of the employer, because they did not contain obligations to bargain, reach an agreement, or require approval from the workers as condition of implementation of decisions. This is why, in the present writer"s view, the directive-provisions were quite weak. It seems, however, that member states are prepared to accept statutory information and consultation requirements if these requirements embrace just a part of the field of labour law.

The most elaborate part of community legislation in the social field is health and safety at work. Even before the implementation of the Single European Act, several directives on the protection of health and safety had been accepted. One of them is mentioned above, others provided more specific standards of protection. The Single European Act itself modified the EEC-treaty by including a specific legal basis for directives to protect the health and safety of workers. This article enables the Council to adopt these directives by a qualified majority. This example demonstrate that however difficult it may be to achieve social policy measures in general, measures on the protection of safety and health of workers seem to be less controversial.

Accordingly the question arises whether there could be a possibility to achieve worker-participation provisions which go beyond information and consultation rights of workers and constitute a right to a far reaching influence on the decision-making power of the employer. The next question is whether these rights could be granted not only within the borders of the member states, but also across national borders. If the latter would be the case such provisions could create worker-participation in health and safety in multinational companies. Before any conclusions can be reached about acceptability by the member states of such provisions it is necessary to examine the mechanisms by which worker representation is regulated in the member states.

To compare the mechanisms by which worker represention is reached in the member states it is necessary to describe the kind of representation systems within the various member states. In Chapter III an overview is given of these representation systems. Two kinds of systems are analysed: representation through a works council (based on statutory provisions or on national collective agreement) and representation through shop stewards or other trade union representatives (based on statutory provisions, collective agreements or voluntary action). Apart from those representatives who represent the workers in general, a lot of countries do have specific representation in safety and health matters. If there is a specific health and safety representation it is based on statutory provisions. The conclusion of this Chapter is that representation at plant level is common in the member states, but the form it has taken in general differs widely. 
The IVth and Vth Chapter treat the mechanism by which representation is achieved. A division in rights is made. In Chapter IV those mechanisms which are important in general economic and social issues as well in the means to effect them in law are examined. In Chapter V those instruments which are important for influencing health and safety matters specifically will be focused upon.

To make comparison between the schemes in the various member states possible the rate of influence of the various powers of the representatives on the employers decision has to be considered. The powers considered are the right to information, the right to be consulted, the right to bargain (and conclude agreements) about health and safety matters and the right of approval of decisions of the employer in health and safety matters. One may question whether the right to bargain is comparable with the right to approve proposals made by the employer. The origin of the first right is entirely different from the second. Nevertheless, when stripped from their ideological background, in the present writer's view, both rights are comparable on their merits. One can compare them bearing in mind the extent of influence upon the employers decision. The right to approve proposals is the stronger of the two rights unless the right to bargain is accompanied by an obligation to conclude an agreement. The conclusion of this part of the chapter is that in most member states worker-representatives do have the statutory right to be consulted on health and safety matters. In a few member states they have the right to approve proposals and in most of the other countries they have the right or the possibility to bargain about these matters. These rights are based on statutory provisions and national collective agreements. Collective bargaining takes place also voluntarily.

The second part of Chapter IV deals with the enforcement of the rights by legal procedure or through industrial action. In most countries workerrepresentatives have the possibility to enforce their rights by (simple) legal proceedings. Only in Great Britain enforcement by the representatives takes place mainly through industrial action.

Chapter V deals with some powers which are especially important in health and safety matters. The examined powers are: the right to supervise health and safety measures in the enterprise, the right of representatives to close down (part of) the enterprise, and the right to appeal to the labour inspectorate (including the obligation of the inspectors to react). Also the rôle of the occupational health services is examined.

Chapter $\mathrm{V}$ focuses also upon the position of the individual worker within the representation system. Because the individual worker has to rely a great deal on his representatives, he carries the risk that his difficulties are not properly dealt with. Also in the systems there is a chance that the worker (especially the atypical worker, such as the part-timer, the homebased and the flexi-time worker) is not represented at all, because of the pre- 
conditions which are imposed before representation becomes operative. In this chapter typical individual rights such as the right to suspend work and the right to complain within the enterprise are examined.

From this chapter the following conclusions are drawn: worker-representatives have the right to supervise the health and safety measures in the enterprise. Only in Denmark, Spain and in France have the representatives the power to shut down (part of) the enteprise in the case of imminent danger. In other countries this power is granted to the labour inspectorate. In most countries the labour inspectorate do not have the obligation to react if they receive a request to take action from the worker-representatives. In all member states, though there are too few inpectors to enforce health and safety effectively. Beneath this, the double rôle of advisor and controller causes problems in the relationship with the representatives.

The individual worker has very few possibilities to do anything about working-conditions if representatives do not pay attention to the employees problems. This can be difficult in particular if the worker is inadequately represented. In the event of imminent danger the employees in all member states do have the right to suspend working. A legal right of complaint within the enterprise is only established in West-Germany. A possible solution to the problem of representation of workers might be found by encouraging representation through homogeneous groups, such as employees in the same kind of professions or work-situations.

In Chapter VI the overall conclusions of the previous chapters are examined with a view to exploring a possible community directive on worker participation in safety and health matters. Such a directive might be based on the recent adopted article 118A of the EEC-treaty. Whether this is possible depends on the interpretation of two terms of the article; namely, minimum requirements and working environment. The first term, in the present writer's view, should be seen in relation to the distribution of powers between the member states and the community. In that context the term "minimum requirements" means only that member states are always allowed to maintain a higher levell of protection. The second term: "working environment" should, in the present writers view, be interpreted as broadly as possible. Not only physical health and safety but also psychological health and the social aspects of the working environment should be covered by article 118A. If this is the case a directive on worker participation in safety and health based on the national legislation and practices is one possibility.

This directive should at least contain the following rights: the right to information, the right to be consulted and the right to participate in decisions about health and safety measures. Participation could be established in three ways: co-determination, the right to approve proposals regarding the general policy in health and safety matters put forward by the enterprise or the right to bargain collectively, with an obligation to reach 
an agreement, on the enterprise policy in health and safety matters. Furthermore a right to appeal to the labour inspectorate, with an obligation upon the inspectors to react should be established.

By defining the concept of company in a broad way, such a directive might apply not only to enterprises but also to holdings with daughters in more than one member state. "The idea would be then that representatives of the employees of all daughters would be involved in determining the enterprisepolicy at the highest level according to the laws of the member state in which the parent-enterprise is established. In this way worker-participation in multinationals in health and safety matters would be realised in a concrete way.

In the following part of this chapter recently adopted directives are examined against the possible draft for community legislation. The older directives are, as has already been explained above, a lot weaker then the draft, because they are linked to the national systems. The most important recent directive is directive $89 / 391$, which contains provisions on worker participation. These are a right to information, a right to be consulted and a right to balanced participation when responding to problems in accordance with the legislation or practices of the member states. Although here is also a linkage with the national systems the directive is going beyond a mere right of consultation. In the present authors view here a right to deliberate with the employer is granted. Nevertheless influence in the way proposed above which would affect the decision-making power of the employer is not granted.

Despite the requirements for worker-participation in the new directives, these provisions are weak when examined against the drafted proposal. Not only the decision-making power of the employer remains intact, but also the concept of concerns is not defined. This means in principle that the term concern, or enterprise, is defined at the national level. So no bordercrossing participation has been achieved through the new directive.

In Chapter VII these conclusions are elaborated and a concrete directive proposal based on the above mentioned ideas is drafted. 

M.V.C. Aalders, Industrie milieu en wetgeving, Hinderwet tussen symboliek en effectiviteit, Amsterdam 1980.

A. Adinolfi, The implementation of Social Policy Directives through Collective Agreements, Common Market Law Review 1988, p. 290-316.

F. Agnelli, Principe e norme generali, in Codice della prevenzione infortuni en dell' igiene del lavoro (V. Varese ed.), Roma 1978 Vol. I.

$O$. Albers, Y. Konijn, Losse en flexibele arbeidsrelaties, Alphen a/d Rijn 1987.

E.A. Alkema, De internationale sociale rechten en het Nederlandse recht, (J.J.M. van der Ven ed.) Nijmegen 1982.

P.W.C. Akkermans, De Grondwet, een artikelsgewijs commentaar, Zwolle 1987.

M. Alonso Olea, F. Rodrigues-Sañudo, Spain, in International Encyclopedia for Labour Law and Industrial Relations, Deventer (losbladig).

G.M. Ambroso, Ambiente e sicurezza del lavoro, Milano 1978.

J.H.T.H. Andriessen, Medezeggenschap gesteund door wet en regelgeving, TVVS 1984, p. 244-252.

G.J.W. Arendsen de Wolff, De informatieplicht van de onderneming, Deventer 1976.

$V$. Aubert, Enkele sociale functies van wetgeving, Proeven van wetgeving, Rotterdam 1971.

S. Bagnara, R. Misiti, H. Wintersbenger e.a., Work and Health in the 1980's, Berlijn 1985.

G.S. Bain, Industrial Relations in Britain, Oxford 1983.

H.L. Bakels, Schets van het Nederlandse Arbeidsrecht, Deventer 1987.

$R$. Barents, Recente ontwikkelingen in de rechtspraak over steunmaatregelen, SEW 1988, p. 352-364.

E. Batstone, Working Order, London 1984.

E. Batstone, I. Boraston, S. Frenkel, The Social Organization of Strikes, Oxford 1978.

G. Bebr, Arbitration tribunals and article 177 of the EEC-treaty, Common Market Law Review 1985, p. 489-504.

J.R. Bellace, H.F. Gospel, Disclosure of Information to Trade Unions, A Comparative Perspective, International Labour Review, Vol. 122, no. 1 1983. 
R. Benedictus, Safety Representatives, in Law at Work, London 1980.

B. Bercusson, Fundamental Economic and Social Rights, Report to the European Community, Florence 1989.

H. wan den Berg, P. Fontuy, T. Jaspers, De ontwikkeling van het stakingsrecht in Nederland, Nijmegen 1978.

$R$ Bernhardt, e.a. Dertig jaar gemeenschapsrecht, Luxemburg 1983.

L. Betten, Het Europees Sociaal Handvest, Europa's stiefkind, NJCMbulletin, 1988, no. 5 .

L. Betten, The Right to Strike in Community Law, North Holland 1985.

L. Betten, The protocol to the European Social Charter: more Rights a better Impact? Netherlands Quarterly of Human Rights vol. 6, 1988, p. 9 ev.

L. Betten, Prospects for a Social Policy of the European Community and its impact on the functioning of the European Social Charter, in The Future of European Social Policy, (Betten e.a.), Deventer 1989.

L. Betten, Het Community Charter inzake fundamentele rechten: een verwarrende Sinterklaassurprise, NJCM-bulletin 1990, no. 1.

E. Blankenburg, Warum es so schwierig ist die Wirksamkeit von Gesetzen zu erforschen, Vortrag anlasslich der auflosung der Socialwissenschaftliche Forschungsgruppe an Max-Planckinstitut für auschlandische und international Privatrecht Hamburg 1982.

R. Blanpain, F. Blanquet, F. Herman, A. Mouty, The Vredeling Proposal, Deventer 1983.

R. Blanpain ed., Comparative Labour Law and Industrial Relations, Deventer 1985.

$R$ Blanpain, Fifty Years of Labour Law in Belgium, in Fifty Years of Labour Law and Social Security, Deventer 1986.

R. Blampain, Belgium, in International Encyclopedia for Labour Law and Industrial Relations, Deventer (losbladig).

A. Bleckmann, Europarecht, Köln, Berlin, Bonn, München, 1985.

J. Bloemarts, Op weg naar een driepartijenmodel voor het sociaal beleid in de onderneming. De FNV over het ontwerp Arbeidsomstandighedenwet, SMA 1978 , p. 590 ev.

G. Boldt, Bundesberggesetz und Arbeitsrecht, Recht der Arbeit $1981 \mathrm{Heft}$ I.

A. Broadhurst, The Health and Safety at Work Act in Practice, London, 1978 .

F. Burrows, Free movement in Community Law, Oxford 1987.

G.H. Camerlynck, G. Lyon Caen, J. Pelissier, Droit du travail, Paris 1984. G.P. Cella, T. Treu, Relazioni industriali. Manuale per l'analisi della esperienza Italiana, Bologna 1982.

$P$. Chaumette, Le CHSCT et le droit de retrait du salarié, Droit Social 1983, p. 425 .

J. Clark, B. Wedderbum, Modern labour law - Problems, Functions, Policies, in Labour law and Industrial Relations, (Wedderburn e.a.) Oxford 1983.

J. Clark, The juridification of Industrial Relations, A Review Article, Industrial Law Journal 1985, p. 78. 
M. Cohen, Le droit des comite's d'entreprise, Paris 1977.

J.V. Coleman, An employers duties at Common Law in Ireland, Dublin 1961.

D. Collins, The European Communities, the Social Policy of the first Phase, Vol. II, The EEC 1958-1972, London 1975.

Commissie der $E G$, Groenboek, Medezeggenschap van werknemers en de structuur van de vennootschap in de Europese Gemeenschap, Bulletin EEG, supplement $8 / 75$.

Commissie der EG, Sociaal Europa: Themanummer: de Sociale dimensie van de interne markt, Luxemburg 1988.

Commission Internationale de Médécine du travail, Le médécine du travail Francaise et l'Europe, Paris 1988.

J. Conaghan, L. Chudleigh, Women in Confinement: Can Labour Law Deliver the Goods? Journal of Law and Society, Vol. 14 no. 1. 1989.

J.P. de Crayenour, De Europese Gemeenschap en het vrije verkeer van vrije beroepsbeoefenaren, Brussel Luxemburg 1983.

D. Curtin, Prospects for a European Social Policy, in The future of European Social Policy (L. Betten ed.), Deventer 1989.

W. Daübler, Das Grundrecht auf Mitbestimmung, Frankfurt am Main 1975 (3e druk).

W. Daübler, Gemeinschaftsrecht und grenzïberschreitende Interessenvertretung, Arbeitsrecht im Betrieb 1989, p. 44-47.

$P$. Davies, K.S. Wedderburn, This Land of Industrial Democracy, Industrial Law Journal 1977, p. 211.

P. Davies, $M$. Freedland, O. Kahn-Freunds Labour and the law, London 1983.

G. Debunne, Vakbonden in Europa, Leuven 1987.

C.T. Dekker, Internationale fusie als uitoefening van het recht van vrije vestiging, Ars Aequi 1989 (Special Europa 1992) p. 65-71.

$M$. Despax, La place de la convention d'entreprise dans le système conventionel, Droit Social 1988 no. 1.

C. Docksey, Employee Information and Consultation Rights in the Member States of the European Communities, Comparative Labor Law, Fall 1985. C. Docksey, Information and Consultation of Employees: the United Kingdom and the Vredeling-Directive, Modern Law Review 1986, Vol. 49, p. 290.

A.F.M. Dorrestein, M. Verhorst, Het algemene informatierecht van artikel 31 lid 1 WOR, TVVS 1982, p. 191.

C.D. Drake, F.B. Wright, Law of Health and Safety at Work, The New Approach, London 1983.

G. Druesne, Liberté de circulation des personnes. Les prolongements de la libre circulation des salarié's, droit de Sejour et de progrès social, 1982, 3, Revue trimestrielle de droit Europeénne, p. 556.

$P$. Dubois, Multinational Enterprises and Collective Bargaining at International Level, Common Market Law Review 1974. p. 146.

$P$. van Dijk, G.J. van Hoof, De Europese Conventie in theorie en praktijk, Deventer 1982. 
P. van Dijk, Is het Europees Sociaal Handvest dan niet Europees. NJB 1989 , p. $1412-1413$.

T. Elias, B. Napier, P. Wallington, Labour law Cases and Materials, London 1980.

G. Etzel, Betriebsverfassungsrecht, Neuwied/Darmstadt, 1987.

P.K Edwards, The Pattern of Industrial Action in Industrial Relations in Britain, (G.S. Bain ed.) Oxford 1983.

Europees Instituut voor Levens- en Arbeidsomstandigheden, Safety and Health at the Workplace, Dublin 1981.

R.D. Fera, The EEC and the Vredeling Proposal; the Debate to Temper Ideology with Realism, California Western Law Journal 1986, vol. 16 p. 250-281.

FIDE-report, The effect of Community Law on National Employment Law, Vol. 2 Thessaloniki 1988.

$K$. Fitting, $F$. Auffarth, H. Kaiser, F. Heither, Betriebs-verfassungsgesetz, München 1987.

FNV, Collectieve Actie een recht, Amsterdam 1988.

F. Gamillscheg, Sixty Years of Labour Law and Social Security in Germany in Fifty Years of Labour Law and Social Security, Deventer 1986.

M. Garcia Femàndez, La liberté syndicale des salariés en Espagne, in The Freedom of the Worker to Organize, Berlijn 1980.

A.J.C.M. Geers, J.KM. Gevers, Arbeidsomstandighedenrecht, Alphen a/d Rijn 1979.

A.J.C.M. Geers, Veilig en wel, De Arbeidsomstandighedenwet, een nieuwe taak voor de OR, Alphen a/d Rijn, 1985.

A.J.C.M. Geers, Recht en humanisering van de arbeid, Deventer 1988.

J.K.M. Gevers, Zeggenschap van werknemers inzake gezondheid en veiligheid in bedrijven, Deventer 1982.

J. Griffiths, Is Law Important? Groningen 1978.

E. Guttiérrez de Cabiedes, Judicial Structures and Legal Proceeding, in Spanish Business Law (B.M. Cremades ed.) Deventer 1985.

H. ter Heide, The Free movement of Workers in the Final Phase, Common Market Law Review (1986-9)6.

B. Hepple, D Freedman, Great Britain, in International Encyclopedia for Labour Law and Industrial Relations, Deventer (losbladig).

B. Hepple, The Freedom of the Worker to Organize in the United Kingdom, in The Freedom of the Worker to Organize, Berlijn 1980.

B. Hepple, The Crisis in EEC Labour law, 16 Industrial Law Journal, 1987, p. 77,86 .

A.W. Heringa, Sociale grondrechten; hun plaats in de gereedschapskist van de rechter, 's-Gravenhage 1989.

G.A.A.J. vart den Heuvel, Industrieel burgerschap een uitnodiging, Deventer 1983. 
P.F. van der Heijden, Teruggeroepen naar de fabriek wegens defecten, NJCM-bulletin 1985 , p. 340-346.

P.F. wan der Heijden, Een nieuwe geschillenregeling in de WOR, TVVS 1989 no. 1.

A. Hick, Whatever happened to the European Social Policy, The European 1987 , p. $48-49$.

H.R.J.M. Honeé, De territoriale werking van de Wet ondernemingsraden, in Ondernemingsraad en vennootschap, Deventer 1982.

H.E. Hörster, Die Koalitionsfreiheit der Arbeitnehmer in Portugal, in The Freedom of the Worker to Organize, Berlijn 1980.

R.W.L. Howells, Worker Participation in Safety; $I$. The Development of Legal Rights, Industrial Law Review 1974, p. 87-95.

A. Hueck, H. Nipperdey, Lehrbuch des Arbeitsrechts II/2, Berlin/Frankfurt 1970.

J.B. Huizink, De ondernemingsraad: Rechtspersoon ?, TVVS 1983, no. 11 . $K$ van Hulle, De harmonisatie van het vennootschapsrecht in de Europese Gemeenschap in Harmonisatie van vennootschaps en effectenrecht, (B. Wachter e.a.) Deventer 1988.

ILO, The Labour and Trade Union Situation in Spain, Geneva 1969.

ILO, Trade Unions and Industrial Relations in Spain, Geneva 1985.

Industriebond FNV, Veilig en gezond op karwei, Amsterdam 1988.

L. Iversen. Arbejderklassen og Arbejdsmiljøet, Kopenhagen 1978 (2e druk).

A.T.I.M. Jacobs, Het recht op collectief onderhandelen in rechtsvergelijkend en Europees perspectief, Alphen a/d Rijn/Brussel 1985.

A.T.J.M. Jacobs, De rechtstreekse werking van internationale normen in het sociaal recht, Preadvies voor Vereniging voor Arbeidsrecht, 1985.

A.T.J.M. Jacobs, Collective Self-Regulation in The Making of Labour Law in Europe, (B.Hepple, ed.) London/New York 1986.

A.T.J.M. Jacobs, Het Nederlandse CAO-recht bezien door een Europese bril, SMA 1988, p. 251.

A.T.J.M. Jacobs, De arbeidsrechtelijke aspecten van de voltooiling van de Europese binnenmarkt, NJB 1988, p. 835-839.

A.T.J.M. Jacobs, De ondermijning van het sociaal recht, Sociaal recht 1989 2.

A.T.J.M. Jacobs, Arbeitnehmervertretungen und ihre Möglichkeiten internationaler Zusammenarbeit nach niederländischem Recht, Arbeitsrecht im Betrieb 1989-2.

P. Jacobson, Denmark, International Encyclopedia for Labour Law and Industrial Relations, Deventer (losbladig).

P. Jacobson, Kollektiv Arbejdsret, Kopenhagen 1981 (3e druk).

H.E Jensen, P. Langa, N. Møller, Dansk Bedriftssundhedtjeneste, Kopenhagen 1983.

E.P. de Jong, Een inleiding in het denken over arbeidsconflicten-recht, Deventer 1975. 
O. Kahn-Freund, A Lawyers Reflections on Multinational Corporations, Journal of the Industrial Relations Societies 1972, p. 351 ev.

O. Kahn-Freund, B. Hepple, Laws against strikes, London 1972.

O. Kahn-Freund, Industrial Democracy, Industrial law Journal 1977, p. 65.

O. Kahn-Freund, Labour and the law, London 1977 (2e druk).

$O$. Kahn-Freund, Labour Law and Industrial Relations in Great Britain and West Germany, in Labour Law and Industrial Relations (K.S. Wedderburn, R. Lewis, J. Clark, eds.) Oxford 1983.

o. Kahn-Freund, Common law and civil law, imaginary and real obstacles to assimilation, in New Perspectives for a Common law in Europe, Leyden 1987.

P.J.G. Kapteyn, P. VerLoren van Themaat, Inleiding tot het recht van de Europese Gemeenschappen, Deventer 1987.

A.G. Karakatsanis, Labor Law, in Introduction to Greek law (K.D. Kerameus, P.J. Kozyris eds.), Athens 1988.

A. Kayser, Grève et lock-out en droit Luxembourgois, no, 6 in Grève et Lockout, E.C.S.C. Publications on Labour Law in the European Communities, Luxemburg 1961.

J.M. Kelly, The Freedom of the Worker to Organize in the Republic of Ireland, in The Freedom of the Worker to Organize, Berlijn 1980.

$R$ Kidner, Trade Union Democracy; Election of Trade Union Officers, Industrial Law Journal 1984, p. 200.

P. Kinnersley, The Hazards of Work and how to Fight them, London 1974. T.B. Koniaris, Greece, in International Encyclopedia for labour law and Industrial Relations, Deventer (losbladig).

F. Koning, Omtrent de ondernemingsraad, SMA 1975, p. 85.

F. Koning, Rechtspraak medezeggenschap, SMA 1980, p. 545.

J.E.W. Koonen, KJ.M. Tercic, Het mijnreglement 1906 en boe het tot stand kwam. Economisch en Sociaal-historisch Jaarboek, 's-Gravenhage 1979.

Y. Konijn, Afroepcontractanten en het recht op loon, SMA 1985, p. 805 ev. A. Koopman-Iwema, Macht, motivatie, medezeggenschap, een studie naar participatief gedrag van leden van overlegorganen in industriële bedrijven, Nijmegen 1980.

C.A.J.M. Kortmann, De Grondwetsherzieningen 1983 en 1987, Deventer 1987.

Y. Kravaritou-Manitakis, New Forms of Work, Labour Law and Social Security Aspects in the European Community, Luxemburg 1988.

F. Kubler, W. Schmidt, S. Simitis, Mitbestimmung als gesetzgebungspolitische Aufgabe, Baden-Baden 1978.

H. Kühn, Betriebliche Arbeitsschutzpolitik und Interessenvertetung der Beschäftigten, Frankfurt am Main 1982.

P. Lakeman, Hoe representatief is het evaluatie onderzoek "de OR en zijn bevoegdheden", OR-informatie 1986, p. 22.

$R$ de Lange, $\boldsymbol{L}$. Mulder, noot bij FNV vs. de Staat der Nederlanden, Recht en Kritiek, 11(1985)3.

D. Lasok, The Professions and Services in the European Economic Community, Deventer 1986. 
D. Lasok, P.A. Stone, Conflict of laws in the European Community, Abingdon 1987.

R.H. Lauwaars, Het voorbehoud van openbare orde als beperking van het vrije verkeer vam personen in de EEG, SEW 1978, p. 838.

R.H. Lauwaars, J.M. Maarleveld, Harmonisatie van wetgeving in Europese organisaties, Amsterdam 1987.

T. Lawlor, M. Rigby, Contemporary Spanish Trade Unions, Industrial Ralations Journal 1986 no. 3.

R.G. Lee, The Tolpuddle martyrs, Employee Relations vol. 9 (1987) no. 1. D. Lewis, Worker Participation in Safety; II. An Industrial Relations Approach, Industrial Law Review 1974, p. 96-104.

D. Lewis, The Health and Safety at Work Act 1974; New opportunities for Worker Participation in Safety at Work, Centre for Socio-legal studies, Oxford 1977.

R. Lewis, B. Simpson, Striking a balance? Employment law after the 1980 Act, Oxford 1981.

LO, Sikkerhedsarbejdet, Vilkar og Muligheder, Kopenhagen 1983.

J.C. Looise, J.Z. Heijink, De OR en zijn bevoegdheden, Nijmegen 1986.

J.C. Looise, Vakbeweging en vertegenwoordigend overleg in veranderende arbeidsverhoudingen, Alphen a/d Rijn 1989.

$M$. Le Friant, Interessenvertretung in multinationalen Unternehmen nach französischem Recht, Arbeitsrecht im Betrieb 1989, p. 36-40.

A.J.H. van Lynden, De individuele werknemer in het arbeidsomstandighedenrecht, SMA 1984, p. 499 ev.

G. Lyon-Caen, Quel avenir pour quel droit social? in Cent ans de droit social Belge, Brussel 1986.

G. Lyon-Caen, J. Pélissier, Droit du travail, Paris 1988.

H. van Maarseveen, Petitierecht, Grondrechten commentaar op H. I van de herziene grondwet, (Jeukens-bundel) Nijmegen 1982.

G. Magrez-Song, La loi du 23-1-1975 en matiére de conseils d'entreprise et de comités de sécurité et hygiene, Journal des tribunaux de travail, $19 \backslash 75$, no. 100 .

M. Maresceau, Het verbindend karakter van richtlijnen volgens de rechtspraak van het hof van Justitie, SEW 1988, p. 665.

G. Marri, Conditions de travail et organisation de travail, le valeur de l'experience ouvrière, in Le syndicat er l'organisation de travail, Paris 1978. $J$. Mégret (ed.), La droit de la Communauté Economique Europeénne, Brussel 1973, vol. 5. p. 195.

L. Mengoni, Grève et lock out en droit Italien, in Grève et Lock out Part V, E.C.S.C. Publications on Labour law in the European Communities, Luxemburg 1961.

A. Mertens, De wet op de arbeidsveiligheid in de Duitse Bondsrepubliek, De veiligheid 54 (1978) deel II.

N. Messina, Ambiente di lavoro, Milano 1979.

F.A.C.M. Michiels, De AROB beschikking, 's-Gravenhage 1987.

M. Monster, Bescherming moederschap, Nemesis 1988, no. 3 . 
T. Morehead Dworkin, E. Steyger, AIDS victims in the European Community and the United States, Are they Protected from Unjustified Discrimination, Texas International Law Journal, Vol. 24 no. 2. 1989.

K.J.M. Mortelmans, De juridische aspecten van de economische en sociale samenhang, in Economische en sociale samenhang, Den Haag 1990.

K Nagels, F. Sorge, Industrielle Demokratie in Europa, Frankfurt 1977.

I. Nahnsen, Bemerkungen zum Begriff und zur Geschichte der Arbeitsschutzes in Arbeitssituation, Lebenslage und Konfliktpotential, Frankfurt 1975.

B. Napier, Gesellschaftliche und rechtliche Rahmenbedingungen für die Gewerkschaftsarbeit in Konzernen in Grossbrittanien, Arbeitsrecht im Betrieb 1989-2.

R. Nilsen, Laerebog i arbejdsret, Kopenhagen 1987.

C. Nørregaard, The Occupational Health Service in Danmark, Kopenhagen 1987.

M.M. Olbers, Opdracht in strijd met de wet, SMA 1984, no. 3.

E. Osieke, Constitutional Law and Practice in the International Labour Organization, Dordrecht/Boston/Lancaster 1985.

N. Pardon, Prosepctive de la médecine du travail dans la CEE, Luxemburg 1986.

L. Parmegiani, State of the Art, Recent Legislation on Workers Health and Safety, International Labour Review, Vol. 121 no. 31982.

J. Pélissier, La fonction syndicale dans l'entreprise après les lois Auroux, Droit Sociall 1984, p. 41-48.

A.A.G. Peters, Recht als project, Ars Aequi 1979, p. 245-256.

B. Perryns, Trade Union Law, London 1985.

P. Pescatore, Some critical remarks on the Single European Act, Common Market Law Review 1987, no. 1.

J. Pipkorn, J. Forman, W. Stabenow, in Kommentar zum E.W.G.-vertrag (von der Groeben e.a.) Baden-Baden 1983, p. 1985-2089.

J. Pipkorm, The Draft Directive on Procedures for Informing and Consulting Employees, Common Market Law Review 1983, p. 723.

C.S. Pissuisse, Grenzeloos optimisme over 1992, Intermediair 9 september 1988.

J.P. Poupon, Le droit des services autonomes de médécine du travail, Droit Social 1980 no. 4 (numero special).

S. Prechal, Gelijke behandeling in de rechtspraak van het Europese Hof van Justitie, Nemesis $1(1984 / 5) 4$, p. 171.

L. Pünnel, Die Einigungsstelle des BetrVG, Neuwied/Darmstadt 1985.

Th. Ramm, Worker Participation, the Representation of Labour and Special Labour Courts, in The Making of labour law in Europe, (B. Hepple ed.) London/ New York 1986.

Th. Ramm, Laissez-faire and State-Protection of Workers, in The Making of Labour law in Europe (B. Hepple ed.) London/New York 1986. 
Redgrave's Health and Safety in Factories, (I. Fife en E. Machin eds.) London 1982.

M. Redmond, Ireland, in International Encyclopedia for Labour Law and Industrial Relations, Deventer (losbladig).

J. van Rens, Wordt de Europese Gemeenschap een sociale Unie, Ars Aequi 1989 (Special Europa 1992 ), p. 176-182.

Report of the Committee of Inquiry on Industrial Democracy (Bullock report), London HSMO 1977.

Report of the Committee on Safety and Health at Work (Robens-report) London HSMO 1972.

Report of the Royal Commission on Trade Unions and Employers' Association (Donovan Report), London, HSMO 1968.

T.J.M. Reubsaet, P.A.M. de Boer, P.C.J. Sweere, H.J.M. van den Tillaart, De Arbowet in uitwoering; een onderzoek naar de ervaringen in de praktijk door het Instituut voor Toegepaste Sociale Wetenschappen, Den Haag 1988. O. Rieper, Styring af arbejdsmiljøet, Kopenhagen 1985.

J. Rivero, J. Savatier, Droit du travail, Paris 1984.

$P$. Rodière, L'adaption du comité d'entreprise aux structures d'enterprise, Droit Social 1983, p. 361.

$M$. Rodrigues-Piñero, $S$. Del Rey Gaunter, Workers Representative Bodies and Collective Bargaining at the Workplace, Notes on the Recent Evolution in Western Europe, The International Journal of Comparative Labour Law and Industrial Relations 1985, no. 2.

M.G. Rood, Naar een stakingswet ?, Deventer 1978.

M.G. Rood, Over de betekenis van het Europees Sociaal Handvest voor het stakingsrecht en het onderhandelingsrecht in de private en de publieke sector, in Het Europees Sociaal handvest (J.J.M. van der ven ed.) Nijmegen 1982.

M.G. Rood, Over collectieve actie of: de HR terug van weggeweest, NJB 1987 no. 10.

$P$. Roos, Europees Vennootschapsrecht, vestigingsvijheid, zetelverplaatsing en IPR, Ars Aequi 1989, (Special Europa 1992) p. 72-80.

M. Rubinstein, The Dignity of Women at Work, Brussel 1987.

J. de Ruyt, l'Acte unique europeén, Brussel 1987.

J.A. Sagardoy, Worker Participation in Spanish Business Law (B.M. Cremades ed.), Deventer 1985.

$P$. Sanders, Het Europees Economisch samenwerkingsverband, in Ter Vermaak Van Slagter, Deventer 1988.

J. Savatier, Le contröle administratif du reglement interieur, Droit Social 1987 , p. 645 ev.

J. Savatier, Le désignation des répresentants du personel au CHSCT, Droit Social 1989 , p. 645-646.

G. Schaub, Árbeidtsrechtshandbuch, München 1987.

P. van Schilfgaarde, Lingeziekenhuis, Ars Aequi 29(1980)11.

$R$. Schintgen, La législation du travail en Grand Duché de Luxembourg, Luxemburg 1977. 
R. Schintgen, La liberté syndicale des salariés au Grand Duché de Luxembourg, in The freedom of the Worker to Organize, Berlijn 1980.

G. Schnorr, European Communities, in Comparative Labour Law and Industrial Relations (R. Blanpain ed.) Deventer 1985.

$Y$. Scholten, Medezeggenschap van werknemers en de structuur van de vennootschap in Europees verband, SEW 1978, p. 714.

C.J.M. Schuyt, Rechtwaardigheid en effectiviteit in de verdeling van de levenskansen, Nijmegen 1973.

S. Sciarra, The rise of the Italian Shop Steward, Industrial Law Journal 1977 , p. $35-44$.

S. Sciarra, Plant Bargaining, The Impact of Juridification on Current Deregulative Trends in Italy, Comparative Labor Law Journal 1987, Vol. 8 no. 2.

S. Sciarra, Restructuring Labour at the Enterprise, in Bulletin of Comparative Labour Relations, Deventer 1987.

Ph. Seguin, Rôle et realité de la négociation d'entreprise dans les relations d'aujourdhui, Droit Social 1988, p. 2-7.

M. Shanks, European Social Policy, today and tomorrow, Oxford 1977.

S. Simitis, Von den institutionalisierten zur Problemgezogenen Mitbestimmung, Arbeit und Recht, 1975 , p. 328 ev.

W. Slagter, SER-advies over de Vredeling-richtlijn, TVVS 1984, p. 122.

H. Slomp, Tj. van Mierlo, Arbeidsverhoudingen in België, Antwerpen 1984.

C. Smuraglia, La sicurrezza e l'iegiene del lavoro nella politica sociale della C.E.E., Rivista giuridica del lavoro e providenza sociale, 1973, nr. 1 p. 76. M. Sojcher-Rouselle, Droit de la sécurité et de la santé de l'homme au travail, Brussel 1979.

A.G. van Solinge, Concernrecht en medezeggenschap, NV 60 (1982, p. 5859.

J.G. Steenbeek, Wet administratieve overheidsbeschikkingen, 's-Gravenhage 1984.

E. Steyger, De Arbeidsomstandighedenwet en het stakingsrecht, NJB 1987, no. 18.

$E$. Steyger, De gemeenschappelijke arbeidsmarkt en het sociale beleid van de Gemeenschap; over discriminatie, distorsies en ingebakken dispariteiten, NJB 1988 no. 8.

E. Steyger, Sociaal beleid en harmonisatie van wetgeving: stiefkind en zorgenkind, Ars Aequi 1989, (Special Europa 1992) p. 168-175.

E. Steyger, Van vrouwenprobleem tot Gemeenschapszaak, in Ongewenste intimiteiten, gewenste rechten, Alphen a/d Rijn 1990.

E. Steyger, Vertrouwen is goed, controle is beter, bevoegdheidsoverdrach: en democratische controle in pre-federaal Europa, in Bestuursrechtelijke Bewegingen (A.W. Heringa, N. Verheij red.) Deventer 1990.

J. Stuyk, 1993 De Europese interne markt, de Lid-Staten, de marktdeelnemers en de burgers, Brussel 1988.

R. Tavitian, Trade Union Trends in Western Europe: A European Perspective in Industrial Relations in Europe London 1985. 
M. Terny, How do We know if Shop Stewards are getting Weaker, British Journal of Industrial Relations 1986, p. 172-173.

A.W.M. Teulings, Ondernemingsraadspolitiek in Nederland, een onderzoek naar de omgang met macht en conflict door de ondernemingsraad, Amsterdam 1981.

A.W.M. Teulings, Prominenten en volgers, Tijdschrift voor arbeidsvraagstukken, 1 (1981)1, p. 51-64.

$B$. Teyssié, Les restructurations, le rôle du comitê d'entreprise, Droit Social 1989 no. 1.

A.W.J. Thomson, S.R Engleman, The Industrial Relations Act, A Review and Analysis, London 1975.

L. Timmerman, Over multinationale ondernemingen en medezeggenschap van werknemers, Deventer 1988.

L. Timmerman, 1992 en de medezeggenschap van werknemers, Kluwer Seminar Europa 1992, 23/24 november 1988.

C.W.A. Timmermans, De structuur van de naamloze vennootschap en het voorstel voor een vijfde EEG-richtlijn, TVVS 1973, p. 168.

C.WA. Timmermans, Directives, Their effect within the National Legal Systems, 16 Common Market law Review 1979, p. 545.

C.W.A. Timmermans, Hamonisatie van wetgeving en Nederlands recht: beeld van bewogen beweging, R.M. Themis 1980, p. 406-431.

C.W.A. Timmermans, Gewijzigd voorstel Vijfde EEG-richtlijn vennootschapsrecht, TVVS 1984, p. 14-15.

C.W.A. Timmermans, Vredelingrichtlijn ten grave gedragen ?, TVVS 1986, no. $86 / 10$.

T. Treu, Italy, in International Encyclopedia for Labour Law and Industrial Relations, Deventer (losbladig).

T. Treu, Fifty Years of Italian Labor Law, in Fifty Years of Labor Law and Social Security, Deventer 1986.

T. Treu, S. Negrelli, Worker Participation and Personel management Policies in Italy, International Labour Review, Vol. 1261987 no. 1.

D. Tsatsos, Die Koalitionsfreiheit des Arbeitnehmers in Griechenland, in The Freedom of the Worker tot Organize, Berlijn 1980.

J.M. den Uyl, Socialisme en vrije ondernemingsgewijze productie, in Inzicht en Uitzicht opstellen over economie en politiek, Amsterdam 1978.

N. Verhaaren, Gelijke beloning in West Europa, Nemesis 3 (1987)5.

P. VerLoren van Themaat, Europa 1992, Ars Aequi 1989 (special Europa 1992, p. 13-24.

G.E. van Vliet, Bedrijvenwerk als vorm van belangenbehartiging, Alphen a/d Rijn 1979.

T. van Vleuten, Zullen wij handhaven? Nemesis 1987, p. 238-247.

E. Vogel-Polsky, L'Acte Unique ouvre-t'il l'espace social europeén?, Droit Social 1989 p. 177-189.

E. Vogel-Polsky, Welke juridische instrumenten zijn nodig voor een sociaal Europa, SMA 1990, no. 2. 
Th. W. Vogelaar, Het nader tot elkaar brengen van de nationale wetgevingen bij toepassing van het Verdrag van Rome, SEW 1974, p. 299-327.

B. Wachter, Ontwikkelingen op het gebied van de medezeggenschap, mede in Europees verband, Geschriften voor de vereniging voor arbeidsrecht, no.3. Alphen a/d Rijn, 1980.

K. Walsh, Strikes in Europe and the United States, New York 1983.

KS. Wedderbum, R. Lewis, J. Clark, Labour law and Industrial Relations, Oxford 1983.

Lord Wedderburn, The Worker and the Law, Harmondsworth 1986 (3e druk).

D. Weiss, La démocratie industrielle; cogestion ou contrôle ouvrir, Paris 1978.

S. Wiedemann, H. Stumpf, Tarifsvertragsgesetz, München 1977.

G. Wiese, Zur rechtliche Bedeutung der Richtlinien der Berufsgenossenschaften, Recht der Arbeit 1978, Heft 2.

G.K. Wilson, The politics of Safety and Health, Oxford 1985.

T. Wilthagen, Hoe werkt de Engelse arbeidsinspectie, Sociaal Recht 1989 no. 1.

J.P. Windmuller, C. de Galan, A.F. van Zweeden, Arbeidsverhoudingen in Nederland, Utrecht/Antwerpen 1983 (4e druk)

J. van Wulfften Palthe, Industriële medezeggenschapsrechten in rechtsvergelijkend verband, Eindhoven 1986.

J. van Wulffen Palthe, Nieuw raamwerk voor EG-harmonisatie: de internationale CAO, Namens 1989, p. 27-34.

G. Zangari, Rappresentanze dei lavoratori e tutela delle salute, II diritto del lavoro 1973, no. 1.

H.J. van Zwam, Veranderingen in het arbeidsomstandighedenrecht, Deventer 1983. 
Hof van Justitie der Europese Gemeenschappen

75/63, Jur. X, p. 369 (Unger)

$61 / 65$, Jur, 1966, p. 274 (Vaassen-Goebbels)

$28 / 66$, Jur, XIV, p. 1 (Nederland vs. Commissie)

VI.4.1.

VI.2.2.

$14 / 68$, Jur, XV, p. 1 (Wilhelm)

29/69, Jur. 1969, p. 419 (Stauder)

II. 2.2 .

II.2.2.

$11 / 70$, Jur. 1970 , p. 1125

(Internationale Handelsgesellschaft)

II.5.1.

4/73, Jur. 1974, p. 491 (Nold)

II.5.1.

$152 / 73$, Jur. 1974, p. 153 (Sotgiu)

IT.5.1.

$173 / 73$, Jur, 1974 , p. 720 (Italië vs. Commissie)

II.1.

33/74, Jur. 1974, p. 1980 (Van Binsbergen)

II. 2.2 .

$36 / 74$, Jur. 1974 , p. 1405 (Walrave-Koch)

II.2.3.

41/74, Jur. 1974 p. 1331 (Van Duyn)

36/75, Jur/ 1975, p. 1219 (Rutili)

$43 / 75$, Jur. 1976, p. 455 (Defrenne II)

$59 / 75$, Jur. 1976 , p. 102 (Manghera)

$51 / 76$, Jur. 1977 , p. 113 (VNO)

II.1.

38/77, Jur. 1977 , p. 2203 (ENKA)

II.3; VII.2.

II.5.1.

II. 1 ; II.3.

VI.2.

II.3.

II. 3 .

$44 / 79$, Jur. 1979, p. 3727 (Hauer)

$91 / 79$, Jur. 1989 , p. 1106 (Commissie vs. Italië)

II.5.1.

VI.2.

110 ,

111/79, Jur. 1979, p. 35 (v. Wesemael)

III.2.3.

136/79, Jur. 1980, p. 2033 (National Panasonic)

VI.4.2.

$69 / 80$, Jur 1981, p. 767 (Worringham)

II. 3 .

96/80, Jur. 1981, p.911 (Jenkins)

155/80, Jur. 1981, p. 1992 (Oebel)

$246 / 80$, Jur. 1982, p. 2326 (Broekmeulen)

$279 / 80$, Jur. 1981, p. 3305 (Webb)

$8 / 81$, Jur. 1982 , p. 52 (Becker)

76/81, Jur. 1982, p. 417 (Transporoute)

$83 / 81$, Jur. 1981 , p. 1035 (Levin)

91/81, Jur. 1982, p. 2133 (Commissie vs. Italië)

102/81, Jur. 1982, p. 1109 (Nordsee II)

II.3.

III.2.2.

VI.2.2.

II.2.3.

VII.2.

II.3.

VI.2.1.A.

II.5; VI.4.1;

VII.2.

VI.2.2. 
126/82, Jur. 1983, p. 93 (Smit)

$13 / 83$, Jur. 1985 , p. 1513 (EP vs. Raad)

14/83, Jur. 1984, p. 1909 (Von Colson en Kamann)

$19 / 83$, Jur. 1985, p. 462 (Wendelboe)

135/83, Jur. 1985, p. 469 (Abels)

$143 / 83$, Jur. 1985, p. 426 (Commissie vs Denemarken)

$179 / 83$, Jur. 1985 , p. 511 (Industriebond FNV)

215/83, Jur. 1985, p. 1039 (Commissie vs België)

$222 / 83$, Jur. 1986, p. 1651 (Johnston)

$105 / 84$, Jur. 1985, p. 2639 (Mikkelsen vs. Danmols)

152/84, Jur. 1986, p. 723 (Marshall)

235/84, Jur. 1986, p. 2291 (Commissie vs. Italië)

71/85, Jur. 1986, p. 3955 (FNV vs Staat)

$139 / 85$, Jur. 1986, p. 1741 (Kempf)

192/85, Jur. 1987, p. 4753 (Newstead)

$225 / 85$, Jur. 1987, p. 2625 (Commissie vs Italië)

80/86, Jur. 1987, p. 3969 (Kolpinghuis)

126/86, Jur. 1987, p. 3697 (Gimenez Zaera)

131/86, 23 februari 1988 (Groot Brittannië vs. Raad)

312/86, 25 oktober 1988, (Commissie vs. Frankrijk) nng 316/86, 30 juni 1988, (Commissie vs. Frankrijk) nng 242/87, 12 juni 1989 (Commissie vs Raad) nng

109/88, 17 oktober 1989 (Danfoss) nng
II.2.2.

VI.2.1.A.

II.3; VI.3.2.B.

VI.3.2.A.

VI.3.2.A.

II.5; VI.4.1.

VI.3.2.A.

II.5; VI.4.1.

II. 3 ; VII.2.

VI.3.2.A.

II.3; VI.3.2.A;

VII.2.

II.5; VII.2.

VII.2.

VI.2.1.A.

II.3.

II. 1 .

II.3; VI.3.2.A;

VII.2.

II.1; VI.2.1.A;

VI. 4.2 .

II.4.2.A;

VI.2.1.A.

II.5.1.

II.5.1.

VI.2.1.A.

VI.2.2.

\section{De lid-staten}

\section{Denemarken}

Faglige Voldgift, 8 december 1977

(pres. forligs-institution $\mathrm{i}$ arbejdsstridligheder)

II.5.

Faglige Voldgift, 12 september 1985

(Plastindustriens Arbejdgiververforening vs Si)

III.2.2.

\section{Duitsland}

LAG Düsseldorf 9 november 1983,

Arbeit und Recht 1984, p. 191

V.2.2.

LAG Frankfurt, 26 februari 1985,

Arbeit und Recht 1986, p. 124

V.2.2.

LAG Berlin, 30 juli 1985 LAGE para. 80 BVG 1982 no. 4 V.2.2.

BAG 16 maart 1982, Arbeitsrechtliche Praxis

IV.2.

BAG 16 september 1986, Der Betrieb 1986, p. 2026

IV.3.3. 


\section{Frankrijk}

Soc. 20 maart 1956, QP 1956, 601

V.6.1.

Soc. 11 juni 1958, QP 1958,919

V.6.1.

Soc. 7 januari 1960, QP 1960, 1008

V.6.1.

Cour de Cass (Soc) 21 juli 1951 Droit Social 1952, p. 117 IV.5.

Cour de Cass (Crim) 30 april 1958 Bull. 369 , p. 682 V.4

Cour de Cass (Soc) 3 oktober 1963, Dalloz 1964, p. 3 IV.5.

Cour de Cass (Soc) 21 juni 1967, Dalloz 1967, p. 753 IV.5.

Cour de Cass (Crim),

7 december 1982, Jur. Soc. 1983, no. 55

IV.3.5.

Cour de Cass (Soc) 2 juli 1987 Bull.V. 428

V.2.2.

Cour de Cass (Soc) 15 oktober 1987 Bull.V 569

V.2.2.

Conseil d'etat, 1 februari 1980 A.D.J.A. 1980, no. 7-8,p. 439 V.5

\section{Italië}

CC. 7 juni 1952 Giurisprudenza Italliana 1952, p. 624

IV.5.

CC. 8 februari 1966, Foro Italiano no. 8 .

II. .5 .

\section{Groot Brittannië}

Civil Service Union vs. CAC, [1980] IRLR, p. 274

IV.2.

General Nutrition vs Yates [1981]2, The Company Lawyer IV.2.

Kodak vs. ASTMS, [1982]16, IRRR January 1983, p. 288 IV.2.

\section{Luxemburg}

Arrêté Grand Ducal, 6 oktober 1945

IV.4.2.

\section{Nederland}

Ktr. R'dam, 29 juni 1978, NJ 1978, 682

IV.5.

Pres RB Gron. 3 mei 1977 , NJ 1978, 14

IV.5.

Hof A'dam (OK) 1 mei 1981, NJ 1981, 271

IV.3.1.

Hof A'dam (OK) 25 juni 1981 NJ 1982, 246

III. 2.1 .

Hof A'dam (OK) 10 december 1981, NJ 1983, 24

IV.6

Hof A'dam (OK) 14 januari 1982, NJ 1983, 28

IV.3.1.

Hof A'dam (OK) 21 januari 1982, NJ 1983, 31

II.2.1.

Hof A'dam (OK) 25 februari 1982, NJ 1983, 27

IV.3.1.

Hof A'dam (OK) 23 juni 1983, NJ 1984, 571

IV.6.

Hof A'dam (OK) 16 februari 1989, TVVS 1989, p.39

I..3.

HR. 24 juni 1966, NJ 1966, 457

HR. 17 november 1967, NJ 1968, 163 
HR. 24 juni 1979, NJ 1979, 629

HR. 30 maart 1984, NJ 1985, 350

HR. 27 september 1985, NJ 1986, 339

HR. 30 mei 1986, NJ 1986, 688

Bedrijfscie Verz. Bedrijf, 19 april 1984

Bedrijfscie Groothandell, 7 juni 1984

Besch. Min. Soc. Zaken, no. 124888,16 november 1976 , Rp. medezeggenschapsrecht $1971 / 1981$, no. 40

Afd. Rp. RvS, 18 februari 1982,

Rp. medezeggenschapsrecht 1981-1982, no. 74

Afd. Rp. RvS, 7 februari 1983,

Rp. medezeggenschapsrecht 1984, no. 55

CRvB, 6 april 1972, RSV 1972, 214
IV.2

V.6.1.

IV.3.4; V.6.1.

IV.4.1.

IV.S.

V.2.2.

V.2.2.

IV.4.2.

IV. 2 .

VI.3.2.A. 
ACAS 181,182

Actieprogramma Sociale Dimensie Interne markt 52,60

Adviesbevoegdheden

- zie consultatiebevoegdheden

Algemene Rekenkamer (rapport) 251, 252

Arbeid, Ministerie van (Sp) 89

Arbeidsenquete 1887 (Ned) 207

Arbeidsgerecht (Sp) 176, 177

Arbeidsinspectie 17, 133, 166, 167, $176,184,189,190,228,231,241-$ $256,261,262,293,295,296,312$, 323,341

- beroep op 241-256

- functioneren van 251-254

- en individuele werknemer 253 256

- overzicht relatie vertegenwoordigers 250

- petitierecht 254,256

- politionele en administratieve bevoegdheden 241,242, 243

- raamrichtlijn 89/391 323

Arbeidsmilieu 285, 287-289, 332, $347,349,376$

Arbeidsomstandighedencommissie $95,120,135,141,146,166,218$, $223,234,248$

Arbeidsomstandighedendienst (Ned) 235

Arbeidsomstandighedenrecht 17 , 20

Arbeidsomstandighedenwet( $\mathrm{N}) \quad 2$, $18,95,104,120,134,146,166$, $167,198,208,220,222,233,234$,
$248,249,251,254,261,262,264$, $288,297,298,317,324,326$

Arbeidsrechtbanken (B) 156, 169, 176, 177

Arbeitsgericht (Du) 153, 167, 175, $179,184,223,248$

Arbeitsschutzausschuss (Du) 102, $103,121,136,167,168$

Arbeitssicherheitsgesetz (Du) 121, 208, 233

Arbejdsmiljo/lovet (Den) 19, 92, $118,143,247,292$

Arbitrage

- commissie (Den) 181

- instantie 64, 176, 222, 293,294, 295

- procedure 92, 181

- regeling 15,17

- bevoegdheid onder artikel 177 EEG-verdrag 293, 294, 295

Arbowet

- zie Arbeidsomstandighedenwet

AROB (wet van 1977) 254

Artikel 118A EEG-verdrag 9, 24, $25,29,60,277,278,296,298,307$, $340,347,349,361,374$

- als rechtsbasis 291

- arbeidsmilieu 287-291

- interpretatie 284-291

- minimumvoorschriften 284-287

- programma van uitvoeringsmaatregelen 279

Bedriffsartsen 180, 224, 225

Bedrijfscommissie (Den) 181, 226, 247 
Bedrijfscommissie (Ned) 185

Bedrijfsgeneeskundige diensten 229-240, 246

Bedrijfsledengroepen (Ned) 113

Bedrijfsraden (Ned) 84

Bedrijfsradenwet (Ned) 84

Belangenbehartiging 97

Beroepswielrennerij 31(n.26)

Berufsgenossenschaften (Du) 248 , 258

Beschwerderecht (Du) 183, 184, 263

Beslissingsbevoegdheid

- gezamenlijke $15,87,88$

Betriebsrat (Du) 3, 83, 121, 155, 178,184

Betriebsvereinbarung (Du) 185, 224

Betriebsverfassungsgesetz (Du) 87, $101,106,136,145,146,153,164$, $175,178,183,184,187,188,208$, 224,263

Betriebsverfassungsorgan (Du) 175

Betriebsversammlung (Du) 145

Bevoegdheidsoverdracht 75

Bezirksarbeiterrate 83 ,

Bullock-committee 93

Bijzondere groepen 211, 212

Centraal Akkoord 92

- no. 5 (B) 160,161

- 1960, 1964, 1970, 1986 (Den) 90, 92, 109

- 1981 (Gr) 95

- 1983 (It) 139

- 1983/1984, 1985/1986 (Sp) 110, 182,216

Central Arbitration Committee (GB) $138,142,181,182$

Centrale akkoorden 86,92

Closed shop (GB) 111, 265

Coal Mines Regulations Act 1872 (GB) 214(n.47)

Code du Travail (Fra) 108, 120, $135,151,221$

Code of Practice (Ir) 140

Codes of Practice (GB) 243, 259

Combine committees 111,112
Comité de groupe (Fra) 107

Comité economique (Fra) 104

Comite d'empresa (Sp) 89

Comité d'entreprise (Fra) 86

Comité d'hygiène, de sécureté et des conditions du travail (CHSCT) (Fra) 120,135, 168, 169, 176, 208, $217,221,228,246$

Comité mixte (Lux) 88

Comité veiligheid, gezondheid en verfraaiing van de werkplaatsen (B) 119, 169, 176, 180, 217, 231, 244

Commissioni interne (It) 85, 91

Communautaire regeling (concept auteur) 291-298, 312, 362-369

Concern 20,292, 347

- ondernemingsraad 106

- veiligheids-gezondsheidsaangelegenheden 343

Conciliatie 181

Consigli dei fabricca (It) 91,111 , 197

Consultatie

- bevoegdheden $87,90,124,165$, 196, 197, 199, 292, 294

- kwalliteit 68,69

- procedure 74, 78, 289

- recht op 5, 15, 16, 50, 65, 70, $130,133,149-153,162-165,166$, $168,169,170,171,175,176,177$, 220

- verplichting tot $61,67,287,311$, 312,321

Délégations du personnel (Lux) 88 Delegados de personel (Sp) 89 Délégues de personnel (Fra) 85

Delegati di reparti (It) 91

Deskundigen (extern) 219-226, 239

Discriminatieverbod 33

Dispariteiten 31, 32, 34, 40, 41

Distorsies 31, 32

Districtsondernemingsraden 83

Donovan-committee 93

Donovan-report 93, 208 
Economisch en Sociaal Comité 37, $57,339,345,350$

Economische en sociale samenhang $26,34,35,36$

ECRM 76,345

EEG-richtlijnen

- zie richtlijnen

EEG-verdrag, passim

- discriminatieverbod 23

- doelstelling 1,23

- interne markt 23, 276, 279.282, 373,375

- medezeggenschap 2

- recht op verblijf werknemers 23 EGKS 298

Einigungsstelle (Du) $154,175,178$, 184, 198, 223

Employment Act 1982 182, 194

Employment Medical Advisory Service 239, 240

Employment Persons (Safety and Health) Bill (GB) 117

Employment Protection Act 1975 (GB) $137,138,148$

Emloyment Protection (Consolidation) Act 1978 (GB) 114

Ergonomie 279

Estatudo de la Trabajadores (Sp)

- zie Werknemersstatuut (Sp)

ETUC 37, 45, 57, 61

Euratom 298

- rl. ioniserende straling 313

Euro-ondernemingsraad 347,348

Europees Parlement 2, 37, 38, 57, $279,283,288,314$

Europees Sociaal Handvest (ESH) $8,18,36,37,77,187,189,194$; 345

Europese Akte 1, 9, 24, 25, 26, $28,29,38,61,276,281,282,344$, 373,376

Europese Commissie 25, 26, 78, $79,275,276,277,289,313,332$, $349,350,354,373$

Europese Ondernemingsraad (Eor) 48

Europese Raad 35, 37

Europese sociale politiek
- zie Sociale Politiek

Europese Stichting (levens-en arbeidsomstandigheden) 298

Europese Vennootschap

- zie statuut SE

Fabrieksinspectie 1833(GB) 206

Factory Inspectors (GB) 251

FNV 248

Fuero de Trabajo 1938 (Sp) 85

Geheimhouding 295, 344

Gekwalificeerde meerderheid (besluiten) 282, 284, 349, 361

Gemeenschapshandvest van Sociale Grondrechten

- zie Handvest

Geschillen 15, 17, 174-185, 223

- besluitvorming 178-185

- individuele werknemer 183,184 , 185

- naleving $174-178$

Gewerbeordnung 247

- zie ook Arbeidsinspectie

Gewerkschaftsbeauftragte (Du)

112,113

Groenboek 49(n.101), 50

Guidance notes 117

Handvest $26,35,36,37,77,78$, $187,339,345,346,350,373$

Harmonisatie, passim

Health and Safety at Work Act 1974 (GB) 2,116, 117, 138,171, $178,196,208,214,229,243,292$, 339,349

Health and Safety Commission (GB) $117,178,239,240,243$

Health and Safety Executive 239, $240,243,252$

Hof van Justitie 25, 41, 42, 54, 60, $61,76,77,282,286,290,293,297$, $320,326,329,339,354,374$

Holding 20, 34(n.39)

- vrijstelling medezeggenschapsregime 11

Hovedaftalen (Den) 90 
Immuniteiten (GB) 93

Individuele werknemer 325,326 , 374

- democratieprobleem 265-266

- klachtrecht 263-265, 295, 342

- overheidsinterventie 268,269

- stilleggen van werk $17,185,257$. 263

- homogene groepen 266-270, 341 Industrial Councils (Ir) 94

Industrial Relations Act 1946 (Ir) 94

Industrial Relations Act 1971 (GB) 93

Industrial tribunals (GB) 259

Informatie

- bevoegdheden $87,90,124,196$, 199

- kwaliteit 67,68

- procedure 78, 289

- recht op $5,15,49,68,69,130$, $133-148,162-165,172,175,176$, 218,292

- afdwingen van 141,142

- inzake veiligheids- en gezondheidsaangelegenheden 134

- verplichting werkgever 134, 309, 310

- zwijgplicht $66,142-145$

- toegang tot $145,146,147$

- verplichting tot 63,64

- verstrekken van $63,67,68,71$, 72

Initiatiefrecht 155,321

Inleenkrachten 211,212

Inspectie

- recht op 16, 172

- raadplegen deskundigen 17,133

Instemmingsrecht $16,49,87,130$, $131,132.153-158,162,165,166$, $167,168,169,172,173,175,189$, $197,199,220,231,295,375$

International Labour Organization (ILO) $7(n .21), 37,78,162,163$, $229,241,251,342,345$

- Convention no. 155345

Joint Labour Committees (Ir) 94
Kantonrechter (Ned) 38, 174, 184, $222,223,233$

\section{Labourregering 117}

Matignon Akkoord 85

Medezeggenschap, passim

- definitie 17, 18

- multinationaal niveau 79,80 , 342-349

Medezeggenschapsinstrumentarium

- definitie 129

- veiligheid en gezondheid 203-214

- overzicht 272

Medezeggenschapsrechten 87

Medisch toezicht 64,304, 305

Minimumvoorschriften 284-287, 349, 375

Mitterand (regering) 228

Mijnbouwwetgeving 207

Nachtarbeid voor vrouwen 211 , 327

"Nieuwe Benadering" 58, 59

Nieuwe technologieën $61,62,70$, $221,236,319$

Occupational Health Services (ILO-Convention) 229

Olievlekwerking 62,70

Onderhandelen

- recht op 16, 87, 132, 158-162, $168,171,173,295,375$

Ondernemer

- definitie 20

Onderneming

- definitie $20,343,347$

- multinationale 34,45

Ondernemingskamer $175,179,199$, 224

Ondernemingsbeleid 84, 295

Ondernemingsraad, passim

Ondernemingsraden

- centrale 106, 107

- commissies 102, 103, 104

- concern 105, 106, 107

- groeps-106, 107 
- instelling 98

- kiesrecht, actief 100

- kiesrecht passief 99, 100

- leden, bescherming 101, 102

- taken 102,103

- en thuiswerkenden 101

- voorzitter 98, 99

- werknemer 101

- wet op de (Ned) 2, 6(n.17), 87, $101,134,153,154,155,163,164$, $166,175,179,198,199,208,218$, $220.222,297$

Ongewenste intimiteiten 97,288

Ordonnance (Fra) 86

Overeenkomst (Collectief) 71-80

- recht op afsluiten 15

Overleg

- kwaliteit 67, 68

- verplichting tot 66

Overzicht werknemersvertegenwoordigers op ondernemingsniveau $96,126,127$

Personeelsvertegenwoordiging 83

Raad van Ministers 59, 60, 61, $275,276,277,279,280,282$

Raamrichtlijn 89/391, (alg) 63, 71, 279 , 316-327, 327-331, 338, 342, $343,373,374$

- Artikel 11 (geschiedenis) 32I, 322

- consultatieverplichting 321

- evenwichtige deelneming 322 , 323,338

- individuele werknemer 325

- informatie 319

- initiatiefrecht 321

- nationale recht 317

- nieuwe technologieën 319

- onderhandelen 316

- overlegverplichting 322

- raadpleging/deelneming 322, 323

- sancties 329

- verantwoordelijkheid werkgever 317,318

- werkingssfeer 317
Randgroepwerknemer 19,100 , $101,265,326,339,340,369,370$

Rapportageverplichting 78, 79, 309 Reichsversicherungsordnung (Du) 168

Reichswirtschafstrat (Du) 83

Representativiteitsvereiste 265

Richtlijnen

- bedoeling 39, 40

- collectief ontslag $62,66,67,68$, 354

- effectiviteit 353,358

- Europese arbeidsverhoudingen $77,79,80,348$

- grondslag 280

- implementatie $71,72,73,75$, 315,316

- interpretatie 41,42

- overgang van ondernemingen 62 , $64,66,68$

- reikwijdte 43

- verschil tussen artikel 100 en $100 \mathrm{~A} 28,29$

- werking van 42

- zevende richtlijn vennootschapsrecht 57

Richtlijnen (veiligheid) voor 1987

- asbest (83/477) 278, 303, 304, 305,306

- chemische, fysische en biologische agentia $(80 / 1107) 62,63$, $64,65,66,278,301,302,310$, 311

- lawaai $(86 / 188) 278,306,307$, 312

- metallische lood (82/605) 278, 302, 303

- veiligheidssignalering $(77 / 567)$ 278,300

- vinylchloridemonomeer $(78 / 610)$ $278,300,301,311$

- zware ongevallen bij industriële activiteiten $(82 / 501) 308,309$, 310

Richtlijnen (veiligheid) na 1987

- verbod specifieke agentia (88/364) 307,308 
- arbeidsplaatsen (89/654) 332, 333

- arbeidsmiddelen (89/655) 333, 334.

- individuele beschermingsmiddeIen $(89 / 656) 334,335$

Richtlijnwoorstellen

- beeldschermen 213,335

- benzeen 315

- biologische agentia 336, 337

- carcinogene agentia 336, 337

- informatie/consultatiemultinationale ondernemingen (zie Vredelingvoorstellen)

- Iumbaal letsel 335

- microgolven 313,314

- vijfde richtlijn $8,46,47,50,51$, $54,55,71,77,81,124,125,372$

Rijkseconomische raad 83

Robens-report 116, 117, 209

Safety Committee Regulations 1977 (GB) 138, 214, 215

Safety in Industry Act 1980 (Ir) 118

Samenwerkingscommissie (Den) 90,123

Samenwerkingsovereenkomst (Den) 90

Sancties van werknemers 17 SER 164

SER fusiegedragscode 163

Shop steward, passim

- ontslagbescherming 113,114

- regulering 108,109,110,111

- taken 114, 115

Sicherheitsausschuss (Du) 102, $103,121,136,167$

Sicherheitsbeauftragten 85,121 , $167,208,218,247.248$

Sociale dumping 279

Sociale politiek $1,26-33,80,275$

Societas Europea

- zie Statuut SE

Stakingsrecht 4, 5, 185-195, 296

- definitie 186

- erkenningsstaking 190
- in grondwet (It, Lux, Gr) 191, 192,193

- solidariteitsstaking 190, 193, 194

- wilde staking $188,189,190,192$, 193, 194

Standing Committee on Employment $6 I$

Statuut SE 8, 46, 48, 52, 53, 54, $69,71,147,293,372$

Stilleggen onderneming 227-229, 296

Thatcher (rede Brugge) 291

Thuiswerkers 212, 213, 269, 326, 369

Tillidsmand (Den) 90

Toezicht 296

- recht op 214-219, 220

Tolpuddle Martyrs 372

Trade Union Congress (GB) 125

Trade Union Democracy Act 1982 (Gr) $90,108,109,159,191$

Tripartite Declaration (multinational enterprises -ILO) 342,346

Unfair Dismissals Act (Ir) 264 UNICE 57,61

Vakbondsafvaardiging

- zie shop steward

Val Duchesse 61, 62

Veiligheidsafgevaardigden (Bel, Lux) 84

Veiligheidscommissie (Den) 215, $226,227,246$

Veiligheidscommissie (Gr) 228

Veiligheids- en gezondheidscommissies (Du) 95

Veiligheids- en gezondheidscomitê's (Bel, Fra, Gr) 87, 95, 168, 169

Veiligheids- en gezondheidswet (Gr) $95,228,231$

Veilligheids- en gezondheidswetten (Du) 95

Veiligheidsgroep (Den) 215, 227, 246, 247 
Veiligheidsvertegenwoordigers 65 , $116-122,194,215,225,226,230$, 246

Veiligheidswet 1844 (GB) 205

Veiligheidswet (Ned) 233

Vennootschapsrecht 44

Verordening (EESV) 69, 373

Vertrauensleute 97

Vertrouwensman 97

Vertrouwenswrouw 97

Vestigingsplaats $30,33,35$

Vestigingsstromen 28

Vredellingwoorstellen $8,46,55-61$, $71,72,80,81,124,147,199,292$, $293,311,328,344,347,361,369$, 372

Vrij personenverkeer $23,24,29$, 33, 34

Vrijheid van vakvereniging 84

Vrijheid wan vestiging 33,34

Werkgever

- definitie 20

Werknemer(s)

- definitie 19,325, 326, 340

- reguliere 6

- vertegenwoordigers van (i.h.a.) $63,65,66,83,84,85$

Werknemersinspecteurs (GB) 208 , 214

Werknemersstatuut (It) 91,110 , $139,140,142,161,171,172,209$, 215,340

Werknemersstatuut (Sp) 89,150 , $176,177,216,225,227,245,260$

Wirtschaftsausschuss $103,136,146$; 152,220

Witboek (Commissie) 52

Worker Participation State Enterprise Act 1977 (Ir) 94

Working Paper on Worker Participation (Ir) 94

World Health Organization

- begrip veiligheid 19

Zurückbehaltungsrecht 188,258 


\section{CURRICULUM VITAE}

Elies Steyger werd op 25 mei 1956 geboren te 's-Gravenhage. Zij behaalde in 1974 het HAVO-diploma aan het Thorbecke-Lyceum te 's-Gravenhage. Daarna zette zij haar opleiding voort aan de School voor de Journalistiek te Utrecht waar zij in 1978 met succes eindexamen deed. In 1984 behaalde zij het doctoraal Nederlands recht aan de Rijksuniversiteit Groningen. Zij is aan verschillende periodieken als verslaggever verbonden geweest en heeft ook enige tijd als free-lance journaliste gewerkt.

Sedert 1985 is zij verbonden aan de juridische faculteit van de Rijksuniversiteit Limburg als universitair docent Europees recht. 